\title{
Rezidencijalno podrijetlo učenika i odabir studija
}

\section{Klepač, Olgica}

Doctoral thesis / Disertacija

2021

Degree Grantor / Ustanova koja je dodijelila akademski / stručni stupanj: University of Zagreb, Faculty of Humanities and Social Sciences / Sveučilište u Zagrebu, Filozofski fakultet

https://doi.org/10.17234/diss.2021.7676

Permanent link / Trajna poveznica: https://urn.nsk.hr/urn:nbn:hr:131:366313

Rights / Prava: In copyright/Zaštićeno autorskim pravom.

Download date / Datum preuzimanja: 2023-04-26

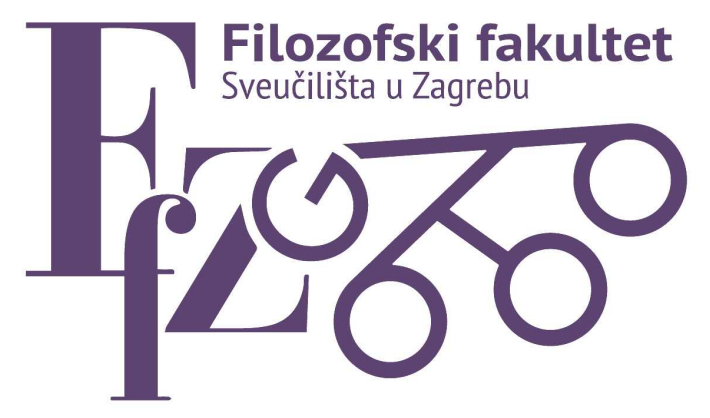

Repository / Repozitorij:

ODRAZ - open repository of the University of Zagreb

Faculty of Humanities and Social Sciences
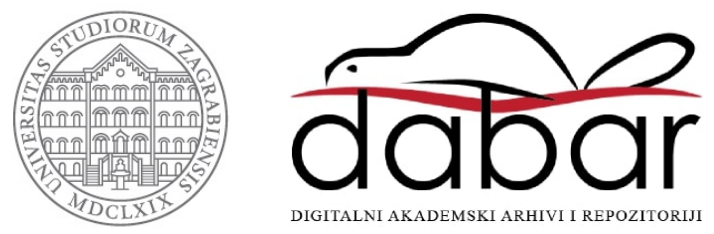
Filozofski fakultet Sveučilišta u Zagrebu

Olgica Klepač

\title{
Rezidencijalno podrijetlo učenika i odabir studija
}

\author{
DOKTORSKI RAD
}

Mentori: izv. prof. dr. sc. Anton Vukelić prof. dr. sc. Branislava Baranović

Zagreb, 2021. 

Faculty of Humanities and Social Sciences

Olgica Klepač

\title{
Students' residential background and study choice
}

\author{
DOCTORAL THESIS \\ Supervisors: izv. prof. dr. Sc. Anton Vukelić \\ prof. dr. sc. Branislava Baranović
}

Zagreb, 2021. 



\section{Zahvale}

U dugotrajnom procesu razvoja ideje i izrade ove disertacije, kada su se izmjenjivali osjećaji razočaranja i ponosa, mnogo se ljudi našlo na putu koji su velikim dijelom vjerojatno nesvjesni velikih tragova koji su ostavili za njen konačni oblik, i koji zaslužuju zahvalnost na početnim stranicama. Stoga želim zahvaliti svojim nekadašnjim radnim kolegama i mentorima dr. sc. Nenadu Fanuku, dr. sc. Branislavi Baranović i dr. sc. Đurđici Žutinić, članovima radnih kolektiva kojima sam imala sreće biti dio, pa makar i kratko, s Odsjeka za kulturalne studije u Rijeci, Instituta za društvena istraživanja u Zagrebu te Zavoda za agrarnu ekonomiku u Zagrebu koji su kroz cijelo to razdoblje gradili i održavali moj istraživački zanos i znanstvene interese. Na tom putu ostvareno je mnogo prijateljstava kroz rad koja su snažnijom podrškom i unatoč svim životnim teškoćama ukazivali kako je mnogo toga moguće, a teškoće su samo da bi krajnji rezultat bio slađi. Posebne zahvale za učenje toga svakako zaslužuje dr.sc. Srebrenka Letina koja je vlastitim primjerom i ljudskom podrškom ostavila duboki i neizbrisivi trag na mom profesionalnom i životnom putu. Istraživačka grupa Ruralije čini me zahvalnom zbog njihove stručne i ljudske podrške te kreativnih poticaja. Zahvaljujem i kolegama na doktorskom studiju, s kojima sam dijelila najveće strahove i sreće, te mentoru Antonu Vukeliću koji me uvijek pokretao kada bih posustala i koji je uvijek znao stvari pojednostaviti kada su se meni činile neizmjerno složenima i neuhvatljivima. U konačnici, na ovim uvodnim stranicama želim zahvaliti i sadašnjim kolegama sa Zavoda za bioekonomiju i ruralni razvoj i mentorici dr. sc. Snježani Tolić koji su dali ovom cijelom podhvatu novi smisao i svrhu.

Ipak, najveće zahvale svakako idu mojoj obitelji koja ima moju bezgraničnu i cjeloživotnu zahvalnost postavljajući me na ovaj put, tješeći me na svakoj krivini, omogućavajući mi sigurno okrilje svaki puta kada bi nestalo tla pod nogama. Cijeli rad posvećujem njima koji su bili inspiracija i motivacija. 



\section{Životopisi mentora}

Izv. prof. dr. sc. Anton Vukelić. Diplomirao je sociologiju 1990. na Filozofskom fakultetu u Zagrebu gdje je i magistrirao s temom „Stratifikacijski položaji etnonacionalnih grupa u Hrvatskoj” (mentor V. Katunarić), te doktorirao 2003. godine s temom „Anomija pojedinih socijalnih grupa suvremenog hrvatskog društva“ (mentor J. Kregar).

Od 1990. godine, kada je stupio u radni odnos na Katedri za sociologiju, Fakulteta strojarstva i brodogradnje u Zagrebu, sudjeluje u izvođenju nastave kolegija Sociologija te Industrijska sociologija i Socijalna psihologija malih grupa. Na Tehničkom veleučilištu sunositelj je kolegija Industrijska sociologija. Na poslijediplomskom studiju FSB-a sudjeluje u izvođenju kolegija Menadžment ljudskih potencijala, a na Tehničkom veleučilištu u nastavi kolegija Ekonomika i menadžment.

Od 2008. godine radi na Filozofskom fakultetu u Zagrebu, Odsjek za sociologiju, Katedra za sociologiju obrazovanja, gdje je nositelj i predavač kolegija Hrvatsko društvo na Odsjeku za sociologiju te kolegija Sociologija obrazovanja pri Centru za obrazovanje nastavnika. Kao mentor ili član povjerenstava sudjelovao je u nekoliko desetaka diplomskih, i doktorskih radova, te je član povjerenstva za stručne ispite predmeta Sociologije, i Politike i gospodarstva. Sudjelovao je u više međunarodnih projekata u području obrazovanja. Radovi: http://bib.irb.hr/lista-radova?autor=175076.

Prof. dr. sc. Branislava Baranović. zaslužna znanstvenica u Institutu za društvena istraživanja u Zagrebu. Bila je ravnateljica Instituta te jedna od osnivačica i predstojnica Centra za istraživanje i razvoj obrazovanja kao znanstvene jedinice Instituta. Kao vanjska suradnica Učiteljskog fakulteta Sveučilišta u Zagrebu od 2007. god. do 2020. god. bila je voditeljica i izvodila je dodiplomsku nastavu na kolegiju Sociologija obrazovanja na Prirodoslovno-matematičkom fakultetu, Sveučilište u Zagrebu. Glavna područja njezinog znanstvenog interesa su sociologija obrazovanja, razvoj nacionalnog kurikuluma, društvene i rodne (ne)jednakosti u području obrazovanja. Vodila je i sudjelovala u izvođenju brojnih projekata u području obrazovanja. Objavila je 6 knjiga i brojne znanstvene radove u domaćim i međunarodnim časopisima. Kao članica ekspertnih grupa i tijela Ministarstva znanosti i obrazovanja sudjelovala je i u izradi strateških policy dokumenata u području obrazovanja i reformiranju nacionalnog kurikuluma za osnovno i srednje obrazovanje. Članica je Council of the European Educational Research. Radovi: https://www.bib.irb.hr/pregled/profil/12646 


\section{Sažetak}

Tematski, rad ispituje donošenje odluka o studiranju, odabiru tipa i mjesta visokog obrazovanja učenika koji odrastaju u ruralnim sredinama.

Teorijsko polazište čini Bourdieuova teorija prakse (2013) i kasnije adaptacije njegovih koncepata kroz pristup „koncept kao metoda“ (Reay, 2004) u ispitivanju nejednakosti u obrazovanju. On je nadopunjen Halfacreeovim trosložnim modelom ruralnog (2006) koji Bourdieuov okvir proširuje uključivanjem prostorne dimenzije.

Koriste se mješovite metode koje povezuju kvantitativno anketno ispitivanje na reprezentativnom uzorku maturanata hrvatskih srednjih škola s kvalitativnim podacima dobivenim kroz intervjue s maturantima jedne ruralne hrvatske regije.

Polazna pretpostavka je da postoje specifičnosti izbora visokog obrazovanja učenika koji odrastaju u ruralnim sredinama s obzirom da odlazak na studij za njih znači i geografsku i (često) društvenu mobilnost. Ispituje se kompleksnost interakcije geografskih i sociokulturnih čimbenika koji utječu na njihove odluke.

Ključne riječi: mješovita metodologija, Bourdieu, rezidencijalno podrijetlo, namjera studiranja, pristup visokom obrazovanju, ruralno-urbane razlike, obiteljski i školski obrazovni resursi, simbolička vrijednost zajednice, obrazovni putovi, socio-prostorna pozicija

\section{Summary}

Thematically, the study examines decision-making process about studying and deciding on the type and place of higher education of students with different residential background. The basic interest of the study (broadly expressed as the influence of students' origin on educational outcomes) connects the disciplines of sociology of education and rural sociology. The main problem arises from research that indicates broader unfavorable economic and demographic trends in rural areas, associated with unfavorable educational trends of lower educational aspirations and results of rural students (Bracken 2007; Hu 2003; Koricich 2018). While education can be considered an important factor in improving personal life chances and 
social status, as well as significant territorial and social prosperity capital, it is also a significant motivating factor for emptying rural areas and worsening their development prospects. The assumption is that there are specifics of higher education choices for students growing up in rural areas, given that going to study means both geographical and (often) social mobility for them. The complex interactions of geographical and sociocultural factors influencing their decisions are examined.

However, the question of whether and how rurality contributes to unequal educational opportunities remains open due to empirical difficulties in determining community impacts, an inadequate controls on variables of origin and living conditions and definitions of rural (Edington, Koehler, 1987; Khattri et al., 1997). The literature review (2.1) highlights the need for careful operationalization of the concept of rural, and the inclusion of a wider range of factors of student decision-making, related to socio-cultural and economic resources, but also symbolic elements (family, school, communal) because going to study has additional meaning for rural student and it is necessary to examine both perceptions and attachment to the place of growing up (Wiborg 2004; Geldens 2005).

In the Croatian context (2.2) the study problem proves to be a prominent issue. The Croatian higher education system in the last 20 years has been marked by significant processes of change (Bologna process, nationwide high school exit exam) and massification of higher education, that are statistically shown as an increase in the number of studies, study programs and the student body. However, the body of research determined the neglect of the social dimension of higher education and the maintenance of educational inequalities (Doolan, 2009; Doolan, Puzić, Baranović 2017; Baranović, 2015). Some also point to elements of rural-urban educational inequalities (e.g. in the experiencing of studying), as well as the need for additional examinations of entry into higher education with regard to residential and / or regional determinants (Farnell et al. 2011). This is especially significant given the research that indicates a deeply hierarchical rural-urban Croatian space (Seferagić 2005), significant uneven socio-geographical development, large regional differences and negative demographic and development trends (Štambuk 2014), and that indicate education as a significant motivating factor for young people to leave rural areas (Žutinić, Bokan 2008). Considering that the rural area in Croatia is not uniform (Lukić 2012), and research indicate regional educational (Klepač 2016) and developmental inequalities (Šundalić, 2010), especially for the region of Slavonia that is marked by significant unfavorable socio-economic and development characteristics, Slavonia is set as an interesting research area. 
The main purpose of the study (2.3) is to identify and describe the elements of sociogeographical and cultural-symbolic barriers that make it difficult for students from rural areas to decide to continue their education and enter higher education. Four research questions guide the study:

1) Are there significant differences between students of different residential backgrounds in study intent, higher education choices, and certain structural and symbolic elements of their family, school, and community of growing up?

2) Is there an effect of students' residential background, with control of certain relevant factors of the family and school context, on higher education decisions?

3) What role does the emotional attachment to the place, a sense of belonging to the local community and a desire to stay in the Slavonia region play in explaining student choices?

4) What is the role of students' perceptions of their socio-spatial positions and feelings related to their rural environment in informing the decision-making process of higher education?

The objectives are expressed as a number of working hypotheses, some of which are answered only nationally, while the more exploratory ones are tested regionally in Slavonia with a wider method usage.

The theoretical lenses (2.4) are provided in Bourdieu's theory of practice (2013 [1977]) and later adaptations of his concepts - social, economic and cultural capital, habitus and fields through the "concept as a method" approach (Reay, 2004) in examining inequalities in education. In that, emphasis is placed on spatial aspects of students' origins (along with other theoretically prominent factors) under the influence of Halfacre's threefold model of the rural (2006) according to which the rural is a social construction, but also material and lived.

Bourdieu's concepts are thus a heuristic tool with implications for research methodology as well. Both, the usability and adaptation of Bourdieu's concepts in spatially and temporally different contexts than the one they originated in, and the posibbility of expanding his theoretical framework in which space gains a more significant role, alongside the class ones are discussed. A significant contribution to the discussion is made by sociogeographic research by Corbett $(2007,2010)$ in Canada and by Rye $(2003,2004,2007)$ in Norway, that use terms such as "rural-urban field" and "geographical habitus", derived from Bourdieu's theory and adapted to spatial research of social reproduction. Additionally, a wider range of rural youth research and identity building in contemporary "mobile" and "risk society" indicate that place and emotional elements of attachment to place still matter (Wiborg, 2006).

Mixed methodology research design (2.5) was created guided by the research questions, and based on the methodological literature (Tashikori and Teddliea 2009, Creswell 2003). The use 
of several methods proved appropriate a) given the insufficient research of the issue in Croatian context, b) due to the starting point in Bourdieu's theory which relies on "dialectics of structures and microaspects", and "includes structuralist and constructivist moment", and c) given the interest in rural whose conceptual complexity is summarized by Halfacree (2005).

These influences were reflected in the structure of the study (two phases at two levels (national and regional)), and in the ways in which aspects of (rural) origin are captured in the study (statistically and qualitatively). Two phases of data collection (survey and interviews) using different tools (questionnaire and protocol; in appendix), and data processing and analysis were done separately: statistically in the SPSS program ( $\lambda$-square, ANOVA, t-test, logistic regression) and narrative coding in NVivo program and interpretive analysis using memo tools. The integration of the results took place in the final stages of data interpretation, which included triangulation techniques.

The main variables (2.6) presented operationalized concepts in the quantitative part of the study: sociodemographic and sociogeographic indicators (gender, residential background, school location); individual educational and cultural characteristics and students' educational orientations (type of school, general school success, educational aspirations and expectations, studying as implied, length of decision making, value of learning, desire for social mobility, cultural, reading and extracurricular practices); family economic and cultural resources (parents' working status, property possession, assessment of financial situation, parents' education, number of books in the household, possession of cultural goods and parents' cultural practices); institutional characteristics of education (status, equipment and incentives of high school, and the importance of the status of the desired study); the symbolic value of the context of growing up and schooling (family incentive practices, family influence on the decision to study, the influence of significant others, the symbolic value of the community). The dependent variables of students' higher education choices were the intention to study (yes and no / don't know), the type of chosen study (professional or university) and the city of study (Zagreb or other).

The basic independent variable of interest - residential background - was created by the process of coding the settlements in which students grew up. The variable was recoded in 2 ways to capture the specifics of plurality of rural in Croatia (Lukić, 2012); in the first case, settlements are categorized as urban, rural and metropolitan. In the second case, rural settlements are classified into 7 types of rural settlements in Croatia (Lukić 2012). Additionally, aspects of residential origin are measured (regionally) by a three-dimensional instrument of the symbolic significance of the community for the students (attachment, 
belonging, desire to stay). Perceptions of rural, relations with community and students' views on education with regard to their residential background were qualitatively examined in interviews.

Data were collected as part of the national research project Social identities, higher education access and course choice. The project was funded by the Croatian Science Foundation and carried out by the research team of the Institute for Social Research in Zagreb.

The survey was conducted (2.7) in the spring of 2014, when a 5\% representative sample of high school graduates from three-year and four-year schools was surveyed in 98 schools $(\mathrm{N}=2106)$. Sample size of those students that intend to study was $\mathrm{N}=1258$. In Slavonia representative subsample of $\mathrm{N}=439$ high school graduates was surveyed. Regionally, additional 20 students were interviewed.

Empirical research at the national level (3) presents the findings of statistical analysis of quantitative national data. The aim is to confirm the assumptions about the existence of differences between students of different residential backgrounds according to their intentions to study and choices of higher education, and other educational and cultural characteristics, economic and cultural family resources, school characteristics and symbolic dimensions of their community.

ANOVA and hi-square tests confirmed that rural students are less likely to opt for postsecondary schooling, and those intending to study are less likely to enroll in university studies. No significant difference was found according to the choice of place of study.

Additional educational differences were also confirmed, as well as differences according to the available economic, cultural and symbolic resources in their families, schools and communities. Students of rural residential origin, despite the fact that they equally value learning, express a desire for social mobility and equally receive incentives to study in schools, express statistically significantly lower educational aspirations and expectations, do not consider studying a "natural" continuation and consider it longer as an option. This is in line with the findings that rural students are more likely to have lower school performance and a lower level of cultural competences, as well as to attend vocational schools, for which they assess lower status. Findings also indicated a less favorable structure of cultural and economic resources available to rural students in their families and schools. Finally, the symbolic influence on the rural students' decision to study was confirmed as weaker incentives from parents, but also as a stronger influence of people outside the family: neighbors and professional associates and professional development counselors. 
Less pronounced differences with regard to the educational characteristics of students were shown between students of different residential backgrounds who intend to study. Nevertheless, a motivational difference was highlighted whereby rural students who intend to study more strongly express a tendency to ascend the social ladder. Also, among students who intend to study, the most unfavorable structure of family economic and cultural capital was shown for rural students, and it becomes more favorable as the level of "urbanity" of settlements grows. At the same time, the resources of parents are of the greatest importance for metropolitan students, along with the geographical availability of other resources in the capital. Students of nonmetropolitan residential backgrounds who intend to study find a significant source of influence, support, and resources in other family members with study experiences and people from the institutional settings outside the family.

For the purposes of the explanation of the students' intention to study and higher education choices, and to determine the effect of residential background on these decisions, two 5-step regression models were constructed, in which the main predictor variable of students' residential background was introduced in the final step. The robustness of the model was also tested on subsamples of students of different residential backgrounds. The results confirmed that the students' residential background, although minimaly (about 1\%), significantly contributes, along with some other individual and contextual variables, to the explanation of students' intention to study.

The rural students' intention to study is largely explained by the individual valuing of learning, the desire for social mobility and the cultural characteristics of the family, but also by the status and location of their schools. An exploratory analysis with a variable of residential background that operationally distinguishes 4 types of rural settlements indicates that there are higher prospects of studying for rural students from settlements with a more differentiated economic base, and from more easily accessible settlements (compared to students from more agricultural settlements).

Regression analyzes for explanation of the the higher education choices of university studies, and Zagreb as a place of study, mostly confirmed the connection of these choices with the individual educational and cultural competencies of students (that is, these are more likely choices for the most successful students). It was confirmed that residential origin statistically significantly $(1 \%)$ contributes to the explanation of both choices; the choice of university study is more likely for students with more developed educational and cultural competencies, with greater availability of family cultural resources and for those who grow up and are going to school in an urban environment (compared to those who study in a small town and grow up 
in a rural area). Choosing Zagreb for study is more likely for more successful students with greater availability of economic resources in their families, who attend status schools in the capital or small towns and who grow up in Zagreb. The likelihood of rural students choosing university study is increased by more developed cultural practices and schooling in large cities (i.e. the availability of cultural and urban environment), while better school success, more developed cultural practices, more stable family incomes and schooling in small towns have predictive value for rural students' choice of Zagreb as a place of study.

Regional analysis of mixed data: Higher education choices of Slavonian students (4.2), presents a lowering of the level of analysis regionally, but also a deepening of the analysis methodologically. The findings achieved by triangulating statistical and narrative data, give a more nuanced insight into the different educational pathways of students of different social backgrounds, and into educational inequalities with regards to the students residential background. The interpretation is also related to the findings of foreign research on similar issues (eg Corbett 2000, 2007; Cairnis 2011; Rye, 2006, 2007, 2011; Wiborg 2004, 2006).

Quantitative analyzes (4.2) indicate different general educational orientations of Slavonian students with regard to their residential origin; earlier, more confident and unquestionable decisions about studying are more pronounced by urban students, while rural students tend to have a stronger orientation towards acquiring a vocation, decisions not to study, and perceive greater obstacles for achieving higher education. These findings are related to their school characteristics; students do point out the differences and are aware of the implications of enrolling certain schools. It turns out that vocational schools, even with excellent results, are a "weaker" path to higher education, which vocational students who intend to study express with the attitude about the wrong choice of high school and feelings of insecurity about future educational success.

Mixed data connect students' different educational orientations with their family socialization environment, that is realized in earlier decisions about the high school (4.2.1.1). Prominent are determinants of cultural and economic capital of the family, with students of more educated parents more often choose gymnasiums as a path to higher education, while other students choose vocational schools with a more pragmatic attitude towards education. For those with a weaker family resource structure, choosing a gymnasium appears to be a risky choice, and for those from rural areas who choose to do so, it means making additional choices (relocation / travel) and the "suffering" of gymnasium "difficult" schooling, for the advantages of a wider range of preparation for study and for life, even in spite of poorer grades. 
Statistically, rural students also show lower levels of personal cultural capital developed outside the school context. For them this means an additional disadvantage if their families are not the socialization framework for the transfer of cultural capital and school remains their only source of cultural resources. This is significant because, statistically, students value learning equally and strive for social mobility regardless of residency. Declaratively, students value education highly, but with more skeptical attitudes about employment opportunities in their rural / regional context. The most ambitious therefore see education as a mechanism for leaving, and other students' doubts about employment opportunities affect the decisionmaking process in which the cost-effectiveness of education is constantly negotiated.

The more unfavorable structure of family resources of rural students (4.1.3.1; 4.2.3.2) was also regionally confirmed. For their parents lower working, material, financial and educational status, as well as less cultural goods and activities, are more likely. Qualitative analysis further highlighted the Slavonian problem of unemployment or underemployment. And symbolically, the influence of parents in their orientation towards higher education is less pronounced among students from rural areas, although in general the incentives for education are above average for all students. The difference is shown in the more pragmatic educational orientation of rural students towards employment, and for those who intend to study, the higher education orientation is based more on "learning from parental experience" who failed / could not study, which does not always mean gymansium enrollment. In general, students agree on the key role of parental incentives and support, especially financial, for the decision to study, and parental influence also appears as support for students' independent decision making, as encouragement to realize their own desires, and in counseling.

Institutionally (4.2.4), it is more likely for urban students to attribute higher status to their schools, so rural students attending lower-grade schools can be seen as an "obstacle" in orienting towards higher education. Also, people with whom students come into contact in a school context can symbolically be an important social resource for rural students who intend to study. Higher education-oriented rural students emphasize the importance of their social networks in empowering their intentions. This is especially noticeable with gymnasium students who develop a "gymnasium identity". For those who attend schools in big cities or away from their parents' home, and especially in high-status schools, schooling is a kind of "urbanization of the mind" and an element of disembedding from the rural. The students emphasized the elements of the institutional habitus of certain schools in shaping educational aspirations. Relationships among students when most of the class expresses an intention to 
study and open communication with teachers develop ones understanding of social spaces, and that understanding enables imagining oneself outside the local context (Corbett 2009).

In line with the prevailing educational orientations of students, the emotional attachment to the community of growing up as well as the desire to stay is more strongly expressed by rural students. Interviews showed that students simultaneously delineate their settlements in accordance with the image of rural idyll (nature, help, neighborhood, tranquility), and with the image of rural dull (backwardness, boredom, gossip, lack of opportunities, hillbilly), similar to foreign research (e.g. Rye 2007). Hierarchized rural-urban images with regard to geographical, cultural and educational characteristics are also visible in students' statements.

Basically, students' stories depict the desire for a "good life", the realization of which is often seen through connected social and geographical mobility, and metaphorically expresses in the process of "higher and further". Sometimes this connection is further encouraged in students who, in pursuit of education and good employment, feel they have to leave. For some students, education is habitually emphasized and aligned with their own self-image and the way they follow their parents, while for others, education is a choice that is largely the only known "normative" path in a limited context.

The image of "learning to leave" often appears as a norm for Slavonian high school graduates in accordance with the notion that succeeding in life means leaving. The whole process of education is perceived as "climbing the stairs" or "taking steps on the road" socially and geographically. In this context, the topic of leaving also arises due to the impossibility of imagining the future of staying (locally, regionally and / or nationally), with or without a diploma.

The way in which Slavonian students align their goals with education decisions always involves a certain significant level of "disembedding" for the most ambitious or simply a "desire to dislocate" with different perspectives of success. These students are more likely to assess their local area as unfavorable in the context of general socio-spatial dynamics and specifically understood "rurality": the diploma takes on the meaning of escaping from places perceived as "provincial", "uneducated" and "backward". The images of Slavonia "in crisis", "burdened by war", "backward thinking" and "primitive people" stand out, reflecting the images of the "passivized region" (Šundalić 2010) from which education is the exit strategy. Only one student demonstrated the ability to imagine himself in his community, by linking experiences of growing up with study plans and a positive view to his "rural future" in which a diploma means staying and working in the countryside. The idea of returning also appears 
as gendered in narratives of the girls who see the possibility of raising a family in an environment that they consider more pleasant and safe.

In conclusion (5), study as a whole is a significant source of information on educational aspects on the rural-urban dimension as well as family and school element that describe "urban-rural field" in the Croatian context.

The assumptions were confirmed that rural students are less likely to choose post-secondary education, and that those who decide to study are more likely to choose vocational studies, while Slavonian rural students are less likely to choose institutions in Zagreb. Differences in educational orientations on the rural-urban dimension can be related to the structure of family capital (which is far less favorable for rural students), and specific educational paths of students (for rural students more prominent towards vocational education). Choosing a high school is a turning point, and affects later educational decisions that are much more uncertain for vocational students. With the dual hierarchical structure of distinguishing between general and vocational education, the Croatian education system is a significant mechanism for supporting educational inequalities that puts high school students in a more favorable position (Baranović, 2015; Klepač, 2016). Schools still can be a significant source of information and social support through the role of professional advisors, communication with teachers, and general academic orientation.

Statistically, residential background confirmed a unique contribution (1\%) to the explanation of students' higher education decisions. Possible obstacles for rural students in making a decision to study are poorer valuation of learning, growing up in families with lower levels of family cultural and economic capital, and attending lower status schools. Those rural students who, in addition to having higher education aspirations, grow up in more economically developed villages or villages better connected to urban centers, and in families with a more favorable structure of cultural resources, have a better chance of overcoming these obstacles.

In Slavonia, the statistical intention to study is predicted by a stronger social mobility desires as a basic motivational mechanism, more favorable economic and cultural resources of the family (stability of income and possession of cultural objects) and schooling in a big city. Interviews with students who intend to study indicated that students enrolled in gymnasiums or schools in large cities, which are contexts in where they develop educationally significant capital, are more likely to decide to study. Nevertheless, such choices pose a higher risk to rural students and mean dissembeddiment from the local with implications for rural areas.

In Slavonia, "rurality" takes on negative meanings as part of the process of answering the question of whether students can imagine themselves locally in the future. Thus, in general, 
education for those with the greatest aspirations is shown to be a mechanism of disembedding and / or relocation in the social and geographical dimension.

The question of the role of education for specific categories of students as well as in specific spaces is raised. In according with findings of foreign research (Corbett, 2000; 2005; Cuervo, 2016; Wiborg, 2004), in the narratives of young Slavonians, education appears as "learning to leave", and students' attitude about the need to relocate and the impossibility of imagining the future in local / regional spaces is noticeable, regardless of whether they strive for higher education or not; most students do not see high school qualifications, or a diploma, in line with local opportunities for achieving a "good life". Education is thus either an exit strategy for leaving undesirable circumstances and / or a driving force from local / regional areas. Authors such as Cuerva (2016) and Zipin et al (2015) emphasize the need for empowering the idea that "a degree transcends spatial constraints", whereby the role of education becomes to enable young people to imagine themselves in different spaces, with and without a degree. This may mean, for those who do not have the ability or desire to leave, the development of aspirations that define success with staying and actively engaging in problem solving in a local context.

Theoretically relying on Bourdieu's conceptual framework, the study analyzes it with regard to the confirmed influences of family and school environment determinants on students' educational outcomes and, adapting it, deepens it in the spatial dimension. The spatial dimension is captured both statistically, by examining the impact of students 'residential background on two levels (regionally and nationally), and semantically, by analyzing students' stories about their educational paths and decisions. The set framework of the study makes a step forward from the prevailing urban-centric perspective and revives interest in sociological spatial studies. By elaborating a mixed methods design, the study, in addition to collecting qualitative and quantitative data on a neglected topic in the Croatian context, is a significant presentation of a possible approach to the study of social phenomena. The prominence of the issue of socio-spatial justice in the education makes a significant contribution to general social dialogue.

Key words: mix methods, Bourdieu, residential background, study intent, higher education access, rural-urban differences, family and school educational resources, symbolic value of community, educational pathways, socio-spatial position 


\section{Sadržaj}

Zahvale

Životopisi mentora

Sažetak

Summary

Popis kratica

Popis tablica

Popis slika

1 UVOD

2 TEORIJSKO METODOLOŠKI OKVIR

$2.1 \quad$ Pregled literature

2.2 Hrvatski kontekst 10

$\begin{array}{lll}2.3 & \text { Svrha i ciljevi studije } & 17\end{array}$

2.4 Teorijske leće 20

2.5 Nacrt istraživanja mješovite metodologije 25

2.5.1 Tijekovi istraživanja - numerički i narativni podaci 26

$\begin{array}{lll}\text { 2.5.2 Istraživački alati } 28 & 28\end{array}$

2.5.3 Analiza - statistička i narativna 29

2.6 KONCEPTI I OPERACIONALIZACIJA (varijable i instrumenti) 36

$2.7 \quad$ Provedba istraživanja i uzorci 49

2.7.1 Uzorak učenika koji namjeravaju studirati i visokoobrazovni izbori 60

2.7.2 Reprezentativnost i struktura regionalnog kvantitativnog uzorka 65

2.7.3 Zastupljenost pojedinih slučajeva prema glavnim karakteristikama u uzorku $\begin{array}{ll}\text { intervjuiranih } & 68\end{array}$

3 EMPIRIJSKO ISTRAŽIVANJE NA NACIONALNOJ RAZINI 72

3.1 Struktura resursa dostupnih učenicima različitog rezidencijalnog podrijetla i njihova namjera studiranja

3.1.1 Namjera studiranja i obrazovne orijentacije učenika različitog rezidencijalnog podrijetla

3.1.2 Obrazovne karakteristike i kulturne kompetencije učenika različitog rezidencijalnog podrijetla

3.1.3 Ekonomsko-materijalna obiteljska situacija i obazovno-kulturno obiteljsko okruženje učenika različitog rezidencijalnog podrijetla

3.1.4 Institucionalne karakteristike školovanja učenika različitog rezidencijalnog podrijetla

3.1.5 Simbolička vrijednost odnosa iz konteksta odrastanja i školovanja za namjeru studiranja učenika različitog rezidencijalnog podrijetla

3.1.6 Zaključno o rezidencijalnim razlikama učenika i njihovoj namjeri studiranja 86 
3.2 Struktura resursa dostupnih učenicima različitog rezidencijalnog podrijetla koji namjeravaju studirati i visokoobrazovni izbori

3.2.1 Rezidencijalno podrijetlo učenika i visokoobrazovni izbori

3.2.2 Rezidencijalno podrijetlo učenika koji namjeravaju studirati, njihove obrazovne karakteristike i kulturne kompetencije

3.2.3 Rezidencijalno podrijetlo učenika koji namjeravaju studirati i obiteljski dostupni resursi 95

3.2.4 Rezidencijalno podrijetlo učenika koji namjeravaju studirati i institucionalne karakteristike obrazovanja

3.2.5 Rezidencijalno podrijetlo učenika koji namjeravaju studirati i simbolička vrijednost njihovih obiteljskih i izvanobiteljskih odnosa

3.2.6 Zaključno o razlikama između učenika različitog rezidencijalnog podrijetla koji namjeravaju studirati

3.3 Učinak rezidencijalnog podrijetla učenika, uz kontrolu relevantnih čimbenika obiteljskog i školskog konteksta, na namjeru studiranja i visokoobrazovne odluke

3.3.1 Objašnjenje odluke učenika o namjeri studiranja

3.3.2 Objašnjenje namjere studiranja učenika različitog rezidencijalnog podrijetla 110

3.3.3 Rezidencijalno podrijetlo učenika, čimbenici obiteljskog i školskog konteksta i visokoobrazovni izbori

3.3.4 Objašnjenje izbora sveučilišnog studija za učenike različitog rezidencijalnog podrijetla

3.3.5 Objašnjenje izbora Zagreba kao željenog mjesta studiranja

3.3.6 Zaključno o učinku rezidencijalnog podrijetla učenika na njihovu namjeru studiranja i visokoobrazovne izbore

4 REGIONALNA ANALIZA MJEŠOVITIH PODATAKA: VISOKOOBRAZOVNI IZBORI SLAVONSKIH UČENIKA

4.1 Uvod

4.2 Obrazovne karakteristike i orijentacije te individualno razvijeni kapitali učenika različitog rezidencijalnog podrijetla

4.2.1.1 Postavljanje puta - izbor srednje škole

4.2.1.2 Školska uspješnost i učenički kulturni kapitali

4.2.2.1 Namjera studiranja i visokoobrazovne aspiracije

4.2.2.2 Nužnost studiranja i odlaska

4.2.2.3 Visokoobrazovni izbori

4.2.3 Obiteljski resursi učenika različitog rezidencijalnog podrijetla

4.2.3.1 Ekonomski obiteljski resursi - mjere i subjektivna značenja 
4.2.3.2 Kulturni obiteljski resursi - mjere i subjektivna značenja

4.2.4 Rezidencijalno podrijetlo učenika i karakteristike srednje škole

4.2.5 Simbolička vrijednost obitelji, škola, zajednica za učenike različitog rezidencijalnog podrijetla

4.2.5.1 Rupa iz koje treba što prije pobjeći

4.2.5.2 Osim što umiru ljudi ništa drugo se ne događa

4.2.6 Zaključno

4.2.7 Objašnjenje namjere studiranja slavonskih maturanata

4.2.8 Objašnjenje visokoobrazovnih izbora slavonskih maturanata

7.2 Protokol za polustrukturirane intervjue

7.3 Analitička matrica - slučajevi 346 


\section{Popis kratica}

\begin{tabular}{|c|c|}
\hline RP & Rezidencijalno podrijetlo \\
\hline RRP & Ruralno rezidencijalno podrijetlo \\
\hline URP & Urbano rezidencijalno podrijetlo \\
\hline MRP & Metropolitansko rezidencijalno podrijetlo \\
\hline $\mathrm{U}_{\mathrm{RRP}}$ & Učenici ruralnog rezidencijalnog podrijetla \\
\hline $\mathrm{U}_{\mathrm{URP}}$ & Učenici urbanog rezidencijalnog podrijetla \\
\hline $\mathrm{U}_{\mathrm{MRP}}$ & Učenici metropolitanskog rezidencijalnog podrijetla \\
\hline $\mathrm{M}_{\mathrm{RRP}}$ & Prosječna vrijednost učenika ruralnog rezidencijalnog podrijetla \\
\hline $\mathrm{M}_{\mathrm{URP}}$ & Prosječna vrijednost učenika urbanog rezidencijalnog podrijetla \\
\hline $\mathrm{M}_{\mathrm{MRP}}$ & Prosječna vrijednost učenika metropolitanskog rezidencijalnog podrijetla \\
\hline 3SŠ & Trogodišnja strukovna srednja škola \\
\hline $4 \mathrm{SS}$ & Četverogodišnja strukovna srednja škola \\
\hline GIM & Gimnazija \\
\hline $\mathrm{VO}$ & Visoko obrazovanje \\
\hline $\mathrm{TP}$ & Tržišno orijentirana poljoprivredna naselja \\
\hline DSJ & Dinamična strukturno jača ruralna naselja \\
\hline $\mathrm{mg}$ & Mali gradovi (subregionalna i slabija regionalna središta) \\
\hline VG & Veliki gradovi (jača regionalna i makroregionalno središte) \\
\hline $\mathrm{RRP}_{-} \mathrm{TP}$ & $\begin{array}{l}\text { kod Ruralno rezidencijalno podrijetlo - tržišno orijentirana poljoprivredna } \\
\text { naselja }\end{array}$ \\
\hline RRP_DSJ & kod Ruralno rezidencijalno podrijetlo - dinamična, strukturno jača naselja \\
\hline URP_nc & kod Urano rezidencijalno podrijetlo - naselja nepotpunog centraliteta \\
\hline $\mathrm{URP}_{-} \mathrm{mg}$ & $\begin{array}{l}\text { kod Urbano rezidencijalno podrijetlo - mali gradovi (subregionalni centri i } \\
\text { slabiji regionalni centri) }\end{array}$ \\
\hline URP_VG & $\begin{array}{l}\text { kod Urbano rezidencijalno podrijetlo - veliki gradovi (jači regionalni centri } \\
\text { i mekroregionalni centar) }\end{array}$ \\
\hline
\end{tabular}




\section{Popis tablica}

Tabela 2.1 Regionalna distribucija visokih učilišta, te udjeli nastavnog osoblja i studentskog tijela 2011. godine

Tabela 2.2 Opisi tipova ruralnih naselja u Hrvatskoj (prema Lukić, 2012) ....................................... 17

Tabela 2.3 Istraživačka pitanja analiza razlika između učenika različitog rezidencijalnog podrijetla.. 18 Tabela 2.4 Istraživačka pitanja objašnjenja namjere studiranja i visokoobrazovnih izbora učenika .... 19 Tabela 2.5 Kodovi slučajeva prema rezidencijalnom podrijetlu sa značenjima................................... 31

Tabela 2.6 Kodovi slučajeva prema školovanju učenika za tip i lokaciju škole sa značenjima ............ 31

Tabela 2.7 Nacrt istraživanja - osnovni ciljevi, pitanja i procedure ................................................... 33

Tabela 2.8 Rezultati analize glavnih komponenti instrumenta Vrijednost pripisana učenju.................. 39

Tabela 2.9 Rezultati analize glavnih komponenti instrumenta Želja za društvenom mobilnošću ........ 40

Tabela 2.10 Rezultati analize glavnih komponenti instrumenta Učeničke kulturne prakse i Učeničke

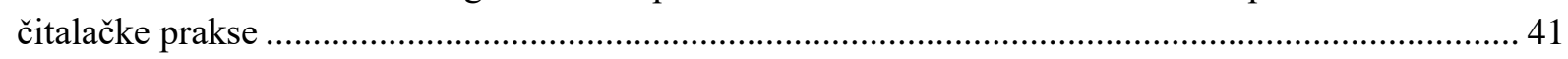

Tabela 2.11 Rezultati analize glavnih komponenti instrumenta Roditeljske kulturne prakse............... 43

Tabela 2.12 Rezultati analize glavnih komponenti instrumenta Karakteristike srednje škole .............. 45

Tabela 2.13 Rezultati analize glavnih komponenti ugleda željenog studija i institucije studiranja pri

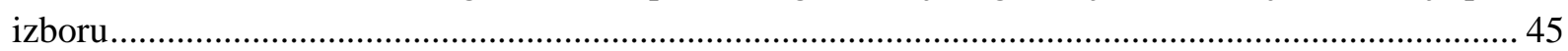

Tabela 2.14 Rezultati analize glavnih komponenti instrumenta Roditeljske poticajne prakse ............. 46

Tabela 2.15 Rezultati provjere faktorske strukture dimenzija utjecaja značajnih drugih na odluku učenika o studiranju.

Tabela 2.16 Rezultati analize glavnih komponenti instrumenta Simbolička vrijednost zajednice

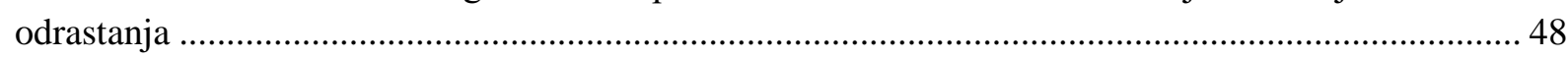

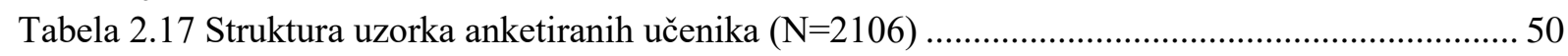

Tabela 2.18 Usporedni prikaz planiranog i realiziranog uzorka prema tipu škole kojeg učenici

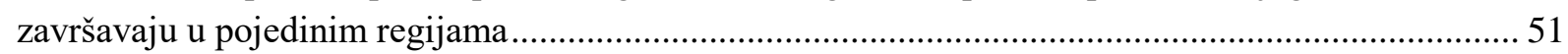

Tabela 2.19 Regionalne razlike spolne strukture uzorka anketiranih učenika ................................... 53

Tabela 2.20 Sociogeografski podaci o strukturi uzorka anketiranih učenika $(\mathrm{N}=2106)$...................... 53

Tabela 2.21 Usporedni prikaz planiranog i realiziranog uzorka učenika pojedinih tipova škole prema

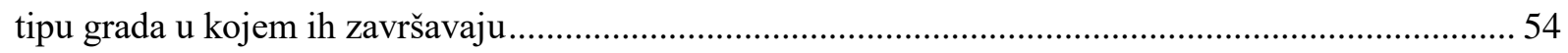

Tabela 2.22 Usporedni prikaz podataka o broju i udjelima učenika različitog rezidencijalnog podrijetla u ukupnom uzorku anketiranih učenika i učenika s validnim podacima o mjestu odrastanja ................ 55

Tabela 2.23 Udjeli učenika 5 najzastupljenijih tipova ruralnih (i urbaniziranih) naselja u uzorku

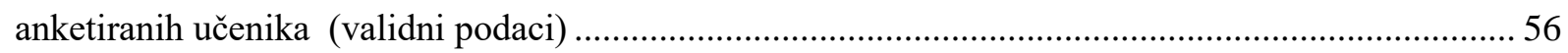

Tabela 2.24 Struktura uzorka anketiranih učenika različitog rezidencijalnog podrijetla prema osnovnim

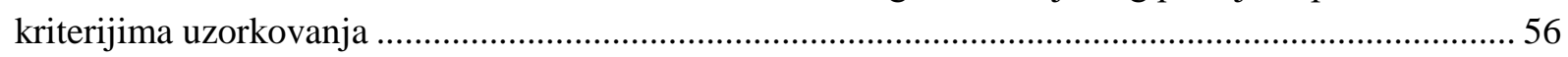

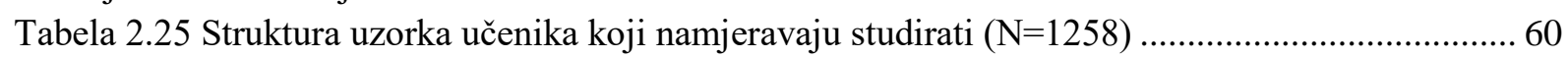

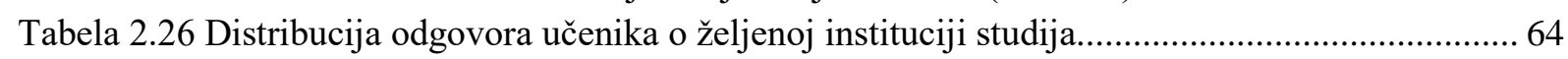

Tabela 2.27 Rodne razlike anketiranih slavonskih učenika prema tipu škole kojeg završavaju ........... 66 Tabela 2.28 Usporedni prikaz udjela učenika prema tipu škole koji škole završavaju u „velikim“ i

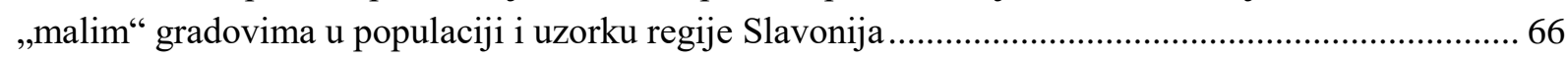

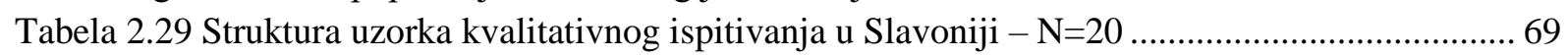

Tabela 3.1 Razlike učenika različitog rezidencijalnog podrijetla prema namjeri studiranja i obrazovnim

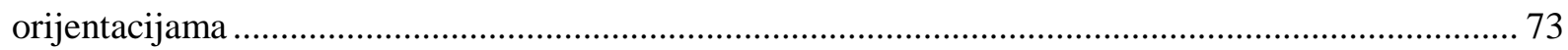

Tabela 3.2 Analiza varijance između grupa učenika različitog rezidencijalnog podrijetla na varijablama školskih karakteristika i osobnih kulturnih kompetencija ............................................. 76

Tabela 3.3 Razlike između učenika različitog rezidencijalnog podrijetla prema radnom statusu i obrazovanju roditelja te obiteljskom posjedovanju knjiga .... 
Tabela 3.4 Razlike na elementima materijalno-ekonomske situacije obitelji između učenika različitog rezidencijalnog podrijetla prema posjedovanju kulturnih dobara i roditeljskim kulturnim praksama .. 79 Tabela 3.5 Razlike između učenika različitog rezidencijalnog podrijetla prema procjenama pojedinih karakteristika svojih škola.

Tabela 3.6 Razlike između učenika različitog rezidencijalnog podrijetla prema procjeni utjecaja članova obitelji na svoju odluku o nastavku školovanja i prema roditeljskim poticajnim praksama za nastavak školovanja.

Tabela 3.7 Razlike između učenika različitog rezidencijalnog podrijetla prema procjeni utjecaja izvaninstitucionalnih i institucionalnih značajnih drugih na njihovu odluku o (ne)studiranju............... 85

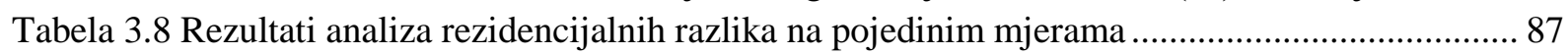

Tabela 3.9 Razlike učenika različitog rezidencijalnog podrijetla koji namjeravaju studirati prema visokoobrazovnim izborima tipa institucije, tipa studija te grada studiranja ................................... 93

Tabela 3.10 Razlike između učenika različitog rezidencijalnog podrijetla koji namjeravaju studirati prema njihovim obrazovnim karakteristikama i kulturnim kompetencijama...................................... 94 Tabela 3.11 Razlike između učenika različitog rezidencijalnog podrijetla koji namjeravaju studirati prema elementima obiteljskih resursa

Tabela 3.12 Razlike između učenika različitog rezidencijalnog podrijetla učenika koji namjeravaju studirati prema procjeni institucionalnih karakteristika obrazovanja.

Tabela 3.13 Razlike između učenika različitog rezidencijalnog podrijetla koji namjeravaju studirati prema simboličkoj vrijednosti obitelji i osoba iz učeničkih društvenih odnosa/mreža ........................ 98

Tabela 3.14 Rezultati analiza rezidencijalnih razlika u poduzorku učenika koji namjeravaju studirati na

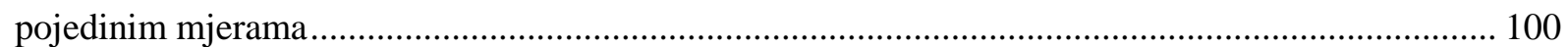

Tabela 3.15 Izbor varijabli za regresijski model objašnjenja namjere studiranja učenika .................. 106

Tabela 3.16 Opći model objašnjenja namjere studiranja hrvatskih maturanata ................................ 107

Tabela 3.17 Rezultati testiranja robusnosti modela objašnjenja namjere studeiranja na poduzorcima učenika različitog rezidencijalnog podrijetla......

Tabela 3.18 Udjeli anketiranih učenika koji su odrasli u pojedinim tipovima ruralnih naselja hrvatskog sociogeografskog prostora prema Lukićevoj analizi (2011)

Tabela 3.19 Regresijski model objašnjenja namjere studiranja za učenike ruralnog rezidencijalnog podrijetla (II) - prema naselju odrastanja

Tabela 3.20 Osnovna istraživačka pitanja vezana uz namjeru studiranja učenika, analize te nalazi i interpretacija.

Tabela 3.21 Izbor varijabli regresijskog modela za objašnjenje visokoobrazovnih izbora

Tabela 3.22 Regresijski model za objašnjenje izbora sveučilišnog studija (nacionalni uzorak) i njegovo testiranje na dvije podskupine učenika.

Tabela 3.23 Osnovna istraživačka pitanja vezana uz učenički izbor tipa studija, analize te nalazi i interpretacija

Tabela 3.24 Regresijski model objašnjenja izbora Zagreba kao mjesta studiranja (macionalni uzorak) i njegovo testiranje na dvije podskupine učenika .

Tabela 3.25 Osnovna istraživačka pitanja vezana uz učeničke izbore mjesta studiranja, analize te nalazi i interpretacija

Tabela 4.1 Rezultati ispitivanja razlika između slavonskih maturanata različitog rezidencijalnog podrijetla prema obrazovnim karakteristikama i orijentacijama, te dostupnim kapitalima i simboličkom značaju konteksta odrastanja i školovanja.

Tabela 4.2 rezultati analize razlika između učenika različitog rezidencijalnog podrijetla prema školskoj uspješnosti i kulturnim kompetencijama .

Tabela 4.3 Razlike slavonskih maturanata različitog rezidencijalnog podrijetla prema 
Tabela 4.4 Razlike slavonskih maturanata različitog rezidencijalnog podrijetla prema procjeni ugleda studija i institucije željenog visokoog obrazovanja.

Tabela 4.5 Razlike između učenika različitog rezidencijalnog podrijetla na elementima obiteljskih kapitala

Tabela 4.6 Model objašnjenja namjere studiranja slavonskih maturanata

Tabela 4.7: Model objašnjenja namjere studiranja slavonskih maturanata (s tipom naselja u modelu)

Tabela 4.8 Rezultati logističke regresije objašnjenja namjere studiranja slavonskih maturanata provjera doprinosa objašnjenju dimenzija simboličke vrijednosti zajednice odrastanja 298

Tabela 4.9 Regresijski model objašnjenja visokoobrazovnih izbora slavonskih maturanata..... 301 Tabela 4.10 Korelacije (Pearson) nezavisnih varijabli sa zavisnim varijablama visokoobrazovnih izbora

Tabela 4.11 Rezultati objašnjenja visokoobrazovnih izbora slavonskih maturanata - izbor sveučilišnog studija, izbor Zagreba kao mjesta studiranja, izbor studiranja u regiji - korigiranim modelom.......... 304 Tabela 4.12Osnovna istraživačka pitanja, analize i nalazi vezani uz objašnjenje namjere studiranja i visokoobrazovne izbore slavonskih učenika 306

\section{Popis slika}

Slika 2.1 Spolna struktura uzorka prema tipu škole kojeg učenici završavaju.

Slika 2.2 Usporedni prikaz udjela stanovništva HR i anketiranih učenika koji žive u 7 tipova ruralnih (i urbaniziranih) naselja Hrvatske 55

Slika 2.3 Omjerni prikaz učenika različitog rezidencijalnog podrijetla anketiranih u gradovima različitog stupnja centraliteta u kojima završavaju škole 58

Slika 2.4 Udjeli učenika različitog rezidencijalnog podrijetla prema tipu škole koje završavaju .......... 59

Slika 2.5 Omjerni prikazučenika različitog rezidencijalnog podrijetla u rodnim kategorijama anketiranih učenika.

Slika 2.6 Omjeri udjela učenika različitog rezidencijalnog podrijetla u ukupnom uzorku i poduzorku onih koji namjeravaju studirati.

Slika 2.7 Udjeli učenika koji biraju studije u različitim znanstvenim područjima................................ 62

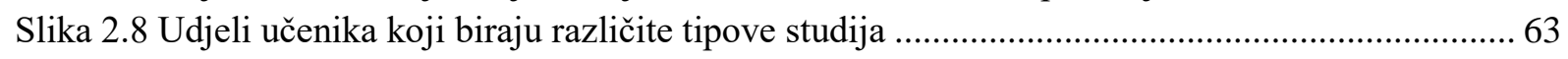

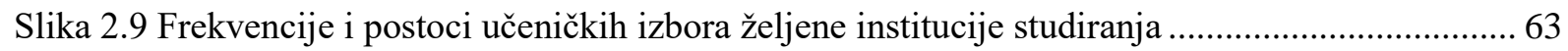

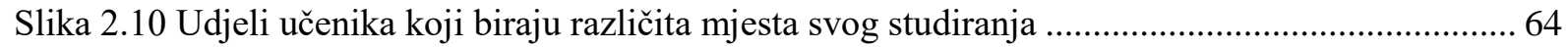

Slika 2.11 Usporedni prikaz broja učenika različitih tipova škola u populaciji i u uzorku učenika završnih razreda srednjih škola regije Slavonija

Slika 2.12 Omjeri učenika različitog rezidencijalnog podrijetla s obzirom na glavne kriterije uzorkovanja (spol, tip škole i centralitet grada u kojem škole završavaju)

Slika 2.13 Udjeli učenika u pojedinim kategorijama rezidencijalnog podrijetla prema tipu naselja odrastanja

Slika 3.1 Razlike učenika različitog rezidencijalnog podrijetla prema namjeri studiranja, neupitnosti te odluke i dužini njenog promišljanja

Slika 3.2 Omjeri udjela učenika različitog rezidencijalnog podrijetla u kategorijama obrazovnih aspiracija i očekivanja

Slika 3.3 Usporedni prikaz udjela učenika različitog rezidencijalnog podrijetla prema stalnosti prihoda njihovih roditelja 
Slika 3.4 Prosječne vrijednosti procjena učenika o utjecaju njihovih značajnih drugih na njihovu odluku o (ne)studiranju

Slika 3.5Rezultati analiza razlike između učenika različitog rezidencijalnog podrijetla prema procjeni utjecaja značajnih drugih osoba na njihovu odluku o (ne)studiranju .86

Slika 3.6 Razlike između učenika različitog rezidencijalnog podrijetla prema područjima odabranih studija .

Slika 3.7 Razlike između učenika različitog rezidencijalnog podrijetla koji namjeravaju studirati prema elementima obiteljskih resursa

Slika 3.8 Razlike između učenika različitog rezidencijalnog podrijetla koji namjeravaju studirati prema procjeni utjecaja značajnih drugih na odluku učenika o (ne)studiranju

Slika 3.9 Opći regresijski model (5 koraka) za objašnjenje namjere studiranja maturanata (nacionalni uzorak)

3.10 Regresijski model za objašnjenje namjere studiranja maturanata odraslih na selu

Slika 3.11Regresijski model za objašnjenje namjere studiranja maturanata odraslih na selu (II) - s varijablom tipa ruralnih naselja u zadnjem koraku

Slika 3.12 Opći regresijski model za objašnjenje izbora sveučilišnog studija (nacionalni uzorak maturanata) izgrađen u 5 koraka

Slika 3.13 Opći regresijski model (5 koraka) za objašnjenje izbora Zagreba kao mjesta studiranja (nacionalni uzorak).

Slika 3.14 Regresijski model za objašnjenje izbora Zagreba kao mjesta studiranja za maturante koji su odrasli na selu.

Slika 4.1 Razlike između učenika različitog rezidencijalnog podrijetla prema namjeri studiranja i obrazovnim orijentacijama

Slika 4.2 Usporedni prikaz udjela učenika različitog rezidencijalnog podrijetla u kategorijama obrazovnih aspiracija i očekivanja

Slika 4.3: Razlika između učenika različitog rezidencijalnog podrijetla prema visokoobrazovnim izborima

Slika 4.4 Razlike između učenika različitog rezidencijalnog podrijetla prema elementima obiteljskih resursa

Slika 4.5 Razlike između učenika različitog rezidencijalnog podrijetla prema procjenama karakteristika srednjih škola 220

Slika 4.6 Opis uzorka intervjuiranih učenika različitog rezidencijalnog podrijetla s obzirom na tip i lokaciju škole.

Slika 4.7 Razlike između učenika različitog rezidencijalnog podrijetla u procjenama aspekata roditeljskih poticaja

Slika 4.8 Razlike između učenika različitog rezidencijalnog podrijetla u procjenama utjecaja značajnih drugih na njihovu odluku o studiranju.

Slika 4.9 Razlike između učenika različitog rezidencijalnog podrijetla na dimenzijama simboličke vrijednosti zajednice odrastanja 260

Slika 4.10 Opći regresijski model za objašnjenje namjere studiranja slavonskih maturanata izgrađen u 5 koraka 


\section{UVOD}

Ovaj rad povezuje područje sociologije obrazovanja, kroz pitanje o pristupu i izborima visokog obrazovanja, te područje ruralne sociologije zainteresirane za socioekonomske karakteristike života mladih u ruralnim sredinama i njihove migracijske urbano-ruralne dinamike. Teorijski okvir tvore koncepti Bourdieuove teorije prakse (2013[1977]), koja je kasnije ekstenzije dobila u teoriji društvene reprodukcije (Bourdieu, 1977). Prema Bourdieuu, razlike u obrazovnim postignućima učenika vezane su uz njihove kulturne, ekonomske i socijalne resurse pri čemu učenici iz obitelji bogatijih resursa postižu bolje obrazovne rezultate, više razine obrazovanja i pohađaju prestižnije obrazovne institucije od učenika siromašnijih resursa. Obrazovnim postignućima doprinosi i sam obrazovni sustav koji privilegira učenike iz viših društvenih klasa, prepoznajući njihov kulturni kapital, i tako doprinosi održanju postojećih obrazovnih i društvenih nejednakosti (Bourdieu, 1977).

Za ruralne učenike obrazovanje je jedan od glavnih mehanizama uzlazne društvene i geografske mobilnosti. Istraživanja u zemljama s velikim ruralnim područjima uz dinamične demografske i ekonomske bilježe i značajne obrazovne trendove (Hertzog, Pittman, 1995). Pokazuje se da na različitim varijablama obrazovnih ishoda učenici ruralnih područja imaju manje aspiracije, niže rezultate na testovima, te u manjem broju diplomiraju i upisuju četverogodišnje studije (Bracken, 2007; Hu, 2003). Ipak, pitanje doprinosi li ruralnost, i kako, nejednakim obrazovnim mogućnostima ostaje otvoreno zbog empirijskih teškoća utvrđivanja učinaka zajednica, te neadekvatnih kontrola varijabli podrijetla i životnih uvjeta te definicija ruralnog (Edington, Koehler, 1987; Khattri i sur., 1997).

Istraživanja kroz bordjuovske leće ukazala su na važnost obiteljskog kulturnog kapitala za migraciju ruralno-urbano čega su bitan dio i migracije mladih kada donose odluke o nakonškolskom putu. Za ruralne učenike, geografska mobilnost omogućava društvenu mobilnost, a veće šanse imaju oni iz viših ruralnih društvenih klasa koji usvajaju poseban urbani habitus (Rye, Blekesaune, 2003) ili kapital mobilnosti (Corbett, 2007). Različite socioekonomske pozicije učenika potiču različite percepcije mjesta i prostora (Corbett, 2007) koje djeluju na (ne)mobilnost unutar urbano-ruralne hijerarhije i ulazak u polje urbanog društvenog sustava (Rye, Almas, 2004). 
Mješovitometodna studija kreirana je s interesom za ispitivanje elementa sociogeografskih i kulturnosimboličkih prepreka koji učenicima iz ruralnih područja otežavaju odluku o nastavku školovanja na visokoškolskoj razini i ulazak u visoko obrazovanje. Podaci su prikupljeni u sklopu nacionalnog istraživačkog projekta Socijalni identiteti, pristup visokom obrazovanju i odabir studija. Navedeni projekt financirala je Hrvatska zaklada za znanost, a proveo ga je istraživački tim Institut za društvena istraživanja u Zagrebu pod voditeljstvom prof. dr. sc. Branislave Baranović.

Teorijski doprinos studije tiče se produbljivanja Bourdieuove teorije i korisnosti koncepata kapitala, habitusa i polja uvođenjem prostornih aspekata u analizu. Metodološki, studija problematizira korištenje mješovitometodnog nacrta istraživanja promičući takve načine pristupa društvenim fenomenima. Integracija rezultata kvalitativnih i kvantitativnih podataka omogućava dublje razumijevanje podataka skupljenih na različitim razinama i različitim metodama, ali i dublje teorijsko razumijevanje statističkih podataka skupljenih za neznanstvene svrhe. Skupljanje i obrada primarnih podataka ograničeni na jednu regiju Hrvatske otvaraju mogućnosti generiranju daljnja istraživačka pitanja koja nadilaze ciljeve ove teze. 


\section{TEORIJSKO METODOLOŠKI OKVIR}

\subsection{Pregled literature}

U osnovi, osnovno istraživačko pitanje koje je potaklo izradu ove studije je interes za to na koje načine nečije porijeklo utječe na izbore vezane uz nastavak školovanja na visokoobrazovnoj razini s posebnim fokusom na odluke učenika iz ruralnih sredina, s obzirom da su to, istraživanja ističu, učenici za koje odluka i odlazak na studij, može biti u većoj mjeri problematičan i otežan. Studija svoje polazište ima u sociologiji obrazovanja i dijelom je smještena u područje šireg izučavanja obrazovnih nejednakosti, s ciljem ispitivanja elemenata na dimenziji ruralno-urbano koji određenim populacijama učenika otežavaju i/ili sprečavaju ulazak u visokoobrazovanje. No isto tako, studija uvelike proizlazi iz područja ruralne sociologije s interesom za migracijske ruralno-urbane prakse mladih. Na sjecištu tih dvaju ishodišta nalazi se donošenje obrazovnih odluka mladih čije su visokoobrazovne prakse dio širih migracijskih odluka u tranzicijskom razdoblju odrastanja s obzirom da odlazak na studij za njih podrazumijeva i odlazak u geografskom smislu. Dodatno se želi studijom naglasiti da je to i pomak u kulturnom smislu koji je u središtu ispitivanja. Takav pristup proširuje raspravu o socijalnoj dimenziji ulaska u visokovo obrazovanje za učenike različitog rezidencijalnog podrijetla koja uz socioekonomske i sociokulturne uvodi i odrednice ,prostora“" u analizu.

Ruralno je samo po sebi koncept vrlo neodređen i teško definirati s obzirom na to da se svoja značenja uvelike dobiva kao „ono što nije urbano“, koristi se u različitim diskursima s različitim svrhama, te u ovisnosti o konkretnom geografskom prostoru i vremenu (Woods, 2005). U literaturi o ruralnom ono se konceptualizira na barem 3 različita načina, a moguće je razlikovati i barem 4 različite definicije (Woods, 2005, 2011; Cloke, 2006; Lukić, 2012).

Za razumijevanje ruralnog, prema Halfacreeovom trosložnom modelu koji prikazuje i razvoj teorijskih pristupa ruralnom prostoru (2006), potrebno je shvatiti trijalektiku odnosa između:

1) reprezentacije prostora (način govora i shvaćanja ruralnog),

2) prostora reprezentacije (materijalna strana ruralnog okoliša), $i$

3) prostornih praksi (dinamike (re)produkcije ruralnog kroz prakse življenja).

Drugim riječima, ruralno je društveni konstrukt, ali i materijalno i življeno.

Početno, s obzirom na kompleksnost fenomena - u osnovi utjecaja ruralnosti na visokoobrazovne orijentacije - postavila su se pitanja o tome postoje li razlike između učenika različitog rezidencijalnog podrijetla s obzirom na visokoobrazovnu orijentaciju? Što 
su osnovne prepreke u postizanju jednakih obrazovnih ishoda učenicima koji odrastaju u različitim okolišima? Kakva je priroda teškoća s kojima se suočavaju mladi u svojim odlukama o nastavku školovanja (i odlazak)? Kako ih možemo empirijski zahvatiti? Kako možemo objasniti postojanje takvih razlika?

Pregled literature obuhvatio je nekoliko područja, prvo, o obrazovnim razlikama između učenika s obzirom na rezidencijalno podrijetlo; drugo, o faktorima koji utječu na razlike u procesu donošenja odluka o visokom obrazovanju, a specifično utjecaju ruralnosti; treće, širem konceptu migracija mladih iz ruralnog područja čega su dio i odluke o studiranju; četvrto, učeničkim percepcijama ruralnog, odlaska i ostanka te studiranja s obzirom na njihovo rezidencijalno podrijetlo u suvremenom mobilnom društvu (Urry, 2007) koje je istodobno i društvo rizika (Giddens, 1990), posebno za mlade od kojih se zahtijeva mobilnost i fleksibilnost u izgradnji identiteta.

U zemljama s velikim ruralnim područjima poput Australije, Kanade, SAD-a, istraživački i politički interes dugo je usmjeren na tu problematiku posebno zbog uzroka/posljedica koje ono ima za čitava ruralna područja. Danas ruralno društvo doživljava dramatične i dinamične promjene pod utjecajem globalizacijskih i modernizacijakih silnica koje uvelike mijenjaju i i karakteristike ruralnog, i ruralni život, i značenje ruralnog - ruralno društvo se restrukturira (Woods, 2005). Ekonomski, opadanjem značaja zanimanja ruralnih područja i relokacijom industrije, mijenja se i klasna struktura, povećava se siromaštvo ruralnih područja porastom zaposlenosti u nisko plaćenim poslovima i nezaposlenosti što proširuje i diskrepanciju ruralne-urbane kvalitete i standarda života. Demografski, proporcija ruralne populacije se smanjuje sve naglašenijom emigracijom sa sela, posebno mladih, smanjuje se broj radno sposobne ruralne populacije, dok se stariji segmenti populacije povećavaju (Hertzog, Pittman, 1995; Woods 2005).

Obrazovni trendovi tiču se nekoliko aspekata. S jedne strane, usporedbe ruralnih/urbanih učenika na različitim varijablama obrazovnih ishoda pokazuju da ruralni učenici imaju manje aspiracije, postižu niže rezultate na testovima, diplomiraju u manjem broju i manje ih je na četverogodišnjim fakultetskim programima (Bracken, 2007; Hu, 2003; Koricich, 2018). S druge strane, takva istraživanja ne daju konačne odgovore.

Postoji duboka veza između formalnog obrazovanja i mobilnosti iz ruralnog područja pri čemu ono djeluje kao ključna institucija iskorjenjivanja za ruralne učenike iz lokalnih zajednica. Ipak, paradoksalno, u kontekstu promjena radikalizirane modernosti i suvremenih ekonomskih uvjeta, ruralne zajednice trebaju obrazovanu mladež, za koju je najvjerojatniji 
odlazak (Corbett, 2009), za svoj vlastiti razvoj, a ne kao izvor radne snage za urbane ekonomije.

Odatle proizlazi istaknuti interes u literaturi za istraživanje obrazovnih aspiracija koje se na individualnoj razini shvaćaju ključnim odrednicama društvene mobilnosti, iz socijalne perspektive određujućim faktorima razvoja ljudskog kapitala s implikacijama za regionalni ili nacionalni rast, a na političkom nivou osnovom prosperiteta zemlje. Također, postavlja se i pitanje paradoksalnog djelovanja geografske mobilnosti koje je važno za obrazovnu politiku, održivi društveni razvoj i gospodarski rast; s jedne strane, viši stupanj geografske mobilnosti veže se uz proširivanje obrazovnih i osobnih mogućnosti pojedinaca te uspješniji razvoj obrazovnog sustava i društva; no, s druge strane, jednosmjerna geografska mobilnost, odljev mozgova i centraliziranost visokih učilišta unutar zemlje može biti negativan element koji doprinosi izolaciji i daljnjem degradiranju sustava i prostora. U tom kontekstu javlja se pitanje o mehanizmima koji bi osigurati povratak najuspješnijih učenika u sredine u kojima su završili srednjoškolsko obrazovanje (Jokić, Ristić Dedić, 2014), ali i pitanje o mehanizmima koji usmjeravaju učenike na razvoj planova odlaska.

Ipak, potrebno je naglasiti kako u području istraživanja razlika učenika iz ruralnih i urbanih područja postoje i međusobno suprotstavljeni nalazi s poukama za buduća istraživanja. Kako upozoravaju Edington i Koehler (1987), različite studije pokazuju i pozitivne i negativne efekte zajednice koje je empirijski teško utvrditi, postavljajući pitanje: što zapravo mjere nađene razlike? Bez kontrole porijekla i životnih uvjeta, nalazi nisu smisleni, a indicije analiziranih studija ukazuju da je ono što se mjeri zapravo razlika u socioekonomskom statusu i/ili etnicitetu. Metodološke probleme neadekvatnih usporedbi ili kontrola varijabli u literaturi koja se bavila utvrđivanjem utjecaja siromaštva i/ili tipa zajednice kao faktora koji učenike dovode u rizik neuspjeha pokazali su i Khatrtri, Riley i Kane (1997). Dodatno, pitanje ima li lokacija ulogu ili je glavni utjecaj socioekonomski ne pružaju jasne rezultate jer se koriste i neadekvatne ili neusporedive definicije ruralnog, ili pak zbog pretpostavke da su cijele ruralne zajednice ugrožene, te ih treba sačuvati zbog vrijednosti jakih komunalnih veza i osjećaja mjesta.

Drugim riječima, postoje velike razlike između ruralnih učenika, škola i zajednica, koje bi istraživanje razlika ruralno-urbano trebalo uzeti u obzir. $S$ te je strane korisno razmotriti pet glavnih faktora koji doprinose nižim aspiracijama ruralnih učenika kako ih opisuju Irvin, Byun, Meece, Farmer i Hutchins (2012). 
Prvo je potrebno razmatrati tržišta rada $\mathrm{u}$ ruralnim sredinama na kojima su povijesno najzastupljeniji tipovi poslova koji zahtijevaju manje obrazovanja. Haller i Virker (1993) objašnjavaju kako različita lokalna tržišta rada, uz obiteljski socioekonomski status, utječu na ograničeno izlaganje ruralnih učenika mogućnostima obrazovanja i karijera pa su učenici ograničeni $u$ onome što mogu zamisliti, što utječe na snižavanje njihovih obrazovnih aspiracija.

Dodatno, ograničeni ekonomski resursi i veće razine siromaštva ruralnih područja postavljaju pitanja o kvaliteti srednjoškolskog i dostupnosti visokoškolskog obrazovanja, i naglašavaju pitanje vaganja troškova i koristi od visokog obrazovanja. Stoga je potrebno shvatiti i uključiti ruralni kontekst kao faktor jer u njemu škole često služe kao dodatni stratificirajući mehanizam. Postoje strukturalne razlike škola ovisno o njihovim lokacijama koji mogu biti izvor razlikama u postignuću i aspiracijama učenika koji ih pohađaju (Bracken, 2007). Troškovi visokog obrazovanja mogu se procjenjivati previsokima pa mladi odgađaju obrazovanje dok se ne zaposle i uštede novce ili nastavljaju školovanje na bližim i jeftinijim regionalnim veleučilištima. Tako Frenette, pitajući se je li udaljenost bitna, pokazuje da postoji značajna participacija na koledžima onih studenata koji žive u njegovoj blizini što uravnotežuje nižu stopu participacije na sveučilištima, a to je kompromis posebno karakterističan za studente iz obitelji nižeg i srednjeg dohotka.

Kao treći faktor utjecaja na snižavanje aspiracija učenika ruralnih područja pojavljuje se kombinacija geografske izolacije i sociokulturnih normi. Tickmayer (2000) posebno ističe značaj mjesta u procesima stvaranja i reprodukcije socijalnih hijerarhija i nejednakosti. Mjesta na kojima ljudi žive svoje živote tvore dio struktura mogućnosti promovirajući neke prakse nad drugima i time su inherentna načinima poimanja svijeta. A to se odražava i u pitanjima preseljenja i zamišljanja budućnosti.

Stoga, kao četvrto, za ruralne učenike preseljenje zbog manjih lokalnih mogućnosti obrazovanja može stvoriti konflikt za one koji žele ostati blizu rodbine i prijatelja. Preseljenje zbog upisa fakulteta za ruralne je učenike jedinstveni dio procesa odrastanja pri čemu svijest o potrebi preseljenja stvara veći konflikt između odluke o migriranju i obrazovanju, i posljedično većim obrazovnim barijerama. U vezi geografske i socijalne mobilnosti za ruralne učenike, želja za ostankom u zajednici može postati negativan pritisak za one koji se moraju odseliti da bi ostvarili svoje planove ili nekompatibilna s ambicioznim aspiracijama. Hektner (1995), zainteresiran za utjecaj komunalnog konteksta na stavove i planove adolescenata u pogledu njihove buduće geografske i društvene mobilnosti, tvrdi da napuštanje roditeljskog 
doma za adolescente može značiti konflikt između nezavisnosti odlaska i sigurnosti ostajanja u blizini.

Konačno, izvor nižih aspiracija učenika odraslih u ruralnoj sredini može biti nedostatak institucionalne potpore (kao strukturni efekt srednjih škola). Hu (2003) deskriptivnom analizom nacionalne baze podataka o obrazovnim aspiracijama, pristupu i izboru visokog obrazovanja pokazuje kako veći broj učenika ruralnih škola ima aspiracije završavanja srednje škole i dvogodišnjih studijskih programa, a općenito je manje ruralnih učenika upisano na fakultete i relativno veći broj upisuje javne institucije. Zaključuje da su ruralni učenici konzistentno u nepovoljnijem položaju, pri čemu je lokacija škole moguća dimenzija nejednakih obrazovnih šansi jer različiti ekonomsko-socijalni uvjeti zajednica reflektiraju i raznolikost problema i mogućnosti u ruralnom obrazovanju.

Sociološka istraživanja ustanovila su vezu između obiteljskog socioekonomskog statusa (SES) i uspješnosti učenika, pri čemu učenici iz obitelji nižeg SES-a pokazuju slabije rezultate. No, različiti aspekti socioekonomskog statusa obitelji mogu imati različiti utjecaj na obrazovne odluke učenika i na različitim nivoima mogu utjecati na živote mladih ljudi. Također, drugi faktori mogu utjecati na obrazovne ishode unutar određenog raspona socioekonomskog statusa, a katkada su društveni faktori značajniji od ekonomskih u objašnjenju različitih obrazovnih ishoda; utjecaj SES-a može biti neutraliziran, osnažen ili posredovan rasponom kontekstualnih, obiteljskih, individualnih karakteristika (obiteljska struktura, tip škole, spol, etnicitet, geografska lokacija, tip stanovanja) (Considine, Zappala, 2002). Važan je kontekst u kojem se odluke donose. Ruralne zajednice razlikuju se međusobno duž dimenzija geografske regije, etničkog sastava, strukture zaposlenosti i pristupa velikim gradovima. To onemogućava generalizacije za ruralne učenike općenito i shvaćanje da su sva djeca iz ruralnih područja u riziku. Ruralno-urbane razlike ne mogu se lako kvantificirati, ali su bitne kategorije i baze samoidentifikacije i identiteta zajednice (Crockett, Shanahan, Jackson-Newsom, 2000). Učenike treba postaviti u kontekst njihovih obitelji, a obitelji i mlade u kontekst njihovih zajednica; obitelj pruža osnovne resurse mladima u procesu donošenja odluke te utječu na njihove planove i položajem obitelji u širem kontekstu (Frigi, Bryce, Anderson, 2007).

Kako ruralnost utječe na odluku o obrazovanju? Faktore koji su ključni s obzirom na dimenziju ruralno-urbano dodatno objašnjavaju u kanadskom kontekstu Andres i Looker (2001) koji, ističući da je geografska lokacija jedan od faktora koji utječe nastavljaju li i gdje 
mladi visoko obrazovanje, pokazuju da život u ruralnim područjima utječe na obrazovna očekivanja koja zauzvrat imaju efekt na obrazovna postignuća; pri tom ruralni učenici imaju niža i očekivanja i uspjeh. Bez obzira na geografsku lokaciju, djeca iz obitelji kojima je barem jedan roditelj pohađao fakultet i ona koja su završila akademske srednjoškolske programe imaju viša očekivanja i uspješnost. No, autori upozoravaju da to nije samo stvar razlike u kulturnom kapitalu učenika, već su efekti geografske lokacije ti koji povezuju sile kulturne reprodukcije. Kako objašnjavaju, zajednice odrastanja učenika predstavljaju različite uvjete postojanja koji djeluju kao setovi dispozicija kroz koje pojedinci internaliziraju objektivne strukture pa su dijelom odgovorne za oblikovanje leća kroz koje individue vide društvo. Zajedno - individualne karakteristike, geografska lokacija i strukture regionalnih sistema visokog obrazovanja - mogu se konceptualizirati kao sile koje djeluju na individue i na osnovi kojih individue djeluju. U središtu se nalaze individualno držani kapitali (roditeljski SES, obrazovanje, dohodak), ili obiteljski resursi. Zajednice, kao i obitelji, oblikuju definicije „ljudi kao mi“ i izvor su i simbolične vrijednosti (uz resurse) koju postavljaju na obiteljski i individualni kapital, ili habitusni elementi izraženi kao simbolički kapital. Konačno, strukture sistema visokog obrazovanja definiraju područje mogućnosti na sjecištu blizine institucije, posjedovanja određenog kulturnog kapitala i sklonosti prema visokom obrazovanju.

Corbett (2007) je pokazao duboku povezanost između geografske i socijalne mobilnosti koja se odvija procesom obrazovanja; različita razumijevanja geografije i prostora obrazovno su važna kroz razvoj kapitala mobilnosti ili, nasuprot, lokaliziranog kapitala. Spajanje obrazovanja i odlaska uzdiže one već privilegirane pri čemu različite socijalne i ekonomske pozicije potiču različite načine viđenja mjesta i prostora, a to je bitno u kontekstu radikalizirane modernosti.

Ukratko, ono na što prethodne studije ukazuju drugačijim rječnikom opisuju McIlveen, Ford, Everton (2005). Prema njima, ruralnost sa dvije važne strane onemogućava pristupa sveučilištima - resursima i načinom razmišljanja. Među najznačajnijima izdvajaju dvije vrste „ruralnih“ prepreka: prve, koje nazivaju psihosocijalnim zaprekama prema sveučilištu, tvore faktori troškova, koji rastu zbog preseljenja iz ruralne zajednice, utjecaja značajnih drugih koji mogu stvoriti negativne dojmove o sveučilištima (odnosno, može se shvatiti kao (ne)podrška obitelji, škola te zajednica za studiranje), te razlike fakultetskog jezika i gradske kulture, koji mogu predstavljati dodatni teret studentima koji su anksiozni zbog napuštanja doma (elementi habitusne (ne)usklađenosti). Bills i Ašćerić iznose podatke pilot studije kojoj 
je namjera bila evaluiranje raspona strategija za povećanje pristupa i sudjelovanja učenika ruralnih i izoliranih regija na Sveučilištu Sjeverne Australije s ciljem razumijevanja utjecaja ruralnosti na iskustva u visokom obrazovanju. Osnovne teme koje su se kristalizirale bile su brige studenata oko financijskih te socijalnih troškova napuštanja doma i brige oko akademskih izazova.

Dakle, odluka o i izbor studiranja ima mnogo dimenzija, a u procjeni troškova i koristi od visokog obrazovanja kod konačne odluke, s jedne strane postoje studijski aspekti izbora vezani uz sposobnost biranja na osnovi razmatranja troškova, blizine institucije ili dostupnosti suprotstavljenih programa; a s druge socijalni aspekti izbora koji uključuju odluku o ostanku kod kuće za vrijeme studiranja, zadržavanja/održavanja veza sa zajednicom i prijateljima ili izborom programa koji odražavaju lokalne vrijednosti (Charles Sturt University, 2009). U studiji kojoj je cilj bio ispitivanje faktora koji utječu na upis visokog obrazovanja i ustrajnost pensilvanijskih ruralnih studenata, Wenfan (2002) otkriva sljedeće veze: oni su povezani sa spolom, socioekonomskim i bračnim statusom, završenim srednjoškolskim programom, završenim znanstvenim srednjoškolskim programom, stavovima prijatelja o važnosti studiranja, prijateljima $\mathrm{s}$ fakultetskim planovima, roditeljskim aspiracijama, roditeljskom uključenošću u planiranje i iskustvom zaposlenja.

No bitno je naglasiti i da postoji vremenska dimenzija odluka - učenički planovi razvijaju se, a u vremenskom slijedu najsnažniji utjecaji na učeničke izbore i mogućnosti pristupa VO-u su socijalno porijeklo (spol, zanimanje i dohodak roditelja, geografska lokacija i bogatstvo područja); školovanje (tip škole, interes); utjecaj značajnih drugih (roditelja, nastavnika te planovi prijatelja); akademska samoprocjena (mišljenje o vlastitoj uspješnosti, te korisnost obrazovanja); obrazovne aspiracije i postignuće (Carpenter, Western, prema Frigo, Bryce, Anderson, 2007).

U konačnici, zbog svega navedenoga, ističe se potreba uključivanja, i razumijevanja, ruralnog konteksta kao faktora obrazovnih izbora, čega je značajan element i sama škola. Za određivanje postsekundarnih smjerova učenika potrebno je razmatrati socioekonomski status obitelji i socioekonomski sastav škola i okružujuće zajednice, strukturu ruralnih škola (veličina, ponuda programa, iskustvo i učinkovitost učitelja) te prirodu vršnjačkih kultura i njihov utjecaj. 
Ruralne studije sve više migracije mladih iz ruralnih prostora pokušavaju biografski razumjeti pri čemu se migracije i orijentacija za (ne)mobilnost razumijevaju u kontekstu života mladih ljudi gdje su klasa, rod i značenje lokalnosti relevantni faktori. Wiborg (2006) je istraživala različite aspekte utjecaja procesa odseljenja i visokog obrazovanja za mlade iz ruralnih područja. Kvalitativna studija ispitivala je društveno i geografsko porijeklo studenata norveških ruralnih područja, njihov odnos prema rodnom mjestu, motivima i iskustvima vezanima s izborima visokog obrazovanja, te refleksije prema odseljenju i razmišljanja o budućnosti vezanima uz posao, obitelj i mjesto stanovanja. Njihov odlazak na studij za njih predstavlja tranzicijsku fazu geografski, socijalno i kulturalno. A njihove odluke o visokom obrazovanju i shvaćanja mobilnosti i preseljenja mogu se shvatiti kao markeri distinkcije u formiranju identiteta u kontekstu globalizirane modernosti. Wiborg (2004) ističe da su stavovi prema ruralnim područjima važan faktor u migracijakim odlukama. Mjesto je geografska lokacija, ima materijalni oblik, ali je i ispunjeno značenjima i vrijednostima (Thomas i Gieryn, prema Geldens 2005). Obrazovna pitanja se bolje mogu razumjeti kada se istražuju unutar mjesta u kojima su mladi locirani i u kojima stvaraju sebe i svoje živote. Strukturni faktori (nedostatak lokalnih mogućnosti za zaposlenje, obrazovanje, naukovanje) po sebi ne objašnjavaju kompleksnost ljudskih migracijskih odluka - percepcije i vezanost za mjesto i zajednicu integralni su dio migracijskih aktivnosti, pri čemu percepcija stavova zajednice mogu djelovati protiv povratka (Geldens, 2005). Herzog, Pittman (1995) ispitivali su stavove studenata o svojoj ruralnoj sredini za koje su pokazali da su iznimno pozitivni te se gotovo polovica učenika namjerava vratiti u svoju zajednicu. Oni predlažu da bi ruralna škola u suočavanju s problemima morala kapitalizirati na obiteljskim i komunalnim vezama.

\subsection{Hrvatski kontekst}

Usporedo sa zahtjevima za visokokvalificiranom, širokoobrazovanom, mobilnom i fleksibilnom radnom snagom, vezanom uz globalne promjene ekonomske restrukturacije i nastajućeg mobilnog društva znanja, raste i potražnje za visokim obrazovanjem u populaciji vezanima uz povećanje osobnih aspiracija i vrijednosti obrazovanja. Općeniti razvoj obrazovnih sustava različitih država usporedo s tim promjenama razvijao se masifikacijom visokog obrazovanja, koje je omogućilo nove mogućnosti društvene i geografske mobilnosti nikada ranije zabilježene te ulazak u visokoobrazovanje širokom spektru tzv. netradicionalnih studenata. Takve pravce masifikacije visokog obrazovanja slijedila je i Hrvatska povećanjem 
broja upisnih mjesta na postojeće studijske programe, uvođenje novih studijskih programa, proširenje oblika studiranja te osnivanje novih visokih učilišta kroz povećanje studentskog tijela $^{1}$, te povećanje ponude studijskih programa (Jokić, Ristić Dedi, 2014). Ipak, unatoč masifikaciji obrazovanja, istraživanja nejednakosti u obrazovanju konzistentno potvrđuju vezu obrazovnih postignuća i društvenog podrijetla učenika, odnosno održavanje nejednakih obrazovnih mogućnosti različitih društvenih slojeva (Puzić i Košutić, 2015), a koji se održavaju i u hrvatskom kontekstu posljednjih 50-ak godina bez obzira na reforme obrazovanja (Doolan, Puzić, Baranović, 2017).

Dakle, pokazuje se da pravci razvoja i promjene sustava visokog obrazovanja u Hrvatskoj, vezani uz razvoj binarnog sustava, te policentričnog razvoj, te sustavne obrazovne promjene uvođenja Bolonjskog procesa 2006. godine, te državne mature 2009. kao osnove upisa učenika na visokoškolske ustanove, nisu polučile željene rezultate socijalne jednakosti pristupu visokom obrazovanju (NVVO, 2011; Filipić, 2014; Doolan, 2009).

Trenutno, u Hrvatskoj postoje tri vrste studija: integrirani sveučilišni, preddiplomski sveučilišni, i stručni studiji, koje je moguće pohađati na: redovno ili izvanredno ${ }^{2}$, i koje su povezane s vrstama visokih učilišta kao nositeljima studija unutar binarnog susstava sveučilišne-stručne razine: sveučilišta, fakulteti i umjetničke akademije izvode sveučilišne, a veleučilišta i visoke škole stručne studijske programe. Osnovni problem sustava je nepotpuna binarnost izražena činjenicom da javna sveučilišta izvode oko $30 \%$ svih stručnih studijskih programa, a 15\% upisnih mjesta na javnim sveučilištima je na stručnim studijskim programima (Jokić, Ristić Dedić, 2014).

Posebno je, u razdoblju 2004.-2007., Ministarstvo naglasak stavilo na jednu stranu binarnog sustava razvojem programa za policentrični razvoj stručnih studija kako bi se u manjim urbanim i regionalnim centrima otvorila nova veleučilišta i visoke škole (Doolan i sur., 2012) te je danas regionalna distribucija javnog visokog školstva primjerenija rasporedu stanovništva nego je to ikad bila. Rezultat je ukupno 122 visoka učilišta sa statusom ustanove, od čega 11 sveučilišta, 15 veleučilišta, 30 visokih škola ${ }^{3}$ u Hrvatskoj. Pri tom se studijski

\footnotetext{
${ }^{1}$ Polovica broja učenika koji su prije 12 godina upisali prvi razred osnovne škole nastavlja svoj obrazovni put u visokom obrazovanju u godini završetka srednjoškolskog obrazovanja (Jokić, Ristić Dedić, 2014.)

${ }^{2}$ Od sredine 90-ih status izvanrednog studenta na sveučilišnim studijima obično je rezultat postizanja slabijeg rezultata u klasifikacijskom postupku (Farnell, 2011).

${ }^{3} \mathrm{U}$ vrijeme provedbe istraživanja bilo je sedam javnih sveučilišta: u Zagrebu, Splitu, Osijeku, Rijeci, Puli, Zadru, Dubrovniku; dvanaest javnih veleučilišta: u Vukovaru, Slavonskom Brodu, Požegi, Čakovcu, Karlovcu, Varaždinu, Zagrebu (2), Gospiću, Kninu, Šibeniku, Rijeci; te tri javne visoke škole: u Virovitici, Križevcima i Zagrebu. Danas je 8 javnih sveučilišta (https://mozvag.srce.hr/preglednik/pregled/hr/tipvu/odabir.html) nakon
} 
programi izvode na 40 lokacija od kojih je 28 gradova istodobno i sjedište visokog učilišta, a u 12 gradova se izvode dislocirani studiji (NVVO, 2011).

No, iako je širenje visokih učilišta u prostoru države pozitivan proces otvaranja mogućnost studiranja dohodovno siromašnijim studentima, prilagođavanja studijskih programa društveno-ekonomskim potrebama područja, zadržavanja visokoobrazovanih u lokalnom prostoru, te popunjavanju praznine na znanstvenoj mapi države visokoškolskim nastavnicima, postoje kvalitativne nepovoljnosti ${ }^{4}$ nastale zbog nekontroliranog širenja postojeće mreže visokih učilišta i studijskih programa u relativno kratkom roku te neusklađenost s potrebama hrvatskog društva, i materijalnim i financijskim resursima (Filipić, 2014).

Tabela 2.1 Regionalna distribucija visokih učilišta, te udjeli nastavnog osoblja i studentskog tijela 2011. godine

\begin{tabular}{|c|c|c|c|c|c|c|}
\hline \multirow{3}{*}{$\begin{array}{c}\text { Gradovi } \\
\text { Zagreb }\end{array}$} & \multicolumn{6}{|c|}{ 2011. godine } \\
\hline & \multicolumn{2}{|c|}{ Visoka učilišta (\%) } & \multicolumn{2}{|c|}{ Nastavnici (\%) } & \multicolumn{2}{|c|}{ Studenti (\%) } \\
\hline & 39,4 & 39,4 & 43,3 & 43,3 & 39 & 39 \\
\hline Osijek & 13,5 & \multirow{3}{*}{43,2} & 10 & \multirow{3}{*}{35,8} & 9,6 & \multirow{3}{*}{34,4} \\
\hline Rijeka & 13,6 & & 12,1 & & 10,7 & \\
\hline Split & 16,1 & & 13,7 & & 14,1 & \\
\hline Dubrovnik & 1,9 & \multirow{3}{*}{4,5} & 1,6 & \multirow{3}{*}{5,8} & 1,1 & \multirow{3}{*}{5,1} \\
\hline Pula & 1,3 & & 1,6 & & 1,7 & \\
\hline Zadar & 1,3 & & 2,6 & & 2,3 & \\
\hline Ostali dijelovi HR & 12,9 & 12,9 & 15,1 & 15,1 & 21,5 & 21,5 \\
\hline
\end{tabular}

Regionalno, prema podacima za 2011. godinu koje iznosi Filipić (Tablica 2.1), u Zagrebu se nalazi 39\% visokih javnih i privatnih hrvatskih učilišta ${ }^{5}$, te isto toliko studenata. U ostalim makroregionalnim središtima nalazi se $43 \%$ visokih učilišta te $34 \%$ studenata, dok ostali sveučilišni gradovi koji nisu makroregionalna središta obuhvaćaju dodatnih 5\% visokih učilišta i 5\% studentskog tijela. Dakle, iako je nešto više visokih učilišta u ostalim sveučilišnim gradovima zajedno (49\%) u odnosu na glavni grad, u Zagrebu je i dalje jednak udio hrvatskog studentskog tijela kao i u ostalim sveučilišnim gradovima (39\%). U ostalim dijelovima Hrvatske, dakle nesveučilišnim gradovima koji izvode studijske programe, nalazi se dodatnih $13 \%$ visokih učilišta i $22 \%$ studenata.

što je 2015. godine Sveučilište Sjever formalno postalo osmo javno sveučilište u Hrvatskoj integracijom ustanova Veleučilišta u Varaždinu i Medijskog sveučilišta u Koprivnici (https://www.unin.hr/)

4 Novi studijski programi često kopiraju kurikulume starijih visokih učilišta, nisu dovoljno prilagođeni potrebama lokalnog i regionalnog područja, te su povezani s niskim troškovima izvođenja, značajan broj nastavnika nema potrebne kvalifikacije, a nastava se često odvija u neadekvatnim prostorima (Filipić, 2014).

${ }^{5}$ Kako navodi dokument Mreža visokih učilišta i studijskih programa u RH, u Zagrebu se nalazi 3 od 13 javnih veleučilišta te privatno veleučilište, jedna od 3 javne visoke škole te 17 od 27 privatnih visokih škola u Hrvatskoj (NVVO, 2011), a dodatno i jedno javno i jedno privatno sveučilište. 
Visoko obrazovanje u Hrvatskoj karakteriziram, dakle, diferencijaciju polja i širenja participacije, a kojeg prati i diferencijacija zahtjeva i potreba studentske populacije (Doolan, 2009), a usporedo je detektiran i problem zanemarivanja socijalne dimenzije ${ }^{6}$. Doolan (2009) je ispitivala oblikovanje obrazovnih izbora učenika različitih socijalnih porijekla u hrvatskom VO te kako doživljavaju svoju prvu godinu studija i napredovanje na studiju. Studija opisuje proces prilagodbe na visoko obrazovanje što uključuje široki raspon životnih promjena $\mathrm{s}$ kojima se vežu brige oko osamostaljivanja, ili ostanka kod kuće. Također učenici su prostore portretirali na dimenziji ruralno-urbano, te iskazivali nostalgične osjećaje doma i česte odlaske kući, s utjecajem na tek djelomičan doživljaj nove lokacije, i zauzimanje položaja između mjesta i osjećaja ne/pripadanja. Studija ukazuje kako emocionalni naboj vezan uz zauzimanje određenih prostora može utjecati na čitavo iskustvo VO-a.

Dodatno, Farnell i suradnici (2011) analizom podataka istraživanja EUROSTUDENT o demografskim karakteristikama i socijalnom profilu studenata, njihovom smještaju, troškovima, potrošnji i izvorima financiranja studija te raspolaganju vremenom, radu uz studij i mobilnosti, ukazuju na određene ranjive skupine poput onih iz obitelji manje obrazovanih roditelja, iz obitelji s nižim prihodima ili nižeg imovinskog statusa ${ }^{7}$. Ipak, obje studije obuhvaćaju neke aspekte socijalne dimenzije u visokom obrazovanju među osobama koje su upisale studij, odakle potreba za istraživanjima koja bi identificirala i ostale oblike nejednakosti za osobe iz ruralnih ili geografski izoliranih krajeva, i to prije njihova ulaska u visoko obrazovanje.

Navedene studije dale su i saznanja o mobilnosti studenata pri njihovom ulasku u visoko obrazovanje. Pokazalo se da hrvatski studenti preferiraju, gdje je moguće, život kod kuće s roditeljima za vrijeme studija, bez obzira na socijalno podrijetlo (Doolan, 2009), što ukazuju da hrvatski studenti ne pokazuju visoke razine mobilnosti kod odlaska na visoko obrazovanje, a u skladu je s podacima EUROSTUDENT-a da oko polovice studentskog tijela u Hrvatskoj za vrijeme studija živi s roditeljima (Farnell i sur., 2011). Doolan (2009) osnovno objašnjenje pronalazi u studentskom shvaćanju studiranja kao akademskog, a ne socijalnog iskustva.

No, prema rezultatima analize ispita državne mature pri izboru studija, Jokić i Ristić-Dedić (2014) pokazuju da postoji želja za geografskom mobilnošću u pravcu Zagreba koji je

\footnotetext{
${ }^{6}$ Socijalna dimenzija visokog obrazovanja odnosi se na institucionalne mjere koje doprinose jednakim mogućnostima pri upisu studija, za vrijeme njegova trajanja i završavanja, s posebnim naglaskom na pojedince iz socijalno ranjivih skupina (Puzić, Doolan, Dolenc, 2006, prema Farnell i sur, 2011).

${ }^{7}$ Među ostalim ugroženim skupinama su pojedinci stariji od 21 godine, roditelji, zaposleni studenti, te oni sa zdravstvenim teškoćama (Farnell i sur., 2011)
} 
najpoželjnija visokoobrazovna destinacija - prvi izbor za učenike iz 16 županija; gotovo polovica ukupnog broja učenika želi studirati u Zagrebu, a 66\% najuspješnijih učenika na prvo mjesto izbora stavlja Zagreb. Objašnjenje velike poželjnosti Zagreba, autori nalaze u centraliziranosti $\mathrm{i}$ širini te percipiranoj kvaliteti ponude studijskih programa u Zagrebu ${ }^{8}$. Manjak želje za mobilnošću pokazuju učenici iz Zagreba koji rijetko biraju studijske programe izvan mjesta u kojem su završili srednjoškolsko obrazovanje. Slično, i ostali makroregionalni centri imaju veliku poželjnost uglavnom za učenike iz tih ili bliskih županija (Jokić, Ristić-Dedić, 2014).

Analiza također utvrđuje visoku razina poželjnosti redovnih studijskih programa, posebice sveučilišnih, ali i porast poželjnosti stručnih studijskih programa (pogotovo u području biomedicine i zdravstva), te nisku poželjnost programa privatnih visokih učilišta. Gotovo svi učenici koji završavaju četverogodišnje srednjoškolsko obrazovanje iskazuju želju za studiranjem, a znakovit je vrlo velik interes učenika koji završavaju strukovno srednjoškolsko obrazovanje od kojih $60 \%$ uspije upisati studijske programe te autori zaključuju da model upisa temeljen na rezultatima državne mature ne predstavlja prepreku za ulazak u VO (Jokić, Ristić-Dedić, 2014).

Unatoč tome, ukazuje Baranović (2015), istraživanja socijalne dimenzije obrazovanja u Hrvatskoj ukazuju na održavanje društvenih i obrazovnih pretpostavki (re)produkcije društvenih nejednakosti u obrazovanju, i u socijalističkom i postsocijalitičkom razdoblju.

No, utjecaj rezidencijalnog porijekla na obrazovne uspjehe nije pomnije istraživan. Rijetka ispitivanja razlika u uspješnosti ruralnih/urbanih studenata ograničena su na pojedine institucije; jedna analiza razlike studenata ruralnog/urbanog porijekla u akademskoj izvedbi na Medicinskom fakultetu je pokazala da su ruralni učenici u većem broju prijavljivali pad godine, i veću vjerojatnost višestrukog pada godine, pokazivali su manji interes za karijeru dopunjenu znanstvenim istraživanjima, no pokazivali su veći interes za traženjem zaposlenja u ruralnim i udaljenim područjima (Polašek, Kolčić, 2006). Jedno ranije istraživanje (Tomanović, 1967) upozorilo je na nepovoljnu obrazovnu poziciju učenika iz ruralnih sredinakoju kumulativno podržavaju većeavjerojatnost njihova odrastanja u obiteljima slabijih materijalnih i kulturnih resursa i zajednicama slabije kulturne ponude i kvalitete škola. Istraživanje IDIZ-a iz 2010. na uzorku studenata Zagrebačkog sveučilišta pak pokazuje kako je tadašnje studentsko tijelo podrazumijevalo najvećim dijelom učenike čiji roditelji imaju

\footnotetext{
${ }^{8}$ U prilog tome govori i podatak da se u Zagrebu izvode studiji iz svih polja znanosti osim dva (Metalurgija, Integrativna bioetika) (NVVO, 2011).
} 
visoko obrazovanje, dok se niže obrazovana populacija roditelja i roditelja poljoprivrednika češće preslikava u istovjetno obrazovanje ili radni status djece (prema Potočnik, 2011). Projekt EUROSTUDENT ispitivao je pristup VO-u, no nije obuhvatio aspekte nejednakosti vezane uz regionalne razlike (Farnell i sur., 2011). Dijelom je taj nedostatak ispravila studija iz 2015. koja je pokazala regionalne razlike vezane uz namjeru studiranja te učenicima dostupne resurse u njihovim obiteljima i školama. Posebno nepovoljnu strukturu obiteljskih i školskih resursa u toj je studiji opisivala regiju Slavonija, za koje je karakteristično i niža razina obrazovnih aspiracija u odnosu na nacionalni prosjek (Klepač, 2015). Jokić i RistićDedić (2014) analizom rezultata državne mature iznose podatke o učeničkim namjerama i izborima studija, no bez dublje teorijske razrade. Doolan (2009) daje prve kvalitativne podatke o socijalnim aspektima studentskih obrazovnih putova i ukazuje da emocionalna vezanost za prostor odrastanja ima utjecaj na iskustva studiranja, što postavlja dodatna pitanja o tome kako se „mjesnost“ oslikava u učeničkim aspiracijama i slikama studiranja ruralnih učenika kada donose odluke studiranju (i odlasku). Dodatno, studija Žutinić Bokan (2008) zainteresirane za aspiracije, motive i namjere odlaska mladih iz ruralnih područja, njihovih mišljenja o kvaliteti i manama života u ruralnom području, pronalaze kako mladi iskazuju subjektivnu vezanost za selo i preferencije prema životu na selu i rad u gradu pri čemu se ističu prostorne i okolišne osobine. Više od polovice ispitanika u njihovom istraživanju je izrazilo namjeru ostanka u svom mjestu, dok se razlozi onih koji žele otići dvostrani: zbog zaposlenja i percipiranog manjka mogućnosti za to na selu, te drugi razlozi od kojih je bitno obrazovanje. Najmanje stabilnim članovima zajednice pokazali su se žene, mlađi od 20 godina, iz radničkih i velikih poljoprivrednih obitelji, oni koji preferiraju grad za život i rad, oni koji vjeruju da je nezaposlenost glavni problem ruralnih krajeva i oni koji su nezadovoljni životom na selu (Žutinić, Bokan, 2008).

Općenito, ruralni sociolozi u Hrvatskoj upozoravaju kako u većini hrvatskih ruralnih krajeva, uključujući periferijske male gradove koji bi trebali biti potpora ruralnoj okolici, kvaliteta života pada, smanjuju se mogućnosti zaposlenja, školovanja, zdravstvenih usluga, funkcije se udaljavaju od sela. „Strukturiranje hrvatskih seoskih prostora se mijenja, sela su sve manja, sve ih je više napuštenih, mreža srednjih i malih gradova ne uspijeva osigurati minimalan potreban standard seoskom stanovništvu. U selu mladi sve rjeđe ostaju, još se rjeđe doseljavaju“ (Štambuk 2014:8). Hrvatska ima izrazitu piramidalnu strukturu mreže naselja koja je izrazito hijerarhizirana u slučaju glavnog grada (Seferagić, 2005), odnosno, ima dvostruku podjelu unutar sebe: između Zagreba i ostatka zemlje, te između većih gradskih 
naselja i ostalih manjih (Svirčić Gotovac 2005). Na seoskoj razini, Župančić (2005) upozorava na nedostatnu rasprostranjenost, odnosno lošu infrastrukturnu opremljenost seoskih krajeva te poželjnost politike dekoncentrirane urbanizacije i osnaživanja mreža manjih naselja, jer je osnovni strukturni hendikep hrvatskih seoskih regija i naseljenosti izrazita niska koncentracija seoskih prostora čega je posljedica postojanje velikog broja malenih i patuljastih naselja. Stoga, u Hrvatskoj se na selo gleda kao na gradu podređen socijalni i gospodarski sustav bitno određen krizom i ovisnošću (Štambuk 2014:24), a što je posebno izraženo u određenim regijama Hrvatske koje pokazuju nejednoslik razvoj. Selo je iz modernizacije izvuklo kompleks zaostalosti, upozorava Šundalić (2003), a tranzicijski proces je potakao širenje predrasuda o selu kao socijalno nižoj destinaciji, a gradu koji pruža brojne mogućnosti napredovanja, bogaćenja, lagodna življenja... Tako Slavonija postaje regija koja manje pruža i u kojoj ostaje manje ambiciozna populacije. Time se i identitet Slavonije kao poljoprivredne i ruralne regije transformirao u identitet nerazvijene i depopulacijske regije (2010).

Ipak, nisu sva sela u Hrvatskoj jednaka; postoji raznolikost ruralnih naselja u Hrvatskoj, čiju je ruralnost iscrpno oslikao Lukić (2012) u doktorskoj disertaciji Mozaik izvan grada koja, analitički smještena na razinu naselja, daje tipologiju ruralnih i urbaniziranih naselja Hrvatske, koji su rezultat klaster analize širokg raspona socioekonomskim pokazatelja razvoja prostora. Tipologija ističe pluralnost ruralnosti u hrvatskom sociogeografskom prostoru. Prema toj analizi, 46\% stanovnika Hrvatske živi u ruralnim (i urbaniziranim naseljima), dok je 54\% stanovništva gradsko. Za očekivati je da je danas taj broj manji. Osnovne karakteristike svakog tipa sažima Tablica 2.2. 
Tabela 2.2 Opisi tipova ruralnih naselja u Hrvatskoj (prema Lukić, 2012)

\section{Klasteri ruralnih naselja u hrvatskom sociogeografskom prostoru}

\section{Ekonomski \\ diverzificirana, pretežito \\ turistička \\ (RRP_EDPT)}

Prosječna veličina je 293 stanovnika, a gustoća naseljenosti $35 \mathrm{st} / \mathrm{km}^{2}$. Geografski su ograničena na priobalni pojas, otoke i male prostore turističkog ili ekonomski diferenciranog zaleđa.

\section{Dinamična, strukturno jača naselja (RRP_DSJ)}

Prosječna veličina je 1085 stanovnika, a gustoća naseljenosti $201 \mathrm{st} / \mathrm{km}^{2}$. Obuhvaćaju područja neposredno uz gradove (oko makroregionalnih (prate osi urbanizacije), te svih regionalnih središta), duž cestovnih pravaca (Središnja Istočna HR) te oko centralnim funkcijama bolje opremljenih naselja istoka HR. Najzastupljeniji u Istočnoj Hrvatskoj, te u sjevernim predjelima HR (Međimurje).

\begin{tabular}{|c|c|}
\hline $\begin{array}{l}\text { Naselja poljop. } \\
\text { ekstenzifikacije i slabe } \\
\text { demog. dinamike } \\
\text { (RRP_PESDD) }\end{array}$ & $\begin{array}{l}\text { Prostorno se isprepliću s naseljima ruralne periferije, a zajedno pokrivaju } 40 \% \\
\text { prostora Hrvatske (Gorska HR, obalno zaleđe, otočka unutrašnjost). } \\
\text { Zastupljenija u središnjoj i sjevernoj Istri. }\end{array}$ \\
\hline Naselja ruralne periferije & Karakteriziraju područja Like, Korduna, Banovine te šibenske Zagore. \\
\hline $\begin{array}{l}\text { Dostupnija, o cirkulaciji } \\
\text { ovisna naselja } \\
\text { (RRP_DCO) }\end{array}$ & $\begin{array}{l}\text { Prosječna veličina je } 314 \text { stanovnika, a gustoća naseljenosti } 85 \mathrm{st} / \mathrm{km}^{2} \text {. } \\
\text { Osnovna karakteristika je velika dostupnost sustava središnjih naselja zbog } \\
\text { koncentracije u sjeverozapadnom i središnjom dijelu HR i guste mreže lokalnih } \\
\text { prometnica (zagrebački prsten te Hrvatsko zagorje. Isprepliću se s dinamičnim, } \\
\text { strukturno jačim naseljima. }\end{array}$ \\
\hline $\begin{array}{l}\text { Tržišno orijentirana } \\
\text { poljoprivredna naselja } \\
\text { (RRP_TP) }\end{array}$ & $\begin{array}{l}\text { Prosječna veličina je } 305 \text { stanovnika, a gustoća naseljenosti } 38 \mathrm{st} / \mathrm{km} 2 \text {. } \\
\text { Najizraženija karakteristika je poljoprivreda kao izvor prihoda kućanstva i } \\
\text { njena tržišna usmjerenost. } \\
\text { Najzastupljeniji u Istočnoj Hrvatskoj. }\end{array}$ \\
\hline $\begin{array}{l}\text { Ostala izvangradska } \\
\text { naselja }\end{array}$ & $\begin{array}{l}\text { Mala naselja infrastrukturno slabo opremljena. Prostorno locirana uz tip naselja } \\
\text { ruralne periferije. }\end{array}$ \\
\hline
\end{tabular}

\subsection{Svrha i ciljevi studije}

Svrha ove mješovitometodne studije je identificirati i opisati elemente sociogeografskih i kulturnosimboličkih prepreka koji učenicima iz ruralnih područja otežavaju odluku o nastavku školovanja na visokoškolskoj razini i ulazak u visoko obrazovanje, prvo, ispitivanjem razlika između učenika različitog rezidencijalnog podrijetla s obzirom na dostupnost i razvijenost obrazovno značajnih kapitala te uloge rezidencijalnog podrijetla u odlučivanju o visokom obrazovanju, nacionalno i regionalno. U drugom eksplorativnom koraku, kroz integraciju dvijeu vrsta podataka, cilj je ispitati i opisati ulogu simboličkih i strukturnih elemenata zajednice odrastanja, uz obiteljske i školske čimbenike u procesu donošenja odluke o visokom obrazovanju, u ruralnoj slavonskoj regiji. 
Studiju vode 4 opća istraživačka pitanja, odnosno cilj je istraživanja četverostruk razrađen kroz veći broj pojedinačnih analiza vođenih radnim hipotezama koje istraživanje stremi potvrditi ${ }^{9}$.

Cilj 1. Istražiti postoje li značajne razlike između urbanih i ruralnih učenika u vezi namjere studiranja, te izbora tipa i mjesta visokog obrazovanja na nacionalnoj i regionalnoj razini.

H1a: Učenici iz ruralnih sredina rjeđe se odlučuju na nastavak školovanja na visokoškolskoj razini.

H1b: Za učenike ruralnog rezidencijalnog podrijetla koji se odlučuju na nastavak školovanja veća je vjerojatnost odabira stručnih studija.

H1c: Za učenike ruralnog rezidencijalnog podrijetla koji se odlučuju na nastavak školovanja manja je vjerojatnost odabira visokoobrazovnih institucija u Zagrebu.

Tabela 2.3 Istraživačka pitanja analiza razlika između učenika različitog rezidencijalnog podrijetla

Istraživačka pitanja analize razlika između učenika različitog rezidencijalnog podrijetla Postoje li značajne razlike između učenika različitog rezidencijalnog podrijetla prema namjeri studiranja i određenim elementima obiteljskog i školskog konteksta?

Potpitanja: postoje li značajne razlike između učenika različitog rezidencijalnog podrijetla

- prema njihovim obrazovnim karakteristikama?

- prema njihovim obrazovnim orijentacijama?

- prema njihovim kulturnim kompetencijama?

- prema dostupnim obiteljskim kulturnim i ekonomskim kapitalima?

- prema simboličkoj vrijednosti obitelji?

- prema karakteristikama srednje škole'

- prema simboličkoj vrijednosti osoba iz svojih društvenih odnosa/mreža?

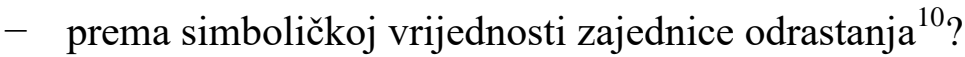

- prema želji za društvenom mobilnošću?

Postoje li značajne razlike između učenika različitog rezidencijalnog podrijetla prema njihovim visokoobrazovnim izborima?

Potpitanja: postoje li značajne razlike između učenika različitog rezidencijalnog podrijetla:

- prema vrsti i tipu studija kojeg namjeravaju upisati?

- prema tipu institucije na kojoj namjeravaju upisati studij?

- prema mjestu studiranja u kojem misle upisati studij?

- prema tome je li studij privatni ili državni, te vrsti studiranja (redovno/izvanredno)?

- prema važnosti ugleda studija i institucije za izbor?

\footnotetext{
${ }^{9}$ Detaljniji popis svih radnih hipoteza koje su vodile pojedine analize kako su se razvijale u tijeku istraživačkog proces prikazene prikazuju Tabela 2.3 prikazuje pitanja vezana uz cilj 1, a Tabela 2.4 s ciljem 2 .

${ }^{10}$ Ispituje se samo regionalno, odnosno ispituje se razlike između slavonskih učenika različitog rezidencijalnog podrijetla prema simboličkoj vrijednosti zajednice odrastanja.
} 
Cilj 2. Istražiti postoji li efekt rezidencijalnog podrijetla učenika, uz kontrolu pojedinih relevantnih čimbenika obiteljskog i školskog konteksta, na odluke vezane uz VO, na nacionalnoj i regionalnoj razini.

H2: Postoji jedinstven doprinos rezidencijalnog porijekla učenika u objašnjenju varijance na varijablama odluka vezanih uz namjeru studiranja (a) $i$ VO izbore (b i c).

Tabela 2.4 Istraživačka pitanja objašnjenja namjere studiranja i visokoobrazovnih izbora učenika

\section{Istraživačka pitanja analize objašnjenja namjere studiranja i visokoobrazovnih izbora učenika različitog rezidencijalnog podrijetla}

Koji skup individualnih, obiteljskih i izvanobiteljskih, te sociogeografskih varijabli najbolje objašnjava učeničku namjeru studiranja?

Postoji li jedinstveni doprinos rezidencijalnog podrijetla, uz kontrolu ostalih varijabli u modelu, objašnjenju učeničke namjere studiranja?

Postoje li razlike u djelovanju modela za objašnjenje namjere studiranja kod učenika različitog rezidencijalnog podrijetla?

Koji skup individualnih, obiteljskih i izvanobiteljskih varijabli najbolje objašnjava namjeru studiranja:

1. učenika odraslih u metropoli

2. učenika odraslih u urbanom okolišu

3. učenika odraslih u ruralnom okolišu

- Doprinosi li objašnjenju namjere studiranja učenika ruralnog rezidencijalnog podrijetla tip ruralnog naselja u kojem odrastaju?

Koji skup individualnih, obiteljskih i institucionalnih, te sociogeografskih varijabli najbolje objašnjava učenički izbor sveučilišnog studija i Zagreba kao mjesta studiranja?

Postoji li jedinstveni doprinos rezidencijalnog podrijetla, uz kontrolu ostalih varijabli u modelu, objašnjenju učeničkog izbora sveučilišnog studija i Zagreba kao mjesta studiranja?

Postoje li razlike u djelovanju modela za objašnjenje izbora sveučilišnog studija i Zagreba kao mjesta studiranja kod učenika različitog rezidencijalnog podrijetla?

Koji skup individualnih, obiteljskih i izvanobiteljskih varijabli najbolje objašnjava izbor sveučilišnog studija i Zagreba kao mjesta studiranja:

1. za učenike koji nisu odrasli u metropoli?

2. za učenike ruralnog rezidencijalnog podrijetla

Cilj 3. Istražiti koju ulogu u objašnjavanju učeničkih izbora ima emocionalna vezanost za mjesto, osjećaj pripadnosti lokalnoj zajednici te želja za ostankom u regiji Slavonija.

H3: Varijable emocionalne vezanosti za mjesto odrastanja, osjećaja pripadnosti u lokalnoj zajednici te želje za ostankom u svom mjestu doprinose objašnjenju varijance kriterijskih varijabli izbora visokog obrazovanja. 
Cilj 4. Ispitati i opisati elemente generalnog procesa razvoja orijentacije prema visokom obrazovanju i donošenja visokoobrazovnih odluka te ulogu učeničke percepcije njihovih socioprostornih pozicija i osjećaja vezanih uz njihovu ruralnu sredinu u informiranju procesa donošenja visokoobrazovnih odluka s posebnim naglaskom na osobna viđenja njihova socioprostornog kretanja u visoko obrazovanje

\subsection{Teorijske leće}

Ova studija Bourdieuovu teoriju uzima kao heuristički okvir i skup alata koji pomažu razmatranje društvenih fenomena u njihovoj složenosti. U ovom poglavlju kratko izlažemo Bourdieuovo definiranje osnovnih koncepata te način njihova operacionaliziranja u drugim istraživačkim kontekstima u odnosu na onaj s obzirom na koji su razvijeni, te načine kako će se navedeni koncepti interpretirati u radu.

U Bourdieuovom okviru postoji nekoliko vrsta kapitala (ili moći), a koje ovise o polju u kojem se koriste (u kojima vrijede kao kapitali). U njegovoj teoriji, ekonomski, kulturni i društveni kapitali (koji su međusobno prevodivi) su obiteljski resursi koji se usvajaju u obitelji s obzirom na njenu društvenu poziciju, a u polju obrazovanja posjedniku pomažu u borbi za postizanje povoljnih rezultata. Ekonomski kapital je odredio u smislu materijalnog posjedovanja, kulturni kapital kao obrazovna kvalifikacija, dok se društveni sastoji od značajnih veza (Bourdieu, 1986). Kulturni kapital predstavlja obiteljski stečenu upoznatost s dominantnom kulturom i kulturne kompetencije učenika U obiteljskom okruženju, on postoji u tri oblika: utjelovljenom koji predstavlja „dispozicije tijela i uma“ (1986), objektificiranom u obiteljskom posjedovanju kulturnih dobara, te institucionaliziranom koji predstavlja zapravo „ono što pretpostavlja“ jer ga odražavaju svjedodžbe i diplome (1986).

Konačno, društveni kapital označava resurse koji su pojedincima dostupni zbog pripadnosti određenoj grupi odnosno ,resurse povezane s posjedovanjem trajnih mreža više-manje institucionaliziranih odnosa međusobnog prepoznavanja i priznavanja“ (Bourdieu, 1986). Kako ističe Doolan (2009), u Bourdieuovom okviru, on se odnosi na korisne osobne kontakte, odnosno resurse pojedinca koji proizlaze iz njegove pripadnosti grupama izvan obitelji.

Ovi istaknuti elementi, bitno je naglasiti, samo su resursi koji postaju kapitali tek ako se koriste i razvijaju u određenom polju u kojem imaju vrijednost. Oni oblikuju habitus (prvenstveno kao klasni habitus) koji Bourdieu definira kao: „sistem trajnih, prenosivih dispozicija koje integrirajući prošla iskustva, u svakom trenutku djeluju kao matrice percepcije, cijenjenja i djelovanja te omogućavaju postizanje beskonačno različitih zadataka“ 
(Bourdieu, 2013[1977]: 82-3). Drugim riječima, on predstavlja individualni dio odnosa između strukture društva i individualnih djelovanja, a nastaje internalizacijom izvanjskih struktura u socijalizacijskom procesu, „dugotrajnim iskustvom društvene pozicije“, a kroz dijalektiku s odgovarajućim poljem, „kada se susretne sa svijetom koji je poznat“, omogućava djelovanje jer se osjeća „poput ribe u vodi“, odnosno prepoznaje svijet i uzima ga zdravo za gotovo (Bourdieu, Wacquant, 1992). Na taj način, omogućava praksu.

Polje, konačno, opisuje kao skupove objektivnih, povijesnih relacija ukotvljenih u određenim vrstama moći (ili kapitala). Polje je relacijsko i u njemu se uvijek odbijaju borbe među pojedincima koji zauzimaju određene pozicije i koji teže zauzimanju novih pozicija, a njihov uspjeh ovisi o kapitalima usvojenima i razvijenima, odnosno o razvijenom habitusu koji odgovara određenom polju.

Dakle, Bourdieuova teorija tvrdi da oni s većim i razinama resursa - kulturnih, društvenih i ekonomskih - koji ulaze u natjecanje u obrazovnom polje za potencijalne nagrade koje nudi imaju prilagođeniji habitus, što znači da bolje razumiju pravila samog natjecanja, te im je natjecanje lakše savladivo i postižu bolje rezultate. Pojedinci viših društvenih klasa razvijaju habitus usklađeniji sa zahtjevima obrazovnog polja, odnosno nastavnog proklamiranog i skrivenog kurikuluma, te su djeca roditelja iz viših klasa habitusno bolje prilagođeni školskim zahtjevima i time uspješniji.

Kako je vidljivo iz prethodne interpretacije, utjecaj polja na habitus i obrnuto djeluje vrlo deterministički i strukturalistički, što je i kritika često upućivana Bourdieu. Nasuprot tome autor upozorava kako je habitus strukturirajući mehanizam koji djeluje iz pojedinca, ali nije niti izričito individualan niti posve determinirajući, već je „,princip generiranja strategija koji osposobljava aktera da se nose s nepredviđenim i stalno mijenjajućim situacijama“ (prema Wacquant, 1992). Nekoliko je mogućih načina shvaćanja promjena: a) one proizlaze iz dinamike unutar polja jer se socijalna reprodukcija ne pojavljuje bez natjecanja, ili b) potaknute su izvanjskim utjecajima u drugim poljima (promjenjene okolnosti poput globalizacijskih i modernizacijskih utjecaja).

Dodatno se postavilo pitanje, sobzirom da je njegova teorija kontekstualno vezana s klasnim francuskim društvom 70-ih godina, kolika je upotrebljivost njegove teorije se u suvremenom mobilnom društvu s masovnim obrazovanjem i potrebom za visokoobrazovanim radnicima, nasuprot opadanju zanimanja radničkog i tvorničkog tipa. I što je s ostalim značajnim strukturnim kategorijama poput spola, etniciteta ili pak rezidencijalnog podrijetla? Imaju li te kategorije značaj i kakav, uz ili nad klasom? 
Bourdieuovi konceptualni alati često su korišteni u obrazovnim istraživanjima za ispitivanje različitih obrazovnih ishoda, iako ne nužno zajedno, a u skladu s društvenim mijenama prilagođavani su i različitim kontekstima. Česte mjere kulturnog kapitala u sociološkim istraživanjima uključuju učeničko sudjelovanje u kulturnim aktivnostima i njihove čitalačke navike (De Graaf i sur., 2000). Flere i sur. (2009) razvili su kompozitnu mjeru koju su tvorili od mjera obrazovnog statusa roditelja, učeničkih posjeta izložbama i kazalištima, učestalosti čitalačkih praksi i umjetničkih aktivnosti. Ispitivao se i roditeljski KK zbog njihove vezanosti s učeničkim (Aschaffenburg, Mass, 1997), te mehanizmi te veze: obiteljsko posjedovanje kulturnih/obrazovnih dobara i komunikacija roditelji-djeca (Jaeger, 2009).

Društveni kapital je često operacionaliziran kao utjecaj značajnih drugih na obrazovne odluke učenika. U kontekstu škole shvaćan je kao učeničke izvanškolske aktivnosti, kontakti učiteljiroditelji, školska klima (Dufur i sur., 2013), te kao informacijska podrška o mogućnostima zapošljavanja/visokog obrazovanja (Stanton-Salazar, Dornbusch, 1995). Vryonides (2007) je ispitivao veze kulturnog i socijalnog kapitala roditelja i učenika: učenički SK operacionaliziran je kao obiteljska pomoć koju očekuju pri ostvarenju planova nakon srednje škole; roditeljski SK shvaćen je kao roditeljske društvene mreže, vrsta tih mreža i spremnost da se koriste za ostvarenje planova djece.

Povezani koncepti polja i habitusa rijetko se operacionaliziraju u istraživanjima (npr. Dumais, 2002; Nora, 2004). Habitus se odnosi na mentalne strukture koje se internaliziraju socijalizacijom, a određene su društvenim položajem pojedinca te usmjeravaju način na koji on razumije svijet i djeluje. Polje je socijalni prostor aktiviranja i natjecanja za kapitale koji omogućuje reprodukciju društvenih nejednakosti. Koristi se i kao koncept koji se odnosi na karakteristike obrazovnih institucija koje doprinose obrazovnom (ne)uspjehu. Tako Reay (1998, 2001) razrađuje pojam institucionalnog habitusa koji u školi obuhvaća učiteljske predrasude o učenicima i/ili poticaje učenika na nastavak školovanja.

Ovaj rad želi upotrebom Bourdieuovih koncepata propitati neke strukturne elemente za koje se pretpostavlja da opisuju ruralno-urbano društveno polje kao i percepcije mladih kao elementa njihova habitusa $\mathrm{s}$ obzirom na njihove društveno-migracijske prakse, odnosno odluku o studiranju kao strategiji nekih učenika, za postizanje društvene i geografske mobilnosti.

U Bourdieuovom teorijskom okviru istraživanje (geografskih) prostora nije bilo od njegovog prvotnog interesa, a prostorna razmatranja su vezana uglavnom uz njegove ranije radove. No, 
njegovi koncepti polja i habitusa imaju izuzetnu prostornu dimenziju, iako ne geografski - oni su društveni prostori. Time, u njegovom okviru rezidencijalno podrijetlo smatra pokazateljem kulturnog kapitala (prema Flere i sur. 2010). Od 70-ih kada je oblikovao svoja najznačajnija shvaćanja o obrazovnoj i društvenoj reprodukciji putem obrazovanja u Francuskoj mnoštvo istraživača je razvilo njegove koncepte te ih prilagođavalo za ispitivanje različitih društvenih fenomena, a među njima i načine na koje se u tom procesu reproduciraju i sami prostori, i kako oblikuju same procese društvene reprodukcije. Stoga, ne iznenađuje da se Bourdieua ističe kao jednog od najznačajnijih autora o mjestu i prostoru ${ }^{11}$, pri čemu su istraživanja geografa, inspirirana njegovim konceptom habitusa, bila posvećena odnosu habitusa i mjesta (Bridge, 2011). Kako tvrdi Corbett, postoji značajan prostor da se u Bourdieuovom okviru razvije nijansiraniji osjećaj o tome kako kulturni kapital i obiteljske obrazovne strategije djeluju u različitim lokacijama (2010) jer klasa još uvijek vrlo živa u kanadskim ruralnim zajednicama.

U tom okviru moguće je razmatrati i postojanje različitih društvenih ruralnih i urbanih sustava kao i geografskog habitusa, kako to čini Rye kada u norveškom kontesktu i kroz bourdjuovske leće razmatra društvene dinamike reprodukcije nejednakosti u obliku stratificirajućih struktura urbanih i ruralnih područja putem obrazovanja i mobilnosti (2003), te povezujući pripadanjem društvenoj klasi s mentalnim mapama koje takav položaj omogućavaju stvarajući predispozicije za unapređenje/reprodukciju vlastite pozicije unutar ruralne društvene strukture.

Rye i Blekesaune (2003) ispitali su dva koraka kauzalne veze: roditeljsko obrazovanje $\rightarrow$ obrazovanje učenika $\rightarrow$ ruralno-urbana migracija. Longitudinalnim praćenjem putanja ruralnih migranata, povezali su klasnu analizu s pitanjima kulture i životnog stila. Rezultati pokazuju da je za migraciju ruralno-urbano primaran kulturni kapital, odnosno obrazovanje roditelja. Migranti koji odlaze na visoko obrazovanje, a zatim ostaju u gradovima i geografski i društveno mijenjaju socijalnu poziciju ulaskom u urbani socijalni sistem, i smještaju se unutar urbane klasne strukture. U kasnijoj analizi (2004), Rye i Almas taj proces nazivaju geo-socijalno klasno putovanje. Na makro razini, pokazuju se da se socijalna stratifikacija ruralnih i urbanih područja reproducira iz generacije $u$ generaciju te se zadržava ruralno/urbana neravnoteža dohotka i stupnja obrazovanosti što rezultira neprivilegiranošću ruralnog. Ipak, na mikro razini, pokazuje se da i oni koji su se nakon visokog obrazovanja vratili doživljavaju socijalnu mobilnost pri čemu geografska mobilnost zbog obrazovanja

\footnotetext{
${ }^{11}$ Vidi Hubbard, P., Kitchin, R.(ur.) (2011). Key Thinkers on Space and Place. Sage. Los Angeeles, London, New Delhi, Singapore, Washington DC
} 
omogućuje društvenu mobilnost u ruralnom društvenom sistemu. Ipak, šanse su veće za one koji dolaze iz viših ruralnih socijalnih klasa i koji usvajaju poseban „urbani“ habitus. Također, nagrade su veće ako se kapital društvenog podrijetla uloži u urbana područja (2007), jer različiti društveni istemi imaju drugačiju logiku djelovanja.

U drugim analizama (2006b, 2007) dodatno naglašava i utjecaj klase na socijalnu konstrukciju ruralnosti, odnosno opise i ocjene tinejdžera u ruralnim područjima o ruralnom pri čemu, nasuprot ideji da mladi zajednice percipiraju tradicionalnima, nerazvijenima, nazadnima, ukazuje da su takve socijalne konstrukcije dio strukturnih svojstava njihova konteksta svakodnevnog življenja. U njegovoj studiji se pokazalo da oni s najvišim, kao i oni s najnižim razinama kulturnog i ekonomskog kapitala, imaju najpozitivnije slike o ruralnom. A također, te percepcije imaju rodnu dimenziju pri čemu su mladići skoniji pozitivnijim procjenama. Ono što želi naglasiti je da migracijske odluke mladih jesu odraz individualiziranog i slobodnog izbora, ali su istodobno strukturirane predispozicijama njihovog ruralnog klasnog habitusa, pri čemu postoji značajna sukladnost između nečije pozicije u društvenoj strukturi, njihove procjene ruralnosti i preferencija duž ruralno-urbane dimenzije s obzirom na buduće mjesto života (2011).

No mehanizme takvih reprodukcija u kanadskom kontekstu je objašnjavao Corbett pri čemu škole djeluju kao iskorjenjivajući mehanizam izdvajajući one najupješnije za visoko obrazovanje i migracije, čime se postavlja problem za zajednice koje ostaju bez značajnog dijela svog kulturnog kapitala. To je posebno naglašeno u suvremenom mobilnom društvu i društvu znanja koje traži visokoobrazovanu radnu snagu, a koje je istodobno društvo rizika, brzih promjena i ekonomske nestabilnosti. Škole naglašavaju imperativ migracije kojim neke uče na odlazak, a neke na ostanak, a istodobno zajednice one koji odlaze proglašava uspješnima, a one koji ostaju zapelima, djelujući time paradoksalno na vlastiti opstanak (Carr, Kefalas 2009). Implicitnim definiranjem obrazovnog uspjeha u terminima mobilne populacije mladih izvezenih u urbana područja, ruralne škole su prešutno promicale eroziju vlastitog ljudskog kapitala. Dominantna je percepcija da je obrazovanje put prema van, no mnogi mladi možda ne posjeduju nužne resurse za upuštanje u nešto što je nepoznato i nesigurno. Ili nemaju razvijene dispozicije kojima se mogu zamisliti $\mathrm{u}$ drugim prostorima $\mathrm{u}$ vremenu $\mathrm{u}$ kojem se cijeni razlikovna sposobnost aktera da postignu identitetsku fleksibilnost kroz mobilnost, što je važna mjera moći u suvremenim društvima (2009). Drugim riječima, migracijske prakse su klasnostrukturni fenomen (Rye, 2007) koji uvelike podržavaju škole kao čiji imperativ mobilnosti usklađen s kapitalom mobilnosti kojeg učenici usvajaju u svojim visokostatusnim obiteljima (Corbett 2007). 


\subsection{Nacrt istraživanja mješovite metodologije}

Zbog podistraženosti problematike u Hrvatskom kontekstu odabran je mješoviti nacrt istraživanja kao najprimjereniji za istraživanje fenomena od interesa te kao najusklađeniji s teorijskim polazištima u Bourdieuovoj teoriji prakse i Halfacreeovom modelu ruralnog. Bourdieuov okvir daje osnovne konceptualne alate: kapitali, habitus i polja, čija dinamika zahtijeva holistički pristup $\mathrm{u}$ razmatranju dijalektike struktura i mikro aspekata što se na istraživačkom planu oblikuje u metodološkom pluralizmu uključujući i strukturalistički i konstruktivistički moment ${ }^{12}$. U istom teorijsko-metodološkom smjeru upućuje i Halfacreeov model trijalektike odnosa (2005) koji naglašava potrebu za shvaćanjem povezanosti reprezentacija prostora - načina na koji govorimo o i kako shvaćamo ruralno, uz prostor reprezentacije (materijalne strane ruralnog), te prostornih praksi (dinamika produkcije i reprodukcije ruralnoga). U ovom radu materijalna strana ruralno-urbane dimenzije se razmatra kroz podatke o resursnoj bazi učenika, a prostorna praksa reprodukcije prostora su odluke o studiranju kao dio širih migracijskih praksi mladih, dok je središte interesa poklonjeno zahvaćanju elemenata lokalnog identiteta u reprezentacijama o njihovim životnim prostorima.

Mnogobrojne su prednosti istraživanja mješovitih metodologija u tome što mogu istodobno adresirati i konfirmatorna i eksplanatorna pitanja te omogućavaju i verifikaciju i generiranje teorije, osiguravaju bolje zaključke pod uvjetom da se metode kombiniraju na način koji ujedinjuje snage kvantitativnog i kvalitativnog pristupa, i stvaraju mogućnost za uključivanje divergentnih pogleda pri čemu razilaženje rezultata dvaju pristupa zahtijeva inventivne strategije njihova pomirenja, dublje proučavanje $\mathrm{u}$ iterativnom istraživačkom procesu za odgovaranje na nastajuća pitanja u istoj studiji i/ili generiranje novih istraživačkih pitanja za daljnja istraživanja (Tashikkori, i Teddlie, 2009). Ova studija pokušava potvrditi određene nalaze inozemnih istraživanja, ali je uvelike orijentirana eksplorativno s ciljem ispitivanja elemenata na koje su ukazala istraživanja, ali nisu dublje ispitana u hrvatskom kontekstu.

Dakle, u pozadini pojedinih izbora izgradnje nacrta stoji pragmatička paradigma (Creswell, 2003) koja u obzir uzima odnos između interesa za određeno istraživačko pitanje i mogućnosti njegova izučavanja u danim okolnostima. Upotrebljavaju se metode koje najbolje odgovaraju potrebi odgovaranja na istraživačka pitanja. Logika zaključivanja je i induktivna i

\footnotetext{
12 Ovaj element posebno je naglašen kod Bourdieua u onome što on naziva strukturalni konstruktivizam ili konstruktivistički strukturalizam u pokiušaju nadilaženja antinomije objektivizma i subjektivizma (Bourdieu, 1989). Ovakav pristup ističe metodploški relacionizam (Bourdieu, Wacquant, 1992).
} 
deduktivna, a epistemološki se usklađuju subjektivno i objektivno gledište, ovisno o fazi istraživanja (Tashikkori, i Teddlie, 2009; Creswell, 2003).

U literaturi o primjeni mješovite metodologije moguće je pronaći mnogobrojne klasifikacije, primjere i pristupe izgradnji nacrta mješovite metodologije, a najčešće se uspostavljaju s obzirom na to kakve metode se koriste (kvantitativne/kvalitativne), kojim redoslijedom, te kojem je dijelu istraživanja dan primat (Tashikkori, i Teddlie, 2009; Plano Clark Ivankova, 2016).

Nacrt istraživanja ove studije (prikazan u Tabali 2.1) u najvećoj mjeri odgovara nacrtu kojeg Tashakkori i Teddlie (2009), nazivaju konvergentni paralelni nacrt. Prema njima, takav nacrt opisuje više tijekova/faza istraživanja koja se odvijaju simultano ili s određenim vremenskim odmakom, i pri čemu jedan dio vodi kvalitativno, a drugi kvantitativno istraživačko pitanje, prikupljanje podataka i analitičke tehnike u pokušaju zahvaćanja komplementarnih prednosti svakog od pristupa njihovim odvajanjem. Zaključci oba dijela studije integriraju se na kraju da bi proizveli meta-zaključke čitave studije na bazi dva tijeka istraživanja, što predstavlja dijalketiku podataka samo u završnim fazama istraživanja (Tashakkori, Teddli 2009).

Ipak, ovdje izgrađeni model prilagođen je s obzirom na, s jedne strane, tehnička i vremenska ograničenja, te, s druge strane, opći interes studije usmjere eksplorativnijim pitanjima o ulozi „ruralnosti“ u obrazovnim izborima.

\subsubsection{Tijekovi istraživanja - numerički i narativni podaci}

Ovdje predstavljeno istraživanje imalo je takva dva dijela, ali i jednu podfazu ispitivanja.

Prva je faza obuhvatila prikupljanje kvantitativnih podataka anketnim ispitivanjem na probabilističkom 5\%-om reprezentativnom uzorku učenika završnih razreda trogodišnjih i četverogodišnjih strukovnih škola te gimnazija u Hrvatskoj (N=2110). Tu fazu vodila su dva kvantitativna istraživačka pitanja $s$ interesom da se u hrvatskom kontekstu, nacionalno i regionalno, ispita postojanje razlika između učenika različitog rezidencijalnog podrijetla $s$ obzirom na njihove visokoobrazovne izbore, individualne karakteristike i dostupne im resurse u obiteljskom i školskom kontekstu te da se utvrdi utjecaj rezidencijalnog podrijetla na oblikovanje njihovih visokoobrazovnih odluka.

No, upitnički prikupljeni podaci su imali i dodatnu istodobnu kvantitativnu međufazu vezanu samo uz regionalno ispitivanje. Za uzorak učenika iz regije Slavonija posebno je izgrađen instrument namijenjen zahvaćanju simboličke dimenzije učeničkih odnosa sa zajednicom osjećajima emocionalne vezanosti i pripadnosti te želje za ostankom u mjestu odrastanja 
nakon srednjoškolskog obrazovanja. Eksplorativno, ovu podfazu vodilo je istraživačko pitanje o postojanju razlika između učenika različitog rezidencijalnog podrijetla prema tim dimenzijama lokalnog identiteta te o utjecaju tih dimenzija na visokoobrazovne odluke.

Druga faza prikupljanja podataka isključivo je regionalna i kvalitativna, a provedena je neposredno nakon anketiranja kada je intervjuirano 15 dobrovoljnih maturanata iz Slavonije, ili s kratkim vremenskim odmakom kada je dodatno intervjuirano još 5 učenika/ca, na osnovi kontakt podatka koje su ostavili u upitniku. Uzorak je svrhovit, i ,komparativan“, u tome što je osnovna težnja bila obuhvat što šireg raspona različitih profila učenika s obzirom na njihovo rezidencijalno porijeklo i njihove namjere nastavka školovanja u trenutku završavanja srednjoškolskog obrazovanja.

Intervjui su odabrani kao dodatna strategija prikupljanja podataka, kako bi se narativno nadopunili numerički podaci te da bi se dublje zahvatili elementi u pozadini donošenja odluka o visokom obrazovanju. Intervjui pružaju bogatstvo podataka i dinamiku odnosa u narativnoj formi, odnosno donose uvid u kompleksne veze elemenata koji mogu djelovati kao prepreka/šansa ulasku u visoko obrazovanje. Fokus na individualne odluke u kontekstima školovanja i odrastanja zahvaća razmatranje i habitusnih elemenata izuzev ispitivanja samo njihovih „objektivnijih“ karakteristika, a također praćenje vremenskog tijeka na dimenziji prošlih, sadašnjih iskustava (pozicija) te budućih želja/ciljeva.

Stoga svojom strukturom, istraživanje uključuje spuštanje razine u tijeku analiza fokusiranjem ispitivanja analiza s nacionalne na regionalnu razinu, te produbljivanje s obzirom na uvođenje novih elemenata u kvantitativnu analizu (dodatni instrument) te proširivanje metodologije kvalitativnim odgovaranjem na određena pitanja. Tako je na istraživanje na regionalnoj razini posve mješovitometodno pri čemu se „miješanje“ pojavljuje:

a) na razini uzorkovanja - jer je uzorak Slavonaca dio šireg nacionalnog uzorka, a uzorak intervjuiranih učenika je izabran iz regionalnog uzorka;

b) na razini analize - jer su kvalitativni podaci triangulirani s podacima iz upitnika, a narativni podaci su doprinosili razumijevanju podataka iz upitnika, te

c) na razini interpretacije - jer je konačna interpretacija rezultat oba tijeka istraživanja $\mathrm{s}$ obzirom na pitanje koji elementi osobno razvijenih, obiteljskih, školskih i komunalnih elemenata opisuju učeničke visokoobrazovne odluke, statistički i narativno. 
Drugim riječima, regionalna analiza odgovara na sva četiri postavljena istraživačka pitanja, pri čemu postoji određena dinamika procesa analize podataka i komunikacije dvaju dijelova studije, neizbježna činjenicom da samo jedan istraživač sudjeluje u cijelom procesu.

\subsubsection{Istraživački alati}

Upitnik (Prilog 7.1) obuhvaća više tematskih područja ${ }^{13}$ s interesom za učeničke orijentacije i namjere nakon srednje škole. Upitnik sadrži osnovne sociodemografske i sociogeografske pokazatelje (spol, rezidencijalno porijeklo, lokacija škole koju pohađaju). Uključuje i neke obrazovne pokazatelje (školsi uspjeh na kraju prošlog razreda, tip škole pohađanja). Bourdieuovi koncepti kapitala, habitusa i polja operacionalizirani u dimenzijama pogodnim za ispitivanje anketnim upitnikom. Varijable kulturnog kapitala predstavljaju kulturne prakse učenika i roditelja, posjedovanje kulturnih dobara, obrazovanje roditelja. Socijalni kapital zahvaća se procjenom učenika o utjecaju relevantnih drugih na odluku o studiranju. Ekonomski kapital ispituje se posjedovanjem materijalnih dobara, te radnim statusom roditelja i procjenom financijske obiteljske situacije. Kao indikator obiteljskog habitusa ispituju se stavovi učenika o roditeljskoj podršci i utjecaju, dok se institucionalni habitusi srednje škole ispituju preko stavova o srednjoj školi, a visokoobrazovnog preko procjene utjecaja ugleda odabranih institucija i studija na odluku o njihovom izboru.

Osnovne varijable ishoda predstavljaju namjera studiranja, te za one koji namjeravaju studirati tip studija i mjesta studiranja.

Pitanjima iz protokola za polustrukturirane intervjue (Prilog 7.2) pokušalo se zahvatiti proces donošenja odluka o studiranju i izborima visokog obrazovanja i značenja koja ispitanici daju prijelazu u visokoobrazovni (urbani) okoliš, kontekstima kroz koje se kreću, te kako opisuju svoje početne i buduće pozicije (horizont budućnosti). Moguće je izdvojiti 3 skupa pitanja:

\section{I. set općenitih pitanja u kojima su ispitanici objašnjavali}

1. Zašto su se odlučili studirati te kako su donijeli odluku (kada, s kim su razgovarali utjecaji i informacije)

2. Što njima osobno znači, i što misle da će im donijeti, studiranje

3. Kako ljudi oko njih (u kontekstima odrastanja i školovanja) govore i shvaćaju studiranje

4. Kako oni vide studiranje i studentski život (čemu se vesele, a što ih straši)

\footnotetext{
${ }^{13}$ Tematska područja te način na koje su koncepti operacionalizirani i mjereni detaljno je opisano u Poglavlju 2.3
} 
II. set konkretnijih pitanja o njihovim vlastitim izborima gdje su objašnjavali

1. Zašto i kako su se odlučili za studij koji im je prvi na listi te postoje li alternative

2. Kako su donijeli odluku o studiranju na instituciji i u gradu u kojem žele studirati

3. Njihovo viđenje polja visokog obrazovanja s obzirom na ugled institucije, studija $i$ značaj mjesta studiranja, te pozicioniranje svojih odluka u tom okviru

4. Njihova informiranost o institucijama i studiranju u gradovima (o polju visokog obrazovanja)

5. Procjene vlastitih šansi i prepreka na putu ulaska u visoko obrazovanje (za sebe i općenito) s naglaskom na financijska razmatranja pri donošenju odluke

\section{III. pitanja o viđenju sebe i odnosima s drugima u kontekstima u kojima se kreće}

1. Identifikacije i poimanje sebe te percepcije slika drugih ljudi

2. Svakodnevni život u svom mjestu (aktivnosti, uključenost, odnosi s ljudima) te stavovi o preseljenju i percepcija promjena odnosa s mjestom i ljudima nakon odlaska na studij

3. Projekcija sebe u budućnost (s 30 godina) s obzirom na posao i mjesto stanovanja

\subsubsection{Analiza - statistička i narativna}

Osnovne analitičke procedure slijedile su paralelne tijekove, usklađene s istraživačkim pitanjima i prilagođene vrsti podataka.

Kvantitativne analize uključuju statističke deskriptivne (kontingencijske i tablice frekvencija, mjere asocijacije, centralne tendencije i varijabiliteta) i inferencijalne analitičke postupke (ttest, ANOVA, multipli regresijski modeli) prilagođene vrstama varijabli i hipoteziranim odnosima među njima. Tako se postojanje razlika između učenika različitog rezidencijalnog podrijetla s obzirom na visokoobrazovne izbore i dostupne resurse ispituje hi-kvadrat analizama kada su u pitanje nominalne varijable, dok se na intervalnim varijablama ispituju t-testom kao razlika između ruralnih i urbanih učenika na regionalnoj razini, a ANOVA-om kao razlika između ruralnih, urbanih i metropolitanskih učenika nacionalno.

Potvrđivanje utjecaja rezidencijalnog podrijetla na namjeru studiranja i visokoobrazovne izbore ispitivana je logističkom regresijskom analizom. Izgrađena su dva logistička regresijska modela u 5 koraka u kojima su zavisne varijable bile namjera studiranja (1=namjeravam studirati, $0=$ ne namjeravam studirati $i$ ne znam), izbor tipa studija ( $1=$ sveučilišni studij, $0=$ stručni studij), te izbor mjesta studiranja ( $1=$ =izbor Zagreba, $0=$ ostalo). Njihova robusnost provjeravala se nacionalno $\mathrm{i}$ regionalno, a dodatno $\mathrm{i}$ za pojedine rezidencijalne kategorije učenika. Model je modificiran dodavanjem dimenzija simboličke vrijednosti zajednice kako bi se regionalno ispitao njihov utjecaj na visokoobrazovne izbore 
regionalno. Sve statističke analize podržavao je statistički programski paket SPSS, a rezultati su prikazani grafički i tablično.

Analiza narativnih podataka bila je daleko kompleksnija i kompjutorski ju je dijelom podržavao specijalizirani softver N-Vivo (Bazeley, Jackson, 2013). U početnim stadijima analize provedeno je raščlanjivanjapodataka (inicijalno ili otvoreno kodiranje). Podaci su reorganizira podatke u kategorije/teme kroz stalnu usporedbu (Strauss, Corbin, 1990; Saldaña, 2009).

Nakon početnog iščitavanja i inicijalnog kodiranja intervjua učenika koji je rezultirao velikim brojem tematskih cjelina prema onome o čemu su učenici govorili,

U sljedećem koraku je napravljena dublja analiza pojedinih slučajeva prema osnovnim varijablama iz kvantitativnog ispitivanja prema podacima iz anketnog upitnika. Takav postupak a) predstavljao je daljnju integraciju dviju vrsta podataka nakon razine uzorkovanja, te b) označavao je pokretanje daljnje analize kvalitativnih podataka i razrađivanje tema nakon inicijalnog kodiranja.

Osnovni cilj je bio opisati same slučajeve - 20 individualnih obrazovnih putova učenika prema ulasku u visoko obrazovanje - prema osnovnim varijablama iz anketnog upitnika kako bi se dobila jasnija slika oko toga koliko pojedini slučajevi predstavljaju tipične ili ekstremne slučajeve. Dodatno, svi podaci su nadopunjavani narativnim opisima kako bi se dobila jasnija slika o značenjima koja stoje iza brojčano iskazanih podataka o pojedinim dimenzija mjerenima u anketnom upitniku.

Određeni elementi su analizirani i za „predstavljenost“ poduzorka intervjuiranih iz većeg uzorka učenika Slavonije s obzirom da je prvotna ideja da se napravi izbor svrhovitog uzorka učenika za razgovor bila otežana (vremenska i organizacijska ograničenja te nevoljkost učenika za sudjelovanje $\mathrm{u}$ intervjuima). Prednost alternativnog pristupa nalazi se $\mathrm{u}$ mogućnosti boljeg povezivanja dviju vrsta podataka i snažnijoj vjeri u uvjerljivost podataka i kvalitetu rezultata koji se povezano predstavljaju u nastavku. Važno je istaknuti: te analize nisu provjeravale reprezentativnost jer je proces izbora pojedinih ispitanika upravljen različitim istraživačkim pitanjima; svrha ovih analiza je deskriptivni opis uzorka kako bi se dobila jasnija slika o osnovnim karakteristikama intervjuiranih učenika, te njihovoj zastupljenosti u uzorku intervjuiranih, odnosno uvjerljivosti da određeni citati, značenja i shvaćanja zaista doprinose boljem razumijevanju kvantitativnih podataka. 
U analizi, svakom učeniku je dodijeljen KOD u obliku pseudonima i pridružene su im oznake za njihovo rezidencijalno podrijetlo, te tip škole koji završavaju s lokacijom.

S obzirom na učeničko rezidencijalnom podrijetlu, ukupno je postojalo 4, odnosno 5 , mogućih kodova koji su prenosili informacije o rezidencijalnom podrijetlu učenika, a prikazani su sa svojim značenjem u Tabeli 2.5. Oznake su bile skraćenice RRP za ruralno i URP za urbano rezidencijalno podrijetlo. Sufiks koda je pak ukazivao na to o kojem tipu naselja se radi kada su u pitanju ruralna, odnosno o kojem stupnju centraliteta se radi kada su u pitanju urbana naselja odrastanja.

Tabela 2.5 Kodovi slučajeva prema rezidencijalnom podrijetlu sa značenjima

\begin{tabular}{cl}
\hline KODOVI: REZIDENCIJALNO PODRIJETLO & Značenje: naselje odrastanja \\
\hline RRP_TP & Tržišno orijentirano poljoprivredno naselje \\
\hline RRP_DSJ & Dinamično strukturno jače naselje \\
\hline URP_nc & Urbano naselje nepotpunog centraliteta \\
\hline URP_mg & Subregionalni centri i regionalni centri slabiji \\
\hline URP_VG & Regionalni centar jači i makroregionalni centar \\
\hline
\end{tabular}

Učenici ruralnog rezidencijalnog podrijetla mogli su imati jedan od dva sufiksa koja su označavala dva dominantna tipa ruralnih naselja u regiji Slavonija: _TP se odnosio na tržišno orijentirano poljoprivredno naselje, dok je sufiks_DSJ predstavljao dinamično strukturno jača naselja. S druge strane, učenici urbanog rezidencijalnog podrijetla također su mogli imati jedan od dva kodna sufiksa:_mg označavao je gradove manjeg stupnja centraliteta, odnosno subregionalne centre i regionalne centre slabije, dok je oznaka_VG označavala one učenike odrasle u velikim gradovima, to jest jačim regionalnim centrima i makroregionalnom centru. Poseban kod URP_nc uveden je za učenika sa specifičnom situacijom odrastanja u naselju izraženih urbanih karakteristika, ali bez usluge srednjoškolskog obrazovanja u naselju odrastanja: kod je označavao da njegov centralitet toga grada nije potpun ( $n \boldsymbol{n c}$ ).

Tabela 2.6 Kodovi slučajeva prema školovanju učenika za tip i lokaciju škole sa značenjima

\begin{tabular}{|c|c|}
\hline KODOVI: školovanje & Značenje koda \\
\hline $3 \mathrm{SS}$ & trogodišnja strukovna škola \\
\hline $4 \mathrm{SS}$ & četverogodišnja strukovna škola \\
\hline GIM & gimnazija \\
\hline _mg & ... u malom gradu (subregionalnom centru ili slabijem regionalnom centru) \\
\hline _VG & $\begin{array}{l}\text {... u velikom gradu (jačem regionalnom centru ili makroregionalnom } \\
\text { centru) }\end{array}$ \\
\hline
\end{tabular}


S obzirom na školovanje učenika, postojalo je 6 mogućih oznaka (Tabela 2.6) sastavljenih od dva dijela. Opća podjela odnosila se na tip škole s obzirom na trogodišnje i četverogodišnje strukovne škole te gimnazije što su predstavljale oznake - 3SS̆, 4SŠ i GIM. Općim kodovima pridruženi su sufiksi koji su prenosili informacije o centralitetu grada u kojem su škole smještene: sufiks_mg odnosio se na subregionalne centre i regionalne centre slabije, dok je sufiks_VG označavao lokaciju škole u jačem regionalnom ili makroregionalnom centru.

Analiza samih intervjua otežana je činjenicom heterogenog tijela ispitanika koje je otežalo razvijanje i objedinjavanje kategorija. U konačnici se, ipak, nije odustajalo od traženja imena jedinstvenog procesa u pozadini svih individualnih priča. Dakle, konačni cilj kvalitativnog ispitivanja bio je opis i razumijevanje elemenata generalnog procesa razvoja orijentacije prema visokom obrazovanju i donošenja odluka u obliku skupne analize slučaja, ali i zahvaćanje specifičnosti kroz pojedine narative slučajeva. Analiza je usmjerena na pronalazak i opis prostornih aspekte koji se pojavljuju u procesu donošenja odluka o visokom obrazovanju maturanata koji su se dali iščitati iz učeničkih narativa o svojim obrazovnim iskustvima i budućim namjerama u vremenskoj i socioprostornoj dimenziji.

Predstavljeni nalazi rezultat su analiza u kojima su prvo analizirani kvantitativni, te je provedena prva razina analiza kvalitativnih podataka u procesu otvorenog kodiranja (kako bi se smanjila velika količina nestrukturiranih podataka na broj kodova s kojima se može baratati u daljnjem procesu analize. Osnovna značenjska jedinica (Tesch 1990) u ovom tijeku je bila vrlo bliska podacima i izdvajala je osnovne aspekte ili dimenzije fenomena. Daljnji koraci analize ticali su se dubljeg razumijevanja pojedinih priča s obzirom na podatke koje su zabilježili u upitniku i opisali u intervjuu, čime su se numeričkim podacima davala dublja narativna značenja. Ispitanici su također svrstani u nekoliko kategorija od kojih su ključne bile one o rezidencijalnom podrijetlu, tipu škole te društvenom statusu što su dimenzije koje su omogućile komparativnu analizu dijelova intervjua unutar pojedinih slučajeva, kao i među njima, te uočavanje konatrdiktornosti i potrebe da se razumiju diskrepantne informacije. U procesu analiza razvijene su i specifične kategorije kodova s informacijama koje su opisivale procese, emocije i identitetske odrednice (Saldaña, 2009; Nagy Hesse-Biber, 2010) koji su se u daljnjim analizama razmatrali u povezivanju kodova. Iščitavanje litertaure je također pomoglo razumijevanje podataka, Tijekovi analiza i interpretacija odvijali su se korištenjem memoa - specifičnog alata N-Vivo programa te je korištenje softverskog programa bilo ograničeno. 
Strategije za utvrđivanje kvantitativne valjanosti i pouzdanosti uključuju empirijsku validaciju konstrukata i statističko testiranje, odnosno provjeru psihometrijskih karakteristika instrumenata pomoću Cronbach alfa koeficijenta i faktorske analize. Strategije za utvrđivanje kvalitativne kredibilnosti, pouzdanosti (trustworthiness) i prenosivosti (transferability) uključuju, vođenje bilješki o procesu donošenja istraživačkih odluka, te triangulacijske tehnike (Shenton, 2004; Cho, Trent, 2006; Seale, 2002; Morse, 2002).

Završna faza obuhvaća integraciju i sintetiziranje zaključaka dva tijeka istraživanja. Kvaliteta tako dosegnutih zaključaka ovisi o kvaliteti svakog dijela istraživanja i utvrđivanju, s jedne strane, kvantitativne interne valjanosti i valjanosti statističkih zaključaka te kvalitativne kredibilnosti i pouzdanosti/uvjerljivosti (trustworthiness); s druge strane, kvantitativne poopćivosti i eksterne valjanosti te kvalitativne prenosivost (transferability) zaključaka u druge kontekste. Strategije za njihovo postizanje uključuju empirijsku validaciju konstrukata i statističko testiranje te revizijski trag (audit trail), odnosno opis procesa donošenja odluka vođenjem bilješki, te triangulacijske tehnike.

Tabela 2.7 Nacrt istraživanja - osnovni ciljevi, pitanja i procedure

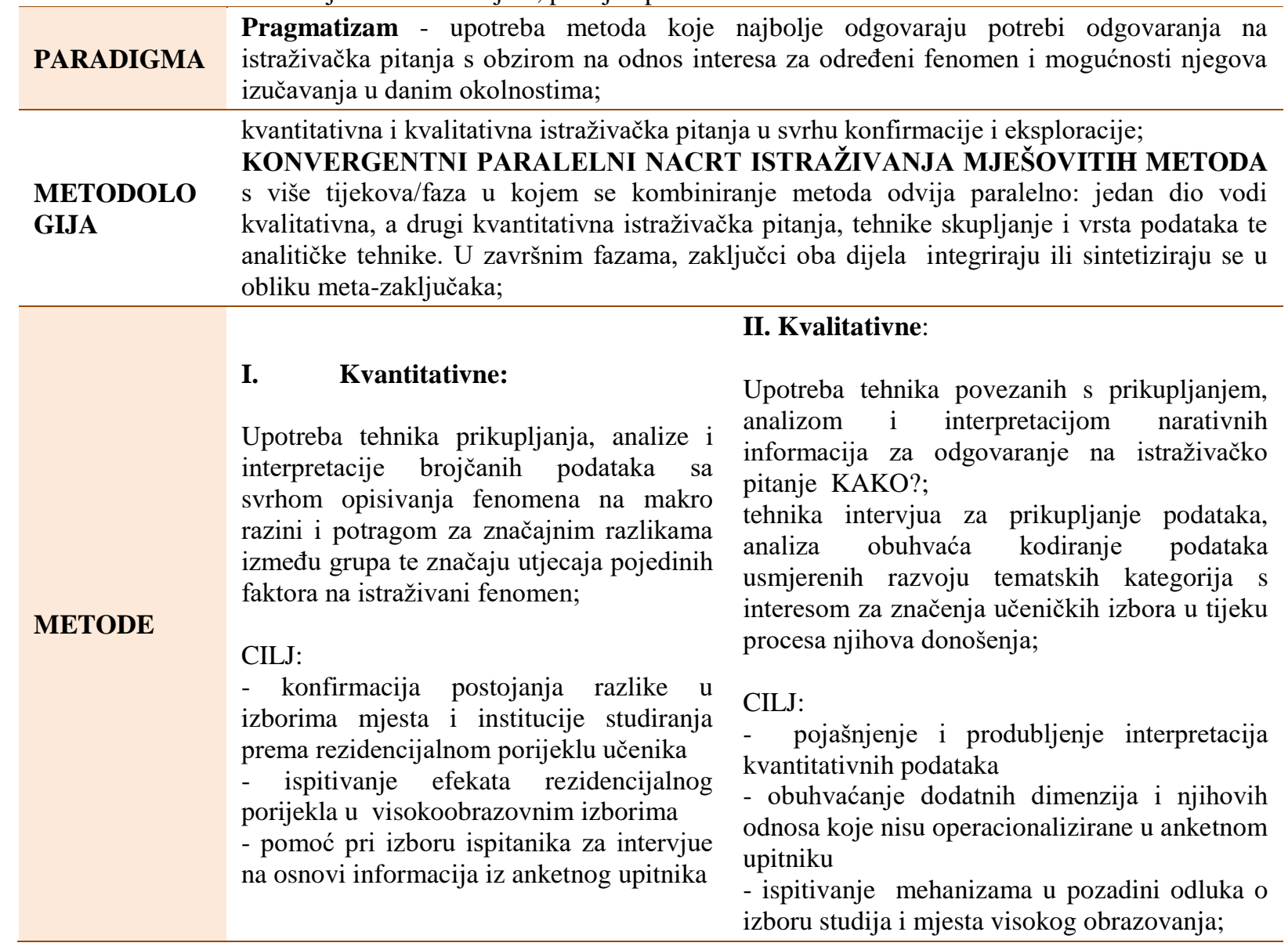


- postavljanje novih hipoteza za buduća ispitivanja

Probabilistički 5\%-tni uzorak učenika $(\mathrm{N}=2106)$ i završnih razreda trogodišnjih i četverogodišnjih srednjih škola u RH $(\mathrm{N}=98)$

- obrada podataka ureda državne uprave u županijama o ukupnom broju učenika i učenica $\mathrm{u}$ pojedinim tipovima škola $\mathrm{i}$ razredima;

TEHNIKE UZORKOVA NJA

- kvantitativni izračun 5\% od ukupnog broja učenika/ca i ukupnog broja razreda prema tipu škole (klaster uzorkovanje) na razini županije, regije i države (stratificirano uzorkovanje);

KVANTITATIVNA: anketni upitnik

- generira veliki broj informacija o širokom rasponu tema (kapitali, habitus i polje, obrazovne aspiracije i namjere,

STRATEGIJE stavovi učenika prema obrazovanju te želja PRIKUPLJAN uzlazne mobilnosti; za regiju Slavonija: JA dodatna tema o vezanosti za mjesto PODATAKA odrastanja, pripadnost i uključenost u život zajednice, želja za doprinosom zajednici te želja za ostankom, odnosno preseljenjem nakon srednjoškolskog obrazovanja);
Neprobabilistički svrhoviti uzorak iz okvira probabilističkog uzorka razreda u kojima je provedeno anketiranje u Slavoniji $(\mathrm{N}=20)$

(olakšava izbor ispitanika i osnova je povezivanja dva tijeka istraživanja)

\section{Svrhovito uzorkovanje}

- identificiranje slučajeva iz raspona varijacija da bi se zahvatila heterogenost populacije;

- izbor se vršio iz statističkog (probabilističkog) uzorka među ispitanicima koji su ispunili anketni upitnik;

- uzorak se razvija kroz sami proces istraživanja

- dobrovoljnost sudjelovanja

- ograničenja: terenski rad (paralelna provedba intervjuiranja s anketnim ispitivanjem; vrijeme)

KVALITATIVNA: intervjui malog broja ispitanika generiraju dubinske informacije kroz odgovore na pitanja (o njihovom obrazovnom putu, obrazovnim željama, percepcijama konteksta kroz koje se kreću i očekivanjima od visokog obrazovanja);

\begin{tabular}{|c|c|c|}
\hline $\begin{array}{l}\text { TEHNIKE } \\
\text { PRIKUPLJA- } \\
\text { NJA } \\
\text { PODATAKA }\end{array}$ & $\begin{array}{l}\text { - većinom zatvorenih pitanja s unaprijed } \\
\text { određenim kategorijama odgovora } \\
\text { - format odgovora većinom je povezan } \\
\text { skalama Likertovog tipa s procjenama na } 5 \\
\text { stupnjeva; } \\
\text { Otvorena pitanja }\end{array}$ & $\begin{array}{l}\text { Polustrukturirani protokoli za intervjue } \\
\text { teme i pitanja unaprijed definirani u obliku } \\
\text { skice; redoslijed pitanja i njihov oblik nije } \\
\text { strogo postavljen; } \\
\text { istraživač odlučuje i o redoslijedu pitanja i } \\
\text { njihovom obliku u tijeku intervjua; }\end{array}$ \\
\hline PODACI & $\begin{array}{l}\text { - numerički kvantitativni podaci } \\
\text { - odgovori na otvorenim pitanjima }\end{array}$ & Narativni podaci \\
\hline $\begin{array}{l}\text { ANALIZA } \\
\text { PODATAKA } \\
\text { Strategije } \\
\text { i tehnike }\end{array}$ & $\begin{array}{l}\text { - statističke - testiranje hipoteza: } \\
\text { 1) deskriptivne (tablice frekvencija, } \\
\text { kontingencijske tablice, mjere asocijacije, } \\
\text { centralne tendencije i varijabiliteta); } \\
\text { 2) inferencijalne (t-test, ANOVA, } \\
\text { logistička regresija) }\end{array}$ & $\begin{array}{l}\text { - iterativna analiza - kretanje naprijed-i-nazad } \\
\text { između podataka i nastajućih kategorija/tema; } \\
\text { - eklektičnost - korištenje miješanih dostupnih } \\
\text { analitičkih alata; } \\
\text { - strategije koje razlamaju (otvoreno kodiranje) } \\
\text { i reorganiziraju podatke kroz konstantnu } \\
\text { komparativnu metodu }\end{array}$ \\
\hline CILJ & $\begin{array}{l}\text { - deskripcija socioekonomskih i } \\
\text { - ispitivanje razlika na varijablama izbora } \\
\text { visokog obrazovanja između ispitanika s } \\
\text { različitim rezidencijalnim porijeklom; } \\
\text { - provjera utjecaja/ doprinosa } \\
\text { rezidencijalnog porijekla na namjeru } \\
\text { studiranja i izbore visokog obrazovanja } \\
\text { - određivanje doprinosa varijabli } \\
\text { emocionalne } \\
\text { pripadnosti i želje za ostankom u mjestu } \\
\text { odrastanja u izborima visokog } \\
\text { obrazovanja; }\end{array}$ & $\begin{array}{l}\text { - produbljenje (i proširenje) interpretacija } \\
\text { kvantitativnih podataka } \\
\text { - obuhvaćanje dodatnih dimenzija/faktora i } \\
\text { njihovih odnosa koje nisu operacionalizirane u } \\
\text { anketnom upitniku } \\
\text { - ispitivanje mehanizama donošenja odluka o } \\
\text { namjeri studiranja te izboru studija i mjesta } \\
\text { visokog obrazovanja; } \\
\text { - postavljanje novih hipoteza za buduća } \\
\text { ispitivanja }\end{array}$ \\
\hline
\end{tabular}




\begin{tabular}{|c|c|c|}
\hline $\begin{array}{l}\text { Pitanja } \\
\text { validnosti } \\
\text { i pouzdanosti }\end{array}$ & $\begin{array}{ll}\text { 1. } & \text { Valjanost (validity) } \\
\text { 2. } & \text { Pouzdanost (reliability) }\end{array}$ & $\begin{array}{l}\text { Pouzdanost/uvjerljivost (trustworthiness): } \\
\text { 1. Kredibilitet (credibility) } \\
\text { 2. Prenosivost (transferability) } \\
\text { 3. Ovisnost (dependability) } \\
\text { 4. } \\
\text { Potvrdljivost (confirmability) }\end{array}$ \\
\hline $\begin{array}{l}\text { Strategije } \\
\text { osiguravanja } \\
\text { kvalitete } \\
\text { podataka i } \\
\text { zaključaka }\end{array}$ & $\begin{array}{l}\text { - pilot istraživanje - empirijska provjera } \\
\text { upitnika; } \\
\text { - think-aloud provjera razumljivosti, } \\
\text { strukture, preglednosti upitnika i } \\
\text { formulacija pitanja u razgovoru s } \\
\text { ispitanicima } \\
\text { - standardni statistički testovi provjere } \\
\text { metrijskih karakteristika instrumenata; } \\
\text { - testovi statističke značajnosti }\end{array}$ & $\begin{array}{l}\text { - revizijski trag (audit trail) - opis procesa } \\
\text { donošenja odluka vođenjem bilješki; } \\
\text { - triangulacijske tehnike } \\
\text { - korištenje dodatnih podataka - potvrda } \\
\text { opravdanosti istraživačkog pitanja u literaturi i } \\
\text { kvantitativnim podacima }\end{array}$ \\
\hline Zaključci & $\begin{array}{l}\text { - povezivanje ishoda tijekova istraživanja } \\
\text { usporedbom rezultata i zaključaka }\end{array}$ & identifikacija područja slaganja i razilaženja \\
\hline
\end{tabular}




\subsection{Koncepti i operacionalizacija (varijable i instrumenti)}

U svrhu dobivanja uvida u to u kojoj su mjeri različiti elementi životnog i školskog konteksta učenika različitog rezidencijalnog podrijetla povezani s njihovim obrazovnim odlukama, upitnik je sadržavao pitanja o socijalnim, kulturnim te ekonomskim aspektima njihovih životnih okruženja, te njihovim obrazovnim karakteristikama i budućim planovima nakon završavanja srednje škole. Pojedine skale prilagođene su na osnovi rezultata upotrebe Bourdieuovih ili drugih koncepata u drugim istraživanjima, a podaci o izvorima navode se u fusnotama, dok je druge skale razvio istraživački tim projekta u sklopu kojeg su prikupljeni podaci. Za sve korištene skale prikazuju se rezultati analiza faktorske strukture i metrijskih karakteristika.

\section{Osnovni sociodemografski i sociogeografski pokazatelji}

Među osnovnim sociodemografskim informacijama, upitnik je prikupljao podatke o:

Spol učenika. Učenici su bilježili odgovor između dvije ponuđene opcije 1=ženski i $2=$ muški.

S obzirom na ciljeve studije značajni su bili podaci o sociogeografskim informacijama: Rezidencijalno podrijetlo. Učenike se tražilo da, kao odgovor na pitanje „Gdje si proveo veći dio života prije upisa u srednju školu'“, upišu točan naziv mjesta svog odrastanja. Njihovi odgovori su kodirani tako da su svim gradskim naseljima dani kodovi prema centralitetu, a ruralnim naseljima prema tipu koji proizlazi iz Lukićeve klaster analize (2011). Klasifikacija je obuhvaćala 7 klastera ruralnosti i 6 stupnjeva urbanosti prema centralitetu naselja. Za postrebe usporednih analiza navedena varijabla reklasificirana je u: $1=$ ruralno rezidencijalno podrijetlo (učenici odrasli u ruralnim (i urbaniziranim) naseljima), 2=urbano rezidencijalno podrijetlo (učenici odrasli u gradskim naseljima), 3 =metropolitansko rezidencijalno podrijetlo (učenici odrasli u glavnom gradu).

Lokacija škole. Informaciju o lokaciji škole u kojima je provedeno anketiranje naknadno su kodirane s obzirom na stupanj centraliteta, odnosno funkcijama koje određena gradska naselja ispunjavaju u regionalnoj mreži naselja. Zadržane su 3 kategorije: 1=glavni grad (učenici koji škole pohađaju u glavnom gradu), 2=veliki grad (učenici koji škole pohađaju u makroregionalnim i jačim regionalnim centrima Hrvatske), te 3=mali grad (učenici koji škole završavaju u gradovima koji su slabiji regionalni i subregionalni centri). 


\section{Obrazovni ishodi}

Osnovni obrazovni ishodi od interesa u radu, i time glavne zavisne varijable dijela analiza, su učenička namjera studiranja, te izbori tipa studija i mjesta studiranja za one koji namjeravaju studirati.

Namjera studiranja ispitala se tako da su se učenici na pitanje „Namjeravaš li studirati'“ odlučivali između odgovora: „da“, „,ne“ ili „ne znam“. Za potrebe logističke regresijske analize, varijabla je naknadno rekodirana u 2 kategorije: $1=$ namjeravam studirati i $0=$ ne namjeravam studirati (što je uključivalo i one neodlučne).

Izbor željenog tipa studija. Učenici su upisivali naziv studija koji žele upisati (prvi izbor). Naknadno, učenički odgovori su rekodirani tako da je klasifikacija odgovarala na pitanje o tipu studija: „sveučilišni studij“ i „stručni studij“. Dodatno, učenički odgovori klasificirani su i prema znanstvenim područjima u trihotomnu klasifikaciju: „studij u tehničkom području“, „studij u društveno-humanističkom području“ i ,studij u nekom drugom području““14.

Izbor željenog grada studiranja. Učenici su upisivali ime gradu u kojem bi željeli upisati studij. Naknadno, učenički odgovori su rekodirani prema tome je li grad u kojem žele studirati: „Zagreb“, „makroregionalno središte“, ili „grad manjeg stupnja centraliteta“. Za potrebe logističke regresijske analize varijabla je naknadno rekodirana u 2 kategorije: 1=izbor Zagreba kao željenog mjesta studiranja i $0=$ izbor mjesta studiranja koje nije Zagreb ${ }^{15}$.

\section{Individualne obrazovne i kulturne karakteristike te orijentacije učenika}

Upitnik je sadržavao i pitanja koja se odnose na ostale individualne obrazovne karakteristike učenika koje možemo shvatiti kao pokazatelje njihova osobnog obrazovnog (i/ili aspiracijskog) habitusa (Baker, Brown, 2008), a koje su povezane i razvijaju se u kontekstima odrastanja i školovanja u ovisnosti o dostupnim resursima. U tom smislu, upitnik je sadržavao pitanja o učeničkom školskom uspjehu i tipu škole, vrijednosti koju pripisuju učenju te njihovim kulturnim kompetencijama. Dodatno, učenici su odgovarali i na pitanja o svojim obrazovnim aspiracijama i očekivanjima, te shvaćanju koliko im se studiranje podrazumijeva i dužini donošenja odluke o studiranju. U konačnici, kao dio projekcije njihova horizonta

\footnotetext{
${ }^{14}$ Dataljniji opis i slikovni prikaz nalazi se u Poglavlju 3.3.2..

${ }^{15}$ Dataljniji opis i slikovni prikaz nalazi se u Poglavlju 3.3.2.
} 
budućnosti i onoga što žele postići u budućnosti, a u čemu obrazovanje ima veliku ulogu, učenici su pitani i o želji za društvenom mobilnošću u odnosu na poziciju svojih roditelja.

Tip škole. Učenike se tražilo da zabilježe koji tip škole pohađaju između izbora 1=trogodišnja strukovna škola, $2=$ četverogodišnja strukovna škola, ili 3=gimnazija, a također su upisivali i naziv obrazovnog programa kojeg završavaju.

Opći školski uspjeh učenika. Učenike se tražilo da upišu svoj opći školski uspjeh na kraju prošlog razreda (škol. god. 2012./2013.), a upisivali su vrijednost s jednom decimalom.

Obrazovne orijentacije obuhvaćaju skup varijabli koje ispituju učeničke obrazovne aspiracije i procjenu njihova ostvarenja (očekivanja), te podrazumijevanje odluke o studiranju i dužinu promišljanja odluke o studiranju kao elemente njihova osobnog obrazovnog habitusa.

Obrazovne aspiracije. Učenicima je postavljeno pitanje o tome koji stupanj obrazovanja žele postići, pri čemu su se odlučivali između odgovora: „završena srednja škola“, „završen preddiplomski studij“, ,završen diplomski studij“, i „,završen poslijediplomski studij“.

Obrazovna očekivanja. Učenici su procjenjivali koji stupanj obrazovanja zaista očekuju da će postići, odabirući jednu od sljedećih kategorija: „završena srednja škola“, „završen preddiplomski studij“, ,završen diplomski studij“, i „,završen poslijediplomski studij“.

Podrazumijevanje studiranja. Od učenika se tražilo da procijene koja ih od tri tvrdnji najbolje opisuje: „Podrazumijeva mi se da ću upisati studij“, „Podrazumijeva mi se da neću upisati studij“, te „Niti mi se podrazumijeva, niti ne podrazumijeva da ću upisati studij“.

Dužina promišljanja odluke o studiranju. Učenike se pitalo koliko dugo su razmišljali o odluci hoće li uopće ići na studij. Mogući odgovori su uključivali sljedeće opcije: „nisam uopće razmišljao“, „kratko sam razmišljao“, „osrednje sam razmišljao“, te „dugo sam razmišljao".

Vrijednost učenja ${ }^{16}$. Učenici su na ljestvici od 1=uopće se ne slažem, do $5=\mathrm{u}$ potpunosti se slažem procjenjivali kakvu vrijednost učenje ima za njih, odnosno koliko se slažu s tvrdnjama o tome zašto uče: „,... da bih razvio vještine koje bi mogle biti korisne za posao“, „... jer je

\footnotetext{
${ }^{16}$ Instrument je modificirana verzija instrumenta Vrijednost obrazovanja namijenjen za ispitivanje elemenata učeničkog habitusa. Izvorno je korišten u: A. Sullivan, 2003. Cultural Capital, Rational Choice and Educational Inequalities. $\mathrm{PhD}$ Thesis
} 
učenje vrijedno samo po sebi“, „...kako bih u budućnosti lakše našao/la posao“, „...zbog osobnog razvoja“, „... kako bih mogao/la nastaviti školovanje“. Konačna skala nastala je zbrajanjem vrijednosti slaganja na pojedinim tvrdnjama nakon što je analiza faktorske strukture pokazala da se radi o jednodimenzionalnoj strukturi instrumenta (Tablica 2.8).Ekstrahirani faktor objašnjava $60 \%$ varijance $\mathrm{s}$ visokim koeficijentom (Crombach $a=0,83$ ) unutarnje konzistentnosti.

Tabela 2.8 Rezultati analize glavnih komponenti instrumenta Vrijednost pripisana učenju

\begin{tabular}{|c|c|c|c|c|}
\hline $\begin{array}{l}\text { Naziv } \\
\text { dimenzije }\end{array}$ & $\begin{array}{c}\text { Objašnjena } \\
\text { varijanca }\end{array}$ & $\begin{array}{l}\text { Cronbachov } \\
\text { a }\end{array}$ & Varijable & $\lambda$ \\
\hline \multirow{5}{*}{$\begin{array}{l}\text { Vrijednost } \\
\text { učenja }\end{array}$} & \multirow{5}{*}{$60 \%$} & \multirow{5}{*}{0,83} & Učim prvenstveno zbog svog osobnog razvoja & 0,82 \\
\hline & & & $\begin{array}{l}\text { Učim prvenstveno kako bih u budućnosti lakše našao/la } \\
\text { posao }\end{array}$ & 0,82 \\
\hline & & & Učim prvenstveno jer je učenje vrijedno samo po sebi & 0,81 \\
\hline & & & $\begin{array}{l}\text { Učim prvenstveno da bih razvio/la vještine koje bi mi } \\
\text { mogle biti korisne za posao }\end{array}$ & 0,76 \\
\hline & & & $\begin{array}{l}\text { Učim prvenstveno kako bih mogao/la nastaviti } \\
\text { školovanje }\end{array}$ & 0,64 \\
\hline
\end{tabular}

Želja za društvenom mobilnošćc ${ }^{17}$. Pitanje želje za društvenom mobilnošću operacionalizirano je u obliku instrumenta sa 6 tvrdnji koje su učenici procjenjivali na skali Likertovog tipa od $1=$ uopće se ne odnosi na mene, do $5=\mathrm{u}$ potpunosti se odnosi na mene. Tvrdnje su bile: „Važno mi je da imam bolji posao nego moji roditelji“, „Želim postići viši stupanj obrazovanja od mojih roditelja“, „Važno mi je da kasnije u životu zarađujem barem koliko i moji roditelji“, „Želim imati jednako visok položaj na društvenoj ljestvici kao i moji roditelji“‘, te „Strah me da kasnije u životu ne budem na nižem položaju od mojih roditelja na društvenoj ljestvici“. Konačna varijabla Želja za društvenom mobilnošću kreirana je nakon provedene analize glavnih komponenti čiji su rezultati prezentirani u Tablici 2.9.

Iako je objašnjenost dimenzije nešto slabija (43\%) rezultati su pokazali da se radi o 6 čestica koje imaju zadovoljavajuću unutarnju konzistentnost (Cronbach $a=0,72$ ) u mjerenju navedenog koncepta. Ovi rezultati bili su osnova kreiranja varijable Želja za društvenom mobilnošću koja je nastala zbrajanjem vrijednosti na svih 6 čestica.

\footnotetext{
${ }^{17}$ Instrument namijenjen ispitivanju koncepta izbjegavanja rizika i opisanog u: Van de Werfhorst, H.G., A. Sullivan, i S.-Y. Cheung. 2003. Social Class, Ability and Choice of Subject in Secondary and Tertiary Education in Britain. British Educational Research Journal 29 (1): 41-62.
} 
Tabela 2.9 Rezultati analize glavnih komponenti instrumenta Želja za društvenom mobilnošću

\begin{tabular}{|c|c|c|c|c|}
\hline $\begin{array}{l}\text { Naziv } \\
\text { dimenzije }\end{array}$ & $\begin{array}{c}\text { Objašnjena } \\
\text { varijanca }\end{array}$ & $\begin{array}{l}\text { Cronbachov } \\
\qquad a\end{array}$ & Varijable & $\lambda$ \\
\hline \multirow{6}{*}{$\begin{array}{l}\text { Želja za } \\
\text { društvenom } \\
\text { mobilnošću }\end{array}$} & \multirow{6}{*}{$43 \%$} & \multirow{6}{*}{0,72} & Želim postići viši stupanj obrazovanja od mojih roditelja & 0,76 \\
\hline & & & Važno mi je da imam bolji posao nego moji roditelji & 0,76 \\
\hline & & & $\begin{array}{l}\text { Važno mi je da kasnije u životu zarađujem barem koliko } \\
\text { i moji roditelji }\end{array}$ & 0,68 \\
\hline & & & $\begin{array}{l}\text { Mojim roditeljima se ne bi svidjelo kada bih imao/la } \\
\text { lošiji posao od njihovog }\end{array}$ & 0,62 \\
\hline & & & $\begin{array}{l}\text { Želim imati jednako visok položaj na društvenoj ljestvici } \\
\text { kao i moji roditelji }\end{array}$ & 0,58 \\
\hline & & & $\begin{array}{l}\text { Strah me da ću kasnije u životu imati niži status u } \\
\text { društvu od mojih roditelja }\end{array}$ & 0,48 \\
\hline
\end{tabular}

Kulturne kompetencije učenika zahvatilo se pitanjima o učestalosti njihovih čitalačkih i kulturnih aktivnosti te sudjelovanju u izvanškolskim aktivnostima koje su shvaćene kao pokazatelji kulturtnog kapitala učenika.

Kulturne prakse učenika ${ }^{18}$. Učenici su na skali od 4 stupnja (1=nijednom, $2=$ otprilike 1 ili 2

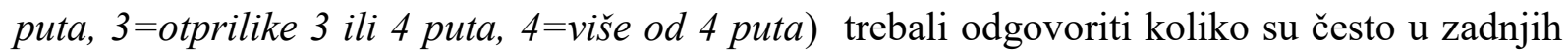
godinu dana: ,posjetili muzeje ili umjetničke galerije“, „,ǐli na kazališne predstave“, odnosno „posjetili operu, balet ili koncerte klasične glazbe“.

Učeničke čitalačke prakse ${ }^{19}$. Učenike se na skali od 5 stupnjeva ( $1=$ nikad ili gotovo nikad, $2=n e k o l i k o$ puta godišnje, 3=otprilike jednom mjesečno, 4=nekoliko puta mjesečno, $5=n e k o l i k o$ puta tjedno ili svaki dan) pitalo koliko često čitaju navedene tipove tekstova, a da nisu školska obaveza: „članke o unutarnjoj politici ili kulturi u dnevnim ili tjednim novinama“, „popularno-znanstvene časopise ili časopise kulturne tematike“, „publicistiku“, „prozu i poeziju“.

U oba slučaja, provedene su analize faktorske strukture instrumenata čiji su osnovni rezultati (Tablica 2.10) potvrdili da se radi o jednodimenzionalnim konstruktima sa zadovoljavajućim razinama objašnjene varijance i unutarnje konzistentnosti čestica svakog instrumenta.

Saturacije tri čestice objasnile su 69\% varijance dimenzije učeničkih kulturnih praksi s pouzdanošću mjerenja od $a=0,77$ (Cronbach), te je na osnovi tih rezultata kreirana varijabla Učeničke kulturne prakse zbrajanjem vrijednosti na pojedinim česticama.

\footnotetext{
18 Instrument je modificirana verzija instrumenta Učenička participacija u elitnoj i popularnoj kulturi namijenjenog za ispitivanje kulturnog kapitala u upitniku PISA istraživanja 2009. godine.

${ }_{19}$ Instrument je modificirana verzija instrumenta Učeničke čitalačke prakse namijenjenog za ispitivanje kulturnog kapitala u upitniku PISA istraživanja 2009. godine.
} 
Četiri čestice različitih publikacija koje čitaju učenici, čija je unutarnja konzistentnost Cronbach $a=0,67$, objasnile su 51\% varijance dimenzije Učeničkih čitalačkih praksi. Također su vrijednosti na pojedinim česticama zbrojene.

Tabela 2.10 Rezultati analize glavnih komponenti instrumenta Učeničke kulturne prakse i Učeničke čitalačke prakse

\begin{tabular}{|c|c|c|c|c|}
\hline $\begin{array}{l}\text { Naziv } \\
\text { dimenzije }\end{array}$ & $\begin{array}{l}\text { Objašnjena } \\
\text { varijanca }\end{array}$ & $\begin{array}{l}\text { Cronbachov } \\
\text { a }\end{array}$ & Varijable & $\lambda$ \\
\hline \multirow{3}{*}{$\begin{array}{l}\text { Učeničke } \\
\text { kulturne } \\
\text { prakse }\end{array}$} & \multirow{3}{*}{$69 \%$} & \multirow{3}{*}{0,77} & U zadnjih godinu dana išao/la na kazališne predstave & 0,85 \\
\hline & & & $\begin{array}{l}\text { U zadnjih godinu dana posjetio/la muzeje ili umjetničke } \\
\text { galerije }\end{array}$ & 0,85 \\
\hline & & & $\begin{array}{l}\text { U zadnjih godinu dana posjetio/la operu, balet ili koncerte } \\
\text { klasične glazbe }\end{array}$ & 0,79 \\
\hline \multirow{4}{*}{$\begin{array}{l}\text { Učeničke } \\
\text { čitalačke } \\
\text { prakse }\end{array}$} & \multirow{4}{*}{$51 \%$} & \multirow{4}{*}{0,67} & $\begin{array}{l}\text { Publicistiku (npr. putopise, biografije poznatih osoba, } \\
\text { knjige povijesne tematike) }\end{array}$ & 0,81 \\
\hline & & & $\begin{array}{l}\text { Popularno-znanstvene časopise ili časopise kulturne } \\
\text { tematike (npr. Geo, National Geographic, Zarez, Vijenac, } \\
\text { Priroda) }\end{array}$ & 0,73 \\
\hline & & & $\begin{array}{l}\text { Članke o unutarnjoj politici, vanjskoj politici ili kulturi u } \\
\text { dnevnim ili tjednim novinama (uključujući i web) }\end{array}$ & 0,68 \\
\hline & & & Prozu i poeziju (romane, pripovijetke, priče, i sl.) & 0,63 \\
\hline
\end{tabular}

Učeničke izvanškolske aktivnosti. Učenici su u formi dihotomnih ,,da-ne“ odgovora $(0=n e$, $1=d a$ ) navodili jesu li barem godinu dana pohađali aktivnosti izvan škole poput „dramske grupe“, „baleta ili suvremenog plesa“, „pjevačkog zbora“, ,glazbene škole“ te „škole stranih jezika ili individualne poduke iz stranih jezika“. Ukupni rezultat je nastao zbrajanjem vrijednosti na svih 5 čestica.

\section{Obiteljski ekonomski i kulturni resursi}

U skladu s postavljenim istraživačkim pitanjima i teorijskim polazištima u Bourdieuovoj teoriji najveći dio upitnika posvećen je ispitivanju resursne dostupnosti u obiteljskom kontekstu. Za odgovaranje na pitanja o strukturi obiteljskog ekonomskog i kulturnog kapitala učenika različitog rezidencijalnog podrijetla, upitnik je sadržavao niz pitanja o ekonomskomaterijalnoj situaciji i obrazovno-kulturnim elementima obitelji. Učenike se pitalo o radnom statusu roditelja, posjedovanju imovine i obiteljskoj financijskoj situaciji kao indikatorima ekonomskog kapitala. Pitanja vezana uz pojedine aspekte obiteljskih kulturnih resursa pokušavala su zahvatiti obiteljski kulturni kapital u tri njegova vida; institucionalizirani kulturni kapital zahvaćen je obrazovanjem roditelja, objektivirani kulturni kapital pitanjima o broju knjiga i posjedovanim kulturnim dobrima dostupnim učenicima u njihovim 
kućanstvima, dok se utjelovljeni kulturni kapital roditelja ispitao pitanjima koja su adresirala kulturne prakse roditelja.

Radni status roditelja. Učenici su zasebno za majku i oca odgovarali o radnom statusu izabirući između kategorija: „stalno zaposlen/a (puno radno vrijeme, u stalnom radnom odnosu)“, „nezaposlen/a (i traži zaposlenje), „zaposlen/a povremeno (npr. sezonski)“, „umirovljenik/ca“, i nešto drugo (npr. preminuo/la; trajno nesposoban/a za rad)“. Za majke je postojala i opcija „domaćica/kućanica (i ne traži posao)“ koja nije imala svog ekvivalenta kod očeva. Varijable su naknadno rekodirane prema izvoru prihoda u tri kategorije: ,prihodi od stalnog zaposlenja“, „povremeni prihodi ili prihodi od mirovine“, te „bez prihoda“. U konačnici, odvojene mjere radnog statusa majke i oca spojene su u mjeru Radni status roditelja_prihodi s kategorijama: 1=oboje sa stalnim prihodima, 2=jedno sa stalnim prihodima, $3=$ oboje bez stalnih prihoda, te $4=$ oboje bez izvora prihoda.

Posjedovanje imovine. Učenici su na skali od 4 stupnja $(0=n i t i$ jedan, $1=j e d a n, 2=d v a, 3=t r i$ ili više) odgovarali koliko računala, automobila i nekretnina posjeduje njihova obitelj. Ukupni rezultat je nastao kao zbroj vrijednosti na ove tri čestice.

Procjena financijske situacije obitelji ${ }^{20}$. Na skali od 5 stupnjeva (1=jedva spaja kraj $s$ krajem, 2=ima za ono što je nužno, 3=ima dovoljno za normalan/prosječan život, 4=je prilično dobrostojeća, $5=$ je bogata), učenici su trebali odgovoriti koja tvrdnja najbolje opisuje financijsku situaciju njihove obitelji.

Obrazovanje roditelja. Učenicima je postavljeno pitanje o najvišem završenom stupnju obrazovanja majke i oca, a odlučivali su se za jednu od ponuđenih kategorija: „nezavršena osnovna škola“, „osnovna škola“, „trogodišnja srednja strukovna škola“, „četverogodišnja srednja strukovna škola“, „gimnazija“, „,viša škola, visoka škola, veleučilište“, „fakultet, umjetnička akademija“, „,magisterij ili doktorat“. Podaci za majku i oca rekodirani su u novu zajedničku varijablu s 4 kategorije, u kojoj se koristio odgovor za roditelja s višim stupnjem obrazovanja: „oboje (ne)završena osnovna škola“, „barem jedan roditelj sa završenom trogodišnjom strukovnom školom“, „barem jedan roditelj sa završenom četverogodišnjom strukovnom školom ili gimnazijom“, „barem jedan roditelj s visokim obrazovanjem“.

\footnotetext{
${ }^{20}$ Instrument je modificirana verzija mjere namijenjene zahvaćanju obiteljske socioekonomske situacije korištenog u upitniku Projekta Talent
} 
Broj knjiga u kućanstvu ${ }^{21}$. Na skali od 6 stupnjeva $(1=0-10,2=11-25,3=26-100,4=101$ -

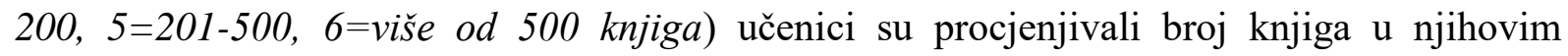
kućanstvima. Varijabla je naknadno rekodirana u tri kategorije: 1=1-25 knjiga, 2=26-200 knjiga, 3=više od 200 knjiga.

Posjedovanje kulturnih dobara ${ }^{22}$. Pri ispitivanju posjedovanje kulturnih dobara učenici su na pitanje imaju li kod kuće: „stručne knjige ili priručnike“, „knjige klasične literature“, „knjige pisane na stranom jeziku“, „umjetnička djela kao što su slike ili skulpture“ i „CD-e ili druge nosače zvuka klasične ili jazz glazbe“ odgovarali pomoću dihotomnih ,,da-ne“( $0=n e, 1=d a)$ odgovora. Ukupni rezultat je nastao zbrajanjem vrijednosti na svih 5 čestica.

Kulturne prakse roditelja ${ }^{23}$. Učenike se pitalo da na skali od 5 stupnja ( $1=$ nikad, $2=$ vrlo

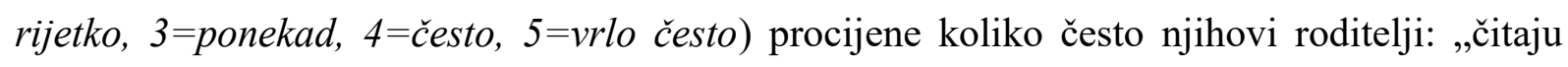
publicistiku“, „,̌itaju prozu i poeziju“, „pohađaju obrazovne tečajeve, programe ili predavanja“, „posjećuju muzeje ili umjetničke galerije“, „,idu na kazališne predstave“ te „posjećuju operu, balet ili koncerte klasične glazbe“.

Tabela 2.11 Rezultati analize glavnih komponenti instrumenta Roditeljske kulturne prakse

\begin{tabular}{|c|c|c|c|c|}
\hline $\begin{array}{l}\text { Naziv } \\
\text { dimenzije }\end{array}$ & $\begin{array}{c}\text { Objašnjena } \\
\text { varijanca }\end{array}$ & $\begin{array}{l}\text { Cronbachov } \\
\text { a }\end{array}$ & Varijable & $\lambda$ \\
\hline \multirow{6}{*}{$\begin{array}{l}\text { Roditeljske } \\
\text { kulturne } \\
\text { prakse }\end{array}$} & \multirow{6}{*}{$57 \%$} & \multirow{6}{*}{0,84} & Roditelji posjećuju muzeje ili umjetničke galerije & 0,86 \\
\hline & & & Roditelji idu na kazališne predstave & 0,83 \\
\hline & & & Roditelji posjećuju operu, balet ili koncerte klasične glazbe & 0,79 \\
\hline & & & Roditelji čitaju prozu i poeziju (romane, pripovijetke, priče) & 0,69 \\
\hline & & & $\begin{array}{l}\text { Roditelji čitaju publicistiku (npr. putopise, biografije poznatih } \\
\text { osoba, knjige povijesne tematike) }\end{array}$ & 0,69 \\
\hline & & & $\begin{array}{l}\text { Roditelji pohađaju obrazovne tečajeve, programe ili } \\
\text { predavanja }\end{array}$ & 0,66 \\
\hline
\end{tabular}

Faktorska analiza pokazala je jednofaktorsku strukturu koja objašnjava 57\% varijance. Cronbach alfa koeficijent unutarnje konzistentnosti skale sastavljene od ovih šest čestica iznosi $\alpha=0,84$. Na osnovi tih rezultata kreirana je varijabla zbrajanjem vrijednosti na svih 6 čestica.

\footnotetext{
${ }^{21}$ Instrument je preuzet iz upitnika PISA istraživanja 2009. godine.

${ }^{22}$ Instrument je modificirana verzija instrumenta Posjedovanje kulturnih dobara namijenjenog za ispitivanje kulturnog kapitala u upitniku PISA istraživanja 2009. godine.

${ }^{23}$ Instrument je modificirana verzija instrumenta Roditeljske kulturne prakse namijenjenog za ispitivanje roditeljskog kulturnog kapitala korištenog u: A. Sullivan, 2003. Cultural Capital, Rational Choice and Educational Inequalities. PhD Thesis
} 


\section{Institucionalne karakteristike obrazovanja}

Školski kontekst predstavlja najznačajniji izvanobiteljski kontekst u kojem učenici mogu dobiti određene značajne resurse i koji ima utjecaj na odluku o nastavku školovanja i izborima visokog obrazovanja. Za zahvaćanje aspekata srednjoškolskog obrazovanja, pri čemu je u velikoj mjeri osnova bila istraživački rad Raey i suradnika (2001), razvijen je instrument za ispitivanje institucionalnih karakteristika srednjih škola koje pohađaju učenici. Također, pokušao se zahvatiti barem jedan aspekt visokog obrazovanja za koji se teorijski pretpostavlja utjecaj na visokoobrazovne izbore učenika - društvena cijenjenost određenih studija i institucija visokog obrazovanja.

Institucionalne karakteristike srednjoškolskog obrazovanja. U pokušaju zahvaćanja polja srednjoškolskog obrazovanja kreiran je instrument s 8 čestica s nekim bitnim aspektima srednje škole. Od učenika se tražilo da na skali procjene od 5 stupnjeva ( $1=$ uopée se ne slažem, do $5=u$ potpunosti se slažem) odrede stupanj slaganja s tvrdnjama o ugledu i cijenjenosti, opremljenosti i socioekonomskoj strukturi škola, te poticajnosti školske klime za nastava školovanja i mogućnosti dobivanja informacija u školi. Faktorska analiza pokazala je trofaktorsku strukturu instrumenta ${ }^{24}$. Konačni rezultati u obliku tri oblimin dimenzije bili su osnova kreiranja varijabli institucionalnih karakteristika srednjih škola (Tabela 2.12).

Tri čestice, čiji je koeficijent unutarnje konzistentnosti Cronbachov $a=0,78$, sadržajno su povezale teškoću upisa srednje škole, uglednost škole te dobru pripremu za studij u dimenziji Škola visokog statusa, objasnivši 49\% varijance institucionalnih karakteristika srednje škole. Druga ekstrahirana dimenzija - Akademski poticajna škola - okupila je čestice vezane uz informiranost o obrazovanju nakon srednje škole i poticaja nastavnika na nastavak školovanja, objasnivši dodatnih 16\%. Unutarnja konzistentnost te dimenzije mjerena Cronbachovim a koeficijentom je 0,70. Treću dimenziju školskog konteksta jednostavno nazvanu Opremljena škola dobrog programa opisuju dvije čestice na kojima su učenici procjenjivali resursnu opremljenost i izvannastavnu programsku ponudu. One su objasnile dodatnih $11 \%$ varijance s unutarnjom konzistentnosšću od 0,69 (Cronbachov a).

\footnotetext{
${ }^{24}$ Toj strukturi najmanje je doprinosila čestica „Većina učenika u mom razredu je iz dobrostojećih obitelji“, te je ona isključena iz daljnje analize.
} 
Tabela 2.12 Rezultati analize glavnih komponenti instrumenta Karakteristike srednje škole

\begin{tabular}{lccllc} 
Naziv dimenzije & $\begin{array}{c}\text { Objašnjena } \\
\text { varijanca }\end{array}$ & $\begin{array}{c}\text { Cronbachov } \\
\boldsymbol{a}\end{array}$ & Varijable s najvećim saturacijama & $\lambda$ \\
\hline $\begin{array}{l}\text { Škola visokog } \\
\text { statusa }\end{array}$ & $49 \%$ & 0,78 & $\begin{array}{l}\text { Moju školu je teško upisati } \\
\text { Moja škola je ugledna } \\
\text { Moja škola me dobro priprema za studij }\end{array}$ & 0,97 \\
\hline $\begin{array}{l}\text { Akademski } \\
\text { poticajna škola }\end{array}$ & $16 \%$ & 0,70 & $\begin{array}{l}\text { U školi možemo dobiti informacije u vezi daljnjeg } \\
\text { obrazovanja }\end{array}$ & 0,65 \\
\hline $\begin{array}{l}\text { Resursna } \\
\text { opremljenost i } \\
\text { dobar program }\end{array}$ & $11 \%$ & 0,69 & $\begin{array}{l}\text { Moja škola je dobro opremljena } \\
\text { Moja škola ima bogat program izvannastavnih } \\
\text { aktivnosti }\end{array}$ & $-0,52$ \\
\hline \multicolumn{1}{c}{ UK } & $\mathbf{7 6 \%}$ & $\mathbf{0 , 8 2}$ & & 0,86 \\
\hline
\end{tabular}

Važnost ugleda željenog studija i institucije kao razloga izbora ${ }^{25}$. One učenike koji namjeravaju studirati pitalo se da na ljestvici od $1=$ uopće se ne slažem, do $5=$ u potpunosti se slažem procijene stupanj svog slaganja o tome koliko im je pri izboru željenog studija bila važna cijenjenost izabranog studija te institucija na kojoj namjeravaju studirati. Za dvije navedene čestice provjerena je unutarnja konzistentnost te faktorska struktura, a rezultati su prikazani u Tabeli 2.13 .

Tabela 2.13 Rezultati analize glavnih komponenti ugleda željenog studija i institucije studiranja pri izboru

\begin{tabular}{|c|c|c|c|c|}
\hline $\begin{array}{l}\text { Naziv } \\
\text { dimenzije }\end{array}$ & $\begin{array}{l}\text { Objašnjena } \\
\text { varijanca }\end{array}$ & $\begin{array}{l}\text { Cronbachov } \\
\text { a }\end{array}$ & Varijable & $\lambda$ \\
\hline \multirow{2}{*}{$\begin{array}{l}\text { Ugled studija i } \\
\text { institucije VO-a }\end{array}$} & \multirow{2}{*}{$83 \%$} & \multirow{2}{*}{0,79} & $\begin{array}{l}\text { Važno mi je da je područje studija koji } \\
\text { namjeravam upisati cijenjeno }\end{array}$ & 0,91 \\
\hline & & & $\begin{array}{l}\text { Važno mi je da je fakultet/veleučilište/visoka } \\
\text { škola koji namjeravam upisati cijenjen }\end{array}$ & 0,91 \\
\hline
\end{tabular}

Navedene analize pokazale su da se radi o visoko povezanim česticama koje objašnjavaju $83 \%$ varijance i imaju visok Cronbachov a koeficijent $=0,79$. Kreirana je varijabla Ugled studija i institucije visokog obrazovanja na način da su zbroijene vrijednosti na dvije varijable.

\section{Simbolička vrijednost konteksta odrastanja i školovanja}

Osim dostupnosti resursima u kontekstima odrastanja i školovanja, upitnik je sadržavao i set pitanja koja su pokušavala zahvatiti simbolički značaj tih konteksta i odnosa koji tvore učeničke mreže s utjecajem na njihovu odluku o studiranju, odnosno njihovo usmjeravanje

\footnotetext{
${ }^{25}$ Istraživački tim projekta sastavio je navedene tvrdnje u svrhu zahvaćanja nekih karakteristika visokog obrazovanja koji su teorijski istaknuti kao moguće značajne odrednice nečijeg izbora studija.
} 
prema visokom obrazovanju. Simbolička vrijednost obitelji/zajednica shvaća se kao obrazovni poticaji u učeničkim kontekstima odrastanja i školovanja, a zahvaća se ispitivanjem obiteljskih poticajnih praksi, utjecajem značajnih drugih na odluku o (ne)studiranju, te odnosima sa širom zajednicom odrastanja.

Pitanja o roditeljskoj podršci učeničkih obrazovnih planova te njihovoj uključenosti u školske aktivnosti učenika, kao i procjena općenitog utjecaja članova obitelji na učeničke visokoobrazovne odluke učenika, bila su usmjerena adresiranju prijenosa kulturnog kapitala unutar obitelji kao elemenata obiteljskog habitusa, koji serijetko operacionalizira i teško ga je zahvatiti anketnim upitnikom.

Obiteljske poticajne prakse ${ }^{26}$ operacionalizirane sa četiri čestice koje opisuju roditeljsku pomoć pri školskim obvezama i interes za školske aktivnosti djece, te njihovo ohrabrivanje studiranja, odnosno što bržeg zaposlenja. Učenici su na ljestvici od 5 stupnjeva (1=uopće se ne slažem, do $5=\mathrm{u}$ potpunosti se slažem) određivali stupanj svog slaganja s tvrdnjama: „Kada mi treba, roditelji mi pomažu kod školskih obaveza“, „Moji roditelji su zainteresirani za ono što radim u školi“, „Roditelji me ohrabruju da nastavim školovanje“, te „Roditelji me ohrabruju da se što prije zaposlim“. Provjera faktorske strukture i unutarnje konzistentnosti skale pokazala je njihovu malu povezanost te se odustalo od smanjivanja dimenzionalnosti instrumenta (Tablica 2.14).

Tabela 2.14 Rezultati analize glavnih komponenti instrumenta Roditeljske poticajne prakse

\begin{tabular}{|c|c|c|c|c|}
\hline $\begin{array}{l}\text { Naziv } \\
\text { dimenzije }\end{array}$ & $\begin{array}{c}\text { Objašnjena } \\
\text { varijanca }\end{array}$ & $\begin{array}{c}\text { Cronbachov } \\
a\end{array}$ & Varijable & $\lambda$ \\
\hline \multirow{3}{*}{$\begin{array}{l}\text { Roditeljske } \\
\text { poticajne } \\
\text { prakse }\end{array}$} & \multirow{3}{*}{$56 \%$} & \multirow{3}{*}{0,56} & Moji roditelji su zainteresirani za ono što radim u školi & 0,84 \\
\hline & & & Kada mi treba, roditelji mi pomažu kod školskih obaveza & 0,82 \\
\hline & & & Roditelji me ohrabruju da nastavim školovanje & 0,55 \\
\hline
\end{tabular}

Inicijalna analiza glavnih komponenti pokazala je jednofaktorsku strukturu instrumenta roditeljske podrške kojoj izuzetno slabo pridonosi čestica „Roditelji me ohrabruju da se što prije zaposlim“. Crombachov alfa koeficijent unutarnje konzistentnosti preostale tri čestica iznosi slabih $a=0,55$.

\footnotetext{
26 Istraživački tim projekta sastavio je navedene tvrdnje i prilagodio instrumente nekih drugih istraživanja $u$ svrhu zahvaćanja elemenata obiteljskog konteksta koji su teorijski istaknuti kao moguće značajne odrednice učeničkih obrazovnih ishoda.
} 
Obiteljski utjecaj na odluku o daljnjem školovanju. Učenici su na skali od 5 stupnjeva (od $1=$ nimalo nisu utjecali do $5=$ =izrazito su utjecali) procjenjivali koliko su na njihovu odluku o nastavku školovanja utjecali „roditelji“ i „braća/sestre“.

Utjecaj značajnih drugih $^{27}$ ispitivao se utjecajem osoba iz užeg i šireg kruga učenika, koji predstavljaju potencijalni socijalni kapital učenika, na njihovu odluku o tome studirati ili ne. Učenici su ga procjenjivali na skali od 5 stupnjeva (od 1=nimalo nisu utjecali, do 5=izrazito su utjecali) za 9 osoba: „članovi šire rodbine“, ,,prijatelj/i“, „,dečko ili cura“, „školski kolege“, „prijatelji ili poznanici roditelja“, „susjedi“, te „nastavnici“, „stručni suradnici u školi“ i „savjetnik za profesionalno usmjeravanje izvan škole“. Kreirane varijable nisu nastale na osnovi faktorske strukture već su vođene teorijski. Odnosno, navedene osobe koje su mogle utjecati na odluku o daljnjem školovanju podijeljene su na one koje se pojavljuju u (izvan)školskom institucionalnom okruženju (,,institucionalni značajni drugi“‘), te na one koje najvećim dijelom pripadaju privatnoj sferi (,,izvaninstitucionalni značajni drugi“).

Tabela 2.15 Rezultati provjere faktorske strukture dimenzija utjecaja značajnih drugih na odluku učenika o studiranju

\begin{tabular}{|c|c|c|c|c|}
\hline $\begin{array}{l}\text { Naziv } \\
\text { dimenzije }\end{array}$ & $\begin{array}{c}\text { Objašnjena } \\
\text { varijanca }\end{array}$ & $\begin{array}{c}\text { Cronbachov } \\
a\end{array}$ & Varijable & $\lambda$ \\
\hline \multirow{6}{*}{$\begin{array}{l}\text { Utjecaj } \\
\text { izvaninsti- } \\
\text { tucionalnih } \\
\text { drugih na } \\
\text { odluku o } \\
\text { studiranju }\end{array}$} & \multirow{6}{*}{$59 \%$} & \multirow{6}{*}{0,86} & Prijatelji ili poznanici tvojih roditelja & 0,82 \\
\hline & & & Školski kolege & 0,81 \\
\hline & & & Prijatelj/i & 0,78 \\
\hline & & & Članovi šire rodbine & 0,77 \\
\hline & & & Susjedi & 0,73 \\
\hline & & & Dečko/cura & 0,67 \\
\hline \multirow{3}{*}{$\begin{array}{l}\text { Utjecaj } \\
\text { instituciona- } \\
\text { lnih drugih na } \\
\text { odluku o } \\
\text { studiranju }\end{array}$} & \multirow{3}{*}{$69 \%$} & \multirow{3}{*}{0,77} & Netko od stručnih suradnika u školi (pedagog, psiholog...) & 0,89 \\
\hline & & & Savjetnik za profesionalno usmjeravanje izvan škole & 0,82 \\
\hline & & & Nastavnici & 0,78 \\
\hline
\end{tabular}

Skalu ,izvaninstitucionalnih značajnih drugih“ čine čestice o članovima šire rodbine, prijateljima, dečku/curi, školskim kolegama, prijateljima/poznanicima roditelja učenika te susjedima, a koeficijent unutarnje konzistentnosti iznosi $\alpha=0,85$. Skalu ,institucionalnih značajnih drugih" koji su mogli utjecati na odluku o nastavku školovanja čine čestice o nastavnicima, stručnim suradnicima u školi i savjetnicima za profesionalno usmjeravanje izvan škole, a njezin Cronbach alfa koeficijent unutarnje konzistentnosti iznosi $\alpha=0,76$.

\footnotetext{
27 Modificiran instrument korišten za zahvaćanje aspekta učeničkog socijalnog kapitala u upitniku za ruralne učenike (University of Oulu, Kajaani University Consortium, AIKOPA, Regional Development Research Group)
} 
${ }^{28}$ Simbolička vrijednost zajednica odrastanja ${ }^{29}$. Za 19 čestica koje sadržajno opisuju vezanost, uključenost i osjećaj pripadnosti te želju za doprinosom zajednici odrastanja, ali i namjere njenog napuštanja, učenici su procjenjivali stupanj slaganja na ljestvici od 5 stupnjeva (1=uopće se ne slažem, do $5=$ u potpunosti se slažem). Analiza glavnih komponenti ukazala je na trofaktorsku strukturu instrumenta ${ }^{30} \mathrm{~s}$ visokim koeficijentima unutarnje konzistentnosti (Tabela 2.16). Na osnovi rezultata kreirane su tri sumativne varijable zbrajanjem vrijednosti čestica koje su tvorile pojedine faktore, koji ukupno objašnjavaju 59\% varijance instrumenta.

Tabela 2.16 Rezultati analize glavnih komponenti instrumenta Simbolička vrijednost zajednice odrastanja

\begin{tabular}{|c|c|c|c|c|}
\hline $\begin{array}{l}\text { Naziv } \\
\text { dimenzije }\end{array}$ & $\begin{array}{c}\text { Objašnjena } \\
\text { varijanca }\end{array}$ & $\begin{array}{l}\text { Cronbachov } \\
a\end{array}$ & Varijable & $\lambda$ \\
\hline \multirow{6}{*}{ Pripadnost } & \multirow{6}{*}{$38 \%$} & \multirow{6}{*}{0,85} & Rado se uključujem u aktivnosti zajednice & 0,91 \\
\hline & & & Svojim radom želim doprinijeti svojoj zajednici & 0,89 \\
\hline & & & Svojim obrazovanjem želim doprinijeti svojoj zajednici & 0,74 \\
\hline & & & Rado pomažem sumještanima & 0,70 \\
\hline & & & Osjećam se bitnim pripadnikom svoje zajednice & 0,62 \\
\hline & & & $\begin{array}{l}\text { Osjećam da bi mi ostali sumještani pomogli kada bi mi } \\
\text { pomoć bila potrebna }\end{array}$ & 0,51 \\
\hline \multirow{6}{*}{ Ostanak } & \multirow{6}{*}{$13 \%$} & \multirow{6}{*}{0,84} & *Ne vidim budućnost u mjestu u kojem živim & 0,91 \\
\hline & & & *Ako želim postići nešto u životu moram se preseliti & 0,88 \\
\hline & & & *Svoj budući život vidim u velikom gradu & 0,82 \\
\hline & & & *Jedva čekam napustiti mjesto u kojem živim & 0,77 \\
\hline & & & $\begin{array}{l}\text { Trenutno mjesto stanovanja odgovara mojim } \\
\text { potrebama i nadama za budućnost }\end{array}$ & 0,53 \\
\hline & & & $\begin{array}{l}\text { Mislim da bih se teško prilagodio na promjenu životne } \\
\text { sredine }\end{array}$ & 0,40 \\
\hline \multirow{5}{*}{$\begin{array}{l}\text { Emocio- } \\
\text { nalna } \\
\text { vezanost }\end{array}$} & \multirow{5}{*}{$8 \%$} & \multirow{5}{*}{0,79} & Mjesto u kojem živim je sigurna sredina za odrastanje & $-0,89$ \\
\hline & & & Moja životna sredina je ugodno mjesto za stanovanje & $-0,83$ \\
\hline & & & Volim ovdje živjeti jer su mi tu prijatelji i obitelj & $-0,69$ \\
\hline & & & Volim prirodu koja okružuje moju životnu sredinu & $-0,50$ \\
\hline & & & $\begin{array}{l}\text { U mojoj životnoj sredini ljudi dijele moje vrijednosti i } \\
\text { način život }\end{array}$ & $-0,42$ \\
\hline UK & $59 \%$ & $\mathbf{0 , 9 0}$ & & \\
\hline
\end{tabular}

Pripadnost je dimenzijasaturirirana varijablama koje su sadržajno povezale uključenost u aktivnosti zajednice, želju za osobnim budućim doprinosom (radom i/ili obrazovanjem),

\footnotetext{
${ }^{28}$ Instrument su ispunjavali samo slavonski maturanti zbog problema vezanih uz provedbu terenskog rada.

${ }^{29}$ Modificiran instrument korišten za zahvaćanje aspekta učeničkog odnosa sa, i stavova o zajednici odrastanja u upitniku za ruralne učenike (University of Oulu, Kajaani University Consortium, AIKOPA, Regional Development Research Group

${ }^{30} \mathrm{U}$ procesu „čišćenja“ instrumenta iz daljnje analize su izostavljene varijable: „U mojoj sredini ljudi ne razumiju kako želim živjeti“, čiji su doprinosi ostalim faktorima bili minimalni, te „Ponosnim me čini kulturna povijest moga kraja“", koja je imala relativno slabe, podijeljene saturacije na dvjema dimenzijama.
} 
međusobno pomaganje njenih članova s čime se povezuje i osjećaj pripadnosti. Crombachov alfa koeficijent unutarnje konzistentnosti iznosi $a=0,85$. Dimenziju

Ostanak je dimenzija koju je opisalo 6 čestica o mogućnosti zamišljanja budućeg života u mjestu odrastanja i nepotrebnosti za preseljenjem uz što se vezuje i procjena teškoće prilagodbe na novu sredinu i želja za ostankom. Unutarnja konzistentnost ove dimenzije iznosi visokih $\mathrm{a}=0,84$ (Crombachov alfa).

Konačno, dimenzija Emocionalna vezanost opisuje pozitivne stavove o svom mjestu kao sigurnom za odrastanje i ugodnom za život što se povezuje sa sociokulturnim elementima (vezama, vrijednostima, načinom života) i ljepotama okružujuće prirode. Crombachov alfa koeficijent od $\mathrm{a}=0,79$, ukazuje na visoku unutarnju konzistentnost varijabli dimenzije.

\subsection{Provedba istraživanja $\mathbf{i}$ uzorci}

Korišteni podaci prikupljeni su u sklopu nacionalnog istraživačkog projekta Socijalni identiteti, pristup visokom obrazovanju $i$ odabir studija ${ }^{31}$. Navedeni projekt financirala je Hrvatska zaklada za znanost, a proveo ga je istraživački tim Institut za društvena istraživanja u Zagrebu pod voditeljstvom prof. dr. sc. Branislave Baranović.

Glavno istraživanje provedeno je u proljeće 2014. godine ${ }^{32}$ kada je anketiran uzorak od 5\% hrvatskih maturanata javnih trogodišnjih i četverogodišnjih srednjih škola $\left(\mathrm{N}=2106^{33}\right)$. Školama su slani službeni dopisi s molbom za sudjelovanjem u istraživanju, a 98 škola je dalo pristanak. U svakoj školi, anketirani su učenici samo jednog razreda, a anketiranje je, anonimno i uz informirani pristanak, provedeno u razredima, tijekom jednog školskog sata.

U sklopu izrade doktorske disertacije neposredno nakon anketiranja, ili s blagim vremenskim odmakom, obavljen je i razgovor s 20 učenika regije Slavonija koji su iskazali interes i ostavili kontakt podatke za sudjelovanje u kvalitativnom dijelu istraživanja. Većina intervjua je obavljena zajedno s anketiranjem te je posjet većini škola bio ograničen na jedan dan. Sami

\footnotetext{
${ }^{31}$ Više o projektu može se saznati na internetskoj stranici: http://www.idi.hr/sipvoos/

${ }^{32}$ Glavnom istraživanju prethodilo je pilot-istraživanje na $5 \%$-tnom reprezentativnom uzorku učenika završnih razreda državnih srednjih škola u Gradu Zagrebu i Zagrebačkoj županiji, 2013. godine kada je anketno obuhvaćeno 539 učenika iz 23 škole. Dodatno, za provjeru razumljivosti i preglednosti strukture upitnika, upotrijebljena je metoda „razmišljanje na glas“ (think-aloud), pri čemu je sedam učenika iz svih tipova škola komentiralo pojedina pitanja u upitniku. Uvidi u rezultate tih provjera doprinijeli su finalnoj modifikaciji pitanja i skala odgovora te opće strukture upitnika.

${ }^{33}$ Realizirani uzorak veličinom uvelike odgovara izračunu od 5\% ukupne populacije srednjoškolskih učenika koji je obuhvaćao 2168 učenika. Blaga odstupanja od zadanog plana rezultat su dinamike anketiranja (npr. ponekad nisu svi učenici bili na nastavi), a nekoliko upitnika je isključeno iz analize zbog prevelikog broja neodgovorenih pitanja (više od 15\%).
} 
istraživački fenomen - proces donošenja odluke o studiranju, studiju i mjestu studiranja utjecao je na rad na terenu, koji je obavljen na samom kraju školske godine, i njegovo ograničeno vremensko trajanje - oko 8 tjedana $^{34}$. To je utjecalo i na dogovaranje intervjua $i$ na selekciju ispitanika. Mogućnost dogovora ovisila je o spremnosti škola da nekoliko učenika oslobode s nastave radi intervjuiranja, ali i o spremnosti učenika na razgovor, pri čemu su se pokušaji dogovaranja intervjua izvan škole pokazali gotovo nemogućim jer je velik broj potencijalnih ispitanika putovao u školu i iz škole neposredno prije, odnosno poslije nastave.

Uzorak za kvantitativno nacionalno istraživanje izrađen je prema populacijskim podacima prikupljenima od ureda državne uprave u županijama o ukupnom broju učenika završnih razreda svih javnih trogodišnjih i četverogodišnjih srednjih škola u pojedinim županijama. Zatim je napravljen je izračun od 5\% od ukupnog broja učenika i 5\% od ukupnog broja razreda prema tipu škole (klaster uzorkovanje) na razini države, regije i županije (stratificirano uzorkovanje), s točnim proporcijama za svaku razinu ${ }^{35}$.

Nakon određivanja potrebnog broja učenika i razreda, škole (i razredi, odnosno programi) su odabrani prema popisu škola. Pri tom se vodilo računa o spolnoj zastupljenosti učenika u pojedinim razredima, te regionalnoj specifičnosti pojedinih programa Tablica 2.17 prenosi osnovne podatke o strukturi realiziranog uzorka.

Tabela 2.17 Struktura uzorka anketiranih učenika $(\mathrm{N}=2106)$

\begin{tabular}{|c|c|c|c|c|c|c|}
\hline SPOL & \multicolumn{3}{|c|}{$\begin{array}{c}\text { Ženski } \\
\mathrm{N}=1042(49,5 \%)\end{array}$} & \multicolumn{3}{|c|}{$\begin{array}{c}\text { Muški } \\
\mathrm{N}=1064(50,5 \%)\end{array}$} \\
\hline $\begin{array}{l}\text { TIP } \\
\text { ŠKOLE }\end{array}$ & $\begin{array}{r}\text { Trogodišnj } \\
\mathrm{N}=5\end{array}$ & $\begin{array}{l}\text { rukovna SS̆ } \\
(26 \%)\end{array}$ & $\begin{array}{r}\text { Četverogod } \\
\mathrm{N}=\end{array}$ & $\begin{array}{l}\text { ja strukovna SS̆ } \\
2(46 \%)\end{array}$ & & $\begin{array}{c}\text { Gimnazija } \\
\mathrm{N}=600(29 \%)\end{array}$ \\
\hline REGIJA & $\begin{array}{c}\text { Dalmacija } \\
\mathrm{N}=496 \\
(24 \%)\end{array}$ & $\begin{array}{c}\text { Istra i } \\
\text { Primorje } \\
\mathrm{N}=196(9 \%)\end{array}$ & $\begin{array}{c}\text { Sjeverozap. } \\
\text { HR } \\
\mathrm{N}=326(15 \%)\end{array}$ & $\begin{array}{c}\text { Slavonija } \\
\mathrm{N}=439 \\
(21 \%)\end{array}$ & $\begin{array}{c}\text { Središnja } \\
\text { HR } \\
N=162 \\
(8 \%)\end{array}$ & $\begin{array}{c}\text { Grad ZG i Zag. } \\
\text { županija } \\
\mathrm{N}=487(23 \%)\end{array}$ \\
\hline
\end{tabular}

Regija. U šest regija kreiranih grupiranjem županija ${ }^{36}$ anketiran je sljedeći broj ispitanika ${ }^{37}$ :

\footnotetext{
${ }^{34}$ Svi intervjui obavljeni su u razdoblju od 24. ožujka - 15. svibnja, 2014.

${ }^{35}$ Rezidencijalno podrijetlo učenika nije bilo osnovni kriterij izbora.

${ }^{36}$ Regija Dalmacija obuhvaća Zadarsku, Splitsko-dalmatinsku, Šibensko-kninsku i Dubrovačko-neretvansku županiju. Regija Istra i Primorje obuhvaća Primorsko-goransku i Istarsku županiju. Regiju Sjeverozapadna Hrvatska čine Varaždinska, Krapinsko-zagorska, Bjelovarsko-bilogorska, Koprivničko-križevačka i Međimurska županija. Regija Slavonija obuhvaća Osječko-baranjsku, Brodsko-posavsku, Požeško-slavonsku, Virovitičkopodravsku i Vukovarsko-srijemsku županiju. Središnja Hrvatska obuhvaća područje Karlovačke, Ličko-senjske i Sisačko-moslavačke županije. Posljednju regiju čini Grad Zagreb i Zagrebačka županija.
} 
1. Dalmacija $-\mathrm{N}=496$, odnosno $24 \%$

2. Istra i Primorje - $\mathrm{N}=196$, odnosno 9\%

3. Sjeverozapadna Hrvatska $-\mathrm{N}=326$, odnosno $15 \%$

4. Slavonija - N=439, odnosno $21 \%$

5. Središnja Hrvatska $-\mathrm{N}=162$, odnosno $8 \%$

6. Grad Zagreb i Zagrebačka županija - N=487, odnosno $23 \%$.

Tabela 2.18 Usporedni prikaz planiranog i realiziranog uzorka prema tipu škole kojeg učenici završavaju u pojedinim regijama

\begin{tabular}{|c|c|c|c|c|c|c|c|c|c|}
\hline \multirow[b]{3}{*}{ REGIJA } & \multirow[b]{3}{*}{ Uzorak } & \multicolumn{8}{|c|}{ BROJ UČENIKA PREMA TIPU ŠKOLE } \\
\hline & & \multicolumn{2}{|c|}{ GIM } & \multicolumn{2}{|c|}{ 4SŠ } & \multicolumn{2}{|c|}{ 3SŠ } & \multicolumn{2}{|c|}{ Ukupno } \\
\hline & & $\mathbf{f}$ & $\%$ & $\mathbf{f}$ & $\%$ & $\mathbf{f}$ & $\%$ & $\mathbf{f}$ & $\%$ \\
\hline \multirow{2}{*}{ Dalmacija } & Planirano & 121 & $26 \%$ & 228 & $48 \%$ & 119 & $25 \%$ & 467 & $22 \%$ \\
\hline & Realizirano & 136 & $28 \%$ & 259 & $52 \%$ & 101 & $20 \%$ & 496 & $24 \%$ \\
\hline \multirow{2}{*}{ Istra i Primorje } & Planirano & 60 & $29 \%$ & 92 & $45 \%$ & 51 & $25 \%$ & 203 & $9 \%$ \\
\hline & Realizirano & 55 & $29 \%$ & 94 & $45 \%$ & 47 & $25 \%$ & 196 & $9 \%$ \\
\hline \multirow{2}{*}{ Sjeverozapadna HR } & Planirano & 76 & $22 \%$ & 156 & $45 \%$ & 113 & $33 \%$ & 345 & $16 \%$ \\
\hline & Realizirano & 70 & $22 \%$ & 148 & $45 \%$ & 108 & $33 \%$ & 326 & $15 \%$ \\
\hline \multirow{2}{*}{ Slavonija } & Planirano & 104 & $23 \%$ & 201 & $45 \%$ & 140 & $31 \%$ & 445 & $21 \%$ \\
\hline & Realizirano & 102 & $23 \%$ & 201 & $46 \%$ & 136 & $31 \%$ & 439 & $21 \%$ \\
\hline \multirow{2}{*}{ Središnja HR } & Planirano & 34 & $23 \%$ & 67 & $45 \%$ & 49 & $33 \%$ & 150 & $7 \%$ \\
\hline & Realizirano & 55 & $34 \%$ & 64 & $40 \%$ & 43 & $27 \%$ & 162 & $8 \%$ \\
\hline \multirow{2}{*}{ Grad Zagreb i Zagrebačka županija } & Planirano & 199 & $36 \%$ & 235 & $42 \%$ & 122 & $22 \%$ & 556 & $26 \%$ \\
\hline & Realizirano & 182 & $37 \%$ & 196 & $40 \%$ & 109 & $22 \%$ & 487 & $23 \%$ \\
\hline \multirow{2}{*}{ UKUPNO } & Planirano & 594 & $27 \%$ & 979 & $45 \%$ & 594 & $27 \%$ & 2167 & $100 \%$ \\
\hline & Realizirano & 600 & $29 \%$ & 962 & $46 \%$ & 544 & $26 \%$ & 2106 & $100 \%$ \\
\hline
\end{tabular}

Tip škole. Najveći broj anketiranih učenika - 962 (46\%) bili su učenici četverogodišnjih strukovnih škola, zatim gimnazija - 600 (28\%), dok je 544 (26\%) učenika iz trogodišnjih strukovnih škola. Postotak anketiranih učenika prema tipu škole ne odstupa bitno od postotka učenika u pojedinom tipu srednjih škola na nacionalnoj razini ${ }^{38}$.

Regionalno, najveći broj gimnazijalaca zahvaćen je u Gradu Zagrebu i Zagrebačkoj županiji (37\%) i Središnjoj HR (34\%), a najmanji u Sjeverozapadnoj HR (22\%) i Slavoniji (23\%). Najveći broj učenika četverogodišnjih strukovnih škola anketiran je u Dalmaciji (52\%), a najmanji u zagrebačkoj regiji i Središnjoj HR (40\%). Najviše anketiranih učenika trogodišnjih strukovnih škola je u Sjeverozapadnoj HR (33\%) i Slavoniji (31\%), dok ih je najmanje u Dalmaciji (20\%) i zagrebačkoj regiji (22\%).

\footnotetext{
37 Najveća odstupanja realiziranog uzorka u odnosu na planirani vidljiva su u regiji Dalmacija koja je nadreprezentirana (495>467), te regiji Grad Zagreb i Zagrebačka županija koja je podreprezentirana $(487<556)$. ${ }^{38}$ Nacionalni udjeli su $27 \%$ učenika gimnazija, $45 \%$ četverogodišnjih, te $27 \%$ trogodišnjih strukovnih škola.
} 
Najveća odstupanja, u odnosu na planirani uzorak, bilježe udjeli učenika u regiji Dalmacija gdje su nadzastupljeni učenici četverogodišnjih strukovnih škola (52\%), a podzastupljeni učenici trogodišnjih strukovnih škola (20\%), te regiji Središnja Hrvatska u kojoj su nadzastupljeni učenici gimnazija (34\%), a podzastupljeni učenici trogodišnjih (27\%) i četverogodišnjih strukovnim škola $(40 \%)^{39}$.

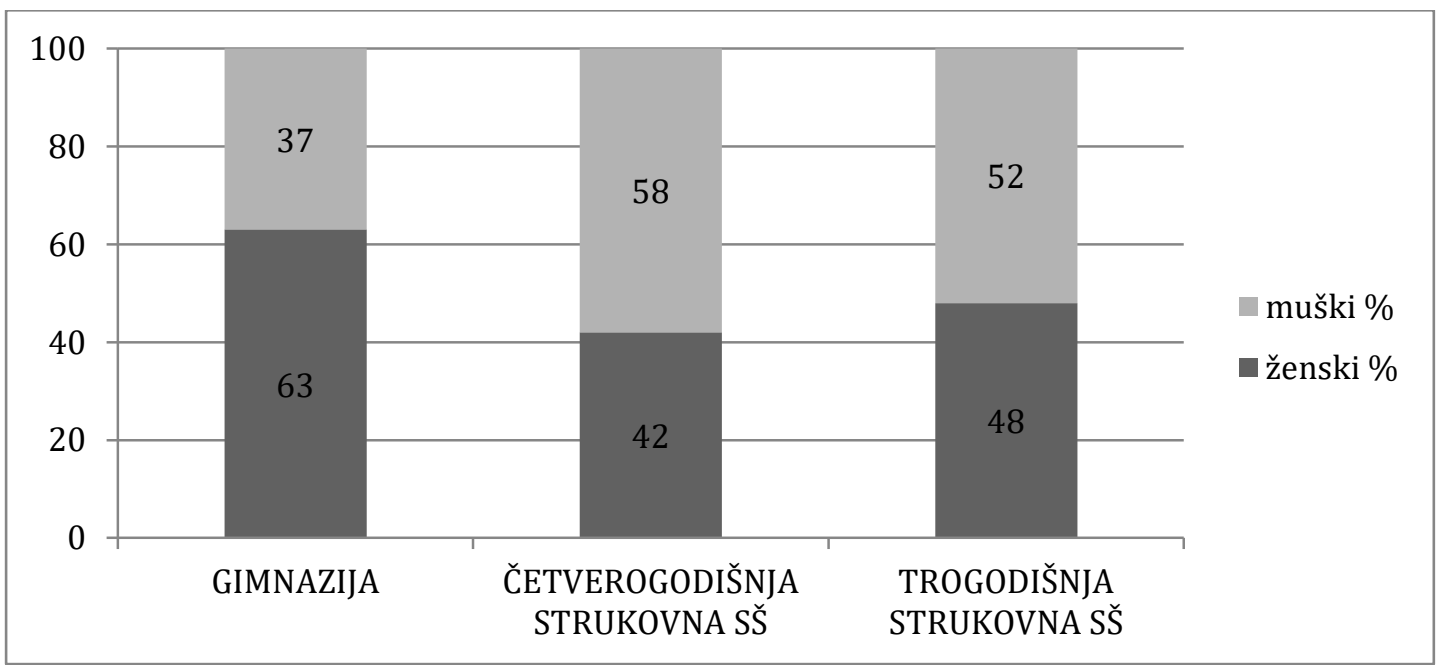

Slika 2.1 Spolna struktura uzorka prema tipu škole kojeg učenici završavaju

Spol. U uzorku je gotovo podjednako djevojaka i mladića - od ukupnog broja anketiranih, 1042 (49,5\%) je djevojaka, a 1064 (50,5\%) mladića.

Ipak, razlike postoje prema tipu škole; više anketiranih mladića završava trogodišnje $(52 \%)$ i četverogodišnje strukovne škole (58\%), dok je više anketiranih gimnazijalki - $63 \%{ }^{40}$ (Slika 2.1).

To se vjerojatno odražava na pojedine nerazmjere na regionalnoj razini vidljive u Tablici 2.19; najizraženije su one u regiji Sjeverozapadna Hrvatska gdje postoji spolna neravnoteža u korist mladića (56\% mladića) te u korist djevojaka u zagrebačkoj (54\%) i regiji Dalmacija $(55 \%)$.

\footnotetext{
${ }^{39}$ Prama podacima ureda državne uprave u županijama, postoje regionalne specifičnosti prema tipu škole kojeg pohađaju učenici. U Dalmaciji najveći broj učenika završava četverogodišnje strukovne škole (48\%), a najmanje učenika četverogodišnjih strukovnih škola je u regiji Grad Zagreb i Zagrebačka županija (42\%). U svim ostalim regijama udio učenika četverogodišnjih strukovnih škola je $45 \%$.

U regijama Sjeverozapadna HR, Središnja HR i Slavonija najveći je udio učenika trogodišnjih strukovnih škola (31-33\%), dok je najmanje učenika gimnazija (22\%-23\%). Nasuprot tome, udio učenika trogodišnjih strukovnih škola u regiji Grad Zagreb i Zagrebačka županija je najmanji (22\%), dok je broj gimnazijalaca daleko najveći $(36 \%)$.

Od ukupnog broja učenika u regijama Dalmacija te Istra i Primorje 25\% pohađa trogodišnje strukovne škole, a udjeli gimnazijalaca su $26 \%$ u regiji Dalmacija i $29 \%$ u Istri i Primorju.

${ }^{40} \mathrm{Na}$ kraju škol. god. 2013./14. učenica je bilo 50\%, iako je 70\% učenica u srednjim umjetničkim, 61\% u gimnazijama, 48\% u tehničkim i srodnim, a samo 35\% u industrijskim i obrtničkim školama (Državni zavod za statistiku, 2015).
} 
Tabela 2.19 Regionalne razlike spolne strukture uzorka anketiranih učenika

\begin{tabular}{|c|c|c|c|c|c|c|c|c|c|c|c|c|}
\hline & \multicolumn{2}{|c|}{ Dalmacija } & \multicolumn{2}{|c|}{$\begin{array}{c}\text { Istra i } \\
\text { Primorje }\end{array}$} & \multicolumn{2}{|c|}{$\begin{array}{c}\text { Sjeverozapadna } \\
\text { HR }\end{array}$} & \multicolumn{2}{|c|}{ Slavonija } & \multicolumn{2}{|c|}{$\begin{array}{c}\text { Središnja } \\
\text { HR }\end{array}$} & \multicolumn{2}{|c|}{$\begin{array}{c}\text { ZG i } \\
\underset{\text { Zagrebačka }}{\text { županija }} \\
\end{array}$} \\
\hline & f & $\%$ & f & $\%$ & f & $\%$ & f & $\%$ & f & $\%$ & f & $\%$ \\
\hline Spol & 496 & 23,6 & 196 & 9,3 & 326 & 15,5 & 439 & 20,8 & 162 & 7,7 & 487 & 23,1 \\
\hline Ženski & 274 & 55,2 & 102 & 52 & 144 & 44,2 & 223 & 50,8 & 76 & 46,9 & 223 & 45,8 \\
\hline Muški & 222 & 44,8 & 94 & 48 & 182 & 55,8 & 216 & 49,2 & 86 & 53,1 & 264 & 54,2 \\
\hline
\end{tabular}

Sociogeografske karakteristike uzorka. Zbog fokusa rada na kontekst odrastanja i školovanja učenika, reprezentativnost uzorka je ispitana i s obzirom na sociogeografske elemente koji nisu bili kriteriji uzorkovanja: rezidencijalno podrijetlo učenika, odnosno tip mjesta u kojem su odrasli, te lokaciju srednje škole, odnosno stupanj centraliteta grada ${ }^{41}$ u kojem učenici završavaju srednjoškolsko obrazovanje. Osnovne podatke o broju anketiranih učenika u svakoj od kategorija dva ispitivana aspekta sažima Tablica 2.20. U nastavku se ispituje i reprezentativnost dobivene strukture uzorka s obzirom na sociogeografske pokazatelje.

Tabela 2.20 Sociogeografski podaci o strukturi uzorka anketiranih učenika $(\mathrm{N}=2106)$

\begin{tabular}{lccc}
\hline REZIDENCIJALNO & Ruralno & Urbano & Metropola \\
PODRIJETLO & $\mathrm{N}=824(39 \%)$ & $\mathrm{N}=963(46 \%)$ & $\mathrm{N}=307(15 \%)$ \\
LOKACIJA & „Mali gradovi“ & ,Veliki gradovi & Glavni grad \\
SREDNJE ŠKOLE & $\mathrm{N}=928(44 \%)$ & $\mathrm{N}=786(37 \%)$ & $\mathrm{N}=392(19 \%)$ \\
\hline
\end{tabular}

Lokacija škole. Učenici su promatrani kroz kategorije stupnja centraliteta grada u kojima pohađaju škole - glavni grad, veliki grad (makroregionalni centar, jači regionalni centar), te mali grad (slabiji regionalni te subregionalni centar).

Prema prezentiranim usporednim podacima udjela učenika različitih tipova škola u gradovima različitog stupnja centraliteta u populaciji učenika i uzorku onih anketiranih (Tabela 2.21) vidljivo je da je veći broj učenika anketiran u „,velikim gradovima“, to jest u hrvatskim makroregionalnim centrima i regionalnim jačim centrima $(37>32 \%)^{42}$. Prema tipu škole kojeg završavaju, ne postoje značajna odstupanja između udjela gimnazijalaca u populaciji i uzorku s obzirom na centralitet grada u kojem završavaju srednju školu. S druge strane, više je

\footnotetext{
${ }^{41} \mathrm{Za}$ klasifikaciju gradova korištena je sociogeografska analiza hrvatskog prostora koju je predstavio Lukić (2012). Gradovi su klasificirani prema stupnju centraliteta, odnosno prema funkcijama koje obavljaju u tom prostoru. Moguće je izdvojiti 6 grupa gradova: glavni grad, makroregionalne centre, jače i slabije regionalne centre te jače i slabije subregionalne centre.

${ }^{42}$ Navedeni rezultati nastali su kao posljedica dinamike anketiranja na terenu i činjenice da je pri kreiranju uzorka učenika korištena metoda klaster uzorkovanja, odnosno odabirali su se razredi unutar određene škole u kojima se vršilo anketiranje prema broju učenika u razredu (time su se zahvaćali klasteri učenika (razredi), odnosno pojedini ispitanici kao dio klastera).
} 
anketiranih učenika četverogodišnjih strukovnih škola u malim gradovima, odnosno subregionalnim i slabijim regionalnim centrima (47>42\%), a manje u velikim gradovima $(46<50 \%)$, nego su njihovi udjeli u populaciji. Obrnuto vrijedi za učenike trogodišnjih strukovnih škola kojih je manje, u odnosu na populacijske udjele, anketirano u gradovima slabijeg stupnja centraliteta $(28<33 \%)$, a više u gradovima većeg stupnja centraliteta $(28>25 \%)$.

Tabela 2.21 Usporedni prikaz planiranog i realiziranog uzorka učenika pojedinih tipova škole prema tipu grada u kojem ih završavaju

\begin{tabular}{ccccccccccc}
\hline & & \multicolumn{2}{c}{ GIM } & \multicolumn{2}{c}{4 4S ̌ } & \multicolumn{3}{c}{3 SS } & \multicolumn{2}{c}{ UKUPNO } \\
\cline { 3 - 11 } & & $\mathrm{N}$ & $\%$ & $\mathrm{~N}$ & $\%$ & $\mathrm{~N}$ & $\%$ & $\mathrm{~N}$ & $\%$ \\
\hline \multirow{2}{*}{ GLAVNI GRAD } & Populacija & 3463 & 37,7 & 4021 & 43,8 & 1696 & 18,5 & 9180 & 21,2 \\
& Uzorak & 159 & 40,6 & 161 & 41,1 & 72 & 18,4 & 392 & 18,6 \\
\hline \multirow{2}{*}{ "Veliki grad" } & Populacija & 3526 & 25,1 & 7040 & 50,1 & 3473 & 24,7 & 14039 & 32,4 \\
& Uzorak & 207 & 26,3 & 362 & 46,1 & 217 & 27,6 & 786 & 37,3 \\
\hline \multirow{2}{*}{ "Mali grad" } & Populacija & 4928 & 24,5 & 8538 & 42,4 & 6677 & 33,1 & 20143 & 46,5 \\
& Uzorak & 234 & 25,2 & 439 & 47,3 & 255 & 27,5 & 928 & 44,1 \\
\hline \multirow{2}{*}{ UKUPNO } & Populacija & 11917 & 27,5 & 19599 & 45,2 & 11847 & 27,3 & 43362 & 100 \\
& Uzorak & 600 & 28,5 & 962 & 45,7 & 544 & 25,8 & 2106 & 100 \\
\hline
\end{tabular}

Rezidencijalno podrijetlo. Osnova klasifikacije anketiranih učenika bila je Lukićeva analiza hrvatskog ruralnog prostora (2012) koja je ukazala da se u Hrvatskoj može razlikovati 7 klastera ruralnih naselja:

1. ekonomski diverzificirana, pretežito turistička naselja sa $6 \%$ stanovništva Hrvatske

2. dinamična, strukturno jača ruralna i urbanizirana naselja sa $17 \%$ stanovništva Hrvatske

3. ostala izvangradska naselja naseljava obuhvaćaju $12 \%$ hrvatskog stanovništva

4. naselja ruralne periferije naseljava nastanjuje tek 1,3\% stanovništva Hrvatske

5. naselja poljoprivredne ekstenzifikacije i slabe demografske dinamike s 5,4\% stanovništva

6. dostupnija o cirkulaciji ovisna ruralna i urbanizirana naselja okupljaju 4,5\% stanovništva

7. tržišno orijentirana poljoprivredna ruralna i urbanizirana naselja s $12 \%$ stanovnika

Učenici klasificirani prema svom rezidencijalnom podrijetlu na osnovi danih podataka $u$ upitniku - njih $\mathrm{N}=1853$ - tvore uzorak učenika koji je osnova daljnjih analiza (Tablica 2.22). 
Taj uzorak učenika s validnim podacima ${ }^{43}$ zahvaća $38 \%$ učenika odraslih u ruralnim, te $62 \%$ odraslih u gradskim naseljima.

Tabela 2.22 Usporedni prikaz podataka o broju i udjelima učenika različitog rezidencijalnog podrijetla u ukupnom uzorku anketiranih učenika i učenika s validnim podacima o mjestu odrastanja

\begin{tabular}{lccccccccc}
\hline & \multicolumn{2}{c}{ Uk. uzorak } & \multicolumn{2}{c}{ Ruralno } & \multicolumn{2}{c}{ Urbano } & \multicolumn{2}{c}{ Metropola } \\
\cline { 2 - 9 } & f & \% & f & \% & f & \% & f & $\%$ \\
\hline $\begin{array}{l}\text { Rezidencijalno podrijetlo } \\
\text { (ruralno-urbano-metropola) }\end{array}$ & 2103 & 100 & 824 & 39,2 & 963 & 45,8 & 307 & 14,6 \\
$\begin{array}{l}\text { Rezidencijalno podrijetlo } \\
\text { (tip naselja odrastanja) }\end{array}$ & 1853 & 100 & 696 & 37,6 & 850 & 45,9 & 307 & 16,6 \\
\hline
\end{tabular}

Prema tipu ruralnih (i urbaniziranih) naselja (Lukić, 2012) u kojem su odrasli podzastupljeni su učenici svih sedam tipova (Slika 2.2), pri čemu je najveća razlika uočljiva kod učenika odraslih u tržišno orijentiranim poljoprivrednim, te naseljima poljoprivredne ekstenzifikacije i slabe demografske dinamike.

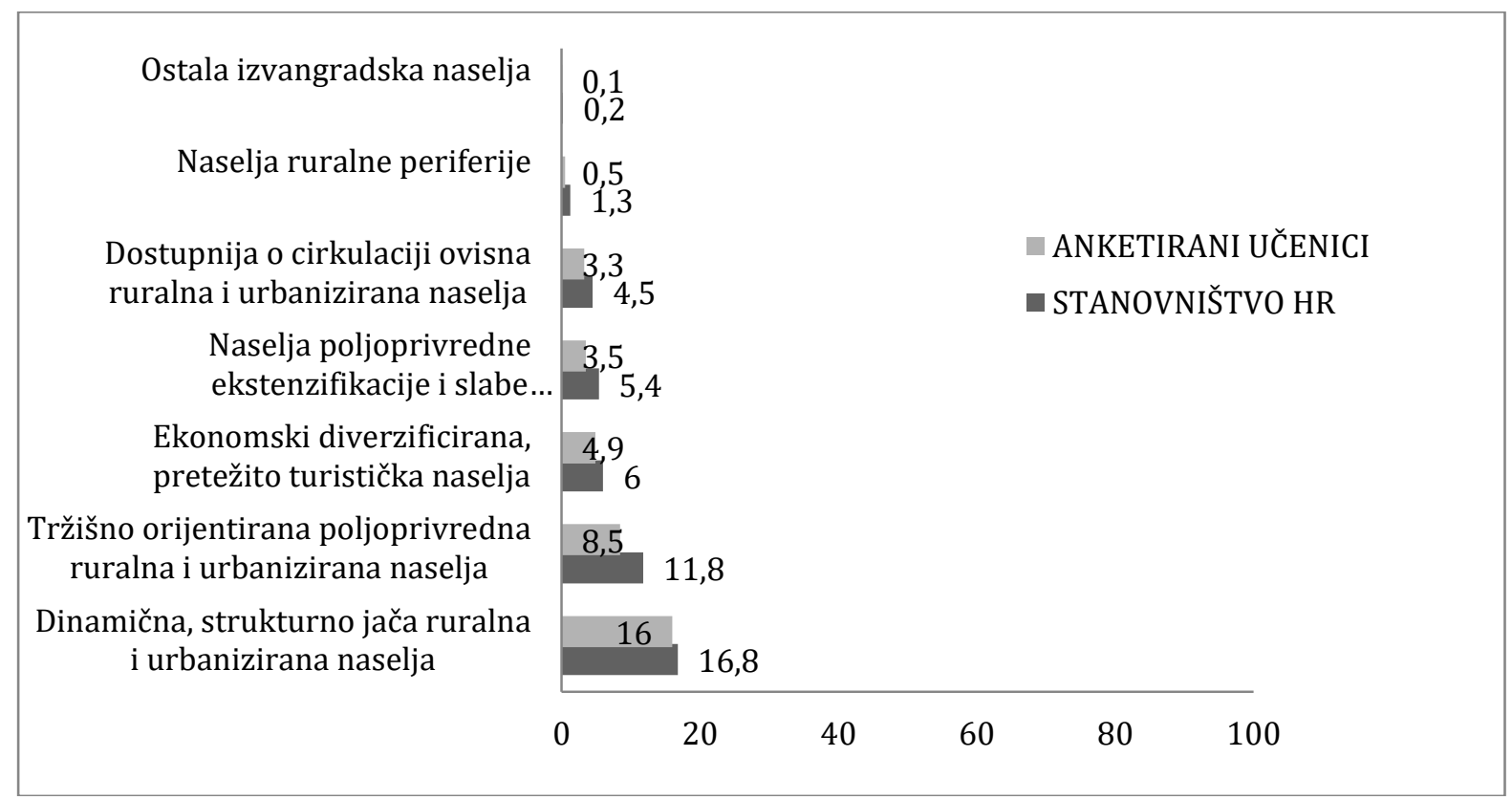

Slika 2.2 Usporedni prikaz udjela stanovništva HR i anketiranih učenika koji žive u 7 tipova ruralnih (i urbaniziranih) naselja Hrvatske

U ostalom, iako u manjem omjeru (1-3\%), učenici svih tipova ruralnih i urbaniziranih naselja slijede udjele u ukupnom stanovništvu te je tako najveći broj (16\%) učenika dinamičnih, strukturno jačih, a slijede učenici odrasli u tržišno orijentiranim poljoprivrednim naseljima

\footnotetext{
${ }^{43} \mathrm{U}$ uzorku anketiranih učenika, na osnovi podataka koje su ostavili učenici, $39 \%(\mathrm{~N}=824)$ anketiranih učenika, ima ruralno rezidencijalno podrijetlo, no određeni broj učenika nije ostavio podatke o nazivu svog mjesta, mjesto njihova odrastanja nije u Hrvatskoj ili se naselje nije moglo klasificirati.
} 
(9\%). S 5\% su zastupljeni učenici ekonomski diverzificiranih/turističkih naselja, s $4 \%$ oni odrasli u naseljima poljoprivredne ekstenzifikacije i slabe demografske dinamike, te s $3 \%$ oni odrasli u dostupnijim, o cirkulaciji ovisnim naseljima. Najmanjim udjelima zastupljeni su učenici naselja ruralne periferije $(\mathrm{N}=9)$ te ostalih izvangradskih naselja $(\mathrm{N}=2)$. U konačnici, od ukupnog broja anketiranih učenika, 674 je učenika ruralnog rezidencijalnog podrijetla s validnim podacima $^{44}$, a njihovu zastupljenost prema tipovima naselje daje Tabela 2.29.

Tabela 2.23 Udjeli učenika 5 najzastupljenijih tipova ruralnih (i urbaniziranih) naselja u uzorku anketiranih učenika (validni podaci)

\begin{tabular}{|c|c|c|c|c|c|c|c|c|c|c|c|c|}
\hline & \multicolumn{2}{|c|}{$\begin{array}{l}\text { Ukupan } \\
\text { uzorak }\end{array}$} & \multicolumn{2}{|c|}{ 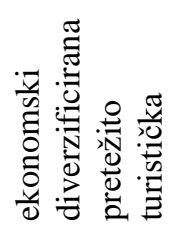 } & \multicolumn{2}{|c|}{ 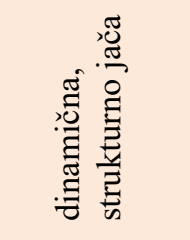 } & \multicolumn{2}{|c|}{ 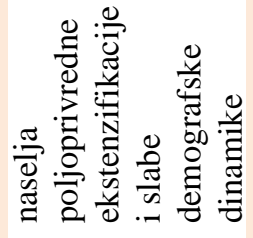 } & \multicolumn{2}{|c|}{ 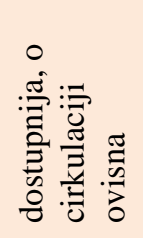 } & \multicolumn{2}{|c|}{ 柋 } \\
\hline & $\mathbf{f}$ & $\%$ & f & $\%$ & $\mathbf{f}$ & $\%$ & $\mathbf{f}$ & $\%$ & $\mathbf{f}$ & $\%$ & $\mathbf{f}$ & $\%$ \\
\hline $\begin{array}{l}\text { Učenici ruralnog } \\
\text { RP }\end{array}$ & 674 & 100 & 91 & 13,5 & 297 & 44,1 & 65 & 9,6 & 62 & 9,2 & 159 & 23,6 \\
\hline
\end{tabular}

Najveći dio (44\%) ih je odrastao u dinamičnim, strukturno jačim ruralnim i urbaniziranim naseljima, dok ih je $24 \%$ odraslo u tržišno orijentiranim poljoprivrednim ruralnim $\mathrm{i}$ urbaniziranim naseljima. Dodatnih 14\% anketiranih učenika odraslo je u ekonomski diferenciranim naseljima, pretežito turističkim, $10 \% \mathrm{u}$ naseljima poljoprivredne ekstenzifikacije i slabe demografske dinamike, dok je 9\% učenika iz dostupnijih, o cirkulaciji ovisnih naselja. Kao što je već upozoreno, općenito je manji broj učenika ruralnog rezidencijalnog podrijetla u ukupnom uzorku, te svakog pojedinog tipa ruralnih naselja, no odstupanja su ujednačena (od 1-3\%) te je najviše učenika odraslo u naseljima u kojima živi i najveći dio populacije, dok ih je najmanje odraslo u tipovima naselja u kojima živi i najmanji postotak stanovništva Hrvatske.

Tablica 2.24 prezentira podatke udjela učenika različitog rezidencijalnog podrijetla u uzorku anketiranih učenika prema regiji, spolu, tipu škole i lokacije škole koju završavaju.

Tabela 2.24 Struktura uzorka anketiranih učenika različitog rezidencijalnog podrijetla prema osnovnim kriterijima uzorkovanja

\begin{tabular}{|c|c|c|c|}
\hline $\begin{array}{c}\text { UKUPNI } \\
\text { UZORAK }\end{array}$ & Ruralno RP & Urbano RP & Metropola RP \\
\hline$\%$ & $\%$ & $\%$ & $\%$ \\
\hline
\end{tabular}

\footnotetext{
$\overline{44}$ Budući da je broj učenika posljednja dva tipa izuzetno mali, tih 11 učenika je isključeno iz daljnjih analiza, kao i 11 učenika čiji se podaci nisu mogli klasificirati i koristiti za daljnje analize.
} 


\begin{tabular}{lcccccccc}
\hline Regije & 1853 & 100 & 696 & 37,6 & 850 & 45,9 & 307 & 16,6 \\
\hline Dalmacija & 454 & 24,5 & 146 & 21 & 305 & 35,9 & 3 & 1 \\
\hline Istra i Primorje & 158 & 8,5 & 58 & 8,3 & 100 & 11,8 & 0 & 0 \\
\hline Sjeverozapadna HR & 278 & 15 & 176 & 25,3 & 98 & 11,5 & 4 & 1,3 \\
\hline Slavonija & 380 & 20,5 & 180 & 25,9 & 198 & 23,3 & 2 & 0,7 \\
\hline Središnja HR & 140 & 7,6 & 54 & 7,8 & 84 & 9,9 & 2 & 0,7 \\
\hline ZG i Zagreb. županija & 443 & 23,9 & 82 & 11,8 & 65 & 7,6 & 296 & 96,4 \\
\hline Spol & 1853 & 100 & 696 & 37,6 & 850 & 45,9 & 307 & 16,6 \\
\hline Ženski & 933 & 50,4 & 352 & 50,6 & 450 & 52,9 & 131 & 42,7 \\
\hline Muški & 920 & 49,6 & 344 & 49,4 & 400 & 47,1 & 176 & 57,3 \\
\hline Tip škole & 1853 & 100 & 696 & 37,6 & 850 & 45,9 & 307 & 16,6 \\
\hline Gimnazija & 560 & 30,2 & 142 & 20,4 & 282 & 33,2 & 136 & 44,3 \\
\hline Četverogodišnja SSŠ & 837 & 45,2 & 324 & 46,6 & 402 & 47,3 & 111 & 36,2 \\
\hline Trogodišnja SSŠ & 456 & 24,6 & 230 & 33 & 166 & 19,5 & 60 & 19,5 \\
\hline $\begin{array}{l}\text { Lokacija škole - } \\
\text { centralitet grada }\end{array}$ & 1853 & 100 & 696 & 37,6 & 850 & 45,9 & 307 & 16,6 \\
\hline Glavni grad & 363 & 19,6 & 44 & 6,3 & 27 & 3,2 & 292 & 95,1 \\
\hline „Veliki gradovi“ & 680 & 36,7 & 239 & 34,3 & 438 & 51,5 & 3 & 1 \\
\hline „Mali gradovi“ & 810 & 43,7 & 413 & 59,3 & 385 & 45,3 & 12 & 3,9 \\
\hline
\end{tabular}

Kako je vidljivo na u Tabeli 2.24, regionalne specifičnosti odražavaju se u udjelima anketiranih učenika različitog rezidencijalnog podrijetla u svakoj od regija. Tako je očekivan velik postotak učenika metropolitanskog rezidencijalnog podrijetla anketiranih u regiji Grad Zagreb i Zagrebačka županija (96\%). Nasuprot tome, najveći broj učenika ruralnog rezidencijalnog podrijetla, u odnosu na one urbanog, anketiran je u regiji Sjeverozapadna HR koja nema izraženi makroregionalni centar, dok suprotno vrijedi za regiju Dalmacija u kojoj je anketirano daleko više učenika urbanog rezidencijalnog podrijetla $(36 \%)$ u odnosu na one ruralnog $(21 \%)$. U ostalim regijama otprilike su podjednaki odnosi postotka anketiranih učenika ruralnog i rezidencijalnog podrijetla. Slika 3.3 prikazuje omjere učenika različitog rezidencijalnog podrijetla anketiranih u svakoj od 6 regija.

Distribucija učenika različitog rezidencijalnog podrijetla prema tome u kojim gradovima završavaju srednje škole pokazuje da je najveći dio učenika anketiran u malim gradovima, odnosno u gradovima do stupnja centraliteta jačeg regionalnog centra (44\%), dok je najmanje učenika anketirano u glavnom gradu $(20 \%)$.

Očekivano, gotovo svi učenici metropolitanskog rezidencijalnog podrijetla pohađaju škole u glavnom gradu (95\%), dok nešto više od polovice učenika urbanog rezidencijalnog podrijetla završava škole u „velikim gradovima“ (52\%), a nešto manje od polovice u „malim gradovima“ (45\%). Najveći dio ruralnih učenika škole pohađa u malim gradovima (59\%). 
Omjerno prema rezidencijalnom podrijetlu učenika (Slika 2.3), velika većina učenika anketiranih u glavnom gradu tamo je i odrasla, dok je više od polovice učenika anketiranih u gradovima većeg stupnja centraliteta odraslo u gradovima.

$\mathrm{S}$ druge strane, tip škole kojeg učenici završavaju pokazuje jasne razlike, i kada je u pitanju rezidencijalno podrijetlo učenika. Općenito, omjeri učenika u uzorku su sljedeći: 30\% gimnazijalaca, $45 \%$ učenika četverogodišnjih te $25 \%$ učenika trogodišnjih strukovnih škola.

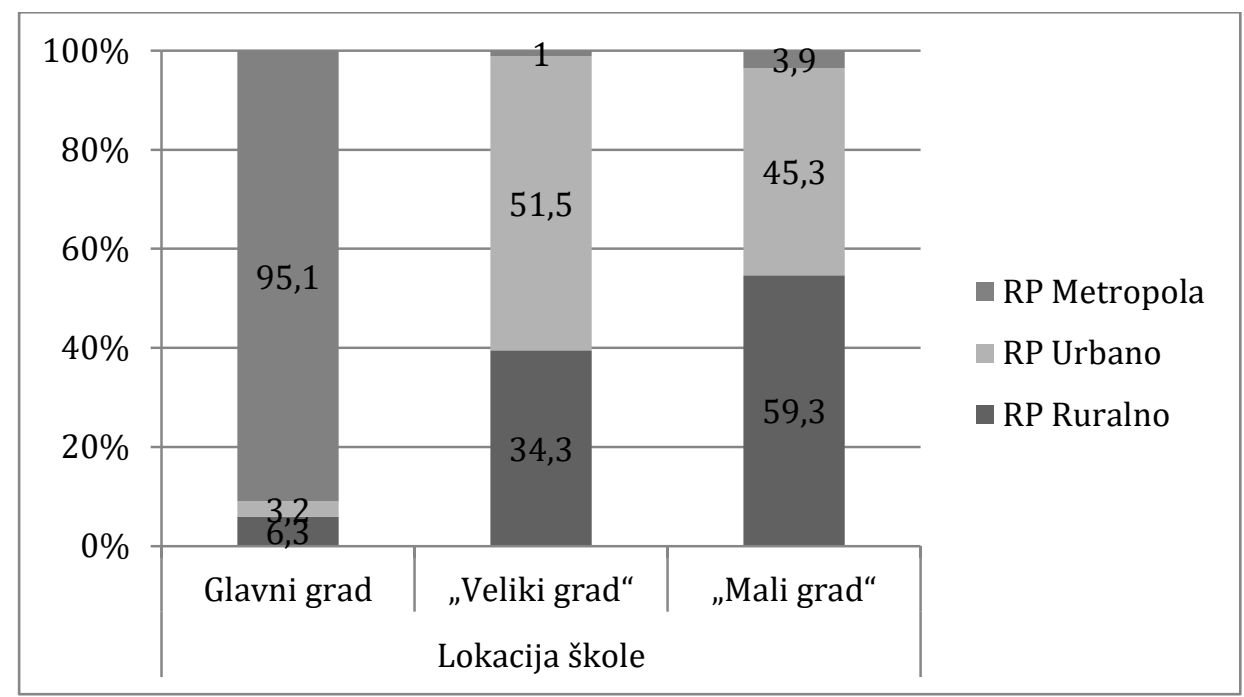

Slika 2.3 Omjerni prikaz učenika različitog rezidencijalnog podrijetla anketiranih u gradovima različitog stupnja centraliteta u kojima završavaju škole

Usporedno, među pojedinim kategorijama učenika prema njihovom rezidencijalnom podrijetlu uočljivo je kako udio gimnazijalaca raste kako raste veličina naselja u kojoj odrastaju učenici; tako $20 \%$ ruralnih učenika pohađa gimnazije, $33 \%$ urbanih, a čak $44 \%$ onih odraslih u glavnom gradu. S druge strane, od ukupnog broja ruralnih učenika $1 / 3$ ih pohađa trogodišnje strukovne škole, a 1/5 učenika odraslih u gradovima. 


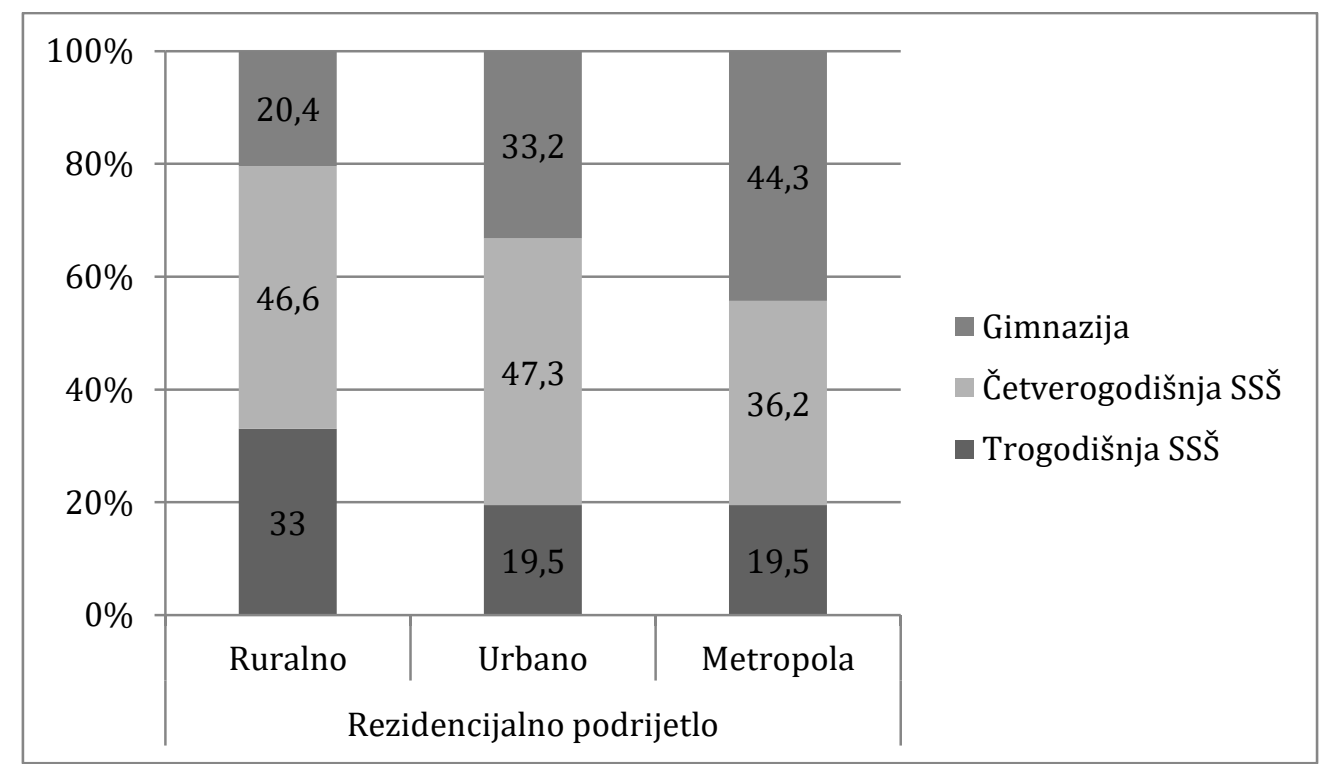

Slika 2.4 Udjeli učenika različitog rezidencijalnog podrijetla prema tipu škole koje završavaju

U konačnici, rodno je u ukupnom uzorku omjer djevojaka i mladića ujednačen, a jedino među učenicima metropolitanskog rezidencijalnog podrijetla postoji nerazmjer te je više mladića odraslih u Zagrebu ukupno anketirano u odnosu na djevojke (M 57\% > Ž 43\%)

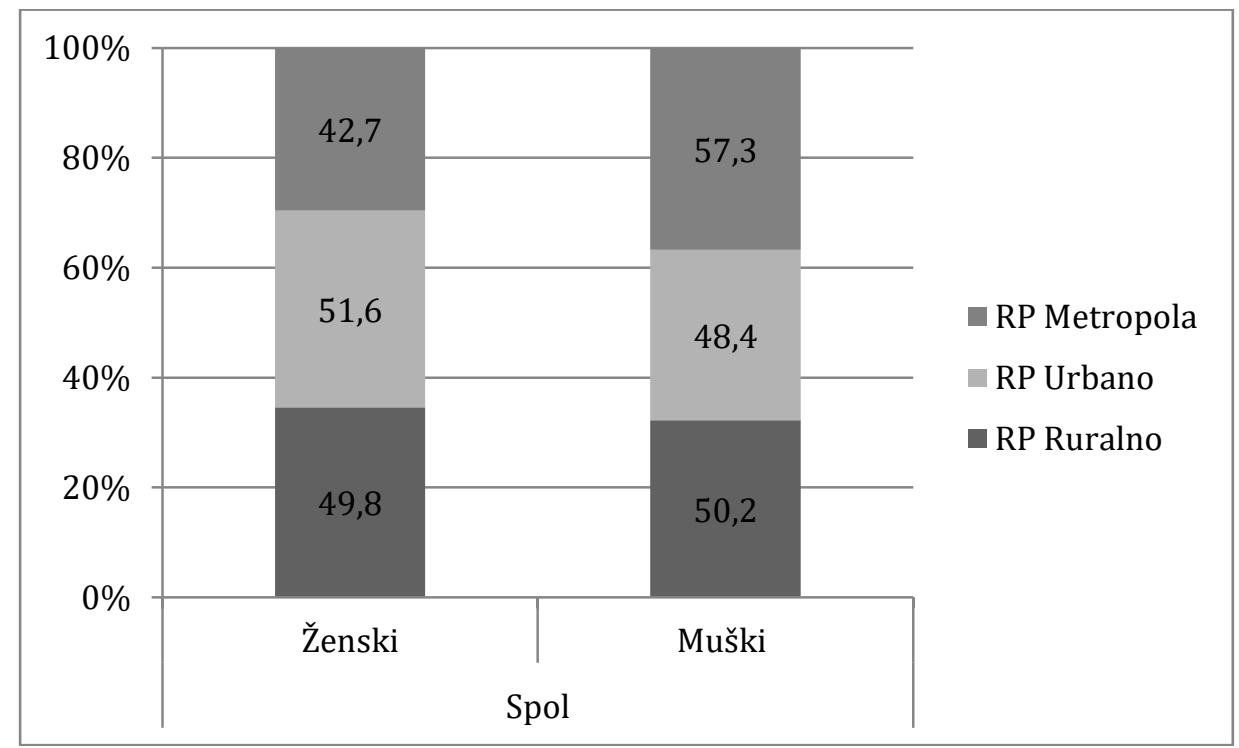

Slika 2.5 Omjerni prikazučenika različitog rezidencijalnog podrijetla u rodnim kategorijama anketiranih učenika 


\subsubsection{Uzorak učenika koji namjeravaju studirati i visokoobrazovni izbori}

Dio analiza usmjerenih ispitivanju visokoobrazovnih izbora maturanata, s posebnim interesom za utjecaj rezidencijalnog podrijetla, provode se na poduzorku onih maturanata koji namjeravaju studirati te su ostavili podatke o svom prvom izboru željenog studija, institucije i mjesta studiranja. Osnovne elemente strukture poduzorka prezentira Tablica 2.25, a Slike 2.7, 2.8 i 2.9 grafički prikazuju frekvencije osnovnih visokoobrazovnih izbora ispitivanih upitnikom.

U uzorku učenika koji namjeravaju studirati više je djevojaka (53\%) od mladića, a iako ga prvenstveno čine učenici četverogodišnjih srednjih škola (94\%), manjinu od 6\% čine i učenici trogodišnjih strukovnih škola koji iskazuju želju za nastavkom školovanja (N=79). Prema rezidencijalnom podrijetlu, prethodne analize su jasno pokazale kako se učenici iz ruralnih sredina u daleko manjem broju odlučuju za nastavak školovanja.

Tabela 2.25 Struktura uzorka učenika koji namjeravaju studirati $(\mathrm{N}=1258)$

\begin{tabular}{|c|c|c|c|c|c|c|}
\hline SPOL & \multicolumn{3}{|c|}{$\begin{array}{c}\text { Ženski } \\
\mathrm{N}=670(53 \%)\end{array}$} & \multicolumn{3}{|c|}{$\begin{array}{c}\text { Muški } \\
\mathrm{N}=588(47 \%)\end{array}$} \\
\hline TIP ŠKOLE & \multicolumn{2}{|c|}{$\begin{array}{c}\text { Trogodišnja strukovna SŠ } \\
\mathrm{N}=79(6 \%)\end{array}$} & \multicolumn{2}{|c|}{$\begin{array}{c}\text { Četverogodišnja strukovna SS } \\
\text { N=629 }(50 \%)\end{array}$} & \multicolumn{2}{|c|}{$\begin{array}{c}\text { Gimnazija } \\
\mathrm{N}=550(44 \%)\end{array}$} \\
\hline $\begin{array}{l}\text { REZIDENCIJALNO } \\
\text { PODRIJETLO }\end{array}$ & \multicolumn{2}{|c|}{$\begin{array}{c}\text { Ruralno } \\
\mathrm{N}=389(31 \%)\end{array}$} & \multicolumn{2}{|c|}{$\begin{array}{c}\text { Urbano } \\
\mathrm{N}=630(50 \%)\end{array}$} & \multicolumn{2}{|c|}{$\begin{array}{l}\text { Metropolitansko } \\
\mathrm{N}=239(19 \%)\end{array}$} \\
\hline REGIJA & $\begin{array}{c}\text { Dalmacija } \\
\mathrm{N}=331 \\
(26 \%)\end{array}$ & $\begin{array}{c}\text { Istra i } \\
\text { Primorje } \\
\text { N=112 } \\
(9 \%)\end{array}$ & $\begin{array}{c}\text { Sjeverozap. } \\
\text { HR } \\
\mathrm{N}=170 \\
(14 \%)\end{array}$ & $\begin{array}{c}\text { Slavonija } \\
\mathrm{N}=215 \\
(17 \%)\end{array}$ & $\begin{array}{c}\text { Središnja } \\
\text { HR } \\
\mathrm{N}=89 \\
(7 \%)\end{array}$ & $\begin{array}{c}\text { Grad ZG i } \\
\text { Zag. županija } \\
\text { N=341 } \\
(27 \%)\end{array}$ \\
\hline $\begin{array}{l}\text { LOKACIJA } \\
\text { SREDNJE ŠKOLE }\end{array}$ & \multicolumn{2}{|c|}{$\begin{array}{l}\text { „Mali gradovi““ } \\
\mathrm{N}=507(40 \%)\end{array}$} & \multicolumn{2}{|c|}{$\begin{array}{l}\text { „,Veliki gradovi } \\
\mathrm{N}=466(37 \%)\end{array}$} & \multicolumn{2}{|c|}{$\begin{array}{c}\text { Glavni grad } \\
\mathrm{N}=285(23 \%)\end{array}$} \\
\hline
\end{tabular}

Stoga ne iznenađuje da je,u odnosu na ukupan uzorak anketiranih učenika, udio učenika ruralnog rezidencijalnog podrijetla manji za $7 \%$, te $\mathrm{u}$ uzorku učenika koji namjeravaju studirati manje od trećine (31\%) je učenika odraslih na selu, dok je najviše porastao broj učenika urbanog rezidencijalnog podrijetla - s $46 \%$ u ukupnom uzorku na polovicu uzorka onih koji namjeravaju studirati (Slika 2.6). 


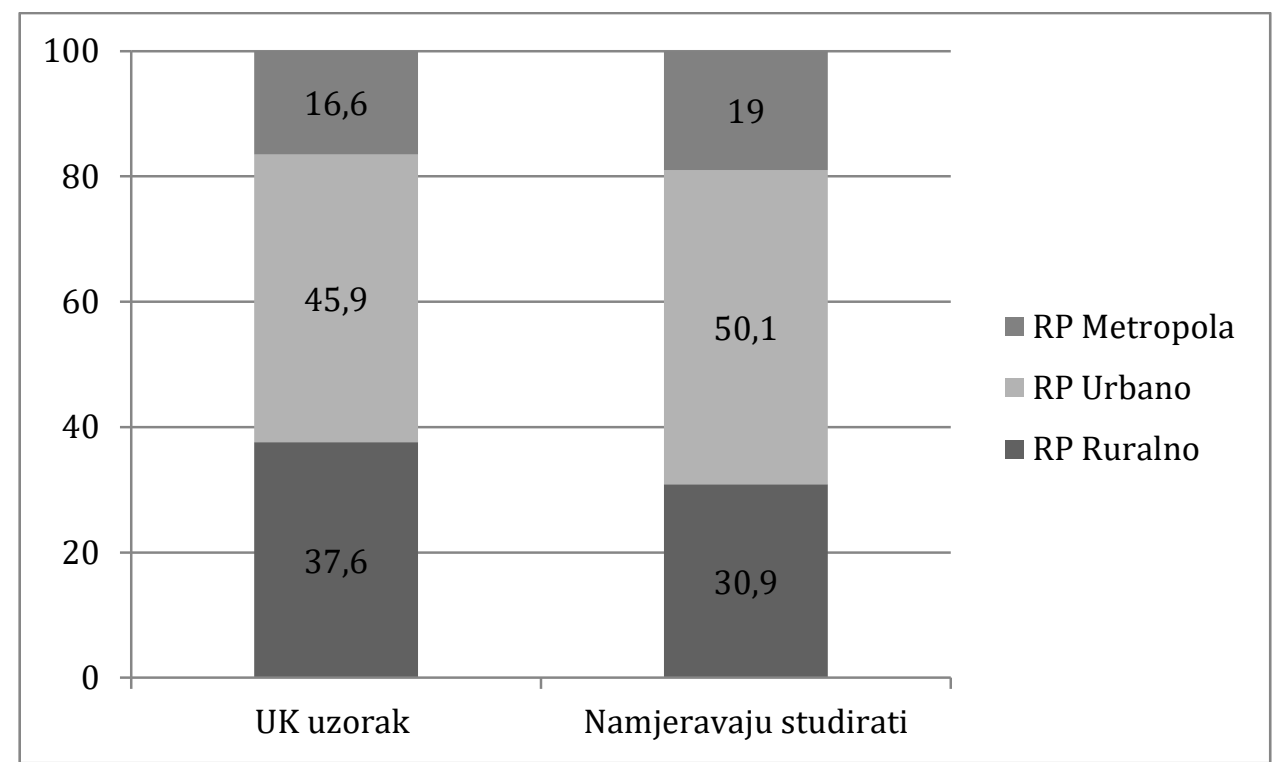

Slika 2.6 Omjeri udjela učenika različitog rezidencijalnog podrijetla u ukupnom uzorku i poduzorku onih koji namjeravaju studirati

Prema ostalim sociogeografskim karakteristikama, regionalno je u uzorku učenika koji namjeravaju studirati sada najviše onih iz zagrebačke i dalmatinske regije (27-26\%), dok je najveća razlika u smjeru smanjenja udjela zabilježena za regiju Slavonija koja je zastupljena sa 17\%. Konačno, i prema lokaciji srednjih škola koje učenici završavaju, u odnosu na početni uzorak zamjetno je povećanje udjela onih učenika koji škole završavaju u glavnom gradu (s 19 na 23\%), dok je manji udjel onih koji škole završavaju u malim gradovima (s 44 na 40\%).

Ukupno je 1344 učenika (64\% uzorka) ostavilo podatke o studiju kojeg žele upisati što je omogućilo njihovu klasifikaciju prema znanstvenom području. Na osnovi 1327 valjana podatka zadržane su dvije kategorije najčešćih izbora studija u području tehničkih $(31 \%)$ i društveno-humanističkih znanosti (40\%) Posljednja kategorija okupila je učenike, njih 30\%, koji studij biraju u nekom drugom području ${ }^{45}$.

\footnotetext{
${ }^{45} 15 \%$ bira studije iz područja biomedicine i zdravstva, $7 \%$ u prirodoznanstvenom području, dok oko $4 \%$ uzorka bira studije u biotehničkom i umjetničkom području.
} 
Društveno-humanističko područje $\mathrm{N}=526$

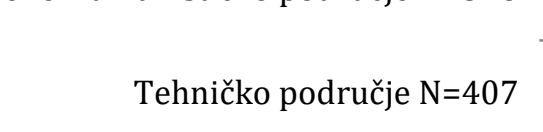

Biomedicina i zdravstvo $\mathrm{N}=198$

Prirodoznanstveno područje N=90

Biotehničko područje $\mathrm{N}=60$

Umjetničko područje $\mathrm{N}=46$

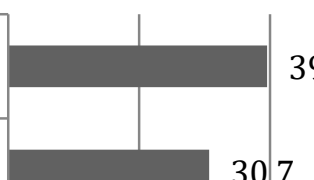

39,6

30,7

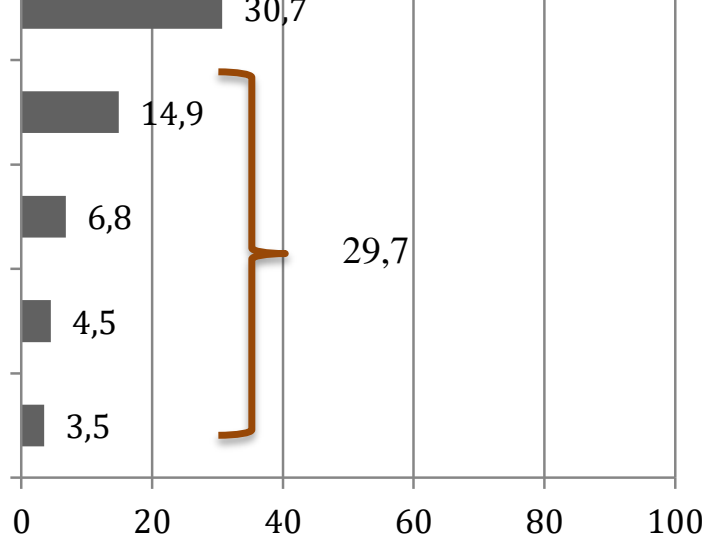

Slika 2.7 Udjeli učenika koji biraju studije u različitim znanstvenim područjima

Dodatno, na osnovi podataka upotrebljivih za klasifikaciju ${ }^{46}$ kreirana je varijabla Tip studija (N=1257) prema tome je li željeni studij sveučilišni ili stručni. Pritom je kategorija izbora sveučilišnog studija okupila prediplomske i integrirane sveučilišne studije koje izabire 85\% maturanata, dok je stručni studij okupio $15 \%$ učenika koji se odlučuju za stručne i stručne preddiplomske studije (Slika 2.8).

Također, učenike se pitalo i na kojoj instituciji žele upisati studij, a 1357 anketiranih učenika (64\%) upisalo je svoj odgovor. Sve institucije su dobile odgovarajući kod. U deskriptivne svrhe navodimo da je gotovo polovica učenika na prvo mjesto svoje liste studija stavila neku instituciju koja je sastavnica Zagrebačkog sveučilišta $(49 \%)^{47}$, a dodatnih $33 \%$ je na prvo mjesto stavilo neku sastavnicu ostalih sveučilišta u Hrvatskoj (13\% bira Sveučilište u Splitu, 9\% u Osijeku, 7\% u Rijeci, 3\% u Zadru, dok 1\% bira Sveučilište Sjever i Sveučilište u Dubrovniku; samo 4 učenika je zabilježilo studij na sastavnici Sveučilišta u Puli).

\footnotetext{
${ }^{46}$ Iz analize su isključeni učenici koji nisu dali podatke upotrebljive za klasifikaciju - njih 74 (3,5\%), i oni koji studij namjeravaju upisati u inozemstvu.

${ }^{47}$ Najfrekventniji su Filozofski fakultet (71), Prirodoslovno-matematički fakultet (60), Ekonomski fakultet (49), Medicinski fakultet (41), Fakultet elektrotehnike i računarstva (37), te Edukacijsko-rehabilitacijski fakultet (37), koji čine sami vrh ljestvice svih institucija na kojima učenici žele upisati studij.
} 


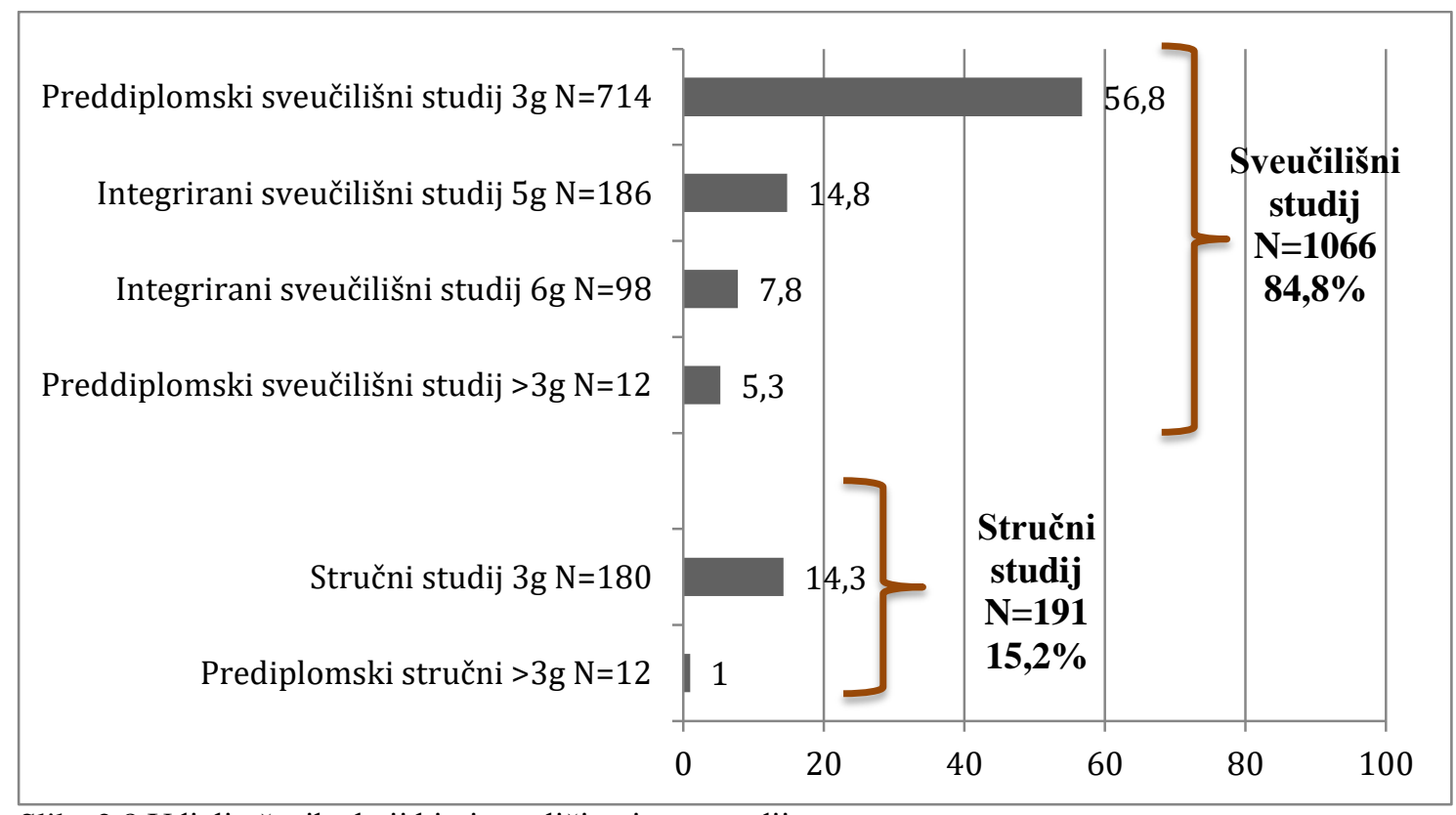

Slika 2.8 Udjeli učenika koji biraju različite tipove studija

Među ostalim visokim učilištima najčešće birana su javna veleučilišta koja se na prvom mjestu nalaze za $8 \%$ učenika ${ }^{48}$. Svi ostali tipovi institucija se na prvom mjestu želja nalaze za izuzetno mali broj učenika; 3\% učenika je odabralo neko privatno veleučilište ili visoku školu. Samo je 6 učenika odabralo privatno sveučilište, a 1 učenik javnu visoku školu.

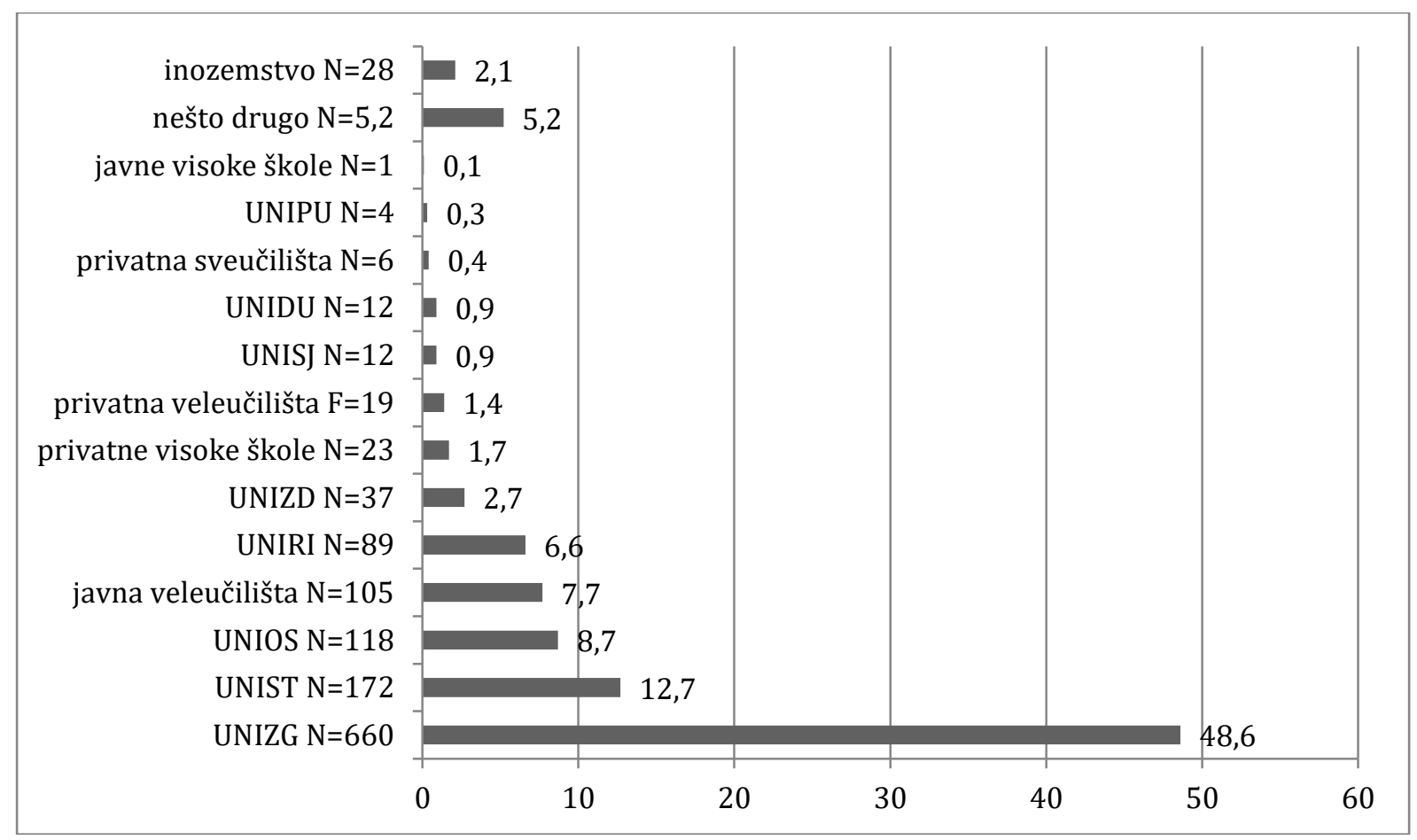

Slika 2.9 Frekvencije i postoci učeničkih izbora željene institucije studiranja

\footnotetext{
${ }^{48} \mathrm{Na}$ ljestvici visokoobrazovnih institucija na kojima učenici žele upisati studij, najfrekventniji odgovori vezani uz upis veleučilišta bili su Zdravstveno veleučilište u Zagrebu (36) i Tehničko veleučilište u Zagrebu (17), dok je 13, odnosno 12, učenika odabralo i Veleučilište u Rijeci te Veleučilište u Karlovcu.
} 
Podaci o frekvencijama odgovora $1258^{49}$ učenika svrstani u tri kategorije: 1) studij na nekoj od sastavnica ZG sveučilišta ${ }^{50}$, 2) studij na fakultetu ili sastavnici koja nije dio Zagrebačkog sveučilišta, te 3) studij na veleučilištu ili visokoj školi, prikazani su u Tablici 2.26. Kako je vidljivo, više od polovice učenika izabire studij na nekoj od sastavnica Sveučilišta u Zagrebu (53\%), dok dodatnih 36\% učenika bira studije na sastavnicama ostalih hrvatskih sveučilišta. Studijski program na veleučilištu ili visokoj školi prvi je izbor za 12\% učenika.

Tabela 2.26 Distribucija odgovora učenika o željenoj instituciji studija

\begin{tabular}{lccccccccc}
\hline & \multicolumn{2}{c}{ Ukupan uzorak } & \multicolumn{2}{c}{$\begin{array}{c}\text { Sastavnice ZG } \\
\text { sveučilišta }\end{array}$} & \multicolumn{2}{c}{$\begin{array}{c}\text { Fakultet/ } \\
\text { sveučilište }\end{array}$} & \multicolumn{2}{c}{$\begin{array}{c}\text { Veleučilište/ } \\
\text { visoka škola }\end{array}$} \\
\cline { 2 - 10 } & f & $\%$ & f & $\%$ & f & \% & f & $\%$ \\
\hline $\begin{array}{l}\text { Tip } \text { VO } \\
\text { institucije }\end{array}$ & 1258 & 100 & 660 & 52,5 & 450 & 35,8 & 148 & 11,8 \\
\hline
\end{tabular}

U konačnici, učenici su bilježili i u kojem gradu žele studirati, a prethodno izneseni podaci već ukazuju da se na samom vrhu tih želja nalazi grad Zagreb. Učenički odgovori analizirani su prema stupnju centraliteta grada u geografskom prostoru Hrvatske u kojem se željeni studij izvodi. Slika 3.10 iznosi osnovne podatke o zastupljenosti učenika u pojedinim kategorijama.

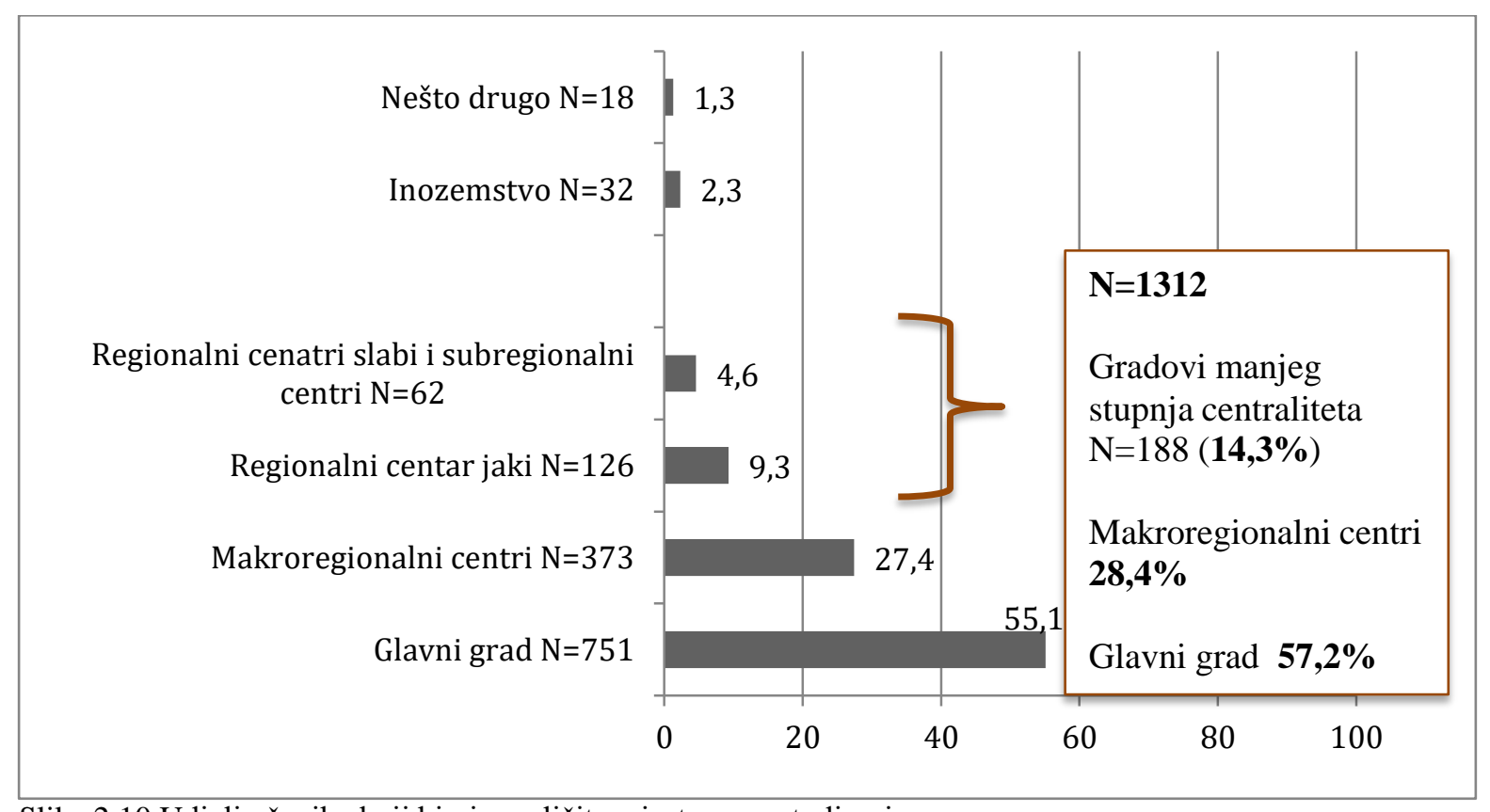

Slika 2.10 Udjeli učenika koji biraju različita mjesta svog studiranja

\footnotetext{
${ }^{49}$ Dio učenika nije dao zadovoljavajuće odgovore o tome na kojoj instituciji se izvodi njihov željeni studij (5\%) ili žele studirati u inozemstvu (2\%), te su oni izostavljeni izostavljeni iz analize.

${ }^{50}$ Zbog izraženog izbora studija koji se izvode na nekoj od sastavnici Zagrebačkog sveučilišta, uz visok interes i poseban status koje to Sveučilište ima u hrvatskom kontekstu, učenici koji su zabilježili takav izbor izdvojeni su u zasebnu kategoriju.
} 
U glavnom gradu želi studirati $57 \%$ učenika, dok ih $28 \%$ bira svoj željeni studij u ostalim makroregionalnim središtima. Najmanji broj učenika - 14\% - izabire kao željeno mjesto svog studiranja neki grad manjeg stupnja centraliteta.

Spomenimo i da samo manjina od $4 \%$ učenika namjerava studirati na privatnoj instituciji ili izvanredno (4\%).

\subsubsection{Reprezentativnost i struktura regionalnog kvantitativnog uzorka}

Kvantitativni uzorak regije Slavonija ${ }^{51}$ obuhvaća 439 anketiranih učenika što čini $21 \%$ ukupnog nacionalnog uzorka, i što je reprezentativan petpostotni uzorak populacije slavonskih maturanata.

Tip škole. Prema tipu škole, udjeli učenika reprezentativni su udjelima u populaciji (Slika 2.11): $23 \%$ maturanata Slavonije pohađa trogodišnje, $46 \%$ četverogodišnje strukovne škole, dok je $31 \%$ gimnazijalaca ${ }^{52}$.

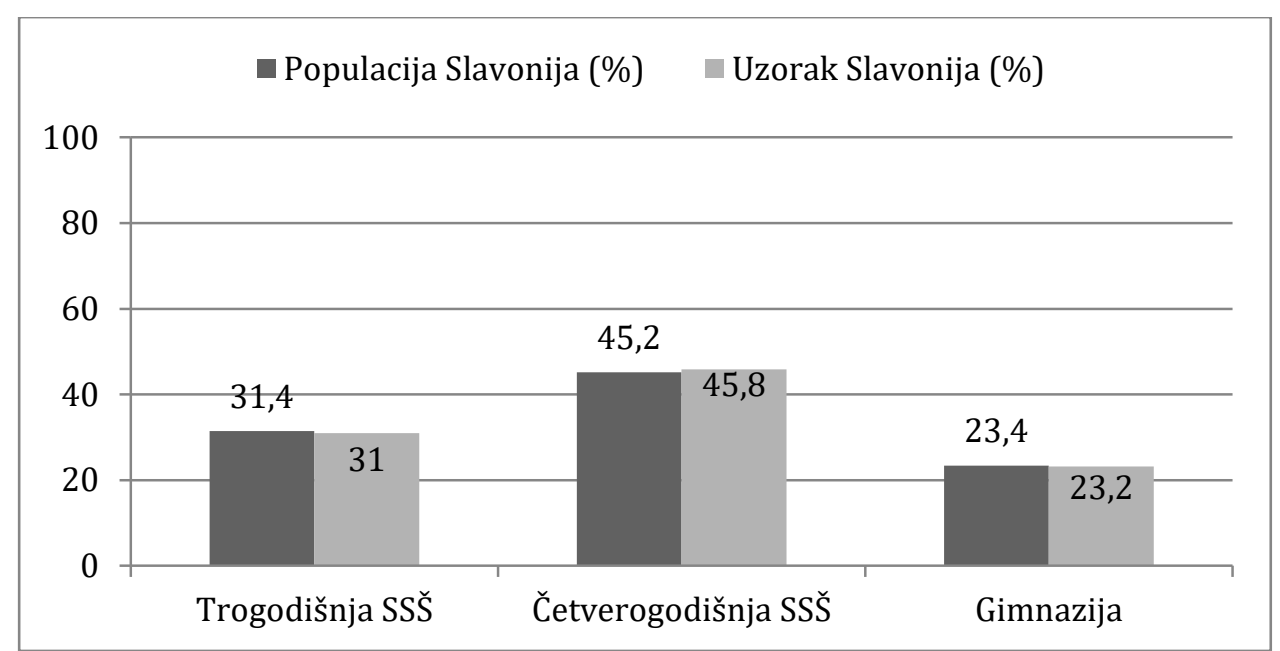

Slika 2.11 Usporedni prikaz broja učenika različitih tipova škola u populaciji i u uzorku učenika završnih razreda srednjih škola regije Slavonija

Spol. Ukupno, udjeli mladića i djevojaka ujednačeni su (51\% djevojaka - 49\% mladića), no rodna zastupljenost ovisi o tipu škole kojeg učenici pohađaju: kako prikazuje Tablica 2.27, više djevojaka (64\%) je anketirano u gimnazijama, dok je blago više mladića anketirano u strukovnim školama (52\% četverogodišnjih i 54\% trogodišnjih).

\footnotetext{
${ }^{51}$ Obuhvaća 5 županija: Osječko-baranjsku, Brodsko-posavsku, Požeško-slavonsku, Virovitičko-podravsku i Vukovarsko-srijemsku županiju.

${ }^{52}$ Takvi udjeli slični su onima u regijama Sjeverozapadna i Središnja HR u kojima je također udio učenika trogodišnjih strukovnih škola u populaciji (oko 32\%) veći od udjela gimnazijalaca (22-23\%), a razlikuje se od dalmatinske, primorske te zagrebačke regije za koje vrijedi suprotno (vidi Klepač, 2016).
} 
Tabela 2.27 Rodne razlike anketiranih slavonskih učenika prema tipu škole kojeg završavaju

\begin{tabular}{lcccccccc}
\hline & \multicolumn{2}{c}{ Uk uzorak SL } & \multicolumn{2}{c}{ GIM } & \multicolumn{2}{c}{ 4SS } & \multicolumn{2}{c}{ 3S Š } \\
\cline { 2 - 10 } & f & \% & f & \% & f & \% & f & \% \\
\hline Spol & 439 & 100 & 102 & 23,3 & 201 & 45,8 & 136 & 31 \\
\hline Ženski & 223 & 50,8 & 65 & $\mathbf{6 3 , 7}$ & 96 & 47,8 & 62 & 45,6 \\
\hline Muški & 216 & 49,2 & 37 & 36,3 & 105 & 52,2 & 74 & $\mathbf{5 4 , 4}$ \\
\hline
\end{tabular}

Zbog fokusa rada na kontekst odrastanja i školovanja učenika, reprezentativnost uzorka ispitana je i s obzirom na sociogeografske elemente: lokaciju srednje škole, odnosno stupanj centraliteta grada u kojem učenici završavaju srednje škole, te rezidencijalno podrijetlo učenika, odnosno tip mjesta u kojem su odrasli. Podaci su prikazani u Tablici 2.28.

Tabela 2.28 Usporedni prikaz udjela učenika prema tipu škole koji škole završavaju u „,velikim“ i „malim““ gradovima u populaciji i uzorku regije Slavonija

\begin{tabular}{lccccccccc}
\hline & \multicolumn{2}{c}{ Gimnazija } & \multicolumn{2}{c}{$\begin{array}{c}\text { Četverogodišnja } \\
\text { S ̌ }\end{array}$} & \multicolumn{2}{c}{$\begin{array}{c}\text { Trogodišnja } \\
\text { SS̆ }\end{array}$} & \multicolumn{2}{c}{ Ukupno } \\
\cline { 3 - 12 } & & FQ & $\%$ & FQ & $\%$ & FQ & $\%$ & FQ & $\%$ \\
\hline \multirow{2}{*}{$\begin{array}{c}\text { Lokacija škole } \\
\text { centralitet grada }\end{array}$} & Populacija & 2079 & 23,4 & 4021 & 45,2 & 2793 & 31,4 & 8893 & 100 \\
\hline \multirow{2}{*}{ „Veliki gradovi“ } & Uzorak & 102 & 23,2 & 201 & 45,8 & 136 & 31 & 439 & 100 \\
\hline \multirow{2}{*}{,Mali gradovi“ } & Populacija & 734 & 22,9 & 1470 & 44,6 & 993 & 31,1 & 3197 & 35,9 \\
& Uzorak & 54 & 29,5 & 89 & 48,6 & 40 & 21,9 & 183 & 41,7 \\
\hline & Populacija & 1345 & 23,6 & 2551 & 44,8 & 1800 & 31,6 & 5696 & 64,1 \\
& Uzorak & 48 & 18,8 & 112 & 43,8 & 96 & 37,5 & 256 & 58,3 \\
\hline
\end{tabular}

Lokacija škole. Populacijski podaci govore da 36\% slavonskih učenika pohađa škole u gradovima najvećeg stupnja centraliteta u regiji, a u uzorku su nadreprezentirani (42\%), dok suprotno vrijedi za učenike koji škole pohađaju u „malim gradovima“ koji su podreprezentirani u uzorku u odnosu na zastupljenost $\mathrm{u}$ populaciji slavonskih maturanata (58\% < 64\%). Pritom, u ,velikim gradovima“ su veći udjeli učenika četverogodišnjih srednjih škola, posebno gimnazija, u odnosu na udjele u populaciji $(30>23 \%)$, dok je u gradovima manjeg stupnja centraliteta anketirano više učenika trogodišnjih strukovnih škola $(38>32 \%)^{53}$.

Rezidencijalno podrijetlo. Anketno, u regiji Slavonija zahvaćeno je 49\% učenika koji su odrasli u ruralnim, te $51 \%$ odraslih u gradskim naseljima. Dakle, uzorak anketiranih učenika je ujednačen prema rezidencijalnom podrijetlu učenika, odnosno naselju u kojem odrastaju.

\footnotetext{
${ }^{53}$ Iako se pri uzorkovanju vodilo računa o veličini grada u kojem se škola u kojoj se provodilo ispitivanje nalazi, osnovni obziri su poklonjeni tome da zastupljenost prema tipu škole bude reprezentativna. Rezultat je nastao kao posljedica izbora da se anketiraju razredi, što je uobičajena praksa prikupljanja ovako velike količine podataka.
} 
S obzirom na njihovo rezidencijalno podrijetlo (Slika 2.12), uzorak je rodno ujednačen, no vidljivo je $\mathrm{i}$ da postoje razlike između ruralnih i urbanih učenika $\mathrm{u}$ njihovom izboru srednjoškolskog programa: ruralni učenici se u manjoj mjeri odlučuju za gimnazije ( $9 \%$ ), a u većoj mjeri za trogodišnje strukovne srednje škole (41\%), dok više od $1 / 3$ urbanih učenika završava gimnazije (37\%), a tek 1/5 trogodišnje strukovne škole (22\%).

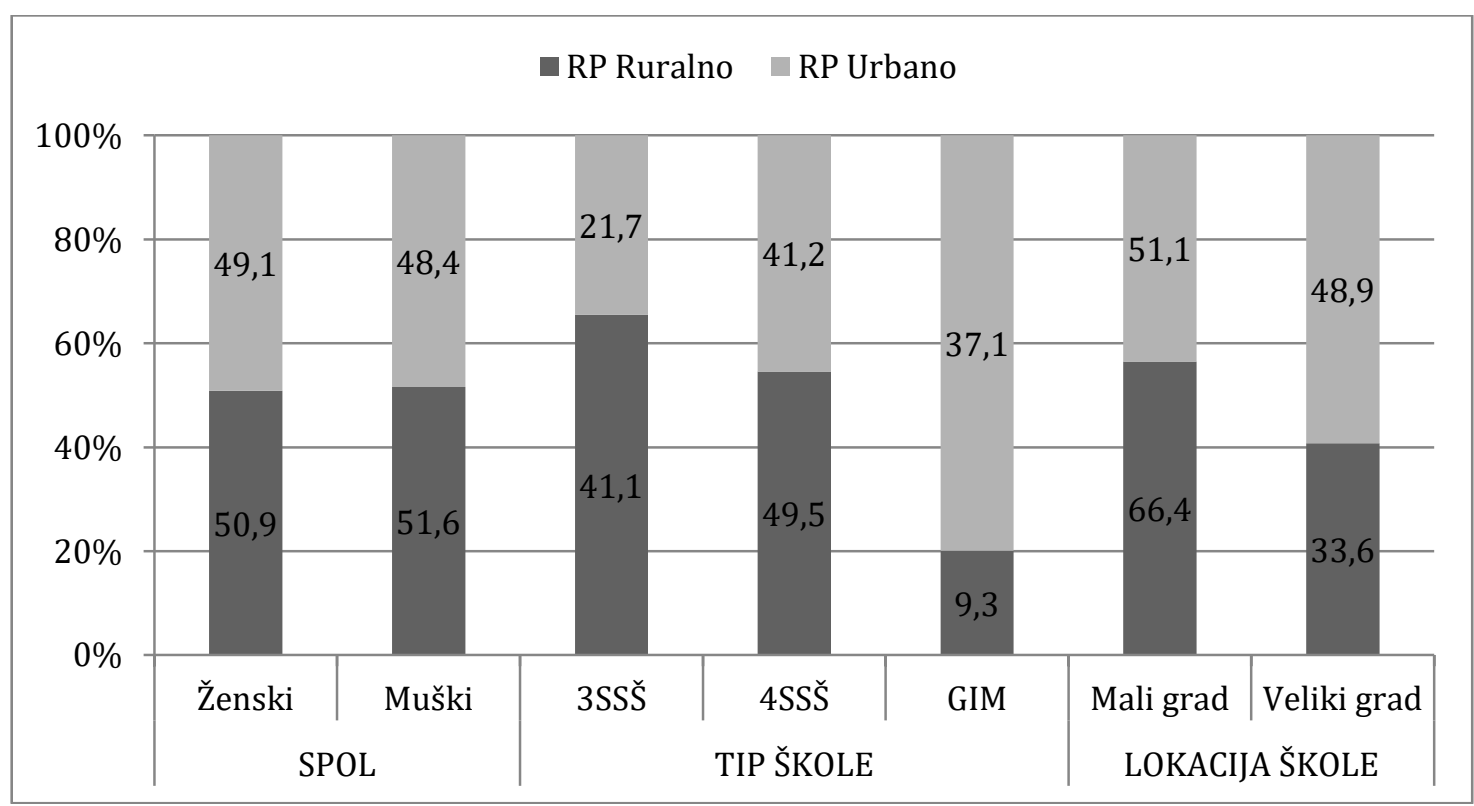

Slika 2.12 Omjeri učenika različitog rezidencijalnog podrijetla s obzirom na glavne kriterije uzorkovanja (spol, tip škole i centralitet grada u kojem škole završavaju)

Očekivano, razlike postoje i prema stupnju centraliteta grada u kojem završavaju škole; podjednak broj urbanih učenika škole pohađa u „malim“ i ,velikim gradovima“, dok 2/3 ruralnih učenika pohađa škole u gradovima manjeg stupnja centraliteta (,mali gradovi“).

Iza dihotomne klasifikacije urbano-ruralno, koja se koristi u daljnjim statističkim analizama, moguće je izdvojiti četiri kategorije učenika prema tipu naselja u kojem su odrasli pri čemu dvije opisuju urbano, a dvije ruralno rezidencijalno podrijetlo. Vidljivo je na Slici 4.3. da je najveći udio učenika anketiranih u regiji Slavonija (29\%) odrastao je u „malim gradovima“, a 24\% u najvećim regionalnim gradovima, dok su najveće kategorije ruralnih učenika oni odrasli u „dinamičnim, strukturno jačim ruralnim i urbaniziranim naseljima ${ }^{54 ، ~}(26 \%)$, te u

\footnotetext{
${ }^{54} \mathrm{U}$ tom tipu naselja živi najveći broj stanovnika Hrvatske (17\%), a obuhvaćaju područja uz gradove, duž cestovnih pravaca koji povezuju Središnju i Istočnu Hrvatsku te velika, centralnim funkcijama bolje opremljena naselja krajnjeg istoka Hrvatske. Nalaze se i oko makroregionalnih centara gdje prate glavne osi urbanizacije, i uz sva regionalna te neka subregionalna središta. Prosječno imaju 1085 stanovnika i prosječnu gustoću naseljenosti od $201 \mathrm{st} / \mathrm{km}^{2}$. Najveći udjeli takvih naselja nalaze se u Istočnoj Hrvatskoj, te Međimurju (Lukić, 2012).
} 
„tržišno orijentiranim poljoprivrednim naseljima“655 (21\%), što su dva tipa naselja najzastupljenija u regiji Slavonija.

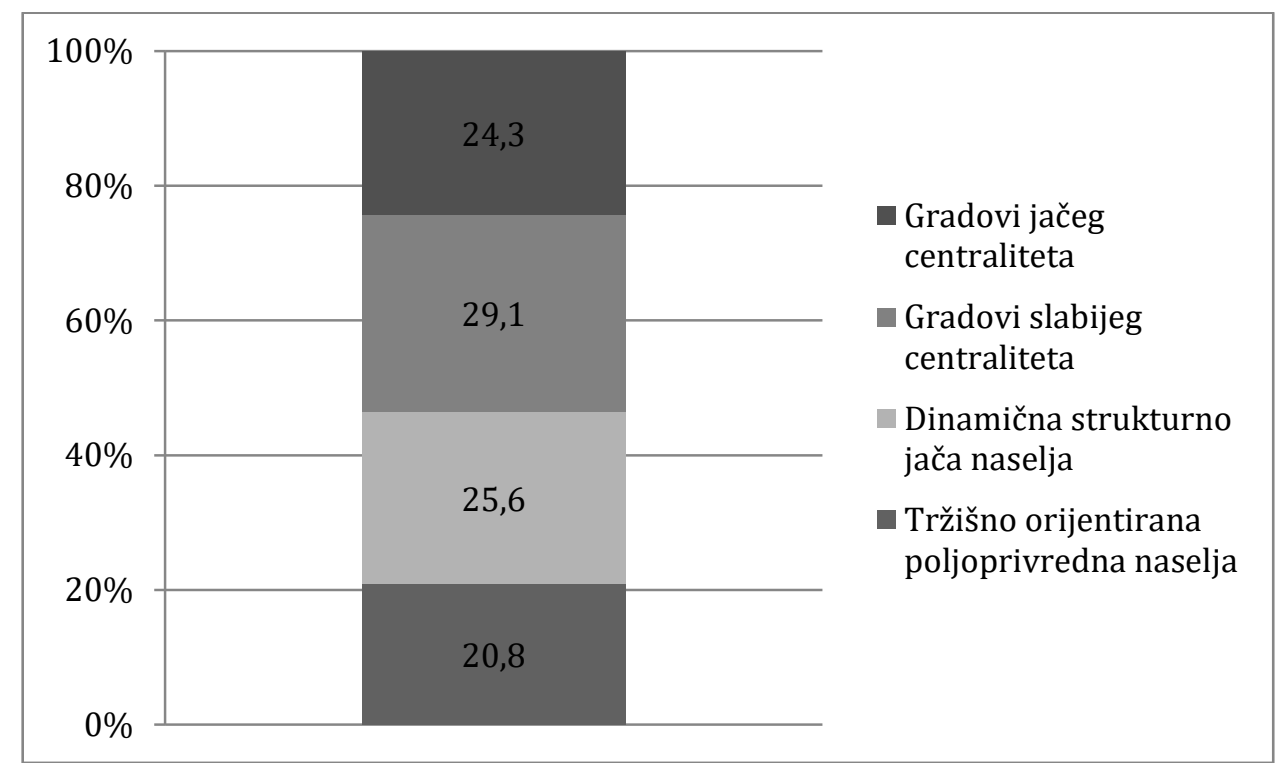

Slika 2.13 Udjeli učenika u pojedinim kategorijama rezidencijalnog podrijetla prema tipu naselja odrastanja

\subsubsection{Zastupljenost pojedinih slučajeva prema glavnim karakteristikama u uzorku intervjuiranih}

Učenike za intervjue zorkovalo se u fazama kako se razvijao sam rad na terenu. U početku izbor ispitanika je bio jednostavniji prema nekoliko informacija koje su učenici mogli dati u razredu neposredno nakon anketiranja - tražili su se učenici različitog rezidencijalnog porijekla koji pohađaju različite tipove škola. Nakon svakog intervjua, on je preslušavan i započinjalo se s transkripcijom u najkraćem mogućem vremenu tako da bi se, s obzirom da je bilo onemogućeno analizirati podatke, barem prema nekim osnovnim karakteristikama i prema sadržaju intervjua razmatralo koji bi profil ispitanika bio najzanimljiviji za nastavak ispitivanja. Drugim riječima, pritisci terenskog rada onemogućili su istinsko teorijsko selektiranje (Corbin, Strauss 1990) te se uzorkovalo u pokušaju pokrivanja što je moguće većeg raspon različitih profila izbora s obzirom na relaciju između (socijalne i geografske) pozicije polaska i željene pozicije.

U završnoj fazi nakon završetka anketiranja, kada su skupljeni svi upitnici, obavljeno je još 5 dodatnih intervjua s učenicima koji su u upitniku ostavili kontakt podatke i time iskazali

\footnotetext{
${ }^{55}$ Geografski su najzastupljenija naselja u Istočnoj Hrvatskoj. Karakterizira ih poljoprivreda kao izvor prihoda kućanstva i njena usmjerenost k tržištu. U ovom tipu naselja živi 12\% stanovništva Hrvatske, a zauzima $24 \%$ prostora Hrvatske. Prosječna veličina naselja je 305 stanovnika s prosječnom gustoćom naseljenosti od $38 \mathrm{st} / \mathrm{km}^{2}$ (Lukić, 2011).
} 
spremnost na sudjelovanje. Oni su, kako bi se omogućila veća heterogenost i usporedna analiza, izabrani na osnovi informacija u upitniku razmatranjem šireg spektra krriterija (poput tipa institucije te mjesta željenog studiranja), a bili su neophodan izvor novih informacija za popunjavanje uzorka. Također se vodilo računa da podjednako budu zastupljeni mladići i djevojke. Cilj uzorkovanja je bio zahvatiti što širi raspon slavonskih maturanata s obzirom na karakteristike njihovih početnih i željenih obrazovnih pozicija, a fokus je stavljen na sjecište namjere studiranja, rezidencijalnog podrijetla i tipa škole kojeg završavaju učenici.

U konačnici je obavljen razgovor s 20 učenika $^{56}$, a Tablica 2.29 opisuje neke osnovne karakteristike konačnog uzorka kvalitativnog dijela istraživanja u Slavoniji. Prema navedenim podacima, heterogenost je postignuta prema osnovnim varijablama od interesa. No ipak, provedba kvalitativnog ispitivanja na samom terenu nije prolazila bez svojih problema koji su zahtijevali prilagodbu planova, a konačni kvalitativni podaci su ukazali i na određene teškoće oko „čistog“" kategoriziranja ispitanika koje se raspravljaju kao dio analiza.

Tabela 2.29 Struktura uzorka kvalitativnog ispitivanja u Slavoniji - N=20

\begin{tabular}{|c|c|c|c|}
\hline SPOL & \multicolumn{2}{|l|}{ Ženski N=11 } & \multirow{2}{*}{$\begin{array}{l}\text { Muški N=9 } \\
\text { GIM N=7 }\end{array}$} \\
\hline TIP ŠKOLE & $3 \mathrm{SS} \mathrm{N}=4$ & $4 \mathrm{SS} \mathrm{S}=9$ & \\
\hline LOKACIJA ŠKOLE & „Mali gradovi““ $\mathrm{N}=13$ & \multicolumn{2}{|c|}{ „Veliki gradovi“ $\mathrm{N}=7$} \\
\hline REZIDENCIJALNO PODRIJETLO & $\begin{array}{l}\text { Ruralno } \\
\mathrm{N}=10\end{array}$ & $\begin{array}{c}\text { „Mali gradovi““ } \\
\text { N=8 }\end{array}$ & $\begin{array}{c}\text { „Veliki gradovi““ } \\
\mathrm{N}=2\end{array}$ \\
\hline Prosjek ocjena & Dobar $\mathrm{N}=10$ & Vrlo dobar $\mathrm{N}=4$ & Odličan $\mathrm{N}=6$ \\
\hline NAMJERA STUDIRANJA ${ }^{57}$ & $\mathrm{Ne}$ zna $\mathrm{N}=4$ & $\mathrm{NE} \mathrm{N}=1$ & $\mathrm{DA} N=15$ \\
\hline IZBOR MJESTA STUDIRANJA & Regija $N=6$ & Zagreb $\mathrm{N}=8$ & Dalje $\mathrm{N}=2$ \\
\hline VRSTA STUDIJA & Stručni studij $N=3$ & \multicolumn{2}{|c|}{ Sveučilišni studij $N=13$} \\
\hline
\end{tabular}

Ukratko, u razgovoru je sudjelovalo 15 učenika koji namjeravaju studirati, barem prema podacima koje su naveli u upitniku ${ }^{58}$, no 16 učenika je ostavilo podatke o svojim

\footnotetext{
${ }^{56}$ Inicijalni cilj je bio obaviti 30 intervjua, no njegovo postizanje su onemogućili specifične situacije rada na terenu i vremenski pritisak. U određenim školama nije postojao interes za sudjelovanje u intervjuu (npr. učenici nisu htjeli izostati s nastave tjelesnog odgoja, prakse, ili priprema za obilježavanje zadnjeg školskog dana). Dodatno, čak i kada je postojao popis potencijalnih ispitanika, postojali su i teškoće kontaktiranja ispitanika, dogovaranja termina i mjesta intervjua, npr. zbog neposjedovanja vlastitog mobitela ili elektroničke pošte, zbog potrebe putovanja, i slično. Konačno, neki učenici su se predomislili nakon prvotno iskazanog interesa, te su kod kasnijeg kontakta povukli svoj pristanak na sudjelovanje u intervjuu.

${ }^{57}$ Spomenimo da je 4 učenika uspješno upisalo svoj željeni studij, pri čemu je jedna učenica nakon prvog neuspješnog pokušaja čekala godinu dana. S druge strane, 6 učenika je upisalo studije koji su se razlikovali od njihova izbora koji su u vrijeme anketiranja izdvojili kao svoj prvi izbor. Pet učenika nije uspjelo upisati studij ili je u međuvremenu odustalo od ideje studiranja. Među preostalih 5 učenika 3 ih nije poduzelo korake prema upisivanju studija, a za učenike trogodišnjih strukovnih škola, koji godinu dana kasnije nisu niti mogli upisati studij, nije poznat konačan ishod.
} 
visokoobrazovnim planovima prema kojima polovica izabire studij u Zagrebu (N=8), dok ih je 17 u inervjuima progovaralo kako želi nastaviti studiratii. Samo troje učenika bira stručni studij. Intervjuirano je jedanaest učenica i devet učenika, od kojih 7 učenika gimnazija ${ }^{59}, 9$ iz četverogodišnjih te 4 učenika trogodišnjih strukovnih škola ${ }^{60}$. Spomenimo i da je gotovo polovica uzorka prošli razred završila s prosječnom ocjenom dobar $(\mathrm{N}=9)$, dok je 5 vrlo dobrih i 6 odličnih učenika.

Polovica uzorka je odrasla na selu pri čemu su podjednako zastupljena dva tipa prevladavajućih naselja (5 iz tržišno orijentiranih poljoprivrednih, te 5 iz dinamično strukturno jačih naselja), dok ih je 8 odraslo u gradovima manjeg stupnja centraliteta $(7+1)^{61}$, a dvoje u najvećim gradovima regije. Trinaest intervjua s učenicima obavljeno je u školama lociranim u tzv. malim gradovima ( 8 u subregionalnim i 5 u slabijim regionalnim centrima), dok je sedam učenika intervjuirano u školama u ,velikim gradovima“, odnosno makroregionalnom $(\mathrm{N}=4)$ i jačim regionalnim centrima $(\mathrm{N}=3)$.

S obzirom na teorijska polazišta, uzorak je morao zahvatiti i heterogenost prema financijskoj situaciji obitelji te prema tome jesu li učenici prva generacija studenata. Veći dio uzorka procijenio je financijsku situaciju svoje obitelji prosječnom $(\mathrm{N}=8)$, dok je jednak broj svoju obiteljsku situaciju procjenjuje iznadprosječnom $(\mathrm{N}=6)$ i ispodprosječnom $(\mathrm{N}=6)$. Također, većina ih nema niti roditelje niti nekoga u obitelji tko je studirao ili trenutno studira - njih 8 (iako velika većina pokazuje želju za studiranjem), dok je 7 intervjuiranih učenika s barem jednim visokoobrazovanim roditeljem, ali od kojeg broja njih 5 planira studirati.

Potrebno je istaknuti da su, s obzirom na interes usmjeren na ispitivanje procesa učeničkih odluka o namjerama studiranja, u uzorku u većoj mjeri nego je to karakteristično za regiju Slavonija zastupljeni učenici s visokoobrazovnim orijentacijama. To znači da su i prema obrazovnim karakteristikama i orijentacijama u uzorku intervjuiranih u blago većem broju

\footnotetext{
${ }^{58} \mathrm{U}$ razgovorima se pokazalo da su neki od učenika, unatoč tome što se razgovor odvijao neposredno pred završetak školske godine, još uvijek neodlučni oko toga namjeravaju li studirati ili ne; od četvero učenika koji su se u upitniku izjasnili da „ne znaju namjeravaju li studirati“ barem dvoje je u intervjuima govorilo o svojim namjerama studiranja, dok su drugi vrlo jasno govorili o tome da ne namjeravaju studirati. $\mathrm{S}$ druge strane, moguće je i među onima koji su se izjasnili kako namjeravaju studirati izdvojiti barem dvoje učenika čije namjere studiranja nisu čvrsto oblikovane i dostatno informirane, te time dovoljno uvjerljive. Pojedinačni slučajevi se raspravljaju u tekstu.

${ }^{59}$ Intervjuirani su učenici iz tri gimnazijska smjera: opće, prirodoslovno-matematičke i jezične gimnazije.

${ }^{60}$ Pri samom izradi uzorka vodilo se računa da budu zastupljeni učenici i onih traženih, i onih raširenih, i onih regionalno specifičnih programa, a također se vodilo računa da budu zastupljeni u podjednakoj mjeri i oni programi koje u većoj mjeri upisuju i završavaju mladići, oni koji u većoj mjeri upisuju i završavaju djevojke te oni programi koje podjednako upisuju mladići i djevojke.

${ }^{61}$ Jedan učenik je odrastao u naselju izraženih urbanih karakteristika, no koji ne omogućava srednjoškolsko obrazovanje te time uvelike utječe na obrazovne mogućnosti učenika. U analizama učenika se smatralo učenikom urbanog rezidencijalnog podrijetla koji odrasta u gradu nepotpunog centraliteta.
} 
zastupljeni učenici gimnazija i iznadprosječno uspješni učenici, a uzorak je i aspiracijama i očekivanjima optimističniji ${ }^{62}$, što je posebno naglašeno za učenike ruralnog rezidencijalnog podrijetla čije su visokoobrazovne namjere i izbori od središnjeg interesa.

Iako je uzorak heterogen s obzirom na osnovne kriterije izbora ispitanika bitno je istaknuti i neke nedostatke konačnog profila uzorka: među ruralnim učenicima prevladavaju djevojke (7 od 10), te nije obavljen niti jedan razgovor s mladićem koji završava gimnazijsko obrazovanje (u poduzorku su dvije gimnazijalke). Također, nije obavljen razgovor s nekim učenikom/com četverogodišnje strukovne škole koji ne želi studirati, iako postoje opisi o pojedinim prevladavajućim obrascima i stavovima prema studiranju koje učenici četverogodišnjih strukovnih škola opisuju kod svojih školskih kolega.

Nasuprot tome, među učenicima na „urbanom“ kraju klasifikacije veći broj intervjuiranih učenika je iz naselja definiranih kao „mali gradovi“, te je tek dvoje učenika (oboje gimnazijalaca) odraslo u velikim gradovima. Općenito, polovicu poduzorka učenika s urbanim rezidencijalnim podrijetlom predstavljaju gimnazijalci, a najveći je nedostatak osjetan kada su u pitanju slučajevi učenika strukovnih škola iz velikih gradova, te djevojaka koje pohađaju trogodišnje strukovne škole.

\footnotetext{
${ }^{62}$ Odnosno, općenito je više učenika koji se izjašnjavaju da žele postići najviše stupnjeve visokog obrazovanja (diplomsku i doktorsku razinu), a više ih smatra i da će u tome uspjeti. U odnosu na regionalne statističke omjere, u uzorku je više ambicioznijih ruralnih učenika - u istom broju kao i učenika urbanog rezidencijalnog podrijetla. Unatoč tome, uzorak omjerno oslikava i potkrepljuje neke druge statističke nalaze istraživanja (npr. o dužini promišljanja odluka, te stavu o podrazumijevanju studiranja).
} 


\section{EMPIRIJSKO ISTRAŽIVANJE NA NACIONALNOJ RAZINI}

\subsection{Struktura resursa dostupnih učenicima različitog rezidencijalnog podrijetla i njihova namjera studiranja}

$\mathrm{S}$ osloncem u inozemnim istraživanjima koja su ukazivala na postojanje urbano-ruralnih razlika na različitim varijablama obrazovnih ishoda učenika, prvi dio analiza sastoji se od njihova utvrđivanja u hrvatskom kontekstu i vođeno istraživačkim pitanjima prikazanim u Tabeli 2.1. S obzirom na polazišta u Bourdeuovoj teoriji, obrazovni ishodi shvaćeni su kao izraz količine dostupnih kapitala u kontekstima odrastanja i školovanja, prvenstveno obitelji, a koji oblikuju i poseban obrazovni habitus učenika različitog rezidencijalnog podrijetla. Iz tog razloga, osnovni cilj Poglavlja 3.1 je potvrditi hipotezu H1a: učenici iz ruralnih sredina rjeđe se odlučuju na nastavak školovanja na visokoškolskoj razini, te dodatno ispitati postoje li razlike koje značajno diferenciraju učenike različitog rezidencijalnog podrijetla prema elementima individualnih karakteristika i obrazovnih orijentacija te ekonomskim, kulturnim i simboličkim elementima konteksta odrastanja i školovanja.

\subsubsection{Namjera studiranja i obrazovne orijentacije učenika različitog rezidencijalnog podrijetla}

Postoje li razlike između učenika različitog rezidencijalnog podrijetla u njihovim namjerama studiranja, obrazovnim aspiracijama i očekivanjima te neupitnosti odluke o studiranju, odnosno potrebi/dužini promišljanja odluke? Taj skup varijabli - nazvan obrazovne orijentacije - shvaća se kao indikacije obrazovnih habitusa učenika koji su vezani s dostupnim resursima u kontekstima odrastanja i školovanja, a pri čemu i rezidencijalno podrijetlo učenika ima ulogu u njihovu oblikovanju. Obrazac pronađenih razlika kao rezultat provedenih hi-kvadrat testova na navedenim elementima prikazuju Tabela 3.1.

Općenito, preko 2/3 anketiranih učenika (69\%) izjasnilo se da namjerava studirati, a usporedno, $22 \%$ ih želi samo završiti srednju školu, dok nešto više - $26 \%$ - očekuje da će i postići taj stupanj obrazovanja. Dodatno, 61\% učenika nije u pitanje dovodilo odluku o studiranju smatrajući da im se studiranje podrazumijeva, iako je manje onih koji o odluci uopće nisu razmišljali (47\%). Možemo reći da je velika većina učenika u uzorku usmjerena prema visokom obrazovanju. 
Tabela 3.1 Razlike učenika različitog rezidencijalnog podrijetla prema namjeri studiranja i obrazovnim orijentacijama

\begin{tabular}{|c|c|c|c|c|c|c|c|c|c|}
\hline & \multicolumn{2}{|c|}{ Ukupni uzorak } & \multicolumn{2}{|c|}{ Ruralno } & \multicolumn{2}{|c|}{ Urbano } & \multicolumn{2}{|c|}{ Metropola } & \multirow{2}{*}{ Hi-kvadrat } \\
\hline & $\mathbf{f}$ & $\%$ & $\mathbf{f}$ & $\%$ & $\mathbf{f}$ & $\%$ & $\mathbf{f}$ & $\%$ & \\
\hline Namjera studiranja & 1836 & 100 & 690 & 37,6 & 845 & 46 & 301 & 16,4 & \\
\hline $\mathrm{Da}$ & 1258 & 68,5 & 389 & 56,4 & 630 & 74,6 & 239 & 79,4 & \multirow{3}{*}{$\chi^{2}(4)=88,66^{*}$} \\
\hline $\mathrm{Ne}$ & 328 & 17,9 & 189 & 27,4 & 105 & 12,4 & 34 & 11,3 & \\
\hline Ne znam & 250 & 13,6 & 112 & 16,2 & 110 & 13 & 28 & 9,3 & \\
\hline Podrazumijevanje studiranja & 1830 & 100 & 684 & 37,4 & 841 & 46 & 305 & 16,7 & \\
\hline Podrazumijeva mi se & 1120 & 61,2 & 351 & 51,3 & 568 & 67,5 & 201 & 65,9 & \multirow{3}{*}{$\chi^{2}(4)=61,91 *$} \\
\hline Ne podrazumijeva mi se & 203 & 11,1 & 119 & 17,4 & 60 & 7,1 & 24 & 7,9 & \\
\hline Niti da, niti ne & 507 & 27,7 & 214 & 31,3 & 213 & 25,3 & 80 & 26,2 & \\
\hline Dužina promišljanja odluke & 1825 & 100 & 685 & 37,5 & 837 & 45,9 & 303 & 16,6 & \\
\hline Nisam uopće razmišljao & 851 & 46,6 & 290 & 42,3 & 413 & 49,3 & 148 & 48,8 & \multirow{4}{*}{$\chi^{2}(6)=13,73^{*}$} \\
\hline Kratko sam razmišljao & 428 & 23,5 & 189 & 27,6 & 179 & 21,4 & 60 & 19,8 & \\
\hline Osrednje sam razmišljao & 314 & 17,2 & 123 & 18 & 136 & 16,2 & 55 & 18,2 & \\
\hline Dugo sam razmišljao & 232 & 12,7 & 83 & 12,1 & 109 & 13 & 40 & 13,2 & \\
\hline
\end{tabular}

Već ovi podaci sugeriraju da postoji obrazac ranog razvoja orijentacije prema visokom obrazovanju koji se pojavljuje kao nešto što se ne propituje i ne dovodi u sumnju barem kod polovice učenika koji namjeravaju studirati. Pretpostavka je da se takav obrazac pojavljuje upravo kod učenika koji završavaju gimnazijsko obrazovanje, a koje vrlo vjerojatnim čini nastavak školovanja.

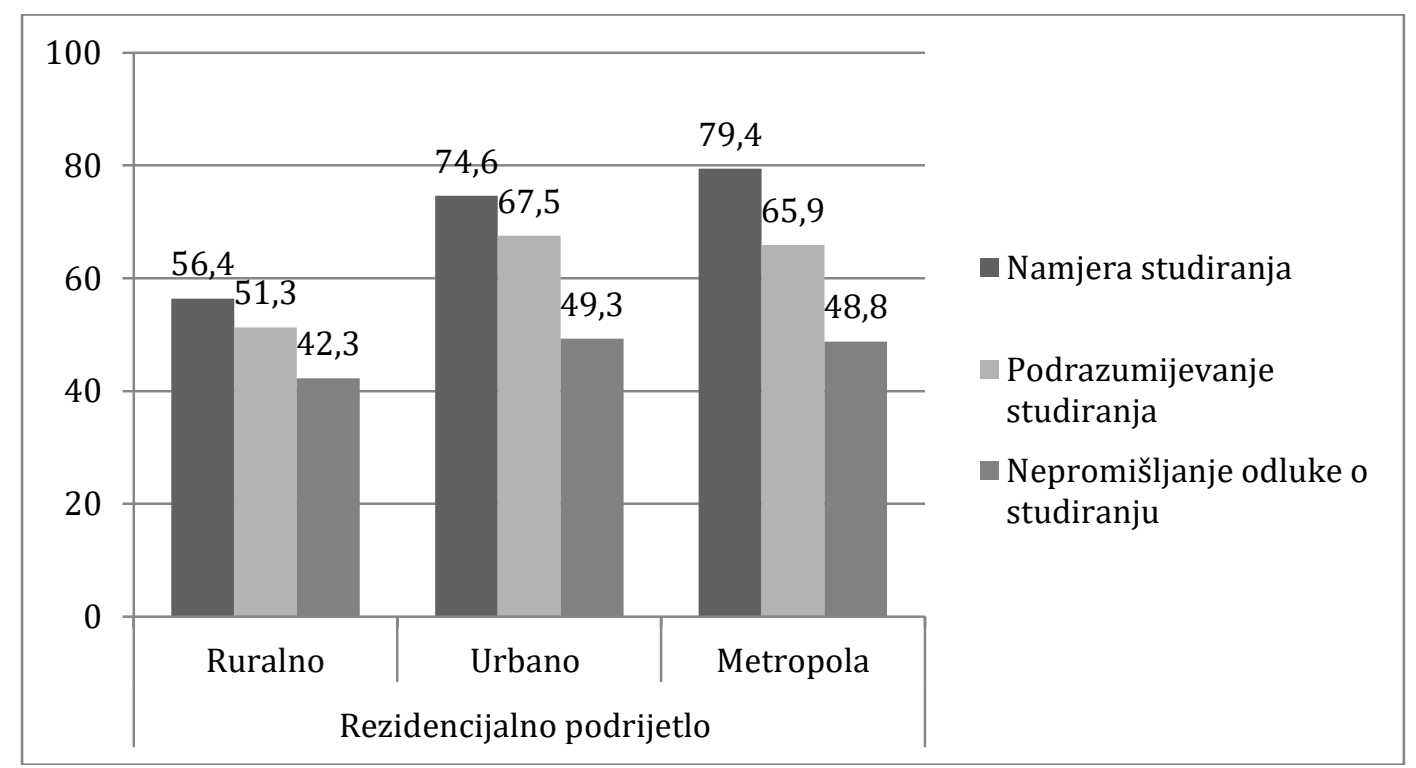

Slika 3.1 Razlike učenika različitog rezidencijalnog podrijetla prema namjeri studiranja, neupitnosti te odluke $\mathrm{i}$ dužini njenog promišljanja

Prema rezidencijalnom podrijetlu učenika, vidljivo na Slici 3.1, daleko manje se onih ruralnog rezidencijalnog podrijetla odlučuje na nastavak školovanja na visokoškolskoj razini - tek 
preko polovice (56\%), u odnosu na učenike odrasle u gradu ( $\mathrm{U}_{\mathrm{URP}}=75 \%$ i $\left.\mathrm{U}_{\mathrm{MRP}}=79 \%\right)$, a također ih i manji broj smatra da im se studiranje podrazumijeva $\left(\mathrm{U}_{\mathrm{RRP}}=51 \%<\mathrm{U}_{\mathrm{URP}}=68 \% \mathrm{i}\right.$ $\mathrm{U}_{\mathrm{MRP}}=67 \%$ ), odnosno nešto manje ih je bez razmišljanja donijelo odluku o studiranju $\left(\mathrm{U}_{\mathrm{RRP}}=42 \%<\mathrm{U}_{\mathrm{URP}}\right.$ i $\left.\mathrm{U}_{\mathrm{MRP}}=49 \%\right)$.

Takvi rezultati na pokazateljima učeničkih obrazovnih orijentacija u skladu su i s obrazovnim aspiracijama učenika. S obzirom na namjeru studiranja, visokoobrazovne aspiracije su općenito visoke, pri čemu najveći broj učenika želi postići diplomsku razinu (42\%), a petina želi i doktorirati (21\%), dok je najmanje poželjna razina visokog obrazovanja ona postizanja preddiplomske razine (15\%). Kako je već izdvojeno, 22\% učenika želi samo završiti srednju školu, što je odluka statistički u značajno većoj mjeri karakteristična za učenike ruralnog rezidencijalnog podrijetla (Slika 3.2); njih 1/3 ne iskazuje želju za nastavkom školovanja, a također ih i manji broj (52\%) teži najvišim visokoobrazovnim stupnjevima (diplomskoj i doktorskoj razini), u odnosu na učenike urbanog i metropolitanskog podrijetla koji izraženo teže upravo najvišim obrazovnim razinama (njih gotovo 3/4).

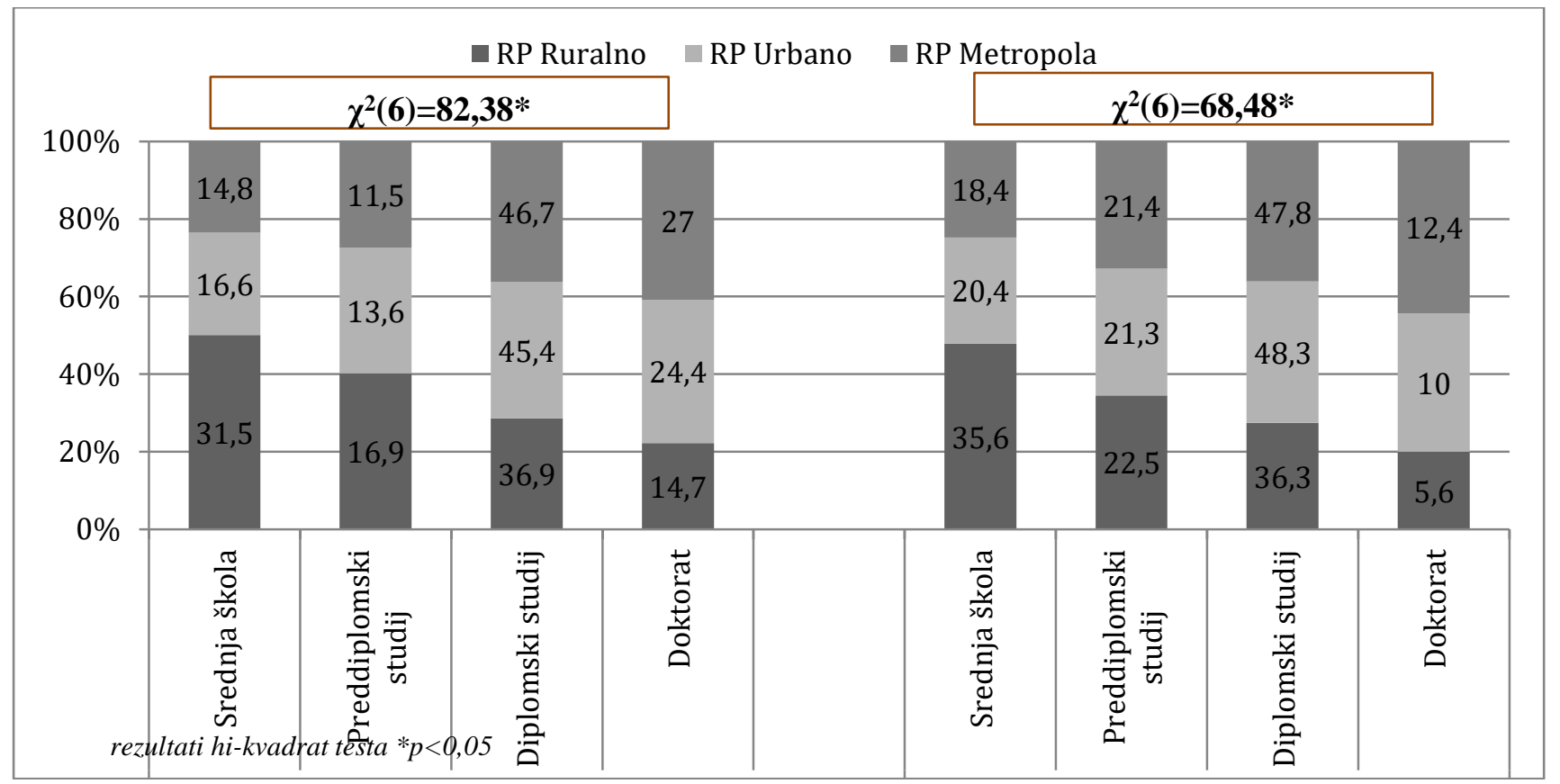

Slika 3.2 Omjeri udjela učenika različitog rezidencijalnog podrijetla u kategorijama obrazovnih aspiracija i očekivanja

Dodatno, iako je kod svih učenika vidljivo percipiranje određenih prepreka u ostvarenju svojih aspiracija, posebno kod ostvarivanja doktorske razine, što je kategorija koja se najviše smanjuje u odnosu na aspiracije (tek 9\% učenika smatra da će postići doktorat u odnosu na $21 \%$ onih koji tom stupnju teže), kod učenika urbanog i metropolitanskog podrijetla 
povećavaju se udjeli u ostalim kategorijama očekivanog postizanja nekog stupnja visokog obrazovanja, dok se za učenike ruralnog rezidencijalnog podrijetla povećavaju udjeli u kategorijama najnižih stupnjeva obrazovanja - one završavanja srednje škole (s 31 na 36\%) i one završavanja preddiplomske razine (sa 17 na $23 \%$ ).

Sve navedeno opisuje obrazac prema kojem učenici ruralnog rezidencijalnog podrijetla $u$ manjoj mjeri namjeravaju, teže i očekuju postizanje nekog stupnja visokog obrazovanja, odnosno pokazuju u manjoj mjeri izražene visokoobrazovne orijentacije. Rezultati potvrđuju hipotezu H1a i usmjeravaju daljnje ispitivanje rezidencijalnih razlikama prema nekim učeničkim individualno razvijenim i učenicima dostupnim resursima u školama i obiteljima, a za koje možemo utvrditi vrijednost visokoobrazovnih kapitala.

\subsubsection{Obrazovne karakteristike i kulturne kompetencije učenika različitog rezidencijalnog podrijetla}

Vrlo ujednačen obrazac rezidencijalnih razlika pokazao se i pri ispitivanju obrazovnih karakteristika učenika kao i njihovih kulturnih kompetencija koje se teorijski postavljaju kao značajni podržavajući elementi s utjecajem na obrazovne ishode učenika.

Ranije se već ukazalo na značajnu razliku prema tipu škole između učenika različitog rezidencijalnog podrijetla (Slika 3.5) za koju se pretpostavlja značajan utjecaj na orijentaciju srednjoškolskih učenika prema visokom obrazovanju. Dodatno, značajan utjecaj na takvo orijentiranje učenika sigurno imaju ocjene.

Na općoj razini, u prošloj godini je prosječni uspjeh maturanata bio vrlo dobar $(\mathrm{M}=3,8)$, ali se razlikovao za učenike različitog rezidencijalnog podrijetla te je statistički značajno niži za one odrasle na selu $(M=3,7)$ u odnosu na prosječni rezultat školske uspješnosti učenika odraslih u urbanim sredinama $\left(\mathrm{M}_{\mathrm{URP}}=3,8\right.$ i $\left.\mathrm{M}_{\mathrm{MRP}}=3,9\right)$. Dodatno, na isti način prosječni rezultati razlikuju učenike različitog rezidencijalnog podrijetla kada su u pitanju njihove kulturne kompetencije (Tabela 3.4), odnosno na mjerama osobnog kulturnog kapitala: učenici ruralnog rezidencijalnog podrijetla imaju statistički niže prosječne rezultate na mjeri učestalosti sudjelovanja u različitim praksama visoke kulture (poput odlazaka u kazalište, muzeje i na operu ili balet) $\left(\mathrm{M}_{\mathrm{RRP}}=1,6>\mathrm{M}_{\mathrm{URP}}=1,7\right.$ i $\left.\mathrm{M}_{\mathrm{MRP}}=1,8\right)$, kao i učestalosti čitanja različitih vrsta tekstova $\left(\mathrm{M}_{\mathrm{RRP}}=2,2>\mathrm{M}_{\mathrm{URP}}=2,4\right.$ i $\left.\mathrm{M}_{\mathrm{MRP}}=2,4\right)$, te pohađanja izvanškolskih aktivnosti $\left(\mathrm{M}_{\mathrm{RRP}}=0,1>\mathrm{M}_{\mathrm{URP}}=0,2\right.$ i $\left.\mathrm{M}_{\mathrm{MRP}}=0,2\right)$ 
Tabela 3.2 Analiza varijance između grupa učenika različitog rezidencijalnog podrijetla na varijablama školskih karakteristika i osobnih kulturnih kompetencija

\begin{tabular}{|c|c|c|c|c|c|c|c|c|c|c|}
\hline \multirow[b]{2}{*}{ Zavisna varijabla } & \multicolumn{2}{|c|}{ UK } & \multicolumn{2}{|c|}{$\begin{array}{l}\text { (1) RP } \\
\text { Ruralno }\end{array}$} & \multicolumn{2}{|c|}{$\begin{array}{l}\text { (2) RP } \\
\text { Urbano }\end{array}$} & \multicolumn{2}{|c|}{$\begin{array}{c}\text { (3) RP } \\
\text { Metropola }\end{array}$} & \multirow[t]{2}{*}{ ANOVA } & \multirow{2}{*}{$\begin{array}{l}\text { Post- } \\
\text { hoc tes }\end{array}$} \\
\hline & M & SD & $\mathbf{M}$ & SD & $\mathbf{M}$ & SD & M & SD & & \\
\hline $\begin{array}{l}\text { Opći uspjeh } \\
\text { prošle godine }\end{array}$ & 3,79 & 0,65 & 3,71 & 0,67 & 3,81 & 0,64 & 3,91 & 0,63 & $\mathrm{~F}(2 / 1826)=10,22 *$ & $\begin{array}{c}1-2 *, 1- \\
3 *\end{array}$ \\
\hline $\begin{array}{l}\text { Uč. kulturne } \\
\text { prakse }\end{array}$ & 1,72 & 0,68 & 1,63 & 0,66 & 1,75 & 0,68 & 1,83 & 0,72 & $\mathrm{~F}(2 / 1843)=10,56^{*}$ & $\begin{array}{c}1-2 *, 1- \\
3 *\end{array}$ \\
\hline $\begin{array}{l}\text { Uč. čitalačke } \\
\text { prakse }\end{array}$ & 2,33 & 0,92 & 2,24 & 0,93 & 2,37 & 0,91 & 2,40 & 0,92 & $\mathrm{~F}(2 / 1841)=4,51 *$ & $\begin{array}{c}1-2 *, 1- \\
3 *\end{array}$ \\
\hline $\begin{array}{l}\text { Uč. izvanškolske } \\
\text { aktivnosti }\end{array}$ & 0,17 & 0,22 & 0,14 & 0,2 & 0,18 & 0,22 & 0,19 & 0,24 & $\mathrm{~F}(2 / 1833)=10,44^{*}$ & $\begin{array}{c}1-2 *, 1- \\
3 *\end{array}$ \\
\hline $\begin{array}{l}\text { Vrijednost } \\
\text { učenja }\end{array}$ & 3,66 & 0,84 & 3,63 & 0,87 & 3,72 & 0,81 & 3,55 & 0,85 & $\mathrm{~F}(2 / 1838)=4,71 *$ & $2-3 *$ \\
\hline $\begin{array}{l}\text { Želja za dr. } \\
\text { mobilnošću }\end{array}$ & 3,57 & 0,83 & 3,58 & 0,83 & 3,59 & 0,82 & 3,48 & 0,89 & $F(2 / 1818)=2,06$ & - \\
\hline
\end{tabular}

${ }^{*} p<0,05$

Prethodne analize ukazuju na slabije visokoobrazovne orijentacije izražene kod učenika ruralnog rezidencijalnog podrijetla, kao i razlike prema obrazovnim karakteristikama koje bitno određuju učeničke pozicije u konačnim stadijima procesa odlučivanja o nastavku školovanja. Postavilo se pitanje znači li to da ruralni učenici ne vrednuju u jednakoj mjeri učenje, odnosno koliko uopće imaju želju za društvenom mobilnošću bez obzira odražava li se kroz obrazovne napore, ili ne. Općenito, prosječni rezultati nacionalnog uzorka maturanata na dvije varijable od interesa (Tabela 3.2) ukazuju da maturanti blago iznadprosječno vrednuju učenje $(M=3,7)$ te iskazuju želju za društvenom mobilnošću $(M=3,6)$. No, rezultati ANOVA testa nisu potvrdili pretpostavljene odgovore s obzirom na rezidencijalno podrijetlo učenika. Naime, kada je u pitanju vrednovanje učenja pokazala se razlika između urbanih grupa učenika: prosječni rezultat učenika odraslih u gradovima je statistički značajno viši $\left(\mathrm{M}_{\mathrm{URP}}=3,7\right) \mathrm{u}$ odnosu na onaj učenika odraslih u metropoli $\left(\mathrm{M}_{\mathrm{MRP}}=3,6\right)$, dok želja za društvenom mobilnošću ne razlikuje učenike odrasle u različitim tipovima naselja.

Stoga su rezultati ovih analiza, koji su pokazali da općenito učenici odrasli na selu podjednako iznadprosječno vrednuju učenje i teže uspinjanju na društvenoj ljestvici u odnosu na položaj svojih roditelja kao i urbani učenici, zadržali istraživački interes za dvije varijable - vrijednost pripisana učenju i želja za društvenom mobilnošću - koje su činile bitan dio kasnijih analiza objašnjenja učeničkih visokoobrazovnih ishoda. 


\subsubsection{Ekonomsko-materijalna obiteljska situacija i obazovno-kulturno obiteljsko okruženje učenika različitog rezidencijalnog podrijetla}

U literaturi je duboko istraživan i potvrđen utjecaj obiteljskog socioekonomskog statusa na obrazovne ishode učenika, te se SES obitelji pokazuje kao bitan čimbenik učeničkog školskog uspjeha i nastavka školovanja na visokoškolskoj razini (Puzić, Košutić 2015). S pretpostavkom da obitelji učenika ruralnog rezidencijalnog podrijetla imaju nepovoljniju strukturu obiteljski dostupnih resursa, ispituju se razlike između učenika različitog rezidencijalnog podrijetla na tri mjere ekonomskog te četiri mjere kulturnih kapitala.

Navedene analize i statistički značajni hi-kvadrati i ANOVA-e, prezentirani u Tabeli 3.3 i 3.5 , potvrđuju sve navedene elemente ekonomskih i kulturnih obilježja obitelji kao značajne odrednice razlike učenika različitog rezidencijalnog podrijetla, te moguće odrednice njihovih namjera studiranja.

Tabela 3.3 Razlike između učenika različitog rezidencijalnog podrijetla prema radnom statusu i obrazovanju roditelja te obiteljskom posjedovanju knjiga

\begin{tabular}{|c|c|c|c|c|c|c|c|}
\hline \multirow[b]{2}{*}{ Zavisna varijabla } & \multicolumn{2}{|c|}{ Ruralno } & \multicolumn{2}{|c|}{ Urbano } & \multicolumn{2}{|c|}{ Metropola } & \multirow{2}{*}{ Hi-kvadrat } \\
\hline & f & $\%$ & $\mathbf{f}$ & $\%$ & f & $\%$ & \\
\hline Radni status roditelja_prihodi & 690 & 37,8 & 834 & 45,7 & 302 & 16,5 & \\
\hline Oba roditelja sa stalnim prihodima & 221 & 32 & 395 & 47,4 & 172 & 57 & \multirow{4}{*}{$\chi^{2}(6)=86,82 *$} \\
\hline Jedan roditelj sa stalnim prihodima & 297 & 43 & 307 & 36,8 & 105 & 34,8 & \\
\hline Oba roditelja bez stalnih prihoda & 118 & 17,1 & 108 & 12,9 & 14 & 4,6 & \\
\hline Oba roditelja bez izvora prihoda & 54 & 7,8 & 24 & 2,9 & 11 & 3,6 & \\
\hline Obrazovanje roditelja & 694 & 37,5 & 850 & 45,9 & 307 & 16,6 & \\
\hline Osnovna škola & 42 & 6,1 & 20 & 2,4 & 7 & 2,3 & \multirow{4}{*}{$\chi^{2}(6)=178,45^{*}$} \\
\hline Trogodišnja SS̆ & 255 & 36,7 & 138 & 16,2 & 41 & 13,4 & \\
\hline Četverogodišnja SŠ & 273 & 39,3 & 385 & 45,3 & 113 & 36,8 & \\
\hline Visoko obrazovanje & 124 & 17,9 & 307 & 36,1 & 146 & 47,6 & \\
\hline Broj knjiga kod kuće & 694 & 37,5 & 849 & 45,9 & 307 & 16,6 & \\
\hline $0-25$ & 331 & 47,7 & 267 & 31,4 & 85 & 27,7 & \multirow{3}{*}{$\chi^{2}(4)=67,93^{*}$} \\
\hline $26-200$ & 280 & 40,3 & 410 & 48,3 & 143 & 46,6 & \\
\hline Više od 200 & 83 & 12 & 172 & 20,3 & 79 & 25,7 & \\
\hline$*_{p}<0,05$ & & & & & & & \\
\hline
\end{tabular}

Na općenitoj razini, najveći dio učenika ima barem jednog roditelja sa stalnim primanjima (82\%). Ipak, postoje rezidencijalne razlike kada je u pitanju stalnost roditeljskih primanja. Najjasnije rezidencijalne razlike (izdvojene na Slici 3.3) pokazale su se u kategorijama učenika koji imaju oba roditelja sa, i oba roditelja bez stalnih izvora prihoda. 


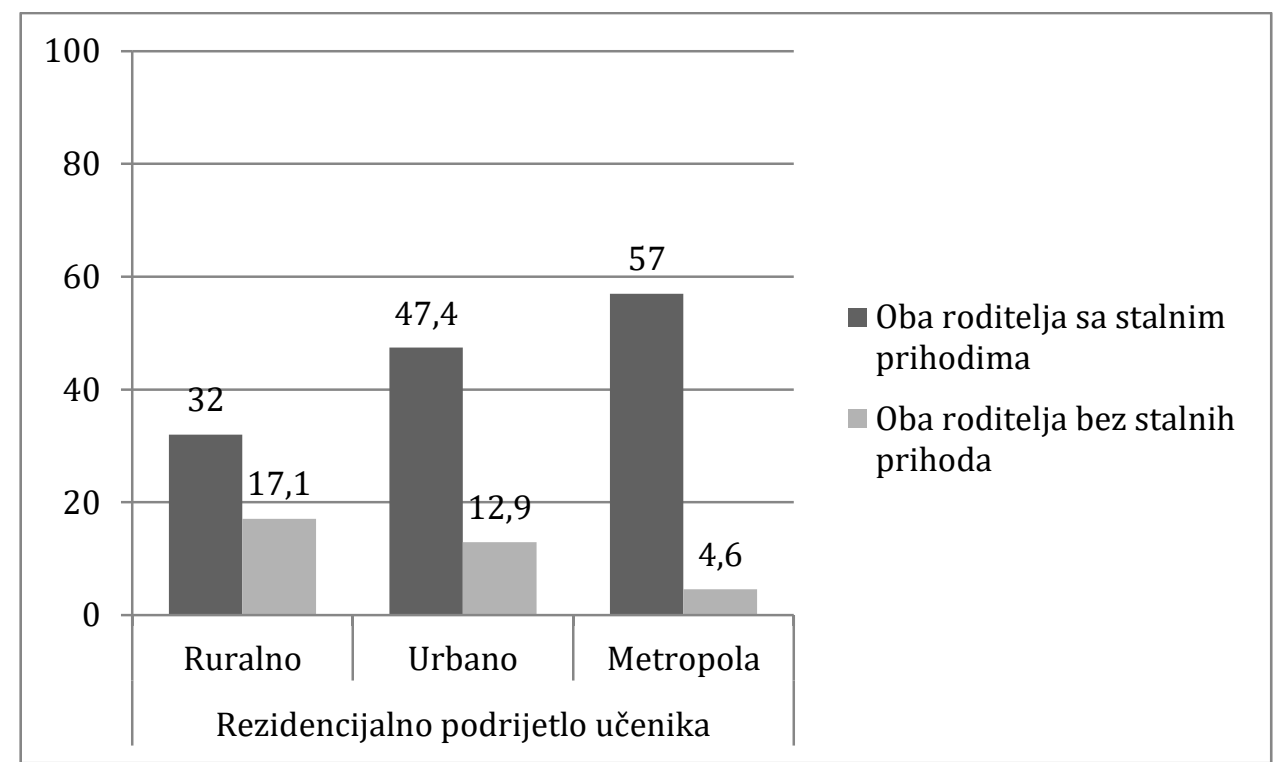

Slika 3.3 Usporedni prikaz udjela učenika različitog rezidencijalnog podrijetla prema stalnosti prihoda njihovih roditelja

Pokazuje se obrazac prema kojem kako se povećava stupanj urbaniteta mjesta odrastanja veličina učenicka, tako se povećava i udio učenika koji imaju oba roditelja sa stalnim prihodima (od $32 \% \mathrm{U}_{\mathrm{RRP}}$ do $57 \% \mathrm{U}_{\mathrm{MRP}}$ ), dok postotak učenika s roditeljima bez stalnih primanja opada (od $17 \% \mathrm{U}_{\mathrm{RRP}}$ do $5 \% \mathrm{U}_{\mathrm{MRP}}$ ).

$\mathrm{Na}$ ostalim mjerama materijalno-ekonomske situacije obitelji provedene su ANOVA analize u potrazi za razlikama između 3 rezidencijalne kategorije učenika. Rezultati prikazani tablično (Tabela 3.14) ukazuju da prema posjedovanju dobara, poput automobila, računala i nekretnina, učenici ruralnog rezidencijalnog podrijetla imaju statistički značajno niži prosječni rezultat $\left(M_{R R P}=1,6\right)$ u odnosu na druge dvije urbane grupe učenika $\left(M_{U R P}=1,7\right.$; $\left.M_{M R P}=1,8\right)$. Dodatno, ruralni učenici skloniji su i financijsku situaciju svoje obitelji procijeniti nižom $\left(\mathrm{M}_{\mathrm{RRP}}=2,9\right)$ u odnosu na učenike odrasle u metropoli $\left(\mathrm{M}_{\mathrm{MRP}}=3\right)$.

Kada se promatraju kulturni elementi obiteljskog okruženja, istraživački najznačajnijim (kao uobičajeno prihvaćen pokazatelj SES-a) izdvaja se onaj o obrazovanju roditelja. U hrvatskom kontekstu, oko $20 \%$ učenika ima barem jednog visoko obrazovanog roditelja, dok ih najveći broj ima roditelje sa srednjoškolskim obrazovanjem, otprilike podjednako četverogodišnjim (39\%) i trogodišnjim (37\%). Ipak, sociogeografski postoje razlike.

Najizraženije rezidencijalne razlike pokazuju se prema tome imaju li učenici visokoobrazovane roditelje ili roditelje s trogodišnjim strukovnim obrazovanjem. Pritom, najveće udjele roditelja s trogodišnjim srednjoškolskim obrazovanjem imaju učenici odrasli na selu (37\%), a daleko manje učenici druge dvije urbane kategorije ( $\left.U_{U R P}=16 ; U_{M R P}=13 \%\right)$. 
S druge strane, kako se veličina naselja odrastanja povećava, tako se u svakoj rezidencijalnoj kategoriji povećava udio učenika čiji su roditelji visoko obrazovani: $18 \% \mathrm{U}_{\mathrm{RRP}}<36 \% \mathrm{U}_{\mathrm{URP}}<$ $48 \% \mathrm{U}_{\mathrm{MRP}}$.

Tabela 3.4 Razlike na elementima materijalno-ekonomske situacije obitelji između učenika različitog rezidencijalnog podrijetla prema posjedovanju kulturnih dobara i roditeljskim kulturnim praksama

\begin{tabular}{|c|c|c|c|c|c|c|c|c|c|c|}
\hline \multirow[b]{2}{*}{ Zavisna varijabla } & \multicolumn{2}{|c|}{ UK } & \multicolumn{2}{|c|}{ (1) RRP } & \multicolumn{2}{|c|}{ (2) URP } & \multicolumn{2}{|c|}{ (3) MRP } & \multirow{2}{*}{ ANOVA } & \multirow{2}{*}{$\begin{array}{c}\text { Post-hoc } \\
\text { test }\end{array}$} \\
\hline & M & SD & M & SD & $\mathbf{M}$ & SD & M & SD & & \\
\hline Posjedovanje imovine & 1,71 & 0,61 & 1,63 & 0,61 & 1,73 & 0,61 & 1,81 & 0,62 & $\mathrm{~F}(2 / 1830)=9,74 *$ & $1-2 *, 1-3 *$ \\
\hline $\begin{array}{l}\text { Procjena financijske } \\
\text { situacije }\end{array}$ & 2,95 & 0,76 & 2,90 & 0,77 & 2,97 & 0,75 & 3,04 & 0,78 & $\mathrm{~F}(2 / 1771)=3,99 *$ & $1-3 *$ \\
\hline $\begin{array}{l}\text { Posjedovanje kulturnih } \\
\text { dobara }\end{array}$ & 0,68 & 0,28 & 0,61 & 0,28 & 0,71 & 0,28 & 0,73 & 0,26 & $\mathrm{~F}(2 / 1836)=38,84^{*}$ & $1-2^{*}, 1-3 *$ \\
\hline $\begin{array}{l}\text { Roditeljske kulturne } \\
\text { prakse }\end{array}$ & 1,91 & 0,78 & 1,73 & 0,72 & 1,98 & 0,78 & 2,12 & 0,84 & $\mathrm{~F}(2 / 1829)=32,85^{*}$ & $\begin{array}{c}1-2 *, 1-3^{*} \\
2-3^{*}\end{array}$ \\
\hline
\end{tabular}

I mjera posjedovanja knjiga u kućanstvu diferencira učenike različitog rezidencijalnog podrijetla prema obrascu: kako raste veličina naselja u kojem su odrasli učenici, tako udjeli učenika u kategoriji s najmanjim brojem knjiga (do 25) padaju $\left(\mathrm{U}_{\mathrm{RRP}}=48 \%\right.$; $\mathrm{U}_{\mathrm{URP}}=31 \%$; $\mathrm{U}_{\mathrm{MRP}}=28 \%$ ), dok rastu oni u kategoriji posjedovanja više od 200 knjiga ( $\mathrm{U}_{\mathrm{RRP}=12 \% \text {; }}$ $\mathrm{U}_{\mathrm{URP}}=20 \% ; \mathrm{U}_{\mathrm{MRP}}=26 \%$ ).

Prema posjedovanju kulturnih dobara, najnaglašenija i statistički značajna razlika je ona između učenika ruralnog rezidencijalnog podrijetla, s jedne, i obje grupe učenika urbanog rezidencijalnog podrijetla, s druge strane. Pri tom, ruralni učenici imaju nižu razinu posjedovanja $\left(M_{R R P}=0,6\right)$ različitih kulturnih dobara poput stručnih knjiga, knjiga na stranom jeziku, klasične literature, umjetničkih djela te nosača zvuka klasične/jazz glazbe $\left(<\mathrm{M}_{U R P} \mathrm{i}\right.$ $\left.\mathrm{M}_{\mathrm{MRP}}=0,7\right)$.

Prema učestalosti roditeljskih kulturnih praksi, rezultati ANOVA-a ukazuju da razlike postoje među svim rezidencijalnim grupama učenika, pri čemu prosječni rezultat raste kako raste stupanj urbaniteta mjesta u kojem su odrasli. Tako je učestalost roditeljskih kulturnih praksi ruralnih učenika statistički značajno rjeđa $\left(\mathrm{M}_{\mathrm{RRP}}=1,7\right)$ od one učenika svih urbanih rezidencijalnih kategorija, a dodatno i za učenike odrasle u urbanom okolišu $\left(\mathrm{M}_{U R P}=2\right)$ u odnosu na učenike odrasle u metropoli $\left(\mathrm{M}_{\mathrm{MRP}}=2,1\right)$.

Zaključno, rezultati ukazuju da postoje razlike između učenika različitog rezidencijalnog podrijetla prema dostupnim ekonomskim i kulturnim resursima u njihovim obiteljima, pri čemu su zabilježene razlike na svim mjerama različitih oblika obiteljskih resursa. 
Najnaglašenije su one između učenika ruralnog i metropolitanskog rezidencijalnog podrijetla, a najvećim dijelom obrazac razlika poprima oblik u kojem se razina dostupnih obiteljskih resursa povećava kako raste „urbanost“ rezidencijalnog podrijetla učenika. Odnosno, struktura mjerenih obiteljskih kapitala pokazuje se najnepovoljnijom za učenike odrasle na selu, dok je ona najpovoljnija za učenike koji odrastaju u glavnom gradu budući da je veća vjerojatnost da će ruralni učenici imati roditelje bez stalnih primanja i s nižim razinama obrazovanja te rjeđim kulturnim praksama, da odrastaju u obiteljima s manje materijalnih i obrazovnokulturnih dobara, u skladu s čime je i veća vjerojatnost lošijih procjena ekonomske situacije. Sve do sada provedene analize pokazuju različitu dostupnost određenih resursa za učenike različitog rezidencijalnog podrijetla koji su osnova razvoja visokoobrazovnih kapitala. Dodatno istraživački interes se usmjerava na izvanobiteljske kontekste i pitanje o značaju institucionalno dostupnih resursa za usmjeravanje učenika prema visokom obrazovanju.

\subsubsection{Institucionalne karakteristike školovanja učenika različitog rezidencijalnog podrijetla}

Naredne analize ispituju stavove učenika o nekim karakteristikama škola koje pohađaju, a koje čine njihov bitan institucionalni okoliš i mogući izvor resursa za usmjeravanje njihovih odluka o nakonškolskim planovima. Prema Bourdieuu (1977), osnova društvene reprodukcije je prepoznavanje kapitala učenika viših društvenih klasa u obrazovnom polju, odnosno njihovo potvrđivanje u školskom kontekstu, koji se tamo iskazuju kao bolji obrazovni uspjeh. Iz tog razloga, izgrađen je instrument koji je ciljao zahvaćanju bitnih aspekata institucionalnog habitusa (Reay i sur, 2001, 2010) njihovih škola. Ispitivao je status, akademski poticajnu klimu te opremljenost i izvannastavnu programsku ponudu srednjih škola koje učenici pohađaju. Eksplorativno orijentirana analiza ispituje rezidencijalne razlike prema tim karakteristikama. Rezultati su prikazani u Tablici 3.5.

Općenito, prema podacima o prosječnim vrijednostima na pojedinim faktorima školskog konteksta, učenici najpozitivnijim procjenjuju akademsku klimu svojih škola $(M=3,5)$, odnosno poticanje na studiranje i dostupnost informacija o studiranju, što je i dimenzija koja ne pokazuje razlike s obzirom na rezidencijalno podrijetlo učenika. S druge strane, učenici daju prosječne procjene kada je u pitanju opremljenost i izvannastavni program $(M=2,7)$, te status škola $(\mathrm{M}=2,8)$ koje pohađaju. 
Tabela 3.5 Razlike između učenika različitog rezidencijalnog podrijetla prema procjenama pojedinih karakteristika svojih škola

\begin{tabular}{|c|c|c|c|c|c|c|c|c|c|c|}
\hline \multirow[b]{2}{*}{ Zavisna varijabla } & \multicolumn{2}{|c|}{ UK } & \multicolumn{2}{|c|}{$\begin{array}{l}\text { (1) } \mathbf{R P} \\
\text { Ruralno }\end{array}$} & \multicolumn{2}{|c|}{$\begin{array}{l}\text { (2) } \mathbf{R P} \\
\text { Urbano }\end{array}$} & \multicolumn{2}{|c|}{$\begin{array}{c}\text { (3) } \mathbf{R P} \\
\text { Metropola }\end{array}$} & \multirow[t]{2}{*}{ ANOVA } & \multirow{2}{*}{$\begin{array}{c}\text { Post-hoc } \\
\text { test }\end{array}$} \\
\hline & M & SD & M & SD & M & SD & M & $\mathrm{SD}$ & & \\
\hline Škola visokog statusa & 2,83 & 1,05 & 2,76 & 1,01 & 2,85 & 1,04 & 2,94 & 1,18 & $\mathrm{~F}(2 / 1833)=3,19 *$ & $1-3 *$ \\
\hline $\begin{array}{l}\text { Akademski poticajna } \\
\text { škola }\end{array}$ & 3,53 & 0,98 & 3,58 & 0,98 & 3,51 & 1,00 & 3,50 & 0,97 & $\mathrm{~F}(2 / 1838)=1,04$ & - \\
\hline $\begin{array}{l}\text { Opremljena škola } \\
\text { dobrog programa }\end{array}$ & 2,68 & 1,10 & 2,75 & 1,09 & 2,59 & 1,06 & 2,75 & 1,21 & $\mathrm{~F}(2 / 1836)=4,70 *$ & $1-2 *$ \\
\hline
\end{tabular}

Iz rezultata analiza varijance na tri dimenzije srednjoškolskog konteksta kao zavisnim varijablama (Tabela 3.5) vidljivo je kako rezidencijalne razlike postoje s obzirom na procjene dviju dimenzija. Statistički značajno se razlikuju rezultati procjena učenika ruralnog rezidencijalnog podrijetla, čija je procjena statusa škola koje pohađaju niža $\left(M_{R R P}=2,8\right)$ od rezultata procjene učenika odraslih u metropoli $\left(\mathrm{M}_{\mathrm{MRP}}=2,9\right)$. $\mathrm{S}$ druge strane, resursnu opremljenost i programsku ponudu svojih škola značajno višom procjenjuju učenici odrasli u ruralnim $\left(\mathrm{M}_{\mathrm{RRP}}=2,8\right) \mathrm{u}$ odnosu na one odrasle u urbanim okolišima $\left(\mathrm{M}_{\mathrm{URP}}=2,6\right)$.

U interpretaciji navedenih podataka moguće je razmatrati i prethodno utvrđene nalaze o nekim vezama učeničkog rezidencijalnog podrijetla i tipa obrazovanja kojeg dobivaju. S obzirom da je vjerojatnije za učenike metropolitanskog podrijetla pohađanje gimnazija, te srednjih škola u glavnom gradu, navedeno može značiti da upravo tim školama učenici procjenjuju i viši status, odnosno smatraju da ih je teže upisati, da su uglednije i da bolje pripremaju za studiranje. S druge strane, ruralni učenici, koji najvećim dijelom pohađaju škole u malim gradovima, ali i gradovima ostalih stupnjeva centraliteta, te koji u najvećoj mjeri pohađaju strukovne programe, svoje škole u većoj mjeri opisuju kao dobro opremljene i s dobrim programom izvannastavnih aktivnosti zbog te stručne usmjerenosti, u odnosu na učenike urbanog rezidencijalnog podrijetla koji profilno tvore vrlo raznoliku grupu, iz raspona gradskih naselja, koji i škole pohađaju u takvim gradovima. Potrebne su dublje analize socioprostornih aspekata polja srednjoškolskog obrazovanja koji bi objasnili sklonost učenika iz urbanih sredina da svojim školama pripisuju nižu razinu opremljenosti i ponude izvannastavnih programa. 


\subsubsection{Simbolička vrijednost odnosa iz konteksta odrastanja i školovanja za namjeru studiranja učenika različitog rezidencijalnog podrijetla}

Uz to što su obiteljski resursi, ekonomski i kulturni, karakteristike konteksta odrastanja koje mogu za učenike različitog rezidencijalnog podrijetla biti značajne odrednice njihovih namjera studiranja, obitelji imaju i dodatni simbolički značaj za učenike i njihove namjere studiranja što se ispituje sljedećim analizama. Osnovne pretpostavke su da osobe u obitelji i obiteljske prakse vezane uz obrazovanje djece odražavaju obiteljski habitus u kojem su učenici socijalizirani te imaju značajnu ulogu u razvoju njihova aspiracijskog (obrazovnog) habitusa (Baker, Brown, 2008) i/ili oblikovanju odluke o nastavku školovanja. Anketno su ti elementi zahvaćeni kao procjene učenika o utjecaju utjecaj članova obitelji (roditelji, braća/sestre) na svoju odluku o nastavku školovanja, te stupnja slaganja s tvrdnjama da im roditelji pomažu u izvršavanju školskih obveza, da su zainteresirani za ono što rade u školi te da ih ohrabruju da nastave školovanje, odnosno da se što prije zaposle. Rezultati analiza s navedenim varijablama kao zavisnima, prikazani su tablično (Tablica 3.6).

Tabela 3.6 Razlike između učenika različitog rezidencijalnog podrijetla prema procjeni utjecaja članova obitelji na svoju odluku o nastavku školovanja i prema roditeljskim poticajnim praksama za nastavak školovanja

\begin{tabular}{|c|c|c|c|c|c|c|c|c|c|c|}
\hline \multirow[b]{2}{*}{ Zavisna varijabla } & \multicolumn{2}{|c|}{ UK } & \multicolumn{2}{|c|}{ (1) RRP } & \multicolumn{2}{|c|}{ (2) URP } & \multicolumn{2}{|c|}{ (3) MRP } & \multirow{2}{*}{ ANOVA } & \multirow{2}{*}{$\begin{array}{c}\text { Post-hoc } \\
\text { test }\end{array}$} \\
\hline & $\mathbf{M}$ & SD & $\mathbf{M}$ & SD & $\mathbf{M}$ & SD & $\mathbf{M}$ & SD & & \\
\hline Utjecaj roditelji & 3,53 & 1,38 & 3,47 & 1,39 & 3,56 & 1,37 & 3,59 & 1,41 & $\mathrm{~F}(2 / 1828)=1,21$ & - \\
\hline Utjecaj braća/sestre & 2,55 & 1,48 & 2,61 & 1,43 & 2,57 & 1,53 & 2,37 & 1,47 & $F(2 / 1806)=2,86$ & - \\
\hline $\begin{array}{l}\text { Kada mi treba, roditelji } \\
\text { mi pomažu kod } \\
\text { školskih obveza }\end{array}$ & 3,66 & 1,32 & 3,65 & 1,32 & 3,63 & 1,35 & 3,74 & 1,26 & $\mathrm{~F}(2 / 1846)=0,81$ & - \\
\hline $\begin{array}{l}\text { Moji roditelji su } \\
\text { zainteresirani za ono } \\
\text { što radim u školi. }\end{array}$ & 3,98 & 1,04 & 3,97 & 1,05 & 4,00 & 1,05 & 3,98 & 1,01 & $\mathrm{~F}(2 / 1847)=0,10$ & - \\
\hline $\begin{array}{l}\text { Roditelji me ohrabruju } \\
\text { da nastavim } \\
\text { školovanje. }\end{array}$ & 4,51 & 0,87 & 4,38 & 0,99 & 4,59 & 0,78 & 4,61 & 0,79 & $\mathrm{~F}(2 / 1845)=12,28^{*}$ & $\begin{array}{c}1-2 *, 1- \\
3 *\end{array}$ \\
\hline $\begin{array}{l}\text { Roditelji me ohrabruju } \\
\text { da se što prije } \\
\text { zaposlim. }\end{array}$ & 3,55 & 1,35 & 3,68 & 1,31 & 3,53 & 1,36 & 3,31 & 1,39 & $\mathrm{~F}(2 / 1842)=8,28 *$ & $1-3^{*}$ \\
\hline
\end{tabular}

Razvidno iz rezultata je da utjecaj roditelja na svoju odluku o (ne)studiranju podjednako visokim $(M=3,5)$ procjenjuju učenici svih rezidencijalnih kategorija, dok je utjecaj braće i sestara procijenjen nešto nižim $(\mathrm{M}=2,6)$, i bez značajnih rezidencijalnih razlika. Dodatno, i 
većina ostalih roditeljskih poticajnih praski imaju relativno visoke rezultate (rang vrijednosti 4), pri čemu učenici bez obzira na mjesto odrastanja slično izraženom procjenjuju roditeljsku uključenost u svoje školske aktivnosti, bilo kroz pomaganje u izvršavanju školskih obaveza $(\mathrm{M}=3,7)$, bilo kroz iskazivanje interesa za njihove školske živote $(M=4)$.

Ipak, rezidencijalne razlike se jesu pokazale, i to za roditeljsku poticajnu praksu koju učenici u najvećoj mjeri smatraju prisutnom $(\mathrm{M}=4,5)$ - da ih njihovi roditelji potiču na studiranja; prosječna vrijednost procjene roditeljskog ohrabrivanja studiranja statistički je značajno niža za ruralne učenike $\left(M_{R R P}=4,4\right)$ u odnosu na druge dvije rezidencijalne grupe učenika $(M=4,6)$. $\mathrm{S}$ druge strane, $\mathrm{s}$ tvrdnjom da ih roditelji ohrabruju na što brže zaposlenje, pokazala se praksom koja je, $\mathrm{u}$ odnosu na učenike metropole $\left(\mathrm{M}_{\mathrm{MRP}}=1,4\right)$, vjerojatnija $\mathrm{u}$ obiteljima ruralnih učenika $\left(M_{R R P}=3,7\right)$. Navedene rezultat moguće je promatrati i u svjetlu činjenice da se ruralni učenici općenito češće odlučuju za strukovne škole, dok učenici metropole u većoj mjeri pohađaju gimnazije koje ih direktnije usmjeravaju prema nastavku školovanja.

Ranije analize pokazale su kako značaj roditelja te obitelji, općenito, kao izvora različitih obrazovno značajnih resursa, može biti značajan za različite putove učenika različitog rezidencijalnog podrijetla nakon srednje škole. A postoje i neki dodatni simbolični elementi izraženi kao poticaji unutar obitelji. Naime, iako se čini da utjecaj roditelja nije odlučujući kada je u pitanju namjera studiranja učenika različitog rezidencijalnog podrijetla budući da ga tek blago iznadprosječnim procjenjuju svi učenici bez obzira na rezidencijalno podrijetlo, ovaj nalaz ipak ne govori o smjeru poticaja jer se učenike tražilo da procjene utjecaj roditelja na donošenje odluka o nakonškolskim pravcima bez obzira jesu li usmjereni na visoko obrazovanje ili ne. U drugim analizama, roditeljsko ohrabrivanje studiranja, odnosno zapošljavanja izdvojili su se kao najznačajniji aspekti roditeljskih poticaja; iako svi učenici procjenjuju snažno izraženim ohrabrivanje studiranja od strane roditelja, ono je statistički značajno slabije izraženo u obiteljima seoskih učenika, dok je značajno izraženije poticanje brzom zapošljavanju. A to su i učenici za koje je vjerojatnije i pohađanje strukovnih škola te nepovoljnija struktura ostalih resursa iz obiteljskog kontekst.

U konačnici, ispitano je i šire socijalizacijsko okruženje učenika u vidu utjecaja osoba iz učeničkih odnosa koje održavaju u kontekstima odrastanja i školovanja na njihovu odluku o (ne)studiranju. Tim pitanjem za 9 različitih osoba, pokušala se zahvatiti simbolička vrijednost konteksta njihova odrastanja izvan obitelji, i društveni resursi učenika za nastavak školovanja koji su im na taj način dostupni. 
Procjene utjecaja osoba izvanobiteljskog učeničkog okruženja pokazuju da učenici općenito nisu skloni drugima pripisivati velik utjecaj na svoju odluku (Slika 3.4).

Nešto veći, prosječni utjecaj osobama izvan obitelji, pripisuju prijateljima $(M=2,7)$, te nastavnicima $(M=2,5)$, dok najslabijim procjenjuju utjecaj stručnih osoba poput suradnika u školama $(M=1,8)$ i savjetnika za profesionalno usmjeravanje $(M=1,7)$, te susjeda $(M=1,7)$.

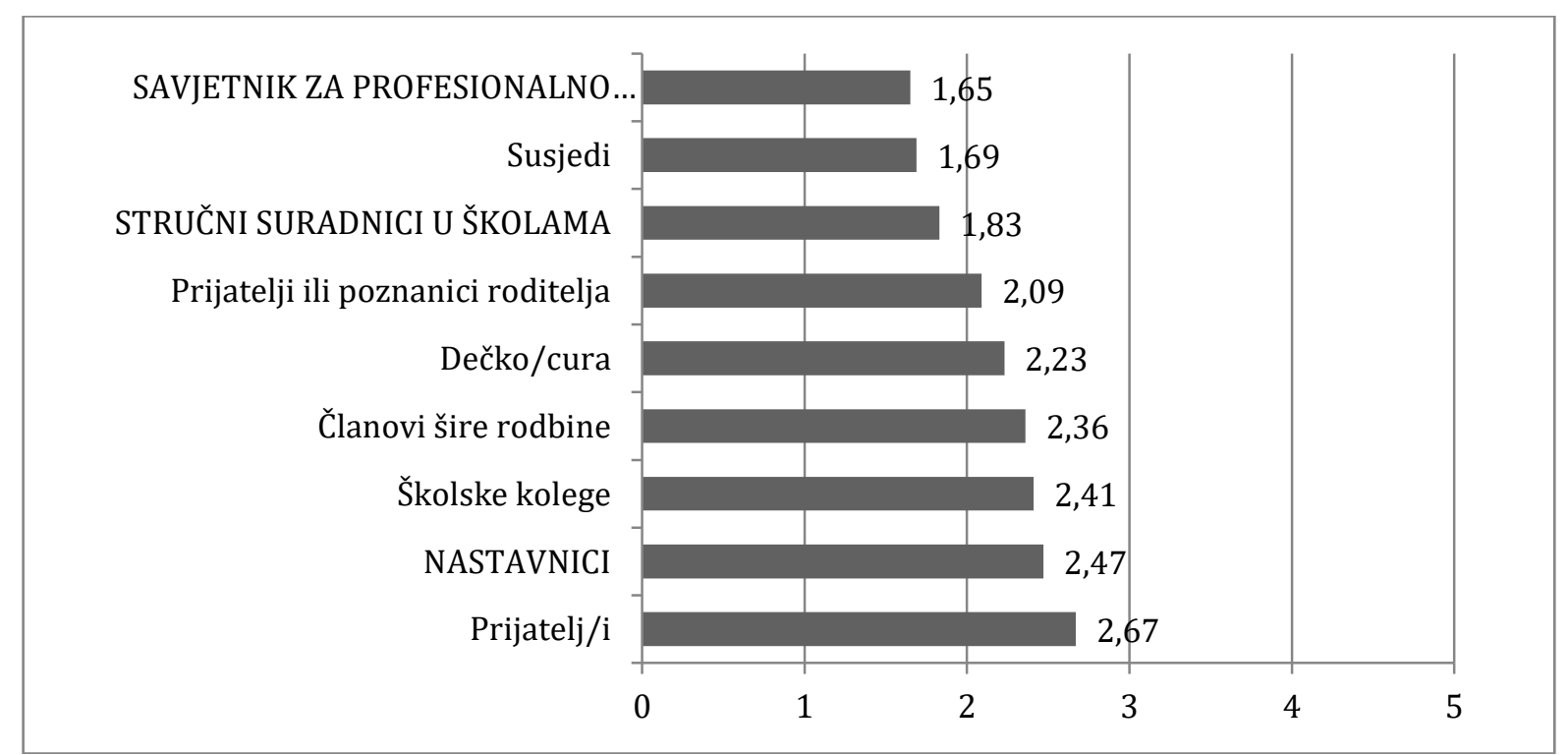

Slika 3.4 Prosječne vrijednosti procjena učenika o utjecaju njihovih značajnih drugih na njihovu odluku o (ne)studiranju

Prvo se postavilo pitanje o razlikama između učenika različitog rezidencijalnog podrijetla u njihovim procjenama utjecaja osoba iz njihovih širih i užih krugova na namjeru studiranja pri čemu su zavisne varijable činili „teorijski“ kreirani faktori: 1) „neinstitucionalni drugi“ (objedinjuje procjene utjecaja osoba iz fizički i/ili emocionalno bližih veza poput rodbine, prijatelja, susjeda), te 2),,institucionalni drugi“ (za stručne osobe koje učenici sreću poput nastavnika, stručnih suradnika, savjetnika za profesionalno usmjerenje).

Rezultati, prezentirani u Tablici 3.7, pokazuju da iako je, općenito, utjecaj osoba i izvaninstitucionalnog $(M=2,2)$ i institucionalnog $(M=2)$ konteksta na učeničke planove nakon srednje škole procijenjenen slabim, postoje rezidencijalne razlike kada je u pitanju utjecaj stručnih osoba; naime, statistički je značajno viši prosječni rezultat ruralnih učenika prema procjeni utjecaja osoba iz institucionalnih konteksta na njihovu namjeru studiranja $\left(\mathrm{M}_{\mathrm{RRP}}=2,1\right)$ u odnosu na druge dvije rezidencijalne kategorije učenika $\left(\mathrm{M}_{\mathrm{URP}}=1,9 ; \mathrm{M}_{\mathrm{MRP}}=1,8\right)$. 
Tabela 3.7 Razlike između učenika različitog rezidencijalnog podrijetla prema procjeni utjecaja izvaninstitucionalnih i institucionalnih značajnih drugih na njihovu odluku o (ne)studiranju

\begin{tabular}{|c|c|c|c|c|c|c|c|c|c|c|}
\hline \multirow[b]{2}{*}{ Zavisna varijabla } & \multicolumn{2}{|c|}{ UK } & \multicolumn{2}{|c|}{$\begin{array}{c}\text { (1) RP } \\
\text { Ruralno }\end{array}$} & \multicolumn{2}{|c|}{$\begin{array}{l}\text { (2) RP } \\
\text { Urbano }\end{array}$} & \multicolumn{2}{|c|}{$\begin{array}{c}\text { (3) RP } \\
\text { Metropola }\end{array}$} & \multirow[t]{2}{*}{ ANOVA } & \multirow{2}{*}{$\begin{array}{c}\text { Post-hoc } \\
\text { test }\end{array}$} \\
\hline & $\mathbf{M}$ & SD & $\mathbf{M}$ & SD & $\mathbf{M}$ & SD & $\mathbf{M}$ & SD & & \\
\hline $\begin{array}{l}\text { Utjecaj } \\
\text { izvaninstitucionalnih } \\
\text { drugih_SK }\end{array}$ & 2,22 & 0,99 & 2,27 & 1,01 & 2,20 & 0,98 & 2,17 & 0,98 & $\mathrm{~F}(2 / 1780)=1,31$ & - \\
\hline $\begin{array}{l}\text { Utjecaj } \\
\text { institucionalnih } \\
\text { drugih_SK }\end{array}$ & 1,96 & 0,99 & 2,08 & 1,05 & 1,92 & 0,95 & 1,81 & 0,89 & $\mathrm{~F}(2 / 1808)=9,46^{*}$ & $\begin{array}{c}1-2^{*}, 1- \\
3 *\end{array}$ \\
\hline
\end{tabular}

Stoga, iako procijenjen slabim, utjecaj stručnih osoba iz institucionalnog okruženja veći značaj ima za učenike odrasle na selu na njihovu odluku o tome hoće li ili ne nastaviti školovanje, u odnosu na one odrasle u gradu.

S jedne strane, moguće je da ti rezultati ukazuju na slabiju dostupnost pojedinim resursima za učenike različitog rezidencijalnog podrijetla s obzirom na tip i/ili lokaciju škole s utjecajem na njihovu slabiju zainteresiranost za studiranje. S druge strane, obzirom na prethodne analize dostupnosti obiteljskih resursa i elemenata obiteljskog konteksta koji ruralne učenike stavlja u nepovoljniju poziciju, moguće je da za ruralne učenike koji namjeravaju studirati institucionalni kontekst postaje značajan izvor dodatne simboličke izvanobiteljske podrške u svojim visokoobrazovnim planovima.

S obzirom na osnovni interes rada, provedene su dodatne analize varijance na pojedinačnim varijablama kako bi se utvrdilo o kojim se konkretno osobama radi kada je u pitanju utjecaj na učeničke odluke o (ne)studiranju. Ove detaljnije analize otkrile su statistički značajne rezidencijalne razlike procjena utjecaja triju osoba (Slika 3.5) čiji je općeniti utjecaj procijenjen iznimno slabim; iz široke grupe izvaninstitucionalnih drugih, učenici ruralnog rezidencijalnog podrijetla statistički značajno snažnijim prosječno procjenjuju utjecaj susjeda $\left(\mathrm{M}_{\mathrm{RRP}}=1,8\right)$, u odnosu na druge dvije urbane kategorije učenika $\left(\mathrm{M}_{\mathrm{URP}}=1,6 ; \mathrm{M}_{\mathrm{MRP}}=1,5\right)$, a iz školskog konteksta, utjecaj stručnih suradnika $\left(\mathrm{M}_{\mathrm{RRP}}=2>\mathrm{M}_{\mathrm{URP}}=1,7 ; \mathrm{M}_{\mathrm{MRP}}=1,6\right)$.

S druge strane, stručne osobe za profesionalno usmjeravanje učenika možemo smatrati rijetkim resursom kojem učenici često nemaju pristup (rijetke škole upućuju ili organiziraju profesionalno usmjeravanje), ili koji često ne iskorištavaju jer ne osjećaju da imaju potrebu za njihovom pomoći. Analiza varijanci pokazala je da utjecaj takvih stručnjaka ima statistički značajno različitu ulogu pri donošenju odluka učenika različitog rezidencijalnog podrijetla, pri 
čemu on opada kako raste veličina naselja rezidencijalnog podrijetla učenika: $M_{R R P}=1,7<$ $\mathrm{M}_{\mathrm{URP}}=1,6<\mathrm{M}_{\mathrm{MRP}}=1,4$.

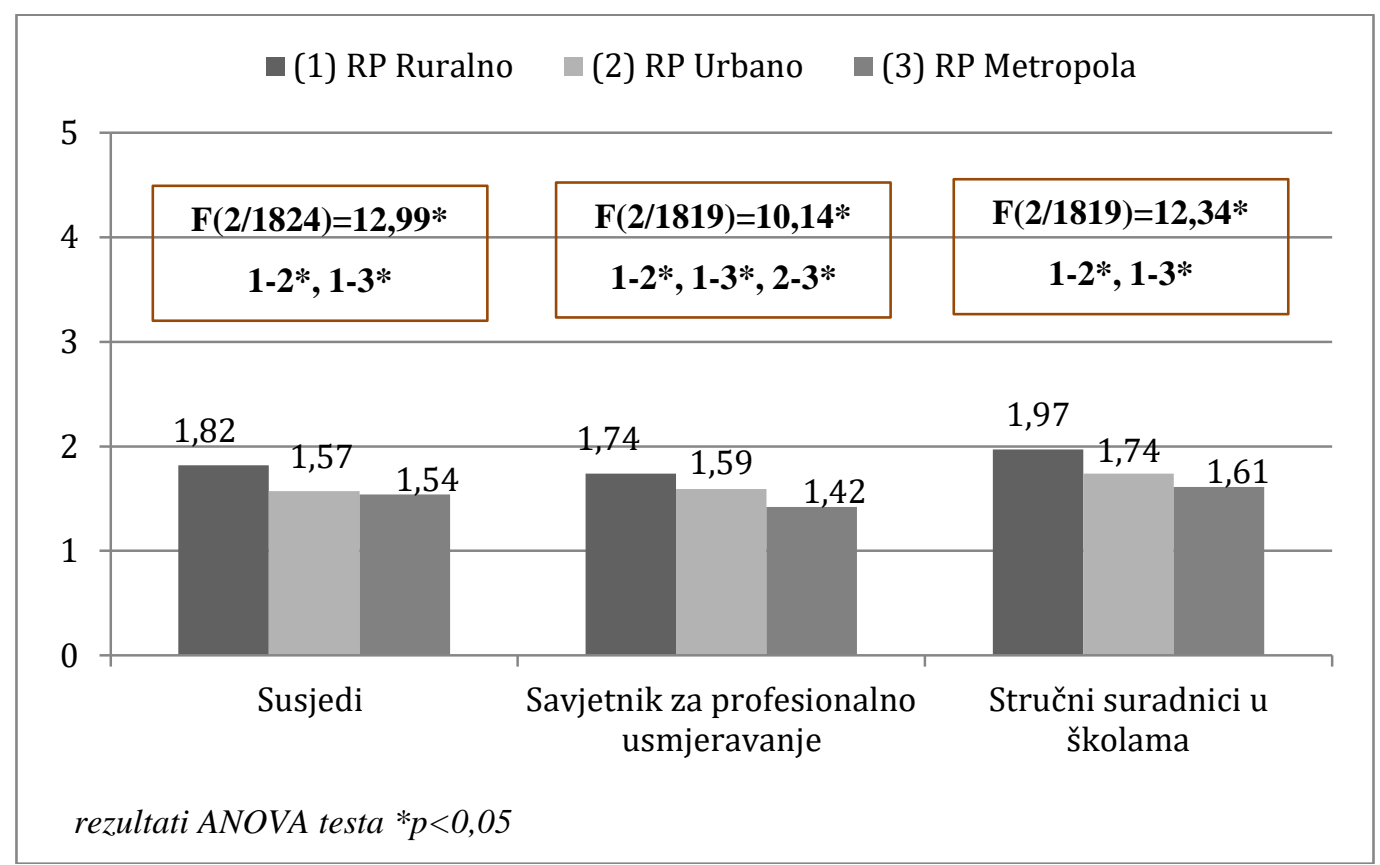

Slika 3.5Rezultati analiza razlike između učenika različitog rezidencijalnog podrijetla prema procjeni utjecaja značajnih drugih osoba na njihovu odluku o (ne)studiranju ${ }^{63}$

Ruralnim učenicima tako susjedi, stručni suradnici i savjetnici za profesionalno usmjeravanje predstavljaju bitan socijalni resurs s obzirom na utjecaj koji imaju na njihovu odluku o (ne)studiranju: oni su dostupni resurs (informacija i/ili podrške) iz neposredne životne okoline učenika, te institucionalnih konteksta.

\subsubsection{Zaključno o rezidencijalnim razlikama učenika i njihovoj namjeri studiranja}

$\mathrm{Na}$ prethodnim stranicama potvrdilo se postojanje statistički značajnih razlika na većini ispitivanih mjera, $\mathrm{i}$ to najčešće pokazujući dva obrasca tih razlika: s jedne strane, porast odnosno smanjivanje udjela ili prosječnih rezultata učenika različitog rezidencijalnog podrijetla kako se stupanj urbaniteta naselja odrastanja povećava, a s druge strane, razdvajanje učenika ruralnog rezidencijalnog podrijetla $u$ odnosu na druge dvije urbane kategorije učenika. Tablica 3.8 sažima nalaze provedenih analiza, a u nastavku se oni interpretiraju.

\footnotetext{
${ }^{63}$ Slika prezentira rezultate provedenih analiza samo za one osobe za koje se pokazalo da pri procjeni njihova utjecaja postoje razlike između učenika različitih rezidencijalnih kategorija.
} 
Tabela 3.8 Rezultati analiza rezidencijalnih razlika na pojedinim mjerama ${ }^{64}$

\begin{tabular}{|c|c|c|c|}
\hline \multirow[t]{2}{*}{$\begin{array}{l}\text { REZIDENCIJALN } \\
\text { PODRIJETLO }^{65} \text { : }\end{array}$} & \multicolumn{3}{|c|}{$\begin{array}{l}\text { 1) } \operatorname{ruralno}(\mathrm{RRP})-\mathrm{N}=694(38 \%) \\
\text { 2) } \operatorname{urbano}(\mathrm{URP})-\mathrm{N}=\mathbf{8 5 0}(\mathbf{4 6 \%}) \\
\text { 3) metropola }(\mathrm{MRP})-\mathrm{N}=\mathbf{3 0 7}(\mathbf{1 7 \%})\end{array}$} \\
\hline & Mjere & Analize & Osnovni nalazi: \\
\hline $\begin{array}{l}\text { SOCIOGEO- } \\
\text { GRAFSKE } \\
\text { VARIJABLE }\end{array}$ & Lokacija škole & $X^{2}$ & $\begin{array}{l}\text { - gotovo svi } \mathbf{U}_{\text {MRP }} \text { pohađaju škole u glavnom gradu } \\
(95 \%) \text {, dok } 52 \% \mathbf{U}_{\mathbf{U R P}} \text { završava škole u ,velikim } \\
\text { gradovima“, a } 45 \% \text { u „malim gradovima“; najveći } \\
\text { dio } \mathbf{U}_{\mathbf{R R P}} \text { škole pohađa u malim gradovima }(59 \%) \text {, a } \\
\text { manjina u glavnom gradu }(6 \%)\end{array}$ \\
\hline $\begin{array}{l}\text { OBRAZOVNI } \\
\text { ISHODI }\end{array}$ & Namjera studiranja* & $X^{2}$ & $\begin{array}{l}\text { - manje } \mathbf{U}_{\mathbf{R R P}}=56 \% \text { se odlučuje na nastavak } \\
\text { školovanja na visokoškolskoj razini }\left(\mathbf{U}_{\mathbf{U R P}}=75 \% \text {; }\right. \\
\left.\mathbf{U}_{\mathbf{M R P}}=79 \%\right)\end{array}$ \\
\hline \multirow{2}{*}{$\begin{array}{l}\text { Obrazovne } \\
\text { karakteristike }\end{array}$} & Tip škole* & $X^{2}$ & $\begin{array}{l}\text { - kako raste veličina naselja odrastanja, raste udio } \\
\text { gimnazijalaca pojedine rezidencijalne kategorije } \\
\text { učenika: } \mathbf{U}_{\mathbf{R R P}}=20 \%, \mathbf{U}_{\mathbf{U R P}}=33 \%, \mathbf{U}_{\mathbf{M R P}}=44 \% \text {; veći } \\
\text { udio } \mathbf{U}_{\mathbf{R R P}} \mathbf{3 3} \% \text { pohađa trogodišnje strukovne škole } \\
\left(>\mathbf{U}_{\mathbf{U R P}} \text { i } \mathbf{U}_{\mathbf{M R P}}=20 \%\right) \text {; }\end{array}$ \\
\hline & $\begin{array}{l}\text { Školski uspjeh* } \\
\text { Vrijednost pripisana } \\
\text { učenju* }\end{array}$ & ANOVA & $\begin{array}{l}\text { - statistički je značajno niži } \mathbf{M}_{\mathbf{R R P}}=3,7 \text { općeg uspjeha } \\
\text { u odnosu na } \mathbf{M}_{\mathbf{U R P}}=3,8 \text { i } \mathbf{M}_{\mathbf{M R P}}=3,9 \\
\text { - statistički je značajno viši } \mathbf{M}_{\mathbf{U R P}}=3,7 \text { vrijednosti } \\
\text { pripisane učenju u odnosu na } \mathbf{M}_{\mathbf{M R P}}=3,6\end{array}$ \\
\hline $\begin{array}{l}\text { Obrazovne } \\
\text { orijentacije } \\
\text { (habitus učenika) }\end{array}$ & $\begin{array}{l}\begin{array}{l}\text { Obrazovne } \\
\text { aspiracije* }\end{array} \\
\text { Obrazovna } \\
\text { očekivanja* } \\
\text { Podrazumijevanje } \\
\text { studiranja* } \\
\text { Dužina promišljanja } \\
\text { odluke* }\end{array}$ & $X^{2}$ & $\begin{array}{l}\text { - veći broj } \mathbf{U}_{\mathbf{R R P}}=32 \% \text { želi samo završiti srednju } \\
\text { školu }\left(\mathbf{U}_{\mathbf{U R P}}=17 \%, \mathbf{U}_{\mathbf{M R P}}=15 \%\right) \text {; a manje ih teži } \\
\text { najvišim visokoobrazovnim stupnjevima }(62 \% \\
\left.<\mathbf{U}_{\mathbf{U R P}}=70 \%, \mathbf{U}_{\mathbf{M R P}}=74 \%\right) \\
\text { - za } \mathbf{U}_{\mathbf{R R P}} \text { najviše se povećavaju kategorije } \\
\text { očekivanih najnižih stupnjeva obrazovanja - } \\
\text { završavanja srednje škole (na } 36 \%) \text { i preddiplomske } \\
\text { razine (na } 23 \%) \\
\text { - manje } \mathbf{U}_{\mathbf{R R P}}=51 \% \text { smatra da im se studiranje } \\
\text { podrazumijeva }\left(\mathbf{U}_{\mathbf{U R P}}=68 \%, \mathbf{U}_{\mathbf{M R P}}=66 \%\right) \\
\text { - manje } \mathbf{U}_{\mathbf{R R P}}=42 \% \text { je bez razmišljanja donijelo } \\
\text { odluku o studiranju }\left(\mathbf{U}_{\mathbf{U R P}} \text { i } \mathbf{U}_{\mathbf{M R P}}=49 \%\right)\end{array}$ \\
\hline $\begin{array}{l}\text { Kulturne } \\
\text { kompetencija } \\
\text { učenika }\end{array}$ & $\begin{array}{l}\text { Učeničke kulturne } \\
\text { prakse* } \\
\text { Učeničke čitalačke } \\
\text { prakse* } \\
\text { Učeničke } \\
\text { izvanškolske } \\
\text { aktivnosti* }\end{array}$ & ANOVA & $\begin{array}{l}\text { - statistički je značajno niži } \mathbf{M}_{\mathbf{R R P}} \text { na sve tri mjere } \\
\text { kulturnih kompetencija učenika u odnosu na druge } \\
\text { dvije urbane kategorije učenika: } \\
\text { kulturne prakse } \mathbf{M}_{\mathbf{R R P}}=1,6<\mathbf{M}_{\mathbf{U R P}} \text { i } \mathbf{M}_{\mathbf{M R P}}=1,8 ; \\
\text { čitalačke prakse: } \mathbf{M}_{\mathbf{R R P}}=2,2<\mathbf{M}_{\mathbf{U R P}} \text { i } \mathbf{M}_{\mathbf{M R P}}=2,4 ; \\
\text { izvanškolske aktivnosti: } \quad \mathbf{M}_{\mathbf{R R P}}=0,1<\mathbf{M}_{\mathbf{U R P}} \text { i } \\
\mathbf{M}_{\mathbf{M R P}}=0,2\end{array}$ \\
\hline $\begin{array}{l}\text { HORIZONT } \\
\text { BUDUĆNOSTI }\end{array}$ & $\begin{array}{l}\text { Želja za } \\
\text { društvenom } \\
\text { mobilnošću }\end{array}$ & ANOVA & $\begin{array}{l}\text { - nema statistički značajnih razlika u } \mathrm{M}=3,6 \text { želje za } \\
\text { društvenom mobilnošću među rezidencijalnih } \\
\text { grupama učenika }\end{array}$ \\
\hline $\begin{array}{l}\text { Ekonomsko- } \\
\text { materijalna } \\
\text { situacija obitelji }\end{array}$ & $\begin{array}{l}\text { Radni status } \\
\text { roditelja* }\end{array}$ & $X^{2}$ & $\begin{array}{l}\text { - kako se povećava veličina naselja odrastanja tako } \\
\text { se povećava i postotak učenika koji imaju oba } \\
\text { roditelja sa stalnim prihodima }\left(\mathbf{U}_{\mathbf{R R P}}=32 \% \text {, }\right. \\
\left.\mathbf{U}_{\mathbf{U R P}}=47 \%, \mathbf{U}_{\mathbf{M R P}}=57 \%\right) \text { dok postotak učenika bez } \\
\text { roditelja sa stalnim primanjima opada }\left(\mathbf{U}_{\mathbf{R R P}}=17 \% \text {, }\right.\end{array}$ \\
\hline
\end{tabular}

\footnotetext{
${ }^{64}$ Tablica navodi osnovne podatke o uzorku, nazive varijabli od kojih su one sa statistički značajnim razlikama označene zvjezdicom $\left({ }^{*} p<0,05\right)$ i kratki izvještaj o nalazima analiza. U tekstu kratica $\mathbf{U}_{\mathbf{R R P}}$ označava učenike $\mathrm{s}$ ruralnim rezidencijalnim podrijetlom, kratica $\mathbf{U}_{\mathbf{U R P O d n o s i}}$ se na učenike s urbanim rezidencijalnim podrijetlom, a

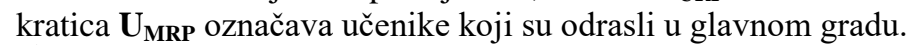

65 Rezidencijalno podrijetlo učenika zavisna je varijabla u hi-kvadrat analizama, a nezavisna u analizama varijance. Navedeni testovi upotrebljavani su s obzirom na pojedine mjere, odnosno radi li se o kategorijalnoj ili kontinuiranoj varijabli.
} 


\begin{tabular}{|c|c|c|c|}
\hline & $\begin{array}{l}\text { Posjedovanje } \\
\text { imovine* }\end{array}$ & ANOVA & $\begin{array}{l}\left.\mathbf{U}_{\mathbf{U R P}}=13 \%, \mathbf{U}_{\text {MRP }}=5 \%\right) \text {. } \\
\text { - statistički je značajno niži } \mathbf{M}_{\mathbf{R R P}} \text { posjedovanja } \\
\text { materijalnih dobara }(=1,6) \text { u odnosu na druge dvije } \\
\text { urbane grupe učenika }\left(\mathbf{M}_{\mathbf{U R P}}=1,7 ; \mathbf{M}_{\mathrm{MRP}}=1,8\right) \\
\text { - } \mathrm{U}_{\mathrm{RRP}} \text { su skloniji financijsku situaciju svoje obitelji } \\
\text { procijeniti nižom }\left(\mathbf{M}_{\mathbf{R R P}}=2,9\right) \text { u odnosu na } \mathrm{U}_{\mathrm{MRP}} \\
\left(\mathbf{M}_{\mathbf{M R P}}=3,0\right)\end{array}$ \\
\hline \multirow[t]{2}{*}{$\begin{array}{l}\text { Obrazovno- } \\
\text { kulturno } \\
\text { obiteljsko } \\
\text { okruženje }\end{array}$} & $\begin{array}{l}\begin{array}{l}\text { Obrazovanje } \\
\text { roditelja* }\end{array} \\
\text { Broj knjiga kod } \\
\text { kuće* }\end{array}$ & $X^{2}$ & $\begin{array}{l}\text { - RU imaju najveće udjele roditelja s trogodišnjim } \\
\text { srednjoškolskim obrazovanjem }\left(37 \%>\mathbf{U}_{\mathbf{U R P}}=16 \% \text {, }\right. \\
\left.\mathbf{U}_{\mathbf{M R P}}=13 \%\right) \text {; kako se veličina naselja odrastanja } \\
\text { povećava, povećava se udio učenika koji imaju } \\
\text { visokoobrazovane roditelje: RU }=18 \%, \mathbf{U}_{\mathbf{U R P}}=36 \% \text {, } \\
\mathbf{U}_{\mathbf{M R P}}=48 \% \text {; } \\
\text { - kako raste veličina naselja odrastanja tako udjeli } \\
\text { učenika pojedinih rezidencijalnih kategorija s do } 25 \\
\text { knjiga padaju }\left(\mathbf{U}_{\mathbf{R R P}}=48 \%, \mathbf{U}_{\mathbf{U R P}}=31 \%, \mathbf{U}_{\mathbf{M R P}}=28 \%\right) \text {, } \\
\text { dok rastu u kategoriji posjedovanja više od } 200 \\
\text { knjiga }\left(\mathbf{U}_{\mathbf{R R P}}=12 \%, \mathbf{U}_{\mathbf{U R P}}=20 \%, \mathbf{U}_{\mathbf{M R P}}=26 \%\right)\end{array}$ \\
\hline & $\begin{array}{l}\begin{array}{l}\text { Posjedovanje } \\
\text { kulturnih dobara* }\end{array} \\
\text { Roditeljske kulturne } \\
\text { prakse* }\end{array}$ & ANOVA & $\begin{array}{l}\text { - } \mathrm{U}_{\mathrm{RRP}} \text { imaju statistički značajno nižu razinu } \\
\text { posjedovanja različitih kulturnih dobara uodnosu na } \\
\text { dvije grupe učenika urbanog rezidencijalnog } \\
\text { podrijetla }\left(\mathbf{M}_{\mathbf{R R P}}=0,6<\mathbf{M}_{\mathrm{URP}} \text { i } \mathbf{M}_{\mathbf{M R P}}=0,7\right) ; \\
\text { - učestalost roditeljskih kulturnih praksi } \mathrm{U}_{\mathrm{RRP}} \\
\text { statistički je značajno rjeđa od one učenika obje } \\
\text { urbane kategorije, a dodatno i za } \mathrm{U}_{\mathrm{URP}} \text { u odnosu na } \\
\mathrm{U}_{\text {MRP }}\left(\mathbf{M}_{\mathbf{R R P}}=1,7<\mathbf{M}_{\mathrm{URP}}=2<\mathbf{M}_{\mathbf{M R P}}=2,1\right)\end{array}$ \\
\hline $\begin{array}{l}\text { Simbolička } \\
\text { vrijednost } \\
\text { obitelji }\end{array}$ & $\begin{array}{l}\text { Utjecaj roditelja i } \\
\text { braće/sestara na } \\
\text { odluku o nastavku } \\
\text { školovanja } \\
\text { Roditeljsko } \\
\text { ohrabrenje nastavka } \\
\text { školovanja* }\end{array}$ & ANOVA & $\begin{array}{l}\text { - nema statistički značajnih } \mathrm{M}=3,5 \text { procjene utjecaja } \\
\text { roditelja i } \mathrm{M}=2,6 \text { procjene utjecaja braće/sestara na } \\
\text { odluku o studiranju između učenika različitog } \\
\text { rezidencijalnog podrijetla } \\
-\quad \mathbf{M}_{\mathbf{R R P}}=4,4 \text { procjene roditeljskog ohrabrivanja } \\
\text { studiranja je statistički značajno niža za u odnosu na } \\
\text { druge dvije rezidencijalne grupe učenika ( } \mathbf{M}_{\mathrm{URP}} \mathrm{i} \\
\left.\mathbf{M}_{\mathbf{M R P}}=4,6\right)\end{array}$ \\
\hline $\begin{array}{l}\text { Simbolička } \\
\text { vrijednost } \\
\text { društvenih } \\
\text { odnosa }\end{array}$ & $\begin{array}{l}\text { Utjecaj } \\
\text { izvaninstituciona- } \\
\text { lnih drugih } \\
\text { Utjecaj } \\
\text { institucionalnih } \\
\text { drugih* }\end{array}$ & ANOVA & $\begin{array}{l}\text { - nema statistički značajnih razlika u M=2,2 procjeni } \\
\text { utjecaja izvaninstitucionalnih drugih između učenika } \\
\text { različitog rezidencijalnog podrijetla } \\
\text { - statistički značajno viši je } \mathbf{M}_{\mathbf{R R P}}=2,1 \text { procjene } \\
\text { utjecaja osoba iz institucionalnih konteksta na } \\
\text { njihovu namjeru studiranja u odnosu na druge dvije } \\
\left.\text { kategorije učenika (M } \mathbf{M}_{\mathbf{U R P}}=1,9 ; \mathbf{M}_{\mathbf{M R P}}=1,8\right)\end{array}$ \\
\hline $\begin{array}{l}\text { Institucionalne } \\
\text { karakteristike } \\
\text { obrazovnih } \\
\text { konteksta }\end{array}$ & $\begin{array}{l}\text { Škola visokog } \\
\text { statusa* } \\
\text { Akademski } \\
\text { poticajna škola } \\
\text { Opremljena škola } \\
\text { dobrog programa* }\end{array}$ & ANOVA & $\begin{array}{l}\text { - postoje statistički značajne razlike } \mathbf{M}_{\mathbf{R R P}}=2,8 \\
\text { procjene statusa škola koji je niži u odnosu na } \\
\mathbf{M}_{\mathbf{M R P}}=2,9 \\
\text { - nema statistički značajnih razlika u M grupa } \\
\text { učenika različitog rezidencijalnog podrijetla prema } \\
\text { procjeni akademske poticajnosti škola } \\
\text { - procjena resursne opremljenosti i programske } \\
\text { ponude } \mathbf{M}_{\mathbf{R R P}}=2,8 \text { značajno viša od } \mathbf{M}_{\mathbf{U R P}}=2,6\end{array}$ \\
\hline
\end{tabular}

Učenici različitog rezidencijalnog podrijetla razlikuju se statistički značajno prema svojim obrazovnim karakteristikama, orijentacijama i kulturnim kompetencijama. Veći udio učenika odraslih na selu pohađa trogodišnje škole, a najmanje ih pohađa gimnazije, pri čemu se udjeli učenika ostalih rezidencijalnih kategorija koji pohađaju gimnazije povećava kako raste 
veličina naselja odrastanja. U skladu s tim, veći broj učenika ruralnog rezidencijalnog podrijetla želi samo završiti srednju školu, te ih manje teži najvišim visokoobrazovnim stupnjevima, a u većoj mjeri i očekuju postizanje tek nižih stupnjeva obrazovanja, odnosno završavanje srednje škole i eventualno preddiplomskog studija. Dakle, manjem se broju učenika ruralnog rezidencijalnog podrijetla studiranje podrazumijeva te ih je manje bez razmišljanja donijelo odluku o studiranju. U konačnici, u odnosu na druge dvije rezidencijalne urbane kategorije učenika, manje ih se odlučuje na nastavak školovanja na visokoškolskoj razini, a potvrđena je prva hipoteza ovog rada. Kao odrednice značajnih razlika između učenika različitog rezidencijalnog podrijetla pokazuju se i njihove obrazovne i kulturne kompetencije; učenici ruralnog rezidencijalnog podrijetla, u odnosu na urbane kategorije učenika, imaju slabiji prošlogodišnji školski uspjeh i u manjoj mjeri sudjeluju u kulturnim, čitalačkim i izvanškolskim aktivnostima. No, unatoč tome, rezultati učenika odraslih na selu ne pokazuju slabiji stupanj želja za društvenom mobilnošću koje je jednako snažno izražena bez obzira na rezidencijalno podrijetlo učenka. Također, nije se niti potvrdilo da ruralni učenici slabije vrednuju učenje u odnosu na druge učenike; već to vrijedi za učenike odrasle u metropoli koji su skloniji učenju pripisati nižu vrijednost $u$ odnosu na one odrasle u drugim gradovima.

Kakva je struktura učenicima dostupnih kapitala s obzirom na njihovo rezidencijalno podrijetlo? I na mjerama obiteljskih resursa ponavlja se ranije opisan obrazac razlika. Tako je vjerojatnije za učenike ruralnog rezidencijalnog podrijetla da imaju roditelje nestalnijih primanja (dok se stalnost primanja povećava kako raste veličina naselja odrastanja učenika), da imaju roditelje nižih stupnjeva obrazovanja (dok se udjeli učenika s visokoobrazovanim roditeljima povećavaju kako raste veličina naselja u kojem su odrasli učenici), te da posjeduju manju količinu knjiga u svojim kućanstvima (dok udjeli učenika koji posjeduju veliki broj knjiga raste kako se povećava veličina naselja u kojem su odrasli). Dodatno, za njih su vjerojatnije i niže razine posjedovanja različitih drugih kulturnih i materijalnih dobara te rjeđe sudjelovanje njihovih roditelja u različitim obrazovnim, čitalačkim i kulturnim aktivnostima, u odnosu na druge dvije rezidencijalne grupe učenika, kao i niže procjene financijske situacije obitelji, u odnosu na metropolitanske učenike. Dakle, struktura je obiteljski dostupnih ekonomskih i kulturnih resursa, nepovoljnija za učenike koji odrastaju na selu.

Pokazuje li se razlika za učenike različitog rezidencijalnog podrijetla prema simboličkoj vrijednost okoline odrastanja i školovanja? Mjere namijenjene zahvaćanju tih aspekata 
uglavnom nisu pokazale statistički značajno različite rezultate procjene (nema statistički značajnih razlika prema procjeni utjecaja roditelja i braće/sestara na odluku o studiranju, prema procjeni uključenosti roditelja u školske aktivnosti i interesa roditelja za školski život svoje djece, kao niti prema procjeni utjecaja izvaninstitucionalnih drugih). Ipak, analize ukazuju da su ruralni učeni skloniji procijeniti u statistički značajno manjoj mjeri roditeljsko ohrabrenje za studiranje i da je za njih značajniji utjecaj stručnih osoba iz institucionalnih konteksta kojima se kreću, posebno utjecaj stručnih suradnika u školama, te savjetnika za stručno usavršavanje, iako je općenito utjecaj tih osoba za većinu učenika slab.

Budući da je najvažniji institucionalni kontekst učenika njihova škola, postavilo se i pitanje resursa koji su učenicima u tom kontekstu dostupni. Kako pokazuju analize, osim simboličke vrijednosti u obliku utjecaja stručnih osoba na namjeru studiranja koja se pokazuje značajnom za kategorije učenika odrasle u ruralnom okruženju, učenici ruralnog rezidencijalnog podrijetla skloniji su u svojim školama pripisati i bolju opremljenost i programsku izvannastavnu ponudu u odnosu na učenike koji odrastaju u urbanom okolišu. Također, značajno različito status svojim školama procjenjuju učenici različitog rezidencijalnog podrijetla pri čemu su, još jednom, učenici ruralnog rezidencijalnog podrijetla skloniji nižim procjenama tog aspekta svojih škola nasuprot učenicima odraslim u metropolitanskoj sredini. 


\subsection{Struktura resursa dostupnih učenicima različitog rezidencijalnog podrijetla koji namjeravaju studirati i visokoobrazovni izbori}

\subsubsection{Rezidencijalno podrijetlo učenika i visokoobrazovni izbori}

S obzirom na sve potvrđene razlike među učenicima različitog rezidencijalnog podrijetla opisane u prethodnim analizama (Poglavlje 3.1), očekuju se i razlike prema njihovim visokoobrazovnim izborima. U sljedeće analize ulazi se s pretpostavkama da je (H1b) za učenike ruralnog rezidencijalnog podrijetla koji se odlučuju na nastavak školovanja veća vjerojatnost odabira stručnih studija, te da je (H1c) za učenike ruralnog rezidencijalnog podrijetla koji se odlučuju na nastavak školovanja manja vjerojatnost odabira visokoobrazovnih institucija u Zagrebu. Ta očekivanja su do određene mjere potvrđuju (Tabeli 3.9), odnosno statistička razlika se potvrđuje kada je u pitanju izbor tipa studija.

Općenito, u najvećoj mjeri, $85 \%$ učenika koji namjeravaju studirati kako svoj prvi izbor odabire neki oblik sveučilišnog studija, no taj je izbor slabije izražen kod učenika ruralnog rezidencijalnog podrijetla koji namjeravaju studirati (79\%), u odnosu na urbane kategorije učenika (87\%). Suprotno, izbor stručnog studija češći je izbor ruralnim učenicima koji namjeravaju studirati - a bira ih $21 \%$ - u odnosu na $13 \%$ učenika odraslih u gradovima.

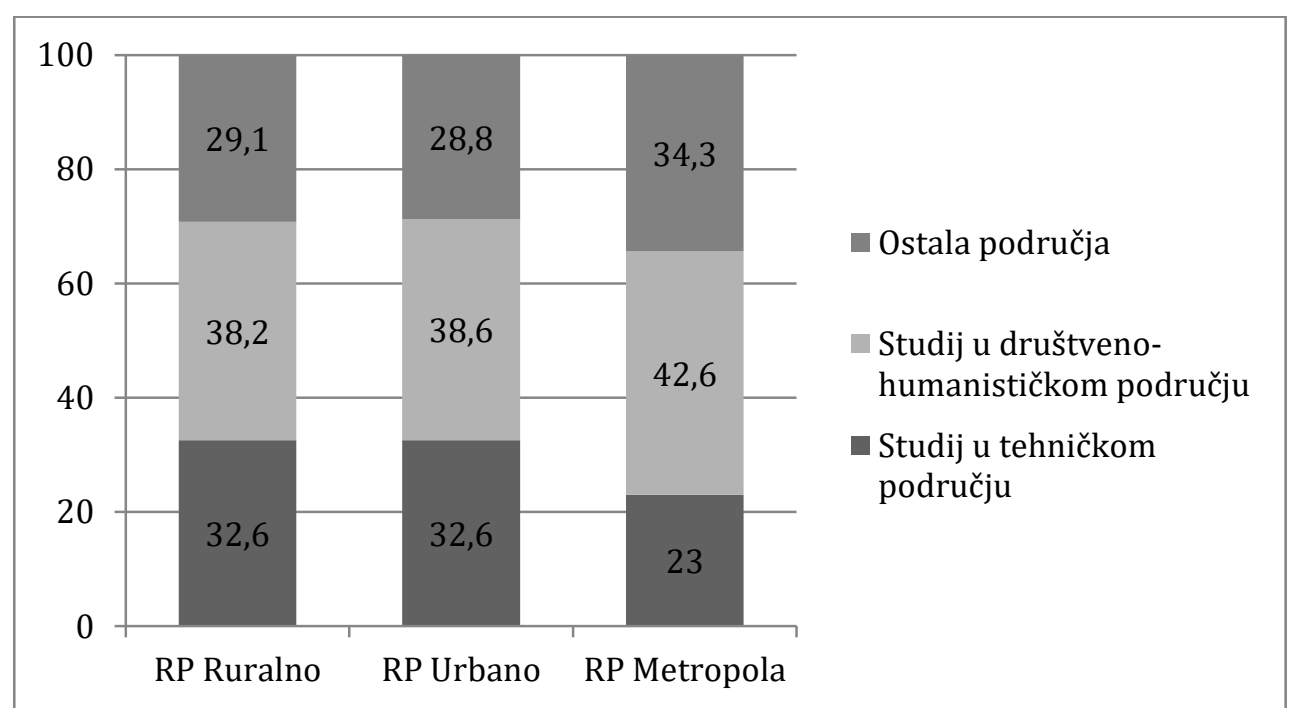

Slika 3.6 Razlike između učenika različitog rezidencijalnog podrijetla prema područjima odabranih studija

U ostalim analizama, razlike se nisu pokazale tamo gdje nisu niti očekivane - kod izbora studija u pojedinom znanstvenom području (Slika 3.6), a dodatno hi-kvadrat test nije dao 
konačne potvrde ${ }^{66}$ kada je u pitanju izbor studija na određenom tipu institucije i mjestu studiranja. Deskriptivno (Slika 3.17), možemo spomenuti da se prema tri definirana područja studija - tehničko, društveno-humanističko i ostala - uočava blago veća tendencija metropolitanskih učenika prema izboru studija u društveno-humanističkom području (43\% > $\mathrm{U}_{\mathrm{RRP}}$ i $\mathrm{U}_{\mathrm{URP}} 38 \%$ ), te ostalim područjima (34\% > $\mathrm{U}_{\mathrm{RRP}} \mathrm{i} \mathrm{U}_{\mathrm{URP}} 29 \%$ ), nasuprot ruralnim i urbanim učenicima koji, pak, u većoj mjeri biraju tehničke studije (33\% > $\left.\mathrm{U}_{\mathrm{MRP}} 23 \%\right)$.

Pokazuje se da je prvi izbor učenika u najvećoj mjeri (za 89\%) fakultet ili sastavnica nekog sveučilišta, što podjednako vrijedi za učenike različitog rezidencijalnog podrijetla ( $U_{R R P} 87 \%$ - U URP 90\%). Time je izbor veleučilišta ili visoke škole karakterističan tek za manjinu učenika (13\% $\mathrm{U}_{\mathrm{RRP}}$ i $11 \% \mathrm{U}_{\mathrm{URP}}$ i $\left.\mathrm{U}_{\mathrm{MRP}}\right)$ bez izraženih rezidencijalnih razlika.

Najuočljivije razlike su one „geografske“ između učenika s ruralnim i urbanim rezidencijalnim podrijetlom, nasuprot onima s metropolitanskim, potvrđujući prijašnje nalaze o nemobilnosti hrvatskih studenata (Jokić, Ristić Dedić, 2014; Doolan, 2009), odnosno nalaze da gotovo polovica studentskog tijela za vrijeme studija živi kod kuće (Farnell i sur., 2011), a što je posebno izraženo kada je u pitanju izbor Zagreba kao mjesta studiranja za učenike odrasle u Zagrebu: njih 94\% bira i studije u glavnom gradu, dok ih se tek 5\% odlučuje za neki studij u gradovima manjeg stupnja centraliteta (najvjerojatnije i dalje u široj regiji u kojoj se nalazi još jedno jedno javno sveučilište). Budući da postoji dostupnost zadovoljavajućih opcija u vlastitim gradu ili široj regiji, 2\% ovih učenika bira i sastavnice nekog drugog sveučilišta, izuzev Zagrebačkog, a 11\% ih bira i neko veleučilište ili visoku školu. Za ove učenike zanemariv je izbor studija u nekim drugim velikim makroregionalnim centrima Hrvatske, te dakle preseljenje za vrijeme studiranja.

$\mathrm{S}$ druge strane, kod učenika odraslih u ostalim hrvatskim gradovima, usporedno s drugim rezidencijalnim kategorijama, želja za studiranjem u Zagrebu najslabije je izražena (47\%), dok je izbor nekog makroregionalnog centra kao mjesta studija najnaglašenija (38\%), a 15\% učenika odlučuje se i za studiranje u nekom gradu slabijeg centraliteta.

\footnotetext{
${ }^{66}$ Teorijske frekvencije u određenim kategorijama manje su od 5.
} 
Tabela 3.9 Razlike učenika različitog rezidencijalnog podrijetla koji namjeravaju studirati prema visokoobrazovnim izborima tipa institucije, tipa studija te grada studiranja

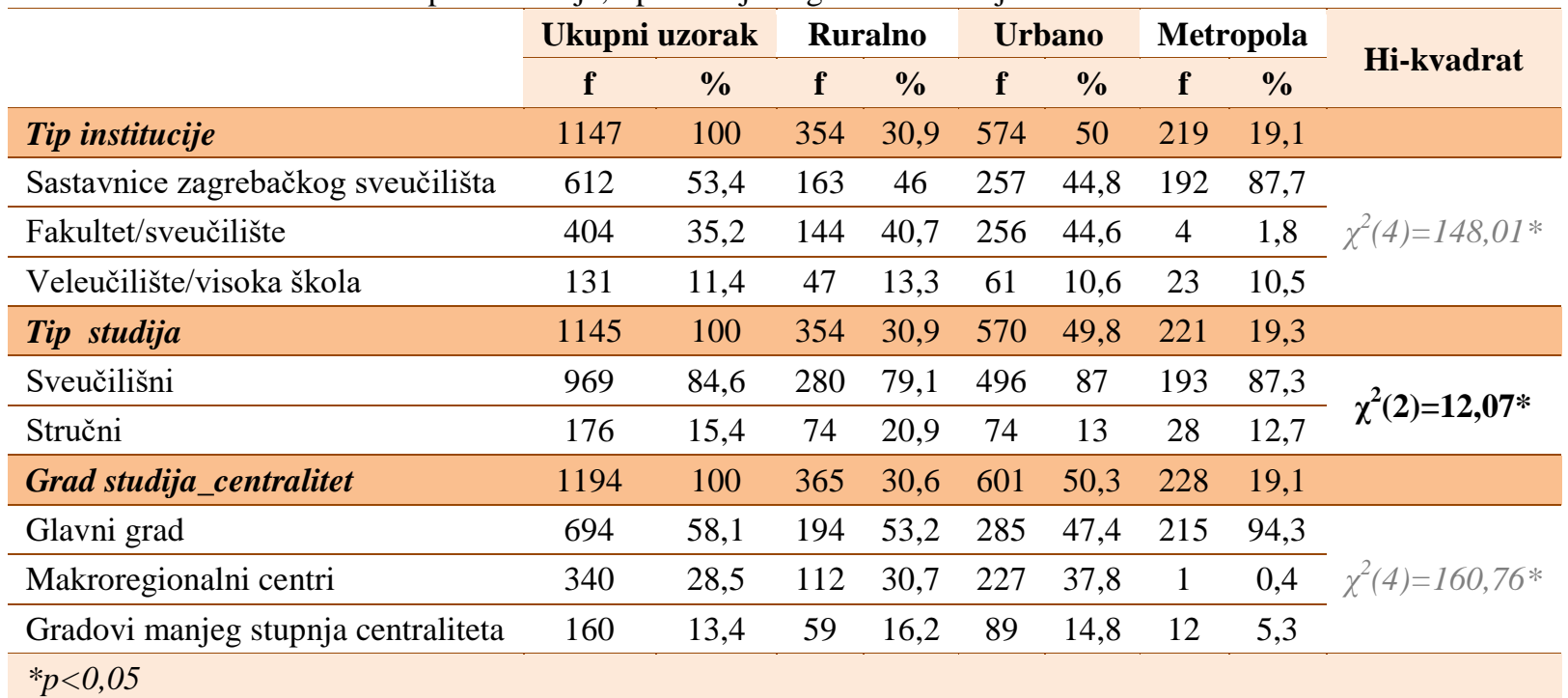

No, odlučuju li se učenici ruralnog rezidencijalnog podrijetla u manjoj mjeri za Zagreb kao mjesto svog budućeg studiranja? Podaci pokazuju da Zagreb bira preko polovice učenika odraslih na selu (53\%) koji namjeravaju studirati, što je u skladu s općim nacionalnim podacima da je za preko polovice učenika (58\%) koji namjeravaju studirati Zagreb najpoželjnija destinacija studiranja ${ }^{67}$. Štoviše, kao i svim ostalim rezidencijalnim kategorijama učenika, izbor Zagreba je najčešći, iako je on daleko naglašeniji kod učenika odraslih u metropoli (94\%), a najslabije kod ostalih učenika iz grada (47\%). U skladu s nacionalnim prosjecima su i izbori ostalih lokacija studija: tako 31\% ruralnih učenika koji namjeravaju studirati bira i makroregionalne centre $(\approx 29)$, dok $16 \%$ bira i gradove manjeg stupnja centraliteta $(\approx 13 \%)$. Zbog svega navedenog ne možemo potvrditi hipotezu H1c.

Sljedeće analize, s interesom za širi okvir odluka i u deskriptivne svrhe, provode se kako bi se dublje opisale karakteristike rezidencijalnih kategorija učenika koji namjeravaju studirati, te potvrdile razlike među učenicima različitog rezidencijalnog podrijetla koji namjeravaju studirati prema obrazovnim karekteristikama, resursima i simboličkoj vrijednosti konteksta odrastanja i školovanja za koje se pretpostavlja da doprinose objašnjenju takvih izbora.

\footnotetext{
${ }^{67}$ Slične podatke iznose i Jokić i Ristić Dedić (2014).
} 


\subsubsection{Rezidencijalno podrijetlo učenika koji namjeravaju studirati, njihove obrazovne karakteristike i kulturne kompetencije}

Sljedeće analize rezultat su dvojakog cilja: deskripcije sociokulturnih i ekonomskih karakteristika učenika koji namjeravaju studirati, a koje se pokazuju kao rezidencijalne statistički značajne razlike, te ispitivanja potencijalne značajnost pojedinih mjera kao prediktora u kompleksnijim analizama kasnijih analitičkih koraka rada. Podsjećamo, poduzorak ovih analiza tvore uglavnom učenici četverogodišnjih srednjih škola $-44 \%$ gimnazija i 50\% strukovnih škola; ali i 6\% učenika trogodišnjih strukovnih škola.

Rezultati analiza razlika između grupa učenika različitog rezidencijalnog podrijetla koji namjeravaju studirati kada su u pitanju neke njihove obrazovne karakteristike i razvijene kulturne kompetencije prikazani su u Tabeli 3.10. Statistički značajni ANOVA testovi potvrdili su da rezidencijalne razlike postoje na tri mjerena aspekta, a post-hoc testovi su ukazali da učenici ruralnog rezidencijalnog podrijetla koji namjeravaju studirati slabije pohađaju izvanškolske aktivnosti $\left(\mathrm{M}_{\mathrm{RR} P}=0,16\right)$, u odnosu na učenike druge dvije ruralne kategorije ( $\mathrm{M}_{\mathrm{URP}}$ i $\left.\mathrm{M}_{\mathrm{MRP}}=0,21\right)$, no i da, kao i urbani učenici, učenju pripisuju višu vrijednost $\left(\mathrm{M}_{\mathrm{RRP}}\right.$ i $\left.\mathrm{M}_{\mathrm{URP}}=3,9\right)$, u odnosu na učenike metropole $\left(\mathrm{M}_{\mathrm{MRP}}=3,7\right)$. Konačno, u većoj mjeri izražavaju i želju za društvenom mobilnošću, u odnosu na rezultate učenika odraslih u glavnom gradu $\left(\mathrm{M}_{\mathrm{RRP}}=3,8>\mathrm{M}_{\mathrm{MRP}}=3,6\right)$.

S druge strane, među učenicima koji namjeravaju studirati ne postoje rezidencijalne razlike kada je u pitanju njihov školski uspjeh te učestalost kulturnih i čitalačkih praksi, te općenito vrijedi da učenici koji namjeravaju studirati imaju prosječno ocjenu vrlo dobar $(M=4)$, te da jednom ili dva puta godišnje $(\mathrm{M}=1,8)$ sudjeluju u kulturnim praksama poput odlazaka u kazalište, muzeje/galerije i na operu, balet ili klasične koncerte

Tabela 3.10 Razlike između učenika različitog rezidencijalnog podrijetla koji namjeravaju studirati prema njihovim obrazovnim karakteristikama i kulturnim kompetencijama

\begin{tabular}{|c|c|c|c|c|c|c|c|c|c|c|}
\hline \multirow[b]{2}{*}{ Zavisna varijabla } & \multicolumn{2}{|c|}{ UK } & \multicolumn{2}{|c|}{ (1) RRP } & \multicolumn{2}{|c|}{ (2) URP } & \multicolumn{2}{|c|}{ (3) MRP } & \multirow{2}{*}{ ANOVA } & \multirow{2}{*}{$\begin{array}{r}\text { Post- } \\
\text { hoc } \\
\text { test }\end{array}$} \\
\hline & $\mathbf{M}$ & SD & $\mathbf{M}$ & SD & $\mathbf{M}$ & SD & $\mathbf{M}$ & SD & & \\
\hline Opći uspjeh prošle god. & 3,97 & 0,60 & 3,95 & 0,61 & 3,97 & 0,59 & 3,99 & 0,60 & $\mathrm{~F}(2 / 1243)=0,38$ & - \\
\hline Uč. kulturne prakse & 1,84 & 0,70 & 1,79 & 0,70 & 1,84 & 0,69 & 1,92 & 0,73 & $\mathrm{~F}(2 / 1254)=2,71$ & - \\
\hline Uč. čitalačke prakse & 2,50 & 0,89 & 2,52 & 0,92 & 2,48 & 0,87 & 2,52 & 0,91 & $\mathrm{~F}(2 / 1252)=0,31$ & - \\
\hline $\begin{array}{l}\text { Uč. izvanškolske } \\
\text { aktivnosti }\end{array}$ & 0,19 & 0,23 & 0,16 & 0,20 & 0,21 & 0,23 & 0,21 & 0,25 & $\mathrm{~F}(2 / 1248)=5,88 *$ & $\begin{array}{l}1-2 * \\
1-3 *\end{array}$ \\
\hline Vrijednost učenja & 3,83 & 0,74 & 3,88 & 0,75 & 3,87 & 0,71 & 3,67 & 0,76 & $\mathrm{~F}(2 / 1253)=6,74^{*}$ & $\begin{array}{l}3-1 * \\
3-2 *\end{array}$ \\
\hline Želja za dr. mobilnošću & 3,70 & 0,80 & 3,77 & 0,77 & 3,70 & 0,80 & 3,56 & 0,85 & $\mathrm{~F}(2 / 1240)=5,25^{*}$ & $1-3 *$ \\
\hline$*_{p}<0,05$ & & & & & & & & & & \\
\hline
\end{tabular}




\subsubsection{Rezidencijalno podrijetlo učenika koji namjeravaju studirati i obiteljski dostupni resursi}

Analize rezidencijalnih razlika učenika koji namjeravaju studirati prema elementima obiteljski dostupnih resursa pokazali su konzistentan obrazac razlika koji grafički prikazuje Slika 3.7. i Tabela 3.11. Pokazuje se kako na svim mjerama obiteljskih ekonomskih i kulturnih resursa postoje rezidencijalne razlike među učenicima koji namjeravaju studirati, te za koje je moguće da su i značajne odrednice njihovih visokoobrazovnih ishoda.

Iz prikaza je jasno da učenici ruralnog rezidencijalnog podrijetla prevladavaju, u odnosu na druge grupe učenika, $\mathrm{u}$ kategorijama $\mathrm{s}$ roditeljima bez stalnih prihoda $\left(\mathrm{U}_{\mathrm{RRP}}=15 \%\right.$ $\left.>\mathrm{U}_{\mathrm{URP}}=11 \%>\mathrm{U}_{\mathrm{MRP}}=2 \%\right)$, trogodišnjeg srednjoškolskog obrazovanja $\quad\left(\mathrm{U}_{\mathrm{RRP}}=26 \%\right.$ $\left.>\mathrm{U}_{\mathrm{URP}}=11 \%>\mathrm{U}_{\mathrm{MRP}}=8 \%\right)$ te manjeg broja knjiga u kućanstvu $\left(\mathrm{U}_{\mathrm{RRP}}=32 \%>\mathrm{U}_{\mathrm{URP}}=25 \%>\right.$ $\mathrm{U}_{\mathrm{MRP}}=22 \%$ ), pri čemu se udjeli učenika smanjuju kako se veličina naselja njihova rezidencijalnog podrijetla povećava.

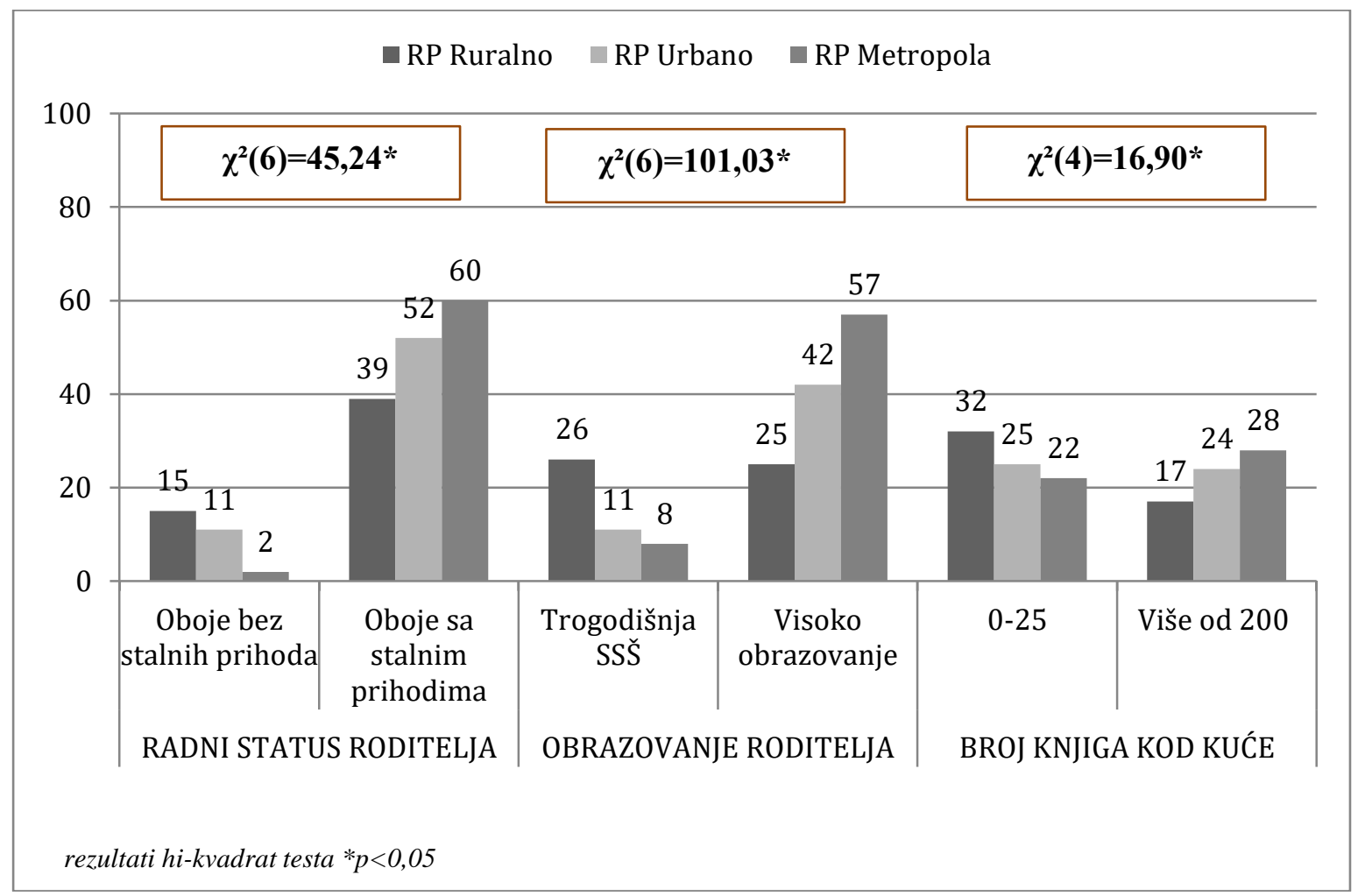

Slika 3.7 Razlike između učenika različitog rezidencijalnog podrijetla koji namjeravaju studirati prema elementima obiteljskih resursa ${ }^{68}$

Obrnuto vrijedi za kategorije učenika čiji roditelji imaju stalne prihode, visoko obrazovanje te obiteljski posjeduju preko 200 knjiga u kojima udjeli učenika prema njihovom rezidencijalnom podrijetlu rastu kako se povećava veličina naselja njihova odrastanja.

\footnotetext{
${ }^{68}$ Prikazuju se rezultati samo onih kategorija nezavisnih varijabli u kojima su uočljive najveće razlike.
} 
Dodatno rezultati analiza varijance (Tabela 3.11) podupiru zaključke o nepovoljnijoj strukturi ruralnih učenika koji namjeravaju studirati, odnosno povoljojoj strukturi obiteljskih resursa učenika odraslih u gradu, a posebno onih odraslih u glavnom gradu, koji namjeravaju studirati.

Pokazuje se da učenici odrasli u metropoli koji namjeravaju studirati imaju statistički značajno viši prosječni rezultat materijalnog statusa obitelji $\left(\mathrm{M}_{\mathrm{MRP}}=1,9\right)$ u odnosu na druge dvije rezidencijalne grupe učenika $\left(\mathrm{M}_{\mathrm{URP}}=1,8 ; \mathrm{M}_{\mathrm{RRP}}=1,7\right)$, a također su skloniji procjenjivati svoju financijsku situaciju boljom $\left(\mathrm{M}_{\mathrm{MRP}}=3,1\right) \mathrm{u}$ odnosu na učenike odrasle $\mathrm{u}$ ruralnim okolišima $\left(\mathrm{M}_{\mathrm{RRP}}=3\right)$.

Ruralni učenici koji namjeravaju studirati, imaju statistički značajno niže rezultate i kada je u pitanju posjedovanje različitih vrsta kulturnih dobara (knjiga, umjetničkih djela, nosača zvuka klasične ili jazz glazbe) $(M=0,7)$, te učestalosti roditeljskih praksi čitanja, pohađanja programa kulturnih institucija ili obrazovnih tečajeva/predavanja $(M=1,9)$, i to u odnosu na obje urbane kategorije učenika.

Tabela 3.11 Razlike između učenika različitog rezidencijalnog podrijetla koji namjeravaju studirati prema elementima obiteljskih resursa

\begin{tabular}{|c|c|c|c|c|c|c|c|c|c|c|}
\hline \multirow[b]{2}{*}{ Zavisna varijabla } & \multicolumn{2}{|c|}{ UK } & \multicolumn{2}{|c|}{$\begin{array}{c}\text { (1) } \\
\text { Ruralno }\end{array}$} & \multicolumn{2}{|c|}{$\begin{array}{c}\text { (2) } \\
\text { Urbano }\end{array}$} & \multicolumn{2}{|c|}{$\begin{array}{c}\text { (3) } \\
\text { Metropola }\end{array}$} & \multirow[t]{2}{*}{ ANOVA } & \multirow[t]{2}{*}{$\begin{array}{l}\text { Post-hoc } \\
\text { test }\end{array}$} \\
\hline & $\mathbf{M}$ & SD & $\mathbf{M}$ & SD & $\mathbf{M}$ & SD & $\mathbf{M}$ & SD & & \\
\hline $\begin{array}{l}\text { Posjedovanje } \\
\text { imovine }\end{array}$ & 1,80 & 0,59 & 1,74 & 0,59 & 1,79 & 0,57 & 1,90 & 0,61 & $\mathrm{~F}(2 / 1247)=5,45^{*}$ & $\begin{array}{c}1-3 *, 2- \\
3 *\end{array}$ \\
\hline $\begin{array}{l}\text { Procjena finan. } \\
\text { situacije }\end{array}$ & 3,02 & 0,74 & 2,96 & 0,73 & 3,02 & 0,74 & 3,13 & 0,73 & $\mathrm{~F}(2 / 1193)=3,75^{*}$ & $1-3 *$ \\
\hline $\begin{array}{l}\text { Posjedovanje kult. } \\
\text { dobara }\end{array}$ & 0,73 & 0,26 & 0,66 & 0,28 & 0,75 & 0,26 & 0,78 & 0,23 & $\mathrm{~F}(2 / 1247)=18,91 *$ & $\begin{array}{c}1-2 *, 1- \\
3 *\end{array}$ \\
\hline $\begin{array}{l}\text { Roditeljske kult. } \\
\text { prakse }\end{array}$ & 2,06 & 0,80 & 1,87 & 0,75 & 2,10 & 0,79 & 2,25 & 0,86 & $\mathrm{~F}(2 / 1242)=17,96^{*}$ & $\begin{array}{c}1-2 *, 1- \\
3 *\end{array}$ \\
\hline
\end{tabular}

\subsubsection{Rezidencijalno podrijetlo učenika koji namjeravaju studirati i institucionalne karakteristike obrazovanja}

No, postoje li razlike između učenika različitog rezidencijalnog podrijetla prema procjenama karakteristika njihova srednjoškolskog, te budućeg visokoškolskog obrazovanja kojem teže? Rezultate provedenih analiza varijanci na četiri elementa prikazuje Tabela 3.12. 
Tabela 3.12 Razlike između učenika različitog rezidencijalnog podrijetla učenika koji namjeravaju studirati prema procjeni institucionalnih karakteristika obrazovanja

\begin{tabular}{|c|c|c|c|c|c|c|c|c|c|c|}
\hline \multirow[b]{2}{*}{ Zavisna varijabla } & \multicolumn{2}{|c|}{ UK } & \multicolumn{2}{|c|}{$\begin{array}{c}\text { (1) } \\
\text { Ruralno }\end{array}$} & \multicolumn{2}{|c|}{$\begin{array}{c}(2) \\
\text { Urbano }\end{array}$} & \multicolumn{2}{|c|}{$\begin{array}{c}\text { (3) } \\
\text { Metropola }\end{array}$} & \multirow[t]{2}{*}{ ANOVA } & \multirow{2}{*}{$\begin{array}{c}\text { Post- } \\
\text { hoc test }\end{array}$} \\
\hline & $\mathbf{M}$ & SD & $\mathbf{M}$ & SD & $\mathbf{M}$ & SD & M & SD & & \\
\hline Škola visokog statusa & 3,03 & 1,04 & 3,05 & 0,99 & 3,00 & 1,04 & 3,21 & 1,11 & $\mathrm{~F}(2 / 1250)=3,28 *$ & $2-3^{*}$ \\
\hline $\begin{array}{l}\text { Akademski poticajna } \\
\text { škola }\end{array}$ & 3,62 & 0,97 & 3,70 & 0,96 & 3,59 & 0,99 & 3,57 & 0,93 & $\mathrm{~F}(2 / 1249)=0,14$ & - \\
\hline $\begin{array}{l}\text { Opremljena škola } \\
\text { dobrog programa }\end{array}$ & 2,76 & 1,12 & 2,85 & 1,13 & 2,65 & 1,07 & 2,91 & 1,23 & $\mathrm{~F}(2 / 1250)=6,18 *$ & $\begin{array}{c}2-1 *, 2- \\
3 *\end{array}$ \\
\hline $\begin{array}{l}\text { Važnost ugleda } \\
\text { studija i fakulteta }\end{array}$ & 3,57 & 1,01 & 3,61 & 0,97 & 3,61 & 1,02 & 3,39 & 1,02 & $\mathrm{~F}(2 / 1248)=4,54^{*}$ & $\begin{array}{l}3-1 * \\
3-2 *\end{array}$ \\
\hline
\end{tabular}

Općenito, svom srednjoškolskom kontekstu učenici koji namjeravaju studirati pripisuju u najvećoj mjeri akademsku poticajnost $(\mathrm{M}=3,6)$, a također je to i jedina karakteristika prema čijoj procjeni ne postoje razlike između učenika različitog rezidencijalnog podrijetla. Dakle, učenici koji namjeravaju studirati u većoj mjeri smatraju da ih u njihovim školama potiču na studiranje, bez obzira na rezidencijalno podrijetlo.

S druge strane, učenici koji namjeravaju studirati osrednjima vide status $(M=3)$, te opremljenost i izvannastavnu programsku ponudu svojih škola $(M=2,8)$, pri čemu se pojedine procjene razlikuju prema učeničkom rezidencijalnom podrijetlu; objema karakteristikama škola urbani učenici koji namjeravaju studirati daju najniže ocjene, s time da statistički značajno niže prosječne rezultate imaju kada je u pitanju procjena statusa škola u odnosu na metropolitanske učenike $\left(\mathrm{M}_{\mathrm{URP}}=3<\mathrm{M}_{\mathrm{MRP}}=3,2\right)$, a u odnosu na obje druge kategorije učenika $\left(\mathrm{M}_{\mathrm{URP}}=2,7<\mathrm{M}_{\mathrm{MRP}} \mathrm{i} \mathrm{M}_{\mathrm{RRP}}=3,2\right)$ kada procjenjuju opremljenost i programsku ponudu.

Konačno, učenici koji namjeravaju studirati odgovarali su i na pitanje o tome koliko je na njihove visokoobrazovne izbore utjecalo to kako procjenjuju ugled odabranog studija i fakulteta. Rezultati su ukazali da ugled studija i fakulteta kao razlog visokoobrazovnog odabira značajnijim procjenjuju učenici koji nisu odrasli u glavnom gradu; prosječno, njihovi rezultati imaju statistički značajno veću vrijednost određivanja važnosti ugleda studija i visokoobrazovnih institucija $\left(\mathrm{M}_{\mathrm{RRP}} \mathrm{i} \mathrm{M}_{\mathrm{URP}}=3,6\right)$, u odnosu na učenike metropolitanskog rezidencijalnog podrijetla $\left(\mathrm{M}_{\mathrm{MRP}}=3,4\right)$. Ovaj rezultat vjerojatno odražava apsekt dostupnosti, ako pretpostavimo da su studiji i visokoobrazovne institucije u Zagrebu one koji uživaju viši ugled, a koji su metropolitanskim učenicima dostupniji u gradu njihova odrastanja. 


\subsubsection{Rezidencijalno podrijetlo učenika koji namjeravaju studirati i simbolička vrijednost njihovih obiteljskih i izvanobiteljskih odnosa}

Kada je u pitanju simbolička vrijednost obiteljskih i društvenih odnosa učenika, statistički značajne razlike između učenika različitog rezidencijalnog podrijetla koji namjeravaju studirati testovi su pokazali samo na dvije mjere, kako je vidljivo iz Tabele 3.13.

Tabela 3.13 Razlike između učenika različitog rezidencijalnog podrijetla koji namjeravaju studirati prema simboličkoj vrijednosti obitelji i osoba iz učeničkih društvenih odnosa/mreža

\begin{tabular}{|c|c|c|c|c|c|c|c|c|c|c|}
\hline \multirow[b]{2}{*}{ Zavisna varijabla } & \multicolumn{2}{|c|}{ UK } & \multicolumn{2}{|c|}{$\begin{array}{l}\text { (1) RP } \\
\text { Ruralno }\end{array}$} & \multicolumn{2}{|c|}{$\begin{array}{l}\text { (2) } R P \\
\text { Urbano }\end{array}$} & \multicolumn{2}{|c|}{$\begin{array}{c}\text { (3) RP } \\
\text { Metropola }\end{array}$} & \multirow[t]{2}{*}{ ANOVA } & \multirow{2}{*}{$\begin{array}{l}\text { Post- } \\
\text { hoc } \\
\text { test }\end{array}$} \\
\hline & M & SD & $\mathbf{M}$ & SD & $\mathbf{M}$ & SD & $\mathbf{M}$ & SD & & \\
\hline Roditelji & 3,64 & 1,37 & 3,62 & 1,33 & 3,66 & 1,37 & 3,64 & 1,42 & $\mathrm{~F}(2 / 1252)=0,08$ & - \\
\hline Braća/sestre & 2,59 & 1,53 & 2,71 & 1,51 & 2,63 & 1,56 & 2,31 & 1,46 & $\mathrm{~F}(2 / 1239)=5,13^{*}$ & $\begin{array}{l}3-1 * \\
3-2 *\end{array}$ \\
\hline $\begin{array}{l}\text { Kada mi treba, roditelji } \\
\text { mi pomažu kod } \\
\text { školskih obveza }\end{array}$ & 3,68 & 1,31 & 3,59 & 1,33 & 3,69 & 1,33 & 3,79 & 1,22 & $\mathrm{~F}(2 / 1253)=1,74$ & - \\
\hline $\begin{array}{l}\text { Moji roditelji su } \\
\text { zainteresirani za ono } \\
\text { što radim u školi. }\end{array}$ & 4,01 & 1,02 & 3,91 & 1,08 & 4,06 & 0,99 & 4,02 & 0,99 & $\mathrm{~F}(2 / 1254)=2,62$ & - \\
\hline $\begin{array}{l}\text { Roditelji me ohrabruju } \\
\text { da nastavim školovanje. }\end{array}$ & 4,70 & 0,66 & 4,65 & 0,77 & 4,71 & 0,61 & 4,73 & 0,61 & $\mathrm{~F}(2 / 1251)=1,30$ & - \\
\hline $\begin{array}{l}\text { Roditelji me ohrabruju } \\
\text { da se što prije zaposlim. }\end{array}$ & 3,28 & 1,36 & 3,27 & 1,35 & 3,31 & 1,37 & 3,19 & 1,38 & $\mathrm{~F}(2 / 1248)=0,68$ & - \\
\hline $\begin{array}{l}\text { Utjecaj } \\
\text { izvaninstitucionalnih } \\
\text { drugih }\end{array}$ & 2,27 & 1,00 & 2,37 & 1,05 & 2,24 & 0,97 & 2,17 & 0,99 & $\mathrm{~F}(2 / 1220)=3,45^{*}$ & - \\
\hline $\begin{array}{l}\text { Utjecaj institucionalnih } \\
\text { drugih }\end{array}$ & 1,96 & 0,97 & 2,14 & 1,08 & 1,93 & 0,93 & 1,76 & 0,84 & $\mathrm{~F}(2 / 1241)=12,1 *$ & $\begin{array}{l}1-2 * \\
1-3 * \\
2-3 *\end{array}$ \\
\hline
\end{tabular}

Iako su učenici koji namjeravaju studirati skloniji odluke pripisivati sebi, rezultati ukazuju da je utjecaj drugih osoba na učeničke odluke o studiranju istaknutiji za ovaj uzorak učenika, i raznovrsniji s obzirom na kontekste u kojima se odvijaju. U obiteljskom kontekstu za učenike odrasle izvan metropole koji namjeravaju studirati značajniji je utjecaj braće i sestara na njihovu odluku o tome studirati ili ne u odnosu na one odrasle u glavnom gradu koji ga procjenjuju značajno nižim $\left(\mathrm{M}_{\mathrm{URP}}=2,6\right.$ i $\left.\mathrm{M}_{\mathrm{RRP}}=2,7>\mathrm{M}_{\mathrm{MRP}}=2,3\right)$.

S druge strane, utjecaj stručnih osoba iz učeničkih institucionalnih konteksta pokazuje razlike među svim grupama učenika koji namjeravaju studirati s obzirom na njihovo rezidencijalno podrijetlo pri čemu najsnažnijim taj utjecaj procjenjuju učenici ruralnog rezidencijalnog podrijetla, a prosječni rezultat opada kako se povećava veličina naselja u kojem su odrasli učenici $\left(\mathrm{M}_{\mathrm{RRP}}=2,1>\mathrm{M}_{\mathrm{URP}}=1,9>\mathrm{M}_{\mathrm{MRP}}=1,8\right)$. 
Pojedinačne analize dodatno ocrtavaju rezidencijalne razlike s obzirom na utjecaj osoba iz institucionalnih okruženja na učeničke odluke o studiranju, pri čemu su učenici ruralnog rezidencijalnog podrijetla koji namjeravaju studirati bili skloniji utjecaj svih osoba procjenjivati najvećim, a statistički značajno je njihov rezultat s obzirom na utjecaj nastavnika viši u odnosu na onaj učenika iz metropole $\left(\mathrm{M}_{\mathrm{RRP}}=2,7>\mathrm{M}_{\mathrm{MRP}}=2,4\right)$, a utjecaj stručnih suradnika viši u odnosu na obje kategorije učenika odraslih u gradskim sredinama $\left(\mathrm{M}_{\mathrm{RRP}}=2>\right.$ $\left.\mathrm{M}_{\mathrm{URP}}=1,7 ; \mathrm{M}_{\mathrm{MRP}}=1,5\right)$. Procjena utjecaja pak savjetnika za profesionalno usmjeravanje razlikuje učenike odrasle izvan metropole, čiji je rezultat statistički značajno viši, u odnosu na one odrasle u metropoli $\left(\mathrm{M}_{\mathrm{RRP}}=1,7 ; \mathrm{M}_{\mathrm{URP}}=1,6>\mathrm{M}_{\mathrm{MRP}}=1,4\right)$.

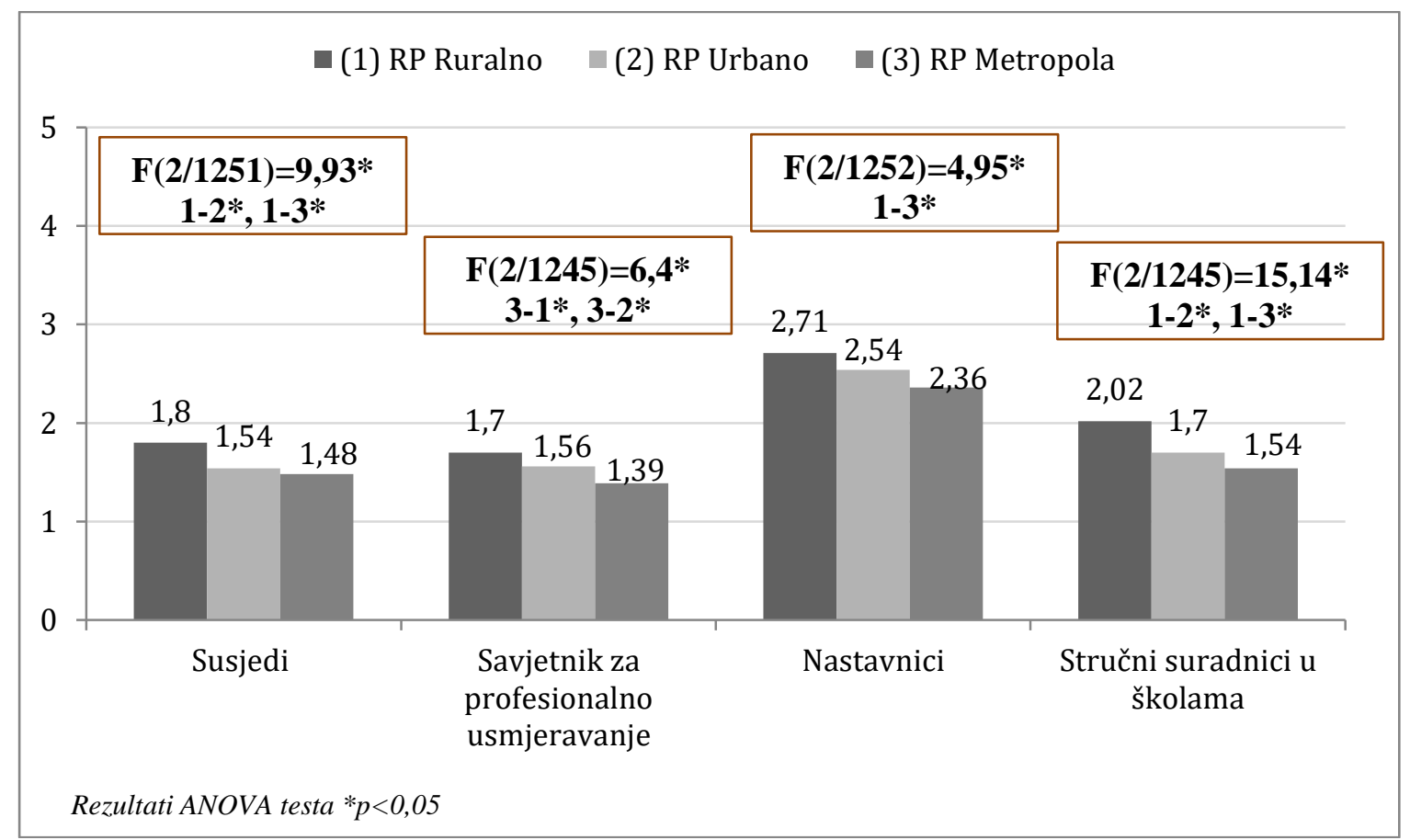

Slika 3.8 Razlike između učenika različitog rezidencijalnog podrijetla koji namjeravaju studirati prema procjeni utjecaja značajnih drugih na odluku učenika o (ne)studiranju

Konačno, iako je slab utjecaj osoba iz izvaninstitucionalnog konteksta na učeničke odluke o studiranju, učenici ruralnog rezidencijalnog podrijetla, čini se, nalaze nešto veću podršku u bliskom rezidencijalnom okruženju: u odnosu na obje urbane kategorije učenika, učenici odrasli na selu koji namjeravaju studirati skloniji su u svojim procjenama većim procjenjivati utjecaj susjeda $\left(\mathrm{M}_{\mathrm{RRP}}=1,8>\mathrm{M}_{\mathrm{URP}} ; \mathrm{M}_{\mathrm{MRP}}=1,5\right)$

Spomenimo da se razlike između učenika različitog rezidencijalnog podrijetla koji namjeravaju studirati nisu pokazale prema njihovim procjenama utjecaja roditelja općenito, kao niti prema bilo kojoj od 4 ispitivanih poticajnih praksi roditelja. Pri tom su mjereni 
elementi obrazovno orijentiranih poticaja procijenjeni iznadprosječno visokim $(M=3,7-4,7)$, ukazujući na značaj takvih roditeljskih praksi kada je u pitanju odluka učenika na studiranje bez obzira na njihovo rezidencijalno podrijetlo.

Roditeljski poticaj brzog zaposlenja, pak, učenici koji namjeravaju studirati procijenili su najslabije, ali osrednje $(M=3,3)$. Moguće da ova praksa nije posve u suprotnosti s poticajima na studiranje, a kod učenika koji namjeravaju studirati dobiva oblik roditeljskih poticaja na što brže završavanje (,,u roku“) studija.

\subsubsection{Zaključno o razlikama između učenika različitog rezidencijalnog podrijetla koji namjeravaju studirati}

Kada su u pitanju visokoobrazovni izbori učenika različitog rezidencijalnog podrijetla, statistički testovi su potvrdili značaj rezidencijalnog podrijetla prema izboru tipa studija. Konkretnije, rezultati pokazuju da je za ruralne učenike vjerojatniji izbor stručnog studija u odnosu na druge dvije rezidencijalne kategorije učenika, čime je potvrđena i hipoteza H1b.

Prema ostalim izborima, izbori su se pokazali u puno većoj mjeri određeni geografski; u najvećoj mjeri studiranje u Zagrebu izabiru oni koji su i odrasli u glavnom gradu, dok je želja za studiranjem u glavnom gradu najslabije izražena (za manje od polovice) urbanih učenika, koji u većoj mjeri biraju studije u nekom makroregionalnom centru. Konačno, nešto više od polovice učenici odrasli u ruralnoj sredini bira studije u glavnom gradu, što ove uzbore ne čini značajno različitim od nacionalnog prosjeka prema kojem oko polovice učenika bira studije u Zagrebu.

Tabela 3.14 Rezultati analiza rezidencijalnih razlika u poduzorku učenika koji namjeravaju studirati na pojedinim mjerama

\begin{tabular}{|c|c|c|c|}
\hline \multicolumn{2}{|c|}{$\begin{array}{l}\text { REZIDENCIJALNO } \\
\text { PODRIJETLO }^{69} \text { : }\end{array}$} & \multicolumn{2}{|c|}{$\begin{array}{l}\text { 1) } \operatorname{ruralno}(\mathrm{RRP})-\mathrm{N}=\mathbf{3 8 9}(\mathbf{3 1 \%}) \\
\text { 2) } \text { urbano }(\mathrm{URP})-\mathrm{N}=\mathbf{6 3 0}(\mathbf{5 0 \%}) \\
\text { 3) metropola }(\mathrm{MRP})-\mathrm{N}=\mathbf{2 3 9}(\mathbf{1 9 \%})\end{array}$} \\
\hline & Mjere & Analize & Osnovni nalazi: \\
\hline $\begin{array}{l}\text { OBRAZOVNI } \\
\text { ISHODI }\end{array}$ & $\begin{array}{l}\text { Tip studija* } \\
\text { Mjesto studiranja }\end{array}$ & & $\begin{array}{l}\text { - } \mathbf{U}_{\mathbf{R R P}}=21 \% \text { se u većoj mjeri odlučuju za stručni studij } \\
\left(>\mathbf{U}_{\mathbf{U R P}} \text { i } \mathbf{U}_{\text {MRP }}=13 \%\right) \\
\text { - želja za studiranjem u glavnom gradu najslabije je } \\
\text { izražena kod } U_{U R P}\left(47 \%<U_{R R P}=53 \%, U_{M R P}=94 \%\right)\end{array}$ \\
\hline $\begin{array}{l}\text { Obrazovne } \\
\text { karakteristike }\end{array}$ & $\begin{array}{l}\text { Tip škole } \\
\text { Školski uspjeh* } \\
\text { Vrijednost pripisana } \\
\text { učenju* }\end{array}$ & ANOVA & $\begin{array}{l}\text { - nema statistički značajnih razlika u prosječnim } \\
\text { rezultatima grupa učenika različitog rezidencijalnog } \\
\text { podrijetla prema školskom uspjehu }(\mathrm{M}=4) \\
\text { - } \mathrm{M}_{\mathrm{MRP}}=3,7 \text { vrijednosti pripisane učenju je statistički } \\
\text { značajno niži u odnosu na } \mathrm{M}_{\mathrm{RRP}} \text { i } \mathrm{M}_{\mathrm{URP}}=3,9\end{array}$ \\
\hline
\end{tabular}

${ }^{69}$ Rezidencijalno podrijetlo učenika je zavisna varijabla u hi-kvadrat analizama, a nezavisna $u$ analizama varijance. Navedeni testovi upotrebljavani su s obzirom na pojedine mjere, odnosno radi li se o kategorijalnoj ili kontinuiranoj varijabli. 


\begin{tabular}{|c|c|c|c|}
\hline \multirow{3}{*}{$\begin{array}{l}\text { Kulturne } \\
\text { kompetencija } \\
\text { učenika }\end{array}$} & \multicolumn{2}{|l|}{ Uč. kulturne prakse } & - nema statistički značajnih razlika u prosječnim \\
\hline & Uč. čitalačke prakse & \multirow[t]{2}{*}{ ANOVA } & $\begin{array}{l}\text { učestalosti učeničkih kulturnih }(\mathrm{M}=1,8) \\
\text { i čitalačkih praksi }(\mathrm{M}=2,5)\end{array}$ \\
\hline & $\begin{array}{l}\text { Uč. izvanškolske } \\
\text { aktivnosti* }\end{array}$ & & $\begin{array}{l}\text { - } \mathrm{U}_{\mathrm{RRP}} \text { imaju statistički značajno niži prosječni rezultat } \\
\text { sudjelovanje u izvanškolskim aktivnostima } \\
\left.\left(\mathrm{M}_{\mathrm{RRP}}=1,16\right) \text { u odnosu na } \mathrm{M}_{\mathrm{URP}} \text { i } \mathrm{M}_{\mathrm{MRP}}=0,21\right)\end{array}$ \\
\hline $\begin{array}{l}\text { HORIZONT } \\
\text { BUDUĆNOSTI }\end{array}$ & $\begin{array}{l}\text { Želja za društvenom } \\
\text { mobilnošću* }\end{array}$ & ANOVA & $\begin{array}{l}\text { - } \mathrm{M}_{\mathrm{RRP}}=3,8 \text { želje za društvenom mobilnošću statistički } \\
\text { značajno viši u odnosu na } \mathrm{M}_{\mathrm{MRP}}=3,6 \text { ) }\end{array}$ \\
\hline \multirow{2}{*}{$\begin{array}{l}\text { Ekonomsko- } \\
\text { materijalna } \\
\text { situacija obitelji }\end{array}$} & $\begin{array}{l}\text { Radni status } \\
\text { roditelja* }\end{array}$ & $\mathrm{X}^{2}$ & $\begin{array}{l}\text { - udjeli učenika s roditeljima sa stalnim prihodima: } \\
\mathrm{U}_{\mathrm{RRP}}=39 \%, \mathrm{U}_{\mathrm{URP}}=52 \%, \mathrm{U}_{\mathrm{MRP}}=60 \% \text { rastu kako se } \\
\text { povećava urbanitet naselja odrastanja, a opadaju } \\
\text { udjeli učenika s roditeljima bez stalnih prihoda: } \\
\mathrm{U}_{\mathrm{RRP}}=15 \%, \mathrm{U}_{\mathrm{URP}}=11 \%, \mathrm{U}_{\mathrm{MRP}}=2 \% \text {; }\end{array}$ \\
\hline & $\begin{array}{l}\text { Posjedovanje } \\
\text { imovine* } \\
\text { Procjena ekonomske } \\
\text { situacije* }\end{array}$ & ANOVA & $\begin{array}{l}-\mathrm{M}_{\mathrm{RRP}}=1,7 \mathrm{i} \mathrm{M}_{\mathrm{URP}}=1,8 \text { statistički posjedovanja } \\
\text { materijalnih dobara značajno niži u odnosu na } \\
\mathrm{M}_{\mathrm{MRP}}=1,9 \\
-\mathrm{M}_{\mathrm{RRP}}=3,0 \text { procjene financijske situacije obitelji niža } \\
\text { u odnosu na } \mathrm{M}_{\mathrm{MRP}}=3,1\end{array}$ \\
\hline \multirow[t]{2}{*}{$\begin{array}{l}\text { Obrazovno- } \\
\text { kulturno } \\
\text { obiteljsko } \\
\text { okruženje }\end{array}$} & $\begin{array}{l}\text { Obrazovanje } \\
\text { roditelja* } \\
\text { Broj knjiga kod } \\
\text { kuće* }\end{array}$ & $\mathrm{X}^{2}$ & $\begin{array}{l}\text { - veći udio } \mathrm{U}_{\mathrm{RRP}}=26 \text { koji imaju barem jednog roditelja } \\
\mathrm{s} \text { trogodišnjim srednjoškolskim obrazovanjem } \\
\left(\mathrm{U}_{\mathrm{URP}}=11 \%, \mathrm{U}_{\mathrm{MRP}}=8 \%\right) \text {; daleko manji udio } \mathrm{U}_{\mathrm{RRP}}=25 \% \\
\mathrm{koji} \text { imaju barem jednog visokoobrazovanog roditelja } \\
\left(<\mathrm{U}_{\mathrm{URP}}=42 \%, \mathrm{U}_{\mathrm{MRP}}=57 \%\right) \text {. } \\
\text { - kako raste veličina naselja odrastanja tako udjeli } \\
\text { učenika pojedinih rezidencijalnih kategorija s } \\
\text { najmanjim brojem knjiga }(\text { do } 25) \text { padaju ( } \mathrm{U}_{\mathrm{RRP}}=32 \% \text {, } \\
\left.\mathrm{U}_{\mathrm{URP}}=25 \% \text {, } \mathrm{U}_{\mathrm{MRP}}=22 \%\right) \text { dok rastu u kategoriji } \\
\text { posjedovanja više od } 200 \text { knjiga }\left(\mathrm{U}_{\mathrm{RRP}}=17 \% \text {, }\right. \\
\left.\mathrm{U}_{\mathrm{URP}}=24 \%, \mathrm{U}_{\mathrm{MRP}}=28 \%\right)\end{array}$ \\
\hline & $\begin{array}{l}\text { Posjedovanje } \\
\text { kulturnih dobara* } \\
\text { Roditeljske kulturne } \\
\text { prakse* }\end{array}$ & ANOVA & $\begin{array}{l}\text { - } \mathrm{M}_{\mathrm{RR}}=0,7 \text { posjedovanja različitih kulturnih dobara } \\
\text { statistički značajno niži u odnosu na druge grupe } \\
\text { učenika }\left(\mathrm{M}_{\mathrm{URP}} \text { i } \mathrm{M}_{\mathrm{MRP}}=0,8\right) \text {; } \\
\text { - } \mathrm{M}_{\mathrm{RRP}}=1,9 \text { učestalosti roditeljskih kulturnih praksi } \\
\text { statistički je značajno rjeđa od one učenika urbanih } \\
\text { kategorija }\left(\mathrm{M}_{\mathrm{URP}}=2,1 ; \mathrm{M}_{\mathrm{MRP}}=2,3\right)\end{array}$ \\
\hline $\begin{array}{l}\text { Simbolička } \\
\text { vrijednost } \\
\text { obitelji }\end{array}$ & $\begin{array}{l}\text { Utjecaj roditelja } \\
\text { Utjecaj braće/sestara } \\
\text { Roditeljsko } \\
\text { ohrabrenje nastavka } \\
\text { školovanja }\end{array}$ & ANOVA & $\begin{array}{l}\text { - nema statistički značajnih razlika u prosječnim } \\
\text { rezultatima grupa učenika različitog rezidencijalnog } \\
\text { podrijetla prema procjeni utjecaja roditelja } \\
-\mathrm{M}_{\mathrm{MRP}}=2,3 \text { procjene utjecaja braće/sestara statistički } \\
\text { značajno niži u odnosu na druge dvije skupine učenika }\left(\mathrm{M}_{\mathrm{RR}}=2,7, \mathrm{M}_{\mathrm{URP}}=2,6\right) \\
\text { nema statistički značajnih razlika u prosječnim } \\
\text { rezultatima grupa učenika različitog rezidencijalnog } \\
\text { podrijetla prema procjeni roditeljskog ohrabrivanja } \\
\text { studiranja }(\mathrm{M}=3,3)\end{array}$ \\
\hline \multirow{2}{*}{$\begin{array}{l}\text { Simbolička } \\
\text { vrijednost } \\
\text { društvenih } \\
\text { odnosa }\end{array}$} & $\begin{array}{l}\text { Utjecaj } \\
\text { izvaninstitucionalnih } \\
\text { drugih }\end{array}$ & & $\begin{array}{l}\text { - nema statistički značajnih razlika u M procjene } \\
\text { utjecaja izvaninstitucionalnih drugih grupa učenika } \\
\text { različitog rezidencijalnog podrijetla }(\mathrm{M}=2,3)\end{array}$ \\
\hline & $\begin{array}{l}\text { Utjecaj } \\
\text { institucionalnih } \\
\text { drugih* }\end{array}$ & ANOVA & $\begin{array}{l}-\mathrm{M}_{\mathrm{RRP}}=2,1 \text { procjene utjecaja osoba iz institucionalnih } \\
\text { konteksta na njihovu namjeru studiranja statistički } \\
\text { značajno viš je u odnosu na druge dvije rezidencijalne } \\
\text { kategorije učenika }\left(\mathrm{M}_{\mathrm{URP}}=1,9 ; \mathrm{M}_{\mathrm{MRP}}=1,8\right) \text {; dodatno, } \\
\text { statistički značajno razlikuju se i } \mathrm{M}_{\mathrm{URP}} \text { i } \mathrm{M}_{\mathrm{MRP}} \text {; }\end{array}$ \\
\hline $\begin{array}{l}\text { Institucionalne } \\
\text { karakteristike } \\
\text { obrazovanja }\end{array}$ & $\begin{array}{l}\text { Škola visokog } \\
\text { statusa* } \\
\text { Akademski poticajna } \\
\text { škola } \\
\text { Opremljena škola } \\
\text { dobrog programa* }\end{array}$ & ANOVA & $\begin{array}{l}\text { - } \mathrm{M}_{\mathrm{MRP}}=3,2 \text { procjene statusa srednje škole statistički } \\
\text { značajno viši u odnosu na } \mathrm{M}_{\mathrm{URP}}=3,0 \\
\text { - nema statistički značajnih razlika u M procjene } \\
\text { akademske poticajnosti škola }(\mathrm{M}=3,6) \\
-\quad \mathrm{M}_{\mathrm{URP}}=2,7 \text { procjene resursne opremljenosti i } \\
\text { programske ponude statistički značajno niži u odnosu }\end{array}$ \\
\hline
\end{tabular}



odnosu na $\mathrm{M}_{\mathrm{RRP}}$ i $\mathrm{M}_{\mathrm{URP}}=3,6$

Prema nekim individualno razvijenim školskim i kulturnim kapitalima, pokazuje se da među učenicima uglavnom ne postoje razlike među učenicima različitog rezidencijalnog podrijetla koji namjeravaju studirati: statističku značajnost ne pokazuju testovi s obzirom na njihov školski uspjeh, sudjelovanje u kulturnim i čitalačkim praksama. Drugim riječima, bez obzira na rezidencijalno podrijetlo učenika, oni učenici koji namjeravaju studirati pokazuju određene obrazovno-kulturne karakteristike koje ih ,predviđaju“ kao kandidate za studiranje: to su učenici boljeg školskog uspjeha $(\mathrm{M}=4)$ i razvijenijih kulturnih kapitala.

Ipak, ono što učenike razlikuje su njihovi rezultati s obzirom na izvanškolske aktivnosti, koji je manji za učenike odrasle u ruralnom okolišu, te želja za društvenom mobilnošću koja je viša kod ruralnih učenika koji namjeravaju studirati. Dodatno, pokazuje se i da metropolitanske učenike razlikuje od druge dvije rezidencijalne kategorije onih koji namjeravaju studirati niža razina vrednovanja učenja.

Kada su u pitanju obiteljski dostupni resursi učenika koji namjeravaju studirati, učenici ruralnog rezidencijalnog podrijetla i dalje karakterizira nepovoljnija struktura obiteljskog ekonomskog i kulturnog kapitala. Odnosno, njihovi roditelji su u većoj mjeri bez stalnih primanja, nižih su razina obrazovanja, i rjeđeg sudjelovanja u kulturnim aktivnostima te nižih razina posjedovanja kulturnih dobara, općenito, i količine knjiga, specifično. Dodatno, za njih je i vjerojatnija niža procjena općenite ekonomske situacije obitelji. Na većini tih mjera pokazuje se obrazac prema kojem kako raste razina „urbaniteta“ naselja njihova odrastanja, tako raste i količina posjedovanih kulturnih i ekonomskih resursa. Time učenici odrasli u metropoli imaju najpovoljniju strukturu obiteljskih kapitala, odnosno, imaju najmanje udjele roditelja bez stalnih primanja i visoke udjele visokoobrazovanih roditelja te odrastaju u obiteljima koje posjeduju najviše kulturnih i materijalnih dobara. Dodatno, materijalno posjedovanje dodatno razlikuje i dvije urbane kategorije učenika koji namjeravaju studirati, te se pokazuje da na toj mjeri i učenici odrasli u hrvatskim gradovima, izuzev Zagreba, pokazuju statistički značajno niže razine od onih odraslih u glavnom gradu

Utjecaj roditelja za učeničke odluke, kao i ohrabrivanje studiranja, učenici različitog rezidencijalnog podrijetla ne procjenjuju značajno različito prema njihovom mjestu 
odrastanja, ali je obiteljski utjecaj značajan preko braće i sestara čiji utjecaja na svoje odluke, statistički značajno većim procjenjuju učenici koji odrastaju izvan metropole, a namjeravaju studirati. Najznačajnije razlike s obzirom na utjecaj osoba na učeničke odluke vezuje se uz utjecaj osoba iz institucionalnog okruženja. Pri tom, značaj savjetnicima, nastavnicima i stručnim suradnicima najvećim procjenjuju učenici za koje prethodne analize pokazuju niže razine obiteljski dostupnih resursa - one koji odrastaju u ruralnim okolišima i namjeravaju studirati, Najmanji utjecaj osobama $\mathrm{u}$ institucionalnom okruženju na svoju odluku o studiranju procjenjuju učenici odrasli u metropolitanskom okuženju. Pri tom utjecaj savjetnika za profesionalno usmjeravanje dodatno je značajniji i urbanim učenicima u odnosu na one metropolitanskog rezidencijalnog podrijetla, a koji žele studirati.

Urbani učenici koji namjeravaju studirati uglavnom imaju rezultate koji se nalaze između rezultata učenika odraslih na selu, s jedne, i onih odraslih u glavnom gradu, s druge strane, ili se pak približavaju rezultatom metropolitanskim učenicima, a nasuprot onima odraslima u selima. No, kako do sada pokazuju analize razlika s obzirom na rezidencijalno podrijetlo učenika koji namjeravaju studirati, rezultati na određenim mjerama ukazuju i na nepovoljniji položaj učenika urbanog rezidencijalnog podrijetla u odnosu na one odrasle u metropoli. To je vidljivo prema procjeni materijalnog statusa obitelji te prema utjecaju braće/sestara na svoju odluku koji u obiteljskom okruženju predstavljaju značajan poticaj prema studiranju svim učenicima izvan Zagreba. No, najizraženije razlike vezane uz učenike urbanog rezidencijalnog podrijetla koji namjeravaju studirati u odnosu na druge dvije rezidencijalne kategorije učenika vezane su uz procjene karakteristika škola koje pohađaju. Naime, iako svi učenici bez obzira na rezidencijalno podrijetlo, akademsku poticajnost u svojim školama procjenjuju relativno prisutnom, urbani učenici skloniji su svojim školama pripisati niže razine statusa ( $u$ odnosu na one odrasle u glavnom gradu), te niže razine opremljenosti i programske ponude (u odnosu na druge dvije rezidencijalne kategorije učenika).

Ovakvi rezultati vjerojatno se odražavaju i kada je u pitanju procjena ugleda željenog studija i visokoobrazovne institucije na kojoj se izvodi. Pri donošenju svojih visokoobrazovnih odluka, za učenike koji namjeravaju studirati a odrastaju izvan glavnog grada takva je karakteristika značajniji razlog nego onima odraslima u metropoli.

Moguće je iz tog kuta promatrati i neke rezultate kojima se učenici odrasli u metropoli razlikuju od druge dvije grupe učenika. S obzirom na veliku dostupnost obiteljskih kapitala, $\mathrm{S}$ jedne, ali također i obrazovnih institucionalnih resursa, u odnosu na druge dvije rezidencijalne 
kategorije učenika, učenici odrasli u gradu značajno nižu vrijednost pridaju učenju i utjecaju osoba iz institucionalnog konteksta na njihovu namjeru studiranja, a također nižom procjenjuju i važnost ugleda studija i institucije visokog obrazovanja na svoju odluku. Moguće je da navedeno upućuje kako se za učenike koji odrastaju u metropoli dostupnost prestižnih institucija, posebno, i visokog obrazovanja, općenito, samim time ne postavljaju na svjesnoj razini kao element pri donošenju odluka. Općenito, dostupnost različitim vrstama obiteljskih i institucionalnih resursa uokviruje manji značaj nekih drugih izvanobiteljskih i izvanškolskih resursa.

S obzirom na ove rezultate moguće je „urbanost" odrastanja u metropolitanskom okolišu u Hrvatskoj shvatiti kao značajan kapital učenika koji namjeravaju studirati. Ove analize pokazuju da se on višim za te učenike, u odnosu na druge dvije rezidencijalne kategorije učenika, pojavljuje prvenstveno u svom ekonomskom obliku, a dijelom i statusno i obrazovno s obzirom da metropolitanski učenici koji namjeravaju studirati u manjoj mjeri teže društvenoj mobilnosti, u manjoj mjeri vrednuju učenje i u manjoj mjeri im je pri izboru studija i institucije studiranja značajan njihov ugled. U odnosu na ruralne učenike taj urbani kapital, uz sve prethodno navedeno, dodatno se izražava i kulturno. No, za razliku od ostalih urbanih učenika koji odrastaju u ostalim gradovima Hrvatske, urbani kapital učenika odraslih u metropoli posebno je naglašen s obzirom na ugled škola koje pohađaju. 


\subsection{Učinak rezidencijalnog podrijetla učenika, uz kontrolu relevantnih čimbenika obiteljskog i školskog konteksta, na namjeru studiranja i visokoobrazovne odluke}

Osnovne analize prvog dijela rada (Poglavlje 3.1) dale su uvid u strukturu razlika između učenika različitog rezidencijalnog podrijetla na različitim mjerama obrazovnih ishoda $\mathrm{i}$ mjerama kapitala kojima imaju pristup u svojim obiteljima, školama, zajednicama. One usmjeravaju daljnje analize s osnovnim interesom za to koji skup varijabli individualnih karaktersitika, konteksta odrastanja i školovanja pomaže objasniti učeničku namjeru studiranja i visokoobrazovne izbore, te pitanjem: postoji li efekt rezidencijalnog podrijetla učenika na namjeru studiranja i visokoobrazovne izbore uz kontrolu ostalih relevantnih čimbenika obiteljskog i školskog konteksta (H2a)?

Za odgovor na ta pitanja izgrađena su dva logistička regresijska modela u kojima su zavisne varijable bile a. namjera studiranja (1=namjeravam studirati, $0=$ ne namjeravam studirati i ne znam), b. izbor tipa studija ( $1=$ sveučilišni studij, $0=$ stručni studij), te c. izbor mjesta studiranja (1=izbor Zagreba, 0=ostalo). Svi regresijski modeli građeni su s obzirom na polazne pretpostavke $\mathrm{i}$ teorijske postavke rada kao i s obzirom na provjere pojedinih mjera $\mathrm{u}$ preliminarnim analizama i specifičnosti svakog pojedinog izbora. Također, robusnost svakog modela izgrađenog za ukupan uzorak hrvatskih maturanata provjeravana je s obzirom na pojedine potkategorije ispitanika. S obzirom na glavni interes rada, modeli se provjeravaju zasebno za učenike različitog rezidencijalnog podrijetla, s posebnim fokusom na učenike ruralnog rezidencijalnog podrijetla. $U$ drugom dijelu rada, s obzirom na fokusiranje analiza na regionalnu razinu, modeli se testiraju i na poduzorku učenika Slavonije (Poglavlje 4.3).

\subsubsection{Objašnjenje odluke učenika o namjeri studiranja}

Regresijski model izgrađen u svrhu objašnjenja namjere studiranja sadrži 5 koraka, koji tvore 11 odabranih varijabli individualnih, obiteljskih, izvanobiteljskih te sociogeografskih varijabli. Odabrane varijable i objašnjenje njihova izbora sažima Tablica 3.15.

Prvi korak uključuje osnovne individualne varijable od interesa. Pošlo se od toga da obrazovanje predstavlja osnovni mehanizam geografske i društvene mobilnosti što su procesi blisko povezani s obzirom na nužnost preseljenja ruralnih učenika odlaskom na studij te, općenito, nižu razinu dostupnih kulturnih i ekonomskih resursa, odnosno socioekonomsku i sociokulturnu poziciju njihovih obitelji, što su potvrdile preliminarne analize. 
Tabela 3.15 Izbor varijabli za regresijski model objašnjenja namjere studiranja učenika

\begin{tabular}{|c|c|c|c|}
\hline $\begin{array}{c}\text { Korak } \\
\text { reg. } \\
\text { modela }\end{array}$ & $\begin{array}{l}\text { Ekološki } \\
\text { pristup }\end{array}$ & Odabrane mjere - prediktori & Objašnjenje izbora \\
\hline I. & $\begin{array}{l}\text { Individualne } \\
\text { varijable }\end{array}$ & $\begin{array}{l}\text { Vrijednost pripisana učenju } \\
\text { Želja za društvenom mobilnošću }\end{array}$ & $\begin{array}{l}\text { Varijable od interesa koje proizlaze } \\
\text { iz polaznih pretpostavki rada }\end{array}$ \\
\hline II. & $\begin{array}{l}\text { Obiteljske } \\
\text { varijable: } \\
\text { kulturni i } \\
\text { ekonomski } \\
\text { kapital }\end{array}$ & $\begin{array}{l}\text { Obrazovanje roditelja } \\
\text { Radni status roditelja } \\
\text { Obiteljska imovina } \\
\text { Broj knjiga u kućanstvu }\end{array}$ & $\begin{array}{l}\text { Osnovne mjere obiteljskih resursa } \\
\text { koje su pokazale značaj u prijašnjim } \\
\text { istraživanjima kao prediktori } \\
\text { obrazovnih ishoda učenika }\end{array}$ \\
\hline III. & $\begin{array}{l}\text { Izvanobiteljske } \\
\text { varijable }\end{array}$ & $\begin{array}{ll}\text { 1. } & \text { Škola visokog statusa } \\
2 . & \text { Akademska poticajnost srednje } \\
\text { Škole } & \\
\text { 3. } & \text { Utjecaj osoba izvanobiteljskog } \\
\text { konteksta }\end{array}$ & $\begin{array}{l}\text { Osnovne mjere izvanobiteljskog } \\
\text { konteksta koje pokazuju značaj za } \\
\text { predikciju obrazovnih ishoda } \\
\text { učenika }\end{array}$ \\
\hline IV. & $\begin{array}{l}\text { Sociogeografska } \\
\text { varijabla }\end{array}$ & $\begin{array}{l}\text { Lokacija škole - prema centralitetu grada } \\
\text { u kojem učenici pohađaju škole }\end{array}$ & Osnovna kontrola \\
\hline V. & $\begin{array}{l}\text { Sociogeografska } \\
\text { varijabla od } \\
\text { interesa }\end{array}$ & Rezidencijalno podrijetlo & $\begin{array}{l}\text { Varijabla od osnovnog interesa } \\
\text { postavljena hipotezom }\end{array}$ \\
\hline
\end{tabular}

Te aspekte zahvatilo se dimenzijama vrijednosti koju učenici pripisuju učenju te želje za društvenom mobilnošću, koje možemo promatrati kao motivacijski mehanizam učenika, a u drugom koraku uvedene su osnovne varijable obiteljskog konteksta koje zahvaćaju kulturne (obrazovanje roditelja i broj knjiga u kućanstvu) i ekonomske resurse (radni status roditelja i obiteljska imovina) dostupne učenicima u obiteljima, a za koje su i druga istraživanja pokazala značajnost kada je u pitanju predikcija učeničkih obrazovnih ishoda. Treći korak uvodi varijable koje zahvaćaju elemente izvanobiteljskog konteksta: institucionalne karakteristike škole koju pohađaju (procjena statusa škola i akademski poticajne klime) te utjecaje osoba iz širih učeničkih rodbinskih, prijateljskih i poznaničkih mreža (utjecaj inzvaninstitucionalnih drugih na odluku učenika o (ne)studiranju). Posljednja dva koraka uvode u analizu dvije sociogeografske varijable kojima se ispituje značaj lokacije škole koje učenici pohađaju (prema centralitetu grada u kojima su škole smještene) te mjesta njihova odrastanja, kako bi se odgovorilo na pitanje o jedinstvenom doprinosu rezidencijalnog podrijetla objašnjenju učeničkih namjera studiranja ${ }^{70}$.

\footnotetext{
${ }^{70} \mathrm{U}$ model, pak, nisu uvedene individualne varijable vezane uz obrazovne karakteristike (ocjene i tip škole) i osobni kulturni kapital učenika. Osnovni razlog izostavljanja tih varijabli je stavljanje naglaska na kontekst u kojima učenici odrastaju i školuju se. Dodatno, velik broj varijabli kulturnog kapitala (učeničkog i obiteljskog) otežava model interkorelacijama. Stoga u model nisu uvršene niti varijable posjedovanja kulturnih dobara u kućanstvu te kulturnih praksi roditelja. Tip škole varijabla je koja objašnjava velik dio varijance mjerenog ishoda, no, u skladu s istraživačkim pitanjem, interes analiza je usmjeren na pojedine karakteristike srednjih škola što model čini informativnijim. Zbog visokih korelacija s ostale dvije mjere školskog konteksta, u model nije stavljena varijabla procjene resursa i izvannastavnog programa škole, a za koju se pokazalo da ima slabu prediktivnu vrijednost. Slični razlozi utjecali su na odluku da se izostavi varijabla koja mjeri utjecaj institucionalnih značajnih drugih na odluku učenika o tome hoće li ili ne nastaviti školovanje. Činilo se da u tom
} 
Osnovni rezultati regresijske analize tako izgrađenog modela za objašnjenje namjere studiranja učenika (nacionalni uzorak) prikazani su u Tabeli 3.16. dok Tabela 3.17 prikazuje usporedne podatke testiranja robusnosti modela na poduzorcima učenika različitog, ruralnog, urbanog i metropolitanskog rezidencijalnog podrijetla, pod pretpostavkom da će različiti skup prediktora pokazati svoju značajnost za objašnjenje namjere studiranja učenika različitog rezidencijalnog podrijetla.

Tabela 3.16 Opći model objašnjenja namjere studiranja hrvatskih maturanata

\begin{tabular}{|c|c|c|c|c|c|c|}
\hline Varijable u modelu & B & S.E. & Wald & df & Sig. & $\operatorname{Exp}(B)$ \\
\hline Vrijednost pripisana učenju & 0,73 & 0,09 & 70,08 & 1 & 0,00 & 2,07 \\
\hline Želja za društvenom mobilnošću & 0,52 & 0,09 & 37,94 & 1 & 0,00 & 1,69 \\
\hline Obrazovanje roditelja & 0,72 & 0,09 & 59,75 & 1 & 0,00 & 2,06 \\
\hline Radni status roditelja & 0,25 & 0,08 & 10,05 & 1 & 0,00 & 0,78 \\
\hline Broj knjiga kod kuće & 0,51 & 0,10 & 24,73 & 1 & 0,00 & 1,67 \\
\hline Obiteljska imovina & 0,38 & 0,11 & 10,79 & 1 & 0,00 & 1,46 \\
\hline Škola visokog statusa & 0,49 & 0,07 & 44,63 & 1 & 0,00 & 1,63 \\
\hline Akademski poticajna škola & $-0,02$ & 0,07 & 0,05 & 1 & 0,82 & 0,98 \\
\hline Utjecaj izvaninstitucionalnih drugih & $-0,03$ & 0,07 & 0,17 & 1 & 0,69 & 0,97 \\
\hline LOKACIJA ŠKOLE (centralitet grada): $r e f=g i$. grad & & & 2,31 & 2 & 0,31 & \\
\hline $1=L o k a c i j a$ škole_veliki grad & $-0,29$ & 0,35 & 0,67 & 1 & 0,41 & 0,75 \\
\hline $2=$ Lokacija škole_mali grad & $-0,43$ & 0,34 & 1,63 & 1 & 0,20 & 0,65 \\
\hline \multirow{3}{*}{$\begin{array}{r}\text { REZIDENCIJALNO PODRIJETLO: } r e f=\text { ruralno } \\
\qquad \begin{array}{r}1=\text { Rezidencijalno podrijetlo_urbano } \\
2=\text { Rezidencijalno podrijetlo_metropola }\end{array}\end{array}$} & & & 14,03 & 2 & 0,00 & \\
\hline & 0,53 & 0,14 & 13,74 & 1 & 0,00 & 1,71 \\
\hline & 0,37 & 0,36 & 1,01 & 1 & 0,32 & 1,44 \\
\hline Constant & $-9,15$ & 0,68 & 180,22 & 1 & 0,00 & 0 \\
\hline Cox \& Snell $\mathbf{R}^{2}=0,11 ;$ Nagelkerke $\mathbf{R}^{2}=\mathbf{0 , 1 5}$ & & & & & & \\
\hline Cox \& Snell $\mathbf{R}^{2}=0,27 ;$ Nagelkerke $\mathbf{R}^{2}=\mathbf{0 , 3 8}$ & & & & & & \\
\hline Cox \& Snell $\mathbf{R}^{2}=0,29 ;$ Nagelkerke $\mathbf{R}^{2}=\mathbf{0 , 4 0 9}$ & & & & & & \\
\hline Cox \& Snell $R^{2}=0,29$; Nagelkerke $\mathbf{R}^{2}=\mathbf{0 , 4 1 3}$ & & & & & & \\
\hline $\begin{array}{l}\text { V. Omnibus test: }(13)=594,76 ; p=0,00 ; \text { Hosmer a } \\
\text { Postotak točnih predviđanja: } 80 \% ; \text { Cox \& Snell } R^{2}=0 \text {, }\end{array}$ & $\begin{array}{l}\text { d Leme } \\
0 ; \quad \text { Na }\end{array}$ & $\begin{array}{l}\text { low Tes } \\
\text { lkerke }\end{array}$ & $\begin{array}{l}(8)=2,71 \\
=\mathbf{0 , 4 2 1}\end{array}$ & & & \\
\hline
\end{tabular}

Sažeto, opći model ukazuje da su sve individualne te obiteljske varijable statistički značajne i doprinose značajno objašnjenju odluke o studiranju, a dodatno doprinos daje i varijabla statusa škole. Osnovno za odgovaranje na postavljeno istraživačko pitanje je podatak da rezidencijalno podrijetlo, kada se kontroliraju ostale navedene dimenzije, iako malo, statistički značajno doprinosi objašnjenju namjere studiranja (V. korak (Nagelkerke $\left.\mathrm{R}^{2}=0,421\right)$ - IV. korak (Nagelkerke $\left.\left.\mathrm{R}^{2}=0,413\right)=0,08 \%\right)$. 
Vrijednost koju učenici pripisuju učenju te njihova želja za društvenom mobilnošću kao prediktori prvog koraka objašnjavaju 15\% varijance, dok objašnjenju namjere studiranja u najvećoj mjeri doprinose obiteljske varijable (2. korak) od kojih sve imaju statistički značajne B koeficijente. Obrazovanje roditelja i njihov radni status, te obiteljska imovina i broj knjiga dodaju $23 \%$ objašnjenja varijance kriterija, te je ukupna objašnjenost modelom nakon drugog koraka 38\%. U trećem koraku u model su dodane tri varijable izvanobiteljskog konteksta, od kojih dvije zahvaćaju neke institucionalne karakteristike srednjoškolskog obrazovanja, a posljednja širi kontekst učeničkih odnosa. Od navedenih varijabli samo procijenjeni status škole ima statistički značajan B koeficijent, a opisani korak analize doprinosi dodatnih 3\% objašnjenju varijance kriterija. U posljednja dva koraka analize model nadograđuju dvije sociogeografske varijable od kojih lokacija škole ne doprinosi značajno objašnjenju, i nije statistički značajan prediktor. Nakon zadnjeg koraka, u kojem objašnjenju kriterija rezidencijalno podrijetlo učenika doprinosi dodatnih 1\%, ukupna objašnjenost modela iznosi $42 \%$ (Nagelkerkeov $\mathrm{R}^{2}=0,421$ ).

Model je grafički prikazan na Slici $3.9^{71}$ koja opisuje izglednost učeničke namjere studiranja. Izglednije da će se u kategoriji onih koji namjeravaju studirati naći oni učenici koji učenju pripisuju veću vrijednost $(B=0,73)$, te iskazuju veći stupanj želje za društvenom mobilnošću $(B=0,52)$. Također, za njih je vjerojatnije da dolaze iz obitelji roditelja višeg obrazovnog statusa $(B=0,72)$, veće stalnosti primanja $(B=0,25)$ te većeg stupnja materijalnog $(B=0,38) i$ kulturnog posjedovanja (knjige) $(B=0,51)$. Dodatno, vjerojatnije je da će učenici koji pohađaju škole kojima procjenjuju viši status iskazivati u većem stupnju namjeru studiranja $(B=0,48)$, bez obzira je li škola smještena u velikom ili malom gradu. U konačnici, rezidencijalno podrijetlo se pokazalo značajno u odluci o studiranju barem kada su u pitanju učenici široke kategorije onih koji su odrasli u urbanim sredinama $(B=0,53)$ : za njih je izglednija odluka o nastavku školovanja u odnosu na učenike odrasle u ruralnim okolišima.

\footnotetext{
${ }^{71}$ Osnovne elemente slike čine kriterij, prikazan u četvrtastom obliku na desnoj strani slike, te prediktori prikazani na dva načina: oni uvedeni u model kao kontinuirane varijable prikazani su kružićima, dok kategorijalne varijable imaju oblik kvadrata. Prediktori su poslagani polukružno oko kriterija redoslijedom uvođenja u analizu počevši od gornjeg desnog kuta, a svaki skup varijabli označen je drugom bojom: individualne varijable 1. koraka plavom, obiteljske varijable 2. koraka crvenom, izvanobiteljske varijable 3. koraka narančastom, te sociogeografske varijable 4. i 5. koraka zelenom. Na strelicama koje povezuju prediktore s kriterijem nalaze se podaci o njihovim direktnim korelacijama s kriterijem te iznosima B koeficijenata regresijske analize pri čemu su statistički značajni koeficijenti označeni zvjezdicama $(* p<0.05$, $* * p<0,01$ ). Dodatno, statistički značajni prediktori naznačeni su ispunjenim (obojanim) oblicima Opisana značenja pojedinih grafičkih rješenja prikaza regresijskih modela vrijede za sve naredne grafičke prikaze.
} 


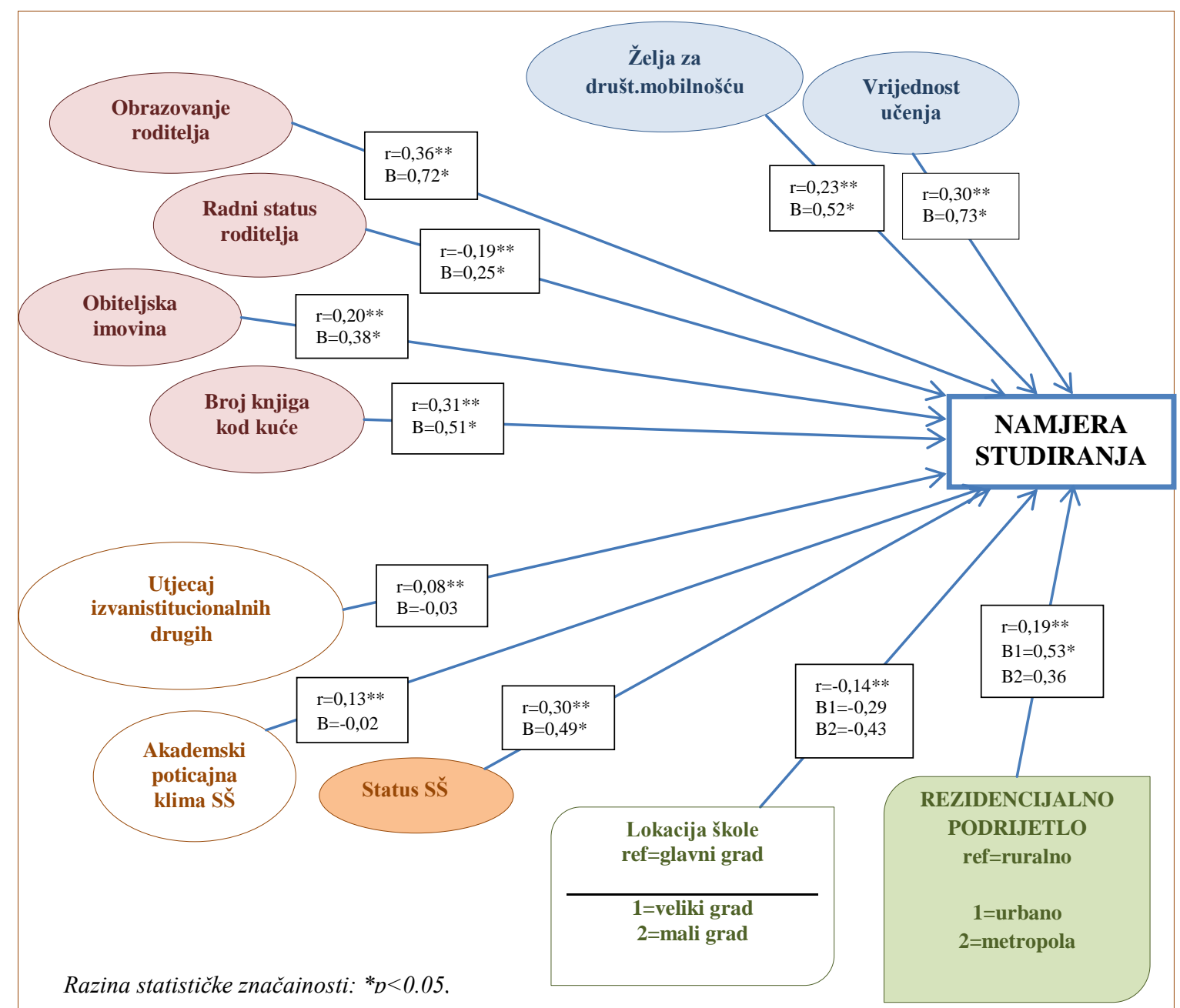

Slika 3.9 Opći regresijski model (5 koraka) za objašnjenje namjere studiranja maturanata (nacionalni uzorak)

Spomenimo i da se za predviđanje učeničke namjere studiranja nije značajnim pokazao utjecaj izvaninstitucionalnih značajnih drugih osoba koji su dio učeničkih rodbinskih, prijateljskih i poznaničkih mreža $(B=-0,03)$, kao niti akademski poticajna školska klima $(B=-$ 0,02). Sve navedeno upućuje da obiteljski kontekst, i u smislu pružanja resursa i visokoobrazovno orijentiranog okruženja, ima osnovni značaj za usmjeravanje prema visokom obrazovanju učenicima koji vrednuju obrazovanje i teže unapređenju društvene pozicije. Dodatni element u tome čini status škole za koji neke druge analize ukazuju da se vezuje uz gimnazije (Košutić, Puzić, 2015) te je s te strane sastavni dio usmjeravanja prema visokom obrazovanju. Dodatno, rezidencijalno podrijetlo u tom spletu odrednica učeničkih namjera studiranja pokazuje jedinstveni doprinos, koji je, iako mali, statistički značajan, i koji ukazuje da su učenici ruralnog rezidencijalnog podrijetla, barem u odnosu na one odrasle u gradovima, u nepovoljnijoj poziciji kada su u pitanju njihovi resursi za nastavak školovanja. 


\subsubsection{Objašnjenje namjere studiranja učenika različitog rezidencijalnog podrijetla}

Naredne analize obuhvaćaju testiranje opisanog općeg modela na poduzorcima učenika različitog rezidencijalnog podrijetla koji bi trebali ukazati koliko je model robusan, odnosno koliko navedeni prediktori dobro predviđaju namjeru studiranja učenika koji su odrasli u sredinama različitog stupnja ruraliteta/urbaniteta. U odnosu na glavni model, i s obzirom na kriterij stvaranja poduzoraka, model ne sadrži zadnji korak analize, a za učenike metropole niti predzadnji korak u kojem se uvodi lokacija škole ${ }^{72}$. Rezultati su usporedno prikazani u Tablici 3.17. pri čemu sive ćelije označavaju razlike između modela (izostavljene prediktore). Također, tablica sadrži i osnovne podatke o objašnjenosti koju modelu daju skupovi prediktora pojedinih koraka, kao i ukupna objašnjenost kriterija cjelokupnim modelom.

Obratimo li prvo pozornost na ukupnu objašnjenost, kreirani model najbolje objašnjava namjeru studiranja učenika odraslih u metropoli - Nagelkerke $\mathrm{R}^{2}=0,51$, a koji ima i najmanje koraka analiza te time i najmanji broj prediktora u modelu. Vidljivo iz sažetih opisa doprinosa pojedinih koraka u dnu tablice je da, usporedno s doprinosima pojedinih skupova varijabli $\mathrm{u}$ analizama na različitim poduzorcima učenika, u regresijskoj analizi namjera studiranja učenika metropolitanskog podrijetla najmanji dio varijance objašnjavaju individualne - 9\%, dok daleko najveći dio - 34\% doprinosa - objašnjavaju varijable obiteljskog konteksta. Dodatno, i varijable izvanobiteljskog konteksta, prvenstveno status škole, daju $8 \%$ objašnjenja varijance.

Nasuprot tome, izgrađeni model u najmanjoj mjeri objašnjava namjeru studiranja učenika urbanog rezidencijalnog podrijetla - Nagelkerke $R^{2}=0,36$ - što je vjerojatno posljedica činjenice da se radi o širokoj kategoriji učenika odraslih u različitim tipovima urbanih naselja (regionalno, veličinom). Objašnjenju namjere studiranja učenika odraslih u urbanim sredinama podjednako doprinose (od 17\%) prva dva koraka, odnosno individualne i obiteljske varijable, dok izvanobiteljske varijable dodatno doprinose s tek $2 \%$, a zanemariv je doprinos posljednjeg koraka, u kojem se u analizu uvodi lokacija škole.

\footnotetext{
${ }^{72}$ Razlog tome je izuzetno mali broj učenika koji su odrasli u glavnom gradu, a škole pohađaju u mjestima koja nisu glavni grad.
} 
Tabela 3.17 Rezultati testiranja robusnosti modela objašnjenja namjere studeiranja na poduzorcima učenika različitog rezidencijalnog podrijetla

\begin{tabular}{|c|c|c|c|c|c|c|c|c|c|c|c|c|c|c|c|c|c|c|}
\hline \multirow{2}{*}{ Varijable u modelu } & \multicolumn{6}{|c|}{ Metropolitansko rezidencijalno podrijetlo } & \multicolumn{6}{|c|}{ Urbano rezidencijalno podrijetlo } & \multicolumn{6}{|c|}{ Ruralno rezidencijalno podrijetlo } \\
\hline & B & S.E. & Wald & df & Sig. & $\operatorname{Exp}(B)$ & B & S.E. & Wald & df & Sig. & $\operatorname{Exp}(B)$ & B & S.E. & Wald & df & Sig. & $\operatorname{Exp}(\mathbf{B})$ \\
\hline $\begin{array}{l}\text { Vrijednost pripisana } \\
\text { učenju }\end{array}$ & 0,68 & 0,26 & 6,83 & 1 & 0,01 & 1,96 & 0,78 & 0,13 & 35,20 & 1 & 0,00 & 2,19 & 0,72 & 0,14 & 28,43 & 1 & 0,00 & 2,05 \\
\hline $\begin{array}{l}\text { Želja za društ. } \\
\text { mobilnošću }\end{array}$ & 0,42 & 0,24 & 3,00 & 1 & 0,08 & 1,52 & 0,57 & 0,13 & 20,18 & 1 & 0,00 & 1,77 & 0,55 & 0,14 & 16,38 & 1 & 0,00 & 1,73 \\
\hline Obrazovanje roditelja & 0,99 & 0,30 & 11,05 & 1 & 0,00 & 2,7 & 0,84 & 0,15 & 33,40 & 1 & 0,00 & 2,31 & 0,55 & 0,14 & 15,87 & 1 & 0,00 & 1,74 \\
\hline Radni status roditelja & 0,27 & 0,25 & 1,23 & 1 & 0,27 & 0,76 & 0,28 & 0,12 & 5,04 & 1 & 0,03 & 0,76 & 0,20 & 0,12 & 2,77 & 1 & 0,10 & 0,82 \\
\hline Broj knjiga kod kuće & 0,37 & 0,30 & 1,50 & 1 & 0,22 & 1,44 & 0,36 & 0,16 & 5,13 & 1 & 0,02 & 1,43 & 0,79 & 0,16 & 23,41 & 1 & 0,00 & 2,19 \\
\hline Obiteljska imovina & 1,56 & 0,40 & 15,59 & 1 & 0,00 & 4,78 & 0,24 & 0,18 & 1,82 & 1 & 0,18 & 1,27 & 0,27 & 0,17 & 2,48 & 1 & 0,12 & 1,31 \\
\hline Škola visokog statusa & 0,94 & 0,24 & 15,45 & 1 & 0,00 & 2,55 & 0,36 & 0,11 & 10,40 & 1 & 0,00 & 1,43 & 0,53 & 0,11 & 21,89 & 1 & 0,00 & 1,70 \\
\hline $\begin{array}{l}\text { Akademski poticajna } \\
\text { škola }\end{array}$ & $-0,21$ & 0,28 & 0,54 & 1 & 0,46 & 0,82 & 0,04 & 0,11 & 0,14 & 1 & 0,71 & 1,04 & 0,02 & 0,11 & 0,03 & 1 & 0,86 & 0,98 \\
\hline $\begin{array}{l}\text { Utjecaj } \\
\text { izvaninstitucionalnih } \\
\text { drugih }\end{array}$ & 0,02 & 0,23 & 0,01 & 1 & 0,94 & 1,02 & $-0,03$ & 0,11 & 0,06 & 1 & 0,81 & 0,98 & $0, \overline{0}$ & 0,10 & 0,13 & 1 & 0,72 & 0,96 \\
\hline $\begin{array}{l}\text { LOKACIJA ŠKOLE: } \\
\text { ref=glavni grad }\end{array}$ & & & & & & & & & 2,80 & 2 & 0,25 & & & & 3,97 & 2 & 0,14 & \\
\hline $1=$ veliki grad & & & & & & & 0,91 & 0,58 & 2,46 & 1 & 0,12 & 2,48 & 0,84 & 0,49 & 2,96 & 1 & 0,09 & 0,43 \\
\hline $2=$ mali $\mathrm{grad}$ & & & & & & & 0,74 & 0,58 & 1,61 & 1 & 0,20 & 2,09 & $\overline{-}, 95$ & 0,48 & 3,94 & 1 & 0,05 & 0,39 \\
\hline Constant & $-11,45$ & 2,10 & 29,77 & 1 & 0,00 & 0 & $-9,92$ & 1,09 & 82,64 & 1 & 0,00 & 0,00 & 8,43 & 1,00 & 70,64 & 1 & 0,00 & 0,00 \\
\hline Korak & \multicolumn{6}{|c|}{ Cox \& Snell $\mathbf{R}^{2}=0,06 ;$ Nagelkerke $\mathbf{R}^{2}=\mathbf{0 , 0 9}$} & \multicolumn{6}{|c|}{ Cox \& Snell $\mathbf{R}^{2}=0,11 ;$ Nagelkerke $\mathbf{R}^{2}=\mathbf{0 , 1 7}$} & \multicolumn{6}{|c|}{$\begin{array}{lr}\text { Cox \& } & \text { Snell } \quad R^{2}=0,14 ; \quad \text { Nagelkerke } \\
\mathbf{R}^{2}=\mathbf{0 , 1 8} ; & \end{array}$} \\
\hline Korak & \multicolumn{6}{|c|}{ Cox \& Snell $\mathbf{R}^{2}=0,26$; Nagelkerke $\mathbf{R}^{2}=\mathbf{0 , 4 3}$} & \multicolumn{6}{|c|}{ Cox \& Snell $\mathbf{R}^{2}=0,23 ;$ Nagelkerke $\mathbf{R}^{2}=\mathbf{0 , 3 4}$} & \multicolumn{6}{|c|}{$\begin{array}{l}\text { Cox \& } \\
\mathbf{R}^{2}=\mathbf{0 , 3 7}\end{array}$} \\
\hline Korak & \multicolumn{6}{|c|}{$\begin{array}{l}\text { Omnibus test: }(9)=101,88 ; p=0,00 ; \\
\text { Hosmer i Lemeshow test: }(8)=8,76 ; p=0,36 ; \text { Postotak } \\
\text { točnih predviđanja: } 86 \% \\
\text { Cox \& Snell } \mathbf{R}^{2}=0,32 ; \text { Nagelkerke } \mathbf{R}^{2}=\mathbf{0 , 5 1}\end{array}$} & \multicolumn{6}{|c|}{ Cox \& Snell $R^{2}=0,24 ;$ Nagelkerke $\mathbf{R}^{2}=\mathbf{0 , 3 5 8}$} & \multicolumn{6}{|c|}{$\begin{array}{l}\text { Cox \& Snell } \quad R^{2}=0,30 ; \quad \text { Nagelkerke } \\
\mathbf{R}^{2}=\mathbf{0 , 4 0 5}\end{array}$} \\
\hline Korak & & & & & & & \multicolumn{6}{|c|}{$\begin{array}{l}\text { Omnibus test: }(11)=216,50 ; p=0,00 ; \\
\text { Hosmer i Lemeshow test: } \quad(8)=1,80 ; \quad p=0,99 ; \\
\text { Postotak točnih predviđanja: } 80 \% \\
\text { Cox \& Snell } \mathrm{R}^{2}=0,24 \text {; Nagelkerke } \mathbf{R}^{\mathbf{2}}=\mathbf{0 , 3 6 2} \text {; }\end{array}$} & \multicolumn{6}{|c|}{$\begin{array}{l}\text { Omnibus test: }(11)=232,06 ; p=0,00 ; \\
\text { Hosmer i Lemeshow test: } \quad(8)=7,19 ; \\
\text { p=0,52; } \\
\text { Postotak točnih predviđanja: } 77 \% \\
\begin{array}{l}\text { Cox \& Snell } R^{2}=0,31 ; \quad \text { Nagelkerke } \\
\mathbf{R}^{2}=\mathbf{0 , 4 1 1} ;\end{array}\end{array}$} \\
\hline
\end{tabular}


Usporedno, prema doprinosu pojedinih koraka regresijskog modela, i prema ukupnom objašnjenju varijance kriterija, između dva opisana testa nalazi se onaj na uzorku učenika ruralnog rezidencijalnog podrijetla. Taj test općeg modela pokazuje najmanje razlike od općeg nacionalnog modela. Najuočljiva razlika odnosi se na doprinos prvog koraka u kojem vrijednost koju učenici pripisuju učenju te njihova želja za društvenom mobilnošću u većoj mjeri pridonose objašnjenju (18\%) namjere studiranja ruralnih učenika.

S obzirom na utvrđene razlike u objašnjenju ukupne varijance namjere studiranja učenika različitog rezidencijalnog podrijetla modelom, očekivano su se pokazale i razlike u prediktorskom skupu u svakoj pojedinačnoj analizi. Kod učenika odraslih u metropoli taj skup čine vrijednost pripisana učenju, obrazovanje roditelja i obiteljska imovina te visokog statusa škola. Rečeno drugačije, namjera studiranja učenika odraslih u glavnom gradu izglednija je za one koji učenju pripisuju veću vrijednost $(B=0,68)$, koji dolaze iz obitelji obrazovanijih roditelja $(B=0,99)$ i boljeg imovinskog stanja $(B=1,56)$ te koji svoje škole smatraju školama višeg statusa $(B=0,94)$. Ovi podaci upućuju da se radi o učenicima s visokom razinom obrazovnog osobnog kao i obiteljskog kapitala, a koji dodatno podržava i srednjoškolski (vjerojatnije gimnazijski) kontekst.

Za učenike urbanog rezidencijalnog podrijetla kao značajni prediktorski skup njihovih namjera studiranja čine varijable: vrijednost pripisana učenju, želja za društvenom mobilnošću, obrazovanje roditelja te njihov radni status kao i broj posjedovanih knjiga, te pohađanje škola koje smatraju školama visokog statusa. Odluka o nastavku školovanja izglednija je za učenike urbanog rezidencijalnog podrijetla koji žele imati veći društveni status u odnosu na svoje roditelje $(B=0,57)$ i koji učenju pripisuju veću vrijednost $(B=0,78)$, koji dolaze iz obitelji koje posjeduju veće razine kulturnog kapitala, odnosno veći broj knjiga $(\mathrm{B}=0,36)$ i obrazovanije roditelje $(\mathrm{B}=0,84)$, i ekonomskog kapitala izraženog kao stalniji prihodi od zaposlenja $(B=0,28)$. Konačno, i kod ovih učenika se bitnim pokazuje procjena svojih škola statusnima $(B=0,36)$ koji je vjerojatno put koji povezuje težnje ovih učenika za budućnost s dostupnim resursima u obiteljima. 


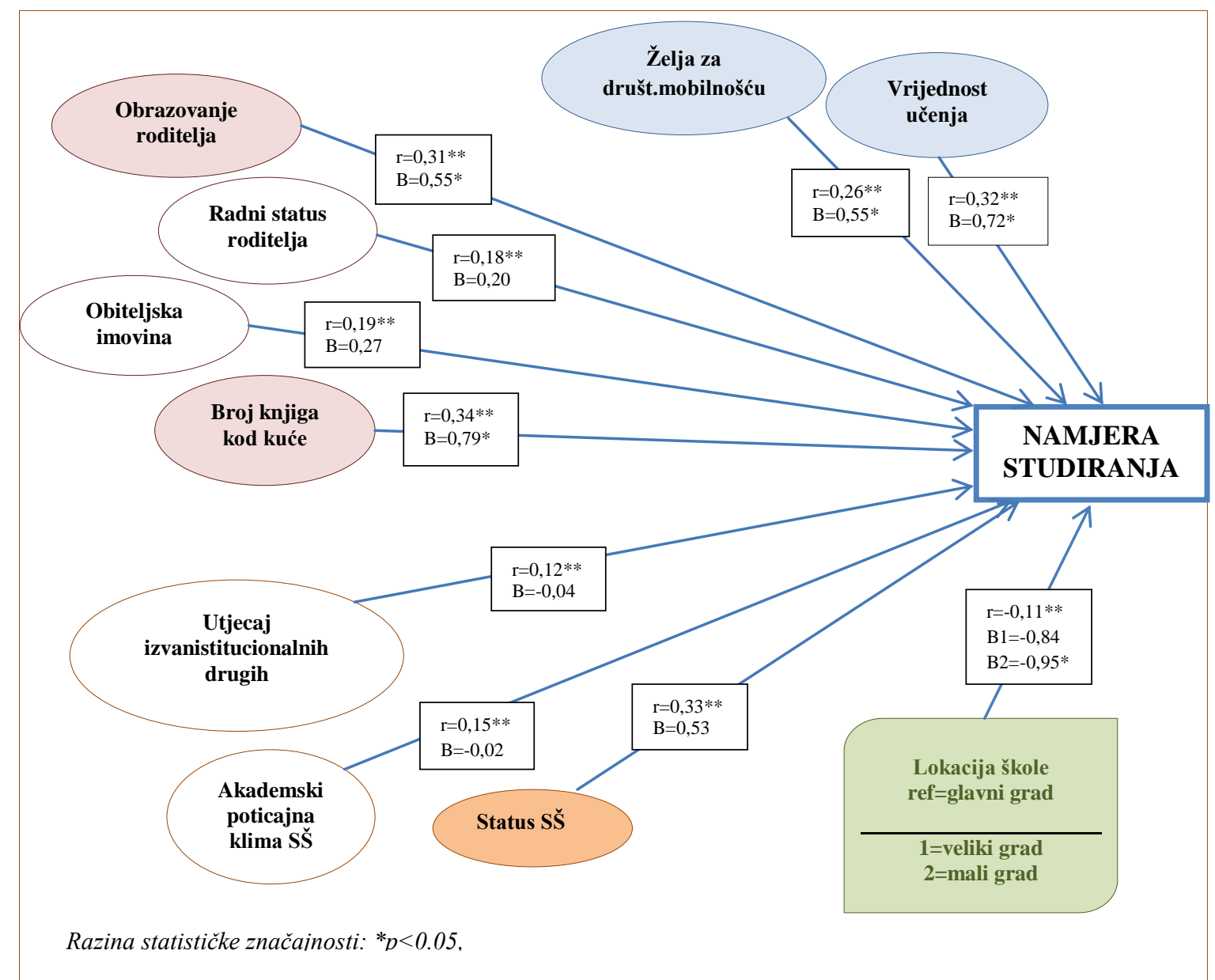

3.10 Regresijski model za objašnjenje namjere studiranja maturanata odraslih na selu

Konačno, i od najvećeg interesa, očekivano se pokazuje da je namjera studiranja ruralnih učenika izglednija za one koji imaju izraženiji stupanj želje za društvenom mobilnošću $(B=0,55)$ te vrijednosti pripisane učenju $(B=0,72)$. No, neočekivano se pokazalo da ekonomski kapital obitelji nema značajnu prediktorsku ulogu kada je u pitanju objašnjenje odluke o studiranju za učenike odrasle na selu: B koeficijenti varijabli radnog statusa roditelja $(B=0,20)$ i obiteljske imovine $(B=0,27)$ nisu statistički značajni. Osnovno objašnjenje nalazi se u prethodnim deskriptivnim analizama koje su „oslikale“ niže razine ekonomskog kapitala u ruralnom prostoru Hrvatske općenito, te time smanjenu mogućnost oslanjanja na tu vrstu resursa. Od obiteljskih varijabli to su mjere kulturnog kapitala: obrazovanja roditelja $(B=0,55)$ te količina obiteljski posjedovanih knjiga $(B=0,79)$. Dodatno, izuzev obrasca koji se ponavlja u svim testovima modela - statistička značajnost procijenjenog statusa škole $(B=0,53)$ kao prediktora namjere studiranja, još jedna varijabla vezana uz mjesto pohađanja škole pokazala je svoju značajnost. Kako je vidljivo iz prikaza na Slici 3.10, u odnosu na učenike koji škole završavaju u glavnom gradu, statistički je manje vjerojatno da će učenici koji škole pohađaju u malim gradovima (ispod razine jačeg regionalnog centra) donijeti odluku o nastavku 
školovanju. Doprinos tog nalaza objašnjenju cijelog modela je mali (IV. korak (Nagelkerke $\mathrm{R}^{2}=0,411$ ) - III. korak (Nagelkerke $\left.\mathrm{R}^{2}=0,405\right)=0,6 \%$ ), ali je značajan. Svakako ukazuje kako su određene sociogeografske varijable povezane s namjerom studiranja, prvenstveno povezujući ostale sociokulturne elemente življenja u i/ili pohađanja škole u određenom prostoru, no i na postojanje jedinstvenog efekta tih varijabli kada se kontroliraju značajnije odrednice obiteljskog i školskog konteksta.

Navedeni nalazi potakli su istraživački interes prema dodatnom ispitivanju postojanja razlika među učenicima koji odrastaju u različitim okolišima što je omogućio način na koji je kreirana varijabla Rezidencijalno podrijetlo učenika. Podsjećamo, učenici su u odgovoru na pitanje „Gdje si proveo najveći dio života prije upisa srednje škole?“ upisivali naziv mjesta koji su naknadno kodirani prema klasifikaciji naselja u realnom sociogeografskom prostoru Hrvatske (Lukić, 2011), nastaloj na bazi širokog seta statističkih pokazatelja. Prema toj analizi, hrvatski prostor karakterizira pluralnost ruralnosti sa 7 tipova ruralnih naselja.

U uzorku anketiranih učenika zastupljeni su učenici 5 tipova ruralnih naselja koja su i regionalno specifična, a njihove udjele prikazuje Tabela 3.18. Od ukupno 674 učenika ruralnog rezidencijalnog podrijetla s valjanim podacima o mjestu odrastanja, $44 \%$ je odraslo u dinamično, strukturno jačim, a $24 \%$ u tržišno orijentiranim poljoprivrednim naseljima. Dodatnih 14\% učenika odraslo je u naseljima ekonomske diverzifikacije, a oko $10 \%$ ih je odraslo u naseljima poljoprivredne ekstenzifikacije $i$ slabe demografske dinamike, te dostupnijima, o cirkulaciji ovisnim naseljim.

Tabela 3.18 Udjeli anketiranih učenika koji su odrasli u pojedinim tipovima ruralnih naselja hrvatskog sociogeografskog prostora prema Lukićevoj analizi (2011)

\begin{tabular}{|c|c|c|}
\hline Klasteri ruralnih naselja u hrvatskom sociogeografskom prostoru & FQ & $\%$ \\
\hline Ekonomski diverzificirana, pretežito turistička naselja (RRP_EDPT) & 91 & 13,5 \\
\hline Dinamična, strukturno jača naselja (RRP_DSJ) & 297 & 44,1 \\
\hline Naselja poljoprivredne ekstenzifikacije i slabe demografske dinamike (RRP_PESDD) & 65 & 9,6 \\
\hline Dostupnija, o cirkulaciji ovisna naselja (RRP_DCO) & 62 & 9,2 \\
\hline Tržišno orijentirana poljoprivredna naselja (RRP_TP) & 159 & 23,6 \\
\hline UKUPNO & 674 & 100 \\
\hline
\end{tabular}

Izvor: prema Lukić, 2011.

Budući su postojali dostupni podaci i klasifikacija, u regresijski model koji pokušava objasniti namjeru studiranja učenika ruralnog rezidencijalnog podrijetla, u zadnjem koraku, uvedena je 
varijabla s kategorijama tipa naselja njihova odrastanja. Pri tom je referentnu kategoriju tvorio tip tržišno orijentirana poljoprivredna naselja (=ref). Pitalo se postoji li efekt odrastanja učenika u određenom tipu ruralnih naselja na njihovu odluku o studiranju. Rezultati su prikazani u Tabeli 3.19 te na Slici 3.11.

Kako je vidljivo, prediktorska značajnost prethodnih koraka analize ostala je neizmijenjena, a posljednji korak u kojem je uvedena varijabla prema tipu naselja u kojima su učenici odrasli doprinijela je objašnjenju ukupnog modela s dodatnih $1 \% \mathrm{u}$ odnosu na prethodni korak. Ovako izgrađen model ukupno je objasnio $44 \%$ varijance namjere studiranja učenika koji odrastaju u ruralnom okolišu (Nagelkerke $\mathrm{R}^{2}$ ). No, što nam govore rezultati analize?

Tabela 3.19 Regresijski model objašnjenja namjere studiranja za učenike ruralnog rezidencijalnog podrijetla (II) - prema naselju odrastanja

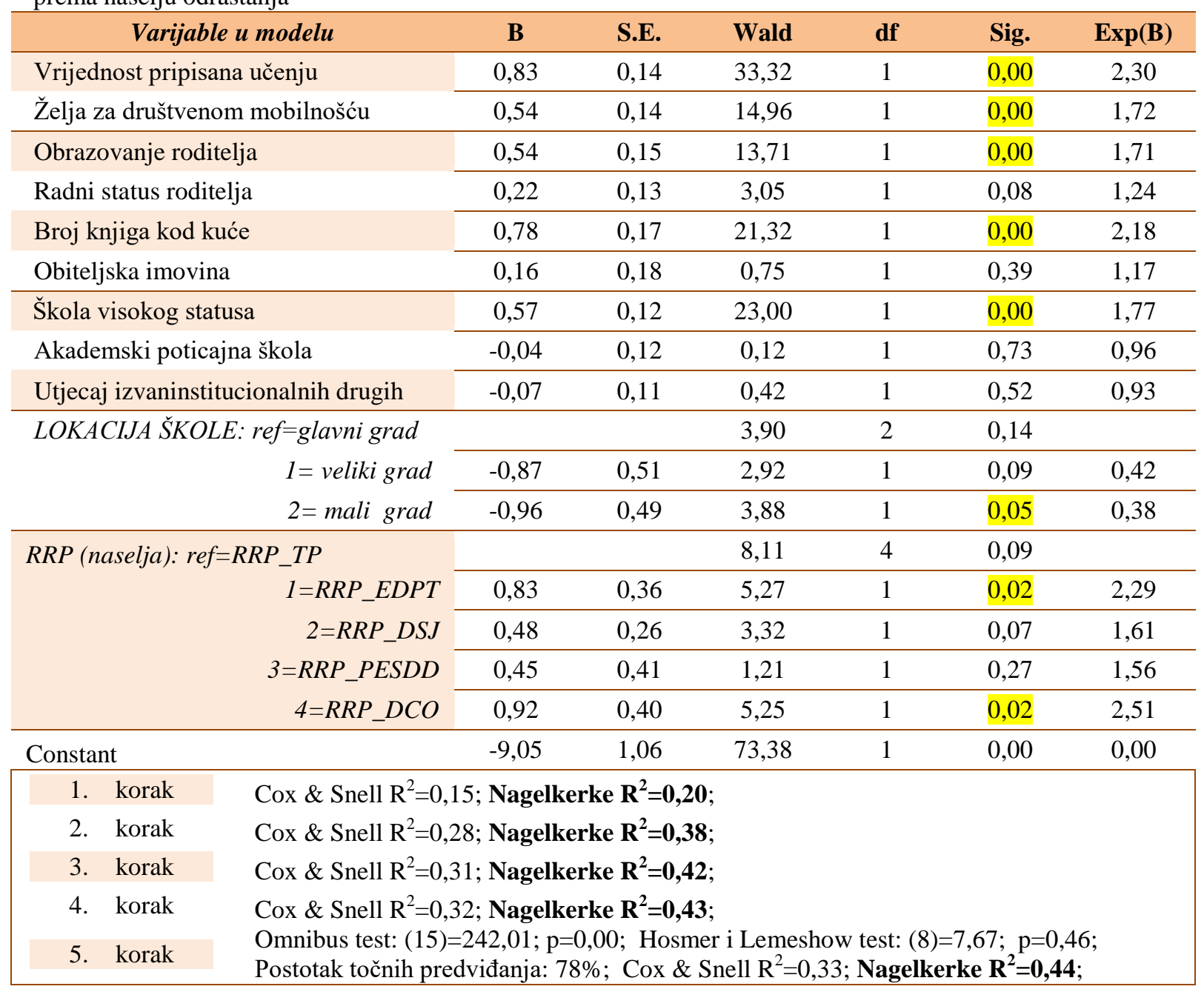

Uz sve prethodno navedene zaključke koji se u ovoj analizi potvrđuju - da je izglednije za ruralne učenike koji namjeravaju studirati visoko vrednovanje učenja $(B=0,83)$ te snažnije 
izražena želja za društvenom mobilnošću $(B=0,54)$, da dolaze iz obitelji bogatijih kulturnim kapitalom (obrazovanje roditelja $B=0,54$; broj knjiga $B=0,78$ ), te da pohađaju škole koje smatraju školama visokog statusa $(B=0,57)$ i koje su locirane u gradovima većeg urbaniteta $(B=-0,96)$ - za te učenike je izglednije i da dolaze iz određenih tipova ruralnih naselja. Analize pokazuju da, od 5 tipova ruralnih naselja u hrvatskom sociogeografskom prostoru, postoji veća vjerojatnost donošenja odluke o studiranju za učenike koji odrastaju u ekonomski diverzificiranim, pretežito turističkim naseljima $(B=0,02)$, te dostupnijim, o cirkulaciji ovisnim, naseljima $(\mathrm{B}=0,22), \mathrm{u}$ odnosu na one koji odrastaju $\mathrm{u}$ tržišno orijentiranim poljoprivrednim naseljima.

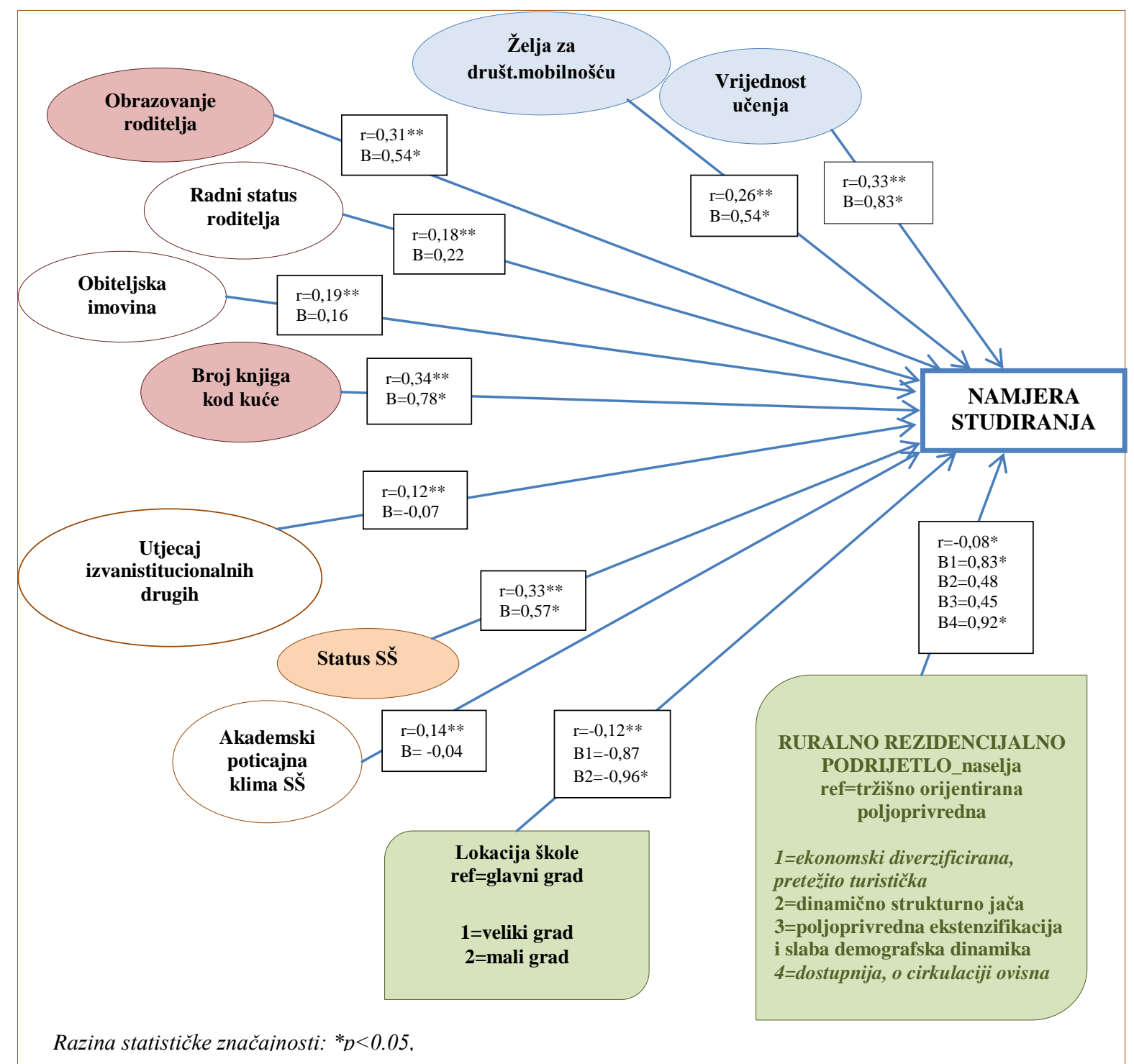

Slika 3.11Regresijski model za objašnjenje namjere studiranja maturanata odraslih na selu (II) - s varijablom tipa ruralnih naselja u zadnjem koraku 
Budući da tipovi naselja odražavaju i određene regionalne specifičnosti i socioekonomske karakteristike $^{73}$, nalazi ukazuju na određene prostorne nejednakosti kada je u pitanju odluka učenika o nastavku školovanja, a s obzirom na mjesto njihova odrastanja. Prema osnovnim karakteristikama, koje zorno dočaravaju i nazivi pojedinih tipova naselja, osnovne pogodnosti dva tipa naselja koje izdvaja analiza vezana su uz dostupnost sustava središnjih naselja povezana razvijenom mrežom prometnica sjeverozapadnog i središnjeg dijela Hrvatske (zagrebački prsten i Hrvatsko zagorje), te ekonomska diverzifikacija priobalnog pojasa (s naglaskom na turizam). Te pogodnosti, povezane s ostalim elementima regresijskog modela, čine većom izglednost učenika koji odrastaju u ruralnim naseljima s tim karakteristikama $\mathrm{u}$ odnosu na one koji odrastaju u naseljima koje karakterizira oslonjenost na tržišno poljoprivredno stjecanje prihoda. S obzirom na podatke o geografskoj lociranosti navedenih naselja ( $u$ istočnim predjelima Hrvatske), ovi nalazi u skladu su i s regionalnim analizama koje potvrđuju da učenici Slavonije u manjem omjeru i statistički značajno različito odlučuju za nastavak školovanja (Klepač, 2015).

U prethodno opisanim analizama prikazan je slijed odgovaranja na pojedina pitanja kako su ona proizlazila iz samog tijeka analiza. Sve opisano tablično je sažeto u Tabeli 3.20. Ukratko, hipoteza $\mathbf{H 2}$ je potvrđena - rezidencijalno podrijetlo, iako malim udjelom (oko $1 \%$ ), statistički značajno doprinosi ukupnom objašnjenju namjere studiranja učenika uz kontrolu ostalih značajnih elemenata individualnih karakteristika i karakteristika obiteljskog i školskog konteksta. Dodatne provjere - testiranje općeg modela na potkategorijama učenika prema njihovom rezidencijalnom podrijetlu - potvrdila su i osnovna očekivanja da postoje razlike u prediktorskom skupu koji objašnjava namjeru studiranja učenika različitog rezidencijalnog podrijetla.

Opći model najbolje objašnjava - 51\% varijance - namjere studiranja učenika koji su odrasli u glavnom gradu pri čemu najveći doprinos objašnjenju daju obiteljske varijable koje pokazuju da je izglednija namjera studiranja urbanih učenika koji dolaze iz obitelji boljeg imovinskog stanja i obrazovanijih roditelja. Dodatno, radi se o učenicima za koje se veliki utjecaj obitelji (36\% objašnjenosti varijance) povezuje s njihovim vrednovanjem učenja i pohađanjem škola višeg statusa. Nasuprot tome nalaze se učenici preostale dvije rezidencijalne kategorije pri čemu snažniji prediktorski utjecaj pokazuju njihove individualne karakteristike povezanim djelovanjem vrednovanja učenja i želje za društvenom mobilnošću,

\footnotetext{
${ }^{73}$ Detaljniji opisi svakog tipa nalaze se u Poglavlju 3.1.1.
} 
te aspekti kulturnih obiteljskih elemenata (obrazovanje roditelja i posjedovanje knjiga). Utjecaj školskog konteksta je u svim analizama vezan za procjenu statusa škola, ali se kod učenika ruralnog rezidencijalnog podrijetla vezuje i uz geografske elemente njihova školovanja i odrastanja. Drugim riječima, dodatne analize pokazale su da postoje sociogeografske odrednice odluke o namjeri studiranja vezane uz mjesto pohađanja srednje škole, odnosno uz pohađanje škole u velikom gradu, te tip naselja odrastanja pri čemu je namjera studiranja izglednija za učenike iz seoskih naselje kojima su u većem stupnju dostupnije centralne funkcije ili se radi o naseljima sa širom ekonomskom diverzifikacijom, $\mathrm{u}$ odnosu na naselja uvelike obilježena poljoprivrednom proizvodnjom. 
Tabela 3.20 Osnovna istraživačka pitanja vezana uz namjeru studiranja učenika, analize te nalazi i interpretacija

\section{Istraživačka pitanja i hipoteze \\ objašnjenju}

Koji skup individualnih, obiteljskih i

I. izvanobiteljskih, te sociogeografskih varijabli najbolje objašnjava učeničku namjeru studiranja?

Postoji li jedinstveni doprinos rezidencijalnog podrijetla, uz kontrolu ostalih varijabli u modelu, objašnjenju učeničke namjere studiranja?
Značajni prediktori i njihov doprinos

Ukupno objašnjenje kriterija modelom: $42 \%$

Izgradnja regresijskog

Uvođenje u model varijable rezidencijalnog podrijetla $\mathrm{u}$ zadnjem koraku;

Usporedna analiza pojedini koraka objašnjenju kriterija;
Individualni prediktori: vrijednost učenja i želja za društvenom mobilnošću - $15 \%$

Obiteljske varijable (obrazovanje i radni statu oditelja, te posjedovanje imovine i knjiga) $23 \%$

Izvanobiteljske varijable: Procjena statusa škole $-3 \%$

Sociogeografske varijable: rezidencijalno podrijetlo učenika - $1 \%$

\section{Interpretacija nalaza}

Izglednije ja da učenici koji namjeravaju studirati: pripisuju višu vrijednost učenju i iskazuju viši stupanj želje za društvenom mobilnošću

dolaze iz obitelji obrazovanijih i roditelja sa stalnim prihodima te većim stupnjem posjedovanja materijalnih dobara i knjiga

pohađaju škole koje u većoj mjeri procjenjuju školama visokog statusa

imaju urbano rezidencijalno podrijetlo, $\mathrm{u}$ odnosu na učenike odrasle na selu

Postoje li razlike u djelovanju modela za

II. objašnjenje namjere studiranja kod učenika Testiranje općeg modela na poduzorcima učenika prema njihovom rezidencijalnom podrijetlu

različitog rezidencijalnog podrijetla?

A Koji sklop individualnih, obiteljskih i izvanobiteljskih varijabli najbolje 1. r vrijednost pripisana učenju (9\%)

2. obrazovanje roditelja i obiteljska objašnjava namjeru studiranja učenika odraslih u metropoli imovina $(34 \%)$

3. procjena statusa škole $(8 \%)$
Namjera studiranja učenika odraslih u metropoli izglednije je za one koji:

pripisuju veću vrijednost učenju

dolaze iz obitelji obrazovanijih roditelja i većeg imovinskog statusa

pohađaju škole koje procjenjuju školama visokog statusa

Namjera studiranja učenika urbanog rezidencijalnog podrijetla izglednije je za one koji: - pripisuju veću vrijednost učenju i

Ukupno objašnjenje modela $-36 \%$;

Koji sklop individualnih, obiteljskih i izvanobiteljskih, te sociogeografskih varijabli najbolje objašnjava namjeru studiranja učenika odraslih u urbanom okolišu

vrijedno

veći stupanj želje za društvenom mobilnošću

obrazovanje roditelja, radni status $\mathrm{i} \quad$ dolaze iz obitelji čiji roditelji imaju broj knjiga (17\%)

$3 . \quad$ procjena statusa škole $(2 \%)$

stalnije prihode 1 veće razine posjedovanog kulturnog kapitala

- pohađaju škole koje procjenjuju školama visokog statusa

Ukupno objašnjenje modela $-41 \%$

Namjera studiranja učenika odraslih u metropoli

Koji sklop individualnih, obiteljskih i izvanobiteljskih, te sociogeografskih varijabli najbolje objašnjava namjeru studiranja učenika odraslih u ruralnom okolišu

\section{vrijednost pripisana}

$(19 \%)$

procjena statusa škole $(3,5 \%)$ izglednije je za one koji:

- pripisuju veću vrijednost učenju i iskazuju veći stupanj želje za društvenom mobilnošću

dolaze iz obitelji s većim razinama 

gradovima

Uvođenje u analizu testiranja

robusnosti općeg modela 5 .

koraka - varijabla tipa

ruralnog naselja u kojem

odrastaju učenici:

ref $=$ tržišno orijentirana

l=ekonomski diverzificirana,

Doprinosi li objašnjenju namjere studiranja učenika ruralnog rezidencijalnog podrijetla tip ruralnog naselja u kojem odrastaju?

pretežito turistička naselja poljoprivredna naselja

Ukupno objašnjenje modela $-44 \%$;

1. vrijednost pripisana učenju i želja za društvenom mobilnošću $(20 \%)$ $(18 \%)$ $2=$ dinamično strukturno jača naselja

$3=$ naselja poljoprivredne

=naselja polj

ekstenzifikacije $i$ slabe

demografske dinamike

4=dostupnija, $\quad$ o cirkulaciji

ovisna naselja

4. lokacija škole (1\%)

5. RURALNO

PODRIJETLO_naselje (1\%) 2. obrazovanje roditelja i broj knjig

Namjera studiranja učenika odraslih u metropoli izglednije je za one koji:

pripisuju veću vrijednost učenju

iskazuju veći stupanj želje za društvenom mobilnošću

dolaze iz obitelji s većim razinama posjedovanog kulturnog kapitala

pohađaju škole koje procjenjuju školama visokog statusa

3. procjena statusa škole $(4 \%)$

pohađaju škole u većim gradovima u odnosu na one koji škole pohađaju u malim gradovima

odrasli su u naseljima koja su ekonomski diverzificirana, pretežito turistička ili dostupnija, o cirkulaciji ovisna, u odnosu na one odrasle u tržišno orijentiranim poljoprivrednim naseljima 


\subsubsection{Rezidencijalno podrijetlo učenika, čimbenici obiteljskog i školskog konteksta i visokoobrazovni izbori}

Postoji li utjecaj rezidencijalnog podrijetla s obzirom na visokoobrazovne izbore tipa i mjesta studija učenika koji namjeravaju studirati? U upitniku ti su učenici, u obliku otvorenih odgovora, upisivali svoje planove u vidu željenog studija, institucije te mjesta studiranja. Navedeni odgovori kodirani su na nekoliko načina, a od osnovnog interesa je koji tip studija žele upisati - sveučilišni ili stručni ${ }^{74}$, te u kojem gradu, odnosno radi li se o Zagrebu, ili gradu manjeg stupnja centraliteta ${ }^{75}$. Osnovna pretpostavka je da rezidencijalno podrijetlo ima utjecaj kod tih visokoobrazovnih izbora, uz ostale varijable obiteljskog i školskog konteksta, posebno kada su u pitanju učenici ruralnog rezidencijalnog podrijetla jer odlazak na studija za njih podrazumijeva preseljenje. Ipak, smatra se da je, dijelom i zbog trenutka u kojem se donosi odluka o studiju, takav utjecaj manji, u odnosu na utjecaj individualnih karakteristika učenika.

S obzirom na postavljeno istraživačko pitanje, te namjeru objašnjenja visokoobrazovnih izbora konceptima koji proizlaze iz Bourdieuove teorije, a proširuju se u sociogeografskoj dimenziji, izgrađen je regresijski model koji je, u odnosu na prethodno prezentiran model za objašnjenje namjere studiranja, sadržavao veći broj varijabli individualnih karakteristika učenika. Konkretnije, u prvom koraku analize regresijski model sadrži varijablu uspjeha učenika, odnosno općeg prosjeka ocjena u prethodnoj godini školovanja, te njihove kulturne kompetencije, mjerene kao sudjelovanje u kulturnim, čitalačkim i izvanškolskim aktivnostima. U sljedećem koraku uvode se varijable obiteljskog ekonomskog i kulturnog kapitala. Treći korak sadrži samo jednu karakteristiku institucionalnog konteksta srednjoškolskog obrazovanja za koju se pokazalo da je općenito važna kod odluka vezanih za studiranje - procjena statusa škole, te varijabla koja zahvaća institucionalni kontekst visokog obrazovanja - procjena ugleda institucije i studija kao odrednice učeničkih izbora. Konačna dva koraka analiza sadržavaju sociogeografske varijable lokacije škole te rezidencijalnog podrijetla učenika. Tablica 3.21 sažeto prezentira sve navedene varijable koje tvore regresijski model i objašnjenja njihova izbora.

\footnotetext{
${ }^{74}$ Prvotna ideja rada bila je ispitati izbor tipa institucije studiranja, no zbog nepotpunog binarnog sustava koji karakterizira hrvatsko visoko obrazovanje, u konačnici je izabrana varijabla izbora tipa studija kao zanimljivija za analizu i koja u većoj mjeri zahvaća realitet razlika izbora učenika.

75 Iako je prvotna ideja bila ispitati i izbore drugih mjesta (npr. ostalih sveučilišnih gradova, ili odabir studija u gradovima manjeg stupnja centraliteta (regionalni centri)) podaci da je u Zagrebu smješteno 39\% visokih učilišta i da obuhvaća 39\% studentskog tijela, te da više od polovice anketiranih učenika bira Zagreb kao svoj primarni izbor izdvojilo je to pitanje najzanimljivijim.
} 
Tabela 3.21 Izbor varijabli regresijskog modela za objašnjenje visokoobrazovnih izbora

\begin{tabular}{|c|c|c|c|}
\hline $\begin{array}{l}\text { Korak } \\
\text { reg. } \\
\text { model } \\
\quad \text { a }\end{array}$ & Ekološki pristup & Odabrane mjere - prediktori & Objašnjenje izbora \\
\hline i. & $\begin{array}{l}\text { Individualne } \\
\text { varijable }\end{array}$ & $\begin{array}{l}\text { Školski uspjeh } \\
\text { Učeničke kulturne prakse } \\
\text { Učeničke čitalačke prakse } \\
\text { Učeničke izvanškolske aktivnosti }\end{array}$ & $\begin{array}{l}\text { Varijable za koje se pretpostavlja } \\
\text { utjecaj na visokoobrazovne izbore }\end{array}$ \\
\hline ii. & $\begin{array}{l}\text { Obiteljske } \\
\text { varijable: kulturni i } \\
\text { ekonomski kapital }\end{array}$ & $\begin{array}{l}\text { Obrazovanje roditelja } \\
\text { Radni status roditelja } \\
\text { Obiteljska imovina } \\
\text { Broj knjiga u kućanstvu }\end{array}$ & $\begin{array}{l}\text { Osnovne mjere obiteljskih resursa } \\
\text { koje su pokazale značaj u prijašnjim } \\
\text { istraživanjima kao prediktori } \\
\text { obrazovnih ishoda učenika }\end{array}$ \\
\hline iii. & $\begin{array}{l}\text { Institucionalne } \\
\text { varijable }\end{array}$ & $\begin{array}{l}\text { Škola visokog statusa } \\
\text { Procjena ugleda studija i institucije } \\
\text { studiranja kao odrednica izbora }\end{array}$ & $\begin{array}{l}\text { Osnovne mjere institucionalnog } \\
\text { konteksta srednjoškolskog i visokog } \\
\text { obrazovanja }\end{array}$ \\
\hline iv. & $\begin{array}{l}\text { Sociogeografska } \\
\text { varijabla }\end{array}$ & $\begin{array}{l}\text { Lokacija škole - prema centralitetu } \\
\text { grada u kojem učenici pohađaju škole }\end{array}$ & Osnovna kontrola \\
\hline v. & $\begin{array}{l}\text { Sociogeografska } \\
\text { varijabla od } \\
\text { interesa }\end{array}$ & Rezidencijalno podrijetlo & $\begin{array}{l}\text { Varijabla od osnovnog interesa } \\
\text { postavljena hipotezom }\end{array}$ \\
\hline
\end{tabular}

Budući su analize o izboru tipa studija i mjesta studiranja u velikoj mjeri eksplorativnog karaktera, s pokušajem da im se da teorijsko objašnjenje, nije očekivana velika objašnjenost modelom. Naredne analize predstavljaju korake tog eksplorativnog procesa pri čemu je kreirani opći model testiran na nacionalnom uzorku učenika, kontroliran s obzirom na upozorenja preliminarnih analiza i deskriptivnim podacima o udjelima učenika na pojedinim varijablama ishoda. To znači da se model namijenjen objašnjenju visokoobrazovnih izbora ne testira za zasebne kategorije učenika prema njihovom rezidencijalnom podrijetlu, već za dvije podskupine učenika: onih koji nisu odrasli u glavnom gradu (one ruralnog i urbanog rezidencijalnog podrijetla), te na poduzorku učenika ruralnog rezidencijalnog podrijetla ${ }^{76}$.

U nastavku slijede rezultati regresijskih analiza, prvo, za objašnjenje izbora sveučilišnog studija (3.3.3), a zatim za objašnjenje izbora Zagreba kao mjesta studiranja (3.3.4).

\footnotetext{
${ }^{76}$ Razlozi tome su sljedeći: testiranje modela i zasebno objašnjenje visokoobrazovnih izbora učenika koji su odrasli u metropoli nije opravdano jer samo 13 učenika želi upisati studij izvan Zagreba, a samo 24 ih misli upisati stručni studij. S obzirom na takve ishode na zavisnim varijablama podaci analiza bi bili vrlo nepouzdani. S druge strane, preliminarne analize objašnjenja visokoobrazovnih izbora učenika odraslih u urbanim okolišima objašnjavaju izuzetno malo varijance (9\%) s malo značajnih prediktora što analize čine nezanimljivima, te je odlučeno da budu isključene iz prikaza.
} 


\subsubsection{Objašnjenje izbora sveučilišnog studija za učenike različitog rezidencijalnog podrijetla}

U osnovi, osnovno istraživačko pitanje o tome doprinosi li rezidencijalno podrijetlo objašnjenju izbora sveučilišnog studija, kada se kontroliraju ostale individualne te varijable obiteljskog i školskog konteksta (H2b), je potvrđeno. Slika 3.12 daje osnovne podatke o prediktorima koji statistički značajno doprinose objašnjenju tog izbora.

Kako je vidljivo, značajnih prediktora je malo i izdvojeni su iz skupova učeničkih individualnih karakteristika, obiteljskog konteksta te sociogeografskih odrednica njihova odrastanja i školovanja. Varijable koje pokušavaju zahvatiti neke elemente institucionalnih konteksta: sadašnjeg (status škole), te budućeg (procjena ugleda studija i institucije studiranja), nisu pokazale značaj za objašnjenje kriterija, a općenito je njihov doprinos objašnjenju u modelu (3. korak) zanemariv.

Općenito, objašnjenost izbora sveučilišnog studija modelom je samo $14 \%$ (Nagelkerke $\mathrm{R}^{2}$ ), pri čemu najveći dio doprinosa nosi prvi korak analize, a svi ostali doprinose s tek oko $1 \%$. Odnosno, individualne karakteristike poput školskog uspjeha učenika i njihovih kulturnih kompetencija u većoj mjeri objašnjavaju, i čine izglednijim, izbor sveučilišnog, u odnosu na izbor stručnog studija. Dodatna $2 \%$ doprinosa objašnjenju daju obiteljske varijable koje opisuju obiteljsko posjedovanje kulturnog i ekonomskog kapitala, te $2 \%$ objašnjenja daju i sociogeografske varijable lokacije škole i rezidencijalnog podrijetla.

Dakle, namjera upisa sveučilišnog studija izglednija je za učenike koji imaju viši opći prosjek ocjena $\mathrm{u}$ prethodnoj školskoj godini $(\mathrm{B}=0,63)$ te koji $\mathrm{u}$ većoj mjeri sudjeluju u kulturnim praksama, poput odlazaka u kazališta, muzeje/galerije te na operu/balet/klasične koncerte $(B=0,68)$. Također je izglednije za učenike čije obitelji karakterizira veća razina kulturnog kapitala, odnosno imaju obrazovanije roditelje $(B=0,25)$ i veći broj posjedovanih knjiga $u$ kućanstvu $(B=0,29)$. Konačno, u odnosu na učenike koji škole završavaju u malim gradovima, namjera upisa sveučilišnog studija izglednija je za učenike koji škole završavaju u velikim gradovima $(B=0,40)$, a u odnosu na učenike ruralnog rezidencijalnog podrijetla, izglednije je za učenike čije je rezidencijalno podrijetlo urbano. 


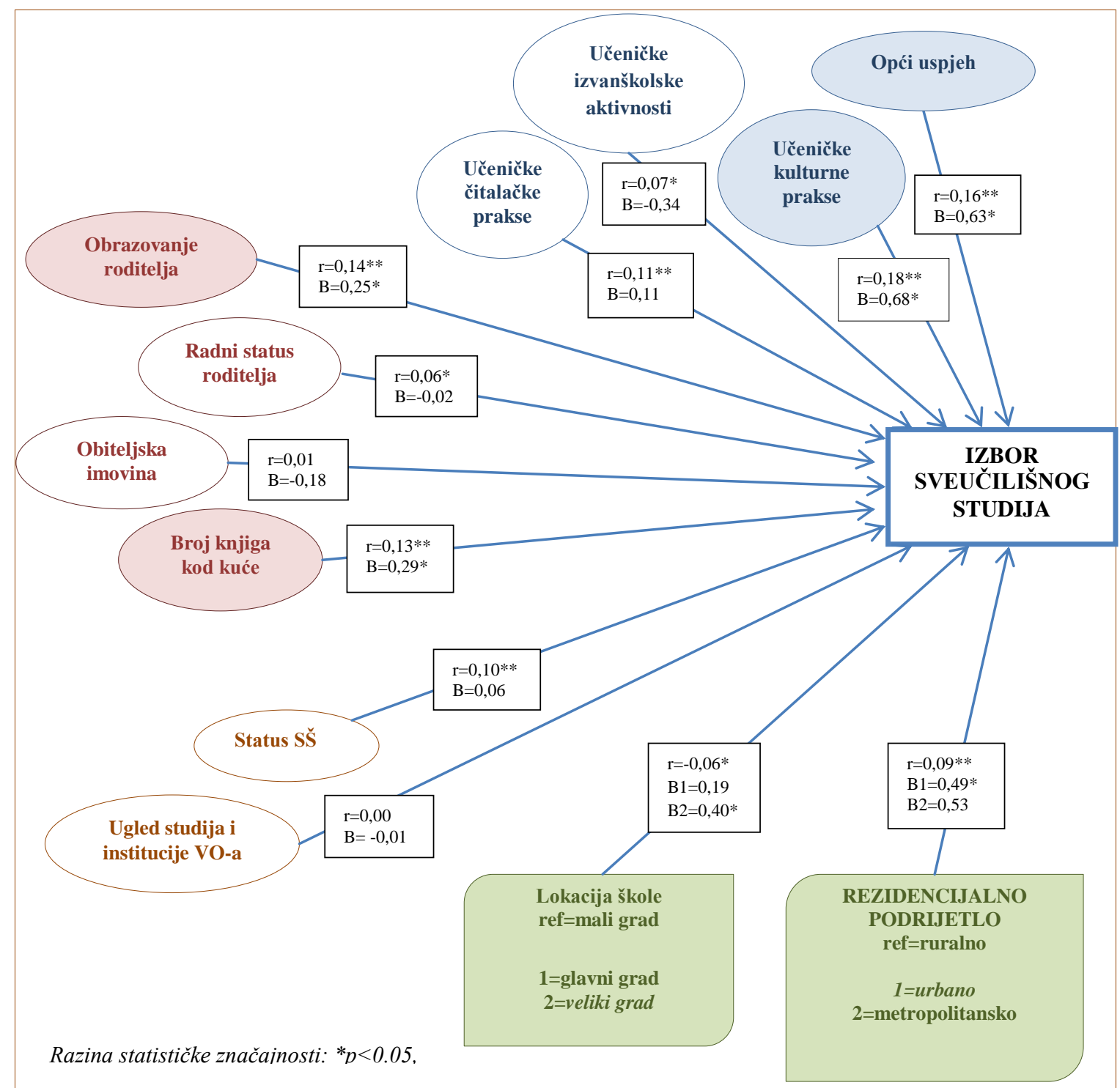

Slika 3.12 Opći regresijski model za objašnjenje izbora sveučilišnog studija (nacionalni uzorak maturanata) izgrađen u 5 koraka

Sličan obrazac ponavlja se i u testu robusnosti modela kada se iz analize isključe učenici metropolitanskog rezidencijalnog podrijetla. Osnovna razlika tiče se smanjivanja broja značajnih prediktora, iako objašnjenost modela ostaje ista - 14\% (Nagelkerke $\mathrm{R}^{2}$ ). U ovoj analizi obiteljske varijable više ne pokazuju statističku značajnost, te izglednost namjere upisa sveučilišnog studija za učenike koji nisu odrasli u metropoli najbolje objašnjavaju prosjek ocjena u prošlom razredu $(B=0,51)$ i njihove kulturne prakse $(B=0,75)$, te sociogeografske varijable mjesta odrastanja i školovanja. Pri tom je izglednija namjera upisa sveučilišnog studija za učenike koji škole završavaju u velikom gradu $(B=0,40)$, u odnosu na one koji škole završavaju u malom gradu, te one odrasle u urbanom $(B=0,49)$ u odnosu na one odrasle $u$ ruralnom okolišu. 
Tabela 3.22 Regresijski model za objašnjenje izbora sveučilišnog studija (nacionalni uzorak) i njegovo testiranje na dvije podskupine učenika

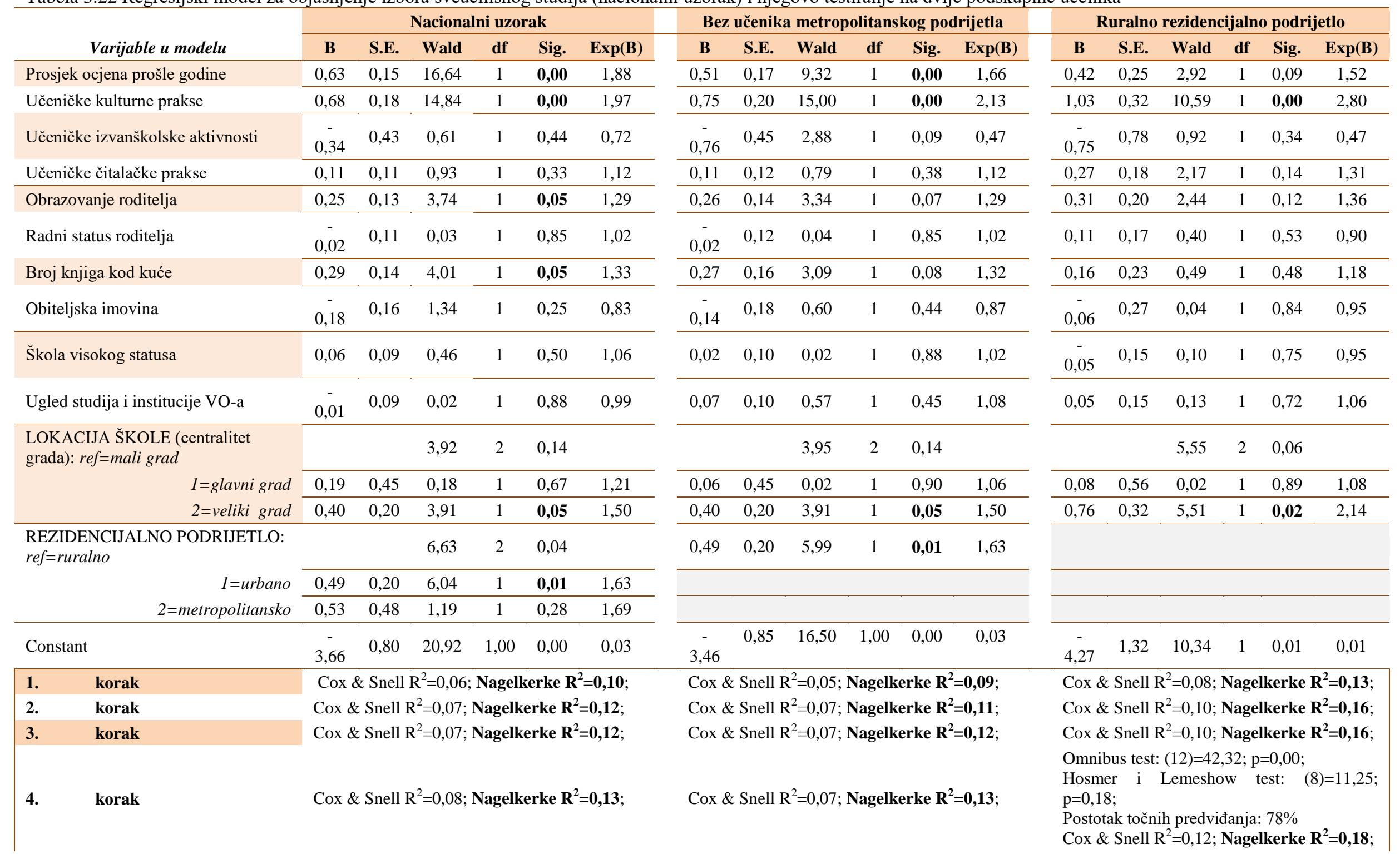


5. korak

Omnibus test: $(14)=92,17 ; \mathrm{p}=0,00$;

Hosmer i Lemeshow test: $(8)=5,70 ; p=0,68$;

Postotak točnih predviđanja: $85 \%$

Cox \& Snell $\mathbf{R}^{2}=0,08 ;$ Nagelkerke $\mathbf{R}^{2}=\mathbf{0 , 1 4}$
Omnibus test: $(13)=73,53 ; \mathrm{p}=0,00$;

Hosmer i Lemeshow test: $(8)=6,32 ; p=0,61$;

Postotak točnih predviđanja: $84 \%$

Cox \& Snell $\mathbf{R}^{2}=0,08$; Nagelkerke $\mathbf{R}^{2}=\mathbf{0 , 1 4}$; 
Konačno, s najmanjim brojem koraka i najmanjim brojem prediktora, model je objasnio najveći postotak varijance izbora sveučilišnog studija za ruralne učenike ${ }^{77}-18 \%$ (Nagelkerke $\mathrm{R}^{2}$ ). Kao značajni prediktori izdvajaju se tek 2 , i to kulturne prakse učenika, te mjesto u kojem završavaju svoje srednje škole. Analiza pokazuje da je najizglednija namjera upisa sveučilišnog studija za učenike ruralnog rezidencijalnog podrijetla koji u većoj mjeri sudjeluju $\mathrm{u}$ različitim kulturnim aktivnostima $(B=1,03)$, te koji škole završavaju u velikim gradovima $(B=0,76)$, u odnosu na one koji škole završavaju u gradovima manjeg stupnja centraliteta.

Sve ovdje provedene analize sažima Tabela 3.23. Jedno od osnovnih saznanja provedenih analiza bila je potvrda pretpostavke da individualne obrazovno-kulturne karakteristike imaju najveću ulogu kada je u pitanju odabir tipa studija, dok je utjecaj institucionalnog konteksta zanemarujuće mali. Utjecaj pak obiteljskog konteksta pokazuje značaj tek kada su u uzorku uključeni i učenici metropolitanskog rezidencijalnog podrijetla, dakle u općem modelu, i to samo svojim kulturnim elementima, ne i prema ekonomskim pokazateljima. Navedeno ukazuje kako izbor tipa studija prvenstveno ovisi o ambicijama učenika, koje se čak ne izražavaju uvijek kao ocjene, već više kao kulturne kompetencije, te o dostupnosti u smislu mjesta u kojem se pohađa srednja škola i koja možda omogućava razvoj tih kompetencija. Ta sociogeografska varijabla pokazuje se značajnom u svim provedenim analizama, odnosno u svim testovima robusnosti osnovnog modela pri čemu su učenici koji škole završavaju u malim gradovima u odnosu na one koji škole završavaju u velikim gradovima u nepovoljnijoj poziciji. Konačno, rezidencijalno podrijetlo statistički značajno doprinosi objašnjenju izbora tipa studija pokazuje svoj značaj i nadopunjuje prethodne interpretacije s obzirom da je veća vjerojatnost da će ruralni učenici pohađati škole u gradovima manjeg stupnja centraliteta. Ipak, činjenica da je uvedeno u zadnjem koraku pokazuje da postoji određeni, mali (1\%), ali statistički značajan jedinstveni doprinos odrastanja u ruralnom, odnosno urbanom okolišu.

\footnotetext{
77 Pri pokušaju objašnjenja ovog izbora odustalo se od detaljnije analize s uvođenjem petog koraka, odnosno varijable rezidencijalnog podrijetla prema tipu ruralnih naselja jer je deskriptivna statistika, odnosno podaci o broju učenika odraslih u pojedinim tipovima naselja u kategorijama mjerenog ishoda, ukazala da bi podaci takvih analiza mogli biti nepouzdani (samo oko 9 učenika odraslih u ruralnim naseljima namjerava upisati stručni studij).
} 
Tabela 3.23 Osnovna istraživačka pitanja vezana uz učenički izbor tipa studija, analize te nalazi i interpretacija

\begin{tabular}{|c|c|c|c|c|}
\hline & Istraživačka pitanja & $\begin{array}{c}\text { Način } \\
\text { odgovaranja na } \\
\text { pitanje }\end{array}$ & $\begin{array}{l}\text { Značajni prediktori i } \\
\text { njihov doprinos } \\
\text { objašnjenju }\end{array}$ & Interpretacija nalaza \\
\hline I. & $\begin{array}{l}\text { Koji sklop individualnih, } \\
\text { obiteljskih i } \\
\text { institucionalnih, te } \\
\text { sociogeografskih varijabli } \\
\text { najbolje objašnjava } \\
\text { učenički izbor } \\
\text { sveučilišnog studija? }\end{array}$ & $\begin{array}{l}\text { Izgradnja } \\
\text { regresijskog } \\
\text { modela u } 5 \\
\text { koraka; }\end{array}$ & $\begin{array}{l}\text { Ukupno objašnjenje } \\
\text { kriterija modelom: } 14 \% \\
\text { Individualni } \\
\text { prošlogodišnji } \\
\text { uspjeh i učeničke kulturne }\end{array}$ & $\begin{array}{l}\text { Izglednije ja da učenici } \\
\text { koji namjeravaju } \\
\text { studirati: } \\
\text { - imaju bolji prosjek i } \\
\text { češće sudjeluju u } \\
\text { kulturnim praksama } \\
\text { - dolaze iz obitelji } \\
\text { obrazovanijih }\end{array}$ \\
\hline & $\begin{array}{l}\text { Postoji li jedinstveni } \\
\text { doprinos rezidencijalnog } \\
\text { podrijetla, uz kontrolu } \\
\text { ostalih varijabli u modelu, } \\
\text { objašnjenju izbora } \\
\text { sveučilišnog studija? }\end{array}$ & $\begin{array}{l}\text { Uvođenje u model } \\
\text { varijable } \\
\text { rezidencijalnog } \\
\text { podrijetla u } \\
\text { zadnjem koraku; } \\
\text { Usporedna analiza } \\
\text { pojedinih koraka } \\
\text { objašnjenju } \\
\text { kriterija; }\end{array}$ & $\begin{array}{l}\text { prakse }-10 \% \\
\text { Obiteljske varijable } \\
\text { (obrazovanje roditelja, te } \\
\text { posjedovanje knjiga) }-2 \% \\
\text { Varijable institucionalnih } \\
\text { karakteristika }-0 \% \\
\text { Sociogeografske varijable: } \\
\text { lokacija skale i } \\
\text { rezidencijalno podrijetlo } \\
\text { učenika-2\% }\end{array}$ & $\begin{array}{l}\text { roditelja i većim } \\
\text { brojem posjedovanih } \\
\text { knjiga } \\
\text { pohađaju škole u } \\
\text { velikom gradu, u } \\
\text { odnosu na one koji } \\
\text { škole pohađaju u } \\
\text { malom gradu } \\
\text { imaju urbano } \\
\text { rezidencijalno } \\
\text { podrijetlo, u odnosu } \\
\text { na učenike odrasle } \\
\text { na selu }\end{array}$ \\
\hline
\end{tabular}

Postoje li razlike u

djelovanju modela za

II objašnjenje izbora sveučilišnog studija kod učenika različitog rezidencijalnog podrijetla?
Testiranje općeg modela na dvije potkategorije učenika: A) isključeni učenici metropole, i B) samo ruralni učenici
Koji sklop individualnih, obiteljskih i

A izvanobiteljskih varijabli najbolje objašnjava izbor sveučilišnog studija učenika koji nisu odrasli u metropoli?
2.

3. -

4. lokacija škole (1\%)

5. rezidencijalno podrijetlo učenika $(1 \%)$

Namjera studiranja
učenika odraslih u
metropoli izglednije je za
one koji:
- imaju bolji prosjek i
češć sudjeluju u
kulturnim praksama
pohađaju škole u
velikom gradu, u
odnosu na one koji
škole pohađaju u
malom gradu

Namjera studiranja učenika odraslih u Ukupno objašnjenje metropoli izglednije je za modela $-18 \%$; one koji:

Koji sklop individualnih, obiteljskih i izvanobiteljskih, te sociogeografskih varijabli najbolje objašnjava izbor sveučilišnog studija učenika odraslih u ruralnom okolišu?
1. učeničke kulturne - češće sudjeluju u prakse $(13 \%) \quad$ kulturnim praksama
2. -
3. -
4. lokacija škole $(2 \%)$




\subsubsection{Objašnjenje izbora Zagreba kao željenog mjesta studiranja}

Već je istaknuto kako učenici u najvećoj mjeri biraju Zagreb kao željeno mjesto studiranja. Stoga se u središtu interesa sljedećih analiza nalazi pokušaj davanja teorijskog okvira za navedeni izbor i njegovo objašnjenje. Izgrađeni model sadrži i dalje 5 koraka analiza pri čemu prvi korak sadrži individualne varijable školskog uspjeha i kulturnih kompetencija učenika, sljedeći korak sadrži indikatore obiteljski posjedovanog kulturnog i ekonomskog kapitala, dok treći korak sadrži varijable koje zahvaćaju neke aspekte institucionalnih konteksta srednjoškolskog te budućeg visokoobrazovnog obrazovanja učenika. Tako izgrađen opći model korigiran je s obzirom na podatak da većina učenika koji srednjoškolsko obrazovanje završavaju u glavnom gradu, a što se uvelike poklapa i s njihovim rezidencijalnim podrijetlom, tamo žele i studirati. Stoga je model testiran na dvije podskupine učenika: prvo, na pouzorku učenika iz kojeg su isključeni učenici odrasli u metropoli, a zatim na poduzorku učenika ruralnog rezidencijalnog podrijetla što slijedi osnovni interes rada.

Osnovni rezultati regresijske analize provedene na nacionalnom uzorku učenika s ciljem objašnjenja izbor grada Zagreba kao željenog mjesta studiranja grafički su prikazani (Slika 3.13). Ta analiza je osnova za interpretaciju osnovnih prediktora koji su pokazali statističku značajnost, te usporednu analizu: prema doprinosu pojedinih koraka (tj. skupova varijabli) modela objašnjenju kriterija, i prema razlikama u značaju prediktora za objašnjenje kriterija u analizama za različite kategorije učenika. Ti rezultati nalaze se u Tabeli 3.24.

Iz svakog skupa varijabli, odnosno svakog koraka izgradnje općeg modela za nacionalni uzorak, postoji statistički značajan prediktor za objašnjenje kriterija. Od individualnih varijabli to su opći školski uspjeh i sudjelovanje učenika u kulturnim aktivnostima. Od varijabli obiteljski dostupnih resursa to je radni status roditelja, a od institucionalnih varijabli je to učenička procjena statusa svojim školama. Na kraju, obje sociogeografske varijable - i centralitet grada u kojem učenici završavaju škole, i mjesto njihova odrastanja - pokazuju se statistički značajnim prediktorima izbora Zagreba kao mjesta studiranja. Ovako izgrađeni model objašnjava ukupno 39\% (Nagelkerke $\mathrm{R}^{2}$ ) varijance kriterija pri čemu najveći doprinos od čak $20 \%$ pokazuje 4 . korak analize.

Općenito, i u općem modelu, i usporedno, u ostalim testovima modela, prvi korak koji uključuje individualne varijable učenika objašnjava oko $12 \%$ varijance izbora Zagreba, do $14 \%$ u analizi iz koje su isključeni učenici odrasli u metropoli. 


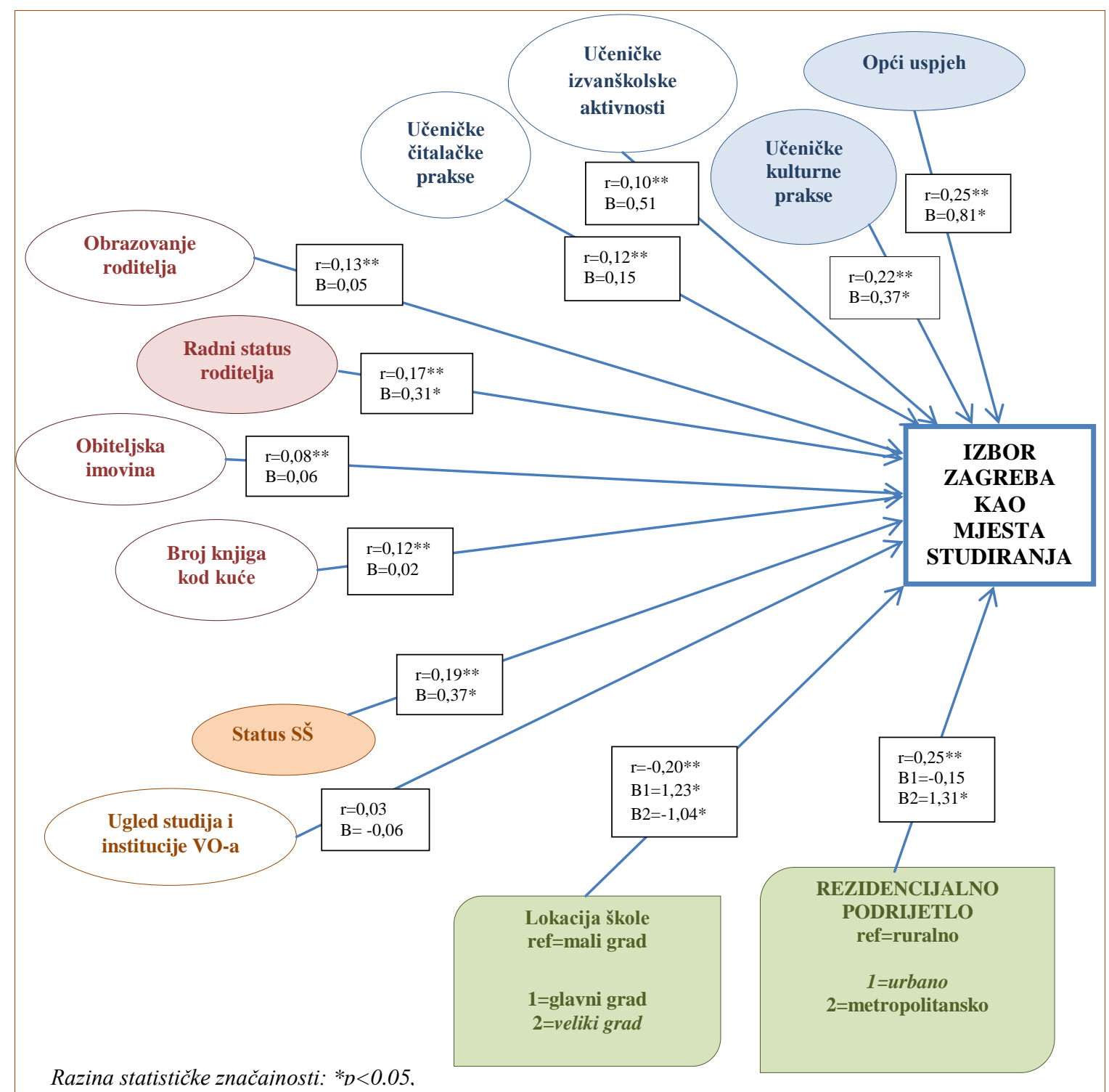

Slika 3.13 Opći regresijski model (5 koraka) za objašnjenje izbora Zagreba kao mjesta studiranja (nacionalni uzorak)

Drugi korak $\mathrm{u}$ kojem se $\mathrm{u}$ analizu uvode obiteljske varijable u općem modelu doprinosi objašnjenjem od 3\%, no razlikuje se za ostale poduzorke: minimalan doprinos od $1 \%$ donosi u analizi iz koje su isključeni učenici odrasli u glavnom gradu, a maksimalan od 5\% u analizu za ruralne učenike. Treći korak - institucionalni aspekti obrazovanja - najmanje doprinose objašnjenju kriterija bez obzira na uzorak na kojem je provedeni test. Pretposljednji korak, odnosno lokacija škole, korak je regresijskog modela koji je objasnio daleko najviše varijance kriterija na ukupnom nacionalnom uzorku (20\%), no manje u analizama na poduzorcima: kada se isključe učenici metropolitanskog rezidencijalnog podrijetla, doprinos tog koraka iznosi $8 \%$, a kada se isključe i učenici urbanog rezidencijalnog podrijetla doprinos je $11 \%$. Konačno, rezidencijalno podrijetlo daje minimalan doprinos od 1\%, no njegov doprinos više se ne potvrđuje kada se iz analize isključe učenici odrasli u glavnom gradu. 
Tabela 3.24 Regresijski model objašnjenja izbora Zagreba kao mjesta studiranja (macionalni uzorak) i njegovo testiranje na dvije podskupine učenika

\begin{tabular}{|c|c|c|c|c|c|c|c|c|c|c|c|c|c|c|c|c|c|c|}
\hline \multirow{2}{*}{ Varijable u modelu } & \multicolumn{6}{|c|}{ Nacionalni uzorak } & \multicolumn{6}{|c|}{ Bez učenika metropolitanskog podrijetla } & \multicolumn{6}{|c|}{ Ruralno rezidencijalno podrijetlo } \\
\hline & B & S.E. & Wald & df & Sig. & $\operatorname{Exp}(\mathbf{B})$ & B & S.E. & Wald & df & Sig. & $\operatorname{Exp}(B)$ & B & S.E. & Wald & df & Sig. & $\operatorname{Exp}(\mathbf{B})$ \\
\hline Prosjek ocjena prošle godine & 0,81 & 0,13 & 39,39 & 1 & $\mathbf{0 , 0 0}$ & 2,25 & 0,75 & 0,13 & 32,93 & 1 & 0,00 & 2,12 & 0,52 & 0,22 & 5,78 & 1 & 0,02 & 1,69 \\
\hline Učeničke kulturne prakse & 0,37 & 0,12 & 9,47 & 1 & $\mathbf{0 , 0 0}$ & 1,44 & 0,36 & 0,12 & 8,96 & 1 & $\mathbf{0 , 0 0}$ & 1,44 & 0,48 & 0,21 & 5,06 & 1 & $\mathbf{0 , 0 3}$ & 1,61 \\
\hline Učeničke izvanškolske aktivnosti & 0,51 & 0,33 & 2,35 & 1 & 0,13 & 1,66 & 0,39 & 0,34 & 1,33 & 1 & 0,25 & 1,47 & 1,21 & 0,64 & 3,55 & 1 & 0,06 & 3,36 \\
\hline Učeničke čitalačke prakse & 0,15 & 0,09 & 2,74 & 1 & 0,10 & 1,16 & 0,19 & 0,09 & 4,29 & 1 & 0,04 & 1,21 & $0,-\overline{0}$ & 0,16 & 0,00 & 1 & 0,95 & 0,99 \\
\hline Obrazovanje roditelja & 0,05 & 0,11 & 0,21 & 1 & 0,65 & 1,05 & 0,04 & 0,11 & 0,10 & 1 & 0,76 & 1,04 & 0,03 & 0,17 & 0,03 & 1 & 0,86 & 0,97 \\
\hline Radni status roditelja & 0,31 & 0,10 & 10,44 & 1 & $\mathbf{0 , 0 0}$ & 0,74 & 0,30 & 0,10 & 9,37 & 1 & $\mathbf{0 , 0 0}$ & 0,74 & 0,49 & 0,15 & 10,87 & 1 & $\mathbf{0 , 0 0}$ & 0,61 \\
\hline Broj knjiga kod kuće & 0,02 & 0,12 & 0,04 & 1 & 0,84 & 1,02 & 0,01 & 0,12 & 0,01 & 1 & 0,92 & 1,01 & $0, \overline{10}$ & 0,20 & 0,25 & 1 & 0,62 & 0,90 \\
\hline Obiteljska imovina & 0,06 & 0,13 & 0,19 & 1 & 0,66 & 1,06 & 0,14 & 0,14 & 1,00 & 1 & 0,32 & 1,14 & 0,40 & 0,23 & 3,03 & 1 & 0,08 & 1,49 \\
\hline Škola visokog statusa & 0,37 & 0,07 & 24,39 & 1 & $\mathbf{0 , 0 0}$ & 1,44 & 0,34 & 0,08 & 19,77 & 1 & $\mathbf{0 , 0 0}$ & 1,40 & 0,24 & 0,13 & 3,31 & 1 & 0,07 & 1,27 \\
\hline Ugled VO & $0, \overline{0}$ & 0,08 & 0,71 & 1 & 0,40 & 0,94 & $0, \overline{0}$ & 0,08 & 0,55 & 1 & 0,46 & 0,94 & 0,05 & 0,13 & 0,15 & 1 & 0,70 & 0,95 \\
\hline $\begin{array}{l}\text { LOKACIJA ŠKOLE (centralitet grada): } \\
\text { ref=mali grad }\end{array}$ & & & 58,42 & 2 & 0,00 & & & & 54,15 & 2 & 0,00 & & & & 30,40 & 2 & 0,00 & \\
\hline \multirow{2}{*}{$\begin{array}{l}1=\text { glavni } \mathrm{grad} \\
2=\text { veliki } \mathrm{grad}\end{array}$} & 1,23 & 0,43 & 8,04 & 1 & $\mathbf{0 , 0 1}$ & 3,43 & 1,18 & 0,45 & 6,96 & 1 & $\mathbf{0 , 0 1}$ & 3,24 & 1,03 & 0,56 & 3,42 & 1 & 0,06 & 2,80 \\
\hline & $\overline{1,04}$ & 0,16 & 43,63 & 1 & $\mathbf{0 , 0 0}$ & 0,35 & $\begin{array}{c}- \\
1,01\end{array}$ & 0,16 & 41,20 & 1 & $\mathbf{0 , 0 0}$ & 0,37 & $\begin{array}{c}- \\
1,33\end{array}$ & 0,28 & 23,25 & 1 & $\mathbf{0 , 0 0}$ & 0,27 \\
\hline \multirow[t]{3}{*}{$\begin{array}{l}\text { REZIDENCIJALNO } \\
\text { ref }=\text { ruralno }\end{array}$} & & & 8,07 & 2 & 0,02 & & 0,15 & 0,16 & 0,85 & 1 & 0,36 & 0,86 & & & & & & \\
\hline & $\overline{-},-15$ & 0,16 & 0,90 & 1 & 0,34 & 0,86 & & & & & & & & & & & & \\
\hline & 1,31 & 0,52 & 6,47 & 1 & $\mathbf{0 , 0 1}$ & 3,71 & & & & & & & & & & & & \\
\hline Constant & $6, \overline{0}$ & 0,68 & 78,09 & 1 & 0,00 & 0,02 & 5,86 & 0,69 & 71,45 & 1 & 0,00 & 0,03 & 5,06 & 1,16 & 19,09 & 1 & 0,00 & 0,01 \\
\hline korak & \multicolumn{6}{|c|}{ Cox \& Snell $\mathbf{R}^{2}=0,09 ;$ Nagelkerke $\mathbf{R}^{2}=\mathbf{0 , 1 2}$} & \multicolumn{6}{|c|}{ Cox \& Snell $\mathbf{R}^{2}=0,10 ;$ Nagelkerke $\mathbf{R}^{2}=\mathbf{0 , 1 4}$} & \multicolumn{6}{|c|}{ Cox \& Snell $\mathbf{R}^{2}=0,09 ;$ Nagelkerke $\mathbf{R}^{2}=\mathbf{0 , 1 2}$} \\
\hline korak & \multirow{2}{*}{\multicolumn{6}{|c|}{ Cox \& Snell $\mathbf{R}^{2}=0,11 ;$ Nagelkerke $\mathbf{R}^{2}=\mathbf{0 , 1 5}$}} & \multicolumn{6}{|c|}{ Cox \& Snell $\mathbf{R}^{2}=0,12 ;$ Nagelkerke $\mathbf{R}^{2}=\mathbf{0 , 1 5}$} & \multicolumn{6}{|c|}{ Cox \& Snell $\mathbf{R}^{2}=0,13 ;$ Nagelkerke $\mathbf{R}^{2}=\mathbf{0 , 1 7}$} \\
\hline korak & & & & & & & \multicolumn{6}{|c|}{ Cox \& Snell $\mathbf{R}^{2}=0,13 ;$ Nagelkerke $\mathbf{R}^{2}=\mathbf{0 , 1 7}$} & \multirow{2}{*}{\multicolumn{6}{|c|}{$\begin{array}{l}\text { Cox \& Snell } \mathbf{R}^{2}=0,13 ; \text { Nagelkerke } \mathbf{R}^{2}=\mathbf{0 , 1 8} ; \\
\text { Omnibus test: }(12)=84,16 ; p=0,00 ; \\
\text { Hosmer i Lemeshow test: }(8)=9,25 ; p=0,32 ; \\
\text { Postotak točnih predviđanja: } 68 \% \\
\text { Cox \& Snell } \mathbf{R}^{2}=0,21 ; \text { Nagelkerke } \mathbf{R}^{2}=\mathbf{0 , 2 9} ;\end{array}$}} \\
\hline korak & \multicolumn{6}{|c|}{ Cox \& Snell $\mathbf{R}^{2}=0,28 ;$ Nagelkerke $\mathbf{R}^{2}=\mathbf{0 , 3 8}$} & $\operatorname{Cox}$ & Snell & ${ }^{2}=0,19$; & 1 & kerke & $2^{2}=0,25$ & & & & & & \\
\hline korak & $\begin{array}{c}\text { Omn } \\
\text { Hosn } \\
\text { Post } \\
\text { Cox }\end{array}$ & $\begin{array}{l}\text { us tes } \\
\text { r i Le } \\
\text { ak toč } \\
\text { Snell }\end{array}$ & $\begin{array}{l}(14)=38 \\
\text { eshow } \\
\text { ih predv } \\
{ }^{2}=0,29 ;\end{array}$ & & $\begin{array}{l}p=0,00 \\
=7,51 \\
74 \% \\
\text { kerke }\end{array}$ & $\begin{array}{l}\mathrm{p}=0,48 \\
\mathbf{2}^{\mathbf{2}}=\mathbf{0 , 3 9}\end{array}$ & $\begin{array}{l}\text { Omn } \\
\text { Hosn } \\
\mathrm{p}=0,2 \\
\text { Post } \\
\text { Cox }\end{array}$ & $\begin{array}{l}\text { ous test } \\
\text { er i } \\
4 ; \\
\text { tak toč } \\
\text { Snell }\end{array}$ & $\begin{array}{l}(13)=19 \\
\text { Lemesh } \\
\text { ih predv } \\
{ }^{2}=0,19 ;\end{array}$ & & $\begin{array}{l}=0,00 \\
\text { est: } \\
68 \% \\
\text { kerke }\end{array}$ & $\begin{array}{l}=10,31 \\
\mathbf{2}^{2}=\mathbf{0}, \mathbf{2 5}\end{array}$ & & & & & & \\
\hline
\end{tabular}


Dakle, izbor Zagreba kao željenog mjesta studiranja izglednije je za učenike koji imaju bolji školski uspjeh $(B=0,81)$ i razvijenije kulturne kompetencija u vidu njihove učestalosti sudjelovanja u kulturnim aktivnostima $(B=0,37)$ te one čiji roditelji imaju stalnije prihode $(B=0,31)$ i koji pohađaju škole kojima procjenjuju viši status $(B=0,37)$. Također, $u$ odnosu na učenike koji škole pohađaju u malim gradovima, izbor Zagreba izgledniji je za one koji škole pohađaju upravo u glavnom gradu $(B=1,23)$, a manje izgledan za učenike koji škole pohađaju u ostalim velikim gradovima Hrvatske $(B=-1,04)$. S tim je u skladu i rezultat da je izbor Zagreba izgledniji, u odnosu na one odrasle ne selu, za učenike odrasle u metropoli $(B=1,31)$.

No, kada se iz analize isključe učenici metropolitanskog rezidencijalnog podrijetla, objašnjenost ukupnog modela, očekivano, pada (25\%), a kao statistički značajan pojavljuje se još jedan prediktor iz seta individualnih varijabli, čime se naglasak izbora Zagreba kao mjesta studiranja stavlja na školsku uspješnost učenika i njihove razvijene kulturne kompetencija. Izbor glavnog grada kao mjesta studiranja izgledniji je za one nemetropolitanske učenike koji su imali bolji prosjek ocjena u prošlom razredu $(B=0,75)$, te koji u većoj mjeri posjećuju programe kulturnih institucija $(B=0,36)$ i čitaju $(B=0,19)$. I dalje jedina obiteljska karakteristika koja povećava izglednost učenika da će Zagreb odabrati za mjesto svog studiranja ostaje stalnost prihoda roditelja $(B=0,30)$. Konačno, izvjesnost izbora Zagreba povećava i pohađanje škola višeg procijenjenog statusa $(B=0,34)$, i koje su locirane $u$ glavnom gradu $(B=1,18)$, u odnosu na one locirane u malom gradu, te za one koji se školuju u manjem gradu u odnosu na one koji škole pohađaju u velikom gradu $(B=-1,01)$

Opisano navodi na zaključak da je odabir Zagreba kao mjesta studiranja vjerojatnije za nemetropolitanske učenike veće uspješnosti i razvijenijih kulturnih kompetencija koji, prvenstveno, u svojoj blizini nemaju dostupne alternative željenom studiju, odnosno moraju se seliti za vrijeme studija te svoje osobno razvijene kapitale i dostupne obiteljske resurse usmjeravaju u studiranje u Zagrebu. S te strane, samo rezidencijalno podrijetlo ne doprinosi bitno objašnjenju izbora Zagreba što u velikoj mjeri „povezuje“ mjesto u kojem učenici završavaju svoje srednjoškolsko obrazovanje.

Takav zaključak dodatno potkrepljuje analiza provedena na uzorku učenika ruralnog rezidencijalnog podrijetla (Slika 3.14) za koje je preseljenje za vrijeme studija nužnost. 


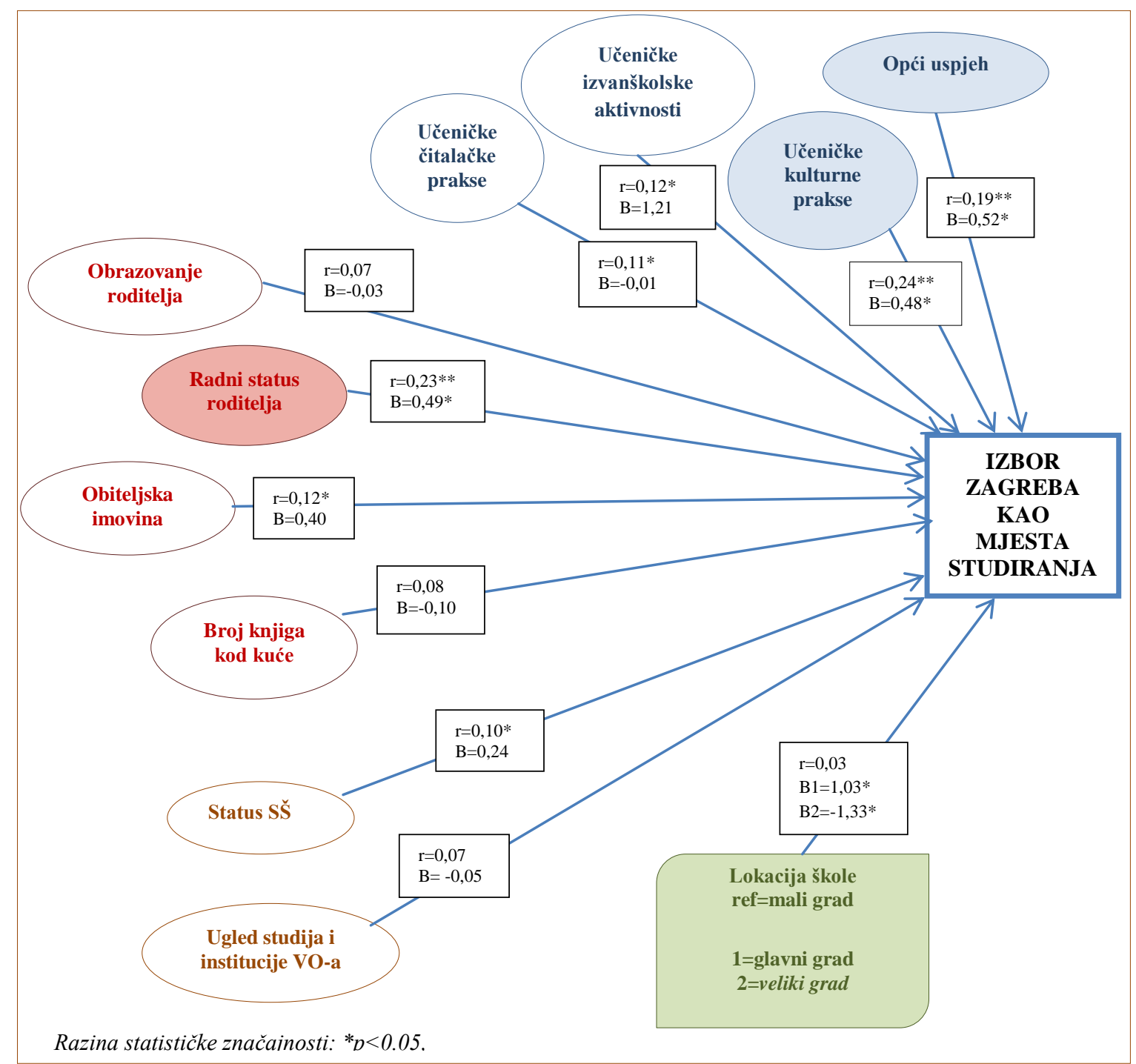

Slika 3.14 Regresijski model za objašnjenje izbora Zagreba kao mjesta studiranja za maturante koji su odrasli na selu

Analiza na tom uzorku učenika izdvaja malo značajnih prediktora od kojih, prema doprinosu objašnjenju, najveći značaj pokazuju individualne varijable (12\%), te lokacija škole (11\%). Odnosno, izbor Zagreba kao mjesta studiranja izglednije je za učenike ruralnog rezidencijalnog podrijetla koji imaju bolje ocjene $(B=0,52)$ te višu razinu kulturnog kapitala izraženog kao učestalost kulturnih praksi $(B=0,48)$, ali i koji u obiteljima imaju dostupan ekonomski kapital, u obliku stalnijih roditeljskih primanja $(B=0,50)$. Uz te odrednice, odluka o studiranju u glavnom gradu vjerojatnija je za one koji škole pohađaju u malim gradovima u odnosu na one koji škole pohađaju u gradovima većeg stupnja centraliteta $(B=-1,33)^{78}$.

\footnotetext{
${ }^{78}$ Spomenimo i da u ovom testu modela postoji barem još 2 varijable koje se pokazuju kao ,potencijalni“ prediktori“ (Wald>2,0), čiji su B koeficijenti „na rubu“ statističke značajnosti ( $\mathrm{p}>0,05)$. To su učeničke izvanškolske aktivnosti $(B=1,21 ; p=0,06)$, i pohađanje škole u glavnom gradu $(B=1,03 ; p=0,06)$.
} 
Tabela 3.25 Osnovna istraživačka pitanja vezana uz učeničke izbore mjesta studiranja, analize te nalazi i interpretacija

\begin{tabular}{|c|c|c|c|c|}
\hline & Istraživačka pitanja & $\begin{array}{c}\text { Način } \\
\text { odgovaranja } \\
\text { na pitanje }\end{array}$ & $\begin{array}{c}\text { Značajni prediktori i } \\
\text { njihov doprinos } \\
\text { objašnjenju }\end{array}$ & Interpretacija nalaza \\
\hline I. & $\begin{array}{l}\text { Koji sklop individualnih, } \\
\text { obiteljskih i } \\
\text { institucionalnih, te } \\
\text { sociogeografskih varijabli } \\
\text { najbolje objašnjava } \\
\text { učenički izbor Zagreba } \\
\text { kao mjesta studiranja? }\end{array}$ & $\begin{array}{l}\text { Izgradnja } \\
\text { regresijskog } \\
\text { modela u } 5 \\
\text { koraka; } \\
\text { Uvođenje u } \\
\text { model varijable } \\
\text { rezidenciialnoo }\end{array}$ & $\begin{array}{l}\text { Ukupno objašnjenje } \\
\text { kriterija modelom: } 39 \% \\
\text { Individualni prediktori: } \\
\text { prošlogodišnji řkolski } \\
\text { uspjeh i učeničke kulturne } \\
\text { prakse - } 12 \% \\
\text { Obiteliske variiable }\end{array}$ & $\begin{array}{l}\text { Izglednije ja da učenici koji } \\
\text { namjeravaju studirati: } \\
\text { - imaju bolji prosjek i češće } \\
\text { sudjeluju u kulturnim } \\
\text { praksama } \\
\text { - dolaze iz obitelji čiji roditelji } \\
\text { imaju stalnije prihode } \\
\text { - pohađaju škole kojima }\end{array}$ \\
\hline & $\begin{array}{l}\text { Postoji li jedinstveni } \\
\text { doprinos rezidencijalnog } \\
\text { podrijetla, uz kontrolu } \\
\text { ostalih varijabli u modelu, } \\
\text { objašnjenju izbora } \\
\text { Zagreba kao mjesta } \\
\text { studiranja? }\end{array}$ & $\begin{array}{l}\text { podrijetla u } \\
\text { zadnjem } \\
\text { koraku; } \\
\text { Usporedna } \\
\text { analiza } \\
\text { pojedinih } \\
\text { koraka } \\
\text { objašnjenju } \\
\text { kriterija; }\end{array}$ & $\begin{array}{l}\text { status roditelja)-3\% } \\
\text { Varijable institucionalnih } \\
\text { karakteristika (status } \\
\text { srednje škole) }-2 \% \\
\text { Sociogeografske } \\
\text { varijable: } \\
\text { - lokacija škole-21\% } \\
\text { - rezidencijalno podrijetlo } \\
-\mathbf{1 \%}\end{array}$ & $\begin{array}{l}\text { - pohađaju škole u glavnom } \\
\text { gradu, a manje je izgledno za } \\
\text { one koji škole pohađaju u } \\
\text { velikom gradu, u odnosu na } \\
\text { one koji škole pohađaju u } \\
\text { malom gradu } \\
\text { - imaju metropolitansko } \\
\text { rezidencijalno podrijetlo, u } \\
\text { odnosu na učenike odrasle na } \\
\text { selu }\end{array}$ \\
\hline
\end{tabular}

Postoje li razlike $u$ djelovanju modela za

II objašnjenje izbora

Zl Zagreba kao mjesta studiranja kod učenika različitog rezidencijalnog podrijetla?
Testiranje općeg modela na dvije potkategorije učenika: 1) isključeni učenici metropole, i 2) samo ruralni učenici
Koji sklop individualnih, obiteljskih i

A izvanobiteljskih varijabli najbolje objašnjava izbor Zagreba kao mjesta studiranja učenika koji nisu odrasli u metropoli?
Ukupno objašnjenje

modela

$-25 \%$;

1. prošlogodišnji

školski uspjeh te učeničke

kulturne i čitalačke prakse $(14 \%)$

$2 . \quad$ radni status

roditelja $(1 \%)$

3. status škole $(2 \%)$

4. lokacija škole

$(8 \%)$

5.

Namjera studiranja učenika koji nisu odrasli u metropoli izglednije je za one koji:

- $\quad$ imaju bolji prosjek i

češće sudjeluju u kulturnim i

čitalačkim praksama

- $\quad$ dolaze iz obitelji čiji

roditelji imaju stalnije prihode

- pohađaju škole

kojima pripisuju viši status

- pohađaju škole u

glavnom gradu, a manje je izgledno za one koji škole pohađaju u velikom gradu, u odnosu na one koji škole pohađaju u malom gradu

Namjera studiranja učenika

Ukupno objašnjenje modela - $18 \%$;

Koji sklop individualnih, obiteljskih i izvanobiteljskih, te sociogeografskih varijabli najbolje objašnjava izbor Zagreba kao mjesta studiranja učenika odraslih u ruralnom okolišu?
1. prošlogodišnji

školski uspjeh i učeničke

kulturne prakse (12\%)

$2 . \quad$ radni status

roditelja $(5 \%)$

$$
\begin{array}{ll}
3 . & - \\
4 . & \text { lokacija škole }
\end{array}
$$
odraslih na selu izglednije je za one koji:

- češće sudjeluju u kulturnim praksama dolaze iz obitelji čiji roditelji imaju stalnije prihode pohađaju škole u malim gradovima u odnosu na one koji škole pohađaju u velikim gradovima 
Dakle, kada je u pitanju izbor grada u kojem će učenici studirati on je u najvećoj mjeri određen samom sociogeografskom pozicijom škole u kojoj učenici dobivaju svoje obrazovanje, a zatim i njihovim individualnim karakteristikama mjerljivima školskim uspjehom i kulturnim kompetencijama. Od obiteljskih varijabli u ovom izboru se značajnijim pokazuju ekonomske varijable, i to u vidu obiteljskih prihoda. Taj osnovni obrazac potvrđuje se u nekoliko analiza, s malim razlikama i s obzirom na specifičnosti poduzoraka na kojima je testiran, potvrđujući relativnu robusnost modela.

\subsubsection{Zaključno o učinku rezidencijalnog podrijetla učenika na njihovu namjeru studiranja i visokoobrazovne izbore}

Dva različita osnovna pitanja pokretala su provedene analize u ovom poglavlju i zahtijevala su drugačije pristupe, i s obzirom na karakteristike učenika, odnosno uzorke, i s obzirom na prediktore koji ih mogu objasniti. S jedne strane, postavljeno je pitanje o namjeri studiranja učenika, skupu varijabli individualnih, obiteljskih i izvanobiteljskih odrednica tog izbora te utjecaju koji sociogeografske varijable mogu imati na tu odluku, odnosno koliko se te odluke razlikuju s obzirom na različito rezidencijalno podrijetlo učenika.

S druge strane, za one učenike koji namjeravaju studirati, eksplorativnije pitanje je bilo koji se skup varijabli - individualnih, obiteljskih i institucionalnih - pokazuje značaj odrednica specifičnih visokoobrazovnih izbora - tipa studija i mjesta studiranja, te koji je utjecaj sociogeografskih varijabli na te izbore, odnosno koliko se te odrednice razlikuju za izbore učenike ruralnog rezidencijalnog podrijetla učenika.

Prethodno predstavljene Tabele 3.20, 3.23 i 3.25 daju sažetke pojedinih postavljenih pitanja, upotrijebljenih analiza te osnovnih nalaza. Ovdje zaključno usporedno ukazujemo na osnovne nalaze imajući u vidu različitost pitanja i uzoraka pojedinih analiza.

Izgrađeni model od 5 koraka (koji su uključivali individualne, obiteljske te izvanobiteljske i sociogeografske varijable) u velikoj mjeri je objasnio namjeru studiranja pri čemu su varijable svakog skupa dale svoj doprinos, koji je veličinom odgovarao „ekološkom modelu“ prema kojima su uvođene u analizu: individualne varijable vrijednosti pripisane učenju i želje za društvenom mobilnošću doprinijele su s $15 \%$ objašnjenja, obiteljske s $8 \%$, izvanobiteljske (prvenstveno školske) s 3\%, te sociogeografske (prvenstveno mjesto odrastanja) s $1 \%$. 
Potvrđena je hipoteza H2a, s obzirom na nalaze da rezidencijalno podrijetlo daje mali, ali jedinstven doprinos objašnjenju učeničkih namjera u sklopu izgrađenog modela koji ukazuje da je namjera studiranja izglednija za one učenike koji više vrednuju učenje i teže društvenoj mobilnosti, koji odrastaju u obiteljima bogatijih kulturnih i ekonomskih resursa, i pohađaju škole višeg statusa te imaju urbano rezidencijalno podrijetlo (u odnosu na one koji odrastaju na selu.

Stoga je provjereno i kako se doprinos ukupnog modela i pojedinih prediktora odražava u namjeri studiranja učenika različitog rezidencijalnog podrijetla. Pokazalo se da model najbolje, i s najvećim razlikama u odnosu na rezultate na ukupnom uzorku, objašnjava namjeru studiranja učenika odraslih u metropoli (51\%). Pri tom najveći doprinos daju obiteljske karakteristike izražene kao viši obrazovni status roditelja i viši imovinski status obitelji - čak 34\%. Taj nalaz u skladu je s prethodnim analizama usporedbe učenika različitog rezidencijalnog podrijetla prema dostupnosti različitih kapitala koji se ukazali na najpovoljniju strukturu takvih kapitala za učenike metropolitanskog rezidencijalnog podrijetla koji namjeravaju studirati. No, ovdje prezentirane analize dodatno daje potvrdu o postojanju određenih sociogeografskih nejednakosti distribucije resursa važnih za pristup visokom obrazovanju. Ovakva obiteljska struktura kapitala povezuje se $\mathrm{i}$ s individualnim vrednovanjem učenja (ne i željom za društvenom mobilnošću, već vjerojatno reprodukcijom društvenog statusa) i obrazovanjem u školama višeg statusa koja namjeru studiranja učenika odraslih u glavnom gradu čini izglednijom. U usporedbi s testovima modela na poduzorcima učenika izvanmetropolitanskog rezidencijalnog podrijetla, doprinos individualnih karakteristika je daleko manji - tek 9\%, dok je doprinos školskih varijabli, prvenstveno statusa, daleko veći - čak 8\%. Budući da znamo da najveći dio metropolitanskih učenika pohađa gimnazije $^{79} \mathrm{i}$ da postoji tendencija da učenici metropolitanskog podrijetla (a koji gotovo u potpunosti i pohađaju škole u glavnom gradu) svojim školama procjenjuju viši status, nalazi nisu iznenađujući i čine logički povezanu cjelinu koja potkrepljuje početne pretpostavke.

Za razliku od te analize, model u najmanjoj mjeri objašnjava namjeru studiranja učenika koji odrastaju u urbanim (36\%), a podjednako za one odrasle u ruralnim okolišima (41\%). Osnovna razlika dva testiranja modela na ta dva poduzorka u odnosu na poduzorak metropolitanskih učenika vidljiva je u porastu značaja individualnih varijabli, odnosno

\footnotetext{
${ }^{79}$ Vidi u poglavlju Uzorak anketiranih učenika različitog rezidencijalnog podrijetla
} 
značaju kojeg želja za društvenom mobilnošću dobiva za te učenike, a povezano s vrijednošću koju pripisuju učenju, te smanjenju objašnjenja obiteljskim varijablama. Blage razlike postoje između 2 testa kada pogledamo ostale odrednice $\mathrm{s}$ kojima se individualni indikatori obrazovno-društvene mobilnosti povezuju. Općenito, u oba testa u usporedbi s utjecajem kojeg pokazuju obiteljske karakteristike za metropolitanske učenike, obiteljski indikatori objašnjavaju upola manje (oko 18\%) varijance namjere studiranja. Taj utjecaj je kod učenika ruralnog rezidencijalnog podrijetla isključivo vezan uz kulturni kapital dostupan u obiteljima i izražen kao broj posjedovanih knjiga i obrazovanje roditelja. Kod učenika urbanog rezidencijalnog podrijetla utjecaji obiteljskog konteksta vezan je i uz ekonomske aspekte, ali ne u vidu imovinskog statusa, već u aspektu stalnosti prihoda od zaposlenja roditelja. Konačno, za učenike urbanog i ruralnog podrijetla, u odnosu na metropolitanske učenike, i školski utjecaj je ponešto različit. Za urbane učenike doprinos pohađanja statusne škole kao odrednice namjere studiranja nešto je manji (2\%), dok se kod učenika ruralnog rezidencijalnog podrijetla povezuje i s lokacijom, odnosno stupnjem centraliteta grada $\mathrm{u}$ kojem završavaju škole (3. +4 . korak modele=4\%). Navedeno upućuje na značaj geografije i/ili dostupnosti određenim „urbanim“ resursima kada je u pitanju namjera studiranja učenika. Dodatno, taj zaključak potvrđuje i nalaz prema kojem je izglednija namjera studiranja učenika odraslih u određenim tipovima ruralnih naselja - ekonomski diverzificiranima, te onima dostupnijima i o cirkulaciji ovisnima - u odnosu na one odrasle u naseljima kojima je tržišno orijentirana poljoprivreda glavni prihod kućanstva. Navedeni tipovi naselja kontekstualno su vezani, odnosno opisuju karakteristike realnih naselja hrvatskog sociogeografskog prostora, a svojom zastupljenošću odražavaju i regionalne karakteristike: ekonomski diverzificirana, pretežito turistička naselja ograničena su na priobalni pojas, otoke i male prostore turističkog ili ekonomski diferenciranog zaleđa, dok se dostupnija, o cirkulaciji ovisna naselja, nalaze u zagrebačkom prstenu te Hrvatskom zagorju. Tržišno orijentirana poljoprivredna naselja pak najzastupljenija su u Istočnoj Hrvatskoj. S obzirom na to, podaci ukazuju i na postojanje regionalnih nejednakosti kada je u pitanju učenička namjera studiranja.

$\mathrm{S}$ jedne strane, prethodne analize potvrdile su teorijske pretpostavke o značaju obiteljskih i školskih resursa za obrazovne ishode učenika. S druge strane, prethodne analize produbile su ih u geografskoj dimenziji pokazujući kako geografski aspekti imaju svoje mnogostrane, iako uvelike indirektne efekte, na učeničku namjeru studiranja. Sljedeći cilj rada bio je ispitati i mogućnost da takve odrednice - dostupnost resursa i sociogeografske varijable obiteljskog i školskog okruženja učenika - utječu i na odabire visokog obrazovanja: tip studija i mjesto 
studiranja. Tim pitanjima prilagođen je i model, koji je kontroliran i prema mjestu odrastanja učenika s obzirom na podatke na koja su ukazala prethodna ispitivanja hrvatskog studentskog tijela i prema kojima gotovo polovica studenata studira u mjestu u kojima su pohađali srednje škole (Farnell, 2011; Jokić, Ristić Dedić, 2014).

U sklopu izgrađenog modela, koji ukazuje da je izgledniji odabir sveučilišnog studija za uspješnije učenike razvijenih kulturnih kompetencija koji odrastaju u obiteljima većih razina kulturnog kapitala i pohađaju škole u velikim gradovima (u odnosu na one koji se školuju u malim gradovima), te odrastaju u gradovima (izuzev Zagreba) (u odnosu na one ruralnog rezidencijalnog podrijetla), potvrđen je mali, ali statistički značajan, doprinos (1\%) rezidencijalnog podrijetla za objašnjenje izbora sveučilišnog studija (H2b).

Također, analize su pokazale prvenstveni prediktivni značaj individualnih varijabli, odnosno da izbor sveučilišnog studija izglednijim čine, doprinosom objašnjenju, bolje ocjene i razvijenije kulturne kompetencije učenika, nego ostale karakteristike obiteljskog i institucionalnog konteksta. To je posebno istaknuto u uzorku učenika koji nisu odrasli u glavnom gradu među kojima je izgledniji izbor sveučilišnog studija za one s boljim ocjenama i razvijenijim kulturnim kompetencijama te školovanje u velikom gradu i „urbano“ odrastanje. Navedeno navodi na značaj urbanosti kao značajnog kulturnog kapitala za sveučilišno studiranje, pri čemu je školovanje u velikom gradu glavna intervenirajuća varijabla za omogućavanje razvoja individualno značajnih obrazovnih kapitala. To dodatno potvrđuje test modela na uzorku učenika odraslih na selu čiji izbor sveučilišnog studija izglednijim objašnjavaju samo osobne kulturne kompetencije i školovanje u velikom gradu.

Vrlo slično, visokoobrazovni izbor vezan uz izbor mjesta studiranja, odnosno Zagreba kao mjesta studiranja, pokazuje dva glavna seta odrednica: s jedne strane, prethodno navedenu vezu između sociogeografskih aspekta nečijeg odrastanja i školovanja s budućim mjestom studiranja, te individualnih karakteristika koje taj izbor omogućavaju.

U sklopu izgrađenog modela, koji ukazuje da je izglednije odabir Zagreba kao mjesta studiranja za uspješnije učenike razvijenih kulturnih kompetencija koji odrastaju u obiteljima većih razina ekonomskog kapitala i pohađaju škole višeg statusa u glavnom gradu, te u malim gradovima ( $u$ odnosu na one koji se školuju u velikim gradovima), te odrastaju u glavnom gradu (u odnosu na one ruralnog rezidencijalnog podrijetla), potvrđen je mali, ali statistički značajan doprinos rezidencijalnog podrijetla $(1 \%)$ za objašnjenje izbora sveučilišnog studija izbora Zagreba kao željenog mjesta studiranja (H2c). 


\section{REGIONALNA ANALIZA MJEŠOVITIH PODATAKA: VISOKOOBRAZOVNI IZBORI SLAVONSKIH UČENIKA}

\subsection{Uvod}

Zašto je odabrana Slavonija? Prvi razlog takvom odabiru nastao je prije provedbe samog istraživanja kao dio početnih pretpostavki i usmjeravanja interesa na regiju koja se $\mathrm{u}$ hrvatskom kontekstu i popularnom diskursu poima kao „ruralni kraj Hrvatske“. U predgovoru knjizi Selo - iz autentičnosti u neprepoznatljivost, Šundalić ističe: „, Istraživati selo i ruralni prostor u Hrvatskoj danas implicira razmišljanje da je riječ o Slavoniji“ (Šundalić 2010: 9). No, radi se i o posebnom shvaćanju ruralnosti toga prostora. U svom ranom posttranzicijskom razdoblju, taj prostor najbolje opisuje pojam periferizacije, pri čemu se periferonost Slavonije odnosi „na geografski smještaj $i$ prometnu nepovezanost, na prostornu udaljenost od političkog centra odlučivanja, na marginaliziranost dominirajuće djelatnosti kraja, na loše privatizacijske odluke koje su ugušile većinu proizvodnih kapaciteta, i dakako, na najdužu ratnu sudbinu s velikim ljudskim i materijalnim gubicima“ (Šundalić 2010:10). Dodatno, dublja osobna upoznatost istraživača (odrastanja i rada) i lakša dostupnost kada je u pitanju terenski rad istraživačkog procesa olakšala je izbor regije Slavonija kao osnovnog konteksta daljnjih ispitivanja.

Drugi razlog izbora regije dale su osnovne preliminarne analize skupljenih podataka anketnim ispitivanjem koje su uključivale analizu regionalnih razlika prema osnovnim elementima učeničkih namjera studiranja i visokoobrazovnih izbora te kapitala dostupnih u obitelji i školama (Klepač, 2015). Nalazi tog ispitivanja ukazali su na postojanje regionalnih razlika i specifičnosti strukture kapitala kojima raspolažu učenici pojedinih regija, a koji su im dostupni u njihovom obiteljskom i školskom okruženju. U odnosu na ostale hrvatske regije, a u najvećoj mjeri zagrebačku, rezultati su ukazali da učenici Slavonije imaju niže razine potencijalno značajnih visokoobrazovnih kapitala kada je u pitanju obrazovanje osoba iz njihova užeg i šireg obiteljskog kruga, posjedovanje knjiga i kulturnih dobara, te roditeljske i učeničke kulturne prakse, a također su za njih karakterističnije niže razine obiteljskog ekonomskog kapitala (posjedovanje imovine i procjena financijske obiteljske situacije). U konačnici, ovi učenici imaju i slabije školske ocjene i tek ih se nešto više od polovice odlučuje za studiranje (što je za 10\% manje u odnosu na nacionalni uzorak).

I navedeni empirijski podaci na nacionalnom uzorku u hrvatskom kontekstu, kao i suvremena strujanja u sociologiji pod utjecajem takozvanog prostornog zaokreta (Lobao, Hooks, 
Tickamyer 2007) ${ }^{80}$, ističu potrebu i produbljuju istraživački interes za regionalna istraživanja, posebno u sociološkim istraživanja društvenih nejednakosti, ili traženje „sociološke sredine koja nedostaje“ (Lobao, Hooks, 2007). Navedeno objašnjava, s obzirom na naglasak koji je pritom stavljen na kontekst, i način na koji je izgrađen nacrt istraživanja, kako je provedeno istraživanje, kako su upotrijebljene tehnike i metode prikupljanja i obrade podataka, te kako su prezentirani rezultati.

Tabela 4.1 Rezultati ispitivanja razlika između slavonskih maturanata različitog rezidencijalnog podrijetla prema obrazovnim karakteristikama i orijentacijama, te dostupnim kapitalima i simboličkom značaju konteksta odrastanja i školovanja

\begin{tabular}{|c|c|c|c|}
\hline \multicolumn{3}{|c|}{$\begin{array}{l}\text { Rezultati analiza rezidencijalnih razlika na pojedinim } \\
\text { mjerama - uzorak slavonskih maturanata }\end{array}$} & $\begin{array}{l}\text { REZIDENCIJALNO PODRIJETLO } \\
\text { 1) ruralno }-\mathrm{N}=210(49 \%) \\
\text { 2) urbano }-\mathrm{N}=\mathbf{2 2 0}(\mathbf{5 1 \%})\end{array}$ \\
\hline & Mjere & Analize & Osnovni nalazi: \\
\hline $\begin{array}{l}\text { SOCIO- } \\
\text { GEOGRAFSKE } \\
\text { VARIJABLE }\end{array}$ & Lokacija škole & $\chi^{2}$ & $\begin{array}{l}\text { - } 49 \% \mathrm{U}_{\text {URP }} \text { završava škole u „velikim gradovima“, a } 51 \% \\
\text { u „malim gradovima“; } \\
\text { najveći dio } U_{\text {RRP }} \text { škole pohađa u malim gradovima ( } 66 \% \text { ), } \\
\text { a } 34 \% \text { u velikim gradovima. }\end{array}$ \\
\hline $\begin{array}{l}\text { OBRAZOVNI } \\
\text { ISHODI }\end{array}$ & $\begin{array}{l}\text { Vrsta studija (za one koji } \\
\text { namjeravaju studirati)* } \\
\text { Mjesto studiranja (za one koji } \\
\text { namjeravaju studirati)* }\end{array}$ & $\chi^{2}$ & $\begin{array}{l}\text { - manje } U_{R R P} \text { se odlučuje na nastavak školovanja na } \\
\text { visokoškolskoj razini }\left(41 \%<U_{U R P}=69 \%\right) \\
\text { - } U_{\text {RRP }} \text { se u većoj mjeri odlučuju za stručni studij }(24 \%> \\
\left.U_{U R P}=12 \%\right) \\
\text { - želja za studiranjem u glavnom gradu slabije je izražena } \\
\text { kod } U_{R R P}\left(28 \%<U_{U R P}=43 \%\right)\end{array}$ \\
\hline \multirow[b]{2}{*}{$\begin{array}{l}\text { Obrazovne } \\
\text { karakteristike }\end{array}$} & Tip škole* & $\chi^{2}$ & $\begin{array}{l}\text { - manje } U_{R R P} \text { pohađa gimnazije }\left(9 \%<U_{U R P}=37 \%\right) \text {, a } \\
\text { više } U_{R R P} \text { pohađa trogodišnje strukovne škole }(41 \%> \\
\left.U_{U R P}=22 \%\right) ;\end{array}$ \\
\hline & $\begin{array}{l}\text { Školski uspjeh* } \\
\text { Vrijednost pripisana učenju }\end{array}$ & t-test & $\begin{array}{l}\text { - } \mathrm{M}_{\mathrm{RRP}}=3,6 \text { općeg uspjeha u prošlom razredu je statistički } \\
\text { značajno niži u odnosu na } \mathrm{M}_{\mathrm{URP}}=3,7 \\
\text { - ne postoje statistički značajne razlike } \mathrm{M}=3,6 \text { rezultatu } \\
\text { vrijednosti pripisane učenju između } U_{R R P} \text { i } U_{U R P}\end{array}$ \\
\hline $\begin{array}{l}\text { Obrazovne } \\
\text { orijentacije } \\
\text { (Aspiracijski/ } \\
\text { obrazovni habitus } \\
\text { učenika) }\end{array}$ & $\begin{array}{l}\text { Obrazovna očekivanja* } \\
\text { Podrazumijevanje studiranja* } \\
\text { Dužina promišljanja odluke* }\end{array}$ & $\chi^{2}$ & $\begin{array}{l}\text { - veći broj } U_{R R P} \text { želi završiti srednju školu }\left(44 \%>U_{U R P}\right. \\
=24 \%) ; \text { a manje ih teži najvišim visokoobrazovnim } \\
\text { stupnjevima }\left(40 \%<U_{U R P}=76 \%,\right) \\
\text { - za } U_{R R P} \text { najviše se povećavaju kategorije očekivanih } \\
\text { najnižih stupnjeva obrazovanja - završavanja srednje } \\
\text { škole (na } 51 \%) \\
\text { - manje } U_{R R P} \text { smatra da im se studiranje podrazumijeva } \\
\left(34 \%<U_{U R P}=62 \%\right) \\
\text { - manje } U_{R R P}=39 \% \text { je bez razmišljanja donijelo odluku o } \\
\text { studiranju }\left(<U_{U R P}=53 \%\right)\end{array}$ \\
\hline $\begin{array}{l}\text { HORIZONT } \\
\text { BUDUĆNOSTI }\end{array}$ & $\begin{array}{l}\text { Želja za društvenom } \\
\text { mobilnošću }\end{array}$ & t-test & $\begin{array}{l}\text { - nema statistički značajnih razlika u } M=3,5 \text { želje za } \\
\text { društvenom mobilnošću između } U_{R R P} \text { i } U_{U R P}\end{array}$ \\
\hline $\begin{array}{l}\text { Kulturne } \\
\text { kompetencija } \\
\text { učenika }\end{array}$ & $\begin{array}{l}\text { Uč. kulturne prakse* } \\
\text { Uč. čitalačke prakse* } \\
\text { Uč. izvanškolske aktivnosti* }\end{array}$ & t-test & $\begin{array}{l}\text { - } U_{R R P} \text { imaju statistički značajno niži prosječni rezultat na } \\
\text { sve tri mjere kulturnih kompetencija }(M=1,4 ; M=0,1 ; \\
M=2,0) \text { u odnosu na } U_{U R P}(M=1,7 ; M=0,2 ; M=2,3)\end{array}$ \\
\hline \multirow[t]{2}{*}{$\begin{array}{l}\text { Ekonomsko- } \\
\text { materijalna } \\
\text { situacija } \\
\text { obitelji }\end{array}$} & $\begin{array}{l}\text { Radni status roditelja* } \\
\text { Posjedovanje imovine* }\end{array}$ & $\chi^{2}$ & \multirow{2}{*}{$\begin{array}{l}\text { - daleko manje } U_{R R P} \text { ima oba roditelja sa stalnim } \\
\text { prihodima }\left(16 \%<U_{U R P}=41 \%\right) \text { dok ih više ima roditelje } \\
\text { bez stalnih primanja }(28 \%>U U=15 \%) \\
\text { - } M_{R R P}=1,4 \text { posjedovanja materijalnih dobara statistički } \\
\left.\text { značajno niži u odnosu na } \mathrm{M}_{\mathrm{URP}}=1,6\right) \text {; } \\
\text { - } \mathrm{M}_{\mathrm{RRP}}=2,8 \text { procjene financijske situacije obitelji niža u } \\
\left.\text { odnosu na } \mathrm{M}_{\mathrm{URP}}=3,0\right)\end{array}$} \\
\hline & $\begin{array}{l}\text { Procjena ekonomske } \\
\text { situacije* }\end{array}$ & t-test & \\
\hline
\end{tabular}

\footnotetext{
${ }^{80}$ Taj „široki pokret 'uprostorenja' sociologije“ (Lobao, Hooks, Tickamyer, 2007: 3) ističe važnost toga gdje su smješteni društveni akteri u geografskom prostoru i kako su sami geografski entiteti oblikovani i oblikuju stratifikaciju, i naglašavaju potrebu promatranja prostora uz rasu, klasu, dob, rod i seksualnost kao važnne izvore različitog pristupa resursima i mogućnostima (Lobao, Hooks, Tickamyer, 2007).
} 


\begin{tabular}{|c|c|c|c|}
\hline $\begin{array}{l}\text { Obrazovno- } \\
\text { kulturno } \\
\text { obiteljsko } \\
\text { okruženje }\end{array}$ & $\begin{array}{l}\text { Obrazovanje roditelja* } \\
\text { Broj knjiga kod kuće* }\end{array}$ & $\chi^{2}$ & $\begin{array}{l}\text { - } \mathrm{U}_{\mathrm{RRP}} \text { imaju najveće udjele roditelja } \mathrm{s} \text { trogodišnjim } \\
\text { srednjoškolskim obrazovanjem }\left(32 \%>\mathrm{U}_{\mathrm{URP}}=14 \%\right) ; \text { a } \\
\text { manje ih ima visokoobrazovane roditelje: } \mathrm{U}_{\mathrm{RRP}}=19 \%< \\
\mathrm{U}_{\mathrm{URP}}=41 \% \text {; } \\
\text { - } \mathrm{U}_{\mathrm{RRP}}=62 \% \text { imaju najveće udjele } \mathrm{u} \text { kategoriji } \\
\text { posjedovanja najmanjeg broja knjiga (do } 25)\left(>\mathrm{U}_{\mathrm{URP}}\right. \\
=34 \%) \text {, dok ih je daleko manje u kategoriji posjedovanja } \\
\text { više od } 200 \mathrm{knjiga}\left(\mathrm{U}_{\mathrm{RRP}}=8 \%<\mathrm{U}_{\mathrm{URP}}=21 \%\right)\end{array}$ \\
\hline & $\begin{array}{l}\text { Posjedovanje kulturnih } \\
\text { dobara* } \\
\text { Roditeljske kulturne prakse* }\end{array}$ & t-test & $\begin{array}{l}\text { - } \mathrm{M}_{\mathrm{RRP}}=0,5 \text { posjedovanja različitih kulturnih dobara } \\
\text { statistički značajno niža u odnosu na } \mathrm{M}_{\mathrm{URP}}=0,7 \\
\text { - } \mathrm{M}_{\mathrm{RRP}}=1,6 \text { učestalosti roditeljskih kulturnih praksi } \\
\text { statistički značajno niža od MURP }=1,9\end{array}$ \\
\hline $\begin{array}{l}\text { Simbolička } \\
\text { vrijednost } \\
\text { obitelji }\end{array}$ & 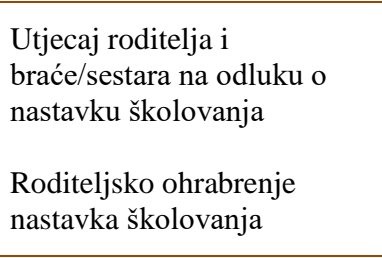 & t-test & $\begin{array}{l}\text { - } \mathrm{M}_{\mathrm{RRP}}=3,3 \text { procjene utjecaja roditelja na odluku o } \\
\text { studiranju statistički značajno niža od } \mathrm{M}_{\mathrm{URP}}=3,7 \\
\text { - nema statistički značajnih razlika u } \mathrm{M}=2,6 \text { procjene } \\
\text { utjecaja braće/sestara na odluku o studiranju između } \mathrm{U}_{\mathrm{RRP}} \\
\text { i } \mathrm{U}_{\mathrm{URP}} \\
\text { - nema statistički značajnih razlika između } \mathrm{M}=4,5 \\
\text { procjene utjecaja roditeljskog ohrabrivanja studiranja }\end{array}$ \\
\hline $\begin{array}{l}\text { Simbolička } \\
\text { vrijednost } \\
\text { društvenih } \\
\text { odnosa }\end{array}$ & $\begin{array}{l}\text { Utjecaj izvaninstitucionalnih } \\
\text { drugih } \\
\text { Utjecaj prijatelja* } \\
\text { Utjecaj susjeda* } \\
\text { Utjecaj institucionalnih } \\
\text { drugih* } \\
\text { Utjecaj stručnih suradnika* }\end{array}$ & t-test & $\begin{array}{l}\text { - } \mathrm{M}_{\mathrm{RRP}}=2,4 \text { procjene utjecaja prijatelja na odluku o } \\
\text { studiranja statistički značajno niža od } \mathrm{M}_{\mathrm{URP}}=2,7 \\
\text { - } \mathrm{M}_{\mathrm{RRP}}=1,9 \text { procjene utjecaja susjeda na odluku o } \\
\text { studiranja statistički značajno viša od } \mathrm{M}_{\mathrm{URP}}=1,6 \\
\text { - } \mathrm{M}_{\mathrm{RRP}}=2,1 \text { procjene utjecaja institucionalnih drugih na } \\
\text { namjeru studiranja statistički značajno viša od } \mathrm{M}_{\mathrm{URP}}=1,9\end{array}$ \\
\hline $\begin{array}{l}\text { Simbolička } \\
\text { vrijednost } \\
\text { zajednice }^{81}\end{array}$ & $\begin{array}{l}\text { Emocionalna vezanost* } \\
\text { Pripadnost } \\
\text { Ostanak* }\end{array}$ & t-test & $\begin{array}{l}\text { - } \mathrm{M}_{\mathrm{RRP}}=4 \text { osjećaj emocionalne vezanosti za zajednicu } \\
\text { odrastanja statistički značajno viša od } \mathrm{MURP}=3,8 \\
\text { - nema statistički značajnih razlika u M=3,4 rezultatima } \\
\text { grupa učenika različitog rezidencijalnog podrijetla na } \\
\text { dimenziji osjećaja pripadnosti } \\
\text { - } \mathrm{M}_{\mathrm{RRP}}=2,8 \text { želje za ostankom u zajednici odrastanja } \\
\text { statistički značajno viša od } \mathrm{M}_{\mathrm{URP}}=2,4\end{array}$ \\
\hline $\begin{array}{l}\text { Institucionalne } \\
\text { karakteristike } \\
\text { obrazovnih } \\
\text { konteksta }\end{array}$ & $\begin{array}{l}\text { Opremljena škola dobrog } \\
\text { programa* } \\
{ }^{82} \text { Ugled studija i institucije } \\
\text { visokog obrazovanja }\end{array}$ & t-test & $\begin{array}{l}\text { - } \mathrm{M}_{\mathrm{RRP}}=2,6 \text { procjene statusa svojih škola statistički } \\
\text { značajno niža od } \mathrm{M}_{\mathrm{URP}}=2,9 \\
\text { - nema statistički značajnih razlika } \mathrm{u} \mathrm{M}=3,5 \text { procjene } \\
\text { akademske poticajnosti škola između } \mathrm{U}_{\mathrm{RRP}} \mathrm{i} \mathrm{U}_{\mathrm{URP}} \\
\text { - nema statistički značajnih razlika u } \mathrm{M}=2,7 \text { procjene } \\
\text { resursne opremljenosti i programske ponude škola } \\
\text { između } \mathrm{U}_{\mathrm{RRP}} \mathrm{i} \mathrm{U}_{\mathrm{URP}} \\
\text { - nema statistički značajnih razlika u } \mathrm{M}=3,5 \text { procjeni } \\
\text { ugleda studija i institucije visokog obrazovanja između } \\
\mathrm{U}_{\mathrm{RRP}} \mathrm{i} \mathrm{U}_{\mathrm{URP}}\end{array}$ \\
\hline
\end{tabular}

U nastavku slijedi usporedni prikaz rezultata istraživanja prema glavnim istraživačkim pitanjima koji povezuju statističke obrade kvantitativnih podataka nadopunjene kvalitativnim informacijama iz razgovora s učenicima. Konkretnije, kvantitativne analize uključivale su ispitivanje rezidencijalnih razlika prema namjeri studiranja i visokoobrazovnim izborima te individualnim obrazovnim karakteristikama i orijentacijama, dostupnim kapitalima u okolišima odrastanja i školovanja slavonskih maturanata koji se mogu operacionalno mjeriti, s proširenim ispitivanjem odnosa prema zajednici odrastanja u pokušaju zahvaćanja njene

\footnotetext{
81 Samo na uzorku slavonskih maturanata

82

Samo za učenike koji namjeravaju studirati
} 
dublje simboličke vrijednosti za učenike. Osnovni cilj tih analiza bio je opis ruralno-urbanog polja s obzirom na prostornu distribuciju kapitala učenika na koju su analize ukazale i konzistentno je potvrđivale na nacionalnoj razini. Ti statistički podaci sažeto su prezentirani u Tablici 4.1, a dodatno se raspravljaju u ovom poglavlju prema cjelinama, i povezuju s kvalitativnim podacima iz intervjua koji ih oslikavaju i analitički produbljuju.

\subsection{Obrazovne karakteristike i orijentacije te individualno razvijeni kapitali učenika različitog rezidencijalnog podrijetla}

Početne točke ovih analiza bile su vezane uz pitanje postoji li, i ako da, dublje ispitati socioprostornu dimenziju dispozicijske strukture učeničkih odluka o studiranju s obzirom na njihove obrazovne karakteristike i orijentacije, te individualno razvijene kapitale koje su bitni elementi „startne pozicije“ prema visokom obrazovanju u trenutku završavanja srednjoškolskog obrazovanja. Naredna poglavlja obuhvaćaju analizu strukture učenicima dostupnih resursa u u kontekstima odrastanja i školovanja, te njihov simbolički značaj, a koji im olakšavaju/otežavaju donošenje odluke o studiranju, s pretpostavkom da postoji veza između opisane dispozicijske strukture učenika i njihova konteksta odrastanja i školovanja u vremenskoj dimenziji. Ovakva operacionalizacija proizlazi iz čuvene Bourdieuove metafore za habitus „plivati kao riba u vodi““ (1989) koja odražava habitusnu prilagođenost učenika iz viših društvenih klasa, i s obzirom na „opremljenost“ kapitalima, ali prvenstveno shvaćanjem da je studiranje nešto normalno, što se ne treba propitivati, čime se studiranje doživljava pozitivnim iskustvom.

Obrazovne orijentacije (ili obrazovni habitus učenika) obuhvaćen je anaketno obrazovnim očekivanjima u odnosu na aspiracije učenika te težini donošenja odluke o studiranju iskazanoj stavom učenika da im se studiranje (ne)podrazumijeva i da (ni)su morali iscrpno promišljati odluku o studiranju, odnosno da su odluku donijeli rano. Statistički značajni testovi potvrdili su konzistentan obrazac urbano-ruralnih razlika prema tim karakteristikama (Slike 4.1 i 4.2.) koje se mogu promatrati kao elementi učeničkih obrazovnih habitusa te usmjeravaju interes prema pitanjima o učeničkim socijalizacijskim kontekstima u kojima se razvijaju (što je predmet analiza sljedećih poglavlja).

Općenito postoji zanimljiva diskrepancija između određenih podataka koji pokušavaju odgovoriti na pitanje koliko to učenika namjerava studirati. Kada ih se direktno pita o njihovim namjerama tek nešto više od polovice slavonskih maturanata (55\%) izjavljuje da 
namjerava studirati ${ }^{83}$, dok ispod polovice smatra da im se studiranje podrazumijeva (49\%) ili da im nije trebalo vremena da promisle odluku (46\%), a čak je 30\% onih koji su odluku o studiranju donijeli tek u srednjoj školi. Nasuprot tome, pokazuje se da su obrazovne želje i očekivanja viši za veći broj učenika: $67 \%$ ih želi, odnosno $63 \%$ čak i očekuje postizanje nekog stupnja visokog obrazovanja ${ }^{84}$.

Već to ukazuju da je sam proces donošenja odluka o studiranju iznimno složen i vrlo često se do samoga kraja pregovara, što dodatno potkrepljuju razgovori s učenicima ukazujući kako za određeni dio učenika odluka o studiranju često ostaje izražena samo kao želja ili nedefinirana mogućnost, no, zbog različitih razloga, ne i dobro informiran ili realističan scenarij djelovanja. Tako se u uzorku intervjuiranih našlo 15 učenika koji tvrde da namjeravaju studirati, ali barem dvoje učenika koji su u trenutku ispitivanja zabilježili da „ne znaju“ u intervjuu iskazuju svoje želje za studiranjem; radi se o učenicima strukovnih škola čije je iskaze na intuitivnoj razini lako razumjeti, no teško klasificirati s obzirom na neodređenost i suprotna shvaćanja u različitim dijelovima intervjua, kako to pokazuje Agatin opis „,... prije u osnovnoj, ono, faks mi nije bio ni na kraj pameti, ali kad sam došla u srednju, kad sam vidjela neke stvari, ne znam, općenito, sa zaposlenjem i tako to... budućnost nam je nikakva čak i bez škole i bez ičega, ono, iskreno, strah me bude budućnosti...

...imam želju studirati jer to mi možda omogućava nešto, budućnost, možda bih imala više vrata otvoreno sa faksom nego bez njega... ne znam ni sama, imam baš želju, pa... voljela bih pokušati pa ako ne uspijem, uvijek ja mogu ... “ (Agata, mg_URP, 4SŠ, mg_SŠ)

Dodatno, možemo govoriti i o učenicima čije namjere studiranja zabilježene u upitniku ukazuju na veću razinu neodređenosti bilo zbog načina na koje je proces upisa studija informiran, ili načina na koji u različitim dijelovima intervjua opisuju svoje ambivalentne želje i namjere - u množini i katkada kontradiktorno - koje se i u najkasnijim fazama odluke pregovaraju. Opisi iz različitih dijelova Marininog intervjua, gdje obrazlaže specifičan pristup studiranju, pokazuju donošenje odluka o studiranju kao proces konstantnog pregovaranja namjera u mijenjajućim okolnostim - i tijekom intervjua, i u životima mladih - sa stavom „,ako prođe prođe“:

„... većina ne ide na državnu maturu i možda od nas 28 ide dvoje, troje koji će 100\% proći... idemo mi sve, to je naša APP - ako prođe, prođe, al' većina, ono, idemo na državnu, $i$ ak' prođemo idemo na faks, ak' ne prođemo, nema veze...(...) teško doći do njega [fakulteta]... tak' da vjerojatno ćemo svi završit u nekom plasteniku...

\footnotetext{
${ }^{83}$ Taj je broj daleko manji u odnosu na nacionalni prosjek (Klepač, 2015).

${ }^{84}$ Pri tom oko trećine želi, a malo iznad toga i očekuje završavanje diplomskog studija, dok doktoratu teži $20 \%$ iako postizanje doktorata očekuje upola manje slavonskih maturanata (9\%).
} 
... to mi je još ono... kad ne znam... stvarno, državna matura, to je ta crta koju ne možemo prijeći, onda kad to prijeđem, onda idem dalje... ne želim planirati i gledat naprijed kad ne znam 'oću ovo proć', a to sigurno neću uspit zato što je preteško...

... to je sad pitanje (smijeh)... pa ne znam... pa vjerojatno hoću [upisati studij], normalno... potrudit ću se da sve bude... da se uspijem, a sad ak' ne uspijem, nema veze... jednostavno... eto... ne znam šta da kažem...

....svi smo isti, svi gledaju jedni druge - kak'će on tak' ću i ja... al' ne gledamo sad ove pametne baš koji odluku donesu „Idem na faks, učit ću i ... “... te baš i ne gledamo... “ (Marina, RRP_TP, 4SŠ_mg)

Iskazi učenika pokazuju kako postoje razlike u intenzitetu odlučnosti i želje te uvjerenosti u ostvarenje namjera, kada je u pitanju studiranje i načinima kako, od kada i zašto se prema studiranju orijentira, odnosno kako na široj razini vrednuju obrazovanje. Također je vidljivo kako učenici emotivno proživljavaju razmatranja o tome što nakon škole općenito, a pogotovo kada razmatraju mogućnosti studiranja; njihovi se odgovori javljaju kao reakcije na strukturne situaciju u kojoj se nalaze i u skladu s načinima kako interpretiraju pozicije s kojih polaze prema daljnjem obrazovanju, a one su dijelom rezultat ranijih dijelova put, a u kojima visoko obrazovanje možda nije bila značajna tema razmatranja. Za dio učenika postoje bojazni vezane uz nemogućnost zapošljavanja, potrebe daljnjeg školovanja i mogućnosti ostvarenja visokoobrazovnih planova nasuprot promjenjivim razinama optimizma u skladu s resursima koje učenici posjeduju, te manja ili veća opterećenost konačnim ishodom s obzirom na vremenski prostor za koji smatraju da im je na raspolaganju do konačnog razrješenja pitanja studiranja, a koje im samo po sebi nije jedina želja i/ili opcija postizanja dobrog života.

Dio problematike je to što je zadatak istraživanja stavljen pred učenike bio da opišu svoj obrazovni put, a on je uvijek, kako tvrdi Wierenga (2009), zahtjevan zadatak učenicima koji u modernom društvu odražava naporan rad izgradnje ,projekta sebe“ (Giddens, 1991). Takve priče odražavaju procese izgradnje identiteta mladih u trenutku kada prelaze u odraslost i donose bitne odluke o budućim životima koji je pod različitim pritiscima u promjenjivom društvu. U suvremenim mobilnim i rizičnim društvima (Giddens, 1990), u kojima silnice modernizacije i globalizacije rastaču poznato, i koji mobilnost isttiču kao vrijednost, karakteristiku i ideologiju (Wiborg, 2003), od mladih se zahtijeva dodatni napor da svoje identitete i projekte sebstva uspostavljaju na pokretnim temeljima. No, to zahtijeva i spremnost na „odlazak u svijet“ mentalno i fizički. Pri tom su učenici različito „osposobljeni“ zamisliti svoj put izvan neposrednog, praktičnog i lokalnog. Stoga se slike barem kod nekih učenika javljaju kao „sanjarske“; kada razmatra odluke o migracijama mladih iz ruralnih područjaKanade, Corbett (2005) govori o grupi onih koji sanjaju različite prostore s naglašenom željom odlaska ali koji nikada ne poduzmu mjere za stvarnim odlaskom s 
obzirom na neusmjerenost svojih planova. Kod nekih drugih učenika one dodatno mogu biti strukturno ograničene, određujući grupu onih koji su ,zapeli. Također, Wieringa (2009), s obzirom na narative mladih razlikuje nekoliko grupa učenika od kojih jedni „lutaju“ (wandering) u svojim pričama, ali koje su vrlo nejasne, kao i one učenike koji se izražavaju samo u lokalnim okvirima. Oba autora takve tipove odluka o migracijama, čega su dio i odluke o studiranju, i priča povezuju s klasom i rodom unutar specifičnih prostora i mjesta u kojima se razvijaju određeni moderni subjektiviteti. Do određene mjere to je moguće promatrati i kod ispitanika u hrvatskom kontekstu.

Postoje li razlike između učenika koji odrastaju u ruralnim i urbanim naseljima prema njihovim obrazovnim karakteristikama i orijentacijama, te kakav je oblik veze između dispozicija učenika u njihovim obrazovnim željama, namjerama i očekivanjima, odnosno koja značenja pripisuju studiranju i svojim očekivanjima od njega?

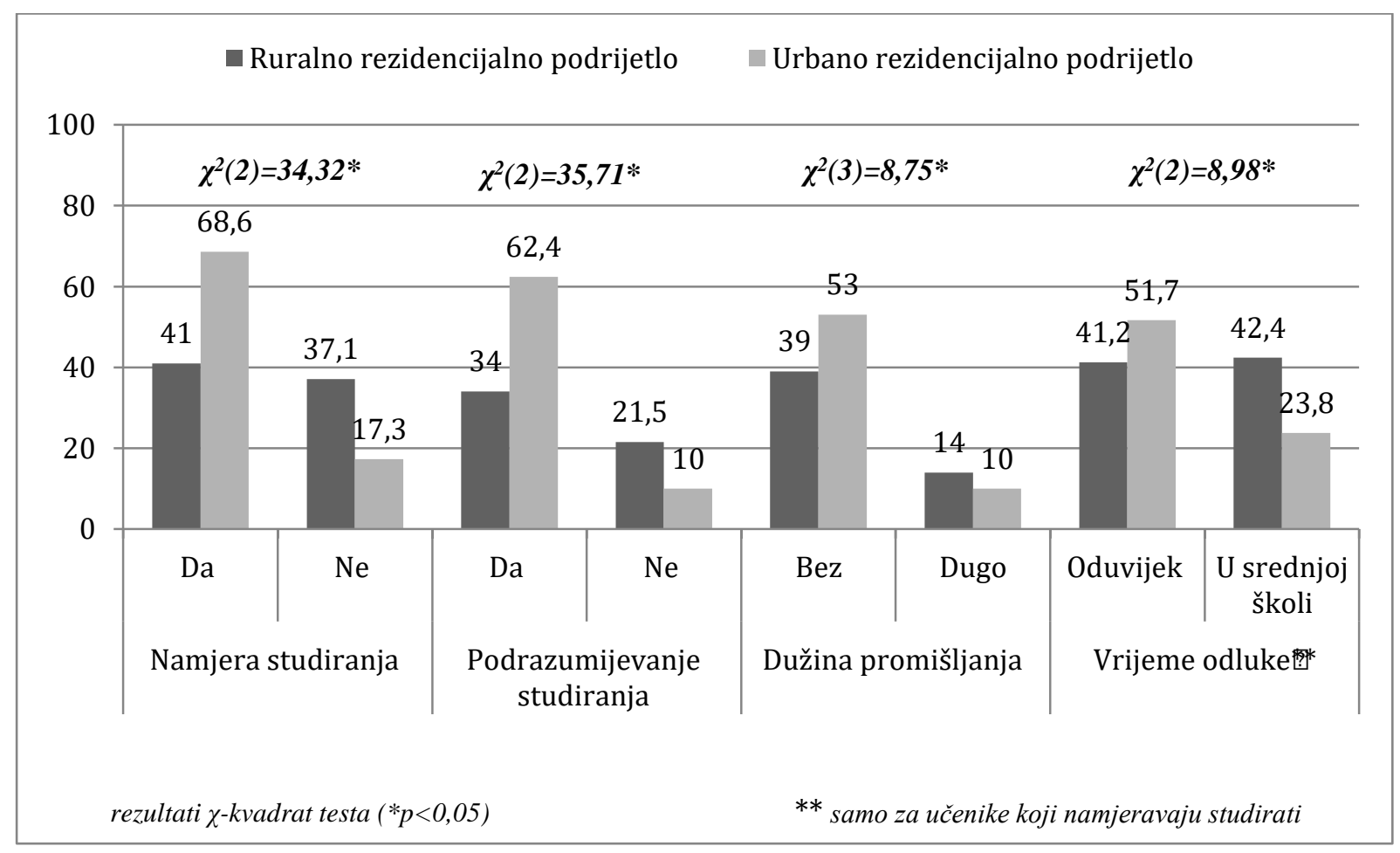

Slika 4.1 Razlike između učenika različitog rezidencijalnog podrijetla prema namjeri studiranja i obrazovnim orijentacijama $^{\mathbf{8 5}}$

Statistički, Slika 4.1 oslikava socioprostornu dimenziju dispozicijske strukture učenika vezane uz visoko obrazovanje. Učenici urbanog rezidencijalnog podrijetla se u daleko većem broju odlučuju za studiranje $\left(69 \%>\mathrm{U}_{\mathrm{RRP}=} 41 \%\right)$, najveći broj $(2 / 3)$ ih aspirira najvišim stupnjevima

\footnotetext{
${ }^{85}$ Grafički su prikazani udjeli učenika u kategorijama nezavisnih varijabli koje pokazuju najveće razlike.
} 


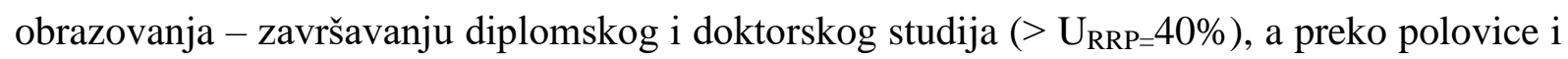
očekuje da će im se to ostvariti. Odnosno, čak i kada se uzmu u obzir sve prepreke koje bi im se mogle naći na putu, učenici urbanog rezidencijalnog podrijetla koji teže postizanju nekog stupnja visokog obrazovanja i dalje zadržavaju nade da će ga ostvariti, iako će on možda biti niži od onog stupnja kojem teže, a gotovo polovica (47\%) i dalje očekuje stjecanje titule magistra. Nadalje, gotovo $2 / 3$ ih smatra da im se studiranje podrazumijeva, dok isto smatra tek 1/3 učenika iz ruralnih naselja. Štoviše, više od polovice „urbanih“ učenika koji namjeravaju studirati procjenjuje da su oduvijek znali da će studirati te time njihova odluka nije istinski promišljana, već se može smatrati dijelom njihovog ranog habitusnog usmjerenja dijelom potvrđenih postignutim školskim pozicijama (tipom upisane škole i/ili ocjenama).

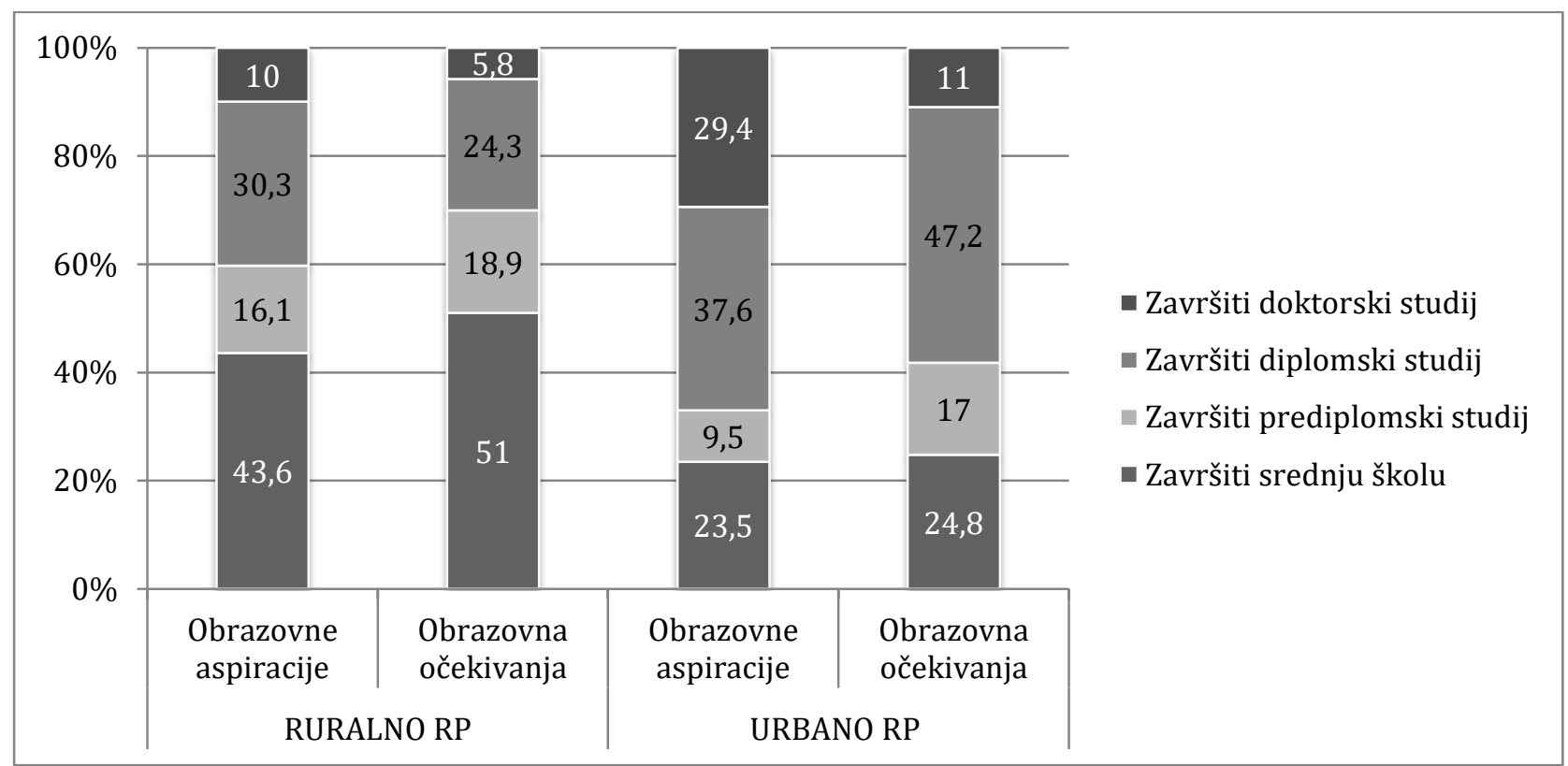

Slika 4.2 Usporedni prikaz udjela učenika različitog rezidencijalnog podrijetla u kategorijama obrazovnih aspiracija i očekivanja

S druge strane, gotovo dvostruko više učenika ruralnog rezidencijalnog podrijetla ne namjerava studirati ili još nije donijelo odluku (59\%> $\left.>U_{U R P}=31 \%\right), 44 \%$ ih želi samo završiti srednju školu (nasuprot $1 / 4 U_{U R P}$ ), a polovica i očekuje da će taj stupanj obrazovanja postići (51\%), što je kategorija koja za njih najviše raste u odnosu na njihove aspiracije (dok se za UURP gotovo uopće ne povećava) (Slika 4.5). Konačno, gotovo polovica učenika odraslih u ruralnim naseljima (45\%) smatra da im se studiranje niti podrazumijeva, niti ne podrazumijeva $\left(>\mathrm{U}_{\mathrm{URP}}=28 \%\right)$, s time da je gotovo polovica $(42 \%)$ onih koji namjeravaju studirati svoju odluku donijela u kasnim fazama školovanja - u srednjoj školi ( $>\mathrm{U}_{\mathrm{URP}=24 \%}$ ). 
Dakle, brojčani podaci dijelom potvrđuju pravac razmišljanja o manjim aspiracijama ruralnih učenika u trenutku završavanja njihova srednjoškolskog obrazovanja te je potrebno razmotriti i različite školske pozicije s kojih učenici kreću prema visokom obrazovanju, pa time i različite vrste prepreka s kojima se suočavaju na svojim obrazovnim putovima, ali i njihovih općenitih motivacija prema daljnjem obrazovanju i obiteljskih stavova. Jer, podaci također ukazuju kako su ruralni učenici u većoj mjeri neodlučni i pesimistični oko svojih odluka i donose ih kasnije na svom obrazovnom putu koji se uvelike odvija, i oblikovan je, putem strukovnog srednjoškolskog obrazovanja.

To je u skladu s podacima o urbano-ruralnim razlikama s obzirom na tip srednje škole koje učenici pohađaju (Tablica 2.12) te prema školskom uspjehu ${ }^{86}$. Drugim riječima, dispozicije učenika odražavaju dijelom obrazovne karakteristike ispitanika, odnosno do tada postignute školske pozicije na kojima su im dostupne različite razine obrazovno značajnih resursa i do kada imaju u različitim mjerama razvijene obrazovno iskoristive kapitale; urbani učenici u daleko većoj mjeri upisuju gimnazije koje od ranije dobi i direktnije učenike usmjeravaju prema visokom obrazovanju, izraženo kao $(\mathrm{K})$ nužnost studiranja, a također urbani učenici postižu i bolje školske rezultate u odnosu na učenike ruralnog rezidencijalnog podrijetla koji također čine ulazak u visoko obrazovanje vjerojatnijim.

„Mješoviti podaci“ uvode posebne elemente vrijedne razmatranja vezanima uz snagu pojedinih odluka i proces njihova donošenja s obzirom na veću neodlučnost i manju uvjerenost u obrazovnu uspješnost učenika nepovoljnijih obiteljskih resursa te onih odraslih u ruralnom okolišu.

Već je istaknuto, uzorak intervjuiranih učenika je, u skladu s kriterijima izbora ispitanika, uzorak u većoj mjeri visokoobrazovno orijentiranih učenika, posebno kada je u pitanju dio uzorka s ruralnim rezidencijalnim podrijetlom; bez obzira na to što su zabilježili u anketnom upitniku, izabirani su učenici koji su bili spremni na istraživački razgovor jer su pokazivali sklonosti nastavku školovanja (17) i nekoliko učenika koji su s obzirom na svoju namjeru studiranja trebali predstavljati negativne slučajeve (3). To je utjecalo i na to da je među intervjuiranima više učenika gimnazija kao i školski uspješnih učenika, odnosno više je učenika koji su u ranijim fazama školovanja oblikovali svoje težnje postizanju nekog stupnja visokog obrazovanja.

\footnotetext{
${ }^{86}$ Opći školski uspjeh mjeren je kao prosjek ocjena na kraju prošle školske godine koji je za slavonske maturante bio ocjena četiri $(M=3,6)$ pri čemu je prosjek na varijabli statistički značajnoveći za $U_{U R P}(M=3,69)$ u odnosu na prosjek $\mathrm{U}_{\mathrm{RRP}}(\mathrm{M}=3,57)$. Prethodne školske godine $18 \%$ učenika je imalo prosjek ocjena odličan, među kojima je i $3 \%$ učenika s prosjekom ocjena 5,0, odnosno s ekstremnim iznadprosječnim rezultatom (2 SD iznad prosjeka).
} 
Konačno, 16 učenika je ostavilo podatke o svojim željama vezanima uz visoko obrazovanje, od čega, ujednačeno prema rezidencijalnom podrijetlu, 12 želi postići diplomsku obrazovnu razinu, no polovica učenika iz ruralnih naselja to i očekuje, dok 4 učenika želi ostvariti doktorat, no samo učenici odrasli u ruralnoj sredini smatraju da će im se to ostvariti, u skladu s njihovim željama završavanja integriranih studija u biomedicinskom području. Ipak, intervjuirani urbani učenici i dalje očekuju najvećim dijelom postizanje diplomske razine (njih 7). Velika većina učenika koja pokazuje želju studiranja smatra i da im se studiranje podrazumijeva (11), kao i da nisu trebali promišljati svoju odluku (8), pri čemu velika većina učenika odraslih u gradu nije u velikoj mjeri propitivala svoje odluke, nasuprot čemu je polovica učenika odraslih na selu ambivalentna o podrazumijevanju studiranja; bez razmišljanja su odluku donijele tek dvije učenice ruralnog rezidencijalnog podrijetla koje se općenito u intervjuima predstavljaju izrazito visokoobrazovno orijentiranima.

Konačni rezultat „mješovite“ analize odgovora učenika pokazuje da su zapravo visokoobrazovne aspiracije s obzirom na snagu njihove želje i dublje uvjerenosti u mogućnosti ostvarenja te želje kao i poduzete korake za ostvarenje tog nauma, što se posebno očituje u njihovim podacima vezanima uz to u kolikoj mjeri im se studiranje podrazumijeva i koliko su dugo promišljali svoju odluku, te onome što žele postići studiranjem. Drugim riječima, intervjuirani učenici ovog uzorka ne otkrivaju manjak aspiracija, koliko otkrivaju različite nesigurnosti, osjećaje neodlučnosti i/ili neusmjerenosti kada su u pitanju njihovi planovi nakon srednje škole, te sumnje u uspješnost svojih odluka koja je velikim dijelom izraz odabira srednje škole, odnosno ranih usmjeravanja obrazovnih putova. Naravno, u različitim omjerima ti osjećaji se pojavljuju kod svih učenika i sastavni su dio donošenja odluka, koji se kao zahtjev postavlja u refleksivnom društvu (Giddens, 1990) i osnova izgradnje uspješnih identiteta, no ipak postoje različiti naglasci za pojedine kategorije učenika, posebno izražene s obzirom na njihove školske pozicije (tip škole i/ili ocjene), što nadopunjuje i dodatno oslikava i razlike učenika na ruralno-urbanoj dimenziji. Učenici ruralnog rezidencijalnog podrijetla općenito u manjoj mjeri pokazuju visokoobrazovnu orijentaciju kada se ona učenicima podrazumijeva i kada je ranije usmjeren obrazovni put koji se ne dovodi u pitanje osim u strategijskim odlukama na ključnim točkama obrazovanja pojedinaca. Jedna od takvih točaka u hrvatskom školskom sustavu predstavlja odabir srednje škole, pri čemu škola djeluje kao stratificirajući mehanizam (vidi Baranović, 2015). 


\subsubsection{Postavljanje puta - izbor srednje škole}

Stoga se učenike pitalo u intervjuima da objasne kako to da su odabirali svoje srednje škole, a što je bio bitan izvor informacija za razumijevanje ranih, i analizu kasnijih, obrazovnih orijentacija s posebnim interesom za djelovanje osnovnih škola koje su pohađali i obiteljske strategije raspravljanja obrazovnih putova.

Osnovni pretpostavljeni putovi proizlaze iz Bourdieuove teorije koja s jedne strane opisuje tendencije reprodukcije klasa u kojem habitus ima središnji značaj time što ugrađuje prošla iskustva u sistem trajućih dispozicija te djeluje kao matrica percepcija i praksi (Bourdieu, 1977). U obrazovanju to znači da roditeljska prošla iskustva usmjeravaju prema visokom obrazovanju kao oblik zadanog puta koji učenici ne dovode u pitanje, nasuprot čemu učenici koji nemaju visokoobrazovane roditelje, i time su prva generacija studenata, raskidaju s obiteljskom prošlošću (Doolan, 2009). S jedne strane, to znači da je velikim dijelom odluka o studiranju, a često i visokoobrazovnim izborima, učenicima visokoobrazovanih roditelja ,neodluka“, to jest nesvjestan i nenamjerni proces donošenja odluka koji je i ranije usmjeren. S druge strane, ostalim učenicima odluka o obrazovanju može biti posebno teška s obzirom na potrebu prilagodbi rano usvojenih dispozicija ako one tradicionalno ne uključuju sliku studiranja, poput učenika iz radničkih i/ili seoskih obitelji.

U tom okviru, ako je obrazovanje značajno, tada se obrazovni putovi obiteljski postavljaju ranije prema visokom obrazovanju odabirom srednjih škola koje taj put postavljaju sigurnijim, doživljavaju se „normalnim“ ili "prirodnim“ bez posebnog razmatranja. U ruralnim obiteljima prevladava instrumentalna orijentacija prema obrazovanju, a visoko obrazovanje dobiva na vrijednosti tek povezivanjem s praktičnošću (Corbett 2005a). Stoga je pretpostavka da će usmjeravanje prema strukovnom obrazovanju i zaposlenju prevladavat u obiteljima nižih društvenih klasnih pozicija. No, u određenim prostorima, moguće je da će različiti oblici obrazovanja imati različitu vrijednost, odnosno obrazovne strategije obitelji djeluju drugačije u različitim lokalitetima. Kako ukazuje Corbett (2010) obitelji djeluju u lokaliziranim prostorima koji su posredovani relativnim društvenim i kulturnim položajima roditelja, a koji poprimaju različita značenja kada učenici ulaze u školu kako bi naučili kolika je vrijednost kapitala njihovih roditelja unutar institucije. U tom okviru, ruralne obitelji općenito u većoj mjeri potiču oblike učenja bliže tradicionalnom učenju kroz praksu, pa time strukovno obrazovanje. Za veći udio ruralnih učenika u obrazovanju oni moraju vidjeti vezu između višeg obrazovanja te kulturnih i geografskih prostora koje nastanjuju (Corbett 2005b). 
Ipak, u vremenu kada se akademska uspješnost definira učenjem napuštanja mjesta praktičnog i prihvaćanje „nevažnog“, oni s većim razinama kapitala bit će i spremniji uložiti u obrazovanje koje je apstraktnije prirode, osvješćujići kod učenika svijest o protorima izvan lokalnog te ih osposobljava za migriranje. To je opći proces koji opisuje skup intervjuiranih učenika, iako sa zanimljivim izuzecima.

Među intervjuiranima otprilike polovica učenika bira srednje škole koje odgovaraju stupnju obrazovanja njihovih roditelja, te dakle postoje značajne iznimke kao i nijansirani opisi samog procesa odnosa između obiteljskih habitusa i onog osnovne škole, odnosno djelovanja svjesnih i nesvjesnih procesa kojima su odlučili o svom obrazovnom putu. U učeničkim narativima, upis bilo koje škole često je pod utjecajem složene kombinacije pozitivnih i negativnih utjecaja, a dvije glavne odluke se tiču odabira između strukovnih škola, te odabira između strukovne škole i gimnazije. Na općoj razini, spominje se utjecaj ocjena, odnosno bodova s obzirom na mogućnosti izbora škola za koje postoji interes, utjecaj prijatelja prema utjecaju roditelja, te ranih visokoobrazovnih aspiracija sa slikom o sebi kao (ne)gimnazijalcu.

Većina učenika u skupu intervjuiranih prije odabira srednje škole je razmatrala mogućnosti studiranja, što ih je usmjerilo na upis gimnazija, no dio onih koji su odabrali strukovne škole je do kraja srednjoškolskog obrazovanja ili posve napustio tu ideju ili je zadržavaju, ali s daleko većim dvojbama oko mogućnosti uspjeha njihovih planova.

\begin{tabular}{|l|c|c|c|}
\hline & $\begin{array}{l}\text { Učenici upisani u } \\
\text { gimnaziju }\end{array}$ & $\begin{array}{l}\text { Učenici upisani u } \\
\text { 4S } \check{S}\end{array}$ & $\begin{array}{l}\text { Učenici upisani } \mathrm{u} \\
\text { 3S }\end{array}$ \\
\hline VO roditelji & $* * * *$ & $* *$ & $*$ \\
\hline $\begin{array}{l}\text { Roditelji s 4SS } \\
\text { obrazovanjem }\end{array}$ & $* * *$ & $* * * *$ & \\
\hline $\begin{array}{l}\text { Roditelji s 3SŠ } \\
\text { obrazovanjem }\end{array}$ & & $* * *$ & $* * *$ \\
\hline
\end{tabular}

Posebno su zanimljive odluke učenika koji su upisali trogodišnje strukovne škole s obzirom da su gotovo svi prije srednje škole razmatrali mogućnosti studiranja, da neki još uvijek ne odbacuje mogućnosti studiranja (iako tek jedan učenik to očekuje), te da je barem jedan učenik prvotno upisao četverogodišnju školu, da je za većinu četverogodišnja strukovna škola bila ili prvi upisani ili željeni izbor, te da je trogodišnja strukovna škola izbor učenika s istim stupnjem roditeljskog obrazovanja, sa značajnim izutetkom učenice $\mathrm{s}$ oboje 
visokoobrazovanih roditelja. Ukratko, trogodišnje srednje škole uglavnom nisu (prvotni) željeni izbor, iako se određeni izbori pojavljuju poželjnijima u odnosu na neke druge.

U najvećoj je mjeri željen izbor učenice koja pohađa trogodišnju strukovnu školu, no on je i ograničen osnovnoškolskim uspjehom i osobnom nezainteresiranošću za školu: „nisam baš bila nešto u osnovnoj školi s učenjem, nisam stajala... pa onda od svih škola baš sam htjela to... super mi je...". Njen konačni izbor oblikovan je na osnovi medijskih slika o svojoj struci s vizijom budućeg željenog zanimanja (,...prvenstveno sam gledala televiziju $i$ sve to, $i$ to mi se svidilo...") i usmjeren aspiracijama o završavanju srednje škole i zapošljavanju. Eventualne mogućnosti budućeg studiranja zadržane su: „... možda bi išla za ... da mogu za profesoricu, recimo, [...] struke (...) ovisi... ako mi se bude... nikad ne znaš... “, iako su dio neke nepredvidive budućnosti i s obzirom na shvaćanje da diploma nosi dodatne mogućnosti koji podupiru visokoobrazovani roditelji.

No, školski uspjeh može djelovati i na drugačije načine, i dalje pozitivno. Franin izbor trogodišnjeg smjera određen je padom razreda na prvotno upisanom četverogodišnjem smjeru. Unatoč tome, učenik taj razvoj događaja ne smatra ograničenjem za nastavak školovanja i procjenjuje ga gotovo aktivno izabranim obrazovnim pravcem koji je, iako dužim i okolnim putem, usklađeniji s njegovim visokoobrazovnim željama i ostvariv s obzirom na procjene vlastitih sposobnosti, volje i truda:

„,... iš'o sam ja ekonomsku školu, ali sam se prebacio (...) pao sam drugi razred, a $i$ ekonomska... nije mi to to (...) idem na praksu u [trgovački lanac] pa imam dosta povezanosti s marketingom, cijenama i svime time... pa $i$ sad isto u [školi] isto sam imao marketing (...) i sad još kak' idem na praksu, i eto ... nije tu ništa teško..." (Frane, URP_mg, 3SŠ_mg).

Usporedno, izbori druga dva učenika čine se u većoj mjeri ograničeni s obzirom da je njihova prva želja bila upis četverogodišnje škole, no s različitim zadovoljstvom konačnim odabirom; u jednom slučaju, osnovnu prepreku je činilo to što se željeni program nije izvodio godine kada je učenik upisivao srednju školu, za sljedeći izbor nije imao dovoljno bodova, te je u konačnici upisao trogodišnji strukovni smjer na osnovi informacija od starijih prijatelja kako je to dobar smjer za zapošljavanje u inozemstvu, što je učeniku sada značajan kriterij za buduće planove. Negdje u tom procesu u potpunosti se izgubila rana ideja o studiranju, a zapošljavanje je postalo daleko značajniji cilj: „... u osnovnoj, jesam [razmišljao o studiranju] ... i onda, evo, kak' sam ovo upis'o... vidio sam, ovaj, da ... da mi se ne da učit 
jednostavno... da mi je to lakše, da završim i idem radit'...", odnosno s obzirom da mu se struka ne sviđa, daleko značajniji cilj postaje odlazak u inozemstvo: ,... mislim da to ne budem radio... nije da mi se nešto posebno sviđa...“(Krešimir, URP_mg, 3SŠ_mg).

Dominik je pak zadržao misao o studiranju kroz srednjoškolsko obrazovanje, no kritički propituje posljedice izbora škole za nastavak školovanja s daleko manjim optimizmom oko konačnih ishoda. Izabrana srednja škola nije bila niti njegov prvi izbor niti su mu to savjetovali roditelji (,...Njima [roditeljima] se nije prvo sviđalo to da sam to upisao, nije ono što sam ja htio upisati $i . .$. dan danas im se ne sviđa što sam to upisao, a ni meni, al'... što je to, tu je...“) - osnovni utjecaj su predstavljali prijatelji:

„... To je nagovor jednog prijatelja bilo, da upišem to... inače ja sam htio upisati za elektrotehničara, to me više zanimala elektrotehnika, i onda ovaj me nagovorio (...) Ne sjećam se [što mi je rekao]..." (Dominik, RRP_DSJ, 3SŠ_mg)

U konačnici, učenikova majka je prva osoba koja ga je potakla na razmatranje daljnjeg školovanja i pomogla mu u prikupljanju informacija oko daljnjih mogućnosti, no koje kod učenika uvelike osvještavaju prepreke koje trogodišnje obrazovanje stavlja za ostvarenje toga plana $(, \ldots$ još bi 2 godine morao ići u školu tak'... jednu godinu moram polagati samo razlikovne ispite, a... na to sam gledao zbunjeno, onda razmišljam, morao bi' učiti čitavu godinu, da naučim sve, onda izgleda teško... “), a posebno kada je u pitanju završavanje nekog željenog smjera:

„... taj smjer oni nemaju u ovoj školi pa bi morao ići u Osijek... tak', htio sam upisat [...], dodatno, zato što baš se veže uz ovu moju nastavu tak' da ne moram polagati baš puno razlikovnih ispita (...)

... Pa kad bi mogao vratiti onda bih upisao za elektrotehničara (...) morao bi' opet krenuti u prvi razred (...) moram se okrenuti..." (Dominik, RRP_DSJ, 3SŠ_mg)

Čak i za one koji nisu razmatrali studiranje, ali su imali dovoljno bodova, upis četverogodišnje strukovne škole se javlja kao bolji izbor:

„... to smo mi svi isto upisivali zbog bodova (...) i ono: „Četri godine, malo bodova, svi ćemo to upisati “... nije to sad kog' šta zanima... a možd' je bio neko kog' je baš to htio bit' $u$ životu, al' nije uspio zbog nas pošto smo upisali se većina zato što je četverogodišnja škola..."(Marina, RRP_TP, 4SŠ_mg)

Osnovne pogodnosti takvog izbora su što ono ne zatvara mogućnosti studiranja iako u trenutku upisa srednje škole učenici koji biraju ne pokazuju želju za tim, no prvenstveno jer označava određeni statusni obrazovni rang, iako ne mora biti dio svjesnog razmatranja pri upisu: „...meni je bilo završit srednju pa makar $i$ trogodišnju, al' eto uspila sam četverogodišnju... “ (Ivana, RRP_DSJ, 4SŠ_mg). Dodatno, za one učenike koji nisu sigurni 
što bi upisali, izbore informiraju različite osobe iz njihova okruženja, prvenstveno prijatelji, koji određene izbore čine poželjnijima od drugih, ali i čitavi proces odlučivanja u većoj mjeri nepromišljenim:

„...P Pa slučajno, preko prijatelja, i tako, društva (...) pa imo sam 'oću trogodišnju, 'oću četverogodišnju i onda sam se odlučio ovdje, bezveze ... prijatelj jedan: ,, 'Ajd', 'ajd'.. ", drugi... i tak' je ispalo..." (Jan, URP_nc, 4SŠ_mg)

Prema iskazima učenika, želja za određenim smjerom je rijetka i odabir se uglavnom vodi negativnim procesom odbacivanja nepoželjnih alternativa i/ili zbog ograničenosti lokalnih izbora, no isto tako i odbacivanjem onih smjerova koji su poželjni, ali ih učenici procjenjuju teškima.

U tom okviru posebno je zanimljiv slučaj učenika koji u uzorku intervjuiranih predstavlja jedinog učenika s prosjekom ocjena 5,0 kroz cijelo njegovo školovanje, a čiji je konačni izbor srednje škole, koji nije bio njegov željeni smjer, uvelike utjecao na njegove kasnije mogućnosti: „...Pa dvoumio sam se (...), i onda sam se... bilo me je strah elektrotehniku, ali bilo je dost' teško..." (Marijan, RRP_DSJ, 4SŠ_mg). Na kraju srednjoškolskog obrazovanja, kada je i mogućnosti zapošljavanja i pripreme za studiranje koje dobiva na svom smjeru procijenio lošima, iznimno je nezadovoljan svojim izborom srednje škole, i unatoč visokom školskom postignuću, izuzetno nesiguran oko mogućnosti stjecanja željenog visokog obrazovanja kao i njegovi roditelji.

Kako je zamjetno, utjecaje prijatelja daleko više ističu učenici, dok se poticaji roditelja često u tim opisima pojavljuju iznimno ambivalentno; iako uglavnom potiču kod učenika ili upisivanje četverogodišnjih škola ili pak gimnazija, veliki dio konačnih izbora učenici pripisuju svom samostalnom odlučivanju, dijelom informiranim s prijateljima.

Najzanimljiviji primjeri su onih učenika koji smatraju da im se studiranje podrazumijeva i koji procjenjuju da su vrlo rano ili barem u osnovnoj školi znali da namjeravaju studirati, ali su izabrali strukovno obrazovanje kao svoj obrazovni put prema visokom obrazovanju. Kod nekih učenika taj put usmjerava želja za radom u određenom zanimanju, pri čemu je odabir gimnazije odbačeno kao alternativa ili nije razmatrano. Bitno je istaknuti i paralelno postojanje procesa u kojem učenici razmatraju pitanje: kakvu $(\mathrm{K})$ sliku o sebi imam, odnosno jesam li ja (K) materijal za gimnaziju, odnosno misle li to drugi i što im to potvrđuje? 
Tako Silvija nije razmatrala upis gimnazije, već je u skladu sa slikom o sebi (,...imam, onako, talenta za crtanje..."), no isto tako u razgovoru s roditeljima i razmatranjem opće situacije sa zapošljavanjem („,.. mama, ono, predložila bolje da upišem neku bolju struku od čega ću moći bolje živjet'... "), odvagala želje i mogućnosti te donijela, kako smatra na kraju srednjoškolskog obrazovanja, „,ратеtnu odluku“ jer: „,...upala sam i u umjetničku, međutim odlučila sam se za ovu zato što, ono, državna firma, uvijek plaćeno (...) i u opisu kad sam gledala preko Interneta ... kao, radi se u labosu (...) tak' da mi je to bilo zanimljivo i super mi je... “. Općenito, završavanje škole koju procjenjuje dobrom i stjecanje struke koju smatra cijenjenom, djelovalo je na njeno samopouzdanje i produbljivanje želje za iskorištavanjem pogodnosti koje završavanje srednje škole dobrog statusa ima za daljnje obrazovanje:

„,...kad mene pitaju koja si [škola], kao: „Medicinska“ - „,Vau, to je super škola... super! “ (...) ako već imaš mogućnost za nešto više, bilo šta bilo, ipak, diploma je diploma, a ne samo završena srednja škola... je l' ti u struci uvijek možeš radit', a možeš radit' i za ono za šta ćeš završit' na fakultetu... "(Silva, RRP_, 4SŠ_VG)

U njenoj slici četverogodišnja škola je izabrana zbog mogućnosti stjecanja dobre struke i boljeg zaposlenja, no i sa željom daljnjeg (K) napredovanja „više i dalje“, iako je ono u većoj mjeri neodređeno i ograničeno izborom srednje škole. Ono što ovu učenicu posebno izdvaja od ostalih učenika strukovnih škola je viša vjera u mogućnosti zapošljavanja osoba sa završenim fakultetom i značaj posjedovanja diplome za povećanje životnih mogućnosti.

$\mathrm{S}$ druge strane, Mislav je razmatrao upisivanje gimnazije, jer je imao ocjene za to, a što se dodatno u njegovom opisu podudara sa shvaćanjem o studiranju njegove obitelji, te što je pravac koji su slijedile njegove sestre. Studiranje se u tom obiteljskom kontekstu oblikuje kao norma, a pravac obrazovanja preko gimnazije kao prirodan:

„,... Nešto što je normalno, znači... sestre su išle u gimnaziju i otišle su na fakultet... ja sam otiš'o u poljoprivrednu školu, isto prolazio sam u osnovnoj s pet... nisam ja... mog'o sam i ja u gimnaziju, ali sam ost'o... otišao u poljoprivrednu školu tako da i ocu pomognem kod kuće, i ne znam.... Njima je normalno bilo da idu one na fakultet... znači, one su to normalno prihvatili: „Idě̌ ... moraš... nema druge“... tako i mene isto sad guraju: moram, moram to završiti... "(Mislav, RRP_DSJ, 4SŠ_VG)

Ipak, posebne okolnosti su vodile Mislavov obrazovni put preko strukovnog obrazovanja, željenog i specifično vezanog za njegove buduće planove održavanja obiteljskog poljoprivrednog gospodarstva i stjecanje daljnjih praktičnih vještina. S jedne strane praktična znanja svakodnevnog života i obiteljski utjecaji, a s druge strane visoko vrednovanje obrazovanja, rezultirali su dobrim ocjenama kao osnovnim poticajem prema daljnjem obrazovanju: „... početkom prvog razreda kad su krenile dobre ocjene, i... tad... to mi se 
činila kao dobra prilika, da iskoristim te dobre ocjene pa da upišem fakultet...". Tako se u priči ovog učenika studiranje javlja kao normalno, kao nešto što mu se podrazumijeva, ali koje je zahtijevalo određeno promišljanje što je rezultiralo kasnijom odlukom, ali i visokim aspiracijama te velikom uvjerenošću u mogućnosti postizanja željenih ishoda u području koje, poput gimnazija na općem obrazovnom planu s učenicima visokoobrazovanih roditelja, povezuje srednjoškolsko strukovno obrazovanje s ruralnim obiteljski način života, odnosno kontekste odrastanja i školovanja u vremenskoj dimenziji pozitivnih iskustva i s uvjerenošću u buduće uspjehe.

Andrea i Aneta, pak, također odlične učenice s visokoobrazovnim namjerama i izraženom željom za područjem studiranja, odbacuju gimnazijsko obrazovanje prvenstveno iz straha od ili zbog lošijih ocjena, odnosno u nadi da će strukovno srednjoškolsko obrazovanje biti „lakši“ put postizanja boljeg školskog uspjeha kako bi se povećale šanse upisa željenih studija:

„... Razmišljala sam [o upisu gimnazije], ali sam slaba bila iz matematike pa nisam htjela da imam tako loš uspjeh u matematici, $i$ onda nisam... “(Andrea, RRP_TP, 4SŠ_mg)

„... nisam htjela gimnaziju jer me bilo strah da možda neću ... da ne bi prošla s pet, a to mi je bio cilj - da prođem s pet da imam bolji prosjek..." (Aneta, URP_mg, 4SŠ_mg)

No, nakon odbacivanja gimnazija, i odabir drugih škola je bio težak s obzirom na lokalne ograničenosti izbora u malom subregionalnom centru (,...možda zato što ovdje nema baš puno izbora srednjih škola i to mi je, ono, još ostalo...", a za Anetu i dodatnim neuspjehom upisa željenog smjera (,... samo što su se neki prijavili koji su imali više bodova pa su me izgurali... "), te učenice u konačnici završavaju škole za koje procjenjuju da ih dobro ne pripremaju za studij, što vodi i njihovom smanjivanju aspiracija kao i slabijim procjenama vjerojatnosti upisa željenih studija:

„... Trebala sam [upisati gimnaziju]... zakinuta sam, ono, totalno, iz matematike, fizike, biologije, i engleskog, zakinuta sam ono u potpunosti ..." (Andrea, RRP_TP, 4SŠ_mg)

U srži, učenice nisu za sebe usvojile sliku (K) materijala za gimnaziju, čak i unatoč drugim poticajima, ili otežano određenim pritiscima obiteljske situacije (prvenstveno financijskim) te odlažu stjecanje željenog obrazovanja do studija putem kojeg u tom trenutku doživljavaju „lakšom“ alternativom gimnazijskom obrazovanju i velikom usmjerenošću na postizanje školske uspješnosti. No, prednosti u obliku ocjena do kraja srednjoškolskog obrazovanja za ove učenice ne umanjuju njihove $(\mathrm{K})$ strahove od neuspjeha u visokom obrazovanju, štoviše, moguće je da su oni još snažniji: 
„,... ne volim da nešto ne uspijem onda se totalno izgubim je l' ne znam sad kad'idem na ispit... kako da padnem?.. to je meni nepojmljivo... ne znam kako bi se nosila s tim..." (Andrea, RRP_TP, 4SŠ_mg)

„... brine me možda da, da nisam dovoljno dobra za to, da neću završit... “ (Aneta,
URP_mg, 4SŠ_mg)

Za razliku od toga, svi gimnazijalci su svjesni mnogostrukih prednosti koje stječu obrazovanjem kojeg dobivaju u svojim školama čak i kada se one ne pretaču u bolji školski uspjeh, i s obzirom na teškoće koje ono nosi, i iako nisu svi pri upisu bili svjesni toga. Svi učenici koji su izabrali gimnazije ističu kako su vrlo rano znali da će studirati i uglavnom nisu razmatrali tu odluku, što je u skladu i sa stavom da im se studiranje podrazumijeva, odnosno bitan je dio onoga kako vide sebe, te viđenja da je studiranje nužno, i u slici njihove željene budućnosti, i u skladu s procjenom mogućnosti zapošljavanja, vremena i stanja u Hrvatskoj.

Veliki dio učenika ističe ocjene kao osnovu koja ih je uopće usmjerila prema gimnazijskom obrazovanju, posebno za djevojke, pri čemu je nekim učenicima to bila potvrda da imaju sposobnosti i kvalitete za obrazovni uspjeh i nakon srednje škole i/ili u željenom području rada. Drugim riječima, postoje učenici koji su rano razvili želje o željenom budućem zanimanju te su svoje energije usmjerili u obrazovni uspjeh za ostvarenje tih želja koji se u školskom kontekstu potvrđivao ocjenama i oblikovao u posebnom $(\mathrm{K})$ učeničkom identitetu:

„... od malih nogu, odmah... nisam ni razmišljala o tome da završim, ne znam, nešto ... strukovno zanimanje i da ostanem na tome (...) čim sam ... jako rano sam propričala, naučila čitati, pisati, sve... stalno sam se bavila školom i svim time (...) ... [roditelji] rekli su mi samo da vide moj kapacitet i da misle da bi bilo sasvim u redu upisati nešto takvo..." (Gordana, RRP_TP, GIM_VG)

Tako je Gordana svoje rane želje u medicinskom području, uz roditeljske poticaje i na osnovi svojih školskih uspjeha, usmjerila na upisivanje gimnazije, dok je Bernarda to isto učinila sa svojim ranim željama za studiranjem jezika. No, izuzev samih ocjena i rane visokoobrazovne želje (koja se može odvijati i preko strukovnog obrazovanja), dodatni mehanizmi djeluju prema „odabiru“ gimnazija: postoji gotovo opći društveni pritisak selektivnog tipa koji učenike usmjerava prema gimnazijskom obrazovanju procjenjujući ih (K) materijalom za školu, a koji učenici procjenjuju sukladnima svojim visokoobrazovnim nastojanjima i željama:

„... mislim, u osnovnoj sam bila odlična učenica (...) nismo toliko općenito svi više učili u osnovnoj, jednostavno su bili ono oni koji su bolji i oni koji su - ne'ko za školu, a neki za koje se znalo da će baš ići u strukovnu... ovu obrtničku... 
... posavjetovala sam se sa roditeljima, sa starijim prijateljima, i odma' su ono... ovdje je to tako uvijek [...]: 'ko prolazi s pet, taj bi treb'o ić' u gimnaziju...

... mislim da imam kapacitet i sposobnost da učim i razvijam svoje znanje... "(Bernarda, URP_mg, GIM_mg)

Utjecaj ocjena i odbacivanje ostalih strukovnih mogućnosti koje se nude, može djelovati prema gimnazijskom obrazovanju i bez specifične vizije željenog zanimanja pri čemu gimnazijsko obrazovanje predstavlja produženo stjecanje općeg obrazovanja do trenutka donošenja konačne odluke u odnosu na lokalnu alternativnu ponudu, pružajući dodatne mogućnosti i na općoj razini stvarajući bolje pozicije za ulazak u visoko obrazovanje:

„...u osnovnoj školi sam bila odlikašica i sve sam prolazila sa pet-nula ... ne znam... nije me ništa baš točno zanimalo, ni tehničke znanosti, ni, ne znam, na primjer hotelijerskoturistička, onda nisam znala šta da upišem, pa sam onda gimnaziju ... nisam se mogla opredijeliti...“(Marija, RRP_TP, GIM_mg)

Ipak, taj izbor nije bio jednostavan za ove učenice s obzirom na ono što gimnazijsko obrazovanje podrazumijeva, a kako Gordana upozorava: „,...o tome [financijama] se zapravo prvo treba razgovarati s roditeljima, i prije upisa u gimnaziju (...) zato što to podrazumijeva upis na fakultet, tako da tko to ne može izfinancirati može se jako razočarati, općenito u sve...". Time gimnazijsko obrazovanje predstavlja rizik onima s ograničenim obiteljskim resursima pa čak i unatoč visokom školskom postignuću, a dodatno je taj rizik, čini se prema prethodnim primjerima, snažnijim doživljen u obiteljima učenicika odraslima u ruralnim sredinama koji su, općenito, instrumentalno orijentirani prema obrazovanju i moraju jasnije vidjeti praktičnu vrijednost obrazovanja (Corbett, 2010). Taj rizik su poduzele i Gordana i Marija donošenjem posebnih odluka o instituciji, odnosno gradu gdje će se obrazovanje odvijati; budući da su obje učenice odrasle na selu bilo koji izbor bi uključivao potrebu putovanja, no ono može biti posebno opterećenje za gimnazijalce s obzirom na težinu škole: „...gubite 2 sata dnevno što bi netko možda odspavao kod kuće, ja sam morala putovati, ali ja sam sebi vrijeme rasporedila u skladu s tim tako da (...) kad god sam primijetila da mi učenje ispašta zbog nečeg drugog, ja sam se odrekla tog drugog...“. Marija se, pak, odlučila za preseljenje i život u domu jer je to bila jeftinija opcija: ,... kada sam ja upisivala, dom je bio 630 kuna pa zbog financijskih razloga... sama karta je bila puno skuplja... pa sam onda $и$ [u grad $70 \mathrm{~km}$ dalje] odlučila... i još bi' na putovanje izgubila oko 2 sata... tako da mi se ovo više isplatilo...“. Oba izbora su također imala posljedice za njihova srednjoškolska iskustva; za Mariju jer je rano napustila roditeljsku kuću, te jer je bila jedina gimnazijalka u domu što uvelike oblikuje njena srednjoškolska iskustva: 
„... kad smo u domu, i ja uvijek imam za učit nešto, $i$ ja sad idem učiti : „Jao, gimnazija, uvijek nešto štreba! “, dok svi: „, Haj"mo na kavu, haj"mo ovo, haj"mo ono.. “... “ (Marija, RRP_TP, GIM_mg)

Stoga, odabir tipa srednjeg školovanja, uključuje daleko kompleksniji proces, posebno učenicima ruralnog rezidencijalnog podrijetla, u kojem učenici vrše i dodatne odabire posebnih programa, institucija i mjesta gdje se obrazovanje odvija, a koji razvijaju i njihovo poimanje prostora i mjesta. U određenoj mjeri moguće je upravo takva iskustva smatrati ključnim trenucima „,iskorjenjivanja“ iz zajednice i kako kaže Gordana: „... prije dok sam možda još i išla u osnovnu školu onda sam se još $i$ družila s ljudima iz sela $i$ iz okolice.. hmmm... trenirala sam, i ono, klasika, druženje - dijete ko dijete... međutim, kada sam krenila u srednju školu, onda promijenila sam društvo i vidjela sam kako su mi se gradili svjetonazori...“. Vrlo slično će i neki drugi učenici pohađanje škole u velikom gradu opisati kao značajna životna iskustva posebno kada su ona prethodna bila iznimno negativna:

„... ja sam u osnovnoj školi bila, kak da kažem, nisam pričala, i tak (...) u osnovnoj školi je to bilo, ono, više izraženo... na neki način i ovi iz sela, kao. „, Ti ni ne pričaš, di ćeš ti škole završit?", ovo, ono... međutim, kad sam ja krenila u srednju, kad sam ja upoznala svu ovu ludu ekipu iz razreda, onda sam počela plesati u KUD-u.. i mislim da me to čak ono, $i$ izvuklo, ne znam kak da kažem..." (Silvija, RRR_TP, 4SŠ_VG).

Gordana je donosila određene odluke u skladu sa svojom visokoambicioznom željom te je istodobno morala promišljati i dodatne elemente svojih izbora. Suprotno učenicima koji su u strahu da neće imati dobre ocjene ako upišu gimnazije, Gordana donosi svoje izbore odbacivanjem strukovnog školovanje u korist gimnazijskog zbog svih dodatnih prednosti koje ono omogućava, ali i uz određene žrtve:

„... dvoumila sam se jer sam htjela studirati medicinu, i mislila sam upisati medicinsku školu, međutim, priprema za fakultet, i općenito, za prijemni ispit i maturu je u medicinskoj školi... oni to ne omogućavaju... “(Gordana, RRP_TP, GIM_VG)

Drugim učenicima u uzorku odabir gimnazijskog obrazovanja je uglavnom oblikovano ranom odlukom o studiranju i obiteljskom potragom za obrazovanjem koje će u najboljoj mjeri poticati ostvarenje tog cilja. Studiranje se potiče kao obiteljska vrijednost, a upoznatost s, ili dostupnost informacija o obrazovnom sustavu i njegovim djelovanjem te specifična znanja o visokom obrazovanju vode odbacivanju strukovnog obrazovanja kao oblika koji u manjoj mjeri omogućava pripremu za visoko obrazovanje. Učenici pak kroz obiteljske dinamike te vrijednosti oblikuju u (K) učeničkom identitetu izraženo učeničkim usmjerenjem na školski uspjeh i potvrdom sposobnosti i kvaliteta i/ili odbacivanjem slike o sebi kao nekome tko je završio neko strukovno obrazovanje. 
„.... Jako rano, odma' ... mislim, znala sam... to je... u osnovnoj školi sam još znala da želim studirati... (...) To je meni normalno... to ... nije postojalo drugi... nije postojala mogućnost da ja ne odem studirati meni u glavi (...) za ove praktične stvari nisam baš najsposobnija tako da... uzmem knjigu i to je ono što znam...

... važno da odeš u kvalitetnu ustanovu za obrazovanje... kao što sam birala i ovu školu zato što sam mislila da je kvalitetna..."(Anica, URP_VG, GIM_VG)

$\mathrm{Na}$ taj način odabir gimnazije je dio (K) obiteljskog usmjerenja za postizanje određenih obrazovnih ciljeva nakon srednjoškolskog obrazovanja. Takvi izbori karakteristični su za učenike koji imaju visokoobrazovane roditelje i to u područjima za koja interes pokazuju i sami učenici, a što roditelji podržavaju i savjetovanjima i davanjem informacija, odnosno svim raspoloživim kulturnim, socijalnim i ekonomskim resursima, koji se za učenike pokazuju kao bitni obrazovni kapitali kada je u pitanju odabir i upis određene škole:

„...majka me oduvijek nekak' pripremala za to... šta ja znam... čini se da sam oduvijek bio poprilično nadareno dijete pa se očekivalo da ću nastaviti ...

(...) ima u [mom gradiću] gimnazija, ali moja majka je radila i kaže da joj se ne sviđa uvjeti (...), kaže mama da je to sve na nekom nižem nivou, pa sam onda došao u Osijek ...

(...) oduvijek sam htio ići u veći grad ... još od početka osnovne škole sam rekao kak' ću jednog dana ići u Osijek u srednju školu (...) jednostavno sam išao za tim šta će mi koristiti u daljnjem životu, te neke stepenice...(Andrej, URP_mg, GIM_VG)

Kako je većina intervjuiranih gimnazijalaca urbanog rezidencijalnog podrijetla, time im je i gimnazijsko obrazovanje dostupno u većoj mjeri. Ipak, u skladu s izborima za postizanje visokoobrazovnih ciljeva, te u skladu s ostalim dostupnim obiteljskim resursima, učenicima su dostupniji i prostorno širi izbor kvalitetnih institucija u skladu s njihovim željenim oblicima obrazovanja, kao i mjestom obrazovanja. Kako dočarava Andrej, i Jakov, neki učenici svjesno žele srednjoškolsko obrazovanje steći u velikom gradu jer se takvo obrazovanje doživljava kvalitetnijim, a čak i unatoč svojim specifičnim interesima roditelji preuzimaju značajne uloge u usmjeravanju učenika prema obrazovanju koje će im pružiti bolje mogućnosti daljnjeg obrazovanja:

„... znala je [mama] preko nekih svojih kolegica, i dosta njih je predložilo [ovu školu] (...) predlagao majci da idem, možda, na neki umjetnički smjer ovdje, ali je ona rekla ... da mogu bolje znanje, da sam, ono, sposobniji za gimnaziju ...

... išli su mi svi predmeti ali sam volio, na primjer, matematiku, fiziku - to nisam morao učiti, bilo mi je dovoljno samo na satu.. i onda, jedostavno to je tako .. mislio sam da će to tako biti i ovdje.. nije sad to neki problem, ali me više umjetnička strana zanima...ovdje dobivam neku podlogu ... “(Andrej, URP_mg, GIM_VG)

„... ja sam veliki obožavatelj sporta općenito (...) u Osijeku ima sportska gimnazija (...) i ja sam sa svojim roditeljima kad sam bio u osnovnoj pričao (...) šta bi mogao upisat', vam'-tam', i bilo je, kao: „Ja bi u Osijek“... i onda je reakcija mojih roditelja bila: „OK, može... 'aj"mo vidjet' u Osijek šta ima “... " (Jakov, URP_VG, GIM_VG) 
Iako se Jakovljeva želja preseljenja nije ostvarila, zbog specifične obiteljske situacije koja je utjecala na roditeljsku procjenu da je učenik premlad za napuštanje roditeljskog doma (,, ... rekla je [mama], kao: „Žao mi je al' ja tebe ne mogu pustit'“, kao... ja imam starijeg brata koji je isto te godine upisivao fakultet... on je upisao fakultet u Zagrebu..."), i iako je izazvala kod učenika veliku ljutnju, s obzirom na lokalne mogućnosti u velikom regionalnom gradu, odluka nije predstavljala poseban nedostatak obrazovnih mogućnosti, niti razočarenje za učenika. Štoviše, upravo je Jakov učenik koji je svojoj školi i svom srednjoškolskom obrazovanju u intervjuu opjevao posebne hvalospjeve: „.. ova gimnazija je pružila meni ... toliko puno znanja, toliku podlogu za fakultet, i naučila me radit, naučila me da se ne mogu opuštat konstantno..."(Jakov, URP_VG, GIM_VG).

U konačnici, osim kao osnovni društveni pritisak škola i obiteljske dinamike koje se kristaliziraju kao selekcija učenika „koji su za gimnaziju“ s obzirom na školski uspjeh i procjenu sposobnosti, i upotrebom obiteljskih resursa i poticaja, postoji i dio učenika za koje se ono odvija nezavisno od odličnog uspjeha, a prema prihvaćanju određenih identitetskih odrednica koje istodobno označavaju ono kako se NE vide - kao učenika strukovne škole, te izrazito s obzirom na želju za mobilnošću. Takav scenarij karakterističan je za učenike visokoobrazovanih roditelja, i koji ističu prvenstveno želju za upisom gimnazije, pri čemu se obrazovanje gimnazijskog tipa bira zbog dodatne 4 godine za jasnije usmjeravanje i/ili stvaranje dobre podloge za omogućavanje lakšeg ulaska u visoko obrazovanje. U svakoj od tih slika značajno je odbacivanje strukovnog obrazovanja kao poželjnog, zadovoljavajućeg ili kao područja u kojem se učenici mogu zamisliti, ali i prihvaćanje posljedica koje ono znači s obzirom na školska opterećenja i prosječne ocjene:

„...ja sam bio nekako, 'ajmo reći, zlatna sredina koja je prolazila i sa četvorkama i sa peticama (...) kad sam ja to sve onak' malo vrtio u glavi i razmišlj'o šta bih ja mogao, šta bih ja želio... jednostavno, sebe nisam vidio ni u tako nekom zanatu jer mislim da moje intelektualne sposobnosti i znanje može i mora biti veće od jednog tokara ili...

(...) iskreno, tol'ko smo zatrpani gradivom općenito u školi... možda će ispast da se žalim, ali se ne žalim, jer sve nekako kad uvidite, znate da vas zatrpavaju jer morate sve znat ..."(Jakov, URP_VG, GIM_VG)

„...još u osnovnoj školi sam htio ići u gimnaziju... imao sam dosta dobre ocjene (...) Pa negdje u sedmom razredu, možda čak $i$ u šestom, $i$ onda sam počeo malo više učiti jer je ... za upis su se bodovali, je l', sedmi i osmi razred...

(...) oni [roditelji] su rekli: ,, 'Ajd' sad malo razmisli, jer moraš biti svjestan da ćeš ti u gimnaziji morati raditi, da nije samo, ono... ne smiješ se jednostavno zezati s tim “... hmmm... ja sam rekao da sam siguran, no evo moji rezultati su malo lošiji od ostalih... " (Dejan, URP_mg, GIM_mg) 
Istaknimo ovdje da su upravo to učenici koji iskazuju iznimnu želje za društvenom i geografskom mobilnošću koja se jasno uočava i u njihovim opisima onoga što žele od visokog obrazovanja i vizijama svoga budućeg života koja nadilazi okvire hrvatskih granica. U njihovim narativima gimanzije su vrlo svjesno odabrane kao škole koje u širem obrazovnom polju u većoj mjeri osiguravaju postizanje željenih životnih ciljeva, unatoč tome što je gimnazijsko obrazovanje teško, i s time predstavlja izuzetnu žrtvu za lakš daljnje korake na postavljenom putu.

\subsubsection{2 Školska uspješnost i učenički kulturni kapitali}

Prethodna analiza provedena je jer postoji splet međupovezanih utjecaja koje treba promotriti kada se pokušava odgovoriti na pitanje o učeničkim namjerama studiranja koja se vremenski razvijaju s većom ili manjom sviješću o posljedicama ranijih izbora i obrazovnih usmjerenja. Ona se pak oblikuju u dinamikama između konteksta odrastanja i školovanja, a unutar određenih prostornih i institucionalnih strukturnih okvira. U trenutka donošenja konačne odluke učenici zauzimaju određene pozicije uvjetovane ranijim odabirima i koje pružaju određene mogućnosti, no koje su oblikovane tijekom srednjoškolskog obrazovanja različitim individualnim razvojima i specifičnim okolnostima. Ovaj kratki pregled već je ukazao na neke rane utjecaje koje sadašnje školske pozicije odnosno tip školovanja kojeg završavaju te njihov školski uspjeh koji im u trenutku donošenja odluika o daljnjim obrazovnim kretanjima i određene početne pozicije kada je u pitanju njihova namjera studiranja. Iako, za gimnazijalce taj put je ranije i direktnije postavljen, a kako opisuju učenici takav put je i s obzirom na uspjeh ulasaka u visoko obrazovanje i sigurniji.

Značajno je bilo, a teorijski je vođeno, ispitati i dodatne elemente koji su dio učeničkih osobnih kapitala i vrijednosnih usmjerenja i koji, uz školski uspjeh, značajno opisuju orijentacije prema visokom obrazovanju, iako nisu direktno vezani uz školske aktivnosti, štoviše koji mogu biti dodatni kapital uz ili unatoč školski i obiteljski razvijenim kapitalima.

Kvantitativno iskazano na općoj razini, slavonski maturanti su prošli razred završili s ocjenom četiri $(\mathrm{M}=3,6)$, dok je 18\% učenika imalo prosjek ocjena odličan, među kojima je i 3\% učenika s prosjekom ocjena 5,0, odnosno s ekstremnim iznadprosječnim rezultatom (2 SD iznad prosjeka). Rezidencijalno podrijetlo značajno razlikuje učenike prema općem školskom uspjehu kako to potvrđuje t-test na ukupnom uzorku slavonskih maturanata (Tabela 4.2). Drugim riječima, pokazalo se da postoje ruralno-urbane razlike u školskoj uspješnosti između 
slavonskih učenika, pri čemu je prosjek učenika odraslih na selu statistički značajno niži $\left(\mathrm{M}_{\mathrm{RRP}}=3,6\right)$ u odnosu na prosjek učenika odraslih u gradu $\left(\mathrm{M}_{\mathrm{URP}}=3,7\right)$.

Iako je pretpostavka bila da će se navedeni rezultati odražavati i u rezultatima vrednovanja učenja i želje za društvenom mobilnošću, to se nije pokazalo; bez obzira na rezidencijalno podrijetlo, slavonski maturanti općenito učenju pripisuju relativno visoku vrijednost $(\mathrm{M}=3,6)$ za postizanje raspona pozitivnih ishoda, a iznadprosječno iskazuju i želju za društvenom mobilnošću u odnosu na društveni status svojih roditelja $(\mathrm{M}=3,5)$.

Uzorak intervjuiranih učenika je, kao cjelina, blago školski uspješniji te je 6 intervjuiranih učenika s iznadprosječnim školskim uspjehom, odnosno onih koji su prošli razred završili s ocjenom odličan, a među njima je i učenik s ekstremnim rezultatom, odnosno s prosjekom ocjena 5,0. Ne iznenađuje da svi ti učenici namjeravaju studirati te da su među tim učenicima oni s najvišim obrazovnim aspiracijama završavanja doktorskog studija, no pokazuje se i da je među odličnim učenicima samo manjina gimnazijalaca, točnije dvoje gimnazijalki, dok je 4 učenika ruralnog rezidencijalnog podrijetla. Uz primjere učenica koje su odabrale gimnazije kao prirodan put za postizanje ranih visokoobrazovnih želja, ocjenama se ističu i učenice koji su strukovno obrazovanje odabrale kako bi postigle bolji uspjeh nego su predviđale da bi mogle postići u gimnazijama. Sve te učenice imaju razvijen $(\mathrm{K})$ učenički identitet orijentiran na školsko postignuće s izraženim visokim obrazovnim aspiracijama. (,,.. jako rano sam propričala, naučila čitati, pisati, sve... stalno sam se bavila školom i svim time... " Gordana, RRP_TP, GIM_VG). Konačno, dva učenika strukovnog obrazovanja i ruralnog rezidencijalnog podrijetla zaokružuju ovaj skup najuspješnijih učenika - jedini odlični učenik koji učenju pripisuje iznadprosječno visoku vrijednost, te učenik čiju izrazitu orijentaciju na školski uspjeh potvrđuje njegov prosjek od 5,0 kroz cijelo njegovo školovanje.

No, s druge strane isto se tako pokazuje da je većina učenika koja je iskazala namjeru studiranja prosječno školski uspješna u relativno širokom rasponu prosjeka ocjena 3-4,5. Samo je jedna učenica u uzorku s ispodprosječnim rezultatom prosjeka ocjena dobar koja ne pokazuje namjere studiranja, pri čemu su ocjene važno, ali u njenoj priči samo djelomično objašnjenje njenih neodlučenih namjera. Učenica ima visok rezultat vrednovanja učenja, kao i još dvoje učenika koji ne znaju misle li studirati. U ostalom, i ostali učenici koji ne namjeravaju studirati imaju dobre ocjene, odnosno prosječne, no koji razvijaju alternativne planove i drugačije vrednuju obrazovanje za njihovo postizanje. Samo se jedan učenik koji ne 
namjerava studirati, izdvaja niskim vrednovanjem učenja za svoje buduće planove, unatoč dobrom školskom uspjehu.

Tabela 4.2 rezultati analize razlika između učenika različitog rezidencijalnog podrijetla prema školskoj uspješnosti i kulturnim kompetencijama

\begin{tabular}{|c|c|c|c|c|c|c|c|}
\hline \multirow[b]{2}{*}{ Zavisna varijabla } & \multicolumn{2}{|c|}{ Uk. uzorak } & \multicolumn{2}{|c|}{ (1) RRP } & \multicolumn{2}{|c|}{ (2) URP } & \multirow{2}{*}{ t-test } \\
\hline & M & SD & $\mathbf{M}$ & SD & M & SD & \\
\hline Opći školski uspjeh na kraju prošlog razreda & 3,63 & 0,65 & 3,57 & 0,68 & 3,69 & 0,61 & $t(430)=-1,97 *$ \\
\hline Vrijednost pripisana učenju & 3,64 & 0,84 & 3,58 & 0,88 & 3,70 & 0,80 & $t(430)=-1,41$ \\
\hline Želja za društvenom mobilnošću & 3,51 & 0,85 & 3,52 & 0,85 & 3,50 & 0,85 & $\mathrm{t}(424)=0,20$ \\
\hline Učeničke kulturne prakse & 1,60 & 0,65 & 1,43 & 0,55 & 1,77 & 0,71 & $t(412,5)=-5,56^{*}$ \\
\hline Učeničke izvanškolske aktivnosti & 0,15 & 0,21 & 0,13 & 0,19 & 0,17 & 0,22 & $t(428)=-2,32 *$ \\
\hline Učeničke čitalačke prakse & 2,17 & 0,94 & 2,01 & 0,92 & 2,33 & 0,93 & $t(432)=-3,58 *$ \\
\hline
\end{tabular}

Ocjene i tip škole, odnosno vrsta srednjoškolskog obrazovanja shvaćeni su u ovom radu kao obrazovni kapital učenika - socijalizacijski izgrađen u školskom kontekstu. Ipak, zajedno ili odvojeno doprinose različito procjenama učeničkom samopouzdanju, a posebno se iz intervjua da iščitati njihovo različito vrednovanje s obzirom na tip škole, odnosno kako ukazuju učenici, kvalitetu znanja. Kako je ukazalo prethodno poglavlje, ocjene poprimaju različita značenja različitim učenicima; u obiteljskom kontesktu razvijaju se kao (K) orijentacija na obrazovanje, odnosno aspiracijski habitus; u osnovnoškolskom obrazovanju velikim dijelom predstavljaju učenicima oznaku $(\mathrm{K})$ „,materijala za gimnaziju“ u procesu $(\mathrm{K})$ diferencijacije, ili, u ruralnim kontekstima, kao stratificirajući utjecaj škola u odabiru onih koji su određeni za uspjeh u terminima mobilnosti (Corbett, 2005). No, takve ocjene postaju značajniji kapitali kada se ulože u apstraktnije obrazovanje koje vodi direktnije visokom obrazovanju i koji je karakterističan za učenike visokoobrazovanih roditelja, učenika koji u većoj mjeri usvajaju vrednovanje obrazovanja, te razvijaju značajne obrazovne kapitale u školi ili izvan nje za lakši ulazak u visokoobrazovanje. Upis gimnazija nije jedini put, ali značajno doprinosi samouvjerenosti učenika, umanjivanju strahova oko upisa željenih studija. Određeni dio odličnih učenika iz skupa intervjuiranih unatoč visokim ocjenama odlučio se za druge obrazovne putove ulažući u druge oblike obrazovanja, koji učenicima s manje dostupnih obiteljskih resursa mogu prestavljati manji rizik, ali i veće emocionalne terete. Drugim riječima, učenici i njihove obitelji s različitih društvenih pozicija na različite načine 
vrednuju obrazovanje i na različite načine su spremni „uložiti“ u njega. To odražavaju i odražava se na njihovim aspiracijama koje se mijenjaju kroz vrijeme i u različitim uvjetima.

Uz obrazovni kapital, značajno je ispitati i neke druge oblike kulturnih kapitala samih učenika koji su također nasljeđuje unutar obitelji, vrednuje unutar školskog sustava, ali se razvija i nezavisno od obitelji i škole. Što je to učenički kulturni kapital i kako se on odražava u visokoobrazovnim orijentacijama učenika različitog rezidencijalnog podrijetla? Osnovne pretpostavke koje proizlaze iz Bourdieuovog teorijskog okvira govore o kulturnom kapitalu kao kompetencijama koje učenici usvajaju prvenstveno u obiteljskom okružju, gdje se kapital nasljeđuje, i koji se kao obrazovni kapital razvijaju školskom okruženju (stečeni kapital), ali i izvan njega (Bourdieu, 1984). Osnovne mjere u ovom istraživanju ticale su se pitanja o razini posjećivanja institucija i programa koje spadaju u područje visoke kulture, kao i općenito tekstovima koje čitaju učenici izvan obavezne školske literature, a konačno pitalo ih se i o izvanškolskim aktivnostima vezanima prvenstveno uz one umjetnički orijentirane. Dakle, radi se o praksama koje se direktno ne vezuju uz njihovo školovanje, a za koje se pretpostavlja da doprinose školskoj uspješnosti, iako se razlikuju od nje, i ne mogu se zahvatiti mjerama poput ocjena. To su vrste praksi koje se, teorijski, potiču unutar obiteljskog okruženja kroz proces socijalizacije i koje u osnovi takve učenike postavlja u bolju poziciju i unutar obrazovnog polja budući ih školski sustav visoko vrednuje. Obiteljske dinamike i roditelji kao primjeri te ukupni obiteljski habitus, a posebno onaj koji visoko vrednuje obrazovanje, čini podržavajući kontekst za orijentaciju učenika prema visokom obrazovanju. Ipak, potrebno je uzeti u obzir i o kojim se to praksama radi te koliko su uopće dostupne ili zašto nisu, ako su obrazovno značajne. Statistički podaci pokazuju da je razina svih navedenih aktivnosti mjerenih u upitniku zapravo niska među učenicima, a posebno kada je su u pitanju kulturne prakse i izvanškolske aktivnosti.

Regionalno, prosječna vrijednost kulturnih praksi za slavonske učenike iznosi tek $M=1,6$. Kvalitativno značenje tog broja pokazuje da se velika većina učenika samo jednom ili eventualno dva puta godišnje sudjeluje u aktivnostima visoke kulture. Tek 3\% ispitanika je u većem broju u posljednjih godinu dana odlazilo u galerije, muzeje, kazališta i/ili operu. Čitalačke prakse, pak, dostupne su u većoj mjeri većem broju ljudi te na svakodnevnoj razini. Također, to može značiti da nisu toliko dobra diskriminatorna mjera ili da imaju manju prediktorsku vrijednost kada je u pitanju visokoobrazovna orijentacija. Općenito, na skali procjena učestalosti čitanja za 4 različite vrste tekstova, prosječni rezultat anketiranih 
slavonskih učenika je $M=2,2$, što znači da je učestalost takvih praksi nekoliko puta godišnje za većinu slavonskih maturanata. Konačno, zahvaćanje aspekata kulturnog kapitala učenika prema njihovom sudjelovanju u izvanškolskim aktivnostima ukazuje da su takve prakse rijetke s prosječnim rezultatom od $\mathrm{M}=0,2$, pri čemu se gotovo $80 \%$ učenika Slavonije nalazi oko tog središnjeg rezultata, koji ukazuje da su učenici barem godinu dana pohađali prosječno približno jednu izvanškolsku aktivnost.

Na svim mjerama osobnog kulturnog kapitala učenika pokazale su se statistički značajne razlike između učenika s različitim rezidencijalnim podrijetlom; tako učenici odrasli na selu,u odnosu na učenike odrasle u gradskim sredinama, imaju prosječno niži rezultat učestalosti i pohađanja kulturnih događaja $\left(\mathrm{M}_{R R P}=1,4<\mathrm{M}_{U R P}=1,8\right)$, čitanja $\left(\mathrm{M}_{R R P}=2<\mathrm{M}_{U R P}=2,3\right)$, te sudjelovanja u izvanškolskim aktivnostima $\left(\mathrm{M}_{\mathrm{RRP}}=0,1<\mathrm{M}_{\mathrm{URP}}=0,2\right)$.

Među intervjuiranima, troje je učenika s nešto češćim praksama, odnosno iznadprosječnim rezultatima, a svi su gimnazijalci urbanog rezidencijalnog podrijetla, pri dvoje iz najvećih regionalnih gradova. S druge strane troje učenika, koje povezuje to da su polaznici trogodišnjih strukovnih škola, rezultat na ovoj varijabli izdvaja kao učenike s nižim razinama osobnog kulturnog kapitala kada je on mjeren njihovom učestalošću u zadnjih godina dana sudjelovanja u praksama visoke kulture.

Ipak, među intervjuiranim učenicima čak 6 učenika imaju blago ili izrazito iznadprosječan rezultat prema učestalosti čitanja, pri čemu svi namjeravaju studirati, gotovo sve su djevojke, te gotovo svi pohađaju strukovne četverogodišnje škole. Također, većina ih je ruralnog rezidencijalnog podrijetla ili su iz relativno izoliranog subregionalnog centra, a također četvero učenika s naglašenijim čitalačkim praksama ima i iznadprosječne ocjene. Ovo navodi na razmišljanje o tome da čitanje predstavlja jednu bitnu aktivnost i važan pokazatelj kulturnog kapitala učenika koji su prostorno u nešto nepovoljnijoj poziciji te također nisu strukturno usmjereni prema visokom obrazovanju, ali jesu aspiracijski i/ili vrednovanjem obrazovanja što potvrđuju i kroz školski uspjeh.

Najbolje rezultate intervjuirani učenici su pokazali na mjeri pohađanja izvanškolskih aktivnosti - niti jedan učenik nije imao ispodprosječan rezultat, a posebno se istakla grupa gimnazijalaca, od kojih većina pokazuje blago iznadprosječne rezultate prema sudjelovanju u izvanškolskim aktivnostima poput pjevačkog zbora, glazbene škole, škole stranih jezika, te plesnih škola ili dramskih grupa.

Pogledamo li sve tri mjere osobnog kulturnog kapitala učenika, općenito su učenici s najvišim razinama kulturnog kapitala gimnazijalci, a posebno oni koji se školuju ili odrastaju u 
gradovima većeg stupnja centraliteta, što za njih znači da u većoj mjeri sudjeluju u praksama visoke kulture i/ili izvanškolskim aktivnostima. Dodatno, učenici, prvenstveno djevojke, strukovnih škola u većoj mjeri svoj kulturni potencijal razvijaju dostupnijim praksama, odnosno čitanjem. Konačno, niske razine kulturnog kapitala u najvećoj mjeri se povezuju s trogodišnjim strukovnim školovanjem.

Kako učenici posebno nisu govorili o svojim kulturnim praksama u intervjuima, ipak u sklopu pitanja o njihovim aktivnostima možemo reći da učenici imaju interese koje razvijaju izvan škola i školskog gradiva; neke od tih aktivnosti su direktnije vezane uz obrazovanje, poput pohađanja škole stranih jezika, a ostale koje se izdvajaju - poput volontiranja u humanitarnim i civilnim udrugama, sudjelovanje u kulturno-umjetničkim društvima, te bavljenje sportom ne možemo nazvati „visokokulturnima“, te je stoga pitanje koliko one razvijaju značajne obrazovne kapitale kako se najčešće shvaća Bourdieuova konceptualizacija ${ }^{87}$. Takve aktivnosti vrlo značajno se u opisima učenika povezuju s njihovim socijalnim mrežama i odnosima u zajednici odrastanja, a s druge strane o njima se progovara i s obzirom na sliku o sebi i kako se obrazovanje uklapa u tu sliku i s tim aktivnostima. Intenzitet takvih aktivnosti nije za sve učenike jednak, niti značajan, no ipak one ih na posebne načine vezuju uz širu zajednicu njihova odrastanja i utječu na osjećaj (ne)pripadnosti, odnosno određivanje svoga mjesta u svijetu. Dodatno, takve slike mogu ukazivati i na negativne aspekte nedostupnosti određenih praksi za kojima učenici pokazuju interes te voditi razvoju unutranjeg konflikta kada je u pitanju slika koju učenici grade o tome kakva osoba žele postati.

\subsubsection{Obrazovni ishodi}

\subsubsection{Namjera studiranja $i$ visokoobrazovne aspiracije}

Kako učenici objašnjavaju svoje namjere studiranja? Među intervjuiranim učenicima troje ih je progovaralo o tome da ne namjeravaju studirati, iako je u upitniku samo jedan učenik jasno to zabilježio kao svoju odluku, dok je drugo dvoje učenika u upitniku zabilježilo da aspiriraju samo završavanju srednje škole, no isto tako i da ne znaju namjeravaju li studirati, što pobuđuje istraživački interes. Dodatno, s obzirom na postavljeni teorijski okvir, čak dvoje od

\footnotetext{
${ }^{87}$ Rachel Winkle-Wagner (2010) je, analizom 105 studija u obrazovanju koje razmatraju kulturni kapital koje kategorizira prema četiri definicije kulturnog kapitala pri čemu kulturni kapital se može shvatiti kao: 1) visokoostatusno znanje ili kompetencije kao svojstvo visokoostatusnih ili elitnih grupa u društvu, 2) kao znanje i kompetencije kulture koja je određena vrijednom u nekom društvenom kontekstu (kontekstualno vrednovanje kulturnog kapitala), 3) kulturni kapital „drugih“ primiejenjen na marginalizirane grupe, te 4) kulturni kapital kao dio Bourdieuove šire teorije socijalne reprodukcije.
} 
tih učenika ima visokoobrazovane roditelje, ali čiji se kulturni kapital nije uložio u natjecanje u obrazovnom polju.

Svo troje učenika su učenici strukovnih škola koji su u određenom trenutku razmatrali mogućnosti studiranja, no na kraju su odustali velikim dijelom ili u potpunosti od njih i razvili alternativne planove svojih putova nakon završavanja srednje škole što postavljaju kao obrazovnu težnju. Dijelom njihove odluke objašnjavaju ocjene i tip škole koji završavaju, pri čemu školska poziciju koju ta dva podatka pokazuju ima i vremensku dimenziju razvoja, dok u većoj mjeri, u trenutku završavanja srednjoškolskog obrazovanja, njihove odluke objašnjava njihov stav da (K) studiranje nije za njih. Najzanimljiviji slučaj u tom pogledu predstavlja Jan kojem put prema visokom obrazovanju nije ograničen njegovom školskom pozicijom (ima prosječne ocjene i završava četverogodišnju strukovnu školu), kao niti obiteljskim poticajima i resursima s obzirom da ima roditelje s visokim obrazovanjem. Ideju studiranja on u puno većoj mjeri odbacuje kao nezadovoljavajuću i kao opciju koja se ne uklapa s učenikovim samopoimanjem i budućim planovima.

„... Razmišljao sam možda, na sportski neki [studij], al' onda sam se odlučio da neću ništa ... za trenera profesionalnog il' tako ... pa zato što mi sport... sport volim najviše (...)o tom mogu pričat do preksutra... al' baš mi škola nešto... jedva čekam sam da završim ... 4SŠ_mg)

... Pa tamo [inozemstvo] mislim ... s ciljem idem igrat nogomet...,,(Jan, URP_nc,

Učenik se u budućnosti želi oblikovati u području sporta koje mu mnogo znači i koje je svojedobno bilo predmet razmatranja studiranja, no odbačeno je kao nezadovoljavajuće s obzirom na to da uključuje učenje, koje učenik slabo vrednuje ${ }^{88}$. Kako učenik smatra, postoje oni učenici koji jesu za studiranje: "Pa studiranje... to je dobro... to je dobro za one koji imaju volju i kojima ide učit... s tim se može postići dosta toga... ali 'ko nije, taj ne treba ni ići, taj je trošak...". Sebe ne poima na taj način te ne smatra da mu se studiranje podrazumijeva. Iako može izdvojiti dodatne mogućnosti vezane uz posjedovanje diplome, osnovni stav koji ima o studiranju je da je ono teško što mu potvrđuju i prijatelji studenti koje poznaje: ,...kako oni pričaju, izgleda teško... na primjer, ovaj jedan je u Slavonskom Brodu i tamo studira, da mu je teško, i financijski, i rokovi, i malo teže za učit i to... pa, i nije baš stalno vesel $i$ to... “. U konačnici, učenik istaknuto vrlo samostalno razvija alternativne planove koji predstavljaju ostvarenje njegovih želja, bavljenje aktivnostima koje voli i u kojima se pronalazi, a koji ne uključuju daljnje obrazovanje nakon srednje škole:

ali mene

\footnotetext{
${ }^{88}$ Radi se o jedinom učeniku među intervjuiranima koji ima ekstremno ispodprosječni rezultat na skali vrijednosti koja se pripisuje učenju $(\mathrm{M}=3,64 ; \mathrm{SD}=0,85)$.
} 
to [studiranje] ne zanima... nije mi to tema...", ali isključuju financijski i psihički trošak studiranja na koji ukazuju njegovi prijatelji studenti.

Vrlo slično svoje priče oblikuju i drugo dvoje učenika koji ne znaju, odnosno ne namjeravaju studirati budući da aspiracijski teže tek završavanju srednje škole, a što se pokazuje kao rezultat njihovih prethodnih obrazovnih putova i $(\mathrm{K})$ samoisključenja iz daljnjeg obrazovanja:

„... Pa ne znam... [vidim studiranje kao] puno učenja, malo slobodnog vremena, $i$ to je to... pa nije to negativno, nego... ne znam ... pa ne vidim se u tome... ne bi mog'o tak' puno vremena provodit' za knjigom i učit'...

... Dok sam bio u osnovnoj, jesam [razmišljao o studiranju] ... i onda, evo, kak' sam ovo upis'o... vidio sam, ovaj, da ... da mi se ne da učit jednostavno... da mi je to lakše, da završim i idem radit' $i$ to je to (...) A onda sam shvatio da nije baš učenje za mene..." (Krešimir, URP_mg, 3SŠ_mg)

„... Pa sad [studiranje vidim kao]... učenje, ne znam... ne vidim ga loše, vidim ga u dobrom (...) šta ja znam... ne moraš svaki dan u školu, dođeš tak', ne znam, nisam ja oko toga...“(Lidija, RRP_DSJ, 3SŠ_VG)

Objektivno mjerena ograničenja za ovo dvoje učenika su nešto veća kada su u pitanju njihove školske pozicije s obzirom da se radi o učenicima trogodišnjih strukovnih škola, a Lidiji su dodatno ograničenje njezine ocjene ${ }^{89}$ koje $\mathrm{i}$ ona ističe $\mathrm{u}$ prvi plan razloga $\mathrm{i}$ upisa svog strukovnog smjera i odluke o nestudiranju: „...da bi' upisala studij prvo moram popravit školu, ocjene... mislim dobra sam u školi, ali nisam da bi, ono, većinom sam oko struke, najviše... tak da... nisam u učenju neka... prolazna sam... više volim svoju struku $i$ nju želim... “. Ipak, u jednakoj mjeri učenica motivacijski ističe želju za bavljenje svojom strukom, pri čemu rad u struci uspoređuje s umjetnošću, i pretače u planove zapošljavanja: ,..u toj struci uživam $i$ volim stvari koje radimo... i odlično mi je zato što je to većinom umjetničke radove radimo ... “(Lidija, RRP_DSJ, 3SŠ_VG).

U konačnici, priče ovih učenika se postavljaju konfliktno s obzirom na vrednovanje visokog obrazovanja; svi ukazuju da visoko obrazovanje donosi bolje mogućnosti i bolji društveni status (,...lakše pronać' posao i tak'... obrazovaniji si, bolje te ljudi gledaju, i tako... premda ja to tako ne vidim... "), no nužno se ne slažu s takvim procjenama ili shvaćanjem da je to nešto što oni žele (ili možda mogu) postići, odnosno da je to jedini način postizanja dobrog života za sebe:

\footnotetext{
${ }^{89}$ Prema analizama kvantitativnih podataka, Lidijin rezultat školske uspješnosti jedini je u uzorku intervjuiranih učenika koji se nalazi ispod prosjeka na varijabli $(M=3,6 ; S D=0,7)$.
} 
„... ja sam slastičar, recimo ja to volim (...) neće me tako uzimat, da sam ja sad nešto posebno, dok njega koji ima studij, ne mora ni znat', on je sad ono ... nešto veliko... " (Lidija, RRP_DSJ, 3SS__VG)

„,... Po meni je čovjek, čovjek... nebitno je li on završio osnovnu školu, srednju ili 100 fakulteta... ti ako si čovjek, ti si čovjek... nema veze škola s tim... drugačije je nešto da si školovan - to je već nešto drugo... “( Jan, URP_mg, 4SŠ_mg)

Svi razvijaju alternativne planove za ostvarenje svoje vizije dobrog života koji su za sve učenike vezani uz zapošljavanje i preseljenje, te koji za dva mladića znače i odlazak u inozemstvo s obzirom na dostupne socijalne resurse, te zaokret od trenutne struke za koju se školuju. Svi učenici u ovom skupu jesu razmatrali studiranje u razdobljima prije upisa ili završavanja srednje škole, no ono se uvelike odbacuju kao trenutna želja. Trenutnost odluke je posebno naglašena u slučaju Lidije koja ostavlja prostor za mogućnost studiranja u budućnosti, što je uvelike želja njenih visokoobrazovanih roditelja („,..Pa možda se predomislim ali za sad ne... za sad imam plan ići radit..."), u njenoj slici profesorice strukovnih predmeta. Dodatno, neodređenost i neodlučnost potiče njeno iznadprosječno vrednovanje učenja nasuprot njenom ispodprosječnom rezultatu školske uspješnosti, koji se kristalizira i u konfliktnom odnosu u njenim opisima studiranja o kojem posredna iskustva ima u obitelji.

Kako je već napomenuto, postoji još učenika čije su odluke vrlo ambivalentne, a za barem još dvoje učenika i diskrepantne kada su u pitanju različiti podaci iz kvantitativnog i kvalitativnog dijela istraživanja. Možda ne iznenađuje da se radi o učenicima strukovnih škola s prosječnim ocjenama koji visoko vrednuju učenje, ali kojima to ne daje dovoljno sigurnu poziciju da bi istakli namjeru studiranja, i što je u skladu s njihovom procjenom da im se studiranje niti podrazumijeva niti ne podrazumijeva. Najjasnije svoju nepovoljnu poziciju opisuje učenik trogodišnje strukovne škole, koji deklarativno želi studirati, ali se ta odluka i dalje čini dalekom, relativno slabo informiranom i teško dostižnom; stoga učenik, barem u trenutku provedbe istraživanja, u velikoj mjeri još uvijek duboko promišlja mogućnosti i odvaguje prednosti i nedostatke studiranja, nema odgovore na neka pitanja o tome što je studiranje $(, \ldots$ teško pitanje...") i kako ono izgleda, te izražava tek težnju za prelaskom barem prvog koraka na tom putu - završavanju srednje škole.

„...P Pa, nije da nisam tražio informacije, malo jesam, malo nisam, ne znam sad to kak' bi rek'o... pola-pola (...) Rekla mi je moja mama šta ide poslije toga ... al' zaboravio sam $\boldsymbol{k a k}^{\prime}$ se zove to ... poslije toga kak' se zove taj dio... Trebam se prvo raspitati koji smjerovi postoje poslije toga... tako da, a sada ne mogu reći odmah šta bi bilo... trebam prvo pogledati šta mogu upisati... 
... govorili su mi ovdje da ako upišem još bi 2 godine morao ići u školu tak'... jednu godinu moram polagati samo razlikovne ispite, a... na to sam gledao zbunjeno, onda razmišljam, morao bi' učiti čitavu godinu, da naučim sve, onda izgleda teško, ali moguće je napraviti to, ako se dovoljno trudi osoba... Pa, na to neću gledat optimistično... uvijek se mogu zeznuti ...tak..." (Dominik, DSJ_RRP, 3SŠmg)

Drugi učenici uvelike neodlučni o svojim nakonškolskim pravcima su u nešto povoljnijoj poziciji s obzirom da završavaju četverogodišnje školovanje, no njihove odluke su donesene vrlo kasno i imaju drugačiju težinu za njih. Općenito, među učenicima strukovnih škola kojima se studiranje ne podrazumijeva prevladavaju financijski razlozi odluke o studiranju izraženo kao bolje mogućnosti zapošljavanja, a često vezano uz viđenje vlastite struke neperspektivnima za zapošljavanje. Ti razlozi snažni su poticaj za uopće razmatranje studiranja čemu je posvećeno mnogo vremena i koje još traje, te za koje ne smatraju da im se podrazumijeva. Posebno snažnu emocionalnu reakciju izazivaju kod Agate: strah je ono što ovu učenicu iznimno motivira za razmatranje studiranja, ali i određena razina vjere $u$ pogodnosti onoga što diploma donosi. No, njene želje su prilično neodređene i nesigurne, vlastite šanse i upisa i završavanja studija procjenjuje relativno lošima, a dijelovi intervjua jasnije naglašavaju kako se radi samo o pokušaju s obzirom na to da joj mogućnosti, kao učenici četverogodišnje škole, nisu zatvorene, i s obzirom na strah od budućnosti:

„,... imam želju studirati jer to mi možda omogućava nešto, budućnost, možda bih imala više vrata otvoreno sa faksom nego bez njega... ne znam ni sama, imam baš želju, pa... voljela bih pokušati pa ako ne uspijem, uvijek ja mogu ... ne znam, puno ljudi odlazi van iz zemlje, znate i sami kakva je stvar, puno mladih odlazi, tamo nalaze svoju sreću, da tako kažem i tako... ja opet vjerujem u faks i nadam se da ću uspjeti... “(Agata, URP_mg, 4SŠ_mg)

Stoga ne iznenađuje da na kraju svoga školovanja učenica i dalje ne zna namjerava li studirati; s jedne strane, postoji želja vezana i uz visoko vrednovanje učenja, te želje za društvenom mobilnošću, no s druge strane je snažno naglašeno pitanje $(K)$ isplativosti obrazovanja.

Ova skupina učenika je još uvijek u snažnom pregovaranju vlastitih odluka pri čemu nisu još sasvim sigurni isplati li se studiranje; jedno od osnovnih razmatranja je koliki trošak vremena, truda i/ili novca studiranje predstavlja i jesu li spremni za preuzimanje tog rizika. Za Agatu studiranje je vrlo konfliktno pitanje: i odgovor na strah od budućnosti, što se prvenstveno odnosi na mogućnosti zapošljavanja i u skladu je s njenim viđenjem sveopće gospodarske i migracijske situacije u regiji, ali specifično se oblikuje i kao emocionalna reakcija (K) straha od neuspjeha u situaciji upisa studiranja:

„...baš se plašim, strašno se plašim budućnosti, pogotovo faksa, a bit će me još više strah ako ne upadnem na faks, ono, šta da radim, ne znam ni sama (...) zastrašuje vas sama 
pomisao na to da bi mogao odustati nakon svega uloženog truda, nakon, ne znam, ono, nakon nekog vremena sve baciti u vodu, zastrašuje vas... “"

U još većoj mjeri neodređenosti i neodlučenosti, ali i ravnodušnosti, takve stavove opisuje i imenuje Marina kao strategiju (K) Ako prođe, prođe:

„,... jednostavno pomislim da ne idem na to jer ak' ne prođem to je ono gubitak vremena... bolje taj novac uložit u nešt' normalno, to jest, ne normalno (smijeh), neg' neš" $u$ što sam sigurna da će uspjet', a ne faks... tak' da ne bi tam' baš ulagala novac, al'... moz̆d' i bi'... ne znam ... to jednostavno, te odluke su mi malo teže, al'... ne znam...

... iako ja baš sad ne želim ič', al' probat' ću... to idem sve na APP-ako prođe, prođe (smijeh) (...) većina, ono, idemo na državnu, i ak' prođemo idemo na faks, ak' ne prođemo, nema veze... “ (Marina, RRP_TP, 4SŠ_mg)

U konačnici, ovi učenici su spremni na pokušaj, no hoće li stvarni rezultat biti upis nekog studija (a pogotovo željenog) u velikoj je mjeri neodlučeno. Slično učenicima koji ne namjeravaju studirati, ovi učenici općenito mogućnosti zapošljavanja, bilo sa ili bez diplome, procjenjuju slabima, i iako im je osnovna motivacija za studiranje $(\mathrm{K})$ povećanje mogućnosti zapošljavanja i životnog standarda, procjenom sveopće situacije na tržištu rada i općeg stanja u Hrvatskoj, nisu duboko uvjereni da bi im daljnje obrazovanje to zaista i omogućilo:

„... Ne znam... ustvari, zašteko sam... oprostite... moram malo razmislit... ne znam... možda bi dobio lakše posao, al' smatram da to nije baš moguće u Hrvatskoj ostvariti jel' danas umjesto da ljudi dobiju posao, oni dobiju otkaze... tak' da, mog'o bi' ja to završit', al' đabe kad pos'o bi' jako teško dobio ... Ne bi bilo lakše... “(Dominik, RRP_DSJ, 3SŠ_mg)

„.. Strah me, pa znači, stanja u državi, općenito toga što... znam, imam poznanicu koja je završila Pravni fakultet prije 2 godine $i$, i dalje nema posla, ni sama ne zna šta da radi... znači, ima tak' super faks završen, $i$.. eto, nema nigdje posla da nađe, ono... užas...

... i s faksom, i bez faksa, teško je naći posao, tak' da... i puno mi kažu ljudi da možda faks je uzaludno bacanje novca $\boldsymbol{i}$ vremena i truda $\boldsymbol{i}$ svega uloženog da na kraju nećeš dobit ništa“"(Agata, URP_mg, 4SŠ_mg)

„... pošto sad u ovoj državi nema novaca, onda svi moraju učit (... ) većinom sad ne može se naći posao ni s fakultetom, a pogotovo bez fakulteta..." (Marina, RRP_TP, 4SŠ_mg)

Ovakva razmatranja nisu ograničena samo na ovu skupinu učenika i u velikoj mjeri odnose se prvenstveno na učenike strukovnih škola i njihova shvaćanja stanja u regiji i državi, mogućnosti zapošljavanja, ali i zadovoljstva izabranom školom, odnosno strukom, a u manjoj mjeri i toga čime se žele baviti u životu. Ovi učenici prihvaćaju opće poticaje na obrazovanje i mobilnost, ali nisu sigurni u njegovu iskoristivost niti u užim, niti u širim okvirima. A također im je privlačana ideja odlaska od doma kao dijela procesa njihove tranzicije u odraslost gdje obrazovanje uklapaju kao moguće slike svoje budućnosti. No, obrazovanje ostaju samo jedna 
od mogućih, i vrlo nesigurnih, alternativa u stalno mijenjajućem svijetu. Oni s većim razinamaekonomskog kapitala djeluju kao svojevrsni kvazi-investitori u obrazovanje i mobilnost, pri čemu je ipak dimenzija prostornog kretanja naglašenija od one obrazovanja.

$\mathrm{S}$ druge strane, primjeri onih s lošijom strukturom obiteljskih resursa, koja je dodatno usložnjena ograničenjima školske pozicije, pokazuju dodatne zanimljive kombinacije odlučnosti i dublje vjere u obrazovanje i nade uspješnosti, s opet naglašenom vremenskom dimenziom odlučivanja.

Ovi učenici smatraju da će im studiranje donijeti prvenstveno i iznad svega bolje mogućnosti zapošljavanja i financijsku sigurnost, no procjenjuju i mogućnosti zapošljavanja osobama $\mathrm{s}$ diplomom boljima od onih bez nje; oni ističu svoju volju i spremnost ulaganja dodatnog truda, u nadi prohodnosti sustava obrazovanja u kojem uspijevaju oni koji se trude - i na tome baziraju svoju sliku o (K) onima koji jesu za studiranje. No, njihove namjere studiranja su također prilično neodređene $\mathrm{i} / \mathrm{ili}$ neinformirane, te katkada i sukobljene drugim alternativnim planovima koji ne uključuju studiranje. Na primjer, Frane, učenik trogodišnje strukovne škole samouvjereno iskazuje odlučnost isticanjem studija kojeg želi upisati, s visokim očekivanjima i optimizmom. No, njegova, zapravo, vrlo fiksirana odluka potvrđuje se tek stalnim iterativnim ponavljanjem koraka koje mora napraviti i uvjete koji se moraju zadovoljiti za njegov budući ulazak u visoko obrazovanje, a koje nije posve informirano s obzirom na procjenu vremena koje mu je na raspolaganju do donošenja konačne odluke:

,...da bi sad ako četvrtu godinu, to planiram obavezno, i maturu, za to bi se potrudio, $i$ onda bi vidio financijski is obitelji, onda bi onaj krajnji korak da upišem....

... pa nije ništa posebno da me sad ono plaši... al' zato što i ne znam baš točno kak' ide taj studij, al' još ću se informirat' o tom svemu... “ (Frane, URP_mg, 3SŠ_mg)

Vrijeme i promjena situacija koje nosi kod mnogih učenika je naglašeno kao element pregovaranja odluka. Tako je Ivana, svoje visokoobrazovne odluke, pod izvanjskim i unutarnjim pritiscima, nekoliko puta mijenjana na obrazovnom putu, kao i naglaske toga kakve su želje, mogućnosti, potrebe studiranja unutar samog intervjua. S jedne strane, naglašava veliki značaj koji studiranje ima za nju i vrlo općenitu, gotovo idealiziranu, želju za znanjem, koja je dodatno potaknuta obiteljskim poticajima; no s druge strane, duboko je ograničena u svojim izborima zbog teške obiteljske situacije. Njene odluke su vrlo neodređene i u procesu stalnog pregovaranja: što bi htjela od onoga što joj je dostupno, pri čemu joj se sve opcije pokazuju u pozitivnom svjetlu i, u biti, predstavljaju napredak u odnosu na trenutnu poziciju. Dodatno, s obzirom na školsku poziciju, lošije ocjene iz matematike i procjenu da je priprema za maturu nedovoljna, postoji $(\mathrm{K})$ strah od neuspjeha koji učenica 
pokušava razriješiti spuštanjem aspiracija i razvojem alternativnih planova, nadama $u$ „promjenu situacije“ i zamišljanjem alternativnih scenarija koji bi imali pozitivne ishode „dobrog života“, lokalno, nacionalno i internacionalno, sa i bez studija, u struci ili nekom posve drugačijem zanimanju.

Ovi učenici ne smatraju da im se studiranje podrazumijeva i velikim dijelom još uvijek promišljaju svoje namjere studiranja, čega će konačni test biti onaj $(\mathrm{K})$ državne mature; studiranje im je ideja koju kasno razvijaju, pod različitim percipiranim ograničavajućim utjecajima, a najčešće s ciljem povećanja mogućnosti zapošljavanja, „lagodnijeg života“" te poboljšanja životnog standarda za one s lošijim financijskim okolnostima.

„... Pa možd' će mi donijeti bolji posao i neć' morat' radit' fizički neš", neg' ću možd' nešt' lakše nešt' ${ }^{\prime} .$. ubrajat će me u bolje zaposlenike (...) mo" ću negdje u uredu radit's fakultetom, a ovak' mogu negdje radit u nekom plasteniku (smijeh) (...) ali je teško doći do njega [fakulteta]... tak da vjerojatno ćemo svi završit u nekom plasteniku (...) stvarno, državna matura, to je ta crta koju ne možemo prijeći... “ (Marina, RRP_TP, 4SŠ_mg)

„...definitivno stalan posao (...) ne želim bit' k'o mama i tata, svake godine novi posao, $\check{c} a k$ i više puta u godini... stalan posao $i$ da, ono, ne moram spajati kraj s krajem, da imam dovoljno za sebe i u budućnosti za svoju obitelj... da ne moram, znači, da mogu uživati i u braku i svemu, da ne moram, ono, razmišljati: „, Od kog' ću nabavit' novce, kak'ću preživit'“ (...) nije bitno da l' je fakultet 3 godine, 5 godina, i da li je to, ne znam, fakultet za fiziku ili je to fakultet za poljoprivredu, jednostavno čovjek mora imat' sreće i bit' uporan, tražit' posao $i$ može se nać', stvarno..." (Ivana, RRP_DSJ, 4SŠ_mg)

„... nakon završetka studija bi možda mogao naći neki bolji posao za veću plaću, $i$ sam taj život, ono... shvaćam da nakon ove škole bih mogao ovak' radit' negdje i mučit'se, $i$ onda ako upišem fakultet možda bi, ono, donekle mogao i uživati... " (Marijan, RRP_DSJ, 4SŠ_mg)

No, iako je time cilj za nošenje s nesigurnostima budućeg života, studiranje je, samo po sebi, nesigurna i rizična odluka od koje se ne odustaje i koja se pregovara do samog kraja pri čemu učenici u većoj ili manjoj mjeri strahuju od rezultata, i žive u nadi pozitivnih ishoda, i/ili promijenjenih okolnosti. U njihovim pričama je osjetno izmjenjivanje strahovanja i rezignacije, konflikta sukobljenih težnji i pregovaranja određenih koraka na putu prema visokom obrazovanju ili pak nekim drugim mogućnostima ostvarivanja dobrog života u skladu sa shvaćanjima prepreka na tom putu, a osnovni test čini (K) državna matura:

„.... želim postič' što više u životu, al' to se ne može zbog tih prepreka, na primjer, ak' želim na faks, a stvarno želim ić' tam', al' neću moć' zbog državne mature, a možd' me stvarno zanima Poljoprivredni fakultet (...) državna matura, to je ta crta koju ne možemo prijeći, onda kad to prijeđem, onda idem dalje... ne želim planirati i gledat naprijed kad ne znam 'oću ovo proć', a to sigurno neću uspit zato što je preteško... “ (Marina, RRP_TP, 4SŠ_mg) 
„... sa pripremom ovak' kol'ko stvarno sam bila redovita, matematika mi nije sjela nikako... kad radimo zajedno onda znam to riješit, al' kad smo radili pojedinačno, zaglavim totalno, mislim... engleski, hrvatski, s tim nemam problema - to znam da, da ću uspjet' proć', al' matematika... to mi je onako... Matematika (smijeh) [mi je najveća prepreka] ... "(Ivana, RRP_DSJ, 4SŠ_mg)

Za sve učenike državna matura predstavlja određenu vrstu bojazni, no ipak ona je daleko naglašenija kod učenika strukovnih smjerova te onih nepovoljnijih obiteljskih resursa, čega je i izvor različitim vrstama neodlučenosti, nesigurnosti i ambivalentnosti u njihovim iskazima, koji iako izržavaju vrednovanje obrazovanja, često to čine $\mathrm{s}$ pitanjem o potrebnim investicijama i njihovoj isplativosti. Određeni učenici takve investicije usmjeravaju podcrtavanjem visokoškolske uspješnosti ili pak odabirom škola, koje često nisu gimnazije, za koje smatraju da ih mogu otvoriti put studiranju kako je prikazano u prethodnom poglavlju.

Tako Marijanovi odgovori, iako i motivacijski, i spuštanjem aspiracija, kao i kasnom odlukom te dugim promišljanjem studiranja, a posebno slabom procjenom vjerojatnosti upisa i završavanja željenog studija, oslikavaju veliku neodlučnost, strahovanje i nesigurnost oko njegovih visokoobrazovnih odluka, ističu njegovu visokoobrazovnu orijentaciju podcrtanu iznadprosječnim ocjenama, točnije njegovom ranom orijentacijom na postizanje visokog školskog uspjeha kroz izrazitu nepraktičnu orijentaciju. Razmatranje toga koliko ih srednja škola dobro priprema za nastavak školovanja ograničava njegove izbore i prisiljava njihovo prilagođavanje:.

„.. na elektrotehnici mi nije loše programiranje, samo što, mislim za to trebam imat nekakva već predznanja, a to mi je slabo s ovom školom (...) nije baš pretjerano snažna ta mogućnost [upisa], dok za ekonomiju, poljoprivredu to smatram da bi možda i bez problema uspio završiti... tako neki jednostavniji fakultet..."(Marijan, RRP_DSJ, 4SŠ_mg)

A dodatna razmatranja čini i financijska situacija obitelji. Ipak, njegov visokoškolski uspjeh i akademsko viđenje studiranja, koji oblikuju i njegovu sliku o sebi (,... kroz učenje i onako, di koje malo slobodnog vremena...") čine ga spremnim na to da prvo matura „testira“ što može upisati, a zatim da sami studij pokaže hoće li mu se sviđati i može li uspjeti u visokom obrazovanju koje, općenito, ne smatra zatvorenim i koje mu je prvenstveno $(\mathrm{K})$ akademski podcrtano stavom da je motivacija bitna za ostvarenje visokoobrazovnih ciljeva: „... kojima je teži fakultet, oni ni nemaju vremena za tako... uživanjem ... a tak' bi i meni bilo da upišem to (...) mislim da je to stvar, ono, navike... 'e l' ako učim redovno, i kad imam slobodnog vremena, ne idem baš nekud posebno... “. 
Ostale učenike u većoj mjeri povezuju snažnije odrednice i usmjerenost prema visokom obrazovanju, no koje su iskazane na različite načine kod različitih učenika; prvenstveno shvaćanjem da im se studiranje podrazumijeva te kao više aspiracije, (relativno) bolje ocjene i jasnije želje, te velikim dijelom ranija usmjerenost i shvaćanje studiranje nužnošću ili iznimnom potrebom, s obzirom na procjenu vlastite pozicije i životnih šansi, kao i s obzirom na analizu vremena i širih struktura mogućnosti za ostvarenje „dobrog života“, ali i istaknutim željama za obavljanjem određenog posla za koje je potrebno visoko obrazovanje. $\mathrm{Ne}$ iznenađuje da su u toj skupini učenika svi intervjuirani gimnazijalci ${ }^{90}$ čije ih škole direktno usmjeravaju prema visokom obrazovanju, te učenici četverogodišnjih strukovnih škola koji su rane želje za studiranjem više ili manje svjesno usmjerili preko strukovnog obrazovanja orijentirajući se na postizanje visokog srednjoškolskog uspjeha, ili stjecanje specifičnih znanja iz određenih područja, za lakši ulazak u visoko obrazovanje.

\subsubsection{Nužnost studiranja i odlaska}

Kako je već do sada oslikano, osnovne razloge studiranja učenika opisuju stavovi o tome koliko je važno studirati s obzirom na procjenu stanja na tržištu rada i mogućnostima zapošljavanja, odnosno postizanja zadovoljavajućeg životnog standarda s obzirom na njihovu trenutnu poziciju i s obzirom na razumijevanje prevladavajuće klime i smjerova razvoja $u$ području zapošljavanja gdje srednjoškolske kvalifikacije gube na vrijednosti. Općenito, iako s različitim naglascima, slavonski učenici smatraju da su mogućnosti zapošljavanja u različitim strukama koje zahtijevaju četverogodišnje obrazovanje loše, dok onima sa diplomama procjenjuju tek osrednje mogućnosti. Drugim riječima, općenito kvalifikacijama učenici daju malu vrijednost za zapošljavanje u kontekstu u kojem se nalaze, iako gotovo na razini dokse prihvaćaju stav o važnosti obrazovanja, i prepoznaju pogodnosti koje diploma može donijeti kada je u pitanju priroda posla i potencijal za budućnost.

$\mathrm{S}$ jedne strane, većinom oni koji ne namjeravaju studirati ili su još u procesu pregovaranja te odluke, odnosno jedna trećina intervjuiranih učenika, izuzetno pesimistično procjenjuje općenite mogućnosti za zapošljavanje bez obzira na stečene kvalifikacije. Takvi stavovi očito ne djeluju poticajno na razvoj visokoobrazovne orijentacije koja bi se iskazala poduzimanjem jasnih osobnih aktivnosti orijentiranih na ulazak $u$ visoko obrazovanje, već samo

\footnotetext{
${ }^{90}$ Dakle, nema gimnazijalaca koji ne namjeravaju studirati iako postoji zabilježeni slučaj u intervjuima: jedan učenik progovara o situaciji svog razrednog kolege koji je, vezano uz financijske teškoće, donio odluku da nakon završetka gimnazijskog obrazovanja neće studirati.
} 
razmatranjima i/ili pokušajima istaknuto određenom dozom o vrijednosti obrazovanja koja je naglašena u modernom društvu s obzirom na isticanje značaja mobilnosti i obrazovanja.

S druge strane, iako ne pretjerano optimistično, trećina učenika, prvenstveno gimnazijalaca, doživljava pozitivnije stanje na tržištu rada, koje im je nacionalno ili internacionalno otvoreno, što usmjerava svoje želje prema studiranju, odnosno poduzimanje određenih rizika, a prvenstveno potaknuto njihovim odlukama donesenim u ranijim fazama obrazovanja i predstavlja im se kao (K) nužnost studiranja, s obzirom na njihovu školsku poziciju i (K) potreba studiranja s obzirom na mogućnosti zapošljavanja i/ili odlaska:

„,... samo s gimnazijom si nitko i ništa, nemaš nikakvu spremu stručnu, ništa (...) iz gimnazije ne mogu apsolutno ništa postići poslije... gimnazija sama po sebi podrazumijeva fakultet (...) i to sam jednostavno znala: moram studirati da bi' nešto napravila...

... nekako studiranje, sada gledam kao nešto obavezno;drugo, pa zbog posla, je l', ne mogu se zaposliti za nešto što bi mi dalo nekakvi normalni život, nekakvu normalu... dobra primanja za koja bi, je 'l, mogla... financijski izdržati... “ (Bernarda, URP_mg, GIM_mg)

„... znam da sa srednjom školom nemam ništa, moram nastaviti dalje studirati... tako sam odlučila (...) u razredu svi žele studirati, je l' mi od ove škole nemamo ništa, ne možemo se zaposliti..." (Marija, RRP_TP, GIM_mg)

„... stvarno ne možeš, ne može se ništa s gimnazijom (...) kad završiš gimnaziju ako nejdeš na fakultet, stvarno ne možeš ništa... “(Dejan, URP_mg, GIM_mg)

„.. nakon četiri godine gimnazije ne mogu tražiti nigdje zaposlenje jer nemam zvanje nikakvo..." (Gordana, RRP_TP, GIM_VG)

Zanimljivo je primijetiti kako, unatoč prednostima koje učenici daju gimnazijskom obrazovanju, gimnazijalci svoje obrazovanje oslikavaju isticanjem aspekta negacije: opisuju ga kao obrazovanje koje ne daje ništa, s kojim se ništa ne može i koje obrazuje osobe koje su „nitko i ništa“. To podcrtava i odluke drugih učenika o tome kako je ne-strukovno obrazovanje rizično, a posebno za one koji nemju odgovarajuće resurse. Stoga je studiranje gimanzijalcima nešto što bi ih konačno oblikovalo u nekom području rada, dalo im temelje za postizanje njihovih osnovnih ciljeva oslikanih slikom „boljeg života“, ali i zadovoljavanjem nekih osobnih intrizničnih želja za radom u nekom području koja zahtijevaju studiranje.

Ipak, gimnazijsko obrazovanje se ne pojavljuje kod svih učenika

Za manjinu učenika pak osnovni naglasci u poticajima prema studiranju vezani su upravo uz promjene u području zapošljavanja u kojem na vrijednosti gubi srednjoškolsko strukovno obrazovanje, i posebno u specifičnim strukovnim područjima lokalno specifičnima. Stoga, takve stavove oslikavaju učenice koje pohađaju strukovne škole i oni koji ne vide budućnost u 
strukovnim kvalifikacijama, a posebno u kontekstu u kojem se nalaze: ruralnom i/ili regionalnom, i s obzirom na promjene vremena u kojem žive:

„....moji roditelji, najprije, oni to [studiranje] smatraju, ono, da je pod mus, kak' bi rekla - da se mora ić' (...) oni su završili srednje škole, ali su vidjeli da od toga nema ništa, da se vrijeme brzo mijenja, da je potrebno više obrazovanje, $i$ onda su uvijek gurali me u tome pravcu... da idem, da se više obrazujem (...) stalno mi pričali kako treba ići na fakultet, kako bez njega nema ništa, pogotovo ovdje ... “ (Aneta, URP_mg, 4SŠ_mg)

„... moje struke za jedno 30 godina možda čak i neće upisivat jer će to sve radit' (...) strojevi (...) mislim da je cijenjena [struka], i... plaća je ok, kol'ko može bit u ovoj državi...

... dosta njih je čekalo, mislim... nisu uopće ništa radili dvije godine, sad kad su vidjeli da nema posla sa srednjom školom, e sad bi oni nešto, tako da.. su se ipak odlučili za [studiranje]...

... ako već imamo potencijala zašto da... zašto da ne odem na nešto više, ako već mogu... bilo šta bilo, ipak, diploma je diploma, a ne samo završena srednja škola... “ (Silvija, RRP_TP, 4SŠ_VG)

Dodatno, ovakve stavove potkrepljuje Jakov čiji narativ iscrtava značaj imanja diplome na nekoliko razina; prvo, za stjecanje struke s obzirom na izraženi proces „obezvrijeđivanja“ kvalifikacija srednjoškolskog obrazovanja, te potražnje na tržištu rada za sve obrazovanijom radnom snagom.

„....ne bih volio se dovesti u situaciju da ne završim neki fakultet ili da ostanem na srednjoškolskom zvanju jer u današnjoj situacijiu kojoj se mi nalazimo, to ne možemo ništa napraviti s time ...

... i kad čitate ... koliko je to zapravo postotak nekakvih obrazovanih osoba na birou “, i onda pogledate: „A-ha, kao, pa srednjoškolska struka, nema tu neke budućnosti“... iskreno, ni sam da imam firmu teško da bih zaposlio nekog tko ima srednju stručnu spremu... teško...

... škola donosi kruh u ruke danas-sutra, a bez toga ste ... ne niko i ništa, al' nemate šta u našem društvu šta možete... ono, ne mo"š bit' ni čistač (...)u današnjem svijetu, il' morate imati dobro obrazovanje ili morate imati dobru vezu ... " (Jakov, URP_VG, GIM_VG)

Takve slike dijelom su dio javnog diskursa i obiteljski podržane, ali i kontekstualno smještene i življene, a koji odaje negativnu sliku krize, nezaposlenosti i korupcije. U tom kontekstu, obrazovanje postaje istaknuto značajno i kao, drugo, (K) izlazna strategija:

... ja sad kad gledam kad dođe netko koji kaže kako se tamo [na studiju] zabavlja ili nešto slično (...) stvarno mi dođe da sjednem i da plačem: „, Pa kako se ljudi možete zezat? Prvenstveno, živite u doba ekonomske krize, $i$ vi se odete još tamo, i zezate “... (Jakov, URP_VG, GIM_VG)

Time je studiranje za ovog učenika „...diploma koja će mi danas, sutra dati kruh u ruke... “, ali i njemu i njegovim prijateljima „....bijeg od [moga grada] ... mislim da prvenstveno mi tu 
osjećamo nekako najviše sve te neke krizne događaje koji se događaju u našoj Hrvatskoj, i da ... kao, najteže nama padaju, i onda svi vide: ,, 'Aj"mo otić' u Zagreb, Osijek, Rijeku... maknut se od ovoga svega, i započet nešta što nas bolje čeka u budućnosti“....”.

U takvim slikama obrazovanje se pokazuje kao glavni mehanizam uzlazne i lateralne mobilnosti, ali u obliku (K) ,izlazne strategije“ za učenike. Određeni broj učenika istaknuto pripada upravo ovoj motivacijskoj kategoriji gdje orijentacija prema visokom obrazovanju predstavlja i put izvan države i s težnjom postizanja boljeg životnog standarda, što se odražava i u odabiru takvih studija koji su usmjereniji na internacionalno tržište.

„...nisam nikada, nije mi uopće prioritet živjeti u Hrvatskoj jer stvarno ne znam šta bi tu... već sam prije, sluš'o sam roditelje kako pričaju kao je to sve loše, kako to ne valja... onda sam si rekao: „Pa zašto ne bi sad, recimo, otišao u Moskvu? Zašto ne bi otišao u Njemačku? Zašto ne bi bilo gdje?" Tamo ima više izbora, nekako životni standard je puno bolji, to me ... baš me vuče prema tim drugim (...) realno gledano ne znam šta bi ja s tim studijem $u$ Hrvatskoj mogao.. ne vidim tu nikakvu budućnost" (Dejan, URP_mg, GIM_mg)

U njihovoj slici naglašena je ideja poboljšanja geodruštvene pozicije s obzirom na dostupnost kapitala koji imaju u svojim visokoobrazovnim obiteljima i prihvaćanjem ideje obrazovanja i migriranja za postizanje željenih rezultata koji nadilaze statuse njihovih obitelji. Naravno, nije kod svih učenika stavljen jednak naglasak kada je odlazak u pitanju. Većina ostalih učenika će daleko više isticati obrazovanje kao vrijednost po sebi, bez obzira na odlazak.

No važno je primijetiti, za one najambicioznije, pogotovo djevojke koje su prva generacija studenata isticanje obrazovanja kao puta odlasku pojavljuje se i u većoj mjeri kao odmak od određenih rodnih slika vezanih uz lokalne prostore mogućnosti i oblikovanje prema određenim slikama urbane obrazovane i nezavisne žene, koja podrazumijeva i odmak od trenutnih situacija, mjesta i ljudi kada se njihov način života, vrijednosti i interesi nisu uklopljeni s onim što smatraju da karakterizira njihovu životnu zajednicu, te kada se ambiciozni ciljevi promatraju neostvarivim na trenutnoj poziciji.

„... pobjeć odavde, tako bi rekla, i promijenit' smjer totalno... ova škola nema apsolutno ... nikakve budućnosti ... ne znam, više obrazovanje sam htjela i zato želim odavde otić'... ovako okruženje kao okruženje nije loše, ali jednostavno nema budućnosti ovdje ...

... novo okruženje... puno, puno veće obrazovanje... ne znam, nekako... sasvim drugačiji život od dosadašnjeg, znači... više slobode, ne znam, ono... kao da se usmjeravam ja prema nečem, znači, što ja stvarno želim, a ne ovo dosad što sam učila i radila, znači, kao da stvaram svoj svijet za sebe, svoj život ...

... ja ne bi mogla raditi sa djecom, ne bi mogla biti profesorica, i tako... ja bi baš htjela biti znanstvenica, raditi u laboratoriju, istraživati nove stvari, i tako..." (Aneta, URP_mg, 4SŠ_mg) 
U tom okviru obrazovanje dobiva vrijednost kao potvrda prostornog identiteta koji se oblikuje u znanstvenim, modernim, urbanim i kulturno raznolikijim kategorijama s ciljem ostvarivanja željene karijere koja se suprotstavlja onom neposrednom. Kako je već istaknuto, takvi stavovi o želji za odlaskom putem obrazovanja odražavaju se i na izborima studija koji postaju dodatni potisni (push) faktor za migriranje s percepcijom nesmetanog kretanja u mobilnom društvu:

„...ja iskreno ni ne planiram, kad završim biologiju, ako završim, ne planiram ostati ovdje, ja planiram izaći vani.. pa ne znam, kolko sam pratila da baš biolozi nemaju ovdje posla i. većinom ljudi ovdje nemaju posla (...) pa, dosta ljudi može ići van... kol'ko ja znam ..." (Aneta, URP_mg, 4SŠ_mg)

Aneta je jedna od učenica u ovom skupu koja želi postići najviše stupnjeve obrazovanje. Motivacije drugih gimnazijalki ne naglašavaju u tolikoj mjeri želju za odlaskom niti nedostatak želje za obitelji, koja relativizira poimanje prostora u kojima bi se htjeli nastaniti, koliko studiranje vide kao osnovu (K) samoostvarenja.

Gordana opisuje svoje doktorske aspiracije prvenstveno vezane uz ostvarenje stjecanja znanja koje podnosi određene žrtve s ciljem postizanja boljih mogućnosti, s jedne strane, te $\mathrm{s}$ nužnošću studiranja, s druge strane: ,.. što ja mogu biti u životu ako ne završim fakultet..? eventualno upisati nešto drugo, ili nešto kraće, ili nekakav tečaj, ali to nije ono, mislim, što bi mene ispunilo... “. Njena želja bavljenjem određenim zanimanjem vrlo je rano oblikovana $\mathrm{i}, \mathrm{u}$ većoj mjeri individualnim aspiracijama i ambicijama koje su izražene u posebnom učeničkom identitetu i akademskoj orijentaciji, s potvrdom u gimanzijskom okruženju i školskim uspjesima. Odlazak kao opcija u njenoj slici se pojavljuje više kao potisak koji iskustveno proživljava s obzirom na planove njene obitelji, slično Anetinoj, za preseljenjem. 


\subsubsection{Visokoobrazovni izbori}

Tabela 4.3 Razlike slavonskih maturanata različitog rezidencijalnog podrijetla prema visokoobrazovnim izborima

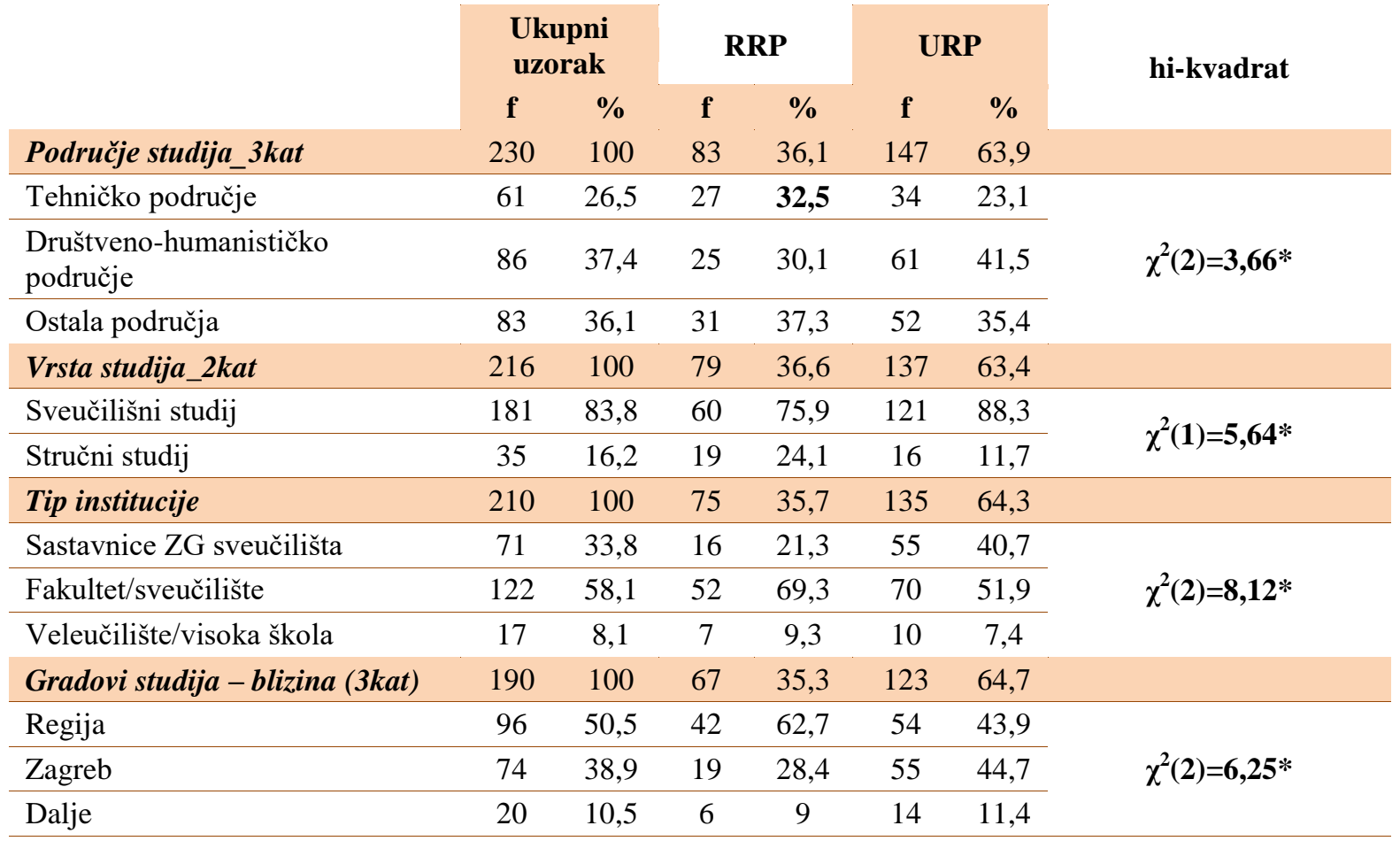

Iako neodlučnosti i neusklađenost odgovora učenika nisu bili neočekivani, osnovna pretpostavka rada je bila da će učenici na kraju školske godine imati jasnije razrađene planove vezane uz namjeru studiranja, te oko željenog/ih studija, pri čemu bi se analiza bazirala na prvom izboru učenika. Takva analiza je velikim dijelom bila kvalitativna s obzirom na potrebu kategoriziranja učeničkih odgovora koji su nerijetko bili neprecizni.

Inicijalno, podaci su analizirani prema području studija koji je učenicima prvi izbor, što je analiza koja je pokazala neke zanimljive podatke u dubljem kvalitativnom dijelu istraživanja. Zatim je ispitano o kojoj vrsti studija se radi, te na kojem tipu institucije i u kojem gradu se studij odvija s osnovnim interesom za mehanizme koji djeluju u pozadini procesa donošenja odluke o visokom obrazovanju, odnosno kako se određeni izbori povezuju čineći narativno smisleni proces.

Općenito, slavonski maturanti se u najvećoj mjeri odlučuju za društveno-humanističke studije koje bira više od 1/3 anketiranih učenika, a slijedi izbor tehničkih studija za više od 1/4 učenika. Konačno, u nešto većoj mjeri slavonski maturanti biraju i studije u području biomedicine i zdravstva - njih $1 / 5^{91}$. Velika većina slavonskih maturanata odabire sveučilišne

\footnotetext{
${ }^{91}$ Biomedicinsko i zdravstveno područje najveća je skupina u trećoj kategoriji izbora nastala agregiranjem sa izborima studija u matematičko-prirodoslovnom, biotehničkom, te umjetničkom području.
} 
studije (84\%) na fakultetima koji nisu sastavnice zagrebačkog sveučilišta (58\%). Dakle, tek $16 \%$ slavonskih maturanata odabire stručne studije bez obzira na instituciju na kojoj se izvode, a $8 \%$ ih izabire neki studijski program na veleučilištu ili visokoj školi. Konačno, kada je mjesto studija u pitanju, polovica učenika regije Slavonija namjerava ili želi studirati u Zagrebu, dok ih se $37 \%$ odlučuje za studiranje u regiji. No, kako pokazuje Slika 4.3, ti visokoobrazovni izbori razlikuju se za učenike različitog rezidencijalnog podrijetla.

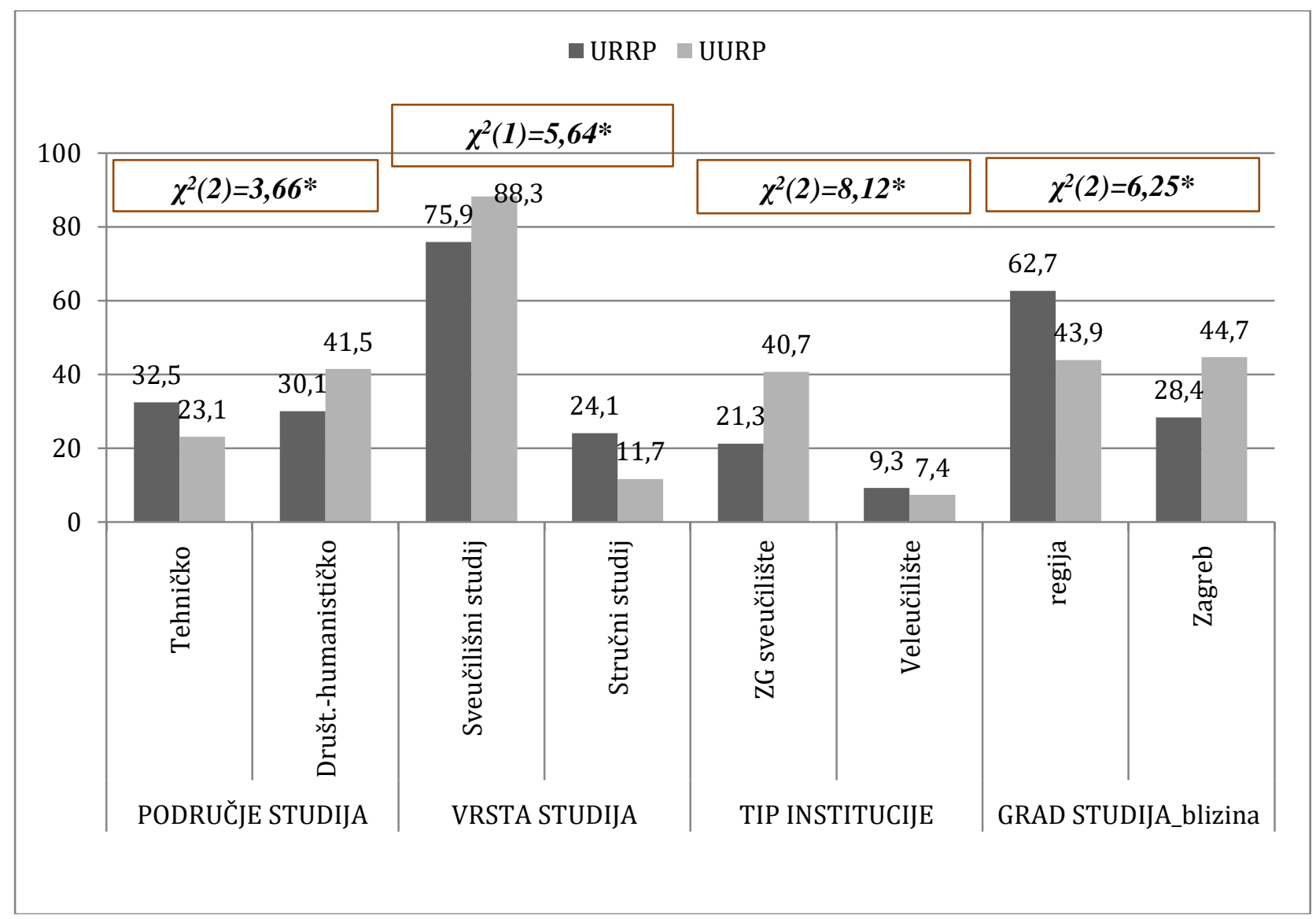

Slika 4.3: Razlika između učenika različitog rezidencijalnog podrijetla prema visokoobrazovnim izborima

Za razliku od učenika ruralnog rezidencijalnog podrijetla, učenici odrasli u gradskoj sredini se u većoj mjeri odlučuju za studije u društveno-humanističkom području ( $\left.42 \%>30 \% \mathrm{U}_{\mathrm{RRP}}\right)$, za sveučilišne studije $\left(88 \%>76 \% U_{\text {RRP }}\right)$, za fakultete koji su sastavnica Zagrebačkog sveučilišta $\left(41 \%>21 \% \mathrm{U}_{\mathrm{RRP}}\right)$, odnosno za studiranje u glavnom gradu (45\%>28\% $\left.\mathrm{U}_{\mathrm{RRP}}\right)$. Nasuprot tome, veća je vjerojatnost da će učenici koji su odrasli u ruralnoj sredini birati studije u tehničkom području (33\%), da će se češće odlučivati za stručne studije (24\%), bilo na veleučilištima ili fakultetima koji nisu dio zagrebačkog sveučilišta, odnosno, da će studirati u regiji (63\%). 
No, ti izbori su u samo relativno vođeni razmatranjem ugleda studija i institucije na kojoj se željeni studijski program izvodi, kako pokazuje Tabela 4.4.

Tabela 4.4 Razlike slavonskih maturanata različitog rezidencijalnog podrijetla prema procjeni ugleda studija i institucije željenog visokoog obrazovanja

\begin{tabular}{lccccccc}
\hline & \multicolumn{2}{c}{ Ukupni uzorak } & \multicolumn{2}{c}{ (1) RRP } & \multicolumn{2}{c}{ (2) URP } & \multicolumn{2}{c}{ t-test } \\
\cline { 2 - 9 } Zavisna varijabla & M & SD & M & SD & M & SD & \\
\hline Važnost ugleda studija i fakulteta & 3,54 & 1,15 & 3,60 & 1,17 & 3,51 & 1,14 & $\mathrm{t}(234)=0,55$ \\
\hline
\end{tabular}

Te visokoobrazovne izbore oslikali su učenici u intervjuima, pri čemu su i neki učenici koji ne znaju namjeravaju li studirati ostavili podatke o svojim željama i koji su uključeni u analizu; stoga je analizirano 16 intervjua (podjednako ruralnog, i urbanog rezidencijalnog podrijetla). Očekivano, razgovori s učenicima otkrili su kako često oni ne razmatraju svoje želje prema područjima, već su njihovi izbori mnogo kompleksniji i katkada obuhvaćaju studije iz više područja. Neki učenici su vrlo svjesni i otvoreno progovaraju i o različitim poticajima, različitim procjenama i o različitim smjerovima svojih dvostrukih želja. Kod drugih učenika je, pak, mnogo naglašeniji aspekt neodlučnosti oko toga što bi željeli, za što smatraju da su sposobni, i onoga što mogu podnijeti s obzirom na financijska opterećenja što se uglavnom pretače u razmatranje udaljenosti studija. Stoga se katkada izbor studija pojavljuje kao jedini odabir koji povratno određuje izbor institucije i mjesta studiranja, ili se pak postavlja kao konfliktno pitanje za učenike koji imaju samo jedan željeni studij koji se izvodi samo na jednoj instituciji/u jednom gradu, a koji smatraju u manjoj mjeri dostupnim. U jednakoj mjeri koliko učenici teško odlučuju o tome da li studirati, i odluka o tome što i gdje studirati vrlo je kompleksna.

Slijedi analiza učeničkih želja s obzirom na studije koji su zabilježeni kao prvu želju u upitniku, i kako taj izbor objašnjavaju u intervjuima. Spomenimo da barem tri učenice, čak i ako navode alternativne studije svom prvom izboru, jasno naglašavaju da imaju samo jedan željeni studij, što im postavlja posebnu vrstu ograničenja na njihove izbore, i što je utjecalo i na njihove kasnije obrazovne ishode ${ }^{92}$. Također, barem troje učenika je imalo neke druge rane želje vezane uz njihovu budućnost, no ti su izbori odbačeni u zadnjim fazama odabira i zamijenjeni su izborima koji su postali „novi prvi izbor“, realističniji, dublje informiran i lakše ostvariv, blizak ranom izboru i podjednako zadovoljavajući; značajno je da je takav

\footnotetext{
${ }^{92}$ Jedna učenica je uspjela upisati svoj željeni studij u prvom pokušaju, dok druge učenice nisu upisale željene studije te godine. Ipak, još jedna učenica je upisala željeni studij nakon godine dana priprema, dok je druga učenica posve odustala od ideje studiranja nakon što nije uspjela upisati željeni studij sa svojom generacijom.
} 
dugotrajniji proces karakterističan za učenike koji su se i u ranijim fazama usmjerili prema visokom obrazovanju. Prvenstveni razlog vezan je za procjenu mogućnosti upisa: učenici su procijenili da bi im prijemni ili dodatni predmeti na državnoj maturi otežali sami proces upisa na određenom studiju, te su prednosti koje trenutno imaju (ocjene i/ili predznanje) odlučili iskoristiti za olakšavanje upisivanja studija koji im je u jednakoj mjeri privlačan. Tako je, na primjer, Andrej odustao od studija u umjetničkom području u korist studija u društvenohumanističkom području za kojeg procjenjuje da bi ga mogao u jednakoj mjeri zanimati:

„... odlučio tu probati studij dramaturgije, i obzirom da je prijemni jako kompliciran, da neću stići to pripremiti do kraja godine uz školu, primaju jako mali broj studenata, pa sam pretpostavio da neću upasti, tako da sam odlučio Povijest umjetnosti... “(Andrej, URP_mg, GIM_VG)

Ipak, i neke stare želje preživljavaju kao alternativne mogućnosti, ako se situacija koja je dovela do njihova odbacivanja promijeni ${ }^{93}$. No, općenito, razmatranja dostupnih resursa $\mathrm{i}$ individualnih sposobnosti u odnosu na karakteristike budućeg željenog posla, te uvjete upisa na pojedinim institucijama kao i prednosti/mane završavanja pojedinih studija, sve to utječe na donošenje učeničkih odluka i usmjerenju prema određenom izboru. Najteži izbori, čini se, postavljaju se za učenike strukovnih škola koji su kasno donijeli odluke o studiranju te iako na prvo mjesto ističu studije koje bi željeli, a koji često znače smjer drugačiji od njihove struke, i svjesni ograničenja svog strukovnog obrazovanja, ipak na drugo mjesto postavljaju studije u području svoga srednjoškolskog obrazovanja za koji procjenjuju veće šanse upisa i mogućnost interesa. Štoviše, u intervjuima progovaraju i ističu upravo te druge izbore kao vjerojatniji smjer svoga djelovanja prema nastavku školovanja.

Među intervjuiranima se našao najveći broj učenika koji bira studije u društvenohumanističkom području: ono je izbor za čak polovicu uzorka (8), najčešće gimnazijalcima, a u još 6 slučajeva se javlja kao drugi izbor bilo istim ili drugim učenicima Nekoliko je skupina izbora moguće izdvojiti prema užem području, a koji oslikavaju učeničke interese: prvo je skupina učenica koje biraju različite, ali srodne studije u popularnom području ,terapijskih znanosti“. Sve učenice su vrlo kasno donijele odluke što se kod gimnazijalke u ovom skupu učenica vezuje uz to da nije bila sigurna što bi točno studirala iako je znala da će to biti u području društvenih znanosti jer sebe vidi u radu s ljudima, odnosno djecom. Stoga postoje alternativni planovi u području odgojno-obrazovnih znanosti, bliskih prvom izboru iz logopedskog područja, no koji su manje željeni i samo su zadovoljavajuće alternative, posebno u skladu s financijskim pitanjima odlaska na studij:

\footnotetext{
${ }^{93}$ Učenikj je u konačnici upisao studij u inozemstvu koji je bio njegova najranija želja kada su se mogućnosti za to otvorile.
} 
„... razumijem i njih [roditelje] i financijsku situaciju, tako da, ne znam... sad mi još ništa ne govore, ali ako mi kažu da ne mogu, na primjer, otići u Zagreb, da upišem nešto u Osijek ili da ostanem u Vukovaru, ja ću to prihvatiti (...) Postoje [zadovoljavajuće alternative] (...) bila bi' na nekom sličnom poslu... opet bi' radila s ljudima ... i s djecom... “ (Marija, RRP_TP, GIM_mg)

Štoviše, s obzirom na određena procijenjena ograničenja, vezana uz teškoću upisa zbog velikog interesa za studij koji se izvodi samo na jednoj instituciji u glavnom gradu, i financije, razvoj alternativa postavlja se kao potreba. Kod druge dvije učenice strukovnih škola želja za upisom studija u ovom području znači zaokret od trenutne struke, i iako su obje učenice, deklarativno, sklone podjednaki interes poklanjati i studiju koji bi se nadovezao na njihovo srednjoškolsko obrazovanje (ili čak više drugih izbora) izražen je naglasak na prvom izboru, ali i svijest o postojanju velikih prepreka za ostvarenje njihovih želja,dijelom zbog strukovnog obrazovanja te dijelom zbog velike poželjnosti njihovih izbora među učenicama općenito: „... ali sam čula da je upad strašan (smijeh), da jako malo primaju i to mi ubija svu nadu ...“ (Agata, URP_mg, 4SŠ_mg). Stoga, i Agata razvija alternativne mogućnosti studiranja u području strukovnog obrazovanja koje se čini izglednijim i također usklađenim s njenom procjenom vlastitih sposobnosti: „... znači, s tim se poklapa moda i dizajn, i... dobra sam $u$ crtanju... baš smo sad imali, ne znam, jučer, pregledavanje crteža i profesorica je uzela par mojih crteža za izložbe $i$ tako to pa vjerujem da bi uspjela u tome... “ (Agata, URP_mg, 4SŠ_mg).

Motivacijski, sve tri učenice prvenstvene razloge izbora studija pronalaze u sukladnosti slike o sebi, svojih sposobnosti i osobina, te aktivnosti, sa zanimanjem za koje bi ih određeni studij obrazovao. Andrea to izražava u najvećoj mjeri povezujući karakteristike svoje osobnosti (,...'aj"mo reć' da sam humana i ne volim se ismijavat' ljudima koji imaju neke tak' određene posebne potrebe, $i$ volim radom pomagati..."), aktivnosti (,..u slobodno vrijeme volontiram...“) i iskustva (,...pošto mi brat malo... ima nekih mentalnih problema, i imam puno prijatelja, tak', koji nisu mentalno zdravi, ne znaju neke svoje odluke... “) za pretakanje u želju za radom u određenom području: „,... to mi je jako privlačno, i mislim da može puno pomoći $i$ meni $i$ drugima (...) volim to... “. No, s druge strane, i s obzirom na procjenu svojih mogućnosti upisa, učenica pregovara i druge izbore, koji nisu zaista željeni, ali se nalaze na listi i učenici je moguće zamisliti svoj uspjeh u tim zanimanjima:

„... mislim, volim ekonomiju i mislim da imam neku, neke točke koje bi mogla uspješni ekonomist (...) realno, svi mogu završiti ekonomiju ako imaju imalo čuke u glavi... 'el' ima puno ekonomista koji su nezaposleni, ali ... mislim da su to ekonomisti koji nisu pravi ekonomisti, da nemaju neke svoje ideje i vizije, kao što bi' ja imala, na primjer, nego su završili fakultet tak' da kažu završio sam fakultet... "“ 
Izbori za sve tri učenice pokazuju kako je teško donijeti jasnu odluku i izabrati studij, s ozbiljnim rizikom za konačne ishode, pogotovo uz financijska ograničenja (,,..oni kažu [roditelji], onak, „Život u Zagrebu je jako skup, ne znamo dal ti to možemo priuštit.. “, $i$ tak... "), te ako nedostaje informacija uopće o različitim studijima, i ako procjenjuju da onaj Željeni studij neće uspjeti upisati: „... k'o na primjer ja ... stave vrste studija u Slavonskom Brodu, Osijeku, Zagrebu, more... sve, ono, različito, nije ništ' isto, nišst' da se nadovezuje jedno na drugo... “(Andrea, RRP_TP, 4SŠ_mg).

Stoga je potrebno istaknuti i kontekste u kojima su učenice ruralnog rezidencijalnog podrijetla u konačnici donijele svoje značajne odluke. Marija je u skladu sa svojom slikom o sebi i visokoobrazovnoj orijentaciji rane želje oblikovala prema području obrazovanja - mogli bi tvrditi tradicionalnom zanimanju za visokoobrazovane u ruralnom okolišu - no život u domu za vrijeme srednjeg obrazovanja smjestio ju je u institucionalni kontekst u kojem je dobila značajan izvor informacija u vidu stručnih osoba o nekim drugim mogućnostima. S druge strane, također suočena s problemom nedostatka informacija, Andrea je povezala sa svojim volonterskim radom, u mjestu školovanja, koji je na sličan način pružio dodatni poticajni element za koji smatra da ne dobiva u svojoj zajednici ili obitelji.

Druga skupina je skupina gimnazijalaca koji biraju jezike bilo kao svoj prvi i jedini izbor, s obzirom da je njihova intrinzična motivacija vezana uz rane odluke koje su oblikovane specifičnim obiteljskim utjecajima i provedene kroz završavanje jezične gimnazije:

„.. baka i dida, s očeve strane, su otišli raditi kao gastarbajteri (...) a s mamine strane su isto otišli tamo raditi (...) i ujak mi je tamo, i ujna i mala sestrična, pa sam često išla (...) $i$ uvijek sam imala kontakt s jezikom, i... još kao dijete smo imali njemačku televiziju (...) ušao mi je u uho, naučila sam ga i jako ga dobro govorim i zanima me i sviđa mi se (...) strašno me privlači, volim ga ... i zato sam odmah znala .. nalazim se u tome, zanima me, ide mi .. logičan izbor..." (Bernarda, URP_mg, GIM_mg)

i/ili s obzirom da svoje poznavanje (u obiteljskom kontekstu) jezika procjenjuju velikom prednošću što će im dodatno olakšati studij, bez obzira je li on prvi i jedini izbor, ili se nekom drugom predmetu daje prednost:

„...još prije me, vuk'o, recimo, ruski jezik ... majka mi je Ruskinja, $i$ više puta sam bio u Rusiji, $i$ želim to studirati...“(Dejan, URP_mg, GIM_mg)

„,...jer sam čuo da je sam po sebi jak smjer povijest umjetnosti pa da ne kombiniram s još jednim jakim smjerom nego sa [jezikom] koji znam ... mislim to pričam kod kuće $s$ mamom, s bakom, djedom..."(Andrej, URP_mg, GIM_VG) 
Kod ovih je učenika bitno istaknuti kako postoje specifične obiteljske okolnosti rađanja i odrastanja u obiteljima u kojima usvajaju specifičnu vrstu jezičnih kompetencija - poznavanje dodatnog jezika - a koji za njih predstavlja posebnu vrstu kulturnog kapitala za buduće visokoobrazovne planove. Moguće ga je poimati kao vrstu kapitala mobilnosti (Corbett, 2007) koji je posebno značajan u osposobljavanju mladih za zamišljanje i razumijevanje prostora i apstrahiranje sebe iz mjesta čime je bitna odrednica učeničke uspješnosti kada je u pitanju apstraktniji nastavni materijal, tei priprema za fakultet. Najveći izborni problemi za ove učenike vezuju se uz kombinaciju predmeta, odnosno izbor institucije na kojoj je moguće studirati određene predmete. Tako Bernarda želi upisati jednopredmetni studij koncentriran na njen željeni jezik što omogućava samo jedna (regionalna) institucija u Hrvatskoj, no koja prima izrazito mali broj studenata, što njen izbor čini vrlo fokusiranim, i dodatno poželjnim zbog procjene studija kvalitetnim, ali alternative problematičnima.

S druge strane, za učenike u ovom skupu, studiranje jezika je u većoj mjeri olakšavajuća okolnost koja im otvara vrata u visoko obrazovanje i olakšava postizanje željenih rezultata, no na različite načine, pa je sami izbor kompleksan za oba učenika kada je u pitanju konkretan studij i institucije izvođenja studija, odnosno mjesta studiranja.

„... mislim da neću imat stalan posao... ne znam... Volio bih pisati (...) mislim mogu ja i ovako pisati al' ne znam, povijest umjetnosti mi je nekako najbliže zaposlenju, najbliže onome što mislim da bih mogao podnijeti raditi, organski podnijeti raditi nešto u nekom smjeru... tako da sam to odabrao kao mogućnost da se zaposlim, a ovako mislim da ću se pokušati pisanjem razvijati ..."

Kod Andreja su posebno iskazane težnje postizanja posebnog životnog stila „muvanja po Europi““ za koji mu diploma samo predstavlja struku, ali ne i željeno područje djelovanja, a s time je sukladan i izbor mjesta studiranja: „... Zagreb zato što je to najbliže Zapadu što mogu doći.. najveće, naj... ne znam... to je vrh, jedino što u Hrvatskoj što mogu zamisliti da mi je dovoljno dobro da budem ...". Taj izbor je njegovim riječima jasno usklađen s onime kako se učenik vidi i što želi biti, a dodatno je istaknuta poželjnost u odnosu na odrastanje u malom gradu i rasnim razlozima: „... multikulturalniji ili malo libaralniji... ne znam, općenito, raznolikiji, šareniji, šta ja znam.. tu mi je sve nešto dosadno i tmurno, ne znam....”.

Vrlo slično i Dejan razmatra bolje mogućnosti i odlazak iz Hrvatske „kapitaliziranjam“ svojih jezičnih kompetencija razvijenih u obitelji. Ipak, njegove težnje, ograničene ocjenama i sa željom osamostaljivanja, a posebno proživljavanja studentskog života, usmjerene su na studiranje na obali. Stoga je on vrlo informiran o studentskom životu u odabranom gradu, ali i 
studiju uz koji mu se brige javljaju: „...i baš sam gled'o, ja dvije godine na studiju ruskog apsolutno ne bi ništa novo naučio... ako se ne varam... jedino kad gramatika počne, to ću baš trebat zagrijat stolicu...“(Dejan, URP_mg, GIM_mg).

Konačno, dvoje učenika koji svoje izbore vrše pod najvećim ograničenjima, s obzirom na dostupne resurse i školske pozicije, biraju studije u području koji se općenito procjenjuju manje poželjnima i manje perspektivnima uvelike zbog velikog broja nezaposlenih osoba u tim zanimanjima. Izbor studija u području ekonomije se učeniku trogodišnje strukovne škole u ovom skupu čini kao logičan izbor s obzirom da u bliskom području završava trogodišnje obrazovanje i namjerava nastavak školovanja : „... Pa da se malo potrudim mog'o bi bez problema (...) a i idem na praksu [u trgovački lanac] pa imam dosta povezanosti s marketingom, cijenama i svime time... i lagano je, i nije mi ništa teško to i sviđa mi se... “. Ipak, odluka u trenutku intervjua još je daleka i slabo informirana (,...mislim da nisam baš tolko dobro informiran... ima još vremena da se informiram. (...) rekli su mi da moram četvrtu godinu i maturu i onda fakultet... ") , a optimizam je oslonjen na očekivanu obiteljsku pomoć i podršku, te vjeru u vlastite sposobnosti i trud i, iznad svega, prohodnost sustava obrazovanja:

... a sad idem u sezonu, idem kod sestrične i muža u Split, pa bi tamo možda ako ostanem $i$ četvrtu godinu komercijalne i tamo bih isto marketing (...) ako odem u sezonu, da mi to bude $i$ za četvrtu godinu i za fakultet... a tu su roditelji još rekli da bi mi pomogli financijski, a i teta isto... tako da imam podršku obitelji... i sad još jedino moja volja i trud ... tak' da bi mog'o ...

...Pa mislim da je velika vjerojatnost, da bi sad ako četvrtu godinu, to planiram obavezno, i maturu, za to bi se potrudio, i onda bi vidio financijski i s obitelji, onda bi onaj krajnji korak da upišem...." (Frane, URP_mg, 3SŠ_mg)

S druge strane, upravo nedostatak obiteljskih resursa ograničava izbore druge učenice u ovom skupu na izbor studija na lokalno veleučilište i programe koji se tamo izvode. Iz tog razloga, iako je studij istaknut kao prvi izbor, nije niti prvotni, niti jedini izbor, niti je snažno željen.

„... Pa nekako pošto nema baš nekog izbora [lokalno] $i$ nekak' mi se to najviše sviđalo, nekak' mi se to, nekak', dopalo na neki način (...) to bi ovak' više nekako došlo zato što čovjek misli da nije baš tol'ko teško, pa idem upisat', lako se prebacim jer bitno mi je sad da upišem nešto, kasnije već ako budem imala neku želju za nečim drugim prebacit ću se ... " (Ivana, RRP_DSJ , 4SŠ mg)

Kroz cijeli intervju učenica iskazuje volju i želju za studiranjem, ali i prepreke koje ograničavaju njene odluke na lokalnu ponudu obrazovnih mogućnosti: „... financijski je situacija takva da je nemoguće ići negdje [...], pa je mama rekla: „Upiš' bilo šta [lokalno], 
kasnije se lako mo"š prebacit' na nešt' drugo “...". S jedne strane njene odluke su onda vođene prilagođavanjem njenih želja s procjenom mogućnosti, prvenstveno zapošljavanja, koje donosi završavanje studija, općenito, te završavanje studija koji su dostupni, specifično, i koliko to zadovoljstva može donijeti što je u različitim dijelovima intervjua izraženo na kontradiktorne načine; s jedne je strane bitan kriterij da se završi bilo što kako bi se povećale mogućnosti zapošljavanja (,,...definitivno stalan posao... ne želim bit k'o mama i tata, svake godine novi posao, čak $i$ više puta u godini... stalan posao $i$ da, ono, ne moram spajati kraj $s$ krajem, da imam dovoljno za sebe $i$ u budućnosti za svoju obitelj..."), a s druge se ističe kriterij „planiram upisati ono što me zanima“, iako jasno ne pokazuje koji bi to studij bio.

„.... neću slušat nešto što me ne zanima, onda ni rezultati neće biti neki... tako da (...) ne mora to bit' upravno pravo, bilo koji drugi fakultet, al' imam stvarno u cilju završit' ga...

... pa ni ne znam (smijeh)... što me najviše..? Pa znanje pošto želim znati više (...) jer meni srednja škola nije dovoljno... želim, znači, naučit nešto što, što će mi stvarno koristit' u životu..." (Ivana, RRP_DSJ, 4SŠ_mg).

A dodatno je značajna i općenita želja za naprosto obrazovanjem i stjecanjem znanja: „,.. $\boldsymbol{u}$ bilo kojem smjeru, šta god da upišem ... normalno, eto primjer, pošto sam poljoprivredna škola (...) u ovoj školi ne mogu dobit sve informacije i nije toliko detaljno kol'ko bi mogla dobit na studiju [voćar, vinar, vinogradar](...) prvenstveno znanje...“, koja se u nekim drugim dijelovima intervjua suprotstavlja nekim drugim odrednicama identiteta: „.. ja jednostavno $k^{\prime} o$ da sam rođena u prirodi ... nisam navikla bit zatvorena ... mene, recimo, škola izluđuje, ovak, ono cijelo popodne, ono sunčan dan da budem unutra...". Za razliku od prethodno opisanih slučajeva, ova učenica je u daleko većoj nedoumici i kada je u pitanju odluka o studiranju i izbor studija, dok je uopće izbor koji može napraviti onaj vezan uz lokalno veleučilište.

Katkada se i samo studiranje postavlja nasuprot njenim vizijama dobrog života u kojima je istaknut obiteljski život i zaposlenje, odnosno poboljšanje trenutne (lokalne) i ekonomske pozicije bez obzira na posjedovanje diplome:

„...volim more al', znači, negdje borova šuma, nikaki centar grada, ništa, da ću otvorit, znači, neki svoj... svoje turističko imanje pošto, eto, jučer sam baš na vijestima gledala kako je u Dalmaciji sve više tražena agroturizam, i onda sam baš neš" mi je došlo u glavu: „Pa vi"š, mogla... pa zašto ne započet nešto tako ako se bude imalo mogućnosti? “, tak' da eto vidim se nekako u tom smjeru..." (Ivana, RRP_DSJ, 4SŠ_mg)

To je slika koja odražava određene elemente ruralne lokaliziranosti kroz povezivanje elemenata poljoprivrede, svoje struke i priode nasuprot gradu. Kod svih ruralnih učenika, u 
različitim omjerima, u pričama zamišljanja budućnosti mogu se prepoznati neki elementi ruralnog lokaliziranog identiteta, koji za njih ima značaj, čak i kada ga u pričama odbacuju.

Ivanin narativ je bio posebno zanimljivo promatrati prema dihotomijama na razini ruralnourbano, prirodno-gradsko, karijera-obitelj, tradicionalno-moderno, struka-obrazovanje, ali i ostanak-odlazak, što su sve elementi njenog pregovaranja i s obzirom na njenu trenutačnu tešku situaciju ograničenja koje opisuje i suženih mogućnosti, i budućih planova „,izmještanja“ iz te situacije. U tom kontekstu, različiti izbori pokazuju svoje mogućnosti i predstavljaju napredak u odnosu na trenutnu poziciju. Za ovu učenicu čak i opcija studiranja postavlja ograničenja s obzirom na procjenu teškoća odlaska: ona procjenjuje dugu razdoblje prilagodbe na studiranje, iako bi nastavila studij u gradu u kojem trenutno pohađa srednju školu, ali s druge strane poznatost predstavlja prednost u učenici kojoj je privlačna slika osamostaljivanja od roditelja i studentski život:

„,... stvarno mislim da bi bio.. da bi bilo vrijeme da se odvojim i zato sam htjela otić negdje dalje studirati (...) dosad nisam ni izlazila, ni ništa posebno, i sa već vidim kak me vuče izlasci... tak da mislim da će mi to bit prepreka, pogotovo zato što znam ovaj dio [grada] $i$ svi smo poznati, i kafići $i$ sve, i uvijek znam gdje tko izlazi (...) sredina sama po sebi je poznata, osobe koje idu ondje na sveučilište su mi poznate, neke su susjedi, tako da.. mislim da ću se uklopit, i samo po tome bit će mi lakše.. znači, prva godin dana dok sama ne nadođem... “(Ivana, RRP_DSJ, 4SŠ_mg)

U skladu s regionalnim omjerima, među intervjuiranima troje učenika bira studij $u$ biomedicinskom i zdravstvenom području. Pri tom, dvoje gimnazijalaca bira studij u ovom području, iako različito motivirano i na različitom tipu institucija: Gordana najvećim dijelom ističe intrinzične razloge ranih želja bavljenja zanimanjem koje će joj željeni studij omogućiti (,...ja baš od malih, malih nogu, ne znam zašto mi je to bilo sve super zanimljivo, tako sam stvarno... nisam ni trenutka razmišljala o nijednom drugom studiju, tako ne mogu baš izdvojiti nekakav utjecaj na to..."), iako se dijelom želje prilagođavaju kako bi se osigurala veća vjerojatnost uspjeha s obzirom na postojeće kapitale, te učenica prvotni studij medicine zamjenjuje bliskim studijem u istom području: „....mislim da ću se manje napatit' (...) jer oni 40\% gledaju prosjek ocjena, a moj prosjek je cijelu srednju školu 4,9, tako nešto... tako da s te strane(...)ocjene imam, one mi se dosta boduju... sad jedino državna matura....". Upravo ta koncentracija na vrlo određeno područje, snažna intrinzična, ali i financijska, motivacija za poboljšanjem mogućnosti zapošljavanja, te visoki školski uspjeh čine ovu učenicu jednom od najuvjerenijih u cijelom skupu intervjuiranih oko postizanja svojih visokoobrazovnih želja: „..ne bi se toliko posvetila tom prvom izboru da mislim da baš... da ga ne mogu upisati...“. 
Jakovljev je izbor daleko više određen dubljim i dugotrajnim razmatranjima potražnje na tržištu rada (posebno Europske unije), pa dakle mogućnostima dobre zarade i osiguravanja dobrog životnog standarda u relativno kratkom roku, zbog čega bira veleučilišni studij. Time je njegov izbor veleučilišta posve suprotan izboru veleučilišta kojeg opisuje Ivana.

Konačno, izbor studija učeniku strukovne škole predstavlja nastavak srednjoškolski stečenog obrazovanja, ali i obiteljske tradicije, što se u njegovoj priči izražava narativom normalnosti odabira i prirodnosti puta na kojem se nalazi usklađenom i sa njegovim budućim životnim planovima i željenom sociogeografskom pozicijom „doktora“ u ruralnom društvenom sistemu. Mislav u svom izboru naglašava prednosti završavanja integriranog sveučilišnog studija: „... jedino zbog tog doktorata... to mi je... kad postanete doktor, znači, ne moraš dodatno, kao, 3 plus dvije, pa ste magistar, nego ovo kad se završi 6 godina, postaje se doktor... “. Dodatno je svjestan značaja koje studiranje, a posebno titula doktora donosi pojedincu: ,..lijepo je kad dođete u društvo i ne'ko vas oslovljava „doktore“...“, no njegov naglasak je puno više stavljen na stjecanje kvalifikacije za bavljenje određenim zanimanjem koje je lokalno cijenjeno: „... studij bi mi donio u prvom redu sve osobno, meni, znači da ... neki veći stupanj, znači, da imam, kao, veći status $u$ društvu i da mi se otvore vrata novog nečeg (...) zbog sebe da imam, kao... dalje u životu, neki oslonac, znači, da nisam bez škole, da ne radim ništa mrljavo kako ljudi kažu, nego samo zbog sebe, da sam uvjeren, znači, da to $\operatorname{mogu...".~Iako~je~Mislav~izrazito~visokoobrazovno~orijentiran~i~studiranje~shvaća~}$ normalnim slijedom i njegovih obrazovnih putova i načina na koje se obrazovni statusi generacijski moraju unapređivati, a što je usmjerenje podržano obiteljskim dinamikama u kojima ide očevim stopama, ipak njegova je odluka razmatrana i odlučena tek u srednjoj školi na osnovi ocjena. Kako učenik ističe, razlog njegova neupisivanja gimnazije potaknuto je širim obiteljskim dinamikama održavanja obiteljskog gospodarstva na kojem je značajna njegova radna pomoć, i koje se uklapaju i u njegove buduće planove, a za koje je spreman poduzeti određene žrtve vezane uz preseljenje i dugo trajanje studija.

Studije u prirodoznanstvenom području biraju dvije učenice iznimno znanstveno orijentirane i duboko intrinzično motivirane za željeni oblik rada koji bi studijem stekli, ali i čitavim načinom života koji bi on omogućio. Ipak, ta osnovna motivacija drugačije je usmjerena kada je u pitanju srednjoškolsko obrazovanje, i drugačije je motivirana s obzirom na dostupne kapitale, a također se i drugačije postavlja s obzirom na buduće planove. 
Aneta,učenica strukovne škole, upisom studija želi zadovoljiti svoju ranu želju o željenom području bavljenja, a koja nije ostvarena upisom srednje škole, no i puno više u smislu društvenog i geografskog napredovanja:

„... novo okruženje... puno, puno veće obrazovanje (...) sasvim drugačiji život od dosadašnjeg, znači... više slobode, ne znam, ono... kao da se usmjeravam ja prema nečem, znači, što ja stvarno želim, a ne ovo dosad što sam učila i radila, znači, kao da stvaram svoj svijet za sebe, svoj život...".

Ono odražava izraženu želju za specifičnim zanimanjem, ali i načinom života: „.. ja ne bi mogla raditi sa djecom, ne bi mogla biti profesorica... ja bi baš htjela biti znanstvenica, raditi u laboratoriju, istraživati nove stvari... " pri čemu postoji samo jedna želja, duboko intrinzična: „,...uvijek me zanimalo, priroda i tako to... naša građa, građa životinja, i tako.. sve općenito iz biologije (...) ostalo manje-više ništa... ima dosta toga, ali ništa mi se ne sviđa...". Pritom prvenstveno misli na one studije koji su joj dostupni regionalno; postoje i neke druge želje no koje su ionako odbačene u procesu donošenja odluka jer učenica svoju financijsku situaciju procjenjuje neusklađenom s mogućnostima studiranja u Zagrebu.

Nasuprot tome, druga učenica u svoj prvi izbor prirodoznanstvenom području detaljno opisuje intrinzičnu i ,prirodnu“ motivaciju za studij, želju i interes za odabrano područje pod velikim obiteljskim utjecajem: „...na neki način želim ostvariti život kao što ga ima moja mama... ona je pročelnica odjela za [...], i... ja bi htjela raditi znanstvena istraživanja jer vidim kakav je njen život i kak' bi' ja htjela svoj život da izgleda (...) [prirodoznanstveni studij] bi mi dao podlogu da idem tražiti posao van na nekom institutu, možda za genetiku, ili tako nešto (...) mislim, to volim...". No, istodobno, ističe i dodatni, u jednakoj mjeri željeni studij u društveno-humanističkom području za koje utjecaje pronalazi izvan obitelji, ali također smatra usklađenima sa svojim viđenjem sebe i svojih kvaliteta, usklađenog sa svojim aktivnostima:

„... volonter u Centru za odgoj $i$ obrazovanje [...] znači... osnovna škola i nastavak studija za djecu s posebnim potrebama, $i$ tamo radim s logopedkinjom na njenim terapijama $i$ sama održavam neke terapije za tu djecu... i, ovaj, tu sam se zaljubila u taj posao, znam da bih bila dobra u tom poslu..."(Anica, URP_VG, GIM_VG)

Velikim dijelom za ovu učenicu izbor koji ističe kao prvi u upitniku, i koji je možda bio rana želja, u intervjuu ustupa prvo mjesto drugom izboru, upis kojega se procjenjuje vjerojatnijim, te, do određene mjere, usklađenijim s budućim životnim planovima, a koji imaju i bitnu sociogeografsku dimenziju povezanu s načinom budućeg života za koje učenica smatra da će ih određeni izbori prisiliti; sasvim konkretno, učenica procjenjuje da će izbor studija u prirodoznanstvenom području zahtijevati puno više rada i truda jer ono predstavlja izuzetno 
kompetitivno područje, da će ,prisiliti“ zapošljavanje u inozemstvu i zahtijevati stalno napredovanje, a to je slika koja je učenici bila ili je još uvijek dijelom privlačna. Ipak, učenica ima i neke druge životne želje i neke druge slike svoga budućeg života koje pregovara:

... Ja se nadam da ću imati obitelj, čovjeka koji me voli, dvoje djece, svoje po mogućnosti (...) i da ću imati posao s kojim ću biti zadovoljna... sad još ne znam koji će bit, ali bi se negdje vidjela u nekoj [...] ordinaciji s normalnim radnim vremenom od 7 do 3, da imam vremena $i$ za obitelj, $i$... slobodne vikende zato da... da imam fiksno radno vrijeme da si jednostavno mogu organizirat život... " (Anica, URP_VG, GIM_VG)

Štoviše, upravo takve buduće želje oblikovale su i njene prvotne izbore prema uzoru na njenu majku-znanstvenicu i život koji su njeni roditelji postigli: „,... htjela bi biti to [znanstvenica, ali uz mogućnost da imam obitelj... znači, da nisam samo u tom... fokusirana na znanost, već da organiziram si život $k^{\prime}$ što imaju moji...". No, procjena učenice da je u tijeku svoga srednjoškolskog obrazovanja dobila slabije obrazovanje od očekivanog (, ... u ovoj školi, recimo, najviše zamjeram profesorici iz kemije što 4 godine mi ništa nismo radili, ja kemiju ne znam zucnit... a volila sam je, obožavala sam je i mislim da mi je uništila ... “), te da je sudjelovala u izvanškolskim aktivnostima koje su razvile neke nove interese u većoj mjeri prilagođene slikama budućeg željenog života, u konačnici učenica zaključuje da je njen prvi izbor manje vjerojatan: „,... ako budem htjela upisat kasnije, i to je moguće... iako mi je to više san, cilj, ali sam svjesna da se nekad ti snovi, ciljevi, se ne ostvaruju... “ (Anica, URP_VG, GIM_VG).

$\mathrm{S}$ druge strane, dvoje učenika izabire studije u biotehničkom području, konkretnije studij poljoprivrede, pri čemu je to izbor samo učenika strukovnih škola; ono jednoj učenici predstavlja nastavak srednjoškolskog obrazovanja, i to jedini mogući prema njenim riječima: „.... sve sam većinom vezano za poljoprivredu, pošto sam poljoprivredna škola i ne mog' niš"... ne mog' ja sad na primjer otič' na Filozofski il' negdje ... kak'ću ja tam' iz poljoprivredne škole?..“ (Marina, RRP_TP, 4SŠ_mg), pa dakle vrlo ograničeni izbor, koji prema njenom mišljenju ne postoji za neke druge škole, a koji je i u njenom slučaju vođen (K) strategijom ako prođe - prođe. Osnovni poticaj za izbor studija, dakle, nije intrinzična motivacija, već se radi o izboru koji se procjenjuje relativno dostupnim s obzirom na prethodno školovanje, pokušaj polaganja državne mature, a potaknut djelovanjima drugih učenika s obzirom na mogućnosti zapošljavanja i privlačnost studiranja nakon posjeta odabrane institucije: „...kad sam bila u [...] na tom fakultetu... onda svidilo mi se tam' (...) 
došla sam tam', vidjela kak' je,... sve je bilo lijepo... i učitelji su tam', ti profesori, predavači... onda smo bili u predavaonici... novi fakultet, sve novo, pa onda...".

Drugoj učenici taj izbor je zaokret od područja u kojem je stjecala srednjoškolsko obrazovanje, s dubljim intrinzičnim razlozima oblikovanima njenim odrastanjem (,...nekako od malih nogu jer sam s djedom radila na polju, uvijek s bakom u vrtu, tu sad kao nekakvo povrće, voće... i prošle godine sam sama uzela radit, što se tiče cvijeća, uzgoj, i dosta dobro mi je to uspjelo (...) i sad... možda, ne znam, počnemo i s tim malo bavit... moji idu stalno i na tržnicu i tako, imamo dosta i zemlje... i uvijek sam ja nekako oko tog cvijeća, meni je sve to zanimljivo...") i njenom vizijom karakteristika budućeg posla(,„...bitno da se radi u labosuto mi je onako (smijeh)..."), ali i analizom mogućnosti koje pruža njeno srednjoškolsko obrazovanje za mogućnosti zapošljavanja i studiranja, koje ona procjenjuje slabijima. Stoga, iako učenica smatra da je njena struka cijenjena, a njena škola ima dobar status, ipak postoje određeni nedostaci njenog srednjoškolskog obrazovanja i za budućnost njenog zanimanja općenito - što oblikuje njene namjere studiranja, i za studiranje, posebno na prestižnijim studijima - što oblikuje njene specifične izbore (,...nisam sad htjela ono forsirat upisat, ne znam, što se tiče mature (...) ima previše toga (...) onda sam rekla: „, 'ajd' ono, ostavit ću sve niže, to mi ionak' traže za sve fakultete“, a uostalom ako ima predispozicije za niže, zašto bi se onda forsirala za nešto..."). Upravo te procjene daju joj osjećaj determiniranosti i samopouzdanja za ostvarenje svojih ciljeva „...mislim, ako već, ako već imaš mogućnost za nešto više, bilo šta bilo, ipak, diploma je diploma, a ne samo završsena srednja škola...", pri čemu se opozicijski postavlja prema shvaćanjima i procjenama drugih osoba iz svoga okruženja vezano uz njene izbore koji su visoko habitualizirani:

„... puno ljudi kad kažem da ću upisati poljoprivredu kaže „Joj kud poljoprivredu baš, kud to... zašto ne upišeš nešto drugo?! “, kao, ,od tog nema budućnosti“... zato što oni gledaju na poljoprivredu kao da je to samo idem sijat' tamo neš" na polju, što zapravo uopće nije, ali... meni se to neda njima objašnjavat'..." (Silva, RRP_TP, 4SŠ_VG)

Konačno, među intervjuiranima tek jedan učenik izabire studij u tehničkom području koje predstavlja orijentiranje prema području koje je otprije željeno, ali nije realizirano upisom srednje škole, i za koje postoji interes. Kroz cijeli intervju učenik jasno naglašava nepogodnosti koje je krivi izbor srednje škole stvorio za ostvarenje njegovih želja, ograničavajući ga na upis stručnog studija, ili alternativno onih studija koje on smatra „nižima“, pri čemu listu čini kriterij ,,stavio sam sve ono što je moguće“: 
„... malo me i strah zato što je... nema ni matematike, ni fizike [u srednjoj školi] ... ima fizike, ali nije toliko jaka koliko taj fakultet zahtijeva (...) onda će mi malo to teže bit', tak' da me... malo me to i odmjerava...

... smatram da sam po znanju sposoban za općenito neki jednostavniji fakultet... nemam baš neke prednosti za neki viši fakultet (...) ekonomiju ili poljoprivredu sigurno upisao ... to jest da bi sigurno upao, a sad... ako ne budem imao drugog izbora onda možda $i$ planiram [upisati]... “(Marijan, RRP_DSJ, 4SŠ_mg)

S obzirom na taj kratki prikaz vidljivo je da su zastupljene sve glavne kategorije učenika, a najveći nedostatak je osjetan s obzirom na manje učenika koji biraju studije u tehničkom području $^{94}$ koje se čak ne pojavljuje niti kao drugi željeni izbor u većoj mjeri; tek jedna učenica kao svoj drugi željeni izbor spominje tehnički studij koji se ovdje pojavljuje s obzirom da učenica procjenjuje da ima kvalitete za taj studij koji je nastavak njenog srednjoškolskog školovanja, te da su joj veće mogućnosti upisa tog studija nego onoga koji je prvi izbor $^{95}$. Štoviše, u intervjuu progovara upravo o tom izboru nasuprot onome što je zabilježila u upitniku kao svoj prvi izbor.

Osnovni stav učenika, općenito, kada je izbor studija u pitanju je da bi se trebalo birati ono što nekoga zanima i ono u čemu se učenici pronalaze, odnosno da tako većina učenika izabire svoje studije:

„... svatko sebi bira šta njemu paše i koji fakultet, $i$ sve to... i nekako šta... postavlja se pitanje, šta bi željela raditi, na primjer, ja nikad ne bi' mogla završiti matematiku, ili nešto tako, ili ne znam, ekonomiju, da sam stalno u papirima, ili pravo da moram studirati... ja znam za šta sam ja... tako mislim da i ostali odabiru prema tome ... " (Marija, RRP_TP, GIM_mg)

S te strane, učenici na pragu svoje odraslosti uvelike koriste diskurs izbora (Cairns, 2011) koji potiče neoliberalno obrazovanja orijentirano razvoju subjektiviteta sposobnih na stalno prilagođavanje i izgradnju identiteta kroz mobilnost. Zajedno s „doksom“ o nužnosti obrazovanja, takav stav izražava Jakov:

„... kad se vi upišete... to je to što ste odabrali, i ne možete krivit ni mame, ni tate, ni dide, ni babe, ni državu, ni sustav, ništa ne možete krivi - vi ste to odabrali... nije odabrao ni Pero, ni Marko, nego vi, i normalno da morate to završit..." (Jakov, URP_VG, GIM_VG)

Kako pokazuju opisani izbori učenika s kojima su provedeni istraživački razgovori, učenici zaista pokušavaju slijediti takav obrazac, no on češće uključuje kontradiktorne elemente i

\footnotetext{
${ }^{94}$ Rezultat je nezainteresiranosti učenika tehničkih škola za sudjelovanje u nastavku istraživanja i intervjuu.

${ }^{95} \mathrm{U}$ ostalom, u nekoliko navrata učenici na listi želja spominju studije informatike iako nije sasvim razvidno radi li se o tehničkom studiju ili društveno-humanističkom.
} 
predstavlja se u obliku trenutnog pregovaranja, nego jasnih želja, istaknutih pravaca djelovanja i koherentnih slika izbora. Postoji svijest o tome kako često učenici ne uspijevaju izabrati ono što ih zanima, kao i o zaprekama koje onemogućavaju ostvarenje želja, ali i o tome kako često to što se želi može biti nedosegnuto. U tom okviru, osnovni problemi vezani uz biranje su neodlučnost i nepronalaženje u nekom području, posebno za gimnazijalce, te općeniti strah od neuspjeha u visokom obrazovanju, odnosno loša priprema škola za upis i završavanje fakulteta, kako ih ističu učenici strukovnih škola. A dodatne iznimne prepreke predstavljaju financijska ograničenja, koja se kada su izbori studija u pitanju u najvećoj mjeri odražavaju na mjesto studiranja, i posljedično na očekivanja od studiranja s obzirom na njegove akademske i socijalne aspekte:

„... u razredu sam ja ostao PAF kad mi je došao jedan dečko i rekao: „Ja možda neću ići na fakultet (...) ja sam ost'o zgrožen na to jer (...) ti si četiri godine pripremao se za to (...) Kako ne, mislim..? " (...) neki ljudi stvarno nemaju, di ljudi stvarno ne mogu poslati to dijete (...) „. Ostani tu [lokalno] i studiraj .. to ti mogu platit'! “... a da l' to to dijete interesira, to je pitanje (...) većini ljudi je jako teško donijeti odluku jer svi mi znamo u kakvoj smo mi situaciji u svojoj obitelji (...) roditelj će investirat u tebe do krajnjih granica, al' opet možda netko nema pa mora potražit' tu soluciju [lokalno] ... jednostavno nema otić' (...) kad neko nema tamo za život, za (...) to je ono što je meni poražavajuće (...) da mi kao mladi moramo odlučivati sad, gdje bi možda trebali u ovim tinejdžerskim godinama uživat' i samo mislit' na neko svoje ... mislit' na ono šta ću ja studirat', a ne da l' to moji roditelji mogu financirat ili ne mogu..." (Jakov, URP_VG, GIM_VG)

Kod nekih učenika su određene prepreke teže premostive, a kod drugih naprosto potiču prilagođavanje u skladu s posjedovanim resursima i razvijenim kapitalima, odnosno $\mathrm{s}$ obzirom na pozicije s kojih kreću prema daljnjem obrazovanju, ako ono za njih ima važnost, odnosno sa stavom (K) diploma je diploma, no koje je uvijek neka kombinacija željenih aspekata studija i budućeg zanimanja i/ili poboljšanja mogućnosti zapošljavanja i stjecanja ugleda, odnosno rezultat je pregovaranja. Najbolje taj proces ilustrira Silva kojoj diploma predstavlja društveno uspinjanje: „... a sad što se tiče fakulteta, mislim da tu isto imam neki rang gore, jer, da se razumijemo, ne mogu svi završit fakultet... ipak tu, ono (...) ali mislim, ako već, ako već imaš mogućnost za nešto više, bilo šta bilo, ipak, diploma je diploma, a ne samo završena srednja škola...“. Ipak, kada su ostali izbori u pitanju, zbog financijske situacije se odlučila na redovan studij izvan struke: „... prvenstveno sam razmišljala na to da bude redovan jer, ono, baš. ovaj, vanredno mi ne mogu plaćat (...) to sam odmah rekla, ono: „,Više laboranstvo - neka hvala, neka plaćaju oni koji imaju, ja ću na neki redovni...", te , unatoč visokim ambicijama, na regionalno sveučilište koje joj nudi dodatne mogućnosti rada posredstvom njenih društvenih veza, te dnevnih putovanja ako situacija ne dopusti preseljenje. 
Dodatno, zbog lošije procijenje pripreme za studiranje njeno pregovaranje uključuje i napetosti s viđenjima okoline o procjenama statusa studija: ... puno ljudi kad kažem da ću upisati poljoprivredu kaže „Joj kud poljoprivredu baš, kud to.. zašto ne upišeš nešto drugo“, kao, ,od tog nema budućnosti“... zato što oni gledaju na poljoprivredu kao da je to samo idem sijat tamo neš na polju, što zapravo uopće nije..." (Silva, RRP_TP, 4SŠ_VG). Sve te dodatne izbore ona pregovara i sa slikom o sebi: u čemu se vidi i kako to postići. U toj slici značajni su joj i odrastanje u ruralnoj sredini s iskustvima kultiviranja prirode, te rad u laboratoriju kao dio strukovnog obrazovanja i privlačnog zaposlenja. Dodatno, iz intervjua su sasvim razvidne dodatne obiteljske odgovornosti koje ona stavlja sebi u zadatak i sa željom pomaganja bratovog obrazovanja. $U$ tom smislu, njen je put $u$ obrazovanje uvelike „,ruraliliziran“, odnosno praktično usmjeren i vezan uz poznato i blisko.

Konačno, učenici koji su u najvećoj mjeri neodlučni oko studiranja, prihvaćaju studiranje kao nešto ,što rade ostali““, i usvajaju specifičnu strategiju orijentiranja na studiranje koja nije izraz specifične intrinzične motivacije, već želje da se pokuša postati student, kao dio dominantne slike o odrastanju:

„... idemo mi sve, to je naša APP - ako prođe prođe ... idemo na državnu, $i$ ak' prođemo idemo na faks, ak' ne prođemo, nema veze (...) svi smo isti, svi gledaju jedni drugekak'će on tak ću i ja... al' ne gledamo sad ove pametne baš koji odluku donesu „Idem na faks, učit ću i ... " (Marina, RRP_TP, 4SŠ_mg)

Ako prođe prođe“ strategija je koja znači pokušaj ulaska u visoko obrazovanje, ali koje je velikim dijelom nepoznanica:

„... to se više ne stavlja ono što te zanima nego stavljaš sve, ono, što ti se čini zanimljivo to staviš... bitno da se ide na fakultet, tak većina razmišlja... sam da upadnemo negdje, bilo gdje, nema veze kakav je fakultet... “(Marina, RRP_TP, 4SŠ_mg)

Ostale karakteristike „biranih“ studija i institucija na kojima se izvode pojavljuju se isprepleteni s osnovnim izborom studija. Ipak, treba spomenuti kako niti jedan naš sugovornik nije ostavio dojam kako zna stvarne razlike koje leže u pozadini tih različitih izbora niti konačnih kvalifikacija koje stječu. Uglavnom shvaćaju da je „5 godina bolje od tri godine“ studija, a posebno se ističu prednosti završavanja integriranih studija u trajanju od 6 godina kao stjecanje doktorata (no i mane vezane uz trajanje). Razlike između institucija uglavnom su još nejasnije gdje i sami učenici priznaju da ne razumiju razliku niti između veleučilišta i fakulteta, kao niti između fakulteta i sveučilišta, osim što vrlo nejasno smatraju da je ,na fakultetu opširnije“" pa da na fakultetu ,bolje nauče“. 
„....Mislim da je razlika u nijansama (...) evo sad moje veleučilište nudi 3 godine studija, ali opet kad pogledate (...) kad završite tri godine, imate diplomu $i$ vi ste ovlaštena osoba da radite u tom svom polju i to svom nekakvom zanatu... nijansa je ono samo što imate $3+2$ opcije na fakultetu, gdje možeš doć' i reć': ,A-ha, ja sam sad magistar, hoću bit inženjer"(Jakov, URP_VG, GIM_VG)

„, ...po meni, nekako, veleučilište nema toliko grana, znači, nema toliko smjerova, $i$ nije toliko opsežno, k'o na primjer studij... studiji su sami po sebi 5 godina, i znači, nekako je sve više detaljnije $i$ više se radi, više se uči, nego na veleučilištima - po meni... ja to tako gledam..." (Ivana, RRP_DSJ, 4SŠ_mg)

„.. učilišta i visoke škole u odnosu na fakultet, ili tako nešto... pa, možda čak dosta ljudi ni ne zna koja je to razlika... kad pitam ono, nekoga fizioterapeuta ili to nešto: „Završio sam fakultet "... to oni kažu (...) 'ko će njih ić' ispitivat' 'e l' to visoka škola ili fakultet, ak' ne'ko ne zna?! ... osobno... mislim da se to baš ne može uspoređivati po opsegu i gradiva $i$ znanja i svega ... Mislim da veleučilište ne pruža baš ... tolike mogućnosti i informacije, jer s razlogom netko tko završi na veleučilištu za višeg fizioterapeuta nije doktor..." (Gordana, RRP_TP, GIM_VG)

No razvidno je u pozadini takvih shvaćanja relativno jasno rangiranje institucija, no koje se ne pokazuje učenicima na jednak način. Jakov očito velik naglasak stavlja na prednosti završavanja stručnog studija i ističe osposobljenost za što brže zapošljavanje na tržištu rada. No, dodatno mu je bitan još jedan element - Zagreb kao mjesto studiranja, u njegovoj slici studiranja kao ,pripreme za život"“:

„... pa korak je pred sam život jer vi morate sami brinut: „A-ha, meni moja mama $i$ tata mogu poslat ovaj mjesec 500 kuna, a mjesec ima 30 dana. 500 kuna na 30 dana (...) uči vas kako će.. kak' vas čeka ubuduće (...) dakle, sve će vas studij, fakultet bilo koji ... normalno, ako ne ostanete u svom gradu..." (Jakov, URP_VG, GIM_VG)

Na jednoj strani, Zagreb je metropola i dio kruga europskih metropola koji time pruža najkvalitetnije znanje, i nalazi se na vrhu obrazovne hijerarhije u Hrvatskoj:

„... Zagreb je metropola, glavni grad Hrvatske, mora pružit adekvatno znanje... sigurno glavni grad Hrvatske neće svojim građanima pružiti nekakvu nižu stopu znanja.. mora im pružiti nešta što će zadovoljiti neke kriterije koji se tiču i Hrvatske i zemalja van Hrvatske...

... sve se slijeva u grad Zagreb.. i grad Zagreb se gradi kao neka „vau“ europska metropola (...) u to se ubraja i to nekakvo obrazovanje gdje će srednjoškolci u Zagrebu moći u svom gradu potražiti nešto što ih zanima i znati da će steći dobro znanje... nije ni čuda što dođete na prijemni... uglavnom ste u gimnaziji prolazili četiri godine s 5,0, svi su vas hvalili, psihologiju rasturate, dođete tamo i onda upiše se od 50 ljudi, ne znam, 39 Zagrepčana, ..., $i$ vi jedan ... i nitko iz [mog grada]..."(Jakov, URP_VG, GIM_VG)

S druge strane, u njegovovom planu kretanja na obrazovnoj i geografskoj ravni, Zagreb predstavlja korak u život koji znači učenje bitnih ,životnih lekcija“ i nošenje s ,pritiskom grada“ koji bi ga pripremio za kompetititivnu utakmicu na tržištu rada Europske unije. 
„... mislim da trebamo otići u veliki grad i biti spremni podnijeti pritisak velikog grada, jer... kažem vam, mi smo punopravna članica Europske Unije... ako se ja ne mogu nositi s pritiskom u naše... u svojoj državi kako ću se nosit s pritiskom kada budem stranac u nekoj državi?!..." (Jakov, URP_VG, GIM_VG)

Općenito učenici prepoznaju rangiranje obrazovanja - u društvenoj i geografskoj dimenziji, što ilustriraju i prethodni Jakovljevi iskazi.

„... i kada kažeš da si, ne znam, i sad za srednju školu, da si gimnazija ili da si neka trogodišnja ... gimnazija, ti si veći status u društvu, tako i na studiju... svi razlikuju, nije isto završiti studij $i$ srednju školu, ili studij medicine $i$, ne znam koji bi sad stavila, poljoprivredni studij, na primjer... ja mislim da to ljudima kada kažeš da oni imaju baš taj neki... utisak drugačiji ostaviš ako si nešto više..." (Marija, RRP_TP, GIM_VG)

„... mislim da u Zagrebu je teže... mislim da su tamo zahtjevniji nego tu, u Osijeku... jedna cura, bila je upisala za ekološkog tehničara i rekla je da je to stvarno teško i onda se prebacila u prodavača tamo u Osijeku i rekla je da je isto teško, i onda kad je došla ovdje... mislim, rekla je puno je teže tamo upisat $i$ za prodavača nego kod nas... tam puno više traže..." (Dominik, RRP_DSJ, 3SŠ_mg)

Time prepoznaju i ugled kao značajan faktor posjedovanja diplome, ističući društveno uspinjanje i selektiranje zaslužnih putem studiranja:

„... što se tiče fakulteta, mislim da tu isto imam neki rang gore, jer, da se razumijemo, ne mogu svi završit fakultet (...) ako već, ako već imaš mogućnost za nešto više, bilo šta bilo, ipak, diploma je diploma, a ne samo završena srednja škola..."(Silva, RRP_TP, 4SS̆_VG)

„... studiranje u društvu znači stvarno neka selekcija, razdvajanje ljudi po nekim zamišljenim ... ne mogu reći staležima, ali mislim, ne možemo svi raditi sve, moramo se razdvojiti očito..." (Andrej, URP_mg, GIM_VG)

A također prepoznaju drugačije vrednovanje diploma određenih studija, određene institucije i iz određenog grada. Kada su u pitanju studiji, studiji računarstva, medicine, te $\mathrm{u}$ prirodoslovnom i medicinskom području, ali i strojarstva uglavnom se ističu kao „teži“, pa time i ugledniji. Dodatno, učenici višu vrijednost pripisuju i studijima koji su ,popularniji“, odnosno teže ih je upisati (poput edukacijske-rehabilitacije i psihologije, ili stručnih studija zdravstva). S druge strane, upravo zbog procjena da je na tržitu rada previše ekonomista i učitelja, pa i pravnika, procjenjuje se da ti studiji ne pružaju dovoljno mogućnosti zapošljavanju. No, sve te klasifikacije studija ovise o konkretnom slučaju i dio su pregovaranja pojedinih učeničkih želja i informacij koje su bitan okvir mogućnosti zamišljanja na određenom studiju, kako je, na primjer ranije opisano Silvijino pregovaranje statusa studija poljoprivrede. 
Općenito se onda i fakulteti na kojima se izvode „bolji“ studiji procjenjuju „težima“, pa time i fakultetima višeg statusa. Dodatno, kvaliteta je također nešto što učenici procjenjuju kao dio ugleda neke institucije, što se katkada povezuje s „težinom“ i stručnošću zaposlenog kadra, i značajnim za nečije životne šanse: „... ako je to neka [institucija] dobrog glasa onda ti je zagarantirano da ćeš imati i neke stručnjake koji će te nečemu naučiti, koji će te usmjeravati, da možda odeš van, možda iskusiš neke svoje potencijale..."(Anica, URP_VG, GIM_VG).

Tome se suprotstavlja studiranje na veleučilištima kada je tip institucije u pitanju, s jedne strane: „... ako odeš na neko veleučilište i to, to je jednostavno tako samo da imaš neku diplomu i da prođeš..."(Anica, URP_VG, GIM_VG).

No, taj nedostatak kvalitete vezuje se i uz fakultete koji nisu u Zagrebu. Kako učenici opisuju, kvaliteta obrazovanja koji upisuju regionalne studije, te nepriznatost diplome regionalnih fakulteta u Europskoj uniji dodatni su kriteriji koji regionalne fakultete stavljaju u lošiju poziciju:

„... [regionalne] fakultete... znam da se jako trude $i$ da puno toga rade, $i$ da stvarno pokušavaju neku svjetsku razinu održati, ali to je ... nisu na takvom glasu pa onda i dobivaju loš... učenike koji nisu potpuno zainteresirani ili za to područje ili tako... tako da ne bi [regionalne] fakultete uvrstila u te prestižne baš zbog tog kadra studenata zato što neki... puno njih ne zanima to područje koje su upisali samo zato da upišu i onda se faks odmah... “ (Anica, URP_VG, GIM_VG)

„... ima dosta njih gdje medicinu iz Osijeka ne priznaju jednako kao medicinu iz Zagreba, nije priznata u Europskoj Uniji, moraju se polagati nekakvi ispiti, dok Zagreb priznaju..."(Gordana, RRP_TP, GIM_VG)

Dodatno, jedna učenica je problem korupcije, tj. kupovanja diploma izdvojila kao značajno obilježje regionalnih fakulteta, koji time gube na kvaliteti: „... ne znam 'e l' to predrasuda, stereotip il' neš", svi za osječki fakultet kažu de ja korumpiran, da su tam'i čistačice korumpirane..." (Andrea, RRP_TP, 4SŠ_mg). Ovaj problem svakako zaslužuje pozornost i ističu ga i ostali učenici i izvan područja obrazovanja. Čini se da učenici u svom regionalnom poimanju imaju i sliku korupcije, koju i Šundalić (2010) ističe značajnim problemom tranzicijskog razdoblja u slavonskom kontekstu, a koji donekle oblikuje i učeničke težnje za odlaskom pa tako i za studiranjem izvan regije.

A kada je u pitanju vrednovanje diplome određenih institucija, one su najnepovoljnije za diplome iz susjednih istočnih država. Time vrednovanje diploma prolazi i proces $(\mathrm{K})$ orijentalizacije diploma drugih pri vrednovanju vlastitih izbora. Prvenstveno, stjecanje takvih 
diploma se doživljava lakšim zbog olakšanog ulaska bez polaganja državne mature, a s druge strane dodatno se njihov ugled umanjuje svojom lokacijom izvan Europske unije:

„...moja diploma i primjerice diploma sa fakulteta $u[X]$, u susjednoj nam državi, neće isto vrijediti vani... ja sam studirao u članici Europske Unije, i došao sam raditi u članicu Europske Unije, i moja diploma, to je moj sud, mora vrijedit više... ja ne kažem da ta osoba koja je studirala tamo nema veću podlogu i više zna od mene, al' takav je život.. pa ni ovu školu nismo upisali svi koji smo zaslužili... isto se upisalo i preko veze.. kažem vam ... to je današnja situacija u društvu i što se prije uklopite u to..." (Jakov, URP_VG, GIM_VG)

„...vanredno, tipa [susjedna država] ... [moje kolegice] rade, $i$ ispite daju samo subotama, što njima odgovara (...) a i... mislim da im je, da im je lakše, da im je bolji prolazak jer su to privatni fakulteti ... ok, plaća se to dosta, ali mislim.. tamo su svi na prolazu, svi su na dobitku, a mislim da im je to cilj..." (Silva, RRP_TP, 4SŠ_VG)

Ipak, iako učenici imaju određenu sliku statusnih studija i institucija kao orijenti, i određene kriterije procjene kvaliteta pojedinih željenih studije i institucija, takvi kriteriji su jasni tek rijetko. Učenici su spremni i stavove i procjene drugih odbaciti kao predrasude, ili nebitne za svoje izbore, štoviše to je često dio pregovaranja i samih učeničkih izbora:

„...kaže se da je [moj željeni studij] u Osijeku najbolji, prati ju Zagreb, Zadar pa Rijeka, ali... to mi ne igra nikakvu ulogu ... mislim, diploma je diploma!.. " (Bernarda, URP_mg, GIM_mg)

„... nije bitno dal je fakultet 3 godine, 5 godina, i da li je to, ne znam, fakultet za fiziku ili je to fakultet za poljoprivredu, jednostavno čovjek mora imat sreće i bit uporan, tražit posao i može se nać, stvarno ..." (Ivana, RRP_DSJ, 4SŠ_mg)

„... ali ja to zapravo ne vidim zašto je to toliko bitno recimo studirati na Filozofskom u Zagrebu, koja je sad razlika sa, ne znam, Josipa Strossmayera u Osijeku.. i navodno je taj u Zagrebu puno bolji, ali... Pa ne znam [po čemu]... oni jednostavno tako... tako izračunaju, ono, veći je grad pa je valjda bolje.. ja ne znam, nisam se uopće o tom informirao..." (Dejan, URP_mg, GIM_mg)

„Pa više se cijene fakulteti iz Zagreba i smatra se da su više... kvalitetniji i sve...zato što ono svi - Zagreb, glavni grad, to je više u ... ljudskoj psihi, ne znam, tako... u glavi $i$ mozgu..." (Andrea, RRP_TP, 4SŠ_mg)

„... Po meni, svaka diploma je jednako vrijedna, na svakom fakultetu si ti jednako učio, ali kao - Zagreb je Zagreb, Vukovar je Vukovar, Osijek je Osijek.. znači, to su kao neki manji gradovi, ali Zagreb - to je Zagreb..." (Marija, RRP_TP, GIM_mg)

Uvelike se izbor grada studija učenicima ne pojavljuje posebnom odlukom koju moraju donijeti, i često ovisi o samom studiju kojeg biraju ((K) gdje upadnem!), no, određenom broju učenika se upravo izbor grada studija pojavljuje od prvenstvenog značaja i određuje daljnje mogućnosti i područja studiranja i/ili studiranja uopće. To se prvenstveno odnosi na visokoambiciozne učenike, povezano i sa željom za stjecanjem kvalitetnog obrazovanja, ali i 
sa željom osamostaljivanja napuštanjem roditeljskog doma: „...ja želim otići u Zagreb, želim se osamostaliti, želim imati, ovaj... tako da, kao neku promjenu, kao neko uživanje i učenje $i$ opet, ne pretjerano učenje $i$ ne pretjerano uživanje, znači.. neko osamostaljivanje $i$ onda nadam se da poslije toga više neću doći čak u roditeljsku kuću i da ću započet svoj život... . (Anica, URP_VG, GIM_VG). U njihovim slikama, ali i općenito u slikama učenika koji budućnost vide u inozemstvu, Zagreb se često postavlja kao jedna točka na tom putu:

„... u Osijeku imam sve, tak' da, ako mogu tu upast', i ovdje završit' [studij], onda super... možda, taj magisterij, te dvije godine, možda to odem u Zagreb, ili negdje..." (Silva, RRP_TP, 4SŠ_VG)

Kako ističe prethodni citat, Silvijin izbor vezan je uz financijska ograničenja, koja se smanjuju studiranjem u regiji, a s druge strane poznatošću grada u kojem je učenica pohađala i srednju školu te društvenih mreža koje bi doprinijele daljnjem smanjivanju razlika. Ono što je također značajno uočiti je način na koji učenica konstruira svoj obrazovni put kao putovanje više, ali i dalje; u trenutnim okolnostima bitno je steći bilo koju diplomu „diploma je diploma“ i vrijednost po sebi, ali daljnje napredovanje pretpostavlja odlazak i poduzimanje geo-socijalnog putovanja iz regije, pa čak i zemlje.

Na općem planu, studiranje se vidi kao kretanje, a istodobno i kao skupo te je stoga i pod najvećim djelovanja financijskih razmatranja. Kada su u pitanju visokoobrazovni izbori učenika, u najvećoj mjeri učenici će upravo financije isticati faktorom koji uvelike otežava donošenje takvih odluka vezanima uz preseljenje, a zatim i neodlučnost, nesigurnost te nedostatk poticaja u obitelji i vezanost uz dom. Stoga je bitno razmotriti neke od tih utjecaja s obzirom na učeničke procjene toga koliko su im određeni resursi dostupni u njihovim obiteljima, školama i zajednicama, te kako ti konteksti oblikuju njihove „odabrane“ putove.

\subsubsection{Obiteljski resursi učenika različitog rezidencijalnog podrijetla}

Prethodne analize ukazuju na važnost ispitivanja socijalizacijskih konteksta u kojima učenici žive i školuju se. Stoga se u nastavku ispituju ruralno-urbane razlike s obzirom na strukturu ekonomskih i kulturnih resursa kojima učenicima imaju pristup u svojim obiteljima, a koji se teorijski i empirijski ističu kao bitni utjecaji i objašnjenja učeničkih obrazovnih ishoda. Osnovna pretpostavka anaaliza mješovitih podataka bila je razumijevanje toga kako objektivni(ji) pokazatelji opisuju društvenu poziciju učenika te kako ih sami učenici interpretiraju, procjenjujući obiteljske resurse koji su im dostupni za njihove buduće planove. 


\subsubsection{Ekonomski obiteljski resursi-mjere i subjektivna značenja}

$\mathrm{Na}$ svim operacionalnim mjerama Bourdieuovih koncepata ${ }^{96}$, statistički značajni testovi potvrdili su postojanje ruralno-urbanih razlika, i ukazali su na općenito nepovoljniju strukturu obiteljskih resursa učenika ruralnog rezidencijalnog podrijetla (Slika 4.4 i Tablica 4.5) koji se smatraju potencijalnim kapitalima za ostvarivanje visokoobrazovnih uspjeha.

$\mathrm{Na}$ regionalnoj razini, blizu polovice (44\%) anketiranih učenika ima jednog roditelja sa stalnim primanjima, a dodatnih $29 \%$ ima oba roditelja zaposlena na stalnom poslu, dok više od 1/4 slavonskih maturanata ima roditelje bez stalnih prihoda ili bez prihoda uopće. No, samo $16 \%$ učenika ruralnog rezidencijalnog podrijetla ima oba roditelja sa stalnim prihodima (nasuprot $41 \% \mathrm{U}_{\mathrm{URP}}$ ), a čak $28 \%$ ih ima oba roditelja bez stalnih prihoda (nasuprot $15 \%$ $\left.\mathrm{U}_{\mathrm{URP}}\right)$.

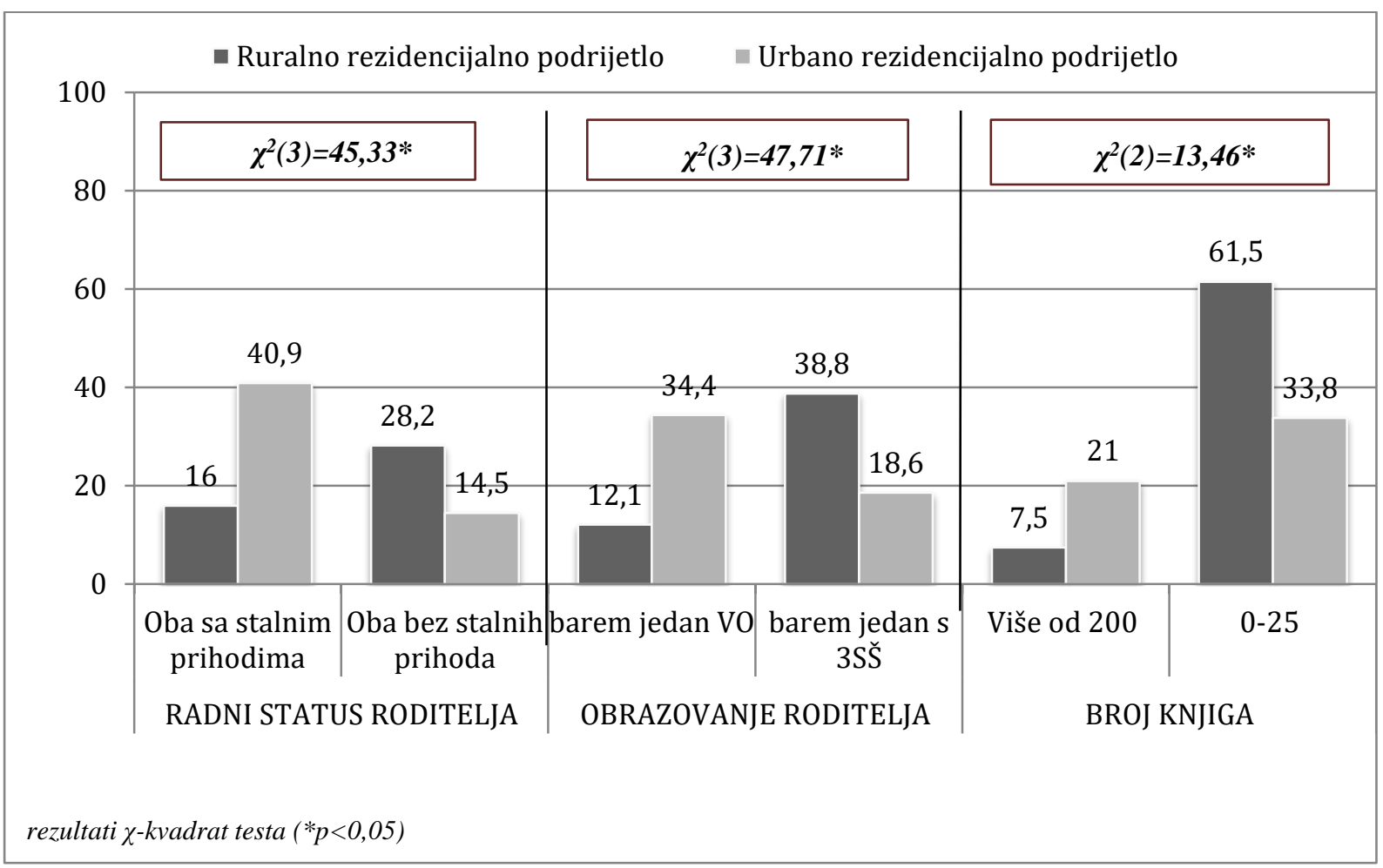

Slika 4.4 Razlike između učenika različitog rezidencijalnog podrijetla prema elementima obiteljskih resursa $^{97}$

Uzorak intervjuiranih $^{98}$ je vrlo slikovit po tom pitanju te se pokazuje da kategorije onih učenika čiji niti jedan roditelj nema stalne prihode ili prihode uopće predstavljaju samo

\footnotetext{
${ }^{96}$ Ekonomski kapital obitelji ispitivan je trima mjerama: radni status roditelja putem stalnosti roditeljskih prihoda, materijalni status obitelji preko količine posjedovanja automobila, računala i nekretnina, te ekonomska situacija obitelji procjenom ispitanika. Kulturni obiteljski kapital ispitan je u tri njegova oblika pri čemu je mjera institucionaliziranog kulturnog kapitala bila obrazovni status roditelja, objektivirani kulturni kapital mjeren je brojem knjiga i posjedovanjem različitih vrsta kulturnih objekata u kućanstvu, a utjelovljeni kulturni kapital mjeren je učestalošću roditeljskog sudjelovanja u različitim kulturno-obrazovnim aktivnostima.

${ }^{97}$ Grafički su prikazani udjeli učenika u kategorijama nezavisnih varijabli koje pokazuju najveće razlike.
} 
učenici odrasli na selu, od kojih svi žele studirati, i čija se razmatranja financijske situacije obitelji odražavaju i u njihovim planovima studiranja i, općenito, onome što žele postići studiranjem:

„... moji nijedno ne rade, tako da je to malo problem... dobro tata malo neš" kao sa strane (...) prvenstveno sam razmišljala na to da bude redovan [studij] jer, ono, baš... ovaj, vanredno mi ne mogu plaćat'... hmmm (...) moram biti u stanu jer ne mogu putovati $i$ ić' na fakultet... hmmm... sad ne znam hoće li mi to uspjeti izrealizirati (...) ako ne - naravno, trudit ću se ono iz petnih žila da to završim i putovat' (...) puno mi prijatelja drži tu lokale po Osijeku, pa bi možda nešto radila kod njih preko onog studentskog..."(Silva, RRP_TP, 4SS_VG)

S druge strane, svi intervjuirani učenici skupa onih koji imaju oba stalno zaposlena roditelja (4) su učenici urbanog rezidencijalnog podrijetla od kojih svi nemaju namjeru studirati. Radni status roditelja je snažno značajan i bitna je otežavajuća okolnost onim učenicima koji namjeravaju studirati, no možda je prvenstveni utjecaj (ne)stalnosti roditeljskih primanja da djeluje kao motivirajuća sila učenicima, kako to objašnjava Ivana.

... stalan posao... to je ono svakak'... ne želim bit k'o mama i tata, svake godine novi posao, čak $i$ više puta u godini... stalan posao i da, ono, ne moram spajati kraj s krajem, da imam dovoljno za sebe i u budućnosti za svoju obitelj... da ne moram, znači, da mogu uživati $i$ u braku i svemu, da ne moram, ono, razmišljati: „, Od kog ću nabavit' novce, kak'ću preživit'?", i to sve..." (Ivana, RRP_DSJ, 4SŠ_mg)

S druge strane, važno je promotriti i ostale mjere namijenjene zahvaćanju obiteljskih ekonomskih resursa jer čak i ako netko nema oba roditelja zaposlena ili roditelje sa stalnim primanjima to ne znači da oni svoju situaciju procjenjuju nezadovoljavajućom ili preprekom za studiranje. Sve ono što imaju ili si mogu priuštiti te koliko mogu uživati u luksuzu važan je element njihovih procjena.

Tabela 4.5 Razlike između učenika različitog rezidencijalnog podrijetla na elementima obiteljskih kapitala

\begin{tabular}{|c|c|c|c|c|c|c|c|}
\hline \multirow[b]{2}{*}{ Zavisna varijabla } & \multicolumn{2}{|c|}{$\begin{array}{l}\text { Ukupni } \\
\text { uzorak }\end{array}$} & \multicolumn{2}{|c|}{ (1) RP Ruralno } & \multicolumn{2}{|c|}{ (2) RP Urbano } & \multirow{2}{*}{ t-test } \\
\hline & $\mathbf{M}$ & SD & $\mathbf{M}$ & SD & $\mathbf{M}$ & SD & \\
\hline Posjedovanje imovine & 1,52 & 0,56 & 1,39 & 0,54 & 1,64 & 0,55 & $\mathrm{t}(429)=-\mathbf{4 , 6 2} *$ \\
\hline Procjena financijske situacije & 2,87 & 0,78 & 2,75 & 0,81 & 2,98 & 0,73 & $\mathrm{t}(413,0)=-\mathbf{3 , 0 1} *$ \\
\hline Posjedovanje kulturnih dobara & 0,61 & 0,28 & 0,54 & 0,29 & 0,68 & 0,26 & $t(431)=-\mathbf{5}, 26 *$ \\
\hline Roditeljske kulturne prakse & 1,74 & 0,71 & 1,56 & 0,61 & 1,92 & 0,75 & $\mathrm{t}(417,2)=-\mathbf{5}, \mathbf{4 7} *$ \\
\hline
\end{tabular}

\footnotetext{
${ }^{98} \mathrm{U}$ odnosu na zastupljenost u pojedinim kategorijama varijable, u uzorku intervjuiranih je blago više učenika $\mathrm{s}$ nepovoljnijim radnim statusom roditelja (7) pri čemu nije intervjuiran niti jedan učenik urbanog rezidencijalnog podrijetla s roditeljima bez stalnih primanja, te niti jedan učenik ruralnog rezidencijalnog podrijetla s oba stalno zaposlena roditelja.
} 
I materijalno (Tabela 4.9), statistički je značajno niži prosječni rezultat slavonskih maturanata ruralnog rezidencijalnog podrijetla $(M=1,4)$ koji, skupno, odražava količinu posjedovanih računala, automobila i nekretnina, u odnosu na onaj učenika urbanog rezidencijalnog podrijetla $(M=1,6)$. Ipak, $3 / 4$ anketiranih (i intervjuiranih) slavonskih maturanata nalazi se oko prosječne vrijednosti na varijabli, dok rijetki izuzeci ukazuju da specifične obiteljske situacije mogu izuzetno djelovati na rezultat (na primjer, neposjedovanje automobila ili posjedovanje nekretnina). Time je i urbano-ruralna distinkcija puno slabije naglašena te se $\mathrm{i}$ ispodprosječnim i iznadprosječnim rezultatima među intervjuiranima izdvajaju učenici različitog rezidencijalnog podrijetla, te roditelja s različitim tipovima zaposlenja. Na primjer, Mislav je odrastao na poljoprivrednom gospodarstvu u obitelji visokoobrazovanih roditelja, te njegova obitelj posjeduje određena dobra, no to ne ukazuje direktno na njegovu procjenu financijske situacije: „,... ono, kako smo prije imali, kol'ko je prije bilo novaca, sad je dosta loše, sad bi čak stavio ovo „, [jedva spajaju] kraj s krajem “... u sredinu kad pogledam, dobro je znači... ne smijemo... “ (Mislav, RRP_DSJ, 4SŠ_VG).

Ipak, postoje određene materijalne pogodnosti koje se mogu smatrati velikim prednostima kada je u pitanju mogućnost studiranja, a opisuje ih učenica koju možemo u cijelom skupu intervjuiranih smatrati učenicom s najpovoljnijom strukturom obiteljskih ekonomskih resursa, i s obzirom na radni (oba roditelja zaposlena u području stručnih profesionalnih djelatnosti) i materijalni status roditelja:

„...imam taj stan, a, ovaj... roditelji su dobrostojeći i oni su mi rekli da će mi, ovaj... $i$ studiranje u stranim zemljama bi mi omogućili, sve u nekim granicama normale, naravno, ali financije nam nisu tu neki veliki problem..." (Anica, URP_VG, GIM_VG)

Upravo ovaj iskaza upozorava kako je potrebno oprezno interpretirati rezultate na pojedinim mjerama; unatoč tome što citat jasno ističe iznadprosječnu ekonomsku situaciju učenice, uz isticanje bitne prednosti za studiranje vezane uz smanjenje troškova stanovanja koje učenici općenito smatraju najvećim troškom studiranja (,...znači prostor za življenje to je, ovaj, najveći trošak [studiranja] inače, a mi ćemo sad samo režije plaćat' tako da nije neki veliki problem...), subjektivno, ekonomsku obiteljsku situaciju u anketnom upitniku ova učenica procjenjuje prosječnom, i objašnjava svoj izbor na sljedeći način:

„... znači, imamo sve što, što trebamo, sve što želimo, a ovaj... imamo i nekretnina $i$ uživancije, $i$... moji su jednostavno napravili tako da sa tim svojim novcima su napravili da mi možemo uživati u svemu onome što volimo, tako da, ugodna atmosfera u obitelji...

... Normalno smatram ... hmmm... da se ne pretjeruje, a opet da se ima sve što bi te činilo sretnim... ne sad neko pretjerivanje ,,pa ja bi sad ovu odjeću od ovoliko novaca “... ne u tom smislu... to nemamo novaca za to, ali imamo za sve što nas čini sretnim, za, ne znam, 2 broda, 2 auta... tak'... živimo super... “ (Anica, URP_VG, GIM_VG) 
Slično, još jedan učenik urbanog rezidencijalnog podrijetla svoju obiteljsku financijsku situaciju procjenjuje nezadovoljavajućom, unatoč činjenici da ima dva zaposlena roditelja i brata na privatnom fakultetu:

„....kad vidim da primjerice moji roditelji rade za neku, sad to ispada stvarno crkavica, stvarno to ispadne da vi ne možete s tim ništa, al' apsolutno ništa...

...član sam obitelji koja ima dva, dvije radne osobe unutar obitelji koje rade u državnim firmama, $i$ kad pogledam da moja mama dođe $i$ kaže: „Pa čovječe, za šta ja radim mjesec dana? ", onda mi dođe da ja... ne, ja tu rečenicu ne želim izgovoriti u svom budućem životu..."(Jakov, URP_VG, GIM_VG)

Upravo takva procjena situacije kod učenika izaziva emocionalne reakcije bojazni za smanjenje financijskih mogućnosti vlastitog studiranja $(, \ldots$ i onda sam razmišljao da: „Šta ak’ meni moja mama dođe $i$ kaže: „Ja tebe ne mogu poslat na fakultet... !? “...), ali prvenstveno ljutnje s obzirom na općeniti standard života u Hrvatskoj i mogućnosti studiranja te toga što znači biti mlada osoba u Hrvatskoj: ,, ... to je ono što je meni poražavajuće, (...) da mi kao mladi moramo odlučivati sad, gdje bi možda trebali u ovim tinejdžerskim godinama uživat i samo mislit na neko svoje ... mislit na ono šta ću ja studirat', a ne da l' to moji roditelji mogu financirat ili ne mogu...".

Vidljivo kod ovih učenika ekonomske okolnosti njihove obitelji djeluje motivacijski pri njihovim visokoobrazovnim odlukama te u smjeru unapređenja njihova budućeg ekonomskog standarda, odnosno društvene mobilnosti kada što je bitan element Jakovljevih planova, i dubokog razmatranja lokalnih mogućnosti studija koje se odbacuju kao nezadovoljavajuće i konačnog odabira studija upravo prema kriterijima traženosti i zapošljavanja za stjecanje „europskog“ standarda. Kod Anice je motivacija također naglašena, ali u većoj mjeri kao reprodukcija roditeljskog statusa, kako to opisuje Anica: „... bi li pristala na manju plaću nego što imaju moji roditelji? - Ne bi'! Htjela bi baš to..."“.

Općenito, učenici su bili skloni pri procjenama svoju financijsku situaciju određivati prosječnom, te je prosječni regionalni rezultat $M=2,9$, no statističke analize su potvrdile kako postoji razlika između učenika s urbanim, čiji je prosječni rezultat viši $(\mathrm{M}=3)$, i onih $\mathrm{s}$ ruralnim rezidencijalnim podrijetlom, čiji je prosječni rezultat niži $(M=2,8)$ na tom mjerenom aspektu. Među intervjuiranima, manje je učenika s prosječnim rezultatima, dok je 6 učenika s ispodprosječnim 6 , onih s iznadprosječnim procjenama koje samo dijelom objašnjava radni status roditelja, te je uočljiva i veza s rezidencijalnim podrijetlom. 
Ukratko, oni učenici koji imaju oba zaposlena roditelja bili su skloniji financijsku situaciju obitelji procjenjivati boljom (izuzev prethodno opisanih slučajeva), te verbalno izražavati zadovoljstvo (iako vrlo slično onima koji su obiteljsku situaciju procijenili prosječnom):

„... Dosta dobro stojimo, što se toga tiče nije problem, tako mi bar roditelji kažu (...) Nemamo baš problema, ono, uvijek se nešto da riješiti... “(Dejan, URP_mg, GIM_mg)

„....Neću reći da je loš, dobar je, živi se, 'aj"mo reć', dobro... za one neke potrebe ima, znači (...) za normalan život ima... dobar i normalan život... ništa neki luksuz, al' normalan život je, ok... “(Krešimir, URP_mg, 3SŠ_mg)

Dodatno, i određeni učenici koji imaju samo jednog zaposlenog roditelja svoju situaciju procjenjuju dobrostojećom: „...Pa mislim da imamo dovoljno za sebe, da nije kao što piše „jedva spaja kraj s krajem“... sve što želim, imam, roditelji što mogu, omoguće mi, što ne mogu, ne omoguće $i$ to je ... zadovoljna sam..." (Agata, URP_mg, 4SŠ_mg).

Jedina učenica u ovom skupu učenika s ruralnim rezidencijalnim podrijetlom je Marina koja iako nema oba zaposlena roditelja svoju situaciju procjenjuje blago iznad prosjeka:

„... pa sad ne znam: ima dovoljno za prosječan, normalan život, i prilično je dobrostojeća... [negdje između] (smijeh) (...) pa isto normalno imamo za šta trebamo, poplaćamo račune $i$ ak' nam šta ostane spremimo il', ono, većinom ide meni (smijeh), i tak'... jednostavno, ja sam zadovoljna, imam sve što trebam, ne tražim puno, ne trebam sad, ne znam, neke gluposti ... Nema [financijskih poteškoća]... fala Bogu!.." (Marina, RRP_TP, 4SŠ_mg)

S druge strane, nekim učenicima upravo činjenica da samo jedan roditelj radi vodi tome da njihove procjene odražavaju ispodprosječnu obiteljsku financijsku situaciju s obzirom na materijalne uvjete: „... Pa... moja mama je, znači, jedina koja radi... tata ne radi... ima ono, kako bi rekla, minimalac, tako da imamo ono što je nužno, nemamo, nemamo ništa ono što bi neki željeli, htjeli, tako nešto što netko iz viših staleža si može priuštiti, na primjer, to si ne možemo priuštiti, nego samo ono nužno za život: hranu, na odjeću i tako to... " (Aneta, URP_mg, 4SŠ_mg).

No najznačajniji je način na koji ovaj skup učenika, u kojem prevladavaju učenici ruralnog rezidencijalnog podrijetla, svoju financijsku situaciju promatra kao otežavajuću okolnost pogotovo kada su u pitanju obrazovne mogućnosti, a u skladu sa specifičnom obiteljskom situacijom:

„... a eto moja obitelj je prosječna, imamo za sve što nam je potrebno nas šestero, preživljavamo (...) od najmlađeg brata koji sad će 3 godine, za njega sve, ovaj... [sestra], ona je drugi razred, njoj za školu i bratu, brat peti [razred], za školu, i za mene isto... " (Frane, URP_mg, 3SŠ_mg) 
„...brat mi je upisao studij u Osijeku (...) tako da njemu isto, kad pogledam, njemu isto ide na stan, pa za džeparac, pa za kartu kući kad ide, a meni tu za dom, pa za džeparac, tak da ja sad kad odem na studij bi' će još teže, a samo mi tata radi... " (Marija, RRP_TP, GIM_mg)

„... „, Ima za ono što je nužno“ - to sam stavila zbog trenutne situacije je l' ne rade, a i mislim da je nužno da moj brat i ja idemo čisti u školu i da mogu platit režije... to je to..." (Silva, RRP_TP, 4SŠ_VG)

Svi ovi učenici obrazovne potrebe članova kućanstva, ističu i kao veliko opterećenje obiteljskog budžeta, i važnu referentnu točku procjene obiteljske ekonomske situacije s obzirom na to može li se ta potreba zadovoljiti. Stoga i njihove buduće namjere studiranja odražavaju i svijest o novim opterećenjima na obiteljska primanja i razmatranje mogućnosti studiranja s obzirom na obiteljske financijske resurse. To je jedna od osnovnih točaka razmatranja izražena općim stavom učenika kako je $(\mathrm{K})$ studiranje skupo što vodi i razvoju posebnih ,izlaznih strategija“ cijelih obitelji i/ili samih učenika koji imaju želju studiranja.

$\mathrm{S}$ jedne strane, nezaposlenost ili podzaposlenost roditelja prisiljava prilagođavanje koje podrazumijeva odlazak na rad u inozemstvo, ili pak preseljenje cijelih obitelji:

„... mama i tata će mi plaćat', a sad kako ne znam (...) oni su planirali ić' vani... moja mama je napravila već dva, tri, završila dve, tri prekvalifikacije (...) kontaktirala ljude iz Njemačke i rekli su sam da moraju naučit' jezik još, naravno, i da može doć' (...) ako to uspije, onda, najvjerojatnije, znači, imat će puno višu plaću, moć' 'u se financirat', a ako ne, ne znam... još nismo našli izlaznu strategiju...“(Aneta, URP_mg, 4SŠ_mg)

„... trenutno cijela moja obitelj odlazi iz manje sredine, znači, selim na more gdje je definitivno drugačija situacija, ako netko hoće pokrenuti nekakav posao, ovdje ne može ništa opstati, tako da... i zbog mog fakulteta, i zato što će brat isto ići dalje, i sve... jednostavno, moralo se doći do nekakvog plana gdje će dolazit jednostavno više novaca u kuću, $i$...

(...) zato što u manjoj sredini nisu baš mogućnosti za školovanje nekakve povoljne, za održavanje studenta jednoga... " (Gordana, RRP_TP, GIM_VG)

Kako i ovi citati pokazuju, općenito učenici se u najvećoj mjeri oslanjaju na roditelje i njihovu (K) financijsku podršku, prepoznajući njihovu veliku požrtvovnost da bi svojoj djeci omogućili obrazovanje, a posebno je teško obiteljima u ruralnim sredinama i onim učenicima koji imaju visoke aspiracije u mjeri u kojoj moraju prilagođavati svoje želje, odnosno spuštati svoje obrazovne aspiracije. Kod učenika koji nisu sigurni u svoje odluke i koji pokazuju (K) strah od neuspjeha, prva linija učeničkih razmatranja je: uložiti u obrazovanje ili ne?

„... voljela bih na more ići radit ili već negdje van i skupit si novac pa sama sebi platit'... pa onda ako i odustanem nakon, ne znam, što mi bude teško ili nešto, neće mi bit žao jer njihove novce sam znači, ono... kako da kažem... ništa dala, tako da... (...) ako ne, naravno, roditelji su tu, uvijek, oni bi, znači, meni sve financirali, ali želja mi je da sama si financiram... “(Agata, URP_mg, 4SŠ_mg) 
„... pa mogu meni moji sve to platit', al' jednostavno pomislim da ne idem na to jer ak' ne prođem to je ono gubitak vremena... bolje taj novac uložit u nešt' normalno, to jest, ne normalno (smijeh), neg' neš' u što sam sigurna da će uspjet', a ne faks... “ (Marina, RRP_TP, 4SŠ_mg)

No, kako ovi citati pokazuju, takva razmatranja u većoj mjeri su vezani s učeničkom neodlučnošću i roditeljskom nesigurnošću o stvarnim namjerama učenika da studiraju, nego roditeljskim nedostatkom sredstava. Štoviše, ovi iskazi podsjećaju na obrazovne strategije učenika koje Corbett (2005) pronalazi u kanadskom ruralnom kontekstu; investitori su učenici koje njihovi roditelji slabijeg kulturnog, ali snažnijeg ekonomskog kapitala potiču na obrazovanje s obzirom na porast vrednovanja obrazovanja, promijenjene okolnosti, $\mathrm{i}$ potražnju za većim kvalifikacijama na tržištu rada, ali koji ih ne usmjeravaju pritom u visoko obrazovanje, već ih „zadržavaju blizu“ usmjeravajući ih u strukovno obrazovanje prilagođenije lokalnom tržištu rada. U konačnici, ipak, ove učenice iako priznaju potrebu studiranja i prednosti posjedovanja diplome, ne povezuju poboljšanje životnih okolnosti migriranjem s obrazovanjem. U njihovim planovima, obrazovanje je mogućnost, ali i rizik, a mogućnosti dobrog života postoje i nevezano s obrazovanjem koje je time neka vrsta prisile, a ne toliko željeno i intrinzično usmjereno.

S druge strane, onim učenicima pak koji imaju veliku želju studiranja, prepoznavanje roditeljske požrtvovnosti u obliku financiranja daljnjeg obrazovanja svoje djece predstavlja i posebnu motivaciju za završavanje fakulteta kao oblika (K) odužiti se roditeljima za njihovo obiteljsko ulaganje u usmjeravanje prema visokom obrazovanju:

„....sigurno ću ga završit'... to prvenstveno i radi sebe $i$, ne znam, da pokažem i neku zahvalnost $i$ roditeljima što me potiču, što me financiraju u tome, što su uvijek tu za mene..." (Marija, URP_mg, 4SŠ_mg)

„,...zato što su oni postigli sve svojim radom da mi imamo nešto dobro, i ja to cijenim ... za ove praktične stvari nisam baš najsposobnija tako da... uzmem knjigu i to je ono što znam..."(Anica, URP_VG, GIM_VG)

Oduživanje roditeljima kao motivacija za završavanje fakulteta postoji kod većeg broja učenika bez obzira na financijsku situaciju obitelji, a posebno kod onih koji veliki naglasak stavljaju na značaj obrazovanja za povećanje životnih šansi i koji su zahvalni za mogućnosti koje su im dobrostojeći roditelji pružili pri čemu jedini zadatak učenika postaje učenje: „...ne znam koliko netko može sa nekim poslom uz studij biti uspješan... (...) meni roditelji govore da će oni bilo šta napravit samo da oni mene izfinanciraju (...) ali da se ja nikako ne brinem oko škole... “(Bernarda, URP_mg, GIM_mg). 
Ipak, taj poticaj je dodatno naglašen kod učenika s lošijom financijskom situacijom obitelji što vodi općenito planovima većih osobnih angažmana koji bi smanjili potrebu roditeljskih financijskih izdavanja preuzimanjem većeg tereta odgovornosti. Takva djelovanja su za one s vrlo ograničenim obiteljskim financijskim resursima vrlo raširena i zahtijevaju ozbiljno manevriranje i prilagođavanje: dijelom su vezana uz orijentaciju na postignuće kako bi se izbjeglo plaćanje studija, stekla stipendije i/ili smještaj u domu, odnosno naglašavanju akademskih aspekata studiranja:

„....nadam se da to donekle ima [novaca] ... s tim da ne ponavljam godinu, nego da redovno, da bi bilo dovoljno novaca (...) postoji mogućnost da ako sad prođem s 5,0 i ovu godinu da ću imat pristup za dom (...) planirao sam da barem prosjek bude da ostvarim stipendiju kak' bi bilo lakše mi za daljnje studiranje (...) s obzirom da bi mi bilo, ono, dosta teško, možda i baš $i$ ne [bih radio uz studij] jer ne bi onda imao vremena za učenje..." (Marijan, RRP_DSJ, 4SŠ_mg)

„... al' sam isto tako čula da baš i ne upada se u domove nešto pretežno... da teško, mislim upast', ono... (...) oni 24-7 na fakultetu i da nema baš ni slobodnog vremena kamoli da može radit'... tako da, to [rad uz studij]mi baš i nije opcija..."(Aneta, URP_mg, 4SŠ_mg)

No, na dobivanje doma i/ili stipendije oslanja se manjina učenika onih školski vrlo uspješnih. Uglavnom prevladava stav da je dom jako teško dobiti (što ovisi i o gradovima studija), a slaba je upoznatost s mogućnostima dobivanja stipendija pri čemu učenici ističu djecu branitelja kao glavnu kategoriju potencijalnih stipendista.

Drugim pak učenicima rad predstavlja osnovni oslonac za razmatranje uopće mogućnosti studiranja, no kako su i prethodni citati upozorili, ono je ograničeno zahtjevnošću studija i razmatranjem rasporeda određenih studija, te dodatni izvor briga da će omesti postizanje visokoobrazovnih ishoda:

„... planirala sam nešto čak, kao, uzet radit, jer ... pogotovo na prvoj godini ... imam predavanja tipa od 9 do 2 i to je sve za cijeli dan, a pošto puno, puno mi prijatelja drži tu lokale po Osijeku, pa bi možda nešto radila kod njih preko onog studentskog, ili tako nešto... pa ako budem mogla nešto... radit' nešto, time pomoć mojima, naravno, da ću radit, $u$ to nema sumnje...

... prepreka [završavanju fakulteta] (...) recimo, ako budem na tom poslu, pa ne stignem sad učit za ovo, ne napravim seminar, il' tako nešto... al' nadam se da neću imati tih problema, da ću se snać'..." (Silvija, URP_TP, 4SŠ_VG)

Kako je balansiranje rada i akademskih obaveza težak zadatak, učenici razvijaju i alternativne strategije rada prije studija stupanjem na tržište rada kako bi zaradili za studiranje, a u uzorku intervjuiranih je to bila značajna strategija poboljšanja financijske situacije za omogućavanje studiranja upravo učenicama odraslima na selu. Katkada to podrazumijeva sezonski rad, no 
postoje i primjeri odgađanja studiranja koji učenici opisuju kao vlastitu opciju ako ne uspiju upisati studij, ili kao planove nekih svojih školskih kolega:

„... ja već dvije godine, eto od svoje šesnaeste, sedamnaeste, idem raditi preko ljeta na more, $i$ ja sebi zaradim tako jedan solidan džeparac, tako da, i ove godine isto idem, tako da mi to jedan veliki dio godine mi to pokrije, ako si pravilno rasporedim... " (Gordana, RRP_TP, GIM_VG)

„...pošto je prva godina besplatna, onda ću to tako, ić' 'u radit' ovo ljeto cijelo, planiram ić' u nadnicu, i to ne planiram ići odma' 8 sati, već 10, 15, kol'ko bude potrebno da što više skupim, pa koliko bude, bude... “(Ivana, RRP_DSJ, 4SŠ_mg)

„... Ja sam, na primjer, odlučila da idem preko ljeta radit na more da si ipak zaradim za studij, neću... na primjer $u$ [svom mjestu] ostat 4 mjeseca i tako... Ništa ne radit' (...) ta 4 mjeseca pa si zaradim, ne znam, za laptop ili barem prvi mjesec za stan ili dom, a poslije..."(Marija, RRP_TP, GIM_mg)

Potrebno je ovdje istaknuti kako su se za neki učenisi upravo iskustva rada daleko od doma isticali kao osnovu pretpostavki da će se lakše prilagoditi na studij i usklađenijim s preuzimanjem odgovornosti na samom studiju.

„... znači, sa šesnaest godine sam otišla prvi puta od kuće na tri mjeseca, i to su moji roditelji vrlo lagano prihvatili, zato što su rekli: ,, ionako ćeš morati otići, bolje da se sama pripremiš na to "... tako da meni to.. ne gledam to kao ništa strašno... " (Gordana, RRP_TP, GIM_VG)

S druge strane, ,pauziranje godine“ učenicima koji slabijim procjenjuju svoje šanse upisa, ali Žele nastaviti školovanje, mogućnost za stjecanje financijskih sredstava, (,, ... ako ove godine ne odem na faks, voljela bih na more ići radit ili već negdje van i skupit si novac pa sama sebi platit... “ Agata, URP_mg, 4SŠ_mg), ali i rizik, kako ga prepoznaju neki učenici, jer odgađanje upisivanja sa svojom generacijom može značiti da se studij nikada neće upisati. „... ima par cura, al' one su isto rekle da će pauzirat' godinu dana pa da će onda nastavit', tak' da... one su isto više za odustajanje nego za ići dalje... “ (Ivana, RRP_DSJ, 4SŠ_mg)

S druge strane, odgađanje studiranja odnosno izlazak na tržište rada katkada se pojavljuje kao dodatni poticaj za studiranje s obzirom na stanje na tržištu rada i produženo vrijeme donošenja odluke o nastavku školovanja: ,, ... dosta njih je čekalo, mislim... nisu uopće ništa radili dvije godine, sad kad su vidjeli da nema posla sa srednjom školom, e sad bi oni nešto, tako da.. su se ipak odlučili za to..."(Silvija, RRP_DSJ, 4SŠ_VG)

Konačno, specifični učenici nadaju se da su financijsku podršku roditelja zaslužili drugim aktivnostima, radom za roditelje i s njima, koji u Mislavovom slučaju ne postavljaju 
akademsku orijentaciju nasuprot praktičnom radu, već vrlo direktno uspostavljaju vezu između praktičnog rada i teorijskog učenja s obzirom na željeni studij i slike budućeg života:

„... prvenstveno, to će mi roditelji, znači, 'e l' se ja kod kuće njima pomažem kao radna snaga, idem sa njima $i$ sve radim, tako mislim da bi ... oni, da, prvenstveno, od njih...." (Mislav, RRP_DSJ, 4SŠ_VG)

Dodatno, osim što je potreba rada uz studij u sukobu s akademskim, može biti u sukobu i s drugim stremljenima učenika koji od studiranja očekuju više od (teorijskog) znanja i stjecanja zanimanja, i koji žele doživjeti i studentski život, raditi na unapređenju sebe i/ili iskoristiti nove mogućnosti koje im se otvaraju odlaskom iz roditeljskog doma i/ili u veliki grad: „....mislim ić' volontirat' za vrijeme studija, tak' da... to bi mi malo previše vremena oduzelo [za rad]..."(Andrea, RRP_TP, 4SŠ_mg).

Stoga, učenici s ograničenim pristupom obiteljskim financijskim resursima pristupaju u većoj mjeri razvijanju izlaznih strategija, opcija financiranja kao i pregovaranju različitih mogućnosti studiranja i prilagođavanja visokoobrazovnih odluka što (re)producira različite slike i očekivanja od studiranja. Velikim dijelom te prilagodbe vezane su uz mjesto studiranja:

„... 'ko nema... mislim da svaki grad pruža određene mogućnosti samo stvar je kakav je student... onaj koji traži bolji noćni život, naravno da neće otić' u Petrinju studirati, mislim... (smijeh) ne znam... ili Požegu ili tako nešto... tako da, sve ovisi kako tko šta traži, kako si tko zamisli uopće taj studentski život..."(Gordana, RRP_TP, GIM_VG)

S obzirom da velika većina učenika naglašava troškove stanovanja najvećim opterećenjem, za one učenike koji lošom procjenjuju financijsku situaciju svoje obitelji, to može voditi odustajanju od određenih željenih studija, odnosno gradova studija, kao i od želja vezano uz određene aspekte studiranja; tako je i smještaj u domu „dvosjekli mač“: to je jeftiniji način studiranja i nekim učenicima jedini način studiranja, ali i prisila suživota $s$ neznancem koji može oblikovati i akademske i socijalne aspekte studiranja, i traži ,žrtve“ u nekom od aspekata:

„... ljudi se obično žale na izbor cimera kojeg dobiju, tako da sam se već nekako pomirila s tim da ću morati učiti, ili, ne znam, u knjižnici, ili tako negdje..." (Gordana, RRP_TP, GIM_VG)

S druge strane, želja za osamostaljivanjem i smještaj u domu ipak može pozitivno djelovati za određene učenike koji su izrazito visokoobrazovno usmjereni. Kako kazuje Gordana, njena prva asocijacija na studiranje je ,puno odricanja .. ne onaj ludi studentski život kako to uglavnom izgleda, i... pa ne znam, dugo to traje (...) i mislim da tih 6 godina, hm, mogu naučiti i sama već živjeti, raspoređivati novac i steći radne navike, tako da mislim da je to jedna velika priprema za sve...". 
Zadržavanje studiranja lokalno/regionalno strategija je smanjivanja troškova koja može značiti nužnost prilagodbe ili konflikt težnji s obzirom na lokalnu/regionalnu ponudu studija i studijske želje učenika, ali također i studiranje u svim njegovim aspektima kao i daljnje životne mogućnosti.

„... moje mišljenje je da roditelj će investirat u tebe do krajnjih granica, al' opet možda netko nema pa mora potražit' tu soluciju [lokalno] ... jednostavno nema otić' $u$ '(...) susjedni grad (...) kad neko nema tamo za život (...) ne mogu te jednostavno poslati..." (Jakov, URP_VG, GIM_VG)

„... neki koji stvarno financijski loše stoje si ne mogu baš priuštiti otići u Zadar, evo (...) mislim, u Slavoniji je dosta jeftinije, cijene su drugačije, i vjerojatno si , mislim, dosta si mogu priušti... tako negdje dalje otići studirati, pogotovo u inozemstvo, je nekima nezamislivo... moraju dići kredite ili tako nešto... “ (Dejan, URP

Jakov, i Dejan, progovaraju posebno iz pozicije gimnazijalca za koje se nemogućnost studiranja čini posebno poražavajuća jer je gimnazijsko obrazovanje teško, direktna je priprema za studij, ali ne daje nikakvu kvalifikaciju za zapošljavanje. I Glorija upozorava na to izražavajući stav da financije trebaju biti bitan dio razgovora s roditeljima prije upisa srednje škole: „,... o tome se zapravo prvo treba razgovarati s roditeljima, i prije upisa $u$ gimnaziju (...) zato što to podrazumijeva upis na fakultet, tako da tko to ne može izfinancirati može se jako razočarati, općenito u sve... ".

No, učenici naglašavaju još neke aspekte, a to je razdoblje mladenaštva i činjenica da studiranje znači više od stjecanja znanja: to je razdoblje osamostaljivanja, odrastanja, preuzimanja brige za sebe i odgovornosti za svoju budućnost - ono je (K) korak u život posebno obilježen stjecanjem vještina baratanja novcem za koji je odlazak od kuće značajna odluka:

„... pa korak je pred sam život jer vi morate sami brinut: „, A-ha, meni moja mama $i$ tata mogu poslat' ovaj mjesec 500 kuna, a mjesec ima 30 dana... (...) uči vas kak'vas čeka ubuduće... i isto ćete morat otvarat' te račune i gledat' da l' morate štedit', da l' ne morate štedit' (...) dakle, sve će vas studij, fakultet bilo koji ... normalno, ako ne ostanete u svom gradu..."(Jakov, URP_VG, GIM_VG)

Stoga, studiranje predstavlja važnu ,životnu školu“ ili „stepenicu koju treba prijeći“ ne samo u akademskom smislu, već u smislu osamostaljivanja i odrastanja, preuzimanja odgovornosti, a što je aspekt studiranja koji najvećim dijelom veseli učenike, uz upoznavanje novih ljudi i mjesta. Ti aspekti studiranja posebno su naglašeni kod gimnazijalaca koji studiranje u akademskom smislu, vide lakšim u odnosu na njihovo gimnazijsko obrazovanje, te time 
prilagođenijima s obzirom na odlazak od kuće i usklađivanje akademskih obaveza i mogućnosti ispunjenog studentskog života.

„... Ja mislim da je to puno lakše od srednje škole da imamo više vremena za sebe ... $i$ mislim da, ne znam, da mi sazrijemo kad odemo, na primjer... znamo da smo čim smo upali na taj faks, znamo da smo spremni, da možemo završiti taj faks, ali ne smijemo se ni opustiti, ne znam, koji misle da je to samo tulumarenje, i to..." (Marija, RRP_PT, GIM_mg)

Opća slika studentskog života obuhvaća sliku (K) kava, druženja i učenja. Većina učenika naglašava želju za ostavarenjem svih aspekata, ipak određeni učenici pokazuju određenu razinu tenzija vezanu uz to. Gimnazijalci koji će biti druga generacija studenata i od kojih svi biraju studije izvan regije, studiranje vezuje uz odrastanje i nužan korak koji priprema za život, kako to opisuje Jakov u prethodnom citatu, koji nije lak i pri čemu su im najveće brige one vezane uz preuzimanje odgovornosti u usklađivanju akademskih i izvanakademskih života:

„... al mislim da bi na studiju imao malo više slobodnog vremena ili malo bolje raspoređeno, to, vrijeme eventualno, ali mislim da će to biti tako... većina vremena u stanu, po kavama, ne znam, odlazak na predavanja, učenje do kasno u noć (...) a opet nedostatak, mislim da opet neću imati vremena koje će biti samo za mene, i da neću morat razmišljat da moram učit, da ne mogu ovo, ili, ne znam ... "(Andrej, URP_mg, GIM_VG)

„... ja želim otići u Zagreb, želim se osamostaliti (...) neko osamostaljivanje i onda nadam se da poslije toga više neću doći čak u roditeljsku kuću i da ću započet svoj život, i svi sretni... Joj... to jedva čekam (...) da ja budem na neki način slobodna... šta moj prijatelj kaže: „, Nitko ti više neće moći reć da ne hodaš bos u bijelim čarapama" (smijeh)... da jednostavno možeš odgovarati za ono što ti radiš i da svoj dan posložiš onako kako ti hoćeš (...) neko uživanje $i$ učenje $i$ opet, ne pretjerano učenje $i$ ne pretjerano uživanje, znači.. " (Anica, URP_VG, GIM_VG)

„.. slušao sam kako je studentski život najbolji, da se ima puno slobodnog vremena zapravo.. hm... da ono, bit ću od roditelja odvojen što mi predstavlja slobodu koju sad baš $i$ nemam $i$ to me dosta veseli..." (Dejan, URP_mg, GIM_mg)

I ostali učenici usvajaju na općoj razini takvi sliku u kojoj se studiranje vezuje uz mnogostruke prednosti samostalnog života, a koje ističu potrebu odlaska.

„... nekakva samostalnost, da mi nema tko kvocat nad glavom i da ću ja živjet sama, znači, sve sama radit, mislim da mi je to isto bio velik poticaj... ja se nadam da će tako biti..."(Silvija, RRP_TP, 4SŠ_VG) 


\subsubsection{Kulturni obiteljski resursi - mjere i subjektivna značenja}

Statistički, razlike između učenika različitog rezidencijalnog podrijetla potvrđuju se i prema svim promatranim kulturno-obrazovnim karakteristikama obitelji: obrazovnom statusu roditelja i učestalosti njihovih kulturnih praksi, te materijalnom posjedovanju različitih kulturnih dobara (Slika 4.4 i Tablica 4.5).

Opći regionalni podaci ukazuju da najvećim dijelom slavonski maturanti odrastaju u kućanstvima s malim brojem knjiga: gotovo polovica (48\%) ih procjenjuje da u kući imaju tek do 25 knjiga i samo 14\% procjenjuje da je broj knjiga u kućanstvu veći od 200, no ipak 2/3 ih u kućanstvu posjeduje približno 3 kulturna objekta $(M=0,6)^{99}$, a dodatna $1 / 4$ posjeduje $\mathrm{i}$ više kulturnih predmeta.

Na obje mjere učenici koji odrastaju u ruralnim područjima imaju statističko značajno niži rezultat obiteljski posjedovanih kulturnih dobara u odnosu na učenike urbanogrezidencijalnog podrijetla $\left(\mathrm{M}_{\mathrm{RRP}}=0,5<\mathrm{M}_{\mathrm{URP}}=0,7\right)$, dok statistički značajno manje knjiga posjeduju ruralni učenici od kojih čak $62 \%$ procjenjuje da u kućanstvu ima do 25 knjiga (u odnosu na 34\% $\mathrm{U}_{\mathrm{URP}}$ ), a gotovo 3 puta manje ih (8\%) smatra da obiteljski posjeduju više od 200 knjiga u odnosu na $21 \%$ učenika odraslih u gradu.

U intervjuima učenici nisu govorili o ovim aspektima svog obiteljskog okruženja te je teško zaključiti kako učenici vide i objašnjavaju ove kulturne karakteristike svojih kućanstava. Deskriptivno, iako nitko od intervjuiranih ne posjeduje manje od prosječna 3 kulturna objekta, začuđuje da ipak 7 intervjuiranih učenika procjenjuje broj knjiga u kućanstvu izuzetno malim od čega takve procjene daje, uz dvoje učenika koja ne namjeravaju studirati, i 5 učenica koje namjeravaju studirati i koje pokazuju razvijenije osobne kulturne kapitale. Nasuprot tome, veći broj intervjuiranih učenika u svom obiteljskom okruženju procjenjuju više kulturnih objekata, od kojih su gotovo svi mladići (6 od 7) i većina (5 od7) ima barem jednog visokoobrazovanog roditelja

Rezultati na mjerama roditeljskih kulturnih praksi, koji je indikator obiteljskog kulturnog kapitala u njegovom utjelovljenom vidu, ukazuju da, iako općenito većina slavonski učenika (67\%) vrlo rijetkima procjenjuju aktivnosti svojih roditelja poput čitanja, pohađanje kulturnih događanja i obrazovnih tečajeva $(M=1,7)$, taj rezultat je za učenike odrasle na selu još niži

\footnotetext{
${ }^{99}$ Učenici su bilježili posjeduju li u kućanstvu stručne knjige, knjige klasične literature te one na stranom jeziku kao i umjetnička djela te nosače zvuka klasične ili jazz glazbe. Njihovi rezultati za tih 5 objekata su zbrojeni kreirana je varijabla s njihovim prosječnim rezultatima. Tako je moguće bilo postići rezultat na rasponu od $0-1$, pri čemu je 0 značilo da učenik ne posjeduje niti jedan od navedenih predmeta, a 1 da posjeduje sva navedena kulturna dobra u kućanstvu.
} 
$(\mathrm{M}=1,6)$ i statistički značajno različit $(\mathrm{t}(417,2)=-5,47 ; \mathrm{p}<0,05)$ od rezultata učenika gradskih sredina $(M=1,9)$, što oslikava i uzorak intervjuiranih učenika u kojem $1 / 3$ učenika ima iznadprosječne rezultate, ali od kojih se samo jedan odnosi na učenicu ruralnog rezidencijalnog podrijetla koja odrasta $u$ blizini makroregionalnog centra $i$ ima visokoobrazovne roditelje. Tek 5\% učenika regije Slavonija takve roditeljske prakse procjenjuje čestima ili vrlo čestima, a među intervjuiranima ih predstavljaju dva gimnazijalca urbanog rezidencijalnog podrijetla čiji su roditelji visokoobrazovani, te koji i na ostalim mjerama obiteljskog kulturnog kapitala pokazuju relativno visoke rezultate:

„,...Majka mi je završila umjetničku akademiju u Bratislavi (...) majka je imala atelijer, slike, vodila me na neke izlože (...) i cijela obitelj općenito mislim da je nadarena za umjetnost... baka mi je krojačica, mi je htjela studirati isto akademiju, ne znam, u slobodno vrijeme slika i ona, izrađuje neke korpice... svi nešto radimo... “(Andrej, URP_mg, GIM_VG)

Dodatno, povremenima kulturne aktivnosti svojih roditelja procjenjuje još četvero učenika urbanog rezidencijalnog podrijetla (troje gimnazijalaca, te učenik trogodišnje strukovne škole), ali i učenica ruralnog rezidencijalnog podrijetla. Barem 4 od tih učenika ima visoke rezultate i na nekim drugim mjerama obiteljskih kulturnih kapitala, a čini se da je snažna objašnjavajuća veza, ali ne jedina, ona s razinom obrazovanja roditelja: visokoobrazovani roditelji u većoj mjeri sudjeluju i u različitim kulturnim praksama, a postavlja se i pretpostavka kako postoji i dodatni sociogeografski element vezan uz rezidencijalne aspekte odnosno dostupnost pojedinih kulturnih aktivnosti.

No značajno je istaknuti i još jedan oblik roditeljskog kulturnog kapitala koji također može značajno oblikovati učenička viđenja i doprinijeti oblikovanju njihovih odluka o životu nakon škole - edukacije roditelja za povećanje šansi zapošljavanja u inozemstvu. Prakse roditelja ulaganja u prekvalifikacije $\mathrm{i}$, vezano s time, planiranje preseljenja za poboljšanje životnih okolnosti, značajno može djelovati na učeničke namjere vezano i uz obrazovanje i uz migriranje: „... oni su planirali ić vani... moja mama je napravila već dva, tri, završila dve, tri prekvalifikacije, isto sad ide... mama je već kontaktirala ljude iz Njemačke i rekli su sam da moraju naučit jezik još, naravno, i da može doć'...“(Aneta, URP_mg, 4SŠ_mg).

Općenito, u regiji Slavonija, kao cjelini, preko 1/4 učenika (28\%) ima roditelje s obrazovanjem do razine završenog trogodišnjeg srednjoškolskog obrazovanja, dok ih ispod 1/4 ima roditelja s nekim stupnjem visokog obrazovanja. No, ti podaci razlikuju se za učenike različitog rezidencijalnog podrijetla: samo $12 \%$ učenika odraslih u ruralnim naseljima (nasuprot $1 / 3$ 
$\mathrm{U}_{\mathrm{URP}}$ ) ima barem jednog visokoobrazovanog roditelja, a dvostruko više učenika odraslih na selu ima roditelje s obrazovanjem do razine završenog trogodišnjeg srednjoškolskog obrazovanja u odnosu na učenike koji odrastaju u gradovima $(39 \%>19 \%)$.

Ruralno-urbane razlike u uzorku intervjuiranih također su vidljive i dodatno istaknute izborom učenika za razgovor sa zanimljivim slučajevima; od 7 učenika koji imaju visokoobrazovane roditelje dvoje je učenika ruralnog rezidencijalnog podrijetla koji pohađaju strukovne škole, pri čemu Mislav želi studirati, a Lidija ne. To su jedini učenici ruralnog rezidencijalnog podrijetla koji pokazuju povoljniju strukturu obiteljskih kapitala, no sa suprotnim visokoobrazovnim namjerama.

„... Tata mi je isto doktor veterine tako da je on to, kao, s očekivanjem... on je... kao da je znao da ću ja to htjet' (...)

... navik'o samradit' uz životinje, i uvijek smo imali životinje, tako da sam ja uvijek uz. njih... nikad se nisam bavio mehanikom, nije se ni otac bavio mehanikom, pa ne znam ni zašto bi otišao, na primjer, na neki drugi... uvijek tu uz životinje... tak da, to je najviše utjecalo na mene - pristup na životinje, otac kako se ponaša prema životinjama s poštovanjem - to je $i$ mene potaklo, tako da ... od malih nogu, uvijek sam uz njega, $i$... to je to..." (Mislav, RRP_DSJ, 4SŠ_VG)

Iako učenici ukazuju na to koliko je utjecaj roditelja značajan kada djeluju kao uzori, a što se $\mathrm{u}$ Mislavovom opisu potvrđuje kao slijeđenje obiteljske biografije u istom studijskom području, ono se ne pojavljuje uvijek u skladu s učeničkim željama: inžinjerstvo (...)

„... mama mi je profesorica [...], ona je išla na fakultet, a tata mi je doktorirao

... Pa ne znam... roditelji uvijek žele, ono, kako su oni da idu njihovim stopama, ne znam... meni osobno nije tako... pa zato ne mogu...

... oni žele da ja upišem fakultet, studij... a ja ono... moram se još predomislit...

... imaju viđenje da ću imat većih prilika, recimo, ako se u životu predomislim za nešto da... opet mogu, onako, bit to što želim... “(Lidija, RRP_DSJ, 3SŠ_VG)

Ostali učenici s visokoobrazovanim roditeljem su učenici odrasli u gradovima od kojih većina završava gimnaziju i namjerava studirati, odnosno od kojih je samo jedan učenik četverogodišnje strukovne škole koji ne namjerava studirati; slično Lidiji, Jan ima alternativne planove usklađene sa slikom o sebi i sliku budućnosti u koju se ne uklapa studiranje:

„,... Nikako [ne namjeravam studirati] (...) Razmišljao sam možda, na sportski neki, al' onda sam se odlučio da neću ništa...

... Pa studiranje... to je dobro... to je za dobro one koji imaju volju i kojima ide učit (...) [ja sam] stalno u sportu, samo kuća, škola, sport i tako...

... Pa da.. o tom mogu pričat do preksutra... al' baš mi škola nešto... jedva čekam sam da završim, $i$ to je to... (Jan, URP_mg, 4SŠ_mg) 
„... Ne [ne namjeravam studirati] ... Pa možda se predomislim ali za sad ne... za sad imam plan ići radit...

... tako želim jednostavno... u toj struci uživam $i$ volim stvari koje radimo... $i$ odlično mi je zato što je to većinom umjetničke radove radimo, s tortama i to... i uglavnom uživam u tome..." (Lidija, RRP_DSJ, 3SŠ_VG)

Ostali učenici s visokoobrazovnim roditeljima čine skup učenika s izuzetno povoljnom strukturom obiteljskih kulturnih i ekonomskih resursa. No, naglasak je donekle u pričama različit za određene učenike s obzirom na njihovu strukturu. Određeni učenici će u većoj mjeri isticati utjecaj koji obiteljsko okruženje ima na kada su u pitanju i njihove rane visokoobrazovne orijentacije, specifično usmjereni obrazovni putovi preko visokostatusnih gimnazija, kao i specifični visokoobrazovni izbori, npr. za Anicu u prirodoznanstvenom, odnosno za Andreja umjetničkom području, koji podržavaju ne samo resursi dostupni u obiteljima, veći poseban način života koji te obitelji razvijaju habitusno.

No, i visokoobrazovno orijentirani učenici koji svoj obrazovni put „započinju“ s nižih razina društveno-ekonomske ljestvice, te bez obzira na upisanu srednju školu, također će isticati određene podržavajue elemente obiteljskog okruženja vezane prvenstveno uz podržavanje njihovih samostalnih odluka, te financijsku podršku i poticanje obrazovanja.

Konačno, među intervjuiranima je i 6 učenika koji pohađaju strukovne škole i namjeravaju studirati, a čiji roditelji imaju trogodišnje srednjoškolsko obrazovanje. Podaci o kulturnim i ekonomskim obiteljskim karakteristikama ukazuju da su u posebno nepovoljnoj situaciji dvije učenice odrasle na selu vezano uz nepovoljne financijske okolnosti nezaposlenosti roditelja, a koja je za jednu učenicu dodatno pogoršana bolešću jednog roditelja, a za obje učenice usložnjena i lošijim procjenama kulturnih karakteristika obitelji. Obje učenice namjeravaju studirati i u intervjuu i izražavaju snažne želje da upišu studij, no, njihova obiteljska situacija, utječe i na njihove izbore i studija i regionalno studiranje, a još značajnije utječe na njihova promišljanja i toga da postoji mogućnost da njihove želje neće biti moguće ostvariti, odnosno stalno vaganje mogućih (zadovoljavajućih) alternativa zapošljavanja u svojim strukama i pregovaranja visokoobrazovnih želja. Njihova općenita obiteljska situacija djeluje u većoj mjeri upravo kao motivacija za stjecanje višeg obrazovanja i uspinjanje na društvenoj ljestvici, odnosno podržava njihovu orijentaciju prema visokom obrazovanju.

Slično vrijedi i za dva učenika ruralnog rezidencijalnog podrijetla s roditeljima koji imaju niže razine obrazovanje kada su u pitanju njihove visokoobrazovne želje, no koji pri procjeni svojih mogućnosti stavljaju veći naglasak na utjecaj srednjoškolskog obrazovanja za 
mogućnosti svoga ulaska u visoko obrazovanje, odnosno krivi izbor srednje škole što je osvješteno tek pri pri završavanju srednje škole kada se mogućnosti zapošljavanja procjenjuju slabima:

„,... Pa završio sam srednju četverogodišnju (...) školu... smatram da sam po znanju sposoban za općenito neki jednostavniji fakultet... nemam baš neke prednosti za neki viši fakultet, to jest jači možda, ako nemam motivacije... “(Marijan, RRP_DSJ, 4SŠ_mg)

Ono što ovaj citat čini posebno zanimljivim je (uz činjenicu da se ovim opisom predstavio istraživačici) to što je Marijan jedini učenik u uzorku s prosjekom ocjena 5,0. Upravo ta izražena (K) orijentacija na školski uspjeh razvijena je kod ovog učenika kao osnovni obrazovni kapital koji podržava njegovu visokoobrazovnu orijentaciju koja na ostalim mjerama nije posebno snažno izražena; ne smatra da mu se studiranje podrazumijeva, odluku o studiranju učenik je kasno razvio (,... tek u srednjoj školi kad sam uvidio da s... nakon ove škole baš $i$ nema nekog posla, s ovom školom, onda sam tek uvidio donekle... želju za studiranjem..."), a čak i u posljednjim fazama donošenja odluke propituje ih s obzirom na svoje želje, mogućnosti, motivaciju, iako je u svojim procjenama prilično pesimističan te ispodprosječnima procjenjuje i vjerojatnost upisa i završavanja fakulteta, a ne očekuje niti da će postići željeni stupanj obrazovanja.

Ove analize i opisani slučajevi pokazuju i oslikavaju određene pravilnosti i veze koje postoje i između različitih vrsta obiteljskog kapitala, ali i njihovo posebno prostorno oblikovanje, kao i između obrazovnih karakteristika i namjera učenika s obzirom na strukturu obiteljskih kapitala, odnosno dostupnost pojedinih resursa kojima učenici imaju pristup u svojim obiteljima. Općenito, obrazovni status kao kulturni kapital te radni status roditelja kao značajna odrednica ekonomskih prednosti u regiji s visokim razinama nezaposlenosti, najznačajniji su obiteljski kulturni i ekonomski poticaji prema studiranju za učenike različitog rezidencijalnog podrijetla putem upisa srednjih škola, a njihove više razine često znače upis gimnazije za učenike. Naravo, ta veza između obrazovanja roditelja i učeničkog obrazovnog kapitala nije pravocrtna i može se kretati u oba smjera, što je već ilustrirano. Ipak, određene teškoće posebno se pojavljuju za one učenike ižih razina obiteljskih kapitala koji žele studirati, ali je njihov obrazovni put ostao vrlo blizak onome njihovih roditelja.

Među intervjuiranima su tri gimnazijalke koje nemaju visokoobrazovane roditelje i ukazivale su na neke manje pogodne elemente obiteljskog ekonomskog i/ili kulturnog okruženja, no i na više razine osobnih kulturnih kompetencija. Također, sve ističu neke druge elemente obiteljskog okruženja koje su se značajnima pokazale u njihovom orijentiranju prema 
visokom obrazovanju, i vezuju se uz posebne aspekte obiteljskog okruženja izraženih kao poticaji na studiranje. U njihovim opisima pokazuje se kao $(\mathrm{K})$ učenje na roditeljskim iskustvima:

„... oni su završili srednju školu, nije nitko išao na studij... oni žele da ja budem više od njih..." (Marija, RRP_TP, GIM_mg)

„... moji roditelji su oboje krenuli na fakultet, nisu ga završili, i kad čujem njih cijelo vrijeme kako im je... zapravo, jako žale zbog toga što nisu uspjeli i kako sada moraju sve težim putem ići, želim prolaziti lakšim putem kasnije, ako se treba sada napatiti, kasnije želim uživati..."(Gordana, RRP_TP, GIM_VG)

oboje imaju završenu srednju ekonomsku... doduše, tata mi je iš'o studirati, ali on je svašta radio, svakakve fakultete mijenjao i to se u biti on samo zezao par godina okolo po Zagrebu, $i \ldots$ ali nekako oboje su uvijek htjeli raditi da imaju nešto, i... tata mi je radio svakakve stvari, od finijih poslova, do teških fizičkih..."(Bernarda, URP_mg, GIM_mg)

\subsubsection{Rezidencijalno podrijetlo učenika i karakteristike srednje škole}

Prema Bourdieuu, osnova društvene reprodukcije je prepoznavanje kapitala učenika viših društvenih klasa u obrazovnom polju, odnosno njihovo potvrđivanje u školama, koji se tamo iskazuju kao bolji obrazovni uspjeh i visokoobrazovna orijentacija. Iz tog razloga, eksploratorno orijentirana analiza ispituje institucionalne karakteristike srednjih škola koje učenici pohađaju s interesom za urbano-ruralne razlike prema procjeni statusa, akademski poticajne klime te opremljenosti i izvannastavne programske ponude srednjih škola. Rezultati su prikazani na Slici 4.5 .

Općenito, svojim školama, i bez obzira na rezidencijalno podrijetlo, sve navedene karakteristike učenici procjenjuju prosječno, pri čemu je poticanje i informiranje za studiranje karakteristika koju u svojim školama prepoznaje najveći broj učenika $(M=3,5)$. Drugim riječima, učenici su smatrali kako u velikoj mjeri u školi mogu dobiti informacije u vezi daljnjeg obrazovanja i kako ih nastavnici potiču na upis studija, a u nešto manjoj mjeri, osrednje $(M=2,8 ; M=2,7)$, su se slagali sa sadržajima da pohađaju školu koja ih dobro priprema za studij, koja je ugledna i koju je teško upisati, te s dimenzijom koja je okupljala sadržaje tvrdnji da pohađaju školu koja ima dobar program izvannastavnih aktivnosti te dobru opremljenost. 


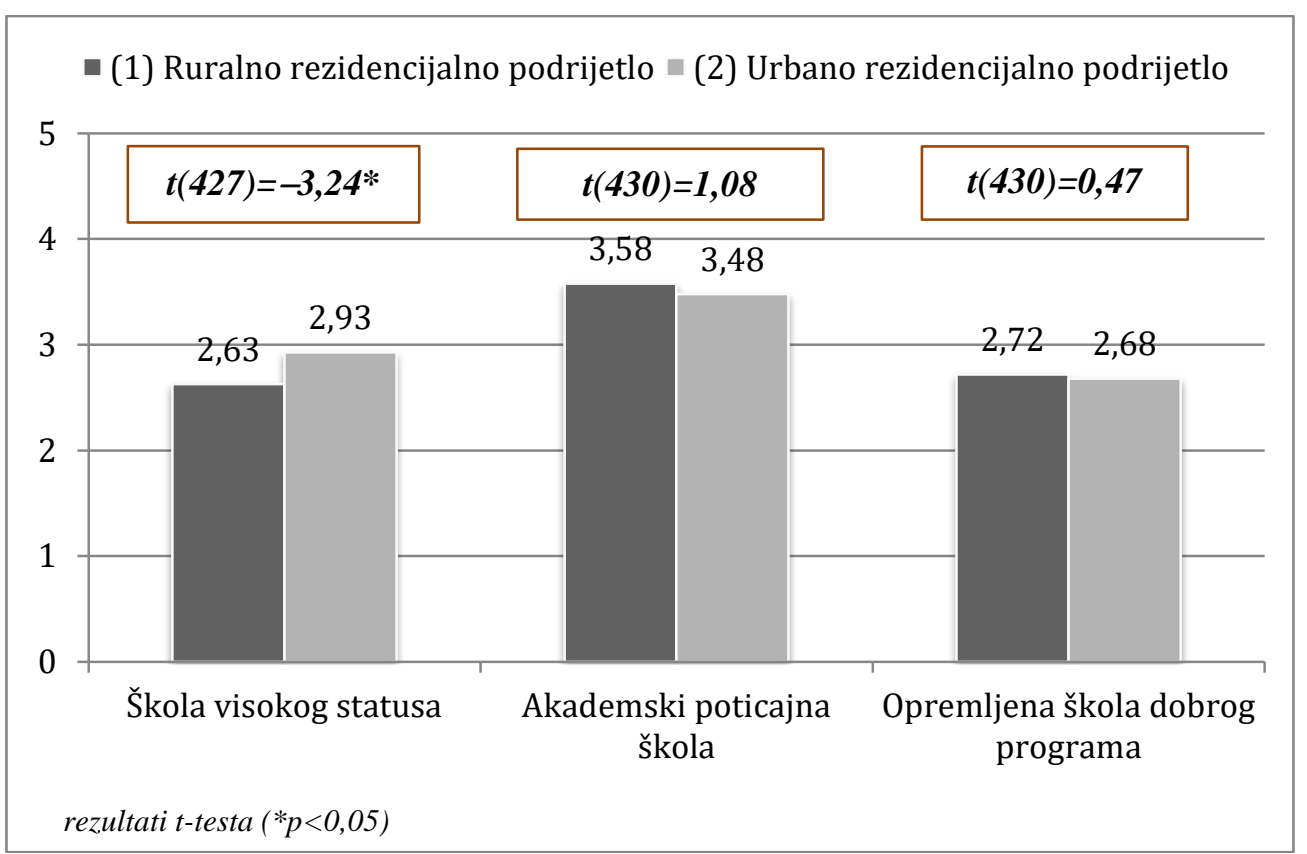

Slika 4.5 Razlike između učenika različitog rezidencijalnog podrijetla prema procjenama karakteristika srednjih škola

Iako učenici različitog rezidencijalnog podrijetla pohađaju različite tipove škola u gradovima različitog stupnja centraliteta diljem regije, te razlike prema mjestu njihova odrastanja nisu nužno očekivane, statistički značajne razlike se ipak pokazuju na urbano-ruralnoj dimenziji kada je u pitanju procjena statusa škola koje pohađaju. Učenici odrasli u urbanim naseljima u većem stupnju, i statistički značajno različito, svoje škole procjenjuju školama visokog statusa $(M=2,9)$ u odnosu na one ruralnog rezidencijalnog podrijetla $(M=2,6)$, što objašnjava nalaz da oni i u većoj mjeri pohađaju gimnazije ${ }^{100}$.

Stoga je posebna pozornost poklonjena podacima iz intervjua i načinima na koji učenici doživljavaju svoje školovanje općenito, te kako procjenjuju prednosti i nedostatke vezane uz završavanje škola koje su upisali s obzirom na pristup resursima značajnima za njihove buduće (obrazovne) planove, a koji razvijajunjihove osobne obrazovne kapitale za nastavak školovanja i oblikuju specifičnu sliku prema visokom obrazovanju (ili visokoobrazovni habitus). Tri dimenzije je u njihovim pričama bilo teško razdvojiti, a s obzirom da se radi o varijablama koje pokušavaju zahvatiti elemente konteksta posebno je bilo teško razlučiti

\footnotetext{
${ }^{100}$ Navedeno dodatno potvrđuju iskazi učenika u intervjuima o tome kako pohađaju teške škole, koje zahtijevaju žrtvovanje, škole koje ih dobro pripremaju i za maturu, i za studij, i za život. Vezano uz takve procjene su i identitetske odrednice koje su gimnazijalci naglašavali u viđenju svog obrazovanja i sebe koje je vezano uz njihovu odlučnost, odgovornost, radnu etiku, sposobnost i inteligenciju te konačno samouvjerenost oko upisa i/ili završavanja studija
} 
„objektivne“ od „simboličkih“ elemenata ${ }^{101}$. Bitno je spomenuti i da su učenici daleko kritičniji u svojim iskazima o kontekstu svog školovanja nego bi se dalo zaključiti prema kvantitativnim rezultatima, posebno kada je u pitanju poticajnost studiranja. Važno je napomenuti da učenici nisu direktno komentirali niti opisivali svoje škole, a prepoznatljivo je kako su i pojedine procjene vezane uz osobna iskustva učenika, njihove obrazovne želje kao i osobne osjećaje strahova/nadanja upletene u pojedine odluke.

Prema tipu i lokaciji škole, odnosno centralitetu grada, u uzorku intervjuiranih zastupljeno je nešto više gimnazijalaca (7) posebno onih koji se školuju u velikom gradu (4), dok je općenito s manje učenika trogodišnjih strukovnih škola (4) vođen razgovor.

Prema rezidencijalnom podrijetlu, pak, manje je intervjuiranih učenika $s$ urbanim rezidencijalnim podrijetlom koji se školuju u velikom gradu, a oni intervjuirani su gimnazijalci, dok je općenito više učenika s urbanim rezidencijalnim podrijetlom intevjuirano u školama u malim gradovima.

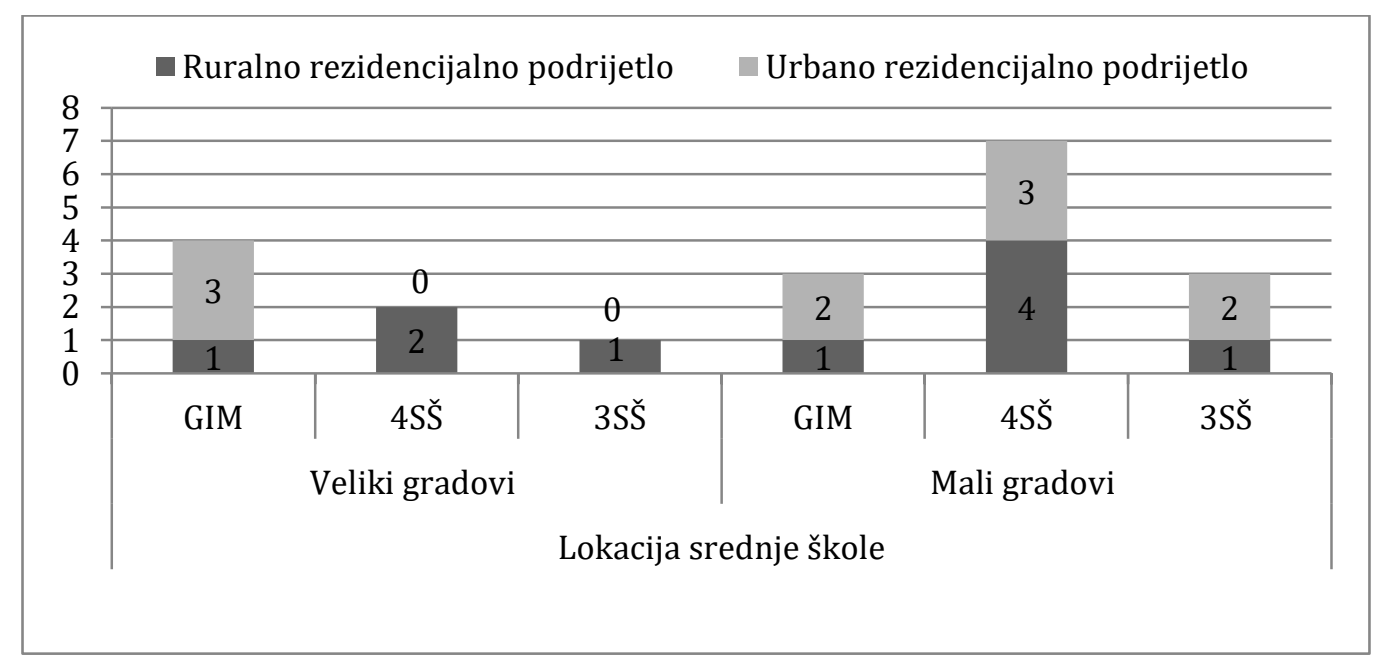

Slika 4.6 Opis uzorka intervjuiranih učenika različitog rezidencijalnog podrijetla s obzirom na tip i lokaciju škole

Intervjuirani učenici najkritičniji su prema aspektu opremljenosti svojih škola, pri čemu su kritičniji učenici ruralnog rezidencijalnog podrijetla, te učenici četverogodišnjih strukovnih škola. Ipak, za razliku od gimnazijalaca koji tom ispodprosječno procijenjenom tehničkoprogramskom aspektu škola dodaju i onu iznadprosječnu kada je u pitanju status škola, većina drugih učenika dodaje barem još jednu negativnu procjenu neke druge karakteristike konteksta školovanja, najčešće upravo statusa. Tako Marina i Ivana procjenjuju ispodprosječnima i status i opremljenost škole, što se u njihovim opisima može povezati sa

\footnotetext{
${ }^{101}$ Elementi za koje se u većoj mjeri procjenjuje simbolička vrijednost školskog konteksta na učeničke odluke obrazlaže se i u poglavlju koje dublje propituje te elemente. U ovom poglavlju utjecaj profesora je neizostavan dio opće klime poticajnosti i akademski usmjerene školske atmosfere, te informiranja o studiranju.
} 
stavom kako većina njihovih kolega ne namjerava studirati i kako, u svojevrsnom začaranom krugu, niti profesori ne stvaraju poticajnu klimu za studiranje, iako obje navode pozitivne primjere i poticaja i informiranja o studiranju i niti jedna nema kvantitativno izražen negativan stav o akademskoj poticajnosti i općoj školskoj klimi:

„... Većina njih [kolega], haha... misli sad na biro,ono, misli: „Idem sad završit srednju školu, na biro, ono, uživat, na more radit, zaradit si, tek tol'ko za grad" (...)

... nas malo, znači, koji stvarno razmišljaju [o studiranju], a i ovi ostali su stvarno dosta neozbiljni, pa onda misle profesori, što bi razrednica rekla: „Čemu pričat, ne znam, tri, četiri učenice koje će ići, kad ne vrijedi pričat' cjelini!? “... znači, one imaju zacrtani cilj, one će to ostvarit', a ovi ostali, nek' rade kak' 'oće... jer oni isto misle da je to stvarno beskorisno jer znaju da neće time ništ' postić' '...

... na pripremama sad za državnu maturu subotama (...) oni će objasnit', al' više onak' $k^{\prime} o$ da rade preko svoje volje... misle: „A 'ko će... zaboravit će to u godinu dana “... znači, ne žele dati neki sav svoj trud jer misle da je uzaludan..." (Ivana, RRP_DSJ, 4SŠ_mg)

To kreira situaciju u kojoj su učenici prepušteni sebi, a čitavi proces ima veću psihološku težinu s obzirom na samouvjerenost u pozitivne ishode. Mnogo učenika ističe kako se za državnu maturu pripremaju samostalno. Dodatno, negativnije procjene karakteristika svojih škola vezane su uz mogućnosti daljnjeg obrazovanja koje je, prema stavovima ovih učenica, otvoreno samo u području njihove struke:

„... zapravo je, pošto sam upisala poljoprivrednu školu idem na poljoprivredni fakultet jer, kao što sam rekla, ne bi mogla upisati Filozofski, i šta ću ja s poljoprivredne škole na tom fakultetu?! Ovak' već imam neš" što sam naučila u srednjoj pa mi je onda lakše na Poljoprivrednom fakultetu..." (Marina, RRP_TP, 4SŠ_mg)

Silvija, pak, učenica koja namjerava promijeniti struku upisom fakulteta, lošijim procjenjuje mogućnosti i pripremu kada su u pitanju poticaji profesora te mogućnost upisa prestižnih fakulteta, no istodobno izražava stavove kako je njena škola kvalitetna i dobrog statusa među školama - kada je strukovno obrazovanje u pitanju:

... ova škola za fakultet ne daje nikakve temelje... mi smo jako, jako dobri što se tiče struke i struku stvarno savršeno znamo, ali što se tiče općih predmeta, mislim da tu nema nikakvih temelja... mi svi iz razreda idemo na pripreme za maturu, učimo sami kod kuće, po skriptama, bivšim maturama...

... upast na medicinu iz naše škole, mislim da je to... ne vjerujem da će itko upasti iz mog razreda iako oni idu na pripreme... ne možeš ti to nadoknadit' sad...

... više nas gnjave s tom maturom, tipa: „Državnu maturu moraš položit', to morate položit', morate učit'... “, i tak'...

... mogu pitati [o studiranju] jedino vanjske suradnike... što se tiče profesora, mislim onak'... oni su totalno ,, 'ladovina “što se tiče toga... “(

Ovako iskazani stavovi ukazuju na potrebu strategijskog pristupa izbora studija i predmeta za polaganje na državnoj maturi s obzirom na to što srednja škola omogućava kao daljnje 
obrazovanje. U tom smislu, strukovno obrazovanje i eventualni nastavak školovanja u području, ali na nižim stupnjevima visokog obrazovanja, moguće je, i prema učenici strategijski pametniji pristup; većina učenika iz njene škole u želji za daljnjim obrazovanjem upisuju veleučilišne studije, a iako njen izbor ne slijedi taj pravac razmišljanja, strategijski razmatra svoje mogućnosti:

„... nisam sad htjela ono forsirat' upisat', ne znam, što se tiče mature, „E sad ću lupit kemiju“... ne znam, kemiju, neda mi se (...) ima previše toga i stvarno je kemiju jako teško položit... ovaj, onda sam rekla: ,'ajd' ono, ostavit ću sve niže, to mi ionak traže za sve fakultete", a uostalom ako ima predispozicije za niže, zašto bi se onda forsirala za nešto... bolje da, ono, završim sad tu školu i upišem to ..." (Silva, RRP_TP, 4SŠ_VG)

Slično svoju školu procjenjuje i Marijan, a kod oboje učenika je izraženo kako to koju školu pohađaju i kako procjenjuju njenu kvalitetu i status utječe i na njihovo poimanje sebe, na samouvjerenost svojih odluka i emocije vezane uz studiranje i vjerojatnost postizanja ciljeva, no u suprotnim pravcima; Silva svoje samopouzdanje crpi iz činjenice da pohađa „dobru školu“ dobrog statusa koja joj je već donijela „rang gore“, i što je poticaj za daljnje školovanje. S druge strane, za Marijana je tek neperspektivnost zapošljavanja sa završenom strukom usmjerila prema nastavku školovanja, ali osjećaj nepripremljenosti u školi za polaganje mature i za studiranje dodatno potiče njegove nesigurnosti u odabiru daljnjih obrazovnih smjerova:

„,...Pa tek u srednjoj školi kad sam uvidio da s... nakon ove škole baš i nema nekog posla, sovom školom, onda sam tek uvidio donekle... želju za studiranjem...

... malo me i strah zato što je... nema ni matematike, ni fizike... ima fizike, ali nije toliko jaka koliko taj fakultet zahtijeva (... ) onda će mi malo to teže bit', tak' da me... malo me to i odmjerava...

... i sve me strah kak'će krenit' na studiju, 'e l'ću moć' to završit's obzirom na kvalitetu srednje škole...

... pa s obzirom na elektrotehniku, pošto nemam prednosti zbog škole, smatram da... nije baš pretjerano snažna ta mogućnost, dok za ekonomiju, poljoprivredu to smatram da bi možda i bez problema uspio završiti... tako neki jednostavniji fakultet... “ (Marijan, RRP_DSJ, 4SŠ_mg)

U takvom kontekstu, doživljaj učenika da ih se potiče na ostvarivanje njihovih želja, ima veliki značaj za učenike, a posebno učenicima trogodišnjih strukovnih škola koji namjeravaju studirati. Kako pokazuje Dominikov primjer, pravodobna reakcija osoba iz institucionalnog okruženja izuzetno je značajna za orijentiranje prema visokom obrazovanju, ali posebno na osobnoj razini - u prepoznavanju i isticanju potencijala učenika u situacijama kada nedostaju informacije i samopouzdanje, odnosno teškoće procjene oko zahtjeva akademskog konteksta: 
„,... jedini 'ko me saslušao ovdje mislim samo pedagoginja i blagajnik, ne

pedagoginja, tajnica, oni su rekli isto da bi bilo dobro, a moj razrednik i ovak' ostali profesori baš nisu gledali ništa... ovaj... obećavajuće u meni...

... Spominju to... Informacije daju, ali ohrabruju - ne baš... oni sve samo kažu, koje su mogućnosti, ali ne ohrabruju uopće to... samo govore informacije, di bi se mogli upisati ili tako što... “(Dominik, RRP_DSJ, 3SŠ_mg)

Agata je jedina učenica koja na sve tri dimenzije pokazuje veliko nezadovoljstvo školom koju završava, a posebno je kritična kada je u pitanju poticanje na, te informiranje u školama o mogućnostima studiranja i priprema za maturu, što uostalom ističe većina učenika strukovnih škola, i što utječe na to da se oni koji žele studirati moraju sami spremati za maturu i informirati o studiranju:

„... ono... naši profesori sad... znači, iz jednog predmeta, engleski profesor nas baš ono, priprema za maturu i stvarno super je profesor što se toga tiče, a za hrvatski $i$ matematiku $i$ ne baš... ono, matematike me užasno strah, jer ju stvarno baš... imam dobre ocjene, ali vjerujem da to moje znanje nije dovoljno za državnu maturu, ne znam ono... a hrvatski, isto, sama se pripremam, počela sam već prije tri mjeseca, sama skupljam sve potrebne podatke i učim ... a što se tiče profesora... ne pripremamo se baš tol'ko kol'ko bi trebali i kol'ko ja čujem da u drugim školama da se pripremaju za državnu maturu i za faks, ono, da ih potiču, da im govore kako, šta, gdje... kod nas baš i nema toga... " (Agata, URP_mg, 4SŠ_mg)

Također, ona je učenica koja jasno izražava i povezuje kvalitetu strukovnog obrazovanja s mogućnostima zapošljavanja i potrebom studiranja, a koje poprimaju snažnu emocionalnu reakciju i kada je u pitanju matura, odnosno obavezni predmeti, i kada je u pitanju studiranje i što ono sve uključuje:

„... kad sam došla u srednju, kad sam vidjela neke stvari, ne znam, općenito, za zaposlenjem i tako to... budućnost nam je nikakva čak i bez škole i bez ičega, ono, iskreno, strah me bude budućnosti, nemam šta skrivati, baš se plašim, strašno se plašim budućnosti, pogotovo faksa, a bit će me još više strah ako ne upadnem na faks, ono, šta da radim, ne znam ni sama, tak da..." (Agata, URP_mg, 4SŠ_mg)

Ponovno je uočljiva emocionalna dimenzija vezana uz procjene vlastitih mogućnosti i uz mogućnosti, ne samo ulaska, nego uklapanja u visoko obrazovanje, koje za učenike strukovnih škola postaje velikim dijelom svojevrsna prinuda s obzirom na šire ekonomske okolnosti i stanje na tržištu rada, s jedne strane. No, s druge strane, odluke o studiranju su dodatno poljuljane odnosima među školama koje također uspostavljaju i reproduciraju jasno razlikovanje o mogućnostima uspjeha učenika s obzirom na vrstu školovanja koje se dobiva:

„... uvijek ovi iz gimnazije gledaju kao: ,, Ma joj to obrtnička škola, oni, ono, manje znaju od nas, manje su pametniji “, da moram tako reći.. uvijek je toga bilo, ali to meni nije toliko stalo do toga, jer ja ipak imam nešto, neku ... struku imam znanje kao i oni u gimnaziji, a imam opet struku (...) sto je meni onako, jako zahvalno, stvarno, super mi je to, tako da 
opet... mislim da nije tako kako oni misle da su oni nešto više od nas... “ (Agata, URP_mg, 4SŠ_mg)

Jedina obrana protiv takvih stavova svodi se na isticanje prednosti posjedovanja strukovnih znanja i vještina, posebno kao sigurnosne mreže u suočenju s potencijalnim neuspjehom ulaska u visoko obrazovanje. U povratnoj sprezi, to na individualnoj razini umanjuje značaj studiranja i produžuje osjećaje nesigurnosti, strahovanja od budućnosti i pregovaranja budućih scenarija, suprotno ostalim učenicima koji su snažno visokoobrazovno orijentirani, u svojoj struci ne vide izglede ostvarivanja „dobrog života“, a čime su motivacijski i pod strukturnim pritiscima usmjereni u visoko obrazovanje:

„... nema uopće u našoj struci nekakvog područja, nekakvih smjerova... ništa ... tako da, fakultet baš moram iči..." (Aneta, URP_mg,4SŠ_mg)

S druge strane, jedini učenici strukovnih škola koji imaju relativno pozitivnije procjene školskog konteksta, odnosno nemaju niti jednu ispodprosječnu procjenu, su Jan i Mislav. Jan ne namjerava studirati, ali iznadprosječno procjenjuje atmosferu akademske poticajnosti što je povezano s njegovim shvaćanjem o ulozi profesora u obrazovnom procesu u kojem se (K) „filtriraju“ oni koji su za studiranje, kao i kvalitetom (teorijskog) znanja koje se stječe u školi za struku koju, iako nije njegovo željeno buduće zanimanje, procjenjuje dobrom: ,..'ko se dovoljno potrudi, može naučiti stvarno, može naučit puno u ovoj struci ... je da nema puno prakse, ali može puno naučiti, teoretski (...) u svakom slučaju dobro pripremi ....". U njegovoj slici, struka koju stječe alternativna je opcija ako mu ne uspiju trenutno ocrtani putovi odlaska u inozemstvo.

Mislava pak možemo smatrati jedinim učenikom ruralnog rezidencijalnog podrijetla $\mathrm{i}$ četverogodišnjeg strukovnog obrazovanja koji pozitivno procjenjuje svoju sveopću školsku klimu, a kvantitativno ona je zabilježena iznadprosječnim ocjenama opremljenosti škole te utjecaja profesora; Mislav namjerava studirati u području svoga srednjoškolskog obrazovanja te time posebno značajnim promatra (praktično) znanje, povezano s opremljenošću škole instrumentima, i praktične informacije koje dobiva u srednjoj školi za njegovo buduće obrazovanje i od profesora koji predaju stručne predmete:

„,... profesori, na primjer, iz struke koji nama predaju, oni nam daju dosta informacija, znači, upoznaju nas kako će biti na fakultetu, kakvi su predmeti, težina... da čak treba težište prebacit, znači, na koje predmete, koji nisu teški, i tako... govore malo o predavanjima, kako bude... malo nas nekad i uplaše ...

... naša škola je dobro opremljena, mi smo upoznati sa, ovim, sa predmetima i sa instrumentima, znači, imamo nove, znači od autoklava i sve... taj pribor koji bude na fakultetu mi imamo, samo još tamo ima i dodatno... al' to je kao veterina u malome ... " (Mislav, RRP_DSJ, 4SŠ_VG) 
Još su dva bitna aspekta koja se nisu pojavila kod nekih drugih učenika koji su svoju struku procjenjivali negativnije i koji žele upisati studij $u$ području drugačijem od područja srednjoškolskog obrazovanja. Prvo, ocjene stečene u školi dale su poticaj i samopouzdanje Mislavu prema studiranju - ne strah da u struci neće naći posao, i podižu aspiracije za upisivanjem prestižnog fakulteta - ne strah da će zbog strukovnog obrazovanja imati problema s upisivanjem fakulteta: „,... početkom prvog razreda kad su krenile dobre ocjene, i... tad... to mi se činila kao dobra prilika, da iskoristim te dobre ocjene pa da upišem fakultet... “. Drugo je istaknuti poseban odnos između učenika i profesora koji predstavlja element atmosfere akademske poticajnosti u školi:,,... 'vamo možemo razgovarati $s$ profesorima i možemo se šaliti... “, ili je to barem u Mislavovom razredu u kojem ,...jedno 90\% [učenika namjerava studirati]... samo troje ne ide dalje kod nas iz razreda... “.

Najpozitivnije procjene karakteristika srednje škole, ipak, najvećim dijelom su vezane uz pohađanje gimnazije te 4 (od 7) gimnazijalaca svoje škole smatra visokostatusnima, a neki i dodatne aspekte procjenjuju izrazito pozitivnima. Uz male izuzetke na osobnim iskustvima, općenito intervjuima gimnaijalci vrlo jasno progovaraju o prednostima pohađanja gimnazija, značaju koje ono ima njima osobno, za njihovu pripremu i za studiranje i za život, ali i društveno, odnosno statusno.

Osnovnu prednost koju ističu gimnazijalci je dobivanje „podloge“ i kvaliteta gimnazijskog obrazovanja općenito za ostvarivanje različitih želja, ali ističu i - vrlo slično učenicima strukovnih škola - razlike između pojedinih ,tipova gimnazijskog obrazovanja“" s obzirom na to koliko su njihovi izbori usklađeni s naglašenim predmetima. Oni učenici koji žele promijeniti „smjer“ imaju osjećaj da ne dobivaju dovoljno podrške za ostvarenje svojih želja izvan prevladavajućih akademskih poticaja, iako na generalnom planu i dalje dobivaju opću podlogu značajnu za ostvarivanje svojih želja:

„... razumijem da je ovo prirodoslovno-matematička, i da bi mi sad trebali nastaviti dalje u tom smjeru, ali (...) ima nas koji smo pogriješili školu, $i$ da je to bilo za očekivati kada smo imali ne znam koliko godina, na kraju osmog razreda... tako da mislim za nas koji imamo neke druge želje nemamo dovoljno mogućnosti u nekom rastu u tim, ne znam, drugim znanostima, osim prirodoslovnim... “(Andrej, URP_mg, GIM_VG)

Suprotno, onim učenicima koji su već odabirom specifičnog gimnazijskog programa odabrali i daljnji obrazovni smjer, „općost“ i „opširnost programa“ stvara teškoće postizanja dobrih 
ocjena i/ili osjećaje opterećenosti gradivom i obvezama, koja je u suprotnosti s postizanjem određenih definiranih ciljeva - polaganje državne mature i upis studija:

„... ja ne razumijem, mi smo recimo jezična gimnazija, ja sad imam i fiziku $i$ matematiku, kemiju k'o svi ostali razredi u gimnaziji, a ja sam se baš opredijelio za jezično usmjerenje, a zapravo ništa time ne dobivam ... ne čini mi se fer (...) da se sad opet moram baviti tol'ko matematikom..." (Dejan, URP_MG, GIM_mg)

„, ... jednostavno previše traže, stvarno previše traže, i preopširni su ti nastavni programi, planovi ... recimo, mi smo jezična gimnazija, ja ću ići jezik studirati $i$ ić' 'u na nižu razinu matematike - ja moram učiti derivacije! Ja ne znam definirati što je derivacija...! Što će mi to, mislim... Umjesto da se mi sada tu na zadnjoj godini fokusiramo na ono što nam treba, pogotovo za maturu, ja moram još i glazbeni odgovarati, moram ne znam likovni odgovarati, što je apsolutno smiješno i nepotrebno... “(Bernarda, URP_mg, GIM_mg)

Dodatno, učenicima koji još uvijek nisu odlučili o željenom pravcu daljnjeg obrazovanja „općost“ gradiva može biti „dvosjekli mač“: svi učenici priznaju prednosti gimnazijskog obrazovanja izraženo kao dobra priprema za maturu i dobra podloga za studiranje, no široke mogućnosti stvaraju i dodatne nedoumice oko pravca daljnjeg djelovanja u kojem pozitivni ishodi ovise o poduzetim strategijama i racionaliziranju snaga:

„... puno je dilema, pogotovo zato što opća smo gimnazija, pa imamo (...) dobru podlogu za sve, za društvene predmete, za prirodne predmete, za sve imamo stvarno dobru podlogu, $i$ vjerujem da je, ne znam, kod nekih ljudi u razredu to je toliko šaren izbor, od prava, ekonomije, Filozofskog fakulteta, FER-a, kemije, sve zajedno najednom i onda se nakupe puno izbornih predmeta koje oni trebaju položiti pa... vrlo često ni ne bude ništa od toga što je zapravo jako žalosno nakon ovako teške škole...“(Gordana, RRP_TP, GIM_VG)

Unatoč prethodno navedenim specifičnim nepogodnostima koje učenici doživljavaju nepravednima ili otežavajućima, posebno je značajno isticanje prednosti gimnazijskog obrazovanja kada je u pitanju kvaliteta obrazovanja, ali ne samo u obliku znanja i pripreme za upis fakulteta, već razvojem specifičnih, s visokim obrazovanjem usklađenih, sposobnosti organizacije vremena, izvršavanja obaveza, radnih navika, načina učenja koji na identitetskoj razini oblikuju slike učenika o sebi i daju im poseban osjećaj ponosa, samopouzdanja, zaslužnosti kao i poseban sustav vrednovanja, vlastitih i tuđih, postignuća mimo školskih ocjena. Prvenstveno ti osjećaji proizlaze iz stavova o zahtjevnosti gimnazijskog obrazovanja: „teška škola“ je gotovo sinonimni opis stresnog školovanja gimnazijalaca, što posebno slikovito opisuje Bernarda:

„,...da ću na kraju četvrtog razreda... da ću imati svakodnevicu kakvu sada imam... da je to toliko truda, odricanja, žrtvovanja... blizu živčanog sloma (...)i jako se puno uči, jako puno, iz svih predmeta, $i$ često u isto vrijeme stave testove $i$ ispitivanja... doduše, ispitivanja su konstantno, cijelo vrijeme, ali pismene provjere zaredaju jedne za drugim ... svi profesori 
nemaju baš obzira, jer jako rijetko tko (...) ne znam kad sam zadnji put radnim danom otišla na kavu, a da nije bio petak, eventualno subota... nedjelja ne - nedjeljom se uči cijeli dan..."(Bernarda, URP_mg, GIM_mg)

„... četiri godine gimnazije u kojima sam kroz četiri godine ispunjavao raspon od 14 do 17 predmeta, gdje sam svaki dan morao biti minimalno spreman za 2 predmeta... mislim da će nakon ovog jednog velikog ogromnog stresa..." (Jakov, URP_VG, GIM_VG)

Takva shvaćanja na nekoliko razina usmjeravaju i pridonose ulasku u visoko obrazovanje, a istodobno uspostavljaju vrednovanje kvalitete znanja koje obuhvaća i nadilazi usvojenost teorijskog znanja u obliku školskog gradiva iskazanih ocjenama, ali i rangiranju tipova obrazovanja i institucija u sociogeografskom prostoru:

„... imate nekoga tko je iz druge škole i ja njima rješavam ispite iz, gimnazije iz Osijeka, ja njima rješavam ispite i šaljem im... dan prije iz tog ispita sam ja u svojoj školi dobila 2, a oni su dobili 5, ja sa istim znanjem, to govori o ... znači, ova škola je teška..." (Anica, URP_VG, GIM_VG)

„... znate da vas zatrpavaju jer morate sve znat', morate baratat' nekim činjenicama, prvenstveno za državnu maturu, a onda i na tom nekakvom fakultetu, jer to će se na fakultetu od vas očekivat' da znate...

(...) ja imam prijatelja koji su evo već sada odustali od fakulteta, a bili su odlični učenici u tim nekim drugim strukovnim školama...

(...) kad vam, dođe netko i kaže: „Ja imam 5 iz matematike“, a ja imam 3... a ja mogu dokazati na primjeru (...) „, Gle ja ću na primjeru dokazati da ja znam matematiku više od tebe, a ti imaš bolje ocjene od mene?! "..." (Jakov, URP_VG, GIM_VG)

„... mi u gimnaziji dobivamo mnogo toga što, recimo netko u obrtničkoj školi, ne dobivaju to neko opće znanje s kojim se ja mogu dosta ponositi..."(Dejan, URP_mg, GIM_mg)

Dakle, gimnazijsko obrazovanje općenito omogućava znanja potrebna za državnu maturu i daje podlogu za daljnje usvajanje gradiva na fakultetu, odnosno povećava vjerojatnost postizanja visokoobrazovnih ishoda. Prvenstveno, smanjuje strah od ulaska u visoko obrazovanje: „... prijatelji koje imam na stomatologiji iz ove škole, kažu da je svaki fakultet lakši od ove škole, tako da... tako da, nemam baš neki strah..." (Gordana, URP_TP, GIM_VG), ali razvija/osnažuje posebne kvalitete koje dodatno povećavaju te izglede, odnosno općenito izglede postizanja ambicioznih životnih planova:

„.... i to vam je ono što mislim da svim školama nedostaje ... hmmm... disciplina koja je ovdje, jer nekak', kod nas baš se zna nekak' red, rad i disciplina (...) oni nekako sve nas žele kopirati i obrazovno i nekakvom strogoćom, a zapravo im ne uspijeva jer učenici koji tamo dolaze nemaju to znanje koje se st'eče ... u osnovnoj školi, a nadograđuje u srednjoj... nego oni dođu tamo s trojkama, četvorkama i onda bi to kao trebalo nadograditi, a to je jako velik raspon koji treba tu nadogradit, a ovi koji su gimnazija to je nešto što ide samo dalje, dalje, dalje..."(Jakov, URP_VG, GIM_VG) 
U konačnici, u učeničkim slikama pokazuje se jasna superiornost gimnazijskog obrazovanja općenitou odnosu na ostale škole, a posebno na određenim institucijama, što učenici spremno i ponosno ističu u opisima svoga obrazovanja koji reproduciraju shvaćanja o školskom statusu $\mathrm{u}$ hijerarhiziranom institucionalnom obrazovnom polju, ali i u geografskom prostoru regije i Hrvatske.

„... kada kažě̌ da si, ne znam (...) da si gimnazija ili da si neka trogodišnja ... gimnazija - ti si veći status u društvu..."(Marija, RRP_TP, GIM_mg)

„... drugačije okolina reagira, ne znam, možda čak me shvaćaju ozbiljnije kada kažem da sam u gimnaziji..."(Gordana, RRP_TP, GIM_VG)

„....svi znaju kad kažete „, Gimnazija“ da to znači nešta... kak' da kažem... ima taj nekakav prizvuk gdje će ljudi reć'. „,A-ha, pa da, on je to prošao, morao je to proć'..." (Jakov, URP_VG, GIM_VG)

„... kad me netko pita koju školu ideš, reć' ćeš u gimnaziju i odmah će znati kako se otprilike odnosit prema meni, nekako drugačije nego da kažem ugostiteljstvo (...) kada kažem da sam gimnazijalac ljudi automatski sa mnom ni ne pokušavaju započinjati neke ćaskanje... ne znam, odma' nekako imaju da mogu neku ozbiljniju ili neku težu temu (...) nekako, smatraju me ozbiljnijim ... (Andrej, URP_mg, GIM_VG)

Gimnazijsko obrazovanje razlikuje se i izdiže iznad strukovnog, a time doprinosi i razlikovanju učenika koji pohađaju različite tipove obrazovanja. Značajno je da takva shvaćanja koja im svakodnevno podržavaju reakcije okoline pružaju učenicima identitetske odrednice (K) gimnazijski identitet koje ih čine samouvjerenijima u njihovim nastojanjima, posebno kada je jedina alternativa biti bez zvanja što je učenicima gotovo poistovjećeno $\mathrm{s}(\mathrm{K})$ biti nitko i ništa:

„... kao puno truda i muke da smo uložili u srednju školu, i da svi koji smo upisali gimnaziju da planiramo nastaviti dalje (...) i da smo puno odgovorniji od ostalih srednjih škola ... a to se vidi i po samom ponašanju..." (Marija, RRP_TP, GIM_mg)

„... stol je baš nekako odskakao od svih nas nekako (...) oni su onak i razgovorom $\boldsymbol{i}$ ponašanjem... i djelovali su, onako ... kao da nisu, ajmo reć,naši...onda sam, bezveze onak, pito jednu curu: „, Oprosti, 'el' ste vi... odakle ste... iz koje ste vi škole? “... kad sam čuo, ne znam, ova je bila jedna iz tehničke, jedna iz ekonomske, dva dečka su bila iz industrijske... jednostavno, baš vidite koliko vas škola nauči prvenstveno odgoju, manirima, odnosno lijepom ponašanju... općenito, koliko vas, ne znam... jednostavno vas ispuni tim nekim... kao, ne da se mi sad izdižemo iznad njih, nego jednostavno se vidi, kad usporedite ponašanje da je to nešto što se jako razlikuje... “(Jakov, URP_VG, GIM_VG)

„... kada smo u gimnaziji ili smo intelektualci ili se smatramo intelektualcima što su nam tako rekli, ali i koji se smatraju intelektualcima opet se trude biti intelektualci tako da... 
s njima mogu porazgovarati makar ovako... mislim, ja sebe smatram intelektualcem i zato, ne znam... tako bi tekao razgovor..." (Andrej, URP_mg, GIM_VG)

Ovakva određenja sasvim su usklađena s viđenjem učenika o tome što je studiranje i što njima želi postići i kako se oblikovati, što uključuje viđenja o osamostaljivanju, izgradnji osobe, prelasku bitnih životnih iskustava, a koja su u usporedbi sa školovanjem u srednjoj školi u određenim aspektima lakši i privlačniji, a u nekima izazovniji, ali i vrijedni.

Učenici su posebno spremni bili izdvojiti određene škole, odnosno određene institucije kao posebno istaknute kvalitetom obrazovanja kojeg daju, a koja se posebno vezuje s onima ambicioznima, i koja na osobnoj razini smanjuje količinu straha od nepoznatog i novog, od gradiva i općenito razvija pozitivne stavove i osjećaje prema visokom obrazovanju:

„... općenito mi svi kažu, prijatelji koje imam na [fakultetu] iz ove škole, kažu da je svaki fakultet lakši od ove škole, tako da ... tako da, nemam baš neki strah..." (Gordana, RRP_TP, GIM_VG)

„... naučila me [škola] da se ne mogu opuštat konstantno, nego da imam (...), nego nekakva radna obaveza, što smatram u životu jako bitno (...) ja ne kažem da smo mi najpametniji, naj ovo, naj ono, al' da. da si znamo rasporedit, da znamo učit, to da, definitivno znamo... mislim da će mi po tom nekom pitanju biti lakše [na fakultetu]...

... mislim da nijedna druga škola $u$ [mom gradu] trenutno, a $i$ unazad par godina, nije konkurentna ovoj našoj školi, i mislim da jedino učenici iz ove škole imaju nekakvu, "aj"mo to nazvat', svjetlu budućnost...

...ova škola je, kol'ko god sam ja tupio: „, Ovo ne valja, ovo je preteško! “... je, da, al ljudi će te naučit nešt' što će ti bit korisno na fakultetu i što će ti trebat dalje u životu..." (Jakov, URP_VG, GIM_VG)

„.. Pa je, mislim ... za našu (...) gimnaziju kažu da je jako, da jako dobro pripremi ljude za faks da se... da naučimo učiti, $i . .$. recimo znam neki učenici da koji su se prebacili (...) u našu ... imamo takvu učenicu u razredu... tamo je prolazila s četiri, ovdje jedva tri, znači, razlike su velike od škole do škole, i to često čujem još od nekih mlađih profesora s kojima smo u kontaktu koji mi kažu da je razlika jednostavno ogromna, da iz [X] gimnazije jednostavno ljudi prolaze puno bolje na fakultetu nego okolo... “ (Bernarda, URP_mg;

U konačnici, takve slike o teškom gimnazijskom obrazovanju, općenito, te stavovi o visokoj kvaliteti i statusu škola koje pohađaju, specifično, utječu i na očekivanja od studiranja, koja kod gimnazijalaca s obzirom na motivaciju za željeni studij te stečene kvalitete i sposobnosti oslikavaju olakšanje i poboljšanje: manje stresa, bolju organizaciju vremena, više vremena za sebe:

„... smatram da sam ja u (...) 4 godine srednjoškolskog školovanja naučio jednu stvar gledajuć' situaciju u društvu općenito i svemu, da je obveza zapravo jedna stvar koja vas gura prema naprijed, barem je to kod mene bilo... i ja sam uvijek bio takav tip koji je uvijek volio postiči nešto više (...) gimnazija će vas gurat' uvijek i pos'o će vas gurat' uvijek... ako imate imalo ambicioznosti u sebi ... to je prvenstveno što je nekako smatram da treba imati 
ambicioznosti, treba se odužiti nekako, i zajednici, ali prvenstveno samom sebi... a to možete dobit, barem po meni, u ovoj školi... "(Jakov, URP_VG, GIM_VG)

S obzirom da učenici gimnazija „moraju“ studirati očekivano je određena doza akademske poticajnosti u njihovim školama, no koja je za različite učenike, prema njihovim osobnim iskustvima, različita i katkada je vrlo kritički razmatraju; učenici očekuju više informacija od svojih profesora kada su u pitanju jasne upute vezane uz polaganje mature, organizirane pripreme, a oni koji nemaju nedoumica oko toga koji fakultet žele upisati voljeli bi slušati više o studiranju i svim detaljima vezanima uz nastavu i studentski život s obzirom da uključuje značnu društvenu i geografsku promjenu: ,... da nam uopće kaže kako je to, kako ide odabir studentskog doma, kakvi su uvjeti, domovi, gdje je najjeftinije jesti, gdje se kretati... i po tom pitanju, ne znam, evo, apsolutno ništa..."(Gordana, RRP_TP, GIM_VG)

Posebno, oni učenici koji pozitivnije procjene daju svojim školama ističu kako ih profesori usmjeravaju, odnosno kako ih savjetuju u skladu s općim stanjem na tržištu rada i sustavu obrazovanja, te da ih podržavaju u njihovim osobnim izborima:

„... naš profesor biologije, super čovjek ... koji nam stvarno kaže onako kako je, ne onako kako se treba pričati, kaže, ne znam, recimo da je ovaj naš obrazovani sistem ne valja nimalo, nit' fakulteti, da mi trebamo ić' van i ... dosta mladih profesora nam kaže: , Idite van, ako možete, ako želite, ako mislite da ćete se snaći, idite van! “ ... “ (Bernarda, URP_mg, GIM_mg)

„... profesorica (...) govorila je neprestano da ne trebaju svi ići na pravo i ne trebaju svi ići na ekonomiju, ne treba Hrvatskoj, ne znam, kol'ko stotina psihologa ... da se malo više fokusiramo, ne znam, na deficitarna zanimanja..." (Gordana, RRP_TP, GIM_VG)

“... negdje prije profesorica pitala: „, Tko će studirati ekonomiju?", nitko ne diže ruke, kao, da bi bar htio ekonomiju... tako da, jako nas potiču na... da nastavimo studirati i gledaju stvari realno kroz sve, kako je stanje u drăavi, i tako dalje... “ (Andrea, RRP_TP, 4SS_mg)

Ovakve stavovi odražavaju i slike o tome koji su to „bolji fakulteti“, odnosno pojavljuju se pri sortiranju njihovih vlastitih shvaćanja o budućim mogućnostima zapošljavanja. Iako se te slike nalaze i sukobljene s barem nekim izborima učenika. Uostalom, slično kako se određeni učenici ne slažu s profilacijom svojim profesora.

A tko su osobe kojima se najviše vjeruje ili od kojih se najviše očekuje u pogledu informacija o fakultetima i studiranju? U školskom kontekstu to su osobe - mladi profesori, među kojima postoji i mogućnost razvoja posebno bliskih odnosa, a zatim i stručni suradnici

„... jedna mlada profesorica je mijenjala jednu koja je otišla na porodiljni (...) jako je draga, i stvarno smo... sprijateljile smo se, i skoro pa smo bile na ,ti “, i s njom sam se... ona je [...] studirala u [...], $i$.. baš sam se s njom puno informirala o tome, ovaj... isto tako je 
došla još jedna mlada profesorica iz Osijeka (...) i s njom sam isto tako pričala, $i$ dalje sam $u$ kontakti s njima..." (Bernarda, GIM_mg, URP_mg)

Za razliku od procesa $(\mathrm{K})$ filtracije, koji se odvija u strukovnim školama kao nastavak diferencijacije u osnovnim školama, i koji je uglavnom pozitivno konotiran utjecaj profesora, barem kod učenika koji se slažu s procjenama profesora (,, ... nastavnici mogu i procijenit tko može ić', tko ne može, po ovom radu - završnom radu... bilo je par takvih slučajeva... (...) to se može ustanoviti nakon tri godine...uvijek netko ima svog favorita (...) potiču nastavnici, u svakom slučaju, oni počinju, a i učenici su naravno toga svjesni, samo što neki pokušavaju preko svojih granica... “ (Jan, URP_nc, 4SŠ_mg)), u gimnazijama se više radi o (K) procesu profiliranja učenika prema određenim područjima:

... mi smo već s njima 4 godine, oni znaju otprilike kakvi su naši interesi, i u čemu smo dobri, u čemu smo slabiji, tipa, neće nekog koji je slabiji iz matematike uputiti na strojarstvo (...) općenito nas odlikaše sve, tko god je odlikaš kod njega se nekako podrazumijeva da ide ili na FER ili na PMF ili Medicinu, tako da ... to je već nekako profiltrirano... “ (Gordana, RRP_TP, GIM_VG)

I taj proces se može pojaviti kao problematičan gimnazijalcima (kao i učenicima strukovnih škola) koji ne namjeravaju studirati u ,području“ na koji je gimnazija pojačanim predmetima (odnosno strukovno) usmjerena kako je već prethodno naglašeno. Status gimnazija općenito određuje mogućnosti upisa studija, čime su strukovne škole u daleko slabijoj poziciji, na općoj razini. Ipak, najveći problem pojavljuje se kada škola ne predstavlja prednost pri upisu studija za koje pruža srednjoškolsko obrazovanje. Nekoliko učenika upravo medicinske škole izdvaja kao primjere.

„... upast na medicinu iz naše škole, mislim da je to... ne vjerujem da će itko upasti iz mog razreda iako oni idu na pripreme... ne možeš ti to nadoknadit sad..." Silva, RRP_TP, 4SS̆_VG)

„,... imam primjer te medicinske škole gdje bi oni možda.. imaju samo predznanje za jedan fakultet, ne mogu ga upisati, isto tako za ekonomsku školu... prilično su ograničeni po pitanju područja..."(Gordana, RRP_TP, GIM_VG)

S druge strane, značajnim se pokazuje i posebna akademska atmosfera u strukovnim školama koju učenici razvijaju međusobno i s profesorima. Posebna vrsta odnosa koji se razvijaju u školskom kontekstu mogu imati poseban značaj i za iskustva srednjoškolskog obrazovanja koja oblikuju očekivanja od studiranja, kao i posebna izvor informacija i/ili poticaja za nastavak školovanja. U strukovnim školama je takav pozitivan primjer opisao Mislav, koji 
pohađa razred u kojem 90\% učenika namjerava studirati, a dodatno se razvijaju osobniji odnosi s profesorima u kojima ih se uvijek može pitati kada postoji bilo kakav problem.

Općenito, takve odnose moguće je smatrati značajnim elementom kojim škola potiče i razvija kod učenika sposobnost shvaćanja društvenih prostora i djelovanja mreža u koje su uključeni učenici, a koji uključuju i odnose između učenika i profesora. No, kako upozorava Corbett (2007) kada ukazuje kako su škole stratificirajući mehanizam, odnosi sa školskim osobljem poseban su izraz kapitala mobilnosti i sposobnosti onih koji su prisvojili resurse da se vide u drugim prostorima, te time značajno utječu na gradnju učeničkih vlastitih mreža koje su nužne za oblikovanje identiteta i postizanje samopouzdanja za postizanje uspjeh u prostorima (za razliku od lokalnih mjesta). Potičući taj oblik kapitala mobilnosti (Corbett, 2007), škole osposobljavaju učenike za pregovaranje mnogostrukih društvenih prostora čime je njihova vlastita pozicija povoljnija kada je u pitanju i visokoobrazovanje i njihova mobilnost. Time nedostatak takve komunikacije i poticaja postaje ograničavajuća okolnost za učenike koji žele nastaviti školovanje u prijelazu prema odraslosti jer im nedostaju mentalne mape u kojima bi sebe smjestili. Prema Corbettu, sve škole djeluju kao stratificirajući mehanizam izabiranjem onih za odlazak. 


\subsubsection{Simbolička vrijednost obitelji, škola, zajednica za učenike različitog rezidencijalnog podrijetla}

Posljednja eksplanatorno orijentirana analiza pokušava odgovoriti na pitanja o simboličkoj vrijednosti konteksta odrastanja i školovanja za skupine učenika različitog rezidencijalnog podrijetla kako bi se zahvatili dodatni aspekti odrastanja i školovanja učenika. Pri tom, svi značajni konteksti, odnosno odnosi učenika s pojedincima i grupama u njima ispitani su i kvantitativno i kvalitativno, a u nastavku se predstavljaju rezultati analiza obje vrste podataka. Simbolički značaj obiteljskog konteksta ispitan je u četiri aspekta poticajnih praksi roditelja ${ }^{102}$, a dodatno učeničkim procjenama o tome koliko su osobe iz obiteljskog konteksta utjecale na njihovu odluku o (ne)studiranju. Za te elemente pokazao se manji socioprostorni značaj, odnosno, statistički značajne ruralno-urbane razlike pokazale su se samo prema roditeljskim poticajima za zapošljavanje (Slika 4.7) i prema općem utjecaju roditelja (Slika $4.8)$.

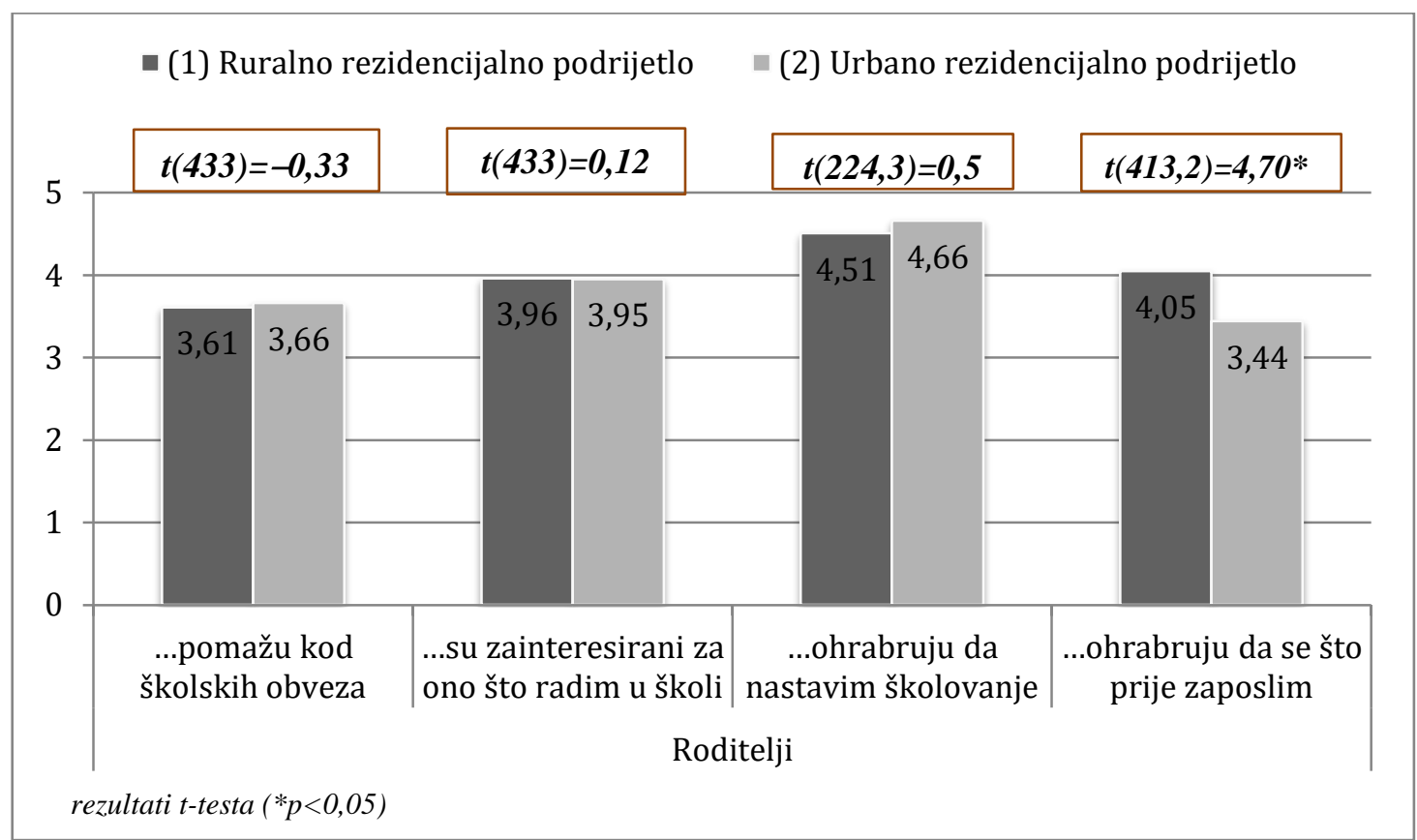

Slika 4.7 Razlike između učenika različitog rezidencijalnog podrijetla u procjenama aspekata roditeljskih poticaja

Općenito, učenici su se iznadprosječno slagali s tim da im roditelji pomažu u izvršavanju školskih obveza $(M=3,6)$ i da se interesiraju za njihove školske aktivnosti $(M=3,9)$, a u najvećoj mjeri procjenjuju da ih roditelji ohrabruju na nastavak školovanja $(M=4,5)^{103}$.

\footnotetext{
${ }^{102}$ Od učenika se tražilo da procijene svoje slaganje (1-uopće se ne slažem, do 5-u potpunosti se slažem) s tvrdnjama o tome da im roditelji pomažu kod školskih obaveza, da ih interesiraju njihove školske aktivnosti, te da ih potiču na nastavak školovanja, odnosno zapošljavanje.

${ }^{103} 88 \%$ učenika se slaže i u potpunosti slaže s tvrdnjom Roditelji me ohrabruju da nastavim školovanje.
} 
Roditeljsko ohrabrenje brzog zaposlenja učenika je, pak, oblik poticaja koji roditelji u manjoj mjeri izražavaju, prema iskazu učenika, $(M=3,7)^{104}$, i koji je izraženiji u obiteljima iz ruralnih naselja $\left(M_{R R P}=4,1>M_{U R P}=3,4\right)$, te se prosječno učenici ruralnog rezidencijalnog podrijetla $u$ najvećoj mjeri uglavnom slažu s tvrdnjom da ih roditelji ohrabruju na brzo zapošljavanje, dok učenici urbanog rezidencijalnog podrijetla prema toj tvrdnji prosječno zauzimaju ambivalentaniji stav. Ti su nalazi, dijelom, u skladu s onima o ruralno-urbanim razlikama u obrazovnim dispozicijama učenika. Uočljiva je veza između izraženije orijentacije stjecanju struke kod učenika ruralnog rezidencijalnog podrijetla i veće poticajnosti na brže zapošljavanje u njihovim obiteljskim kontekstima. No, isto tako poticaji roditelja za studiranje ne razlikuju učenike različitog rezidencijalnog podrijetla i visoko ga procjenjuju. Drugim riječima, velika većina učenika procjenjuje da ih njihovi roditelji potiču na nastavak školovanja, no kako ukazuju i kvantitativni i kvalitativni podaci, najveća razlika tiče se pravca kojim su obrazovni putovi učenika različitog rezidencijalnog podrijetla usmjereni, pri čemu učenici nisu skloni, općenito drugima, a u velikoj mjeri niti roditeljima, pridavati veliku utjecajnu ulogu pri donošenju njihovih obrazovnih odluka.

Corbett (2005), kada su u pitanju učenici ruralnih područja, takve razlike objašnjava različitim odgojnim praksama u kojima , s obzirom na istaknutost obrazovanja za suvremenu ekonomiju i s općom restrukturacijom lokalnih ekonomija koja kerira dominantnu sliku o tome da je obrazovanje put za van (2005b), obitelji s nižim razinama resursa svoju djecu usmjeravaju prema obrazovanju, ali se ono promatra i s velikom dozom skepticizma i ambivalencije jer je potreba obrazovanja konstitutivni dio istih silnica koje rastaču ruralni način života. Pragmatizam obitelji onih nižih klasa $u$ ruralnim područjima, ukorijenjen $u$ dubokom lokalnom znanju i praktičnim vještinama, odvaja njihovu djecu od akademskih smjerova (2005b) i zadržava ih u poznatom.

Općenito, postoji stav učenika da se na studiranje teško odlučiti učenicima koji nemaju podršku roditelja, i da roditelji na mnogo razina utječu na učeničke obrazovne odluke, od onih sasvim suptilnih do onih posve direktnih. Štoviše, čitav način života te radna i obrazovna iskustva roditelja oblikuju obiteljske dinamike odnosa prema studiranju u koje se onda uklapaju i budući obrazovni planovi učenika u skladu s procjenom pripadaju li ili ne u kategoriju onih koji su za studiranje:

.... moj dečko, on nema podršku obitelji (...) rekao je da želi studirati, no oni su mu rekli: „’Šta ćeš ti na studiju? Studiranje nije za tebe! “... znači, prvo je njima najteže zato što

\footnotetext{
${ }^{104} 55 \%$ učenika se ne slaže i uopće ne slaže s tvrdnjom Roditelji me ohrabruju da se što prije zaposlim.
} 
ako nemaš podršku obitelji, ako nemaju tak' pogled na svijet, onda ni tebe neće, ovaj, smatrati, 'aj"mo reći, dovoljno dobrim da bi ti studirao..." (Anica, URP_VG, GIM_VG)

„... on [dečko] je isto zbog obiteljskih problema morao čak i srednju školu napustiti, jednostavno mu, roditelji mu nisu dali da ide u školu dalje...“(Ivana, RRP_DSJ, 4SŠ_mg)

„... ima ljudi, učenika... nisu mu roditelji završili, pa ne zna 'e l'će i on, pa roditelji mu ne daju dobar primjer, pa ne zna... tako da, mi mu govorimo da ide [studirati], a on ... roditelji ga važu da ne ide, tako da..." (Mislav, RRP_DSJ, 4SS̆_VG)

„... previše žive načinom, na način kako im žive roditelji, znači: bit ću kod kuće, radit ću zemlju, to je sve što ću znat' u životu, tako da ... mislim da oni uopće... mislim da nemaju ni stav, ili kad bi pitala nekoga... puno njih nije završilo ni srednju školu, da se razumijemo, koji su mladi od mene, ispisali su se, njima se to neda... mislim da je to sve do odgoja koji proizlazi iz kuće... jer kad tebe roditelj potiče da ti radiš nešto, prvenstveno radit ćeš zbog sebe, a drugo da ... mislim, ne da se ponose tobom, nego da dokažeš da možeš, da si sposoban za nešto, a šta su ovako oni dokazali? Da su sposobni za sjedit' $i$ spavat' kod kuće..." (Silva, RRP_TP, 4SŠ_VG)

Ipak, suprotno ovim primjerima, intervjuirani učenici, koji većim dijelom namjeravaju studirati, u svojim iskazima opisuju pozitivne poticajne prakse roditelja posebno u oblicima (K) podrške učenika na samostalno donošenje odluka, $(\mathrm{K})$ ohrabrivanje ostvarivanja vlastitih želja, i obećanjem (K) financijske pomoći, što su uz $(\mathrm{K})$ savjetodavnu/informativnu ulogu roditelja, značajni elementi roditeljskog utjecaja u učeničkom procesu donošenja odluke o studiranju.

Općenito, intervjuirani učenici uvelike smatraju da ih roditelji snažno podržavaju i potiču na studiranje te da su relativno uključeni u, i pokazuju interes za, njihovo školovanje. No, postoje izuzeci: dvoje učenika koji koji iznimno slabim procjenjuje roditeljsko poticanje studiranja, ali i poticanje zapošljavanja što je u skladu s njihovim visokoobrazovnim namjerama. Štoviše, Dejan naglašava i kako su roditelji imali velik utjecaj pri donošenju njegove odluke o studiranju, što je vjerojatno vezano uz njihovo visoko obrazovanje i ostale elemente roditeljskog okruženja čega je dio i specifičan oblik „obrnute psihologije“ u obiteljskim dinamikama ovog učenika:

„.. ... onda oni su dosta podupirali , možda ... nisu bili strogi, ali vodili su računa kol'ko učim, šta učim, nekad su me i ispitivalime da vide jesam li zaista naučio, i to ono... dosta me to čak i motiviralo, međutim danas recimo više me ne motiviraju nego mi izmišljaju što loše ocjene... recimo... to me malo, to me spusti recimo...

... jer govore „Ma šta ćeš ti upisati, vidi si ocjene!?", al' vjerujem da ću upisati i već sam se počeo pripremati za maturu, i smatram da... će sve dobro ispast', da ću upisati željeni fakultet (...) čak me to malo ohrabruje jer, ono, želim pokazati da sam zapravo ja u pravu, a ne oni..." (Dejan, URP_mg, GIM_mg) 
U Dejanovoj priči zamjetna je, ipak, uključenost roditelja u obrazovna pitanja i razgovori s učenikom o studiranju. Učenik sam priznaje da njegovi školski uspjesi nisu najbolji što je izvor roditeljskih briga, i na koje su roditelji upozoravali učenika i prije samog upisa škole: „,... oni su rekli: „, 'Ajd' sad malo razmisli, jer moraš biti svjestan da ćeš ti u gimnaziji morati raditi, da nije samo, ono... ne smiješ se jednostavno zezati s tim “... hmmm... ja sam rekao da sam siguran, no evo moji rezultati su malo lošiji od ostalih, mislim, nisu katastrofalni, al', ono... “. U konačnici, roditelji potiču njegovo studiranje koje će financirati, a koje mu je, kao posljedica upisa gimnazije, i nužnost, te za koje učenik tvrdi da je njegova odluka. Drugim riječima, ovog učenika u većoj mjeri karakterizira rana visokoobrazovna orijentacija, koja je uvelike potaknuta željom za društvenom mobilnošću, ali ne i orijentacija na iznimnu školsku uspješnost, već u većoj mjeri oslonjenost na obiteljski stečene kapitale: rano usvojene jezične kompetencije koje određuju izbor željenog studija te financijsku podršku obitelji koja mu omogućava šire izbore u visokoobrazovnim odlukama i studiranje na moru. Drugim riječima, obiteljske kapitale koristi za postavljanje puta kooji bi spriječio silaznu mobilnost u odnosu na društveni status svojih obitelji.

Za razliku od toga, Agata i Marina svoje roditelje koji nisu visokoobrazovani, a financijski podržavaju odluke svoje djece, iako ih uglavnom potiču na zapošljavanje, moraju uvjeriti u svoju kasno razvijenu želju za nastavkom školovanja, a koju i same učenice još uvijek pregovaraju sa sobom, kako bi se zajedno sa svojim obiteljima odlučile da je studiranje vrijedno ulaganja truda, vremena i novca:

„... nikad prije nismo baš vodili taj razgovor... ne znam ni sama zašto... mislim da još nije bilo ni vrijeme za taj razgovor, tek sam krenila u srednju školu, prvi razred, ono... da mi je samo završit srednju školu...

... prije i nisu baš nešt', ono: „Joj ti ćeš na faks “, ovo-ono... al' sad'...

... nisu me oni, sama sam baš... njima sam rekla, ono... nisu me shvaćali ozbiljno (...) šalili su se „Ma ti ćeš na faks?! “... nisu me ozbiljno shvaćali... to me živciralo užasno...

... kad sam kasnije stvarno pokazala zanimanje... ja sam njima govorila: „Ja želim na faks, ja želim na faks! “, i onda su oni, kao... stvarno, čujem ja njihove razgovore, kao: „Pa ona stvarno želi na faks “, kao: “ Ako stvarno želi neka proba“, ono ,,Ima pravo, pa vidjet ćemo kako će ići" "...

... kako matura sada se bliži i svaki dan učim (....) i kako vide da ja učim podupiru me baš ono, govore, i vjerujem da bi mi omogućili to kada bih htjela... (Agata, URP_mg, 4SŠ_mg)

„... pa mogu meni moji sve to platit, al' jednostavno pomislim da ne idem na to jer ak' ne prođem to je ono gubitak vremena... bolje taj novac uložit' u nešt' normalno, to jest, ne normalno (smijeh), neg' neš" u što sam sigurna da će uspjet', a ne faks (...) ali oni [roditelji] se naravno brinu da to neće biti studiranje, neg da ću ja otić da se malo zabavim, tu godinu jednu, i onda ću doć' kuć' vjerojatno... al'podupiru me, normalno ak' ću učit i sve... " (Marina, RRP_TP, 4SŠ_mg) 
Unatoč površnoj sličnosti Dejanovog i Agatinog opisa utjecaja roditelja koji bi se mogao u određenim elementima opisati kao nepoticajnost, utjecaj roditelja je za ovo dvoje učenika posve različit s obzirom i na ishodišta (razlike u razinama obiteljskog kulturnog kapitala), s obzirom na obrazovne putove na kojima su učenici i s obzirom na konačne rezultate; oboje učenika namjerava studirati pri čemu im je važna motivacija društvena mobilnost, no kod učenika koji su prva generacija studenata kao Agata, i nisu prisiljeni na nastavak školovanja stjecanjem struke nakon četverogodišnjeg obrazovanja, a kojima je studiranje puno neizvjesnije i u većoj mjeri zastrašujuće, pa time i veći rizik, donošenje odluka o nastavku školovanja daleko je kompleksniji i emocionalno teži zadatak. Pogotovo kada se odluka donosi i provodi samostalno što Agata tvrdi. Marina je pak u većoj mjeri ravnodušna izražavanjem svoga puta u množini uklapanjem u grupu i slijedeći druge sa stavom „kako drugima tako i meni““ i strategijom (K),,ako prođe prođe“. Dakle, svi ovi učenici prihvačaju dominantnu sliku o potrebi obrazovanja, ali imaju različite razine usvojenih dispozicija i razumijevanja obrazovnih prostora. Aspiracijski njihove su želje prvenstveno oblikovane kroz dominantne slike o potrebi obrazovanja, a dodatno i o studiranju kao značajnom aspektu moderne adolescencije.

Andrea pak ima posve različite obiteljske okolnosti i iskustva odrastanja u obitelji siromašnijoj resursima i visokovrijednim kulturnim kapitalima, te, uz Gordanu i Anetu, predstavlja visoko ambiciozne učenice koje se uvelike u pitanjima školovanja, i orijentacije na studiranje, oslanjaju na sebe: „... Nisu [me roditelji usmjeravali na studiranje] ... Nisu ... “. Roditelji ovih učenica, prema njihovim određenjima, nisu u velikoj mjeri uključeni u njihovo školovanje, a odluke su uvelike njihove samostalne, iako se opći utjecaj roditelja razlikuje za tri učenice s obzirom na obiteljske dinamike. Za gimnazijalku je utjecaj obitelji podržavajući, ali pritom su sve obrazovne aktivnosti prepuštene njoj s obzirom da postoji njena rana intrinzična motivacija, te izražen (K) učenički identitet koji se potvrđuje i školskim uspjesima:

„.. Pa ja moram priznati da su moji roditelji bili dosta pristrani u cijelom mom školovanju, ovaj... često razrednica meni zna reć' kao: „Pa joj, nisu bili dugo na informacijama “,.. ali oni ne shvaćaju da bi možda trebali doći zato što, niti ima izostanaka, niti ima loših ocjena, pa ni ne vide to baš, ono... niti kod kuće ima previše priče o tome, to je kao moja stvar...

... jako rano sam propričala, naučila čitati, pisati, sve... stalno sam se bavila školom $i$ svim time (...) kad god sam primijetila da mi učenje ispašta zbog nečeg drugog, ja sam se odrekla tog drugog, tako da mi je [obrazovanje] zapravo najbitnije od svega...

... rekli su mi pružiti svu podršku, ali da sama odaberem što hoću i kako ću, i da moram biti svjesna toga da je cijeli studij na meni, ne na njima... oni će mi omogućiti što treba, ali na meni je to hoću li ga završiti ili ne..." (Gordana, RRP_TP, GIM_VG) 
Podržavajući element izražava se kao $(\mathrm{K})$ podrška samostalnosti i preuzimanja odgovornosti, ohrabrivanje visokoobrazovnih aspiracija, koji su i svojevrsni oblik učenja na iskustvima roditelja (,...moji roditelji su oboje krenuli na fakultet, nisu ga završili, i kad čujem njih cijelo vrijeme kako im je... zapravo, jako žale zbog toga što nisu uspjeli i kako sada moraju sve težim putem ići, želim prolaziti lakšim putem kasnije...) te obećanje financijske pomoći koji se javlja kod još nekoliko učenica (gimnazijalki) čiji roditelji nisu visokoobrazovani, ali obiteljske dinamike ocrtavaju visoko vrednovanje obrazovanja i požrtvovnost roditelja za podržavanje učeničkih želja o studiranju koje je vrsta obiteljskih projekata.

Vrlo slične stavove izražava Aneta, no s bitnom razlikom isticanja snažnijeg i stalnijeg utjecaja roditelja s obzirom da učenica pohađa četverogodišnju strukovnu školu te nije direktno usmjerena prema visokom obrazovanju. U njenom narativu, roditelji predstavljaju dodatni poticaj koji joj ukazuje na $(\mathrm{K})$ potrebu studiranja i koji kroz razgovor održava i ohrabruje ideju nastavka školovanja, a koji su usklađeni i s njenim (K) učeničkim identitetom, i njenim željama za radom u određenom području:

„... to sam zapravo oduvijek znala, zato što su moji roditelji tako orijentirani i onda tome je oduvijek bilo tako da idem na fakultet (...) vidjeli da od toga nema ništa, da se vrijeme brzo mijenja, da je potrebno više obrazovanje, i onda su uvijek gurali me u tome pravcu... da idem, da se više obrazujem ...

(...) otkako se sjećam, otkako sam krenila u srednju školu, mi smo znači, odmah od prvog razreda... su stalno mi pričali kako treba ići na fakultet, kako bez njega nema ništa, pogotovo ovdje, $i$... stalno, stalno mi govore o fakultetu $i$ kako je to pravi smjer da idem ..." (Aneta, URP_mg, 4SŠ_mg)

Ipak, takav obiteljski sporazum oko obrazovnih ciljeva ove učenice nije se usmjerio u ranijim fazama i u gimnazijsko obrazovanje. Učenica kao bitan element svog izbora srednje škole izdvaja strah od lošeg uspjeha, odnosno strah da bi loš gimnazijski uspjeh zatvorio njene mogućnosti studiranja. No, moguće je pretpostaviti da nisu postojali dodatni mehanizmi i/ili informacije koji bi, učinkovito se boreći s njenim strahovima, svjesno povezali njenu orijentaciju na školski uspjeh i rano razvijenu visokoobrazovnu orijentaciju u gimnazijsko obrazovanje u kojem sama kvaliteta, općost i širina obrazovanja pomažu postizanje obrazovnih ciljeva unatoč ocjenama. Slično vrijedi i za Andreu, no koja u potpunosti odbacuje ideju da su roditelji na bilo koji način utjecali na njene odluke.

Kako i prethodni primjeri pokazuju, roditeljski utjecaj poprima različite i mnogostruke oblike za različite učenike; najčešće je zamjetan u pitanjima mogućnosti financiranja studija - što je čini se razlog Andreine slabije procjene roditeljskih poticaja na studiranje: “... oni kažu, onak', „Život u Zagrebu je jako skup, ne znamo da l' ti to možemo priuštit'“... “, kao i savjetovanja oko pojedinih smjerova, ili informiranja pojedinih odluka, s kojima se učenica 
nužno ne slaže:,, ... tata, on obožava pravo, i on cijelo vrijeme mene tjera da upišem pravo, znači, ne bi htio da upišem ovo što sada (...) znači: „Ak' upišeš pravo, imat ćeš novaca“, a nije to tak'..."). Zamjetno je kako Andrea poticaje svojih roditelja doživljava drugačije od druge dvije učenice; velikim dijelom njena obiteljska situacija i način na koji roditelji s njom razgovaraju o studiranju učenica doživljava u većoj mjeri ograničavajućim za ostvarenje vlastitih želja koji su vezani uz samo jedan željeni studij koji se izvodi samo u Zagrebu. No, također je zamjetna praktična usmjerenost njenih roditelja zbog slaba uloge kod njenog odabira srednje škole pri čemu su je pokušali uvjeriti u upis gimnazije, ali je odluka ipak prepuštena njoj čime je nisu uspjeli uvjeriti da je (K) materijal za gimnaziju: „,... nisu oni [roditelji] nišst', uglavnom, posebno išli na to... „Sam' upiši nešto... “ (...) oni su isto htjeli da gimnaziju, malo su tak' višse bili nego za [strukovnu], al' onda su shvatili da, onak', socjenom iz matematike, tri, ništa (smijeh).... “. Strukturno, ovaj element iz njenog narativa ukazuje na slabije poznavanje onoga što Bourdieu opisuje kao „osjećaj igre“ ili načina na koji obrazovni sustav funkcionira i u kojem su ocjene samo jedan element prohodnosti kroz obrazovni sustav. Gimnazijsko obrazovanje je procjenjeno rizičnijim i preapstraktnim, unatoč djelovanju ostalih osoba iz institucionalnih okruženja ,...ravnatelj $i$ pedagoginja zvali na, da razgovaram s njima da se prebacim u gimnaziju..." koji su ukazivali na drugačija značenja $\mathrm{i}$ mogli su predstavljati značajan izvanobiteljski utjecaj, posebno obiteljima s nižim razinama dostupnih kapitala i u ruralnim sredinama. U konačnici je prevladao utjecaj obiteljskog habitusa koji sigurnijim procjenjuje strukovno obrazovanje i duži put do visokog obrazovanja. Stoga, čak i unatoč procjenama drugih institucionalnih aktera i dobrim ocjenama, učenica ne razvija sliku sebe kao gimnazijalke.

Također usklađeno s izborom učenika za sudjelovanje $\mathrm{u}$ istraživačkom razgovoru, nešto je manje učenika koji tek blago iznadprosječno izražavaju stav ${ }^{105}$ da ih roditelji potiču na brzo zapošljavanje (5), pri čemu i jedna gimnazijalka, iako se uglavnom odnosi na učenike strukovnih škola koji nisu sigurni hoće li i koji ne namjeravaju studirati:

„...Pa ne znam ... mama i tata su mi govorili da je to dobro, al' oni to kažu i gotovo... onda ja sve sama svoje odluke donosim... sama sam upisala šta sam htjela, sve sam sama do sad napravila... a i ja baš ne volim slušat druge, to jest, ne sad da ne slušam, neg' jednostavno... to je moj život i ja ću seb' sama napravit' ili loše ili dobro... " „,...oni se naravno brinu da to neće biti studiranje, neg' da ću ja otić' da se malo zabavim, tu godinu jednu, i onda ću doć' kuć' vjerojatno... al' podupiru me, normalno ak' ću učit i sve..." (Marina, RRP_DSJ, 4SŠ_mg)

\footnotetext{
${ }^{105}$ Tek blago više iznad prosjeka, odnosno blizu granice od $1 \mathrm{SD}$ udaljeno od prosjeka $(\mathrm{z}=0,9)$.
} 
„.... a oni... vole moj izbor [struke], oni su uz mene, i tako (...) oni žele da ja upišem fakultet, studij... a ja ono... moram se još predomislit... “(Lidija, RRP_DSJ, 3SŠ_VG)

„... Roditelji su mi htjeli u srednjoj školi da idem na fakultet, al' nisu me previše forsirali... kad sam ja odlučio da neću ić', onda neću ić' $i$... nisu se bunili puno...

(...) Pa... lakše pronać' posao i tak'... obrazovaniji si, bolje te ljudi gledaju, i tako... premda ja to tako ne vidim, ali... “(Jan, URP_nc, 4SŠ_mg)

„... Pa ne znam [koji je stav roditelja o studiranju] ... nismo o tome nikada pričali ... mogu pretpostavit da je dobro, da imaju sve dobro mišljenje o tome, ali sad nam je prva da se zaposlim ... to im je prvo, najvažnije (...) nisu nikada onak' izražajno da ja to moram, i to je to... nego onak', bitno je da se zaposlim, da imam svoj život... “ (Krešimir, URP_mg, 3SŠ_mg)

U tom kontekstu, ovakav poticaj se doživljava pozitivnim izrazom (K) podrške učeničkih samostalnih odluka. No, razvidno je i iz ovih učeničkih priča nedostatak dosljedne i stalnije komunikacije, ili točnije, promišljenije razmatranje mogućnosti studiranja kao dio obiteljskih dinamika, pogotovo u ranijim obrazovnim fazama, kao i iznimna prepuštenost samostalnosti donošenja obrazovnih odluka učenicima.

Dodatno je više onih koji se izuzetno ne slažu sa stavom da ih roditelji potiču na što brže zapošljavanje (7), gdje očekivano prevladavaju gimnazijalci (5), te dvoje vrlo odlučnih i visokoobrazovno orijentiranih učenika četverogodišnjih strukovnih škola. No, učenike razlikuju drugačiji stavovi kada su u pitanju poticajni oblici praksi sudjelovanja njihovih roditelja u njihovim školskim aktivnostima, kao i prema utjecaju koji pripisuju roditeljima i ostalim članovima obiteljskog okruženja na svoju odluku o studiranju.

Anica je jedina učenica čiji su rezultati konzistentni i visoki: iznadprosječno procjenjuje i interes i pomaganje svojih roditelja u pitanjima školovanja, kao i utjecaj roditelja i brata na svoju odluku o studiranju, a dodatno te utjecaje oslikava i objašnjava u skladu sa svojim težnjama i izborima u intervjuu na vrlo koherentan način:

„... Jak, jak utjecaj... ne znam, ja sam baš iz jedne stabilne obitelji ... oni ne traže... oni meni nikad nisu forsirali da ja budem kao oni, niti su me... hm... znači za školu, ništa... ne stvaraju nikakav pritisak na mene, ali ja jednostavno njih gledam kao uzore, i onda su mi tak', i onda su mi normalno takvi i planovi...

... na neki način želim ostvariti život kao što ga ima moja mama... ona je pročelnica (...) odjela za matematiku, $i$... ja bi htjela raditi znanstvena istraživanja jer vidim kakav je njen život i kak' bi ja htjela svoj život da izgleda ... znači, zato što su oni postigli sve svojim radom da mi imamo nešto dobro, i ja to cijenim ... za ove praktične stvari nisam baš najsposobnija tako da... uzmem knjigu i to je ono što znam...

... [otac] On je profesor matematike u srednjoj školi...

... brat mi je... ovaj... na FER-u, tako da... i on isto ima velika očekivanja od života, velike ambicije, tako... jednostavno nam je to tako... "(Anica, URP_VG, GIM_VG) 
Učenica smatra da je imala roditeljsku zainteresiranost za njeno školovanje i pomoć pri izvršavanju školskih zadataka, a kako prethodni citat pokazuje, i kvantitativni rezultati potvrđuju, i utjecaj roditelja te brata ne njenu odluku o studiranju koja je u ovom obiteljskom kontekstu shvaćena kao „normalan slijed“ i izraz je (K) obrazovne reprodukcije u određenom području (prirodoslovno-matematičkom) i $(\mathrm{K})$ društvene reprodukcije s obzirom na (K) način života roditelja, u kojem su roditelji, s njihovim obrazovnim i radnim iskustvima, uzori učenici. U skladu s tim je i niska procjena poticaja na zapošljavanje od strane roditelja za ovu učenicu s visokoobrazovnim osobnim habitusom, a koji učenica izražava i u svojoj (K) učeničkoj slici sebe: „... za ove praktične stvari nisam baš najsposobnija tako da... uzmem knjigu i to je ono što znam... “, i koji podupiru ostali obiteljski resursi.

Vrlo slično čitavi obiteljski kontekst i resursi djeluju i u Mislavovom slučaju koji također predstavlja oblik $(\mathrm{K})$ roditelji kao uzor te $(\mathrm{K})$ reprodukciju obiteljskog društvenog statusa i načina života, no u ruralnom društvenom sistemu ili polju (Rye 2003, 2007):

„... naviko sam radit uz životinje, $\boldsymbol{i}$ uvijek smo imali životinje, tako da sam ja uvijek uz njih... nikad se nisam bavio mehanikom, nije se ni otac bavio mehanikom, pa ne znam ni zašto bi otišao, na primjer, na neki drugi... uvijek tu uz životinje... tak' da, to je najviše utjecalo na mene - pristup na životinje, otac kako se ponaša prema životinjama s poštovanjem - to je i mene potaklo, tako da ... od malih nogu, uvijek sam uz njega, $i$...

... otac se bavi poljoprivredom... ja se s njim, pomažem znači... i mama... sestre su većinom na fakultetima (...) imamo uzgoj crnih slavonskih svinja, znači da, svinje imamo, nešto ovaca, imamo konje... uvijek u doticaju sa životinjama i to mi je priraslo srcu...

... tako nešto, znači, malo i funkcionalno, to mi se sviđa, i zato mislim završit' fakultet $i$ tako neš" kod sebe, malo obnovit' zdanje, znači, uvest' neki... svježu krv, kako bi' rek'o, da se može to još malo... uspijemo nadogradit' i sačuvat to što imamo... “(Mislav, RRP_DSJ, 4SŠ_VG)

Nasuprot tim primjerima, elementi osobnog obrazovnog habitusa, te dakle visokoobrazovna orijentacija, najvećim dijelom posreduju utjecaj roditelja posebno za učenike prve generacije studenata i one s nepovoljnijom strukturom obiteljskih resursa, koji je posebno istaknut kod Gordane:

„... oni osobno nikada nisu utjecali na mene, znači, oni su meni i pri upisu u srednju školu rekli: „Ako ćeš ti biti sretna kao frizerka, kuharica, bilo što, ti to upiši “... stvarno, ne mogu reći da mi nisu niti jednom riječju natjerali na nešto... rekli su mi samo da vide moj kapacitet i da misle da bi bilo sasvim u redu upisati nešto takvo... a, poslušala sam ih, ali u vidu studiranja također rekli su mi pružiti svu podršku, ali da sama odaberem što hoću i kako ću, i da moram biti svjesna toga da je cijeli studij na meni, ne na njima... oni će mi omogućiti što treba, ali na meni je to hoću li ga završiti ili ne ... “(Gordana, RRP_TP, GIM_VG)

„.. uvijek, ohrabruju me, i riječima, i ako trebaju neke instrukcije, i ako mi zapne u školi uvijek me ohrabruju, ako trebaju ... ako oni mogu nešto pomoći... vidim da... baš se bore..." (Marija, RRP_TP, GIM_mg) 
Kako prethodni citat pokazuje, jedna od najvećih podrška roditelja odvija se održavanjem razgovora o studiranju, i odnosi se na podržavanje učenika pri njihovim odlukama, pogotovo kada su ambiciozni i potencijalno ,zastrašujući“ učenicima, te stoga obuhvaća i ukazivanje na učeničke sposobnosti i isticanje vjere u njihov uspjeh, kao i eventualno savjetovanje o mogućim pravcima, posebno s obzirom na mogućnosti zapošljavanja:

„... šta god da ja odlučim oni su uvijek uz mene, jer... oni su završili samo trogodišnju školu, tako da uvijek... pošto je i moj brat isto upis'o dobru školu, i ja ovu, ono... uvijek nas potječu da idemo još više da budemo što bolji...

... oni su uvijek znali da ja imam visoke ciljeve i da ono što ja zacrtam da ja to moram ostvarit', tako da, kad su me pitali hoću li studirati, ja sam rekla da hoću, onda su rekli: „Pa ok, ak' ti upadneš na to, ti ćeš to završit 100\%, ti si takva! “... tako da... prvo se pričalo o nekoj srednjoj školi, šta ja želim, ovo, ono... sad kad je, pred kraj, ono, sad me pitaju šta ću dalje, i tako... nije to da je bila neka prisila ili nešt', uvijek sam imala vlastiti izbor što se tiče toga... " (Silvija, RRP_TP, 4SŠ_VG)

Općenito, kada se slavonske maturante pitalo koje su osobe utjecale na njihovu odluku o (ne)studiranju, već je istaknuto, učenici nisu bili skloni pripisivati značajan utjecaj drugim osobama, i tek nešto veći utjecaj daju članovima obitelji, roditeljima $(M=3,5)$ i braći/sestrama $(M=2,6)$, te prijateljima $(2,6) \mathrm{i}, \mathrm{u}$ školskom okruženju, nastavnicima $(\mathrm{M}=2,5)$ te kolegama $(\mathrm{M}=2,4)$. Ostalim osobama je daleko manji broj učenika pripisao značajan utjecaj ${ }^{106}$, a najmanje susjedima $(M=1,7)$, stručnim suradnicima $u$ školi $(M=1,8)$ i savjetniku za profesionalno usmjeravanje $(\mathrm{M}=1,7)$.

U uzorku učenika za kvalitativno ispitivanje značaj pojedinih osoba još je slabije istaknut te tek 5 učenika, bez obzira na svoje namjere studiranja, ističe izniman značaj roditelja na svoju odluku o (ne)studiranju, uglavnom učenici čiji su roditelji visokoobrazovani ili imaju visokoobrazovne orijentacije za svoju djecu, a niti jedan učenik ne ističe snažniji utjecaj svojih braće i sestara, iako se u pojedinim učeničkim pričama taj utjecaj može detektirati, bilo kada je u pitanju samo studiranje i studentski život ili odabrani studij. Posebno su zanimljivi slučajevi onih učenika koji su prva generacija studenata, a čiji stariji braća i/ili sestre studiraju. Pokazalo se da iskustva braće/sestara učenika mogu biti značajna referentna točka vlastitih planova, specifično kada je u pitanju upoznavanje sa studentskim životom, akademskim obavezama i preseljenjem u grad:

„... kad je sestra išla studirati, $i$ kad sam se upoznala sa studentskim životom, kad sam došla kod nje u stan, onda sam definitivno „,To ću i je napravit!“ ...

\footnotetext{
${ }^{106}$ Visok utjecaj na odluku o nastavku školovanja (utjecali i izrazito utjecali) za roditelje procjenjuje 57\%, za braće/sestre $31 \%$ učenika, za prijatelje $28 \%$, za nastavnike $26 \%$, a slijede školske kolege, članovi šire rodbine, dečko/cura (22\%) i prijatelji/poznanici roditelja (16\%).
} 
... mislim, fora mi je to što sam stalno s prijateljima u kontaktu, dolaze svi kod mene, ne moraju polagat' oni svojim roditeljima račune, tak' ni ja svojim.. " (Andrea, RRP_TP, 4SŠ_mg)

„... Brat [mi je studirao elektrotehniku] ... pa, on mi kaže da ... hm ... da bi možda mogao to, ali moram puno učiti, $i$ sad... al' bilo bi mi puno, puno teže nego njemu (...) Pa, možda brat, on mi je možda poticaj...

... kad sam išao jednom kod brata za vikend, onda mi je ono [studiranje] poznatije ... “ (Marijan, RRP_DSJ, 4SŠmg)

Upoznavanje sa studentskim životom, kao važan element mogućnosti zamišljanja i razvijanja osjećaja uklapanja u nove kontekste, posebno je istaknut u tim opisima u skladu sa željama učenika za promjenom dotadašnje slike o sebi i svoje pozicije. Studentski život i elementi osamostaljenja i slobode od roditeljskog nadzora, ali i za ostvarenje vlastitih pravaca djelovanja, u tom su okviru posebno privlačni učenicima, i najvećim dijelom su dio onoga što veseli vezano uz studij, a možda i dodatno oblikuje njihove težnje.

„... mislim, fora mi je to što sam stalno s prijeteljima u kontaktu, dolaze svi kod mene, ne moraju polagat oni svojim roditeljima račune, tak ni ja svojim, brat mi ne skače kad učim, mama me ne zove, ništ.. ona sva glupa pitanja „Di je daljinski? “, il' tak' nešt'..." (Andrea, RRP_TP, 4SŠ_mg)

„... da je budem na neki način slobodna... šta moj prijatelj kaže: „, Nitko ti više neće moći reć da ne hodaš bos u bijelim čarapama " (smijeh) ... da jednostavno možeš odgovarati za ono što ti radiš $i$ da svoj dan posložiš onako kako ti hoćeš..." (Anica, URP_VG, GIM_VG)

S druge strane, korisne informacije tiču se i preuzimanja odgovornosti, odnosno akademskih zahtjeva koje studiranje zahtijeva za ostvarenje obrazovnih aspiracije, no koje može djelovati s obzirom na dotadašnja školska iskustva zastrašujućim i stvoriti kod učenika osjećaje nesigurnosti, pa čak i neodlučnosti ako odluka o odlasku na studij nije čvrsta:

„... ne znam sad kad' idem na ispit... kako da padnem?... to je meni nepojmljivo... ne znam kako bi se nosila s tim... na primjer, sestra kad je na prvom roku pala ispit, ja: „,Joj, pa '"de uči!', ona onak' „A-ha “... uči kad joj se da i na drugom roku je prošla s četiri, a ja bi ono odma' krenila učit, štrebat' il' tak' neš", onda bi možda završila na psihijatriji zato što sam učila, il' tak' neš" (smijeh)... "(Andrea, RRP_TP, 4SŠ_mg)

No, postoji i element želje za društvenom mobilnošću koji slikovito opisuje Agata za koju dodatna motivacija za nastavak školovanja stvara mogućnost da će biti prva u obitelji koja će steći diplomu, no što proizvodi i dodatna strahovanja vezana uz nepoznavanje „pravila igre“ i kontradiktorne informacije iz okoline:

„,... imam baš sestru stariju koja je isto prošle godine završila ovaj smjer i ona, ono, baš nema volju za studiranjem i nikad nije to njima ni pokazivala nešto (...) Iz moje [obitelji] nije još nitko [studirao], tako da ja želim biti prva koja je otvorila to (smijeh)... 
... ne znate šta vas očekuje, hoće li to stvarno biti, ono, med i mlijeko, ili će biti: želim ići kući, ne želim više ovdje biti... svatko ima neke strahove od nečeg nepoznatog... " (Agata, URP_mg, 4SŠ_mg)

Dodatno, za učenike s nepovoljnijom strukturom obiteljskih resursa, potrebe školovanja braće i sestara, uz vlastite želje studiranja, učenike dovode u posebne konfliktne pozicije i potrebu razmatranja, pregovaranja i prilagođavanja visokoobrazovnih namjera. U najvećoj mjeri takve prilagodbe tiču se zadržavanja studiranja lokalno, odnosno regionalno:

„... razumijem i njih i financijsku situaciju, tako da, ne znam ... sad mi još ništa ne govore, ali ako mi kažu da ne mogu, na primjer, otići u Zagreb, da upišem nešto u Osijek ili da ostanem u Vukovaru, ja ću to prihvatiti...“(Marija, RRP_TP, GIM_mg)

„....[roditelji] kažu, onak': „Život u Zagrebu je jako skup, ne znamo da l' ti to možemo priuštit'..."(Andrea, RRP_TP, 4SŠ_mg)

S druge strane, s obzirom na neposredno promatranje iskustva financiranja studiranja starijih braće/sestara uokviruju i financijska razmatranja učenika s obzirom na to kako će njihovo studiranje izgledati, koliku podršku mogu očekivati i iz kojih izvora:

„... pošto moja sestra nije radila uz studij, pošto je moj tata stalno davao novce, pa mora i meni (smijeh) (...) Imat ću ja stipendiju, al' to tata isto neće znat' (smijeh) (...) mislim, [tata]on zna da sestra prima stipendiju, sestra je u studentskom domu, al' pošalje joj i tata (...), onda brat pošalje još ... “ (Andrea, RRP_TP, 4SŠ_mg)

„.... stariji brat je upisao fakultet gdje tri godine iznosi 100000 kuna (...) i onda sam razmišljao da: „, Sta ak' meni moja mama dođe i kaže: „,Ja tebe ne mogu poslat na fakultet“..? (...) Ali sad je moj stariji brat gotov sa svojim fakultetom..." (Jakov, URP_VG, GIM_VG)

Važno je ovdje podsjetiti i da nemaju svi učenici braće i/ili sestara te time nemaju nikakvih iskustava utjecaja tih drugih članova obitelji na njihovu odluku o (ne)studiranju, a njihove obiteljske dinamike dobivaju sasvim novu kvalitetu koja može utjecati i na odluke o studiranju: „... moji roditelji... ja sam jako bliska s oba svoja roditelja, mislim nemam braće $i$ sestara, i ja... mislim, stvarno smo jako bliski oduvijek (...) meni roditelji govore da će oni bilo šta napravit samo da oni mene izfinanciraju...“(Bernarda, URP_mg, GIM_mg)

No, općenito, bliskost s roditeljima i braćom/sestrama učenici i odvojenost od njih za vrijeme studiranja značajan je dio razmatranja pri donošenju odluka o studiranju:

„... plaši me pa, pa samostalan život, šta ne znam stvarno oću ja bit sposobna, znači, sve to.. hmmm... druga stvar, zato šta ću bit sama, neću imat nikog uz sebe bliskog (...) a obitelj isto neće bit blizu u nekim situacijama, pogotovo kada mi bude stvarno kriza ili nešto.. to me plaši ..." (Ivana, RRP_DSJ, 4SŠ_mg) 
„... moja obitelj živi kao pleme $i$ da će meni faliti i ono... baš sam jako vezana $i$ za maти i za tatu..." (Gordana, RRP_TP, GIM_VG)

„... Mislim da mi, ono, da ću se naviknit na takav život, jer, ono, mislim da mi, ono, neće posebno falit roditelji, a viđat ću ih ono preko vikenda, i nadam se da bi trebalo biti dobro..." (Marijan, RRP_DSJ, 4SŠ_mg)

U najvećoj mjeri o tim aspektima progovaraju upravo ruralni učenici, no također takva razmatranja se i pomiruju sa stavovima o tome kako je studiranje potreban korak u odrastanju i stjecanju obrazovanja. Tako se emocionalni elementi odluka o studiranju na osobnom planu manje pokazuju kao problem, ali se ističu kao bojazan:

„... sve zavisi od čovjeka, znači, ako.. ako niste navikli možda, to vam dođe kao nekakav šok.. sve zavisi kako su vezani netko za obitelj $i$ (...) Pa meni će biti mali šok vjerojatno zbog malo odvojenosti i.. al ovako mislim da će bit u redu jer ipak je to stepenice, to se mora prekoračit, htjeli mi - ne htjeli... moramo

(...) [binem se] A mislim da ću u jednom trenutku, ako mi ikad... da ću se vratit, možda bude predug studij... da ... jedino to..."(Mislav, RRP_DSJ,

No, općenito se pokazuju značajnim elementom koji ima utjecaj na iskustva studiranja, kako to u norveškom kontesktu pokazuje Wiborg (2006), a na Zagrebačkom sveučilištu Doolan (2009):

„... a moguće, sad ako imaju, sad ako se ne žele odvojiti tak od obitelji, da ostanu što bliže mjestu stanovanja da studiraju tak..." (Frane, URP_mg, 3SŠ_mg)

„...dok recimo, moja prijateljica, ona ne može izdržat tako, ona više-manje svaki tjedan je kod kuće...“ (Marijan, RRP_DSJ, 4SŠ_mg)

Katkada iskustva studiranja nekih drugih članova šire obitelji mogu biti značajan prozor u svijet visokog obrazovanja za učenike, bilo kao koristan izvor informacija, ili oblikovanja dojmova o studiranju i/ili poticaja na studiranje:

„... Pa, za vrijeme mog odrastanja je tetka studirala tak' da sam imao neki uvid kako je to, puno učenja i to sve..." (Andrej, URP-mg, GIM_VG)

„... Pa o studiranju jedino s tetom, ovako... ona je upravni završila faks, studij i onda sam s njom tak' .. i rekla je isto, kao, da ... bi trebao četvrtu, poslije ovaj [studij] (...) ona zna to kak'je, s njom sam se zato najviše informirao..." (Frane, URP_mg, 3SŠ_mg)

„....sestrična ide na Ekonomiju u Osijeku, bratić ide na FER, i tak' da... svi su onak' na mene baš kao: „, To ti je dobro“", kao, „, Bit će ti super!“", i stvarno baš su mi (...) itekako korisni... stvarno, što god me zanimalo, uvijek su mi rekli, $i$, ono, ne znam... čak i ako me nije zanimalo oni su mi sve objasnili, i onda sam se počela nekak' više interesirat za to ..." (Ivana, RRP_DSJ, 4SŠ_mg) 
S druge strane, učenici koji će biti druga generacija studenata u daleko većoj mjeri se oslanjaju na informacije iz obiteljskog kruga, kada su u pitanju općenite informacije o visokom obrazovanju, i kruga prijatelja kada su potrebne referentne točke s obzirom na vlastite odluke. Dakle, takve informacije ne moraju djelovati direktnim poticajima već na mnogo suptilnijoj razini usporedbe i/ili usklađivanja vlastitih viđenja o vrijednosti određenih odluka i tuđih mišljenja o njima, te vlastitih nastojanja s onima drugih prijatelja. Sličan obrazac pokazuju i kvantitativne analize na dimenziji urbano-ruralno: prema utjecaju pojedinačnih osoba iz različitih učeničkih krugova, postoje značajne ispitivane urbano-ruralne razlike (Slika 4.8).

Prosječno, i statistički značajno različito, učenici urbanog rezidencijalnog podrijetla skloniji su procjenama da su njihovi roditelji imali utjecaj na njihovu odluku o tome da li studirati ili ne $\left(M_{U R P}=3,7\right)$, dok su učenici ruralnog rezidencijalnog podrijetla skloniji bili taj utjecaj procjenjivati ambivalentnije $\left(\mathrm{M}_{\mathrm{RRP}}=3,3\right)$. Povežemo li to s prethodnim analizama, ukazuje se važnost roditelja pri usmjeravanju prema visokom obrazovanju, ali koji su širi od same uključenosti u školske aktivnosti djece, te (deklarativnog) poticanja studiranja, prema čemu su obitelji učenika jednako poticajne bez obzira na rezidencijalno podrijetlo. Također, urbani učenici višim, odnosno osrednjim, procjenjuju ( $\left.M_{U R P}=2,7>M_{R R P}=2,4\right)$ utjecaj svojih prijatelja na odluku o studiranju, u odnosu na učenike ruralnog rezidencijalnog podrijetla. S druge strane, iako im se pripisuje slab utjecaj na odluku o studiranju, utjecaj susjeda i stručnih suradnika u školi snažniji je u slučaju odluka učenika ruralnog rezidencijalnog podrijetla $\left(\mathrm{M}_{\mathrm{RRP}}=2>\mathrm{M}_{\mathrm{URP}}=1,7\right)$. Analiza ukazuje da za učenike koji odrastaju u ruralnim naseljima, $\mathrm{i}$ čija je struktura obiteljskih i školskih resursa općenito nepovoljnija, osobe iz institucionalnog školskog (no uglavnom ne školski kolege) te bližeg rezidencijalnog okruženja (susjedstvo) mogu biti važan socijalni resurs i simbolički utjecaj za donošenje odluke o (ne)studiranju.

Time značajno viši utjecaj na odluku o studiranju učenika urbanog rezidencijalnog podrijetla imaju bliske osobe obiteljskog i prijateljskog kruga, što su uvelike i oslonci učenika koji su druga generacija studenata $\mathrm{i} / \mathrm{ili}$ onih koji pohađaju škole koje ih direktnije usmjeravaju prema visokom obrazovanju. „Mješoviti podaci“ ove studije ukazuju kako se značajan roditeljski utjecaj odražava kao rano usmjeravanje obrazovnih putova visokoobrazovno orijentiranih učenika u gimnazijsko obrazovanje što je kontekst ključan za razvoj osnovnih znanja, sposobnosti i osobina koje su korisne i nagrađuju se u procesu selektiranja učenika za i kasnije u visokom obrazovanju. To je u većoj mjeri karakteristično za učenike urbanog 
rezidencijalnog podrijetla koji se općenito mogu u svojim obiteljima osloniti na veći raspon resursa u ostvarivanju svojih visokoobrazovnih planova. Dodatno, utjecaj prijatelja, pak, koji su većini gimnazijalaca i školske kolege pokazuje se poticajnim s obzirom na nužnost studiranja, prijenos informacija te pružanjem osnovne referentne točke, ali i pozitivne konkurencije, a za postizanje boljih obrazovnih ishoda. Ali bitan dio toga je i razvoj posebnog (K) gimnazijskog identiteta, osjećaja „mi“ nasuprot „njih“, čega je sastavni dio osjećaj zaslužnosti i samouvjerenosti i svijest o razlikama u svjetonazorima, ponašanjima, interesima:

„..zapravo se i družim većinom s gimnazijalcima ... nekako ne mogu nać' neki zajednički jeziks, ne znam, nekim drugim školama... bio sam u domu i pokušao, ali ne ide, ne znam... Zato što, kada smo u gimnaziji ili smo intelektualci ili se smatramo intelektualcima što su nam tako rekli, ali i koji se smatraju intelektualcima opet se trude biti intelektualci tako da... s njima mogu porazgovarati makar ovako... mislim, ja sebe smatram intelektualcem $i$ zato, ne znam ... tako bi tekao razgovor..." (Andrej, URP_mg, GIM_VG)

„... primjerice ovi ljudi koji su završavali industrijsku školu, jednostavno smo tokom srednjoškolskog školovanja se udaljili (...) jednostavno više nema tog nekog kontakta, toga ... ono, svo društvo je iz razreda i prijatelji se nalaze u ovoj školi, ovaj... a izvan ove škole, mislim da ima, pa da troje prijatelja koji su ili završili ovu školu pa su na fakultetu trenutno, ili su jednostavno, primjerice, će sad upisat srednju školu, ali dakle nisu.... Društvo se uglavnom bazira na društvu iz gimnazije..." (Jakov, URP_VG, GIM_VG)

„... kada idem školu prolazim odavde, lijevo, i pokraj obrtničke škole, s njima smo u smjeni je l'.. i onda oni stoje i gledaju: „Ha vidi gimbača! Ha vidi torbu tešku punu knjiga nosi! Ha, ha, ha! "; oni zapravo nas sprdaju , izruguju... ja ne želim omalovažavati, ali mi smo iznad njih, realno, bit' ćemo! (...) ne može meni, ne znam, neki strojar, poljoprivrednik ismijavati jer idem u dobru školu... to je apsolutno nelogično!.. " (Bernarda, URP_mg, GIM_mg)

S druge strane, učenicima strukovnih škola u većoj mjeri prijatelji nisu i školske kolege, osim u slučajevima pohađanja škola koje se smatraju ,dobrim školama“ koje pripremaju za struku i otvaraju perspektive studiranju, pogotovo ako se radi o strukama cijenjenima u društvu i s perspektivom boljeg zapošljavanja. Te slučajeve predstavljaju Mislav i Silvija, oboje učenici ruralnog rezidencijalnog podrijetla koji škole pohađaju u velikim regionalnim gradovima, a što je posebno za Silviju imalo značajan utjecaj (K) životnih iskustava koji su je oblikovali slično prethodno opisanima za gimnazijalce - značili su izmještanje iz sredine koja je bila nepoticajna, i u institucionalni kontekst koji joj znači „rang gore“, a dodatno otvara mogućnosti daljnjeg (K) napredovanja „dalje i višse“.

„,... ja sam u osnovnoj školi bila, kak da kažem, nisam pričala, i tak... imala sam neke svoje faze.. hmmm (...) na neki način i ovi iz sela, kao: „Ti ni ne pričaš, di ćeš ti škole 
završit?", ovo, ono... međutim, kad sam ja krenila u srednju, kad sam ja upoznala svu ovu ludu ekipu iz razreda (...) mislim da me to čak ono, i izvuklo..." (Silvija, RRP_TP, 4SŠ_VG)

Intervjuirani učenici kao cjelina bili su skloniji slabijim procjenjivati i utjecaj prijatelja/ kolega, te nastavnika na svoju odluku, te tek po 4 učenika procjenjuje utjecaj prijatelja $\mathrm{i}$ nastavnika snažnijim. Ipak, taj utjecaj ključnim se pokazuje za određene učenike s visokoobrazovnim orijentacijama, i načinom kako je njihov obrazovni put oblikovan.

Bitno je dublje razmotriti taj utjecaj koji imaju prijatelji odnosno (K) ljudi s kojima se družim na učeničke odluke o visokom obrazovanju, ili još značajnije na sveopću visokoobrazovnu orijentaciju posebno za učenike odrasle na selu ili one koji općenito svoje mjesto doživljavaju „ruralnim“ s obzirom na bitne aspekte te sredine kao konteksta koji ih stavlja u nepovoljnu poziciju s obzirom na njihove obrazovne aspiracije i opće vrednovanje obrazovanja.

Gordana, učenica koja iznimno naglašava značaj obrazovanja kao bitni aspekt svoje slike o sebi, značajno ističe nepripadanje u svoju ruralnu zajednicu $\mathrm{i}$ opisuje proces $(\mathrm{K})$ „,iskorijenjivanja“ koji je označilo njeno upisivanje gimnazije u velikom gradu:

„... prije dok sam možda još $i$ išla u osnovnu školu onda sam se još i družila s ljudima iz sela $i$ iz okolice... hmmm... trenirala sam, i ono, klasika, druženje - dijete k'o dijete... međutim, kada sam krenila u srednju školu, onda promijenila sam društvo i vidjela sam kako su mi se gradili svjetonazori, i da možda oni... ja imam jednog prijatelja koji ide sa mnom u gimnaziju $i$ to je zapravo jedini s kojim se družim $i$ njegova sestra koja je završila gimnaziju, ovaj, ide sada na fakultet... hmmm... jedino se mi međusobno družimo tamo, s ovim ostalima baš ne mogu naći nekakav zajednički jezik ili zajedničku temu, tako da ... a mislim $i$ ne osjećam neku pretjeranu potrebu da se tamo družim s njima... " (Gordana, RRP_TP, GIM_VG)

Ona izgrađuje čvrsti gimnazijski identitet vezama ljudi s kojima se druži i mjestima u kojima provodi većinu vremena „... općenito se družim... društvo mi je iz grada...“. Pohađanje gimnazije u velikom gradu joj je omogućilo podršku u njenim visokoobrazovnim stremljenjima:

„,... svi su [prijatelji]uglavnom u školi, i svi su usmjereni baš , eto fakulteti, prvenstveno Zagreb, i to je... imamo mi klapu medicinara (smijeh), i eto (...) uglavnom se tako formiramo svi... znamo što nam to donosi i težimo tome... "(Gordana, RRP_TP, GIM_VG)

U sličnom pravcu o značaju koji izvanobiteljski kontekst ima za njegovanje visokoobrazovnih orijentacija ukazuju i Andrejevi te Marijini iskazi, čiji je obrazovni put Gordaninom sličan „,izmještanjem“ iz konteksta koji se procjenjuju manje obrazovno poticajnima, odnosno siromašnijima mogućnostima, pogotovo kvalitetnim i uvelike „ruralnima“. Gordana je svoje 
školovanje odabrala u velikom gradu i gimnaziji koja ja prema shvaćanjima učenika jedna od „visoko statusnih“ u regiji, iako se nije preselila. Andrej i Marija učinili su i dodatan korak, iako pod različitim okolnostima, i s dodatnim opterećenjima, te se preselili u dom. Ta iskustva značajan su dio (K) životnih iskustava koji su ih oblikovali, i koji su umnogome značili odvajanje od načina života s kojim su odrasli radi obrazovanja. U toj situaciji ranog napuštanja doma radi obrazovanja, osnažuje njihovu „gimnazijsku identifikaciju“, koja postaje očita u kontekstu doma: oboje ukazuju na teškoće situacije u kojoj je teško pronaći zajednički jezik s drugim osobama koji nisu gimnazijalci i imaju drugačije adolescentske interese:

„...zapravo se $i$ družim većinom s gimnazijalcima ... nekako ne mogu nać neki zajednički jeziks, ne znam, nekim drugim školama... bio sam u domu i pokušao, ali ne ne ide, ne znam..." (Andrej, URP_mg, GIM_VG)

Marijini izbori su u većoj mjeri izraz kompromisa između želje za pohađanjem gimnazije i dostupnosti željenog obrazovanja, odnosno financijskih teškoća podmirenja troškova obrazovanja. Njene odluke usklađene su s njenim visokoobrazovnim ciljevima, s jedne, i dostupnim obiteljskim resursima, s druge. Sama iskustva srednjoškolskog obrazovanja pod njihovim utjecajima pokazuju se ipak ograničenijima u nekim aspektima. S pozitivne strane, institucionalni kontekst učeničkog doma omogućio je pristup stručnom osoblju koje je informacijama djelovalo u pravcu razvoja određenih visokoobrazovanih želja učenice, koje su prvotno bile ograničene onime što je mogla vidjeti u svojoj zajednici odrastanja - biti učiteljica. No na drugoj strani, s obzirom da je bila jedina gimnazijalka u domu, teže joj je bilo održavati prijateljstva s ostalima koji su imali manje akademskih obveza. Na taj način, njeno školovanje je prouzročilo određene konfliktne odnose između težnje za obrazovanjem uz rano napuštanje doma, razvijanje identitetskih odrednica gimnazijalke u kontekstu koji posprdno određuje i obrazovna stremljenja i njene identitetske odrednice ruralnog podrijetla: „...kada sam rekla iz kojeg sam sela, prvo su mislili da se šalim, nitko nije nikad ni čuo za to selo... na primjer, meni nije sramota reći odakle sam ja ... al' ja stojim iza toga što sam sa sela...“(Marija, RRP_TP, GIM_mg). Dijelom, Marija se već u srednjoškolskom obrazovanju nalazi između mjesta, podijeljena oko pripadanja svojoj zajednici s kojom pronalazi sve manje dodirnih točaka: „...ima nas [mladih] na prste jedne ruke nas možete izbrojati... i svi su ovako otišli studirati u neke veće gradove... nitko se ne zadržava (...) na primjer cure, ne idu... neki idu na fakultet, neki su već završili srednju školu, ne planiraju dalje, ne znam hoće li se udat ili nešto... “ , te je možda njen ulazak u visoko obrazovanje olakšan interpretacijom „normalizacije“ njenog puta koji slijede i ostale djevojke iz njene zajednice. 
Slično, i Andrea i Aneta, visokoobrazovno orijentirane učenice, razlikuju utjecaj prijatelja i školskih kolega jer pohađaju strukovne škole u kojima utjecaj školskih kolega na svoju odluku o studiranju ne procjenjuju značajnom. Obje učenice razmatrale su upisivanje gimnazija, ali su odustale od tog obrazovnog pravca, i u trenutku odlučivanja o nastavku školovanja svoju poziciju procjenjuju u velikoj mjeri nepogodnom kada je u pitanju uspjeh njihovih visokoobrazovnih namjera. Unatoč tome, što u svom srednjoškolskom kontekstu ne vide podršku školskih kolega, ostale osobe institucionalnog konteksta, a pogotovo stručni suradnici, čine se značajnim izvorom informacija i općenito podrške njihovim visokoobrazovnim željama. S druge strane, prijateljski utjecaj je osjetan, ali se izražava kao (K) ljudi s kojima se družim, što znači ograničavanje na određeni krug prijatelja koji imaju slične izbore njihovima:

„... [u moj krug ljudi ne spadaju] na primjer, ljudi koji ne vide fakultet kao nešto što će im... nešto dobro... nešto što će im pomoći.. hmmm, ne znam, netko tko ne razmišlja baš puno o budućnosti nego samo ono, sadašnjost, partiji i tako to..."(Aneta, URP_mg, 4SŠ_mg)

Općenito, učenici strukovnih škola koji namjeravaju studirati, a pohađaju škole u kojima se manjina odlučuje na to, mogu doživjeti svoju okolinu iznimno nepoticajnom i otežavajućom:

„... misle [kolege] da sam glup što 'oću dalje upisati, zato što oni neće dalje upisati... tak'... u biti njima smeta zato što oni ne mogu upisati, a ja hoću upisati..." (Dominik, RRP_DSJ,

Nasuprot procjenama uzorka anketiranih slavonskih maturanata, stručni suradnici u školama su osobe koje su za ovaj skup intervjuiranih učenika pokazale relativno najveći značaj te ih 7 iznadprosječno procjenjuje njihov utjecaj na svoje odluke, iako samo dvije učenice taj utjecaj smatraju iznimnim - učenice ruralnog rezidencijalnog podrijetla koje pokazuju visokoobrazovnu orijentaciju i imaju visoke aspiracije. Među ostalima prevladavaju učenici ruralnog podrijetla ili učenici slabije dostupnosti različitim oblicima obiteljskih resursa.

„,... pa jedini 'ko me saslušao ovdje mislim samo pedagoginja i blagajnik, ne pedagoginja, tajnica, oni su rekli isto da bi bilo dobro, a moj razrednik i ovak' ostali profesori baš nisu gledali ništa... ovaj... obećavajuće u meni... “(Dominik, RRP_TP, 3SŠ_mg) 


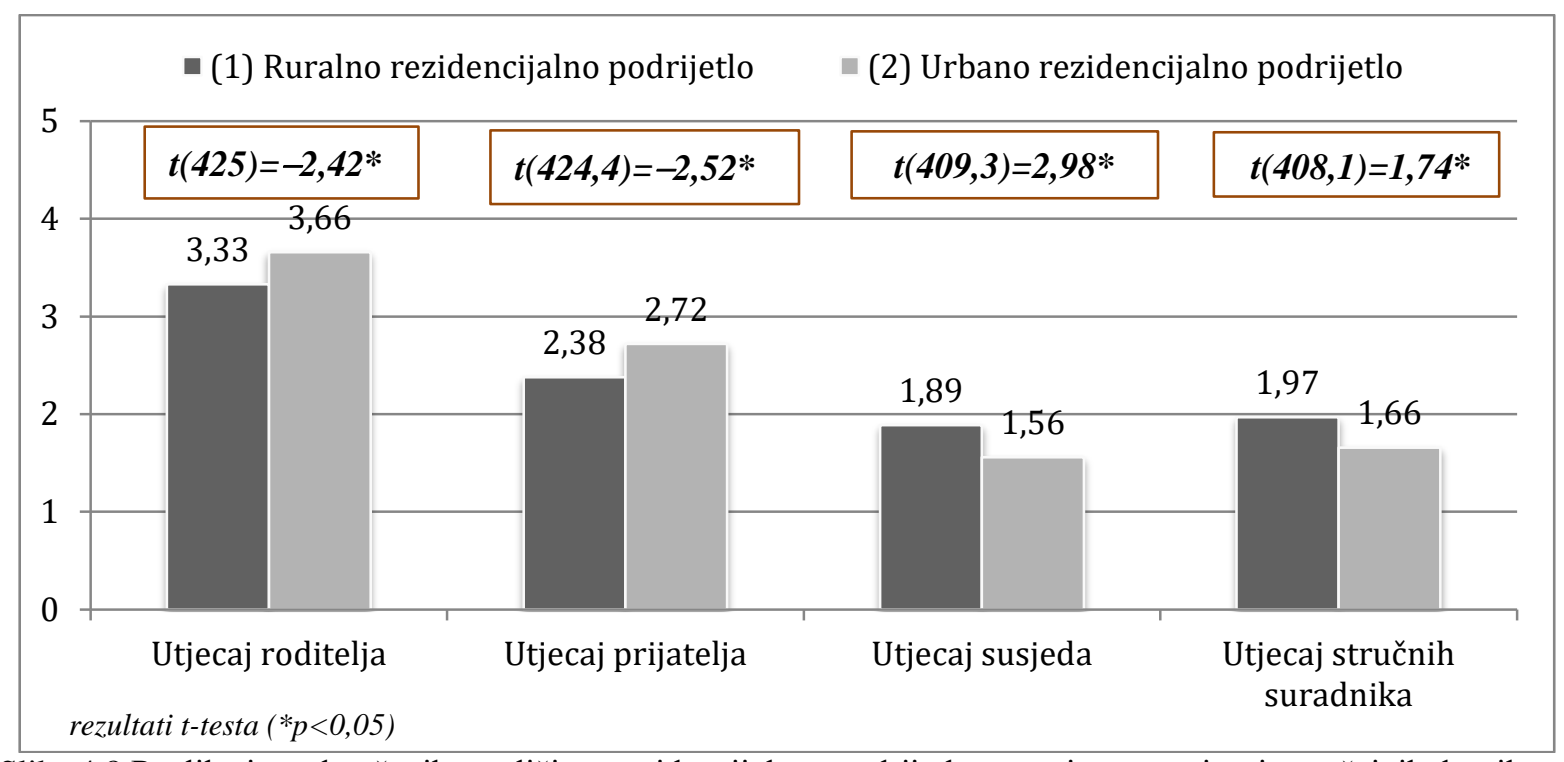

Slika 4.8 Razlike između učenika različitog rezidencijalnog podrijetla u procjenama utjecaja značajnih drugih na njihovu odluku o studiranju ${ }^{107}$

Kako su već ranije istakli neki učenici, nepovoljne okolnosti vezane uz odluku o studiranju vezuju se uz to kako druge osobe procjenjuju nečije sposobnosti i osobine označavajući ih onima koji jesu ili nisu za studiranje. To je osnovni proces u pozadini odluka koji se pregovara kroz cijeli proces obrazovanja i učenika samoga sa sobom i s okolinom s obzirom na svoje školske i obiteljske pozicije. Stoga (K) ljudi s kojima se družim ima ključnu ulogu za učenike jer to postavlja temu studiranja na dnevni red, oblikuje slike o studiranju, definira one zaslužne, informira mogućnosti i prepreke, osigurava podršku, pomoć i pravac djelovanja. Posebno su značajne jer tek kod odnose s drugim ljudima mladi uspostavljaju odrednice svoga identiteta, koji se stvara i postiže u stalnom procesu kroz individualne izbore i u interakciji s drugima (Wiborg 2003).

U intervjuima je tako istaknut problem koji učenicima ruralnog rezidencijalnog podrijetla čine poticaji iz okoline, katkada vezani uz podcjenjivanje značaja obrazovanja, a katkada vezano uz nedostatak ljudi koji mogu biti primjer ili dati koristan savjet. U općenito nepovoljnim uvjetima za nastavak studuiranja, Dominik ukazuje kako nedostatak visokoobrazovanih osoba može biti posebna prepreka kada je u pitanju donošenje odluke o studiranju.

„,... Ne, ne poznajem nikoga tak, s takvim, višom školom... Ne, osim ovog mog jednog prijatelja, ali on je upisao gimnaziju... ne znam ovak' nikog da je išao na fakultet... Pa, ako nema nikoga u selu, onda nemam s kime da razgovaram o tome...

... Susjed.. da... on ima višu završenu školu pa... njegova žena i on, oni su me... oni su baš isto dolazili... on je htio da upišem za fizioterapeuta, ali preko biroa, ovaj, 6 mjeseci obuka, iš'o tamo na ispit u školu, treba položit', a ostale dane bi išao na praksu... oni su rekli

\footnotetext{
${ }^{107}$ Prikazuju se samo rezultati statistički značajnih testova.
} 
da bi bilo jako dobro da upišem dalje, a ovak' ostali - nitko nije rekao ništa... mislim iz mog sela..." (Dominik, RRP_DSJ, 3SŠ_mg)

Prethodnim citatom koji iznosi Dominik ilustracija je statistički istaknute značajne razlike prema kojoj su učenicima ruralnog rezidencijalnog značajne osobe poput susjeda. Ostali učenici ruralnog rezidencijalnog podrijetla također će istaknuti upravo sredine svoga odrastanja i manjak visokoobrazovanih u svojim slikama ruralnoga kao veliki problem. Kod nekih će on izazvati ambivalentne reakcije jer su i sami utjecaji kontradiktorni, no katkada će izazivati iznimno negativne reakcije učenika, i njihovo oslikavanje svojih mjesta odrastanja „zaostalima“ i, ,primitivnima“:

„...Pa ne baš (smijeh) ne [znači mi podrška iz okoline], zato što ja najviše vjerujem sebi, ne baš drugima ... zato što su ljudi primitivni po mom mišljenju...Pa ljudi svi gledaju za sebe, svi bi htjeli: ,, 'Ajd' upiši ti, ne znam, neku goru školu, a ja ću bolju “, il' tak'... nitko ne bi bio realan... nitko te ne bi podržao, jako je malo takvih ljudi, po mom mišljenju...

...ljudi oko mene, većinom u [mom selu] nisu neki obrazovani ljudi... svi su završili neke trogodišnje škole, rijetko tko je završio neki fakultet, i oni koji su, oni su neki daljnji susjedi, uglavnom ne pričamo nešto o tome...

... Pa pozitivno, normalno gledaju [na studiranje] ... Pa normalno zato što nekad znaju: „, A, ti si s fakulteta, ti si uzvišena “, il' tak' neš", a nekad onak'... zavisi kako... “" (Andrea, RRP_TP, 4SŠ_mg)

Općenito, u slici slavonskog sela u učeničkim očima vrlo je istaknuta neobrazovanost, nedostatak mladih i nedostatak visokoobrazovanih. Takve slike mogu djelovati na smanjenje aspiracija, no o njima progovaraju učenici samo kada ističu utjecaje koje okolina ima na smanjenje odluka o obrazovanju i/ili nastavku studiranja drugih učenika iz ,ruralnih sredina“:

„... mislim financije očito [utječu na odluku o studiranju], ali... $i$, ne znam, možda $i$ sredina u kojoj žive ... ne znam, valjda vide budućnost u vinogradima, i poljoprivredi, ili možda nisu bili dovoljno u svijetu da shvate da je potrebno imati neko znanje, da su zadovoljni s onim što imaju tamo i da će tamo i ostati..."(Andrej, URP_mg, GIM_VG)

Andrej u svom iskazu vrlo jasno suprotstavlja „znanje“ i „bivanje u svijet“ nasuprot „poljoprivredi, vinogradima“ i „ostanku“, te ističe potrebu obrazovanja i mobilnosti koja se posve uklapa u njegove životne planove i s njegovim iskustvima odrastanja u malom gradu, školovanja u velikom gradu te studiranja u glavnom gradu. Na taj način, i nasuprot tim slikama, izgrađuje i sliku svoje „urbane“ budućnosti: „.. mislim da ću se tu negdje motat po Europi, mislim da ... želim biti u gradu u kojem nije bitno dal je noć, mogu otić i kupit si sladoled, ne znam..." Njegova visokoobrazovna orijentacija pokazuje se kao potvrda njegovog prostornog identiteta koji se habitusno oblikuje slikama o širim prostorima i učenjem toga da svoju zajednicu vidi apstraktnom, a dodatno je potaknuta iskustvom života 
kao osobe druge boje kože i nacionalnosti u vrlo rasno i nacionalno homogenom društvu. On jasno uspostavlja društveno razlikovanje u odnosu na svoju zajednicu u kategorijama mobilnosti, i temelje za izgradnju svoga identiteta nalazi u mobilnosti i potrazi za kozmopolitizmom. Njegova povoljna društvena i kulturna pozoicija na određene načine označava mjesta i prostore koje koristi za oblikovanje svoga identiteta (Wiborg 2003).

Vrlo slično, i Andrea preuzima značenja koja pripisuje prostorima i mjestima, kroz razlikovanje provincije i metropole, za izgradnju slike o sebi kao osobe koja ne pripada u kulturne okvire svoje zajednice i teži za daleko neodređenijim izmještanjem u prostoru putem obrazovanja koje bi potvrdilo njeno razlikovanje od zajednice:

„... živim na selu, u selu su ljudi svi onak za poljoprivredu, niš ne gledaju sa strane zakona, nego sve gledaju sa svoje strane, zašto se iznio zakon ili nešto, bezveze (...) ljudi kad idu svi se za bulje u tebe, nikog više ne doživljavaš onak, kao što u Zagrebu... ovi sa sela svi: „, Gle šta je obuko?? “, a u Zagrebu niš ne gledaš, sam prolaziš, nije te briga za čovjeka pored, ili nešto... i imaju više... mo"š više stvari vidjet, na primjer, kod nas na selu kad bi vidjeli homoseksualca, oni bi ga utukli.. u Zagrebu, ono, to, mislim, osim onih skinjara, oni bi, ali svi ovi ostali oni gledaju s pozitivne strane ko što ja gledam pozitivno na njih.. ovi u selu našem.. to nikom niš... ja mislim da kad je bio referendum da jedino moj glas je bio za, to jest protiv.. tak da, ima više tih stvari koje se može vidjeti, na koje nećeš gledat sa čuđenjem... na primjer, kad prolazi osoba s invaliditetom u selu svi na prozor gledaju nekoga sa invaliditetom čovjeka koji je, onak, u kolicima sa ... a u Zagrebu to nije tak, gledaš čovjeka normalno, ko svakog čovjeka..." (Andrea, RRP_TP, 4SŠ_mg).

Poput Andreja, učenica naglašava uskogrudnost ruralne sredine i potragu za širim vidicima, ali s određenom dozom odnosa prema svojoj zajednici čime je njena želja za obrazovanjem značajnije istaknuta kao potvrda lokalnog ne-identiteta:

„... jedva čekam doć sa diplomom, i onak, lijepo uzvišeno hodati, onda da oni svi gledaju: „, Gle ova je tu.. što se umislila“ “(...) njih koji imaju sve neke svoje predrasude, cijelo vrijeme ogovaraju, kao što sam već rekla, svi o svakom sve znaju. onda jedva čekam doć u selo i onda da onak: „Imam diplomu“, da oni svi pričaju o meni..." (Andrea, RRP_TP, 4SŠ_mg)

Slično će istaknuti i neki drugi učenici, no koji ipak prepoznaju rodne razlike utjecaja sredine, te koje mogu biti uzor vlastitih planova:

„... stav kod dečki je nikakav, cure koje znam, znači, njih 5 iz sela je već na fakultetu, a njih 2 su uspješno diplomirale, ove ostale sad, jel, idu na fakultet, ostalih (...) mislim da, oni su... previše žive načinom, na način kako im žive roditelji, znači: bit ću kod kuće, radit ću zemlju, to je sve što ću znat' u životu, tako da... mislim da nemaju ni stav, ili kad bi pitala nekoga... puno njih nije završilo ni srednju školu... “ (Silvija, RRP_TP, 4SŠ_VG)

I ova učenica suprotstavlja obrazovanje „način života roditelja“, što se također odražava u njenim slikama svojih budućih planova koji su također obilježeni (K) napredovanjem više i 
dalje: „... planiram što više ovdje školu završiti, znači ne ostati na 3 ako mogu na 5 i na nešto više, $i$ otići raditi negdje van gdje ljudi cijene rad, a ne ostat ovdje $i$ visit na Birou..." (Silvija, RRP_TP, 4SŠ_VG). A to je čini se putanja koja oblikuje slike mnogih mladih Slavonaca, pri čemu ipak postoji i rodna dimenzija razlika u tome što su djevojke te koje prvenstveno odlaze na studiranje. One koje ostaju predstavljaju „negativan primjer“ i nemobilnosti, i nesamostalnosti, pa dakle neodraslosti, a koji dodatno utvrđuju sliku u kojoj diploma ima malu vrijednost u seoskoj sredini:

„... imam jedan negativan primjer djevojke koja je... išla je u ovu školu, prolazila sve $s$ peticama, Ekonomski fakultet sve s peticama, i nije joj se otvorila prilika da radi u svojoj struci, $i$, negdje ovdje u okolici (...) i ona je trenutno nezaposlena već godinama, ali to je njezina krivnja jer se ne želi odvojiti od kuće (...) i ako već nema posla.. al stvarno, teško je naći zaposlenje visoko obrazovnom čovjeku a da to nije, ne znam, ili škola ili banka, a kolko toga ima na selu..." (Gordana, RRP_TP, GIM_VG)

Stoga će katkada učenice naći na nerazumijevanje u svojim okolinama s obzirom na njihove planove:

„... Pa uglavnom, tamo na selu, svi su malo zaostaliji.. pa onda ... pa zaostaliji u smislu... kad sam otišla u srednju školu: „Zašto baš u [grad udaljen 70 km]?, imaš još,... bolje da si ostala pomagat, ne znam, tako neke kućanske poslove mami ili nešto ", $i$ onda „Zašto još i studirat? 'E l' ti nije dosta škole? Možeš se zaposliti i ovako“... “ (Marija, RRP_TP, GIM_mg)

„... ono kad te pitaju ljudi: „Joj, šta ćeš sad? Šta ovo, šta ono“, i onda kad im kažeš, neki će te špotavat, neki će reći: „,Joj super!'”, neki onak, boli ih briga što... pitali su te čisto iz znatiželje, da znaju kak vodiš život..." (Silva, RRP_TP, 4SŠ_VG)

Iako, utjecaje zajednice je teško tako direktno odrediti i vrlo često su mnogovrsni, te se učenici sučeljavaju s različitim stavovima o obrazovanju, pri čemu se ono s jedne strane smatra manje vrijednim u odnosu na rad i ostanak, a s druge strane se vrednuje kao nešto što donosi bolje prilike. Kod visokoobrazovno orijentiranih učenika, nadvladava stav da je studiranje potrebno u prostoru i vremenu u kojima se nalaze, ali je manje mjesno značajno:

„... Pa mogu reći da imam podršku, zapravo... jer ja sam i sa sela, i sve je tamo gotovo, ima eventualno nekoliko ljudi koji su završili fakultet, ali i oni su ostali usko vezani uz svoju zajednicu bez da idu negdje dalje, i oni... završili su to, i oni, ono, razumiju o čemu se tu radi... zapravo mogu reći da imam i podršku i razumijevanje od njih... (...) znaju, mislim, da to i donosi bolje prilike u životu, pogotovo sada kada je ovakva situacija...

(...) prema fakultetu to što kažu: „Ako nemaš vezu, ne mo"'š uspjet'! “, kako: „, Vidi kol'ki su završavali fakultet, stoje nezaposleni! Šta i ti bezveze tu ... mo"šs ostat nezaposlena! “, ovo-ono.. tako, eto po tom pitanju, nalazimo nerazumijevanje... " (Gordana, RRP_TP, GIM_VG) 
„,... ima nekih ljudi koji su uvijek tvrdoglavi, i oni kažu: „Nemoj ič“... al to su većinom, kako bi reko, neki primitivni ljudi - oni ne razumiju, oni žive u nekih svojih... u svojoj kući, i imaju takvo okruženje koje nije baš nekako pozitivno da reagira [studiranje]... ... al ovako, na primjer, ostali, oni me podržavaju... pa znaju da nema posla i da se mora... moramo nešto stvorit, nešt novo, i tako da...

... ja razumijem ljude, oni kažu „,Nemoj ić na fakultet! “, pa ja njega razumijem, kod njega nitko nije išao na fakultet, znači, njegova djeca nisu išla na fakultet.. pa ja znam da ta osoba ne zna šta će drugo reć' i ona kaže meni svoje iskustvo života... ja poštujem njegovo iskustvo života, i oni će valjda poštivati moj kad ja odem na fakultet... " (Mislav, RRP_DSJ, 4SŠ_VG)

Ipak, među intervjuiranima postoje i dva zanimljiva primjera u kojima se diploma pojavljuje kao potvrda lokalnog identiteta iako s posve različitim osnovnim poticajima i vezama s određivanjem društvenog statusa svojih obitelji i sebe. S jedne strane, radi se o učeniku koji zbog visoke razine kulturnog (visokoobrazovani roditelji) te prvenstveno njihova društvenog statusa u zajednici i društvenom kapitalu koji se iskazuje uz obavljanje značajne uloge i uključenost $\mathrm{u}$ zajednicu te povezuje šire prostore poznanstava i prijeteljstava $(, \ldots z b o g$ kvalitete društva, znači, ne nalazimo se sad u lošem društvu, nemamo nikakvih sukoba $i$ jednino po tom sam išo.. znači, većinom dobri smo s ljudima i oca, znači, svi poštivaju mog oca, poštivaju zato što je bio i načelnik i bio je dosta ljudi pomogao (...) tatino društvo, i tu veterinari dolaze često kod nas, tako da ... otac moj ima isto zato puno prijatelja, i po državi, $i$ van ove naše države, svuda ima puno prijatelja..."), te po uzoru na svoga oca želi diplomom osigurati jednaki društveni status, poljoprivredni način života i potvrditi svoj lokalni identitet:

„... mislim završit fakultet i tako neš kod sebe, malo obnovit zdanje, znači, uvest neki... svježu krv, kako bi reko, da se može to još malo... uspijemo nadogradit i sačuvat to što imamo..."(Mislav, RRP_DSJ, 4SŠ_VG)

Nasuprot tome, Ivana učenica s daleko nepovoljnijom strukturom obiteljskih kapitala, će sličnim kriterijima odrediti društveni status svojih roditelja, ali u smislu nedostatka:

„... tata nije rodom iz mog sela (...) i kada je došao tu ljudi ga baš i nisu prihvaćali... jednostavno, ne znam ni ja zašto (...)više čujemo o sebi samima neke stvari koje mi ne znamo o sebi... ljudi previše izmišljaju nešt i onda nismo baš omiljeni (...)

... primjer, netko tko je stvarno, kako bi rekla, dobar sa svima i netko tko ima i dobro financijsko stanje normalno da će bit, poželjan u društvu i da će ono svi, ne znam, kao htjet $s$ njim bit u društvu i pričat s njim (...) nego s nekim, eto primjer, stausa kao što smo mi ...

... primjer, neka osoba ima dobar status, znači, financijski i u društvu, i neko sad dođe drugi, i svidi mu se ta osoba, pomoć će mu u traženju posla, u nečem, na primjer, kad bi moja mama došla tamo, stali bi i gledali u nju: , Šta si ti došla?“..."(Ivana, RRP_DSJ, 4SŠ_mg

Upravo u nedostatku prihvaćenosti u zajednicu i nedostatku prijeteljskih mreža svojih roditelja koju povezuje i kao uzrok i kao posljedicu s lošom ekonomskom obiteljskom 
situacijom, motivacijski razvija ideju da bi diploma možda značila njenu dublju prihvaćenost u zajednicu iz koje se osjeća isključeno.

U ruralnom kontekstu, takve mreže roditelja (prijateljske i one koje omogućavaju dobivanje posla, te cijenjenost nečijeg obavljanja posla i odnosa prema poslu i ljudima pojavljuju se među najznačajnijim odrednicama društvenog statusa u učeničkim iskazima, a posebno kod učenika s ekonomski slabijim obiteljskim resursima. Za određene učenike, oslanjanje na takve vrste društvenih kapitala roditelja svakako predstavlja značajan izvor perspektiva za zapošljevanje, a velikim dijelom se mogu interpretirati, osloncem na Corbetta (2000) kao tradicionalni načini učenja praktičnog rada izvan formalnog obrazovanja, i nasuprot njemu, i tradicionalnog načina pronalaska zapošljavanja u lokalnom kontekstu. Ono je važan dio procesa habitusnog prijenosa u radničkim obiteljima ruralnih zajednica:

„... kad bi trebo ocijenit svoje roditelje ... njih stvarno zovu svugdje da idu raditi, baš ono... poznaju ih ljudi tak da, a preko mojih roditelja oni upoznaju mene jer s njima idem ja radit. i evo, moji roditelji, sad su radili kod jednog čovjeka $u[X]$ i ja sam išao isto raditi.. ipak dodatna zarada... (Dominik, RRP_DSJ, 3SŠ_mg)

te izraz lokalnog (maskulinog) identiteta koji može biti prepreka razvoju ili u sukobu s donošenjem odluke o studiranju:

... aktivan sam, volim raditi, većinom neke teške poslove... lagani poso, to me baš ne zanima, nije opterećenje, ono, za tijelo, više volim baš teške poslove (...) bio sam sa očuhom prije nekih mjesec dana rušio nadstrešnicu, a taj sam dan trebo otić na praksu, a na praksi je dosadno, nema ništa onako teško pa sam radije otišo rušit nadstrešnicu ... ipak, ima grede tam, to treba nosit, pa onda to je teško, otišli smo pomoći radije... jest da sam dobio neopravdano, al kog briga, bar sam pomogao..."(Dominik, RRP_DSJ, 3SŠ_mg)

Na općoj razini, učenici ističu da se svakako teže odlučiti onima koji odrastaju na selu na studiranje, iz mnogih razloga:

„... tu jako puno utjecaj okoline...i mislim da im se teže, definitivno, odlučivat... to je ono financiranje, što se tiče troškova prijevoza, troškova u stanu, možda nekakav i strah od neuspjeha ... mislim da je to dosta ovako, možda čak i problem..." (Silvija, RRP_TP, 4SŠ_VG)

Corbett (2000) ističe da uz ekonomske, i emocionalne veze ruralnih prostora mogu djelovati ometajuće za stjecanje obrazovnih potvrda za ruralnu mladež. Emocionalna vezanost učenika izražava se kao jasnoća oko toga tko su i gdje s obzirom na pripadnost zajednici i poznavanje mjesta u obliku lokalnog identiteta (2009). Glavni mehanizam iskorjenjivanja učenika iz njihovih mjesta ima škola koja označava svojevrsnu „urbanizaciju uma“ i time podržava 
geografsku mobilnosti učenika iz lokalnih mjesta prema apstraktnim prostorima (2010). Stoga, emocionalna vezanost za dom i osjećaj odgovornosti kod studenata se mogu naći u konfliktu s njihovom željom ili potrebom da se identitetski izgrađuju slobodnim izborom i samorazvojem kretanjem koje mobilno društvo ističe kao vrijednosti (Wiborg 2003, 2004). Stoga je odnos učenika sa zajednicom odrastanja ispitivan je na još jedan način.

Podsjećamo, za regiju Slavoniju kreiran je instrument namijenjen ispitivanju odnosa učenika prema zajednici u kojoj su odrasli, odnosno, osjećajima prema društvenom, kulturnom i prirodnom okolišu njihovih života, uklopljenosti i aktivnog sudjelovanja u svojoj sociokulturnoj sredini, kao i potrebama/ mogućnostima međusobnog pomaganja i osobnog doprinosa zajednici, te općenito mogućnosti zamišljanja svog budućeg života u mjestu svog porijekla. Metoda glavnih komponenti otkrila je 3 dimenzije odnosa učenika i njihove zajednice odrastanja ${ }^{108}$.

Dimenzija nazvana Pripadnost u najvećoj mjeri sadržajno obuhvaća stavove o sadašnjoj aktivnoj uključenosti u život zajednice te želje za budućim doprinosom radom i obrazovanjem prosperitetu zajednice. Dodatno, dimenzija je obuhvatila i element međusobnog pomaganja među članovima zajednice - i osobnoga, i onoga za kojega se vjeruje da ne bi izostao od sumještana u slučajevima nužde. Konačno, sve te aspekte zajedničkog djelovanja, pomaganja i pojedinačnog doprinosa komunalnom kolektivu povezuje osjećanje pripadanja.

Dimenzija Želja za ostankom okupila je sadržajno stavove koji isključuju preseljenje s obzirom na perspektivu ostvarivanja budućnosti u trenutnim sociogeografskim prostorima, ali i zadovoljavanje trenutnih potreba, a koja isključuje nužnost preseljenja, život u velikom gradu i općenito želju za brzim odlaskom ${ }^{109}$.

Treća dimenzija simboličkog utjecaja zajednice odrastanja nazvana je Emocionalna vezanost za mjesto odrastanja. U najvećoj mjeri saturirale su je viđenje nostalgično povezano s djetinjstvom i doživljajem mjesta svoga odrastanja kao sigurne i ugodne okoline za odgajanje djece i obiteljski život. Najizraženiji osjećajni element „doma“ je onaj kao mjesta koje se voli

\footnotetext{
${ }^{108}$ Detaljnije o provedenoj analizi glavnih komponenti opisano je u poglavlju 2.3

${ }^{109}$ To su tvrdnje s kojima su se u najmanjoj mjeri učenici slagali; u najvećem broju učenici se u potpunosti nisu složili s tvrdnjama kako njihovo mjesto odgovara njihovim potrebama i nadama za budućnost (23\%) te da bi se teško prilagodili na promjenu životne sredine $(26 \%)$.

Više od $1 / 4$ učenika svoj je stav o tome da jedva čekaju napuštanje mjesta u kojem žive opisalo kao „ni da ni ne“, no također se tek nešto manji broj učenika u potpunosti složio (23\%) i u potpunosti odbacili tu tvrdnju (23\%).

$40 \%$ učenika se u potpunosti složilo s tvrdnjom, a dodatnih $23 \%$ se složio s tvrdnjom da se moraju preseliti ako nešto žele postići u životu; dok se, uz $20 \%$ onih koji su se složili s tvrdnjom, $38 \%$ učenika posve složilo sa stavom da ne vide budućnost u mjestu u kojem žive; a svoju budućnost u velikom gradu zamišlja preko polovice učenika (19\% se složilo, a 32\% učenika se posve složilo s tvrdnjom).
} 
zbog dugotrajnih međuljudskih veza koje se tamo razvijaju unutar obitelji i s prijateljima te prema prirodnim ljepotama, posebnim karakteristikama okoliša koje predstavlja materijalnu stranu prostora u kojem se razvijaju ti odnosi, te poseban način života i životne vrijednosti ${ }^{110}$. Općenito, želja za ostankom je najslabije izražena dimenzija među učenicima $(M=2,6)$ pri čemu njena prosječna vrijednost oslikava ambivalentne stavove, dok učenici najsnažnije ističu emocionalnu vezanost sa zajednicom odrastanja $(M=3,9)$. Obje dimenzije pokazuju i statistički značajne ruralno-urbane razlike.

U procesu usporedne analize pokazalo se (Slika 4.9) da ruralni učenici imaju statistički značajno veći prosječni rezultat kada je u pitanju njihova želja za ostankom $(M=2,8)$ te osjećaj emocionalne vezanosti za zajednicu odrastanja $(\mathrm{M}=4)$ u odnosu na učenike urbanog rezidencijalnog podrijetla $\left(\mathrm{M}_{\mathrm{URP}}=2,4 ; \mathrm{M}_{\mathrm{URP}}=3,8\right)$. Osjećaj pripadnosti, pak, ne pokazuje razlike između učenika različitog rezidencijalnog podrijetla; učenici izražavaju podjednaku, osrednju $(M=3,4)$, razinu uključenosti u aktivnosti zajednice, međusobnog pomaganja njenih članova te želje za budućim vlastitim doprinosom (radom i/ili obrazovanjem) zajednici.

Kako zorno prikazuje slika, simbolička vrijednost zajednice značajnije je izražena kod učenika koji žive u ruralnijim zajednicama, a koji se u većoj mjeri odlučuju na prestanak školovanja,dok se ona smanjuje kako raste urbanitet mjesta odrastanja učenika. Ti nalazi postavljaju pitanja o utjecaju i značenjima sredine odrastanja, u njenim prirodnim i socijalnim elementima, kako je učenici razumijevaju u pokušajima objašnjenja svojih visokoobrazovnih namjera.

\footnotetext{
110 Pretpostavka je bila i da bitan dio ove dimenzije čini i kulturni aspekt odrastanja koji bi bio dodatna emocionalna veza s ,domom“, izražen također i kao zajedničke vrijednosti i način života. No učenici su mnogo ambivalentnije reagirali na tvrdnju Ponosnim me čini kulturna povijest moga kraja. Više od jedne četvrtine učenika (28\%) zauzelo je stav „ni da, ni ne“, i iako se i velik broj učenika složio s tvrdnjom (27\% u potpunosti) taj postotak je daleko manji u odnosu na slaganje s ostalim elemenata koji su ispitivali emocionalnu vezanost sa zajednicom odrastanja. Tvrdnja je izbačena iz instrumenta s obzirom da je relativno slabo doprinosila stvaranju dviju dimenzija.

Dodatno, iz daljnjih analiza izbačena i tvrdnja namijenjena provjeravanju uklopljenosti vlastitih vrijednostii i načina života u zajednici no koja je bila negativno konotirana u upitniku - U mojoj sredini ljudi ne razumiju kako želim živjeti. Analiza je utvrdila da ona tvori zasebnu dimenziju, a u distribuciji odgovora više od 1/3 učenika (35\%) zauzelo je središnju neodređenu poziciju. Očito je za maturante, u trenutku odluke o budućim nakonškolskim pravcima, procjena vlastitih vrijednosti i način života u skladu s onima koje dijele ljudi koji ih okružuju u njihovoj zajednici konfliktno pitanje, a kako pokazuju učenički intervjui, pogotovo učenicima $\mathrm{s}$ izraženijim visokoobrazovnim orijentacijama i životnim ambicijama.
} 
- (1) Ruralno rezidencijalno podrijetlo $\quad$ (2) Urbano rezidencijalno podrijetlo

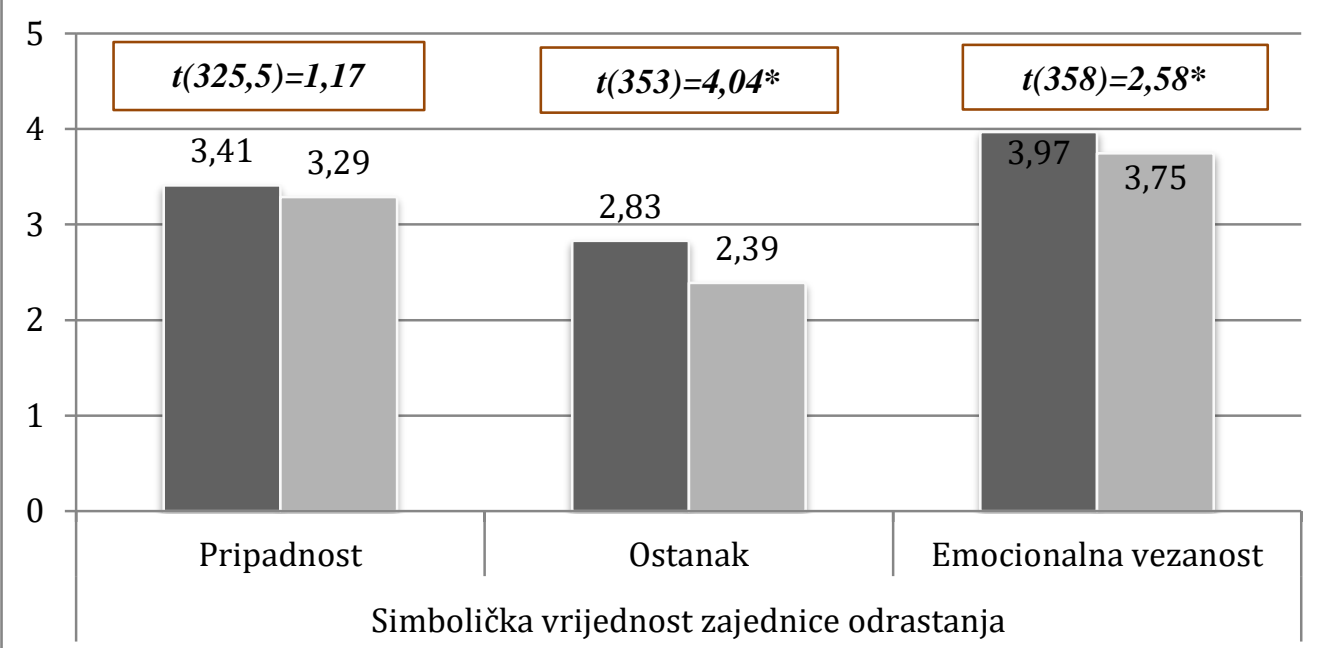

rezultati t-testa $(* p<0,05)$

Slika 4.9 Razlike između učenika različitog rezidencijalnog podrijetla na dimenzijama simboličke vrijednosti zajednice odrastanja

Kao jedno od objašnjenja toga zašto se učenici „ruralnih sredina“ u manbjoj mjeri odlučuju za obrazovanje objašnjenje za postavlja se teza o postojanju konflikata koji za ruralne učenike nastaje zbog potrebe preseljanja za obrazovanje uz istodobno htjenje za ostankom blizu rodbine i prijatelja (Irvin i sur. 2012). Kako podaci ukazuju na suprotne smjerove prevladavajućih obrazaca - želja odlaska uz istodobno visoku emocionalnu vezanost za mjesto svog odrastanja, pretpostavka je da određena razina konflikta postoji posebno za učenike koji namjeravaju studirati, no u intervjuima se ona ne pokazuje iznimno naglašeno s obzirom na opće procjene učenika.

U iskazima učenika, tri dimenzije su međusobno isprepletene, a dodatno se odražavaju u slikama učenika i kada je u pitanju njihov odnos prema obrazovanju i s obzirom na njihove obrazovne aspiracije, i u slikama učenika o njihovoj budućnosti. Cilj je narednih analiza ukazati na načine na koje učeničke slike o sebi i budućim životima odražavaju socioprostorne dinamike, odnosno duboko su prostorno oblikovane.

Općenito, skup intervjuiranih učenika kao cjelina uglavnom odražava opće stavove učenika regije o svom odnosu sa zajednicom odrastanja, a to se posebno odnosi na učenike urbanog rezidencijalnog podrijetla. $S$ druge strane ruralni učenici se u manjoj mjeri zadržavaju na prosječnim procjenama, odnosno njihove procjene pretežu ili iznadprosječnim ili ispodprosječnim procjenama. 
Brojčano podjednako intervjuiranih učenika iskazuje veću iznadprosječnu emocionalnu povezanost sa zajednicom svoga odrastanja - 4, koliko ih iskazuje i manje razine emocionalne vezanosti. Slično vrijedi i za dimenziju pripadnosti (odnos 4-3). Samo su stavovi o ostanku daleko negativniji, i izražava ih iznadprosječno četvrtina učenika u odnosu na samo dvoje onih s pozitivnim stavovima, a pri tom su daleko negativniji učenici urbanog rezidencijalnog podrijetla. Također je zamjetno u narativima ispitanika da izraz ruralno ne upotrebljavaju, iako svoja mjesta i iskustvene prostore označavaju pojmovima koji ga oslikavaju; stoga i je značenje „ruralnog“ za njih različito s obzirom na položaj koji imaju unutar urbano-ruralne sociogeografije; drugim riječima, „ruralno“ se u slavonskom kontekstu odnosi ne samo na sela već je socijalna konstrukcija primjenjiva za različite životne prostore učenika.

$\mathrm{Na}$ općenitoj razini, narative je moguće pratiti na dimenzijama dviju slika, one ruralne idile, koja uključuje elemente poput priroda, solidarnost, kooperacija/susjedstvo, mirnoća, te slike ruralne tuposti/dosade $(d u l l)$, koje uključuju slike zaostalosti, dosade, tračanja, nedostatka mogućnosti, nemodernosti, seljačine, a koje su istakla i druga istraživanja (npr. Rye 2006b, 2007). Također, u učeničkim iskazima vidljive su i hijerarhizirane slike na ruralno-urbanoj dimeniji s obzirom na geografske, kulturne, mentalne te obrazovne značajke.

\subsubsection{Rupa iz koje treba što prije pobjeći}

U najvećem dijelu učenici pokazuju relativnu emocionalnu vezanost za zajednice u kojima odrastaju zbog različitih „ugodnih“ aspekata vezanih uz svoje odrastanje koji povezuju elemente obiteljskog života i razvoja prijateljstava, te prirodne karakteristike i općenitu sociogeografsku poznatost. Tako je jedan od najčešćih opisa vezna uz odrastanje u slavonskim gradovima da se radi o malim mjestima velike poznatosti s privlačnim prirodnim okruženjem koji mirom i tišinom pobuđuje osjećaje ugodnosti. Socijalni element povezanosti je posebno uočljiv za razvoj prijateljstava, no u mnogo većoj mjeri među učenicima urbanog rezidencijalnog podrijetla:

„,...malo smo mjesto, ali... meni je jako ugodan život ovdje... ugodno mjesto mi je za boravak, i... s nekim ljudima se znam od malena, zajedno odrastamo ...

... pa mislim, ljudi svakako s kojima sam odrasla, a kojima se viđam svakodnevno, družim ...isto tako većina rodbine je ovdje, pa tako nema manjka kontakta...

... nije problem doći s jednog kraja grada na drugi, i eto što ima ne znam možda najviše pola sata hoda, a'l to baš ono točno s jednog kraja na kraj... do svega se lako dođe, lako se bilo ka, bilo šta dogovorimo ... meni je to super!.." (Bernarda, URP_mg, GIM_mg)

„... jako je mirno, mjesto za djetinjstvo, za odrasti (...) i tu sam dosta prijatelja upoznao...“(Dejan, URP_mg, GIM_mg) 
„... Pa bitno mi je sad to kol'ko sam tu vremenski proveo, što sam sve proživio, stek'o prijatelje, društvo (...) uvijek mogu otić prošetat u brdo, a imamo $i[X]$ jezero tu... priroda je lijepa, okoliš... nije nešto pretjerano velik gradić, sve znam ... “ (Frane, URP_mg, 3SS_mg)

„... malo, simpatično, prekrasno...Obožavam [život tamo] (...) a malo mjesto, simpatično, puno ljudi, dosta ljudi, a sve znaš $i$ tako..." (Jan, URP_nc, 4SŠ_mg)

„... grad koji je ugodan za život... baš je ugodan ... napravljen za stanovnike, ima sve, a nije... a nema previše ... nema gužve, nema, hmmm ... sve se može prehodati pješke, a tu je sve (...) obožavam [moj grad] $i$ imala sam predivno djetinjstvo, $i$ livade $i$ hrpu djece, $i$ svi trče $i . .$. jednostavno ... Te slike uvijek su u glavi, i jednostavno ne bi' mogla zamisliti bolje mjesto za odgajanje svoje djece... mislim da bi bili sretni ovdje, $k^{\prime} o$ što sam ja bila sretna ..." (Anica, URP_VG, GIM_VG)

Tako se i kod onih učeni koji su skloni istaknuti manje razine povezanosti sa svojim mjestom, mogu istaknuti barem jedan element koji ih veže za njihovu zajednicu ili koji vole, najčešce oni vezani uz obitelj i prijatelje te prirodne elemente, odnosno mir $(, \ldots$ iskreno ne znam šta jako volim, nemam pojma... možda to... tu prirodu“(Agata, URP_mg, 4SŠ_mg).

S druge strane, čak i oni koji iskazuju vezanost sa svojim mjestom spremno ističu i negativne strane života u svojim mjestima, a koji vrločesto uključuju iste karakteristike, pri čemu ono što pokazuje svoje prednosti ima i svoje mane za adolescente izražene u sociokulturnim aspektima okoline:

„...recimo, kada dođe... kada je u pitanju neka modna pojava, $i$... kada se vidi nešto novo, ljudi često osuđuju! (...) ljudi svi sve skoro znaju, to nekad zna biti mana i većina ljudi zato ne vole ovo mjesto, ali, pa mislim, meni to ne smeta (Bernarda, URP_mg, GIM_mg)

„... što jednostavno, ne moš nikog novog upoznat, s vremenom, ono, što nije recimo slučaj u [velikim gradovima] ... ne postanu ti ljudi dosadni, al' možda dobiješ želju nekog novog upoznat ... recimo, ja prolazim gradom, ja možda ne znam tu osobu osobno, nisam nikada pričao, al' znam 'ko je .. i gotovo za svakog tako znam (...) recimo, kad se neko, ne znam, kad nešto novo obuće, onda svi onak komentiraju s prijezirom (...) u većim gradovima neću dobiti takve kritike, za frizuru, za patike, za majicu s natpisom.. to se ovdje jednostavno... recimo, diskriminira.."(Dejan, URP_mg, GIM_mg)

Tada u prvi plan iskaču opisi monotonosti i dosade i nezadovoljavajućih aspekata malih slavonskih gradova vezano uz ono što nudi za zadovoljavaanje mladenačkih potreba: URP_mg, GIM_mg)

$$
\text { „... pogotovo preko ljeta, dosta bude monotono, nema se šta radit..." (Dejan, }
$$

„,...pa moj život u [mom gradu] nije baš nešto... što se tiče, onako, izlazaka, većinom biram izlaske u [susjednu državu], što se toga tiče, jer u [mom gradu] nije mi baš nešto (...) 
mi nemamo u $X$ iskreno nikakav, ajmo reći, noćni klub ili nešto, imamo samo jedan koji .... grozan, ono, mislim, tu ne volim baš ići..." (Agata, URP_mg, 4SŠ_mg)

„... tu mi je sve nekako dosadno, što su svi ljudi isti, ništa se ne događa, ne znam... želim biti u gradu u kojem nije bitno dal' je noć, mogu otić i kupit si sladoled, ne znam..." (Andrej, URP_mg, GIM_VG)

Iz učeničkih iskaza daju se iščitati i osjećajni elementi odnosa prema svojoj društvenoj i prirodnoj sredini, pri čemu mali slavonski gradovi predstavljaju zlatnu sredinu između manjih naselja i velikih gradova koji na taj način poprimaju pozitivne i negativne karakteristike $u$ životima mladih. Kako su i prethodni citati ukazali, tom kontekstu upravo oni „ruralniji elementi“ zajedničarskih odnosa ističu se kao prednosti:

„... ovdje su ljudi moz̆da malo susretljiviji kao, ne znam, kao zajednica su.. uvijek ima točno da će vam netko ako vam nešto ne ide dobro, ili ako vam nešto zašteka, da će vam uvijek netko uskočiti u pomoć, dok, ne znam, u velikim gradovima, bar ja imam dojam, da to nije tako, da se većinom ljudi ni ne pozdravljaju, samo prođu jedan pored drugog... ovdje je to drukčije, to je manja zajednica, većinom svak svakog zna, $i$ ono.. zato i ima nekih svojih loših strana, ali većinom je dobro..."(Aneta, URP_mg, 4SŠ_mg)

Stoga, pozitivni elementi odrastanja i trenutne sociogeografske pozicije sukobljavaju se i pomiruju kada su u pitanju slike svoje budućnosti. Što najbolje objašnjava Aneta: ,„,... volim [moj grad] zato što tu jednostavno osjećam da je dom pa onda... zato mi se sviđa ... sa ljudima, sa mjestom općenito [postoji povezanost]...“(Aneta, URP_mg, 4SŠ_mg).

Drugim riječima, postoji određeni osjećaj doma zbog kojeg mjesto odrastanja zauzima posebno mjesto u učeničkim slikama, i potvrđuje se kao izvor identiteta čak i kada se taj značaj potire njegov značaj (,...i to što sam iz X nije mi neka uloga, iz nekog grada moram biti (...) nišs" posebno, grad ko grad (...) uvijek ima mana i prednosti.." (Agata, URP_mg, 4SŠ_mg)) ili u planovima u kojima sadašnji dom više neće biti mjesto praksi i interakcija mladih, već samo slika ili uspomena, koja u perspektivi odlaska uglavnom poprima osjećaje nostalgije.

Stoga, negativne i pozitive slike odnosno osjećaji uglavnom supostoje kod učenika i nisu presudne za ostanak. Za Agatu koja planira odlazak, dom se zadržava u sjećanju i nekoj viziji budućnosti u kojoj se posjećuje rodbina, ali ista ta vizija budućnosti gradi se s obzirom trenutne slike u kojima se povezuju slike o sebi i što želim postati, nasuprot onima koje mogućnosti trenutna sociogreogfska pozicija postavlja za osobni razvoj u budućnosti:

„... uvijek to ostaje vaš grad kojem se uvijek volite vratiti, gdje ste vi odrasli, gdje ste proveli svoje djetinjstvo, gdje su svi vaši, gdje ste uvijek prvi puta imali nešto, nešto što vam je ostalo u sjećanju, tako da vjerujem da ću se uvijek voljeti vratiti ovdje ako bi otišla ikada ... 
mislim, koliko god taj grad meni bio, ne znam, možda premali ili nešto da ja želim otići, uvijek ću ja njega voljeti, i uvijek će taj grad meni biti poseban ..." (Agata, URP_mg, 4SŠ_mg)

U osnovi, kako pokazuju prethodni citati, svoje vlastite pozicije maturanati interpretiraju u skladu s pitanjima adolescentskih interesa, u kojima je grad i dom i dosada, no kod nekih učenika oni su istaknuto obrazovno i kulturno orijentirani. Time se odrastanje u malom gradu promatra dodatno neusklađeno s vlastitim, obrazovnim i životnim, ambicijama, ali i osnovom zakinutosti. Tako će mnogo učenika objašnjavati obrazovne izbore prvenstveno vezane uz nedostatak izbora u manjim gradovima, a zatim i nedostatak dodatnih obrazovno-kulturnih sadržaja koji bi zadovoljili njihove obrazovne i kulturne interese

„... s obzirom da je to mali grad, mislim da dosta utječe zato što ovdje, ono, ne pruža dosta tih sadržaja i svega toga, tako da, mislim... nismo dovoljno, znači, bačeni u kulturu, kako bih rekla, ne znam... nemamo baš nekog doticaja sa tih.. sadržaja, znači, da se mi možemo orijentirati na to što mi želimo ako želimo, nego moramo otići negdje drugdje, na primjer, u Osijek, $i$ tražit neke druge alternative i sadržaje zato što ovdje nema... tako da, dosta utječe zato što, na neki način smo zakinuti zato što smo iz malog grada i nemamo puno toga..." (Aneta, URP_mg, 4SŠ_mg)

Dodatno, nije samo odrastanje u malom gradu i /ili školovanje u malom gradu problem zbog određenih nedostupnosti vezanih uz veličinu grada. „Ruralni elementi“ malih zajednica, visoke poznatosti, otpora prema novinama ukazuju na, kako prethodni citat ističe, „,nedostatak kulture“, specifičnog mentaliteta šireg okruženja koji povratno oblikuju i specifične pravce djelovanja. Obrazovno, ono označava „zakinutost“, ako se iz određenog konteksta ne može izmjestiti, te ambivalentno shvaćanje o kvaliteti samog obrazovanja, mogućnosti i samouvjerenosti oko uspjeha u visokom obrazovanju.

Visokoobrazovno orijentirani Andrej kvalitetu školovanja u skladu sa svojim obrazovnim aspiracijama, i u skladu sa svojim obiteljskim resursima, nije procijenio zadovoljavajućom:

„... općenito recimo kad je neka sredina manja da... mislim, moglo bi to značiti da ondje ima manje učenika pa više recimo šanse za odgovaranje, veće znanje, ali opet $s$ druge strane, nekako tamo svi se znaju, svatko zna svakoga, to je sve...

... ima i u [mom gradu odrastanja] gimnazija, ali moja majka je radila i kaže da joj se ne sviđa uvjeti, mislim... zato što tamo je gimnazija i poljoprivredna škola i turistička sve na okupu $i$ onda isti profesori predaju tu, tamo nešto sve.. uglavnom, kaže mama da je to sve na nekom nižem nivou..." (Andrej, URP_mg, GIM_VG)

U njegovm shvaćanju čitava sredina „ruralizira“ obrazovu kvalitetu malih gradova što utječe na kvalitetu obrazovanja, na orijentaciju prema daljnjem školovanju, i na uspjeh u visokoom obrazovanju: 
„... ne znam, imam dosta prijatelja koji studiraju, njima je sve to dosta teško $i$ naporno, ali ... ne znam, mislim da, ne znam, jednostavno oni su ti iz [malog grada], je l'... mislim da nemaju dovoljno predznanja da uopće uživaju u školovanju pa su njima to sve strani pojmovi ... neki osnovni pojmovi, oni su prvi put čuli za to... “ (Andrej, URP_mg, GIM_VG)

Takve negativne procjene sežu još dublje i ukazuju na posebne nepogodnosti u elementima nedostataka različitih vrsta resursa, ali i elementima mentaliteta, vrijednosti i načina života koji učenici često ističu u dihotomijama selo-grad, mali grad-veliki grad, ostala mjestaZagreb, te neodređenije ovdje-dalje.

U prethodnom citatu, učenik ističe utjecaje sredine odrastanja u koju je smješten mali grad koja prvo, cijelu sredinu određuje ruralnom - poljoprivrednom i nemobilnom nasuprot znanju i „bivanju u svijetu“ to jest obrazovanju i mobilnosti. Dodatno, kada su u pitanju obrazovni ciljevi, cijela sredina je označena manje kvalitetnom, te ograničavajućom i kada je u pitanju orijentacija prema, i uspjeh u visokom obrazovanju.

Unutar takvih dihotomija oblikuju se buduće namjere učenika koje proizlaze iz, te projiciraju i ponovno uspostavljaju složene hijerarhizirane interakcije sociogeografskog i obrazovnog polja. Jer unutar tih mreža i procjenom vlastitih resursa i karaktersitika upravljaju svoje putanje prema osobama koje žele biti i budućnostima koje žele imati. Osnovno pitanje o njihovom ostanku je time vezano za pitanje mogu li sebe i svoju budućnost zamisliti u kontekstu u kojem odrastaju.

U tom kontekstu, Aneta opisuje dosadu u malom gradu kao nedostatak kulture i obrazovnih sadržaja koji bi nju zanimali s obzirom na njeno samopoimanje i obiteljsko isticanje značaja obrazovanja:

„... nema ovdje baš neke kulture... Dosada (smijeh) (...) baš ne volim izlazit pa većinom, ono... moji teritoriji su knjižnica i tako to... tako da... meni je općenito stvarno dosadno ovdje zato što nema nekih stvari koje su meni sviđaju, koje me zanimaju... nema nekih seminara, na primjer, o tako nekim stvarima, na primjer, biologija, ne znam, tako neki znanstvenički smjer nešto.. znači, nema nekih predavanja, seminara kao obrazovanje naknadno i tako to.. nema baš ..."(Aneta, URP_mg, 4SŠ_mg)

U konačnici, niti ona niti Andrej, čija se slika budućnosti označuje metafora „muvanja po Europi“, ne doživljavaju okoliše svoga odrastanja usklađenima s njihovim slikama o sebi koje su u osnovi ,urbane“:

„,...nisam uopće uključena u život zajednice (... ) ako su neke predstave, obavezno idem na to, ako se neki filmovi prikazuju, što se baš i ne prikazuje, idem na to, ako se, na znam, nešto u knjižnici događa... najviše zapravo knjižnica i organizira tako te neke stvari... “ (Aneta, URP_mg, 4SŠ_mg) 
Za Andreja je odgovor jednostavniji s obzirom na veći stupanj osjećajne nevezanosti, nepripadanja i odvojenosti, još za vrijeme srednjoškolskog obrazovanja, a koji zatvara i mogućnosti nekog budućeg razvoja odnosa s mjestom odrastanja:

„... nemam tamo nešto kontakta s ljudima, nit' osjećaji da me vuku, ne znam.. volim otić odmorit, ali tek kad sam stvarno umoran, ne volim ovako bezveze otić'(...) Također... izolirano, ne znam.. nemam neke posebne povezanosti... nije da, ne znam, želim završit neki studij pa se tamo zaposlit il' nešto slično tome - to nikako ne dolazi u obzir..." (Andrej, URP_mg, GIM_VG).

Pritom, studij samo znači još jedan korak dalje od zajednice odrastanja: „,... [moje studiranje još više promijeniti odnose s mojim mjestom], mislim da ću se još više udaljit, zapravo..."

Općenito, kod većeg dijela učenika, takvi razvoji su željeni kao sastavni dio proživljavanja studentskih dana u kojima se odvija i proces izgradnje identiteta koji je kod mnogih učenika usmjeren prostorima i od lokalnog: „...Ja mislim da će mi se dosta svjetonazor promijeniti...“ (Dejan, URP_mg, GIM_mg). U tom smislu, konflikt se učenicima ne pojavljuje u većoj mjeri, odnosno odnos prema zajednici odrastanja ostaje ambivalentan, a posebno kod onih visokoobrazovno orijentiranih sa stavom da je studiranje korak u sam život i korak koji se mora proći.

Drugi učenici će ipak pitanje o sudjelovanju u zajednici, a posebno kulturnim aktivnostima drugačije shvatiti i isticat će uključenost $u$ aktivnosti vezane uz razvoje lokalnog/regionalnog identiteta, koji kod njih razvijaju i dublje odnose i povezanost sa zajednicom, i osjećaj dublje uklopljenosti, pripadanja i želje za budućim doprinosom. Ipak, to ne znači i planove ostanka s procjenom realnih mogućnosti što učenike stavlja u određeni konfliktni položaj, ali koji se isto tako racionalno objašnjava prihvaćanjem stava $(\mathrm{K})$,za poslom se ide“ koji je dodatno motiviran razumijevanjem svoje klasne pozicije i željom za njenom promjenom.

U najvećoj mjeri usklađenost učeničkih izvanškolskih aktivnosti s njihovim (obrazovnim) karakteristikama i planovima, možemo promatrati u slučaju učenice koja pohađa školu stranog jezika, koja se za nju zaista pojavljuje kao obrazovno razvijani kapital usvojen unutar obitelsjkog konteksta i razvijan izvan škole. Bernarda je učenica koja je odrasla u obitelji gastarbajtera u kojoj je bila izložena, u kojem je upoznala i zavoljela strani jezik, što je oblikovalo njezine srednjoškolske odluke i što je usmjerava prema visokom obrazovanju u jezičnom području. Jezične kompetencije koje stječe obiteljski i školski dodatno tako razvija i 
u aktivnostima koje je usmjeravaju prema željenoj budućnosti, barem kada se radi o profesionalnom području djelovanja. $U$ toj slici bitan je dio njenog samopoimanja spremnost $i$ na mobilnost: „,... čak razmišljam i o studiranju vani... meni to stvarno nije problem otići od kuće, nikada to nisam doživljavala kao nekakav problem, daljinu od rodnog grada, ovaj, vani... snašla bi' se vjerujem jako dobro...“, štoviše ona regionalnog zadržavanje poima kao oblik samoograničavanja: „,meni osobno nije problem, stvarno mogu bilo gdje, bilo kako, bilo s kim, al' znam da neki ljudi kažu: „Idem do Osijeka, ne idem dalje“; sam sebi postavljaš granice, sam se ograničavaš“!... “. Takve stavove dodatno podržavaju i njeni profesori: „,... dosta mladih profesora nam kaže: „Idite van, ako možete, ako želite, ako mislite da ćete se snaći, idite van!..“. Sve ovdje opisano ukazuje na razvoj posebne vrste kapitala mobilnosti u obliku stranog jezika i kroz obiteljska putovanja, koja kod učenice razvijaju šire razumijevanje društvenih i geografskih prostora. Oni se provode širokoraprostranjenim mrežama i unutar škole i u svojoj zajednici. No kada se postavlja pitanje mjesta u kojem zamišlja svoju budućnost, za učenicu se konflikt postavlja snažnije s obzirom na njene druge aktivnosti u mjestu njenog odrastanja. Izvan školskog konteksta, učenica sudjeluje i u kulturnim manifestacijama tradicijskog tipa kojim razvija specifičan odnos vezanosti za svoj kraj i lokalnog identiteta koji izražava dijelom kroz želju za radom i životom u gradu svom odrastanja, i ističe: „... ne smatram da je ovo rupa iz koje treba što prije izaći, kako veliki dio vršnjaka misli, ne težim nikakvom Zagrebu...". Za učenicu se konlikt razrješava kroz poimanje „...otiči negdje dalje studirati, ali zašto ne vratiti se? ... dobro mi je ovdje ...“, no ponovno se postavlja kada učenica procjenjuje ostvarivanje svojih želja malo vjerojatnima. U konačnici, učenica prihvaća kao osnovnu strategiju konačnih odluka o budućnosti - $(\mathrm{K})$ za poslom se ide, a kapitali koje razvija učenica prvenstveno su oni koji je osposobljavaju za odlazak iz svoje zajednice odrastanja i/ili prema inozemstvu.

Ono što je uočljivo je da učenici koji pozitivnije vrednuju svoje okoliše odrastanja, ostvaruju sa zajednicom dublje osjećaje povezanosti kroz aktivnosti koje razvijaju; ukoliko se doživljava manjak takvih mogućnosti time je nemogućnost zamišljanja sebe u okolišu odrastanja koji se označaje „deficitnim“ potiče zamišljanja sebe u drugim prostorima. Ipak, takav „rad“ na projiciranju sebe u prostorima koji su nesigurni i nepoznati za određene je učenike, s obzirom na dostupne resurse i razvijene kapitale, daleko teži.

Za mladiće uključivanje u njihovu zajednicu se prvenstveno ostvaruje kroz sport koji učenicima čine značajan korijen njihovih lokalnih, ali i širih mreža; aktivno bavljenje sportom i djelovanje u nekom sportskom klubu, dodatno može poticati i pravac obrazovanja $u$ 
specifičnom području, iako se u niti jednom intervjuiranom slučaju nije proveo u djelo. Oba učenika ističu značajnu ulogu koju sporta ima za njih na prvom mjestu kako vide sebe kroz sport i kako se sportom uklapaju u širu sredinu:

„...ja sam veliki obožavatelj sporta općenito (...) stvarno sam bio ...sa sportom, na reprezentativnom okupu za nogomet kad sam imao 14. godina (...) hm... strašno sam puno unutar sporta i igrao sam razno razne sportove po godinu, dvije, tri, pet, deset, ovoga...

„....mislim prvenstveno da sam kroz taj nekakav svoju sportsku aktivnost stekao neko svoje mjesto u zajednici jer na nekakav sportski događaj koji dođem skoro 60\%, 70\% ljudi ja tamo znam ... i mislim da sam sam sebe, ugradio sebe u zajednicu [svoga grada] kroz sportske aktivnosti..."(Jakov, URP_VG, GIM_VG)

„... Pa zato što mi sport... sport volim najviše (...) stalno u sportu, samo kuća, škola, sport i tako... prijatelji, kave i to je to.. pa evo, probudiš se, jedeš, kava, škola, sad dođem kuć', trening, onda poslije tog' utakmica...

... uvijek nogomet, pa se okupi puno ljudi, turniri, koncerti.. misa naravno, i tak'... [ima] puno događanja..."(Jan, URP_nc, 4SŠ_mg)

Tako učenici kroz sport oblikuju (rodne) slike o sebi i svoje pripadnosti koje se dodatno odvaguju s obzirom na pitanja obrazovanja i željenog budućeg života. Obrazovanje kao mehanizam posreduje tu sliku i sliku njihove budućnosti: za oba učenika sport se oslikava u njihovim obrazovnim željama, prije upisa srednje škole, ali se i sukobljava s obrazovnim namjerama:

„... ima sportska gimnazija koja ima sam, ajmo reć, prizvuk gimnazija gdje vas oni obrazuju ali većinom vas baziraju na sport kako bi oni, kao, školovali mlade sportaše... i ja sam se, sa svojim roditeljima kad sam bio u osnovnoj pričao u petom mjesecu šta bi mogao upisat ..."(Jakov, URP_VG, GIM_VG)

„.. Razmišljao sam možda, na sportski neki, al' onda sam se odlučio da neću ništa ... za trenera profesionalnog il' tako... Prije upisa u srednju ... I na kraju sam onda odlučio da ništa (...) najbitnija mi je naravno ova u sportu, u nogometu ... pa da.. o tom [sportu] mogu pričat do preksutra... al' baš mi škola nešto... jedva čekam sam da završim ..." (Jan, URP_nc, 4SŠ_mg)

Oba učenika namjeravaju napustiti Hrvatsku u budućnosti te pokušati razviti karijere u skladu s onim što im je značajno. Jakov je nakon što mu se želja o pohađanju sportske gimnazije nije ostvarila zbog potrebe preseljenja u makroregionalni centar, donio odluku o upisu opće gimnazije u svom gradu, što je izbor koji na kraju svoga školovanja procjenjuje, boljim: „...nijedna druga škola u [mom gradu] trenutno, a i unazad par godina, nije konkurentna ovoj našoj školi, i mislim da jedino učenici iz ove škole imaju nekakvu, ajmo to nazvat, svjetlu budućnost...“. Nasuprot tome, Jan je u skladu sa slikom o sebi procijenio da „studiranje nije 
za njega“ i odlučio se za razvoj sportske karijere $\mathrm{u}$ inozemstvu nasuprot nastavku obrazovanja, i s osloncem na svoje društvene mreže zbog kojih ne ide u nepoznato.

Dakle, teško je govoriti o takvim aktivnostima kao kulturnim kapitalima za postizanje njihovih obrazovnih namjera, što je kod određenih učenika izraženo i kao područje konflikta oko toga koje područje zaslužuje više osobnog angažmana, te se postavlja kao prioritet. Ipak, oni označavaju značajne društvene kapitale. S obzirom da su se među intervjuiranima našlo nekoliko učenika kojima su sportske aktivnosti značajan izvor pripadnosti i veze sa zajednicom, iako ne i odluke o ostanku, a katkada čak ne i velike vezanosti za zajednicu odrastanja, moguće je promatrati takve sportske veze izvorom informacija i stavova o mogućnostima zapošljavanja i/ili obrazovanja, te poticajima i podrškom za određene pravce djelovanja.

Uključenost u zajednicu i osjećaj pripadnosti ne znače i planove ostanka.

„... dost mirnim... miran život.... Neću reći da je loš, dobar je, živi se, 'ajmo reć', dobro... za one neke potrebe ima, znači... al' za budućnost se ne vidim ovdje... to je to (...) Pa jedino prijatelji i obitelj... drugo me ništa ne veže .. " (Krešimir, URP_mg, 3SŠ_mg)

„... naravno da se želim, da kažem, maknuti iz grada, mislim ono, jer tu budućnost nije baš neka, mali je grad i nemam ništa od njega... naravno da je puno bolje živjeti u Osijeku ili Zagrebu, ili nekim većim gradovima ..."(Agata, URP_mg, 4SŠ_mg)

Zanimljivo je primijetiti kako učenica u prethodnom citatu odlazak iz svoga grada i odlazak u veliki grad označava „normom“, no takvo shvaćanje ne ističe samo manjina učenika. Općenito, kako pokazuje Rye (2006a), preferencije mladih za životom u velikom gradu u njihovim dvadesetim godinama, prevladavajuća je želja. Ipak, rezidencijalne preferencije se razlikuju u različitim fazama života, te se mladi često s obitelji zamišljaju u ,ruralnijim okolišima. Određene učenice u ovom skupu intervjuiranih dobro to ilustriraju. Dodatno, učenici su vrlo skeptični prema mogućnostima dobivanja posla, a pogotovo zadovoljavajućeg posla u svom gradu, ali i regiji ili Hrvatskoj. A to je dodatno istaknuto za one koji teže specifičnim karijerama i pogotovo onima koje zahtijevaju visoko obrazovanje. Učenici u svojim obiteljima, u svojim sredinama, u svojim školama, ali i putem medija, dakle izravnijim i neizravnim odnosima, doživljavaju cijelu svoju sredinu krajnje neperspektivnom za ostvarivanje dobrog života i to i za zapošljavanje općenito, za „dobro zapošljavanje“, a posebno za one s diplomom.

„,... [moji prijatelji] nemaju gdje... za njih nema ništa.. ovdje gdje idemo na praksu nemamo posla 'e l' nemaju ni oni majstori koji su već tamo .. tak' da ne vidimo se ni mi tamo 
... jako je malo posla, a i oni koji rade, rade zato što imaju iskustva, je l' obrtnici traže majstore s iskustvom... mi smo tek počeli tak' da ništ' od toga

(...) Ja mislim da [studij može posluži za razvoj karijere] ... A teško... tu teško... za dalje da... znači, 'ko ode da se više ne vraća... to je to... “ (Krešimir, URP_mg, 3SŠ_mg)

A također, vide i šire načine rješavanje problema koje usvaju kao vlastite izlazne strategije -

(K) ljudi odlaze za poslom koji u većoj mjeri omogućavaju veliki gradovi:

„... pa puno više mi je otvoreno vrata za neke poslove [u većim gradovima], ako bi bilo poslova nego u manjim gradovima, puno više.. znam da, ono, ljudi idu u velike gradove s nadom za poslom, tako da ..." (Agata, URP_mg, 4SŠ_mg)

To je općenita slika ruralno-urbanog polja u kojem veći gradovi imaju više i pružaju više, a na samom vrhu hijerarhije nalazi se glavni grad:

„... mi iz sela moramo nešto napravit, moramo ić u $O$. [subregionalni centar slabi], ovi iz O.... znači, ono što ne možemo napraviti u $O$., to idemo u $N$. [subregionalni centar jaki], iz N. u Osijek, a oni iz O. [makroregionalni centar] u Zagreb... znači, sve je u Zagrebu (smijeh) sva znači događanja, su u Zagrebu.. imaš sve na jednom mjestu, ne moraš ići negdje dalje da bi nešta..." (Andrea, RRP_TP, 4SŠ_mg)

„... ako ste u Zagrebu, tu vam je.. veći su, kao, centri na primjer ako završite ekonomiju, možete tamo dobit. tamo su ipak centri velikih banki i ako se tamo dobro pokažete, ipak je tamo veća mogućnost, već ste pri centru, znači, već ste pri vrhu... možete prije doći stepenicu gore nego što može doć netko u Splitu, netko u Rijeci... " (Mislav, RRP_DSJ, 4SŠ_VG)

Već smo ukazali da se učenički planovi orijentiraju velikim dijelom u skladu sa sveopćom procjenom stanja u državi, a pogotovo s pogledom na mogućnosti zaposlenja i promjenama na širem planu zapošljavanja. Učenici u skladu s time uvelike zamišljaju svoje budućnosti . Katkada ih procjene usmjeravaju na preseljenje - u veliki grad ili inozemstvo - bez daljnjeg obrazovanja što se prevenstveno odvija oslanjanjem na socijalni kapital koji omogućuje mobilnost. Katkada, procjene situacije usmjeravaju prema visokom obrazovnaju s obzirom na shvaćanje da je sa srednjoškolskim obrazovanjem nemoguće dobiti zaposlenje, u lokalnim, regionalnim ili nacionalnim okvirima, ili pak u inozemstvu ako im je cilj upravo to. Mobilnost je tada u većoj mjeri povezana s obrazovanjem, i u većoj mjeri djeluje kao potisni faktor kada se samo visoko obrazovanje smatra mehanizmom ograničenog povratka zbog neusklađenosti s lokalnim tržištem rada, te dakle prisiljava odlazak u skladu sa željom društvenog uspinjanja, odnosno postizanja onoga što učenici definiraju svojim oblikom „dobrog života“.

„... Pa u Hrvatskoj... hm... s ovom situacijom, ne znam baš, al' ja iskreno ni ne planiram, kad završim [željeni studij], ako završim, ne planiram ostati ovdje, ja planiram izaći vani... pa ne znam, kol'ko sam pratila da baš [s tom strukom] nemaju ovdje posla i... većinom ljudi ovdje nemaju posla..." (Aneta, URP_mg, 4SŠ_mg) 
„Pa znam da tu karijeru [u prirodoznanstvenom području] ne bi' mogla ostvariti nikako, to je jasno... a i tko zna, pa tu u Hrvatskoj kol'ko nema posla moram otić... za poslom se ide... gdje me život odnese, gdje bude bilo posla..." (Anica, URP_VG, GIM_VG)

„...nije mi uopće prioritet živjeti u Hrvatskoj jer stvarno ne znam šta bi tu... već sam prije, sluš'o sam roditelje kako pričaju kao je to sve loše, kako to ne valja... onda sam si rekao: „Pa zašto ne bi sad, recimo, otišao u Moskvu? Zašto ne bi otišao u Njemačku? Zašto ne bi bilo gdje? " Tamo ima više izbora, nekako životni standard je puno bolji, to me ... nije mi cilj, al'realno gledano ne znam šta bi ja s tim studijem u Hrvatskoj mogao... ne vidim tu nikakvu budućnost..." (Dejan, URP_mg, GIM_mg)

Stoga, učenici su još uvijek neodlučni oko konačnih planova buduće geografske lokacije, no zamišljaju se u sociogeografskim prostorima koji nisu njihove lokalne zajednice, ili nadilaze regionalne pa čak i nacionalne okvire, i predstavljaju prostore „boljeg života“. Za one koji su privrženiji svome domu moguća je određena doza konflikta, no koja se razrješava racionalnim promišljanjem sljedećih koraka i predanošću ostvarenja ciljeva:

„... zato što sam htjela baš pobjeć odavde, tako bi rekla, i promijenit smjer totalno... Ne znam, možda, promjena okruženja... jednostavno smatram da ova škola nema apsolutno nikakvog... nikakve budućnosti $i$ da... ne znam, više obrazovanje sam htjela $i$ zato želim odavde otić, ovako okruženje kao okruženje nije loše, ali jednostavno nema budućnosti ovdje, tako da.. zbog toga želim nešto totalno drukčije..."(Aneta, URP_mg, 4SŠ_mg)

„... Studiranje?... prvenstveno vide bijeg od [svog mjesta] zato što je i... mislim da prvenstveno mi tu osjećamo nekako najviše sve te neke krizne događaje koji se događaju u našoj Hrvatskoj, $i$ da mi nekako ih, kao, najteže nama padaju, i onda svi vide: „Ajmo otić u Zagreb, Osijek, Rijeku... maknut se od ovoga svega, i započet nešta što nas bolje čeka u budućnosti“"” (Jakov, URP_VG, GIM_VG)

U takvom okviru, spremnost na mobilnost i/ili razvoj specifične vrste „urbanog“ kapitala (Rye, Blekesaune, 2003) ili kapitala mobilnosti (Corbett, 2009) značajna je učenicima koji teže visokom obrazovanju i „boljem životu“ koji lokalno ne vide ostvarivim. A posebno značajnima čine se za ruralne učenike koji su u nepogodnijoj situaciji kada je u pitanju struktura resursa koja im je dostupna, ili pak, češće, upotreba postojećih kapitala za mobilnost. Obrazovanje se tu pojavljuje kao osnovni mehanizam poticanja odlaska, a u učeničkim slikama za postizanje individualnih napredovanja. No, kako upozorava Rye (2007), migracije su klasnostrukturni fenomen, odnosno iako su migracijske odluke odraz individualiziranog i slobodnog izbora, strukturirane su predispozicijama njihovog ruralnog klasnog habitusa; postoji značajna sukladnost između nečije pozicije u društvenoj strukturi, njihove procjene ruralnosti i preferencija duž ruralno-urbane dimenzije s obzirom na buduće mjesto života. 


\subsubsection{Osim što umiru ljudi ništa drugo se ne događa}

Određeni odgovori i način na koji neki učenici urbanog rezidencijalnog podrijetla progovaraju o svojim životima i mjestima otkrivaju ruralizirane slike tih malih slavonskih gradova. Stoga što je ruralno? Kako se onda vidi selo? S jedne strane, čini se da sela gube svoj identitet, ako je suditi prema Jakovljevom stavu, no kojeg ipak ne uspijeva posve objasniti:

„... primjerice, nazovimo to sela koja su par kilometara od [mog grada], to za mene više nisu sela jer su, ajmo reći, nekakva predgrađa... jer iskreno, ja više ne znam stvarno tko u tim nekim bližim, ajmo reć, selima se bavi ili drži domaće životinja ... to mene barem naučili da su to karakteristike sela: da ćete tamo vidjeti ljude koji sjede ispred kuće, dakle, prvenstveno bake, djedove koji će... dakle, ono, baš seoska neka atmosfera, kak da vam objasnim... dakle, svi svakog znaju, a opet svi su sa svima dobri.. razumijete? A nekako kad se provezete nit vi više vidite da se tamo negdje djeca igraju.... ok, možda nemaju neki šoping-centar, ali da je za mene naselje ... ljudi sa sela uvijek imaju u glavi, kao: „Joj u gradu imaš puno više mogućnosti", al' možda to tako i nije u gradu jer u gradu imate masu situacija gdje bi jako voljeli pobjeć na to selo i odmorit se..."(Jakov, URP_VG, GIM_VG)

Takve slike svakako su vezane uz šire promjene modernizacije ruralnih društava diljem svijeta pod utjecajem globalizacije i modernizacije, ali i kontekstualno ima poseban značaj s obzirom na zakašnjele modernizacijske procese u hrvatskom seoskom prostoru (Štambuk, 2014), te otegnute teškoće tranzicijskog procesa koji su izmijenili identitetske odrednice Slavonije i Baranje kao ,žitnice Hrvatske“ (Šundalić, 2010).

Ipak, učenici u većini slučajeva svoje slike izgrađuju upravo na toj dihotomiji. Na općem planu, i u slici ruralno-urbanog polja kojeg je na najelementarnijoj razini moguće pojmiti kao mrežu naselja povezanih i obilježenih dostupnošću resursa i centraliziranih u Zagrebu kao glavnom gradu, sela čine bazu s najmanjom dostupnošću različitim resursima:

„... mi iz sela moramo nešto napravit, moramo ić u $O$. [subregionalni centar slabi], ovi iz O.... znači, ono što ne možemo napraviti u $O$., to idemo u $N$. [subregionalni centar jaki], iz N. u Osijek, a oni iz O. [makroregionalni centar] u Zagreb... znači, sve je u Zagrebu (smijeh) sva znači događanja, su u Zagrebu.. imaš sve na jednom mjestu, ne moraš ići negdje dalje da bi nešta..." (Andrea, RRP_TP, 4SŠ_mg)

No, dodatno taj prostor puni se dodatnim značenjima. U iskazima učenika vidljivo je tradicionalno oslikavanje sela koje se vezuje uz fizički rad, poljoprivredu i prirodnost okoliša.

„... ljudi sa sela znaju više o poljoprivredi pošto su samim time odmalena, $\boldsymbol{i}$ djeca $\boldsymbol{i}$ sve, okruženi su i životinjama i ljudima $\boldsymbol{i}$, znači, poljoprivredom općenito... sjećam se ja kao mala išla sam kidat metlice, uvijek bi, ono, sa lojtricama malim kidala metlice, dok, recimo, ljudi iz grada to ne bi radili... tak' da mislim da u svakom slučaju, ljudi iz sela su nekako... više su naučeni radu nego ovdi iz grada..." (Ivana, RRP_DSJ, 4SŠ_mg)

Najpozitivniji pak prikaz ukazuje na zajedničarske elemente zajedničkog života, poznatosti i pomaganja: 
„.... živim u jednom malom selu, i svi smo dobri jedni s drugima, uvijek jedni drugima pomažemo, posuđujemo stvari, ono, svako svakom priskače u pomoć (...) svi smo isti... različiti jesmo, ovako, po nacionalnosti $i$ tko je bogatiji, 'ko je... al' mi na to ne gledamo, jednostavno pomažemo jedni drugima, nema sad nekih (...) prava smo zajednica... bar kod mene u mom selu, a ima i sela koji niko ne priča s nikim, i tako..." (Marina, RRP_TP,

Ipak, to je samo jedan takav primjer od 20 intervjua. Nasuprot tome, jedna učenica izražava manjak emocionalne povezanosti sa svojim selom upravo jer primjećuje propadanje zajedničarskih odnosa koje povezuje i $\mathrm{s}$ vrlo negativnim poimanjima iskazano urnabormativnim konceptima: „... Ja ne volim svoje mjesto gdje živim... ne volim zato što ljudi su ... ja kažem da su ljudi tamo zatucani (...) svakakvih aktivnosti da se organizira sad ćemo svi pokosit tamo neš di niko ne živi da svi počistimo to, tak... nema nikakvih aktivnosti baš tamo..." (Andrea, RRP_TP, 4SŠ_mg). Svoje rezidencijalno podrijetlo ona određuje „provincijskim“ koji nije uskalđen sa slikom onoga kako ona zamišlja sebe: u kozmopolitskijim i tolerantnijim okolišima.

Većina drugih učenika će, nasuprot slobodi koju omogućava priroda, isticati najnegativnijim aspektima upravo preveliku poznatost i manjak privatnosti iskazano kao (K) plemenski nadzor:

„... ne volim, a to što zabijaju nos gdje god stignu... mala je to zajednica, tako da... k'o pleme neko, ne znam, stvarno to mi se nikako ne svida - privatnost nula posto, nula bodova... sve znaju, kada ti je tko došao u kuću, kada je otišao, ne znam, gdje je ovaj, gdje je onaj, sve poprate, $i$ ne znam ni kako više... to mi se apsolutno ne sviđa..." (Gordana, RRP_TP, GIM_VG)

„... ima nas manje ljudi, onda ljudi, onak, kad im je dosadno u svom životu, imaju, znaju, sve o svakom ..." (Andrea, RRP_TP, 4SŠ_mg)

Dodatno, kroz usporedbe s velikim gradovima, a prvenstveno Zagrebom, oslikavaju i dodatne sociokulturne i socioekonomske aspekte viđenja suvremenog sela koje označava i urbanormativno označavanje slavonskog sela, kojeg ova učenica istodobno podržava i pregovara:

„... na primjer, Zagreb, isto su ljudi potpuno drukčiji... kak' da to kažem... ne znam... mi smo još uvijek vam više k'o zaostali, na primjer, za Zagrebom...

... kad dođe netko 'vam' iz Zagreba, on je nama potpuno čudan: „Šta si ti 'vamo doš'o? ", a mi kad dođemo tam', mi smo za njih, 'aj"mo reć', neke seljačine (smijeh) „Vid' ovih sa sela... ne znaju kak' se ponašat' treba! ", i tako... A da, nas ovak' kad dođemo... mi smo jednostavni takvi ljudi, na primjer, preveseli i neozbiljni ...

... (smijeh) Pa iz grada se svi prenemažu, zapravo... onak', prave se da su neš" bolji od nas odavde, sa sela, a mi smo normalni, nama su svi isti pa se ponašamo svugdje... u Zagrebu bi se vjerojatno trebalo ponašati kulturnije i ... a mi se ponašamo tamo k'o da smo 
'vamo, k'o da smo kod kuće, ono, osjećamo se svugdje dobrodošli, da smo ... jednostavno tak'i smo...

... kad smo došli u Zagreb jednom ... stvarno se vidjelo da smo... da nismo iz Zagreba, da smo došli ... neko daleko selo... baš se vidjelo po ponašanju našem... mi nismo ... ostali smo isti ... oni iz Zagreba su tak' malo kulturniji pa ..." (Marina, RRP_DSJ, 4SŠ_mg)

Zanimljivo je kako u svom iskazu ova učenica iskazuje zapravo duboke stavove pripadnosti u relacijama mi-vi, koji na općoj razini nisu shvaćeni potpuno negativno nego više kao stvar pregovaranja značenja toga što je ruralno i urbano s odrazom u kulturnim aspektima i ponašanjima.

U još značajnijoj mjeri, učeničkiiskazi odražavaju promjene ruralnog u slavonskom kontekstu - depopulacija stanovništva, odlazak mladih na visoko obrazovanje, promet, opadanje bavljenja poljoprivredom i značaj medija i suvremene tehnologije u adoslescentskim životima te izrazita nezaposlenost i gubljenje zajedničarstva. Učenici se prema navedenim elementima drugačije odnose stvarajući uglavnom ambivalentne slike kada pokušavaju odrediti svoju poziciju i oslikati budućnost koju za sebe žele.

Na općoj razini, ruralni učenici su skloniji iskazivanju dublje emocionalne povezanosti koja se u najvećoj mjeri osjeća u stavovima u odnosu s prirodom, jer su učenici izuzetno kritični prema većini drugih elementata „ruralnosti“ koje prepoznaju u svojim okolišima i koje oslikavaju vrlo negativno - izuzev odrastanja. Ruralni okoliš u takvom okviru je vrlo tradicionalan, okrenut poljoprivredi, ali uglavnom bez nje, obilježen nedostatkom usluga, razvoja interesa i često obilježen pojmovima „zaostalost“, „zatucanost“, „provincija“, unatoč svim prednostima zajedničarskih odnosa i prirodnog okoliša kojeg koriste, uživaju i vole. Učeničke živote oblikuju i šire socioprostorne dinamike koje mijenjaju ruralne prostore i koje oblikuju načine na koje vide svoje mjesto i svoje živote u njima, i kako praktično žive svoje živote. Takva shvaćanja utječu na to da manjoj mjeri nego bi se očekivalo, i za razliku od učenika odraslih u gradu, učenici uspijevaju istaknuti pozitivne elemente i povezanost sa svojim mjestom odrastanja.

Poseban problem koji učenici ističu vezan je uz nezaposlenost, ali ne samo lokalnim okvirima, a pogotovo za one s diplomom koji kod učenika podržavaju i stav da je preseljenje nužno ponovno potvrđujući strategiju $(\mathrm{K})$ za poslom se ide: 
„... Pa i nisu baš neke šanse jel pošto nema u ovom kraju baš posla pa je bez obzira el ima .. ako ima diplomu trebala bi ići negdje dalje, u neki grad i tražit posao..." (Marijan, RRP_DSJ, 4SŠ_mg)

U tom okviru, selo se suprotstavlja diplomi, a želja da se ostane sukobljava se želji za radom, posebno visokoobrazovanima. Stoga oni koji odlaze, ne vraćaju se, ali uspostavljaju i obrasce koji se reproduciraju:

„.. ima nas [mladih] na prste jedne ruke nas možete izbrojati... i svi su ovako otišli studirati u neke veće gradove... nitko se ne zadržava..." (Marija, RRP_TP, GIM_mg)

„... Pa nemaju šta raditi... bolje da idu negdje, ne znam, u neku drugu državu s tom diplomom ak' je već imaju da završe neš" bolje, da nađu neš" bolje... ak' su se već tol'ko trudili, dogurali do diplome, zaš" bi sad završili na nekom selu (smijeh) ... Ne[na selu ne treba visoko obrazovanih]... šta će (smijeh) ... (Marina, RRP_DSJ, 4SŠ_mg)

Emocionalna vezanost je prisutna i u većoj mjeri je praktično izražena s obzirom na mogućnosti koje ruralni okoliš u većoj mjeri dopušta „snalaženje“ učenicima, u nedostatku nekih drugih aktivnosti, no koje su i do određene mjere ograničene nedostatkom vremena bilo zbog obrazovnih obaveza ili pomaganja roditeljima. Stoga su elementi prirode, posebno u odnosu na odrastanje, odnos s prirodom posredovan poljoprivredom, i općenito mir i tišina nalaze na prvom mjestu pozitivnih obilježja života na selu.

„,... Pa baš ta mirnoća... ta mirnoća bez obzira što sam na glavnoj cesti pa ono kamioni u 5 ujutro ispusti baš onak' neki zvuk ... ali nije, ne, na primjer kao ovdje [u gradu]... definitivno, puno manje, onako, buke... pod šumom smo i okruženi poljima i baš mi se to stvarno sviđa, $i . .$. "(Ivana, RRP_DSJ, 4SŠ_mg)

„... prirodu, tu tišinu, mir, kad tamo dođem, ja se tamo opustim, manje vremena provodim i na kompjutoru, uvijek tako nekako vani sam, radim oko cvijeća ili tako nešto... tako da me to jednostavno opušta kada odem tamo..." (Marija, RRP_TP, GIM_mg)

„... možda jedino što mogu izdvojiti mir i tišinu, ne znam.. kad poželim izaći na dvorište i sunčat se, ja ću izaći na dvorište i sunčat se... da sam u gradu, gdje bi to napravila?! Jedino, eto, po tom pitanju nekakve slobode..."(Gordana, RRP_TP, GIM_VG)

A kako pokazuje sljedeći primjer, takve aktivnosti katkada dodatno osamljuju učenike u njihovom osjećaju nepripadanja i nedostatka mogućnosti u mjestu odrastanja, pa čak i suprotstavljaju s obzirom na shvaćanja o obrazovanju, što je dio procesa pregovaranja njihovih pozicija i daljnjih pravaca razvoja, ali isto tako i nesigurnosti, neodločnosti i konflikata koju dodatno podupire nedostatak reusrsa okolišima odrastanja i školovnanja. Učenice su bile spremnije svoju sliku o sebi osnivati na prirodnijim elementima okoliša i isticati aktivnosti u prirodi u nedostatku nekih drugih. 
„...vozit se biciklom i gdje god uhvatim slobodnog vremena, bilo kakve aktivnostisam da sam u prirodi.. mene to već, stvarno... ja jednostavno $k^{\prime} o$ da sam rođena u prirodi ... nisam navikla bit zatvorena ... mene, recimo, škola izluđuje, ovak, ono cijelo popodne, ono sunčan dan da budem unutra je l' ja sam jednostavno: uzet psa na povodac i ne znam šetat ga kraj rijeke il' negdje, livade, bilo šta.. ne trebaju mi ni drugi ljudi.. sam'... da budem sama $\boldsymbol{i}$ da sam vani meni je to dovoljno... (Ivana, RRP_DSJ, 4SŠ_mg)

„... Kave, ako neko treba nešto pomoć, organiziranje tih smotri, odlaženje na nastupe [KUD-a]... puno te male djece dolaze, recimo, kod mene da im pokažem engleski ili tako nešto.. onda, sad ak' je nešto za ovu udrugu za prijateljicu... vožnja biciklom, $i$ tako.. uglavnom, nemam sad baš puno vremena što se tiče škole, završni i sve, al' kad imam vremena, obično pomognem mojima, je l', kući i to sve, a onda navečer, uvijek su to neke kave il' kartanje i tako..." (Silva, RRP_TP, 4SŠ_VG)

Takvi opisi više se pokazuju u kontrastu prema onome kako učenici doživljavaju život u gradu, i pokušaj izdvajanja određenih specifično ruralnih i pozitivnih karakteristika. Uglavnom prevladava stav da okoliš odrastanja ne nudi puno adolescentima za njihov društveni život u odnosu na isticanje gradova kao ,prostora za višse“:

„.... što se tiče, na primjer, ovako da se imamo gdje sastajat mladi, nemamo uvijek, na primjer, ako želimo negdje izać, moramo ići dalje u drugo selo ili grad,.. na primjer, tamo nema ni knjižnice ako ja želim doći za vikend pa podignit si neku knjigu il' nešto ... pa nema baš društvenog ili ovako nešto... “ ( Marija, RRP_TP, GIM_mg)

„... Pa miran... miran, hmm... bez puno, ne znam, nekih događanja, sve je više onako monotono, svaki dan je većinom isti, nema nekih događanja, previše... Pa ni nema ... nema ni prijetelja puno, ni aktivnosti... hmmm.... Prijetelji... iskreno, iz sela, s nikim nisam povezana, iz sela se stvarno s nikim ne družim ..." (Ivana, RRP_DSJ, 4SŠ_mg)

Kada su kulturne prakse u pitanju radi se o onima dostupnima i/ili mladim ljudima zanimljivijima: sviranje u crkvi, sudjelovanje u KUD-ovima i tradicijskim kulturnim manifestacijama. Navedene aktivnosti je zanimljivo promatrati u okviru dihotomije tradicionalno/moderno ili ruralno/urbano. Gimnazijalka ruralnog rezidencijalnog podrijetla koje je svoje interese razvijala sviranjem u crkvi, što je aktivnost koja joj je značajna prvo u slici sebe, a zatim i kao odraz (lokalnog) društvenog statusa njene obitelje: „...moji roditelji su baš cijenjeni, na primjer mi kao djeca smo jako cijenjeni... na primjer, ja sviram u crkvi, $i$ ne znam.. „ona svira u crkvi, ona je pristojna, ona, opet, ide u gimnaziju,... “, tak' da..." (Marija, RRP_TP, GIM_mg). No, ograničenja ruralnog konteksta odrastanja i gimnazijske obrazovne obaveze zbog kojih živi u domu prisiljavaju za ovu učenicu odgađanje posvećivanje aktivnostima koje voli za razdoblje nakon srednje škole stoga se razvija slika o studiranju u većem gradu koji osim dobivanja kvalifikacije omogućava i ,izgradnju sebe“: 
„...Ja smatram za studiranje još više izgraditi sebe, postiči nešto od sebe $i$ (...) više se unaprijediti $i$ tek onda naći posao $i$ raditi (...) nadam da ću imati $i$ vremena za sebe više nego u srednjoj školi...Pa na primjer, ja sam prije svirala klavir pa sam htjela, na primjer, kada otiđem na studij da nastavim svirati klavir, je l' ovamo nemam vremena, stvarno... kad dođem iz škole budem i umorna stvarno i onda se pripremat za budući dan, i tako sve... mislim da bi imala... na primjer $\boldsymbol{u}$ većem gradu, i neke sportske aktivnosti ili bilo šta drugo ..."(Marija, RRP_TP, GIM_mg)

Slično, još jedna učenica ruralnog rezidencijalnog podrijetla $\mathrm{u}$ skladu $\mathrm{s}$ lokalnim mogućnostima i za obrazovanje i za izvanškolske aktivnosti, mora vršiti izbore s obzirom na to kakva osoba želi biti i što joj je važnije. Gordani je iznimno značajan sport koji je dugo trenirala, no postoji nešto još važnije što čini značajan dio njenog identiteta:

„... to mi je [obrazovanje], u biti, najbitnije u životu.. ne znam, imala sam ja $i$ slobodno aktivnosti prije, rukomet sam trenirala godinama, ali ja sam jednostavno vidjela da jedno ispašta zbog drugog, i u biti, kad god sam primijetila da mi učenje ispašta zbog nečeg drugog, ja sam se odrekla tog drugog, tako da mi je to zapravo najbitnije od svega..." Gordana, RRP_TP, GIM_VG

U velikoj mjeri, dnevno putovanje zbog školovanja kao i potreba putovanja na treninge izvan mjesta svoga odrastanja stvaraju nedostatak vremena i sukob koje izvanškolske aktivnosti imaju s drugim dijelovima samopoimanja - onog visokoobrazovno orijentiranog - stoga u studiranju vidi mogućnosti za razvoj svojih posebnih interesa, koji je zapostavljen tijekom gimnazijskog obrazovanja. U velikoj mjeri, ove učenice odrasle u slavonskim selima donijele su ranije odluke o upisu ,teških“ škola u velikom ili udaljenom gradu koje im predstavljaju potrebu žrtvovanja nekih drugih aspekata života značajnima za njih, a posebno pod opterećenjem potrebe putovanja ili života u domu. Ti dodatni izbori o konkretnoj školi i mjestu studiranja ostavili su tragove na njihovim iskustvima srednjoškolskog života kao i odnosa sa zajednicom odrastanja, no na različite načine. Gordana će istaknuti: „...ja se ni ne osjećam kao da živim na tom selu, jer ne provodim tamo vrijeme nikad... to je samo onak' nešt', mjesto gdje ja boravim...Pa ne sudjelujem uopće (smijeh).. odem na misu nedjeljom $i$ to je vrhunac.. e, šetam psa! To je jedini moj kontakt općenito sa ulicom i selom...". Njeni prijatelji uglavnom su gimnazijalci iz grada, a koji podržavaju i njene obrazovne želje, ali i predstavljaju specifičan krug ljudi „,istomišljenika“ s kojima postiže razumijevanje koje ne uspijeva postići u ruralnom kontekstu svog odrastanja:

„... ja imam jednog prijatelja koji ide sa mnom u gimnaziju $i$ to je zapravo jedini $s$ kojim se družim i njegova sestra koja je završila gimnaziju , ovaj, ide sada na fakultet... hmmm... jedino se mi međusobno družimo tamo, s ovim ostalima baš ne mogu naći nekakav zajednički jezik ili zajedničku temu, tako da... a milsim i ne osjećam neku pretjeranu potrebu da se tamo družim s njima... " (Gordana, RRP_TP, URP_VG) 
Općenito, među učeničkim aktivnostima ističe se bavljenje sportom , koja se u jednakoj mjeri bave i oni koji namjeravaju i oni koji ne namjeravaju studirati, te kao aktivnost koja je najdostupnija u većini okoliša, te su vrlo često rekreativnog oblika, i bitni dio nečijeg osjećaja pripadanja u širu zajednicu, posebno za mladiće. Ipak, u najvećoj mjeri treniranje nekog sporta se doživljava u suprotnosti sa onim obrazovnim, barem onima koji namjeravaju studirati kako to pokazuje prethodni primjer.

Ruralnim učenicima se često takve aktivnosti pojavljuju više rekreativnog karaktera u skladu s njihovom procjenom manje dostupnosti nekim drugim aktivnostima, uopće, ili onih njima zanimljivima. Takve aktivnosti razvijaju i specifične odnose s prirodnim okolišem i uklapaju se s drugim aktivnostima koje oblikuje živote mladih u ruralnom okolišu.

Određeni konteksti - oni ruralni - su otvoreniji pružanju sportskih ili sličnih aktivnosti u prirodi. Sljedeći primjeri ukazuju kako ruralnim učenicima koji svoje okoliše odrastanja, na općoj razini, procjenjuju nedostatnima oblikuju svoja shvaćanja o sebi - lokaliziraju svoju subjektivnost (Cairns, 2011) - kroz prakse koje koriste:

„... Pa.. teško pitanje.. ne idem u selo baš, pa... Pa, tjedno ovak odemo igrat nogomet, sa prijeteljima... aktivan sam, volim raditi, većinom neke teške poslove... lagani pos'o, to me baš ne zanima, nije opterécenje, ono, za tijelo, više volim baš teške poslove... Nema baš [neke druge aktivnosti] ... osim što umiru ljudi ništa drugo se ne događa... “" (Dominik, RRP_DSJ, 3SŠ_mg).

Bitno je uočiti kako ovaj opis ima značajnu rodnu dimenziju naglaska fizičke aktivnosti (i sporta) kao izraza specifične slike ,ruralne muškosti“. U drugim dijelovima intervjua, takvo viđenje sebe pojašnjava i određene nekonzistentnosti i neodlučnosti kada su u pitanju obrazovni aspekti: učenik opisuje situaciju u kojoj je izostao s nastave kako bi s ocem išao raditi, unatoč tome što učenik visoko vrednuje učenje i želi nastaviti školovanje:

„...više volim kad sam pametniji od drugih, i tak... volio bih da imam... da ostvarim još više od ovog (...) prije 2 tjedna pisali test iz hrvatskog, poslije tol'ko godina sam opet dobio peticu, i to samo zato što sam 2 i pol sata učio hrvatski, i naučio sam za 5, i jedini sam u razredu dobio 5, tak da sam ... ono bio sam sretan, a $i$... sad kad neko dobije onak, na primjer, ja dobijem četvorku, netko dobije peticu, razljutim se, jednostavno jer znam da sam $i$ ja mogao dobiti peticu al' nisam dobio... [osjećam se] glupo, kak' bi se reklo... pa znam da sam mogao dobiti bolju, ali nisam, $i$ onda... onda... ljut sam jednostavno, kak' bi rekli, uzrujan il'šta.. nije mi svejedno...". (Dominik, RRP_DSJ, 3SŠ_mg)

Ovi iskazi iz različitih dijelova intervjua, dodatno podcrtavaju učenikovo nezadovoljstvo upisanom školom i neodlučnost koja izvire iz načina na koji opisuje planove oko daljnjih pravaca nakon srednje škole. Nasuprot tome, učenik s najboljim prosjekom ocjena među intervjuiranima gradi prvenstveno sliku o sebi obrazovnim elementima - prema tome koju 
školu pohađa i što bi htio studirati, a nasuprot sportskim aktivnostima, te nasuprot sudjelovanju u lokalnim aktivnostima, a posebno onima sportskima:

„...Pa završio sam srednju četverogodišnju [X] školu... smatram da sam po znanju sposaban za općenito neki jednostavniji fakultet. nemam baš neke prednosti za neki viši fakultet, to jest jači možda, ako nemam motivacije, $i .$. ne bavim se nikakvim sportskim aktivnostima...

...Pa recimo kad se nešto to organizira, ne uključim se ili u većini slučajeva ne idem kad je nekakva organizacija, i onda po tome smatram da ne ... baš $i$ ne što se tiče, ovako, sportskih $i$... to ne nešto, ali gledamo serije i tako..." (Marijan, RRP_DSJ, 4SŠ_mg)

Slično, i ostali učenici ruralnog rezidencijalnog podrijetla, bez obzira na svoju dublju povezanost i uključenost u život zajednice, isticat će u pojedinim dijelovima intervjua sukobe između uklapanja dodatnih aktivnosti s ostalim školskim i specifično radnim obiteljskim obvezama, te bavljenje aktivnostima koje su u većoj mjeri povezani s provođenjem vremena $u$ prirodi ili s prirodom kroz sportske i poljoprivredne djelatnosti. Takve učeničke prakse važan su način kako učenici promatraju sebe i oblikuju svoje obrazovne orijentacije i migracijske tendencije. Dublje promatranje toga kako učenici provode svoje svakodnevne živote pomaže i bolje razumijevanje određenih neodlučnosti i nesigurnosti kada su u pitanju namjere učenika nakon srednje škole.

U tom kontekstu je zanimljivo usporediti slučajeve dvoje učenika strukovnih srednjih škola koji su odrasli na selu i školuju se u velikom gradu, i koji se, opisujući svoje visokoobrazovne izbore, osvrću na svoje odrastanje i način života u ruralnom okolišu. U Mislavovom narativu, daleko je osjetniji utjecaj obiteljskog života i dublja emocionalna vezanost za zajednicama u kojima živi, te ljubav za određeni način života vezan uz uzgoj životinja sa željom za stjecanje obrazovanja koje će mu omogućiti njegovo održavanje. Stoga su učenički rani izbori vezani uz upis poljoprivredne srednje škole koja mu je značajna zbog stjecanja specifičnih stručnih znanja u željenom području djelatnosti, i usmjerene reprodukciji profesionalnog i društvenog statusa svoga oca, te povratku u rodni kraj nakon završenog studija.

„,... Moj život u mome mjestu... znači, imam dvije sestre, otac i majka... oni se, znači, otac se bavi poljoprivredom.. ja se s njim, pomažem znači.. i mama ... sestre su većinom na fakultetima... eto imamo, bavimo se, imamo uzgoj crnih slavonskih svinja, znači da, svinje imamo, nešto ovaca, imamo konje.. uvijek u doticaju sa životinjama i to mi je priraslo srcu..." (Mislav, RRP_DSJ, 4SŠ_VG)

U tom kontekstu, učenik pruža konzistentan narativ o utjecajima koji su oblikovali njegove odluke koje su duboko prostorno oblikovane, i uklopljene s njegovom lokalnom slikom o sebi pri čemu ističe ,živim na selu“, ali i budućim planovima. Stoga će i pod pitanjem studiranja istaknuti: 
„.. a ne mislim se ja totalno preselit u Zagreb (smijeh), ja ću samo tamo otić kao stanovat'... ja se mislim vratit' jer ja volim svoj zavičaj $i . .$. po meni, moram donijet' svom selu, svojoj okolini donijet', taj, malo... privremeno [preseljenje zbog studija] samo... ništa dugotrajno..." (Mislav, RRP_DSJ, 4SŠ_VG)

Kod ovog učenika je moguće promatrati određenu dozu konflikta, ali ne kada je u pitanju studiranje po sebi, koje se obiteljski potiče, već u većoj mjeri činjenica da studij dugo traje i zahtijeva preseljenje, pa time i razdoblje prilagodbe zbog promjena koje studij donosi:

„...Pa meni će biti mali šok vjerojatno zbog malo odvojenosti i.. al ovako mislim da će bit u redu jer ipak je to stepenice, to se mora prekoračit, htjeli mi-ne htjeli ... moramo...", ali ipak bez pretjeranog straha jer učenik ima plan vratiti se: „... kad dođu sestre one kući što nisu dugo bile tu, poznaju ih ljudi uvijek, one poznaju druge ljude.. nikad nije bilo sad nekog izopćenja.. malo će se umrtvit, znači, neću bit tu fizički al valjda ću i dalje moć pomagat kad završim fakultet..." (Mislav, RRP_DSJ, 4SŠ_VG)

Slično, i učenica koja namjerava studirati u području biotehnologije svoje visokoobrazovne izbore objašnjava motivacijom poznatosti i odrastanja, iako su njena životna iskustva i školska iskustva te osjećaj uklopljenosti u zajednicu odrastanja i budući planovi vrlo različiti. Odrastanje u ruralnom okolišu potiče njene osnovne želje: „.. s djedom radila na polju, uvijek s bakom u vrtu, tu sad kao nekakvo povrće, voće...", iako ono predmetno nije povezano s njenim srednjoškolskim obrazovanjem, već se više razvija u djelatnostima izvan škole:

„.. prošle godine sam sama uzela radit, što se tiče cvijeća, uzgoj, i dosta dobro mi je to uspjelo prošle godine, ove godine je uspjelo još bolje.. i sad sam ono sretna ko malo dijete, kako mi je sve to uspjelo, i sad.. možda, ne znam, počnemo i s tim malo bavit... " (Silvija, RRP_TP, 4 SŠ_VG)

Najvažniji utjecaj srednje škole očituje se u poticanju samopouzdanja sa stavom da završava cijenjenu školu i stječe cjenjeno zanimanje, što joj otvara mogućnosti daljenjeg (K) napredovanja više i dalje u skladu s njenom slikom o sebi: „... ja imam visoke ciljeve $i$ da ono što ja zacrtam da ja to moram ostvarit...".

Za oboje učenika i druge aktivnosti, koje su im dostupne, značajnim su dijelom toga kako oblikuju svoje adolescentske živote, iako u različitoj mjeri potiču njihov osjećaj pripadanja. Iako će i Mislav istaknuti stavove svoje zajednice koji se ne uklapaju s njegovim težnjama za visokim obrazovanjem (,... oni kažu „Nemoj ić na fakultet!“, pa ja njega razumijem, kod njega nitko nije išao na fakultet, znači, njegova djeca nisu išla na fakultet... pa ja znam da ta osoba ne zna šta će drugo reć i ona kaže meni svoje iskustvo života... ja poštujem njegovo iskustvo života, i oni će valjda poštivati moj kad ja odem na fakultet..."), primjer njegovog visokoobrazovnog oca i želja za reprodukcijom njegovog statusa u ruralnom društvenom 
sustavu (Rye, Almas, 2004) izražavaju se kao (K) mogućnost zamišljanja sebe u budućnosti u ruralnom okolišu s čime su usklađene i njegove mnogobrojne aktivnosti.

„...imamo te šokačke zabave i spremanje tako, spremim se.. ima pokladno jahanje uvijek... kako mogu pridonijet tako da si znači obaveze, da si nekako sve uklopim, znači, ne mogu ja sad otić i cijelo vrijeme igrat nogomet za Župu (...) al' odem pomoć ... dost' aktivno sam ..."

„... Meni je dosta bitna za veterinu kad dolazim sa sela, jer svi govore, i otac.. tak mi je tata rekao i na fakultetu.. on je imao više predznanja nego ovi sa grada kad su išli na veterinu... ne ovako teorijsog znanja nego više praktičnog... znači, profesori, kad je on išao na praksu u Sarajevo kad su bili, uvijek su govorili drugi: „, Ajde Tomice dođi, ideš s nama, pokaži “.. jer je tata bio završio vamo za veterinarskog tehničara, radio je praksu i on je imao već, znači, imao je zalet taj u praksi...“(Mislav, RRP_DSJ, 4SŠ_VG)

Nasuprot tome, iako i Silvija koristi sve pogodnosti ruralnog okoliša koje joj se pružaju i razvija mnogostruke veze sa zajednicom odrastanja ne pronalazi sliku sebe u budućnosti uklopivu u lokalnu pa čak i nacionalnu sredinu. Njena slika o sebi, sada i u budućnosti, konfliktnija je na svakom koraku izbora, posebno s obzirom na nedostatak značajnih resursa. Svoje planove stjecanja visokog obrazovanja i odlaska u inozemstvo ona uvelike oblikuje u suprotnosti na ono što ostali mladi rade i kako usmjeravaju svoje živote, a time i cjelokupnom mentalitetu i neperspektivnosti života u ruralnom okolišu:

„... planiram što više ovdje školu završiti, znači ne ostati na 3 ako mogu na 5 i na nešto više, $i$ otići raditi negdje van gdje ljudi cijene rad, a ne ostat ovdje $i$ visit na Birou jer mislim da to nema smisla... učiti tolike godine da bi, ne znam, sjedila kod kuće i gulila krumpire, mislim da je to, ono.. bezveze..."

„... [mladi u mom selu]previše žive načinom, na način kako im žive roditelji, znači: bit ću kod kuće, radit ću zemlju, to je sve što ću znat' u životu, tako da... mislim da oni uopće.. mislim da nemaju ni stav ... puno njih nije završilo ni srednju školu..."

U tom kontekstu, odrastanje i život na selu ipak su značajni učenici; svoja iskustva procjenjuje značajnima za to kakva je osoba postala, i iako ne uspijeva posve objasniti zbog čega je odrastanje na selu „bolje“ (,... mislim da, u gradu kada bi živjela, recimo, ne bi mogla steći iskustva kao što je, na primjer, to s djedom što sam kao mala obilazila polja... hmmm... ne bi mogla se igrat ispred kuće, recimo, ne bi mogla tako otić' na igralište tamo šutat' loptu, ili otić' plesat' KUD...“), radi se o specifičnom praktično izgrađenom lokalnom identitetu kao izvoru samopouzdanja za postizanje uspjeha na odabranim putovima koji podrazumijeva izmiještanje s trenutnih loših okolnosti obrazovanjem i odlaskom. Studiranje tako znači samo još jednu stepenicu „dalje i više“ koja nosi i neke promjene i dodatno razlikovanje od nekih negativnih urbanormativnih oznaka manje vrijednosti: ,..to je bio neki skup ... hmmm... kada je dotična gospođica jedna, je li, jedna iz Osijeka rekla: „ok, mi sad Osječani ostajemo, vi 
seljaci idite!"... to mi je baš diglo tlak, tad sam se posvađala s njom... “ (Silva, RRP_TP, 4SŠ_VG)

Ovakve aktivnosti teško je shvatiti kao kulturni kapital u bordjuovskom smislu, ali značajnim je uočiti potencijale koje ima za razvoj lokal(izira)nog kulturnog i društvenog kapitala ruralnih zajednica. Osnovna prepreka pri tom se pokazuje nemogućnost zamišljanja budućih života u lokalnom okruženju pri čemu većina primjera pokazuje kreiranje slike o sebi u odnosu na ono što ne karaakterizira okružujuću zajednicu.

I ostali učenici ruralnog okoliša će slično svoje iskustva ruralnog odrastanja promatrati pozitivnim oblikujućim iskustvima za razvoj osobe, iako ona najčešće djeluju kao motivirajući mehanizam za izmještanje iz ruralnog okoliša, načina života koji ga obilježava i ljudi koji ga nastanjuju. Iako se učenicama katkada pojavljuju konfliktniji kada su u pitanju slike njihovih budućih života, odnosno kada se postavlja pitanje zasnivanja obitelji.

Za ovu učenicu, značajnim se kroz cijeli intervju pokazuje isticanje određenih aktivnosti specifično nogometa i kartanja - kao specifičnih aktivnosti vezanih uz izgradnju rodnog identiteta postizanja ekonomske sigurnosti i nezavisnosti: „.. da ću dobiti svaki mjesec plaću, da ću moć platit režije, školovati svog brata, pomoći mojima, i da ću imati svoj život, da ću izgradit svoj život onako kako ja želim...". U kontekstu ovog intervjua to znači stjecanje visokog obrazovanja i odlazak izvan granica države, ali i iskorijenjivanje iz zajednice odrastanja s obzirom na ono što primjećuju u svojim okolišima:

„..cure koje znam, znači, njih 5 iz sela je već na fakultetu, a njih 2 su uspješno diplomirale, ove ostale sad, je l', idu na fakultet..." (Silva, RRP_TP, 4SŠ_VG)

„... cure, ne idu... neki idu na fakultet, neki su već završili srednju školu, ne planiraju dalje, ne znam hoće li se udat ili nešto..." (Marija, RRP_TP, GIM_mg)

„... prijateljice iz osnovne škole... njih , ne znam, $60 \%$ se već udalo, jer njima... nema nikakve drugačije ambicije, njima je to to, a meni je to nepojmljivo... šta još, stavljaju čizme u prozor... o čem mi pričamo?!.." (Gordana, RRP_TP, GIM_VG)

Iako sve visokoobrazovno orijentirane učenice obrazovanje postavljaju kao prioritet i utječu na posebno oblikovanje rodnog identiteta u kojem se želja za ekonomskom nezavisnosšću i sigurnošću postavlja nasuprot želji za osnivanjem obitelji, za neke učenice se cilj u većoj mjeri oblikuje kao ostvarivanje boljeg životnog standarda što uključuje zadovoljivanje osnovnih životnih potreba sebe i svojih obitelji. Takve slike nisu uvijek geografski jasno određene, a učenice su daleko spremnije svoje ambicije društvene i geografske mobilnosti 
pregovarati kada se u sliku uključi buduća obitelj. Tada se slike budućnosti u većoj mjeri usklađuju sa slikama vlastitog odrastanja i života, kao i uključivanjem želja drugih članova tih novih obitelji:

„.. ja bih ipak željela da moje dijete može više negdje da je prirodno okruženje živjeti... tako da mislim da je manji grad..."(Marija, RRP_TP, GIM_mg)

„.. jednog dana želim imati $i$ djecu $i$ obitelj i posao i karijeru tako da sve to planiram uskladiti... ne znam kako, ali planiram.. i tako se vidim kao jednu ženu koja ima i obitelj $i$ posao, ako to postoji uopće... Nemam ništa određeno [što se mjesta tiče]... gdje me život odnese... jer mislim, ako sam rekla da ću biti udana, onda ne mogu sama odlučivati o tome, to će svakako biti..."(Gordana, RRP_TP, GIM_VG)

Sve ove učenice će istaknuti kako ih je oblikovalo to što su sa sela, a iskazi upućuju da je to, uz interpretaciju svoje klasne pozicije, prvenstveno motivacijski mehanizam za postizanje što boljeg uspjeha u budućnosti. To je najočitije kod učenice koja općenito pokazuje nisku emocionalnu vezanost za svoje mjesto, nisku razinu pripadanja i želje za ostankom.

Jedan od osnovnih slika u načinu kako se predstavila učenica bilo je preko njenih aktivnosti, a koje usmjeravaju i njene visokoobrazovne izbore. Kod nje postoji interes za pomaganje ljudima koji imaju teškoća te koje je odražavaju kao humanu „,..u slobodno vrijeme volontiram, i sad da neka karakteristika za mene, za volontere kažu da su humani, što... ajmo reć da sam humana $i$ ne volim se ismijavat ljudima koji imaju neke tak određene posebne potrebe, $i$ volim radom pomagati... “. Nasuprot tome što je ona, postavit će način na koji shvaća svoju zajednicu i što osjeća prema njoj:

„....Ja ne volim svoje mjesto gdje živim... ne volim zato što ljudi su ... ljudi tamo zatucani, i ono, svi gledaju način govora na kojem pričaju, izražavanja... zato ne volim to baš (...) u selu su ljudi svi onak za poljoprivredu (...) znači, ljudi kad idu svi se zabulje u tebe (...) ovi sa sela svi: „, Gle šta je obuko??" (...) kod nas na selu kad bi vidjeli homoseksualca, oni bi ga utukli... [nije] k'o što ja gledam pozitivno na njih (...) ja mislim da kad je bio referendum da jedino moj glas je bio za, to jest protiv.. (...) na primjer, kad prolazi osoba s invaliditetom u selu svi na prozor gledaju nekoga sa invaliditetom čovjeka koji je, onak, u kolicima sa ... “ (Andrea, RRP_TP, 4SŠmg).

S obzirom da se prethodni opisi svog odmaka i razlikovanja od svoje zajednice odvija i kroz dihotomiju selo-Zagreb, u svom narativu učenica opisuje „urbanu“ sliku o sebi s obzirom na svoje karakteristike, stavove tolerancije prema razičitosti i liberalinih političkih stavova, te njene želje za obrazovanošću i volontiranjem. Kako u svojoj zajednici ne pronalazi niti zadovoljavajuće kulturne ili obrazovne aktivnosti, rad u udruzi pronalazi u mjestu školovanja, a osim što su takve aktivnosti izravno oblikovale njene želje za područjem obrazovanja, označile su i razvoj društvenih mreža za informiranje i poticanje studiranja, te time njen 
društveni kapital značajan za razvoj želje studiranja: „,...i onda putem tih voditelja volontera.. tamo.. baš puno sam se informirala (...) Oni su rekli da je to jako humano i jako dobro što planiram to studirati... “ (Andrea, RRP_TP, 4SŠ_mg).

U takvom okviru diploma za ovu učenicu dobiva posebno značenje odvajanja i razlikovanja od „ruralnog“, kako ga ona vidi u svome mjestu:

„... to je selo, provincija (...) to što sam... svi gledaju te kao seljačina, zato što... ja ne volim te predrasude, i zato... ima svugdje, ajmo tak reć, kao što oni nazivaju „seljacima“ pod navodnicima, i mislim da je to jako zakinuto od strane sviju ljudi, to je ono u ljudskoj psihi...

... mislim da ću [studiranjem]sebi postići lagodan život, mislim ako nastavim one plus dvije godine, $i$ ako ne... mislim da bi me ljudi puno više cijenili u društvu nego ako završim neku trogodišnju školu, mis.. oni koji su na višem sloju, mislim, malo višem, uzvišeno bi se ponašali prema meni to bi sve oni svojim efektima il' nešt': „Ah... Ti si seljak!“, ili tako $n e s ̌ t '$..." (Andrea, RRP_TP, 4SŠ_mg)

Nasuprot tim prevladavajućim stavovima, samo dvoje učenika ističe vrijednost diplome u ruralnom okolišu, odnosno zadobivanje statusa u ruralnom društvenom sustavu; to su učenici koji mogu zamisliti svoj život u ruralnom okolišu, pri čemu je Mislavu to odlučeni plan prema dalje ostvarenju povratka, a velika motivacija stjecanja diplome vezan je uz održavanje života koji trenutno vodi sa svojom obitelji:

„... studij bi mi donio u prvom redu sve osobno, meni, znači da ... neki veći stupanj, znači, da imam, kao, veći status u društvu i da mi se otvore vrata novog nečeg (...) kad se se nekom kaže da je doktor, ipak je to kao neka titula, označuje se i ...više u društvu nešto znači nego meni osobno (...) lijepo je kad dođete u društvo i ne'ko vas oslovljava ,doktore “, i... to je ... da ..." (Mislav, RRP_DSJ, 4SŠ_VG)

Za Ivanu je diploma, odnosno studiranje, u većoj mjeri neodlučeno zbog nepovoljnije prvenstveno ekonomske situacije, ali je time i mehanizam za veću prihvaćenost u lokalnom kontekstu:

„... ljudi onako ne primjećuju me baš ... a opet mislim da kad bi nešto postigla da ću sa studijem i sa svima, mislim da bi razglasile bi se sigurno po selu... mislim pošto baš u selu i nema puno ljudi koji idu na fakultet mislim da bi bila nekako prihvaćenija u tom društvu nego što sam sad..." (Ivana, RRP_DSJ, 4SŠ_mg) 


\subsubsection{Zaključno}

Ukratko, prethodne analize, u svom statističkom dijelu, potvrdile su konzistentan obrazac urbano-ruralnih razlika na gotovo svim mjerenim aspektima visokoobrazovnih odluka slavonskih maturanata, njihovih obrazovnih karakteristika i orijentacija, te dostupnosti resursa u njihovim obiteljskim i školskim okruženjima. Osnovnu nadopunu činilo je dublje ispitivanje simboličkih elemenata odrastanja i školovanja.

Prvotne analize su ukazale da za razliku od učenika urbanog rezidencijalnog podrijetla, koje u većoj mjeri karakterizira orijentiranost prema visokom obrazovanju, odnosno ranije, uvjerenije i neupitnije odluke, za učenike odrasle u ruralnoj sredini vjerojatnija je orijentiranost stjecanju struke i odluka o nestudiranju, nepodrazumijevanje studiranja, a s obzirom na konačne očekivane stupnjeve obrazovanja, i veće percipirane prepreke postizanja visokog obrazovanja. Dijelom, pronađene ruralno-urbane razlike objašnjavaju tip škole i ocjene, što su podaci koji skupno opisuju poziciju učenika u završnim fazama procesa donošenja njihovih odluka na kraju srednjoškolskog obrazovanja. Drugim riječima, ruralni učenici u većoj mjeri upisuju strukovne škole, a daleko manje gimnazije, a također postižu niže rezultate školske uspješnosti u odnosu na one odrasle u gradovima, što uvelike utječe na njihove daljnje obrazovne pravce (Klepač, 2016).

Kvalitativni podaci u većoj mjeri su, ali očekivano i ne isključivo, te razlike povezali i s odrednicama kulturnih i ekonomskih kapitala obitelji pri čemu učenici obrazovanijih roditelja u većoj mjeri odabiru gimnazije kao put u visoko obrazovanje, dok će ostali učenici u većoj mjeri prema visokom obrazovanju kretati preko strukovnog obrazovanja. Usporedni primjeri učenika s visokoobrazovnim roditeljima urbanog i ruralnog okoliša ipak pokazuju određene razlike i naglašavaju ulogu lokalnog identiteta u odlukama mladih o obrazovanju i diplome u ruralnom okolišu. Takvi izbori su kompleksni i mnogodimenzionalni, no zamjetljivo je da se roditeljski utjecaj slabije pojavljuje u izborima oko upisa strukovnih škola, osim za učenike koji su izrazito školski uspješni i čiji su izbori u većoj mjeri oslonjeni na učenje na roditeljskom iskustvu, kao svojevrsni nastavak onoga što njihovim roditeljima nije uspjelo. Općenito, postoji stav - izražen nezadovoljstvom krivih izbora - kod strukovnih učenika koji namjeravaju studirati, te se strukovne škole čak i uz odličan uspjeh pokazuju ,slabijim“ usmjerenjem prema visokom obrazovanju, a kod učenika izaziva osjećaje nesigurnosti i strahovanja oko uspjeha te snižavanje obrazovnih aspiracija. Općenito, pokazalo se da se visokoobrazovna orijentacija kod učenika izražava na različite načine i s različitim stupnjem uvjerenosti u postizanje uspjeha te je za određene učenike ono samo izraz prihvaćanja značaja 
obrazovanja, ali se još uvijek pregovara s pitanjem oko isplativosti ulaganja u obrazovanje, posebno za one koji su kasnije donijeli odluku o studiranju na osnovi procjena loših mogućnosti zaposlenja, a ne intrinzično motivirano. Također, kod određenih učenika su narativi i planovi bili vrlo neodređeni ukazujući na teškoće oko zamišljanja sebe u okolišima visokog obrazovanja i/ili grada. Onima sa slabijom strukturom obiteljskih resursa odabir gimnazija se pojavljuje kao posebno rizičan odabir, a onima koji se odluče na taj put, znači dodatne izbore i ,podnošenje žrtve“ teškog gimnazijskog obrazovanja (što će svi gimnazijalci isticati vezano uz svoje gimnazijsko obrazovanje). No, također će se isticati i prednosti gimnazijskog obrazovanja u širem rasponu priprema - i za fakultet i za život, čak i unatoč lošijim ocjenama.

Dodatno, statistički, učenici ruralnog rezidencijalnog podrijetla imaju i niže rezultate na mjerama osobnog kulturnog kapitala razvijenog izvan školskog konteksta što ih stavlja u dodatno nepovoljnu poziciju kada je namjera o studiranju u pitanju. Ipak, kvalitativno je ukazano kako učenici s nižih socioprostornih razina sudjeluju u različitim aktivnostima koje su im dostupnije, iako se ne mogu nazvati kulturnim kapitalom u bordjuovskom smislu, a posebno iskorištavanjem „prirode“ kao resursa u situaciji nedostatka drugih aktivnosti za mlade.

Razlike se statistički nisu pokazale među učenicima prema njihovom vrednovanju učenja i želji za društvenom mobilnošću, što su mjere na kojima učenici imaju slične i relativno više rezultate bez obzira na rezidencijalno podrijetlo. Narativni podaci potvrdili su veopće visoko vrednovanje obrazovanja za postizanje životnih uspjeha, ali i skeptičnije stavove o mogućnostima zapošljavanja - bez i s diplomom, pogotovo u ruralnom / regionalnom kontekstu. Također se pokazalo da postoji manjina učenika koji istaknutije teže visokom obrazovanju za odlazak, što je strategija koja povezuje migracije i obrazovanje u pravcu sociogeografskog napredovanja koji se vezuje i stavom o većoj dostupnosi mobilnosti, i stavom da ne znaju što bi s diplomom u svojoj sredini u kojima se diploma iz određenog područja doživljava neusklađenom s određenim lokalnim, regionalnim ili nacionalnim prostorima.

Ispitivanje dostupnosti kulturnih i ekonomskih resursa socijalizacijskog okruženja obitelji ukazuje na nepovoljniju strukturu obiteljskih kapitala ruralnih učenika za nastavak školovanja, što je dodatno istaknuto u kvalitativnoj analizi ukazujući na problem nezaposlenosti ili podzaposlenosti u Slavoniji. Za njihove roditelje je vjerojatniji slabiji radni, 
imovinski, financijski i obrazovni status, te niže razine posjedovanja kulturnih dobara i rjeđe sudjelovanje u kulturnim aktivnostima. Analize su potvrdile i simboličku važnost roditelja pri usmjeravanju prema visokom obrazovanju, što je snažnije izraženo kod urbanih učenika. No, ukazano je i da je utjecaj roditelja širi od samih poticajnih praksi koje općenito učenici procjenjuju iznadprosječno. U intervjuima učenici su prilično usuglašeni oko stava da su poticaji roditelja i podrška, a posebno financijska, iznimno značajni za nečije orijentiranje prema visokom obrazovanju. Posebno se utjecaj roditelja istaknuo kao podrška donošenja samostalnih odluka, ohrabrivanje ostvarivanja vlastitih želja, financijska podrška, te savjetodavna uloga.

Izvan obitelji, procjena višeg statusa školama koje pohađaju vjerojatnija je za urbane učenike, čime je za ruralne učenike status škola moguća ,prepreka“ odlasku na studij. Simbolički pak, analize ukazuju da osobe iz školskog konteksta mogu biti važan socijalni resurs ruralnim učenicima koji namjeravaju studirati. U intervjuima, učenici, posebno oni visokoobrazovno orijentirani, te oni iz ruralnih sredina, isticali su značaj koji njihove društvene mreže imaju u poticanju i osnaživanju njihovih namjera. To je posebno uočljivo kod gimnazijalaca koji uspostavljaju određeni gimnazijski identitet isticanjem razlika u odnosu na druge grupe učenika. Ruralnim pak učenicima koji škole pohađaju u velikim gradovima ili dalje od roditeljskog doma, a posebno u školama koje procjenjuju višestatusnima, predstavlja i vrstu „urbanizacije uma“ ili transformacije geografskog habitusa, te značajan element iskorjenjivanja iz mjesta koji učenici interpretiraju kao značajna oblikujuća iskustva. S obzirom na veću vjerojatnost pohađanja strukovnih te škola lociranih u manjim urbanim sredinama za ruralne učenike, potrebno je ispitivanje dodatnih institucionalnih i sociogeografskih aspekata obrazovnog polja. Ovo istraživanje pokazalo je da određene škole doprinose boljim obrazovnim rezultatima ne samo akademskim usmjerenjem već i specifičnim institucionalnim habitusom koji na učenike djeluje poticajno kada većina učenika iz razreda namjerava studirati i kada učenici održavaju otvorenu komunikaciju s profesorima. Takvi odnosi razvijaju, tvrdi Corbett (2005), dublje poznavanje društvenih prostora pa time omogućava i upravljanje vlastitim društvenim mrežama, i zamišljanjem sebe izvan lokalnog.

Na općenitijoj razini, emocionalna vezanost za zajednicu odrastanja kao i želja za ostankom snažnije je izražena kod ruralnih učenika, što je u skladu s obrazovnim orijentacijama učenika. Kvalitativno se pokazalo da učenici svoja naselja istodobno ocrtavaju i u skladu s ruralnom idilom i sa slikom tuposti, te ambivalentnim odnosom prema „domu“. Stoga, na generalnoj razini prevladavaju negativne slike problema ruralnih sredina, a osnovni proces o 
kojem učenici progovaraju u intervjuima je označen metaforom „dalje i više“, koji ovdje kratko prezentiramo.

Kako pokazuje prethodna analiza, pitanje o obrazovnim putovima izuzetno je kompleksno i Iako postoje različiti naglasci u pojedinim pričama što se tiče toga što žele postići obrazovanjem naglašena je slika napredovanja više $\boldsymbol{i}$ dalje, što je interakcijska veza dvaju polja koja su hipotezirana kao osnovna pretpostavka istraživanog fenomena. Slike učenika oslikavaju želju za „dobrim životom“ shvaćeno vrlo općenito, no najčešće povezivanjem lateralne i vertikalne društvene mobilnosti. Katkada je ta veza dodatno potaknuta ograničenjima koje jedna strana veze postavlja (kod učenika koji u želji za dobrim obrazovanjem, a zatim i zaposlenjem smatraju da moraju otići), u drugim slučajevima ta veza je indirektnija kod učenika koji zbog različitih ograničenja odustaju od daljnjeg školovanja i dobar život žele pronaći izmještanjem iz percipiranih nepovoljnih okolnosti, odnosno preseljenjem. No, u svim slučajevima vidljivi su izraziti (socio)prostorni koncepti u oblikovanju osobe, dobrog života i budućnosti.

„Dalje i više” fraza je koja se ponavlja, zajedno ili odvojeno u brojnim intervjuima učenika. Prepoznata je kao izraz želje za uzlaznom društvenom mobilnošću, kao i geografskom mobilnošću odlaska, a osnovni mehanizam ostvarenja tog cilja je obrazovanje. Ipak, pri tom je nekim učenicima obrazovanje habitusno naglašeno i usklađeno s vlastitim identitetskim odrednicama toga kako učenici sebe vide i što žele postati, dok je drugima obrazovanje izbor $\mathrm{u}$ većoj mjeri jedini viđeni put $\mathrm{u}$ ograničenom kontekstu zapošljavanja i življenja. S druge strane, moguće je čak razmatrati kako neki učenici obrazovanjem razvijaju kapitale (povezivanje kulturnog kapitala i kapitala mobilnosti) koji im omogućavaju ili prisiljavaju odlazak, dok se s druge strane socioprostorna mobilnost kod drugih učenika bez Želje/mogućnosti obrazovanja oslanja na druge vrste kapitala, prvenstveno društveni.

Ta slika pojavljuje se kao norma mladih induvidualnosti u mobilnom društvu koje podržava slike potrebe odlaska i potrebe obrazovanje da bi se uspjelo. Cijeli proces obrazovanja doživljava se kao „penjanje stepenicama“ ili „pravljenje koraka na putu“, potaknut habitusno ili dominantnim slikama javnog diskursa, pri čemu je krajnji cilj ostvarivanje boljeg života pa time i odlazak iz Hrvatske kroz nezamislivost ili neodrživost svoje pozicije u geografskom polju (lokalno, regionalno i/ili nacionalno), ali i na razini srednjoškolskog obrazovanja (u obrazovnom polju). Iako, su sugovornici bili različiti na gotovo svim varijablama opisa uzorka, sljedeća dva „slučaja“ dočaravaju način na koji učenici shvaćaju obrazovanje i način na koji svoje ciljeve usklađuju sa svojim obrazovnim odlukama u detektiranom osnovnom 
procesu koji uvijek uključuje određenu točku „,iskorijenjivanja“, i „,želju za izmještanjem“ Drugim riječima, na razini aspiracija, iskazi su vrlo slični, no putovi koje učenici opisuju izuezetno su drugačiji u drugim nijansama koje na osnovi istraživan autora poput Corbetta jasnije možemo objasniti razmatranjem njihove mogućnosti zamišljanja koja se u intervjuima iskazuje jasnoćom iskaza obrazovnog puta s bazom u društvenom statusu pojedinca.

Andrej je učenik odrastao u malom gradu Slavonije u obitelji s relativno visokim razinama kapitala, prvenstveno kulturnog i društvenog, koji su duboko oblikovali njegove visokoobrazovne izbore i informirali sve njegove odluke na obrazovnom putu. U njegovoj priči, studiranje mu se javlja kao prirodni slijed koji je razvijan od ranog djetinjstva, a koje slijedi prostorno kretanje kao pokazatelj napredovanja i izraz slike napredovanja koji povezuje razvoj specifične osobe (intelektualca), posebnog načina i stila života (koji karakterizira učenje kroz mobilnost) te time i zauzimanje posebnih sociogeografskih prostora:

„...jednostavno sam išao za tim šta će mi koristiti u daljnjem životu, te neke stepenice, recimo... tako... mislim nije to ništa posebno utjecalo samo taj neki cilj na kraju da budem kao zadovoljni građanin, da se maknem iz države, recimo...

...Pa, mislim ... nekak' sam sebi zacrtao... iz [malog grada] došao sam do Osijeka, ići ću dalje u Zagreb... tako da ako ostanem na mjestu to bi mi zapravo bila više stepenica unazad... ne znam, ne bi '... mislim, ja se nadam tako kretati, a sad di ću završiti, ne znam...

...općenito sam Zagreb [za studij] odabrao zato što je to najbliže Zapadu što mogu doći... najveće, naj... ne znam... to je vrh, jedino što u Hrvatskoj što mogu zamisliti da mi je dovoljno dobro da budem ..." (Andrej, URP_mg, GIM_VG)

Silva je, s druge strane, učenica odrasla u ruralnom okolišu, i odrasla u obitelji ograničenih resursa, nije upisala gimnaziju, već strukovnu školu u velikom gradu, koja u manjoj mjeri omogućava „visoke izbore“, ali ipak predstavlja „rang gore“ i omogućava projekciju puta:

„... [fakultet] mislim da tu isto imam neki rang gore, jer, da se razumijemo, ne mogu svi završit fakultet... ali mislim, ako već, ako već imaš mogućnost za nešto više, bilo šta bilo, ipak, diploma je diploma, a ne samo završena srednja škola...

„,... ovdje mi je... u Osijeku imam sve, tak' da, ako mogu tu upast', i ovdje završit' [studij], onda super... možda, taj magisterij, te dvije godine, možda to odem u Zagreb, ili negdje, ali ove tri godine, temeljne, mislim da mi je bolje da završim ovdje gdje imam sve, a onda da idem na nešto višse i pucam na nešto dalje(...) planiram što više ovdje školu završiti, znači ne ostati na 3 ako mogu na 5 i na nešto više, $i$ otiči raditi negdje van gdje ljudi cijene rad, a ne ostat ovdje i visit na Birou..." (Silva, RRP_TP, 4SŠ_VG)

Stoga, na Silvinom putu „diploma je diploma“, mogućnost ostvarenja dobrog života u prostorima u kojima se može uspjeti, čime prostor odrastanja označuje „nepokretnim“, „lijenim“, i „neambicioznim“, opterećenim nezaposlenošću. Ona suprotstavlja svoju sliku o sebi s takvom okolinom: 
„... recimo, sa prijateljem koji ide to, na Poljoprivredni fakultet, ja mogu pričat o bilo čemu jel on je intelektualac i mogu pričat s njim o bilo čemu.. tako da mislim da tu ima malo razlika..."

I iako njene slike djetinjstva djeluju motivacijski kada je izbor studija u pitanju koji je obilježen jednom slikom ruralnosti, (,...nekako od malih nogu jer sam s djedom radila na polju, uvijeks bakom u vrtu, tu sad kao nekakvo povrće, voće..."), ona su dio sjećanja.

Oni najambiciozniji svoje steremljenje „dalje i više“ oblikuju prema napredovanju uspinjanjem na društvenoj ljestvici, i geografski izvan Hrvatske, no određeni učenici posebno oni s ruralnim rezidencijalnim podrijetlom osvrću se na svoje podrijetlo razmatranjima o tome kakvom će ih osobom poimati u sredini njihova podrijetla. Ti učenici u većoj mjeri imaju sposobnost zamišljanja u prostorima svoga odrastanja obilježenog određenim shvaćanjem „ruralnosti““ prostora i doživljajem općih socioprostornih dinamika, ili pak diplomu ističu kao bijeg iz onoga što se doživljava ,provincijom“, „,neobrazovanim“ i ,zaostalim“.

„Pa ... mislim da ću sebi postići lagodan život, mislim ako nastavim one plus dvije godine, $i$ ako ne... mislim da bi me ljudi puno više cijenili u društvu nego ako završim neku trogodišnju školu, mis.. oni koji su na višem sloju, mislim, malo višem, uzvišeno bi se ponašali prema meni to bi sve oni svojim efektima $i l^{\prime}$ nešt': „Ah... Ti si seljak! “, ili tako $n e s ̌ t '$..." (Andrea, RRP_TP, 4SŠ_mg)

Općenito, u perspektivi budućeg zaposlenja, vremena i stanja u Hrvatskoj, studiranje se ističe kao (K) „,nešto pod muss” bez obzira na tip škole koji završavaju učenici, ali koji u najvećoj mjeri izražavaju visokoobrazovno orijentirani učenici:

„....Moji vršnjaci svi... većinom, velika većina, na, studij gledaju kao nešto pod muss... jednostavno to je tako ... i ne znam... jer dosta njih je iz gimnazija, $i$ čak neki sa strukovnim $i$ obrtničkim školama također misle nastavit studij jer jednostavno danas to je potrebno da bi se radilo negdje..." (Bernarda, URP_mg, GIM_mg)

„... $i$ kad čitate, ne znam, toliko i toliko ljudi nezaposlenih, gledate malo, informirate se: „A-ha, 'aj"mo, vidjet' taj biro... koliko je to zapravo postotak nekakvih obrazovanih osoba na birou", $i$ onda pogledate: „A-ha, kao, pa srednjoškolska struka, nema tu neke budućnosti “, jer... iskreno, ni sam da imam firmu teško da bih zaposlio nekog tko ima srednju stručnu spremu... teško... tak' da... ne bih volio se dovesti u situaciju da ne završim neki fakultet ili da ostanem na srednjoškolskom zvanju jer u današnjojsituaciji u kojoj se mi nalazimo, to ne možemo ništa napraviti s time..." (Jakov, URP_VG, GIM_VG)

Većina učenika s kojim je obavljen razgovor imanje diplome ne poima sukladnim ruralnom. Jedino Mislav ima sposobnost zamišljanja sebe u prostorima odrastanja povezujući to $\mathrm{s}$ diplomom, te ostankom i radom, a ne odlaskom: „... pa znaju da nema posla $i$ da se mora... moramo nešto stvorit, nešt novo, i tako da (...) meni će biti mali šok [odlazak na studij] 
vjerojatno zbog malo odvojenosti i.. al' ovako mislim da će bit u redu jer ipak je to stepenice, to se mora prekoračit, htjeli mi - ne htjeli... moramo...". On želi podržati svoj način života unošenjem modernih elemenata u one tradicionalne, što je prema Šundaliću, način na koji se treba promišljati ruralni razvoj Slavonije, koja je označena „pasiviziranom regijom“.

Mnogi učenici ističu slike Slavonije „u krizi“, „opterećene ratom“, „ograničenih razmišljanja“ te ,primitivnom okolinom“ ili provincijom.

Nasuprot tome, jedino Mislav povezuje svoje odrastanje sa svojim budućim planovima i pozitivne „ruralne budućnosti“ u kojem studiranje znači bitan korak za povratak:

„... od malih nogu, uvijek sam uz njega [oca], $i$... to je to ... eto imamo, bavimo se, imamo uzgoj crnih slavonskih svinja, znači da, svinje imamo, nešto ovaca, imamo konje.. uvijek u doticaju sa životinjama i to mi je priraslo srcu

... Vidim se kod kuće, valjda ću bit oženjen (smijeh) vjerojatno, i.. da imam ergelu konja, to mi je želja, da..." (Mislav, RRP_DSJ, 4SŠ_VG)

Brojeći Mislava, samo je dvoje od dvadeset učenika u uzorku izrazilo da se nakon studija žele vratiti u svoje mjesto odrastanja - učenica malog slavonskog grada i učenik ruralnog rezidencisjlnog podrijetla, a dodatno je još dvoje učenika ruralnog rezidencijalnog podrijetla izrazilo želju za budućim nastanjivanjem u okolišu ruralnijih karakteristika, to jest $\mathrm{u}$ značajnom prirodnom okruženju, ili veće primjerenosti za odgoj djece: ideja povratka se javljao rodno obojena kod djevojaka koje mogući scenarij podizanja obitelji vide u sredini koju procjenjuju sigurnijom ili ugodnijom za odrastanje, a na osnovi svojih pozitivnih emocija vezanih uz odrastanje, i ostale elemente manje sredine.

Za razliku od toga, većina drugih učenika je upravo težnju odlaska na studij s ciljem stjecanja specifičnih znanja i specijalizacije u određenom području isticala kao razloge svoga odlaska. U njihovim slikama njihovo buduće visoko obrazovanje i mogućnost zaposlenja u Slavoniji, pa čak i u Hrvatskoj, su se sukobljavali. Moguće konflikte uvijek razriješava stav: „za poslom se ide“, što znači da se uvijek primjenjuju iste prakse s utjecajem na reprodukciju čitavog sustava.

„... i stvarno bih htjela u Osijeku, eventualno [na moru] studirati, i... u budućnosti, ono stvarno kada bi me pitali koje mi je posao iz snova, ja bih rekla: predavati [strani] jezik u ovoj gimnaziji ... Nemam uopće tu ambiciju, ne smatram da je ovo rupa iz koje treba što prije izaći, kako veliki dio vršnjaka misli, ne težim nikakvom Zagrebu - dapače me odbija, ne bih htjela tamo uopće, nekako... ne znam... otići negdje dalje studirati, ali zašto ne vratiti se ... dobro mi je ovdje ... Pa.. htjela bih završiti [studij], zaposliti se u gimnaziji, ovoj, ja bi to baš jako željela ..., ,(Bernarda, URP_mg, GIM_mg)

U ostalom, kada je pitanje razvoja karijera, bavljenja željenim poslom za osiguravanje egzistencije sebe i svoje obitelji, otići je osnovni glagol kojim opisuju svoje buduće pravce 
kretanja. U točki u kojoj završavaju srednje škole i odlučuju se za studiranje i studij, njihov horizont budućnosti ocrtava pravac "dalje i višse“ ili ,penjanje stepenicama“.

Kada slavonski učenici izražavaju narativno svoje obrazovne putove, nužno upliću sebe pozicionirajući se u kontekst Slavonije, odražavajući „strukturu osjećaja“ koja uvelike odražava regionalni identitet ocrtan negativnim elementima. Iako su takve slike dio javnog diskursa, one nisu posve naučene nego su i življene. Mnogi učenici imaju obitelji koje nemaju posao, koji su se suočili s problemom korupcije, čije se obitelji sele, ili im prijatelji nisu uspjeli na fakultetu ili imaju nezaposlenog susjeda s diplomom.

Među intervjuiranima samo je jedan učenik koji do određene mjere povezuje svoj lokalni identitet i mogućnosti uspjeha u svom lokalnom kontekstu. Njegov primjer pozitivno odražava ideju razvoja ruralnih prostora koju Šundalić iznosi a koja uključuje inventivno kombiniranje modernog i tradicionalnog (2010).

Neki drugi sigurno će ostati ,zapeli“ (Corbett 2005) lokalno bez mogućnosti da studiraju i da se odsele, ali će nastaviti živjeti u lokalnom kontekstu i jedini mogu djelovati na promjenu strukture osjećaja. Stoga, ideja koju izlažu Zipin i suradnici (2015) čini zanimljiv osvrt na ulogu ruralnog obrazovanja koja se treba fokusirati na razvoj aspiracija onih koji ostaju.

Kako se može prepoznati i u ovom radu, uvelike se o aspiracijama govorilo ili kao proizvodu habitualizzirane logike ili proizvoda doksične logike. Između te dvije logike se učenici nepovoljnije razine kapital, zarobljeni habitusom klasne pozicije, a privučeni dominantnim slikama o meritokratskom obrazovanju koje nagrađuje teški rad, talent i zalaganje, doživljavaju deficitarnima. Ovi autori predlažu razmatranje treće vrste logike u kojoj se aspiracije razumijevaju kao složen društveno-kulturni fenomen, „kao nastajući osjećaj potencijalnih alternativnih budućnosti koja se temelji na življenim sociokulturnim resursima“, koje nazivaju „rezervama aspiracija“ (Zipin i sur. 2015:231).

Konačno, podaci o frekvencijama učenika prema pojedinim visokoobrazovnim izborima pokazali su da je za one ruralne učenike koji namjeravaju studirati u manjoj mjeri izražen izbor sveučilišnih studija i studija koji su u Zagrebu, iako podjednako učenici različitog rezidencijalnog podrijetla procjenjuju da je na njihov odabir utjecao ugled studija i institucije studiranja $(M=3,6)$. Unatoč tome, u kvalitativnom dijelu se pokazalo da u manjoj ili većoj mjeri učenici razlikuju određene studije kao bolje ili lošije, što se procjenjivalo uglavnom prema težini, te s obzirom na lokaciju u Zagrebu. Ipak, takva rangiranja se pregovaraju, posebno kada su njihovi izbori u pitanju. 


\subsubsection{Objašnjenje namjere studiranja slavonskih maturanata}

Posljednji dio analiza još jednom testira izgrađene modele za objašnjenje, prvo namjere studiranja, a zatim i izbor studija i mjesta studiranja, ovaj puta na regionalnom uzorku slavonskih maturanata. S obzirom na rezultate analize i spuštanje razine analize regionalno, a time i smanjivanje uzorka, očekivan je određeni stupanj homogenizacije uzorka te time i mogućnost različitog skupa varijabli koje pokazuju prediktorski značaj za objašnjenje obrazovnih ishoda. Dodatno, modeli su korigirani u skladu s brojem ispitanika, odnosno smanjen je broj ulaznih varijabli koji čine model, kada su u pitanju visokoobrazovni izbori u kojim analizama je sudjelovao manji broj učenika koji namjeravaju studirati i koji su ostavili podataka o željenim izborima visokog obrazovanja ${ }^{111}$.

Tabela 4.6 Model objašnjenja namjere studiranja slavonskih maturanata

\begin{tabular}{|c|c|c|c|c|c|c|c|}
\hline & Varijable u modelu & B & S.E. & Wald & df & Sig. & $\operatorname{Exp}(B)$ \\
\hline \multicolumn{2}{|c|}{ Vrijednost pripisana učenju } & 0,29 & 0,18 & 2,72 & 1 & 0,10 & 1,34 \\
\hline \multicolumn{2}{|c|}{ Želja za društvenom mobilnošću } & 0,47 & 0,18 & 6,98 & 1 & 0,01 & 1,60 \\
\hline \multicolumn{2}{|c|}{ Obrazovanje roditelja } & 0,30 & 0,20 & 2,31 & 1 & 0,13 & 1,35 \\
\hline \multicolumn{2}{|c|}{ Radni status roditelja } & 0,35 & 0,17 & 4,17 & 1 & 0,04 & 0,71 \\
\hline \multicolumn{2}{|c|}{ Broj knjiga kod kuće } & 1,08 & 0,23 & 22,86 & 1 & 0,00 & 2,95 \\
\hline \multicolumn{2}{|c|}{ Obiteljska imovina } & 0,08 & 0,26 & 0,10 & 1 & 0,76 & 1,09 \\
\hline \multicolumn{2}{|c|}{ Škola visokog statusa } & 0,30 & 0,16 & 3,62 & 1 & 0,06 & 1,35 \\
\hline \multicolumn{2}{|c|}{ Akademski poticajna škola } & $-0,08$ & 0,14 & 0,33 & 1 & 0,57 & 0,92 \\
\hline \multicolumn{2}{|c|}{ Utjecaj izvaninstitucionalnih drugih } & 0,22 & 0,14 & 2,44 & 1 & 0,12 & 1,24 \\
\hline \multicolumn{2}{|c|}{$\begin{array}{l}\text { LOKACIJA ŠKOLE (centralitet grada): } \\
\text { ref=veliki grad }\end{array}$} & $-0,61$ & 0,28 & 4,63 & 1 & 0,03 & 1,84 \\
\hline \multicolumn{2}{|c|}{$\begin{array}{l}\text { REZIDENCIJALNO PODRIJETLO: } \\
\text { ref=ruralno }\end{array}$} & 0,54 & 0,28 & 3,60 & 1 & 0,06 & 1,71 \\
\hline \multicolumn{2}{|c|}{ Constant } & $-7,09$ & 1,15 & 37,88 & 1 & 0,00 & 0,01 \\
\hline I. & \multicolumn{7}{|c|}{ Cox \& Snell $\mathbf{R}^{2}=0,06 ;$ Nagelkerke $\mathbf{R}^{2}=\mathbf{0 , 0 8}$} \\
\hline II. & \multicolumn{7}{|c|}{ Cox \& Snell $\mathbf{R}^{2}=0,27 ;$ Nagelkerke $\mathbf{R}^{2}=\mathbf{0 , 3 6}$} \\
\hline III. & \multicolumn{7}{|c|}{ Cox \& Snell $\mathbf{R}^{2}=0,29 ;$ Nagelkerke $\mathbf{R}^{2}=\mathbf{0 , 3 9}$} \\
\hline IV. & \multicolumn{7}{|c|}{ Cox \& Snell $\mathbf{R}^{2}=0,30 ;$ Nagelkerke $\mathbf{R}^{\mathbf{2}}=\mathbf{0}, \mathbf{4 0}$} \\
\hline V. & \multicolumn{7}{|c|}{$\begin{array}{l}\text { Omnibus test: }(11)=127,60 ; p=0,00 ; \text { Hosmer and Lemeshow Test: }(8)=9,93 ; p=0,27 \\
\text { Postotak točnih predviđanja: } 76 \% ; \quad \text { Cox } \& \text { Snell } R^{2}=0,31 ; \quad \text { Nagelkerke } \mathbf{R}^{2}=\mathbf{0 , 4 1}\end{array}$} \\
\hline
\end{tabular}

\footnotetext{
$111 \mathrm{~S}$ obzirom na navedene valjane podatke na varijablama uključenima u regresijske analize, broj učenika uključenih u objašnjenje namjere studiranja je $\mathrm{N}=348$, a broj učenika uključenih u objašnjenje visokoobrazovnih izbora je $\mathrm{N}=186$. Pri tom se $\mathrm{N}=148$ učenika izjasnilo da ne namjerava studirati nasuprot $\mathrm{N}=200$ onih koji namjeravaju studirati. Od 186 učenika koji namjeravaju studirati, samo ih N=29 bira stručni studij, a N=73 ih se bira studij u Zagrebu. Prema preporukama da se broj varijabli uskladi s brojem ispitanika - 10ispitanika u slabije popunjenoj kategoriji zavisne varijable $=1$ prediktorska varijabla - navedeno znači da bi u analizama tipa studija u regresijskom modelu moglo biti samo 3 varijable, a u modelu ispitivanja izbora Zagreba samo 7 . Ti izračuni nisu posve poštivani zbog eksplorativnog pristupa koji je zahtijevao veći broj varijabli u modelu da bi se ispitao utjecaj pojedinih prediktora za koje je teško postaviti početne pretpostavke.
} 
Prezentirana tablica (Tabela 4.6) strukturira podatke rezultata logističke regresijske analize u kojoj je, na regionalnom uzorku maturanata Slavonije, testirana robusnost modela izgrađenog za objašnjenje učeničke namjere studiranja.

Ukupno, izgrađeni model objašnjava 41\% varijance namjere studiranja slavonskih maturanata (Nagelkerke $\mathrm{R}^{2}$ ) te prema ukupnoj objašnjenosti model djeluje vrlo slično kao i na nacionalnoj razini. Nešto značajnije razlike pokazuju se prema doprinosu objašnjenju pojedinih koraka analize. I u ovom testu najveći doprinos objašnjenju učeničke namjere studiranja daju obiteljske varijable (26\%), što je nešto više u odnosu na doprinos na nacionalnom testiranju modela (za 3\%). S druge strane, udio prvog koraka - individualnih varijabli - u objašnjenju namjere studiranja slavonskih učenika gotovo je dvostruko manji $(8 \%<15 \%)$.

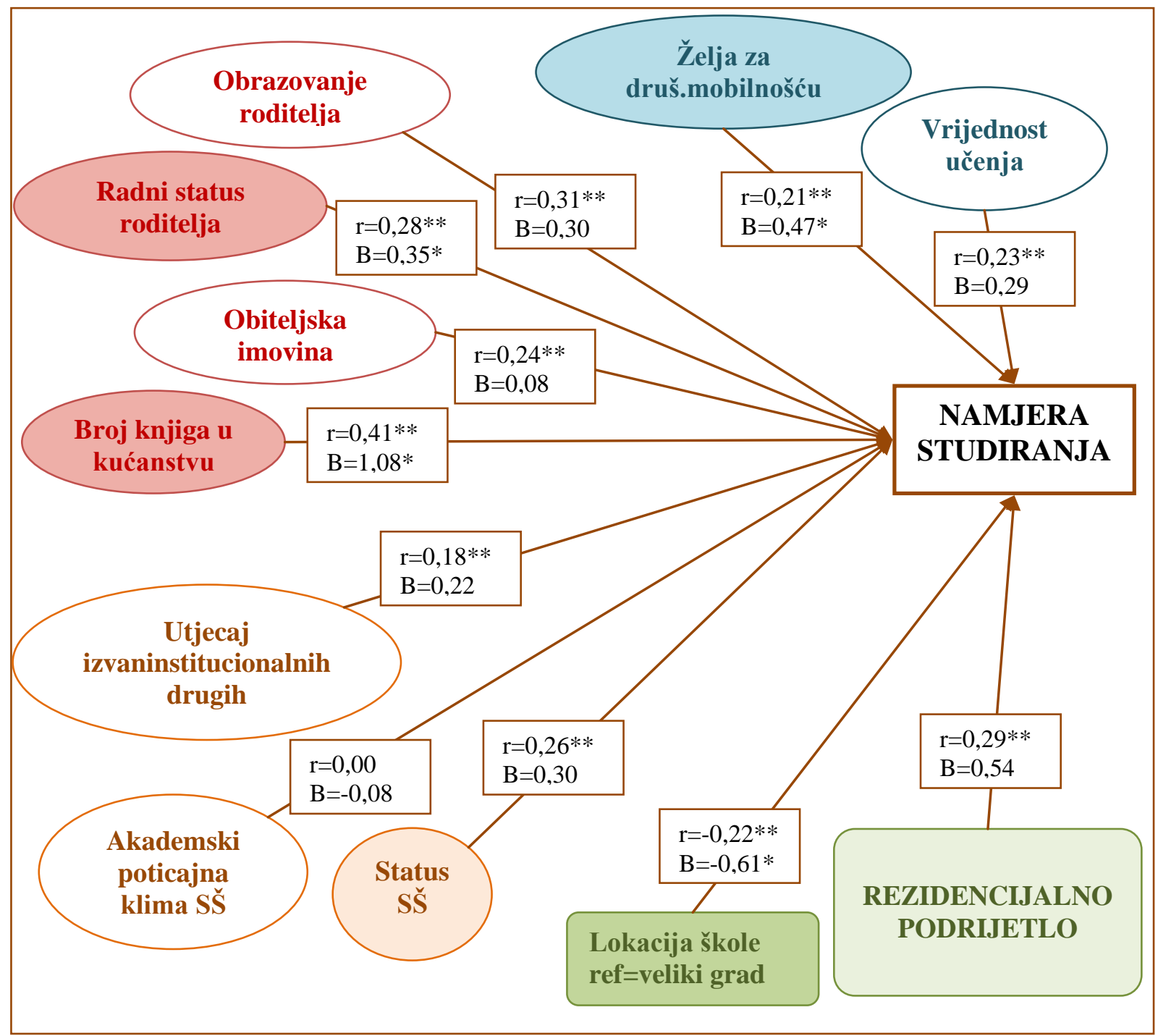

Slika 4.10 Opći regresijski model za objašnjenje namjere studiranja slavonskih maturanata izgrađen u 5 koraka 
Najizraženije razlike djelovanja modela na nacionalnom i pouzorku učenika Slavonije tiču se statističke značajnosti pojedinih prediktora. Slikovni prikaz (Slika 4.10) ističe kako je manje značajnih prediktora. Veća izglednost namjere studiranja slavonskih maturanata povezana je sa željom za društvenom mobilnošću $(B=0,47)$, s radnim statusom roditelja $(B=0,39)$ i brojem posjedovanih knjiga u kućanstvu $(B=1,08)$, te lokacijom škole $(B=-0,61)$. Drugim riječima, za slavonske maturante izglede da će se odlučiti nastaviti školovati nakon srednje škole povećava njihova snažnije izražena želja za društvenom mobilnošću te povoljnija struktura obiteljski dostupnih ekonomskih i kulturnih resursa, kao i pohađanje škola u velikim regionalnim gradovima, u odnosu na učenike koji se školuju u gradovima manjeg stupnja centraliteta. S obzirom na postavljeno istraživačko pitanje valja istaknuti da se rezidencijalno podrijetlo učenika dihotomnih kategorija ruralno/urbano nije pokazalo kao statistički značajan prediktor $^{112}$, te je način na koji rezidencijalno podrijetlo može doprinijeti učeničkoj odluci o nastavku školovanja testirano na još jedan način.

Djelovanje modela provjereno je uvođenjem u model varijable rezidencijalnog podrijetla $\mathrm{s}$ četiri kategorije nastale s obzirom na podatke o nazivu mjesta odrastanja učenika. Pri tom je kao referencijalna kategorija odabrano odrastanje u tipu tržišno orijentiranih poljoprivrednih naselja (RRP_TP=ref), a ostale kategorije su činili sljedeći tipovi: 1=dinamična, strukturno jača ruralna naselja (RRP_DSJ), 2=gradovi slabijeg stupnja centraliteta, te 3=gradovi jačeg stupnja centraliteta (makroregionalno i jača regionalna središta).

Kada je model ovako prilagođen (Tabela 4.7), objašnjenost namjere studiranja slavonskih učenika blago raste (Nagelkerke $\mathrm{R}^{2}=0,43$ ), a rezidencijalno podrijetlo pokazuje svoju prediktorsku značajnost za barem jednu kategoriju učenika - one koji odrastaju u gradovima slabijeg stupnja centraliteta. Drugim riječima, veća želja za društvenom mobilnošću $(B=0,48)$, kao individualna karakteristika učenika, bolje obiteljsko prihodovno stanje $(B=0,39)$ i posjedovanje knjiga $(B=1,10)$, te status škola $(B=0,36)$ i školovanje u velikim gradovima $(B=-$ 1,00) kao i odrastanje u gradovima slabijeg stupnja centraliteta, u odnosu na one koji odrastaju u tipu tržišno orijentiranih poljoprivrednih naselja $(B=0,98)$ značajni su prediktori koji povećavaju izglednost namjere studiranja slavonskih maturanata.

\footnotetext{
${ }^{112}$ Pogled u tablično prikazan rezultat regresijske analize (Tabela 4.10) ukazuje da se varijabla rezidencijalnog podrijetla nalazi na samom rubu statističke značajnosti $(p=0,06)$ (uz visoku vrijednost Wald=3,60), što ukazuje na potencijalnu prediktorsku važnost. Slično vrijedi i za varijablu Škola visokog statusa (Wald=3,62; $p=0,06)$.
} 
Tabela 4.7: Model objašnjenja namjere studiranja slavonskih maturanata (s tipom naselja u modelu)

\begin{tabular}{|c|c|c|c|c|c|c|}
\hline Varijable u modelu & B & S.E. & Wald & df & Sig. & $\operatorname{Exp}(B)$ \\
\hline Vrijednost pripisana učenju & 0,35 & 0,18 & 3,67 & 1 & 0,06 & 1,41 \\
\hline Želja za društvenom mobilnošću & 0,48 & 0,18 & 6,98 & 1 & 0,01 & 1,62 \\
\hline Obrazovanje roditelja & 0,31 & 0,20 & 2,43 & 1 & 0,12 & 1,37 \\
\hline Radni status roditelja & 0,39 & 0,18 & 4,83 & 1 & 0,03 & 0,68 \\
\hline Broj knjiga kod kuće & 1,10 & 0,23 & 22,23 & 1 & 0,00 & 2,99 \\
\hline Obiteljska imovina & 0,04 & 0,26 & 0,02 & 1 & 0,88 & 1,04 \\
\hline Škola visokog statusa & 0,36 & 0,16 & 4,91 & 1 & 0,03 & 1,43 \\
\hline Akademski poticajna škola & $-0,11$ & 0,14 & 0,62 & 1 & 0,43 & 0,89 \\
\hline Utjecaj izvaninstitucionalnih drugih & 0,21 & 0,14 & 2,20 & 1 & 0,14 & 1,24 \\
\hline LOKACIJA ŠKOLE (centralitet grada): ref=veliki grad & $-1,00$ & 0,39 & 6,54 & 1 & 0,01 & 2,73 \\
\hline $\begin{array}{l}\text { REZIDENCIJALNO PODRIJETLO: } \\
\text { orijentirana poljoprivredna naselja }\end{array}$ & & & 6,99 & 3 & 0,07 & \\
\hline $1=$ dinamična, strukturno jača naselja & 0,21 & 0,40 & 0,28 & 1 & 0,60 & 1,23 \\
\hline $2=$ gradovi slabijeg stupnja centraliteta & 0,98 & 0,40 & 6,07 & 1 & 0,01 & 2,67 \\
\hline $3=$ gradovi jačeg stupnja centraliteta & 0,09 & 0,51 & 0,03 & 1 & 0,87 & 1,09 \\
\hline Constant & $-7,32$ & 1,23 & 35,64 & 1 & 0,00 & 0,01 \\
\hline \multicolumn{7}{|l|}{ Cox \& Snell $\mathbf{R}^{2}=0,06 ;$ Nagelkerke $\mathbf{R}^{2}=\mathbf{0 , 0 9}$} \\
\hline \multicolumn{7}{|l|}{ Cox \& Snell $\mathbf{R}^{2}=0,28 ;$ Nagelkerke $\mathbf{R}^{2}=\mathbf{0 , 3 7}$} \\
\hline \multicolumn{7}{|l|}{ Cox \& Snell $\mathbf{R}^{2}=0,30 ;$ Nagelkerke $\mathbf{R}^{2}=\mathbf{0}, \mathbf{4 0}$} \\
\hline \multicolumn{7}{|l|}{ Cox \& Snell $\mathbf{R}^{2}=0,31$; Nagelkerke $\mathbf{R}^{2}=\mathbf{0 , 4 1}$} \\
\hline \multicolumn{7}{|c|}{$\begin{array}{l}\text { Omnibus test: }(13)=132,94 ; p=0,00 ; \text { Hosmer and Lemeshow Test: }(8)=9,54 ; p=0,30 ; \\
\text { Postotak točnih predviđanja: } 78 \% ; \text { Cox \& Snell } R^{2}=0,32 ; \quad \text { Nagelkerke } \mathbf{R}^{2}=\mathbf{0 , 4 3}\end{array}$} \\
\hline
\end{tabular}

Zaključno, ovaj skup varijabli potvrđuje teorijski pretpostavljene utjecaje koje na učeničku namjeru studiranja, općenito, imaju obiteljski i školski resursi povezani s osobnim obrazovnim orijentacijama. Ipak, najznačajnija individualna karakteristika je želja za društvenom mobilnošću (ne vrijednost učenja ${ }^{113}$ ), a od obiteljskih su bitne i ekonomska i kulturna dimenzija, u vidu stalnosti primanja i dostupnosti veće količine knjiga. Najznačajnija karakteristika škole koju pohađaju učenici je status. No, kako potvrđuju analize, one su povezane i s određenim geografskim aspektima i školovanja i odrastanja. Pokazalo se da pohađanje škola u velikom gradu (u odnosu na pohađanje škola u malim gradovima), kao i odrastanje u malim gradovima u odnosu na odrastanje na selu (odnosno tržišno orijentiranim poljoprivrednim naseljim), doprinosi objašenjenju namjere studiranja učenika Slavonije.

Naredne analize, pak, u pokušaju objašnjenja namjere studiranja stavljaju naglasak na simboličke elemente zajednice odrastanja koji su se mjerili upitnikom. Osnovno pitanje na koje analiza pokušava odgovoriti je: doprinose li dimenzije osjećaja pripadnosti, želje za

\footnotetext{
${ }^{113}$ Kako pokazuje tabela 4.11, Vrijednost učenja se nalazi na rubu statističke značajnosti, ali statistički test tu varijablu ne potvrđuje kao značajnog prediktora.
} 
ostankom i emocionalne vezanosti učenika sa zajednicom odrastanja njihovoj namjeri studiranja? Stoga se u model u posljednjem koraku uvode tri varijable simboličke vrijednosti zajednice koje su zahvaćale osjećaj pripadnosti i emocionalne vezanosti učenika sa zajednicom njihova odrastanja, te želju za ostankom u zajednici odrastanja. Budući je analiza eksplorativna, a dodatno i zbog razloga metodološke prirode (broj varijabli u modelu i interkoleracije dimenzija koje se uvode u analizu) napravljena su i dodatna testiranja, odnosno provedene su tri dodatne analize u kojima je u svaki od narednih modela uvedena samo jedna od navedenih dimenzija. Osnovni rezultati koji ne potvrđuju doprinos tih dimenzija prikazani su u Tablici 4.8.

Iako se niti jedna od varijabli simboličke vrijednosti zajednice ne pokazuje kao značajan prediktor namjere studiranja slavonskih učenika, analize također ukazuju na različito djelovanje modela kada se dodatne varijable uvedu u analizu. Općenito, navedene varijable blago podižu ukupnu objašnjenost varijance kriterija, što je vjerojatno rezultat dodavanja varijabli i čemu ne treba pridavati dodatnu pozornost. No, i broj značajnih prediktora opada.

Kada se sve tri varijable u zadnjem koraku uvedu u analizu i kontroliraju, statistički značajni prediktori su individualne karakteristike učenika, odnosno više vrednovanje učenja $(B=0,45)$ i Želja za društvenom mobilnošću $(B=0,49)$ te kulturni obiteljski kapital (broj knjiga $B=1,00$ ). Same dimenzije simboličke vrijednosti zajednice ne pokazuju prediktivni značaj kada je u pitanju njihova namjera studiranja.

Kada je u modelu samo varijabla Pripadnost, uz prethodno navedene, značajan prediktor postaje i status škole $(B=0,33)$.

Kada je u modelu samo varijabla Ostanka, namjera studiranja izglednija je za učenike koji teže društvenoj mobilnosti $(B=0,49)$ i koji uz veću dostupnost kulturnim resursima (broj knjiga $\mathrm{B}=1,04$ ) imaju i veću dostupnost ekonomskim resursima, odnosno njihovi roditelji imaju stalnija primanja $(B=0,35)$.

Najveći broj prediktora, pak, značajan je kada je u modelu emocionalna vezanost učenika sa zajednicom njihova odrastanja (a za koju analize pokazuju općenito visok stupanj), a značajni prediktori dolazi iz gotovo svih koraka analize. Tako se namjera studiranja pokazuje izglednijom za učenike koji visoko vrednuju učenje $(B=0,43)$ i teže društvenoj mobilnosti $(B=0,45)$, koji odrastaju u obitelji većim kulturnih $(B=1,0)$ i prihodovnih resursa $(B=0,40)$ te koji pohađaju statusne škole $(B=0,35)$ u velikim gradovima $(B=-0,56)$. 
Tabela 4.8 Rezultati logističke regresije objašnjenja namjere studiranja slavonskih maturanata - provjera doprinosa objašnjenju dimenzija simboličke vrijednosti zajednice odrastanja

\begin{tabular}{|c|c|c|c|c|c|c|c|c|c|c|c|c|c|c|c|c|c|c|c|c|}
\hline \multirow[b]{2}{*}{ Varijable u modelu } & \multicolumn{5}{|c|}{ Sve tri dimenzije u modelu } & \multicolumn{5}{|c|}{ Dimenzija pripadnost } & \multicolumn{5}{|c|}{ Dimenzija ostanak } & \multicolumn{5}{|c|}{ Dimenzija emocionalna vezanost } \\
\hline & B & S.E. & Wald & Sig. & $\operatorname{Exp}(B)$ & B & S.E. & Wald & Sig. & $\operatorname{Exp}(\mathrm{B})$ & B & S.E. & Wald & Sig. & $\operatorname{Exp}(\mathrm{B})$ & B & S.E. & Wald & Sig. & $\operatorname{Exp}(\mathrm{B})$ \\
\hline Vrijednost učenja & 0,45 & 0,21 & 4,87 & 0,03 & 1,57 & 0,48 & 0,20 & 5,90 & 0,02 & 1,61 & 0,29 & 0,19 & 2,40 & 0,12 & 1,33 & 0,43 & 0,19 & 5,18 & 0,02 & 1,54 \\
\hline $\begin{array}{l}\text { Želja za društvenom } \\
\text { mobilnošću }\end{array}$ & 0,49 & 0,19 & 6,51 & 0,01 & 1,63 & 0,41 & 0,19 & 4,90 & 0,03 & 1,51 & 0,49 & 0,19 & 6,91 & 0,01 & 1,64 & 0,45 & 0,19 & 5,87 & 0,02 & 1,57 \\
\hline $\begin{array}{l}\text { Obrazovanje } \\
\text { roditelja }\end{array}$ & 0,30 & 0,21 & 2,02 & 0,16 & 1,35 & 0,36 & 0,21 & 2,91 & 0,09 & 1,43 & 0,30 & 0,21 & 2,05 & 0,15 & 1,35 & 0,34 & 0,20 & 2,85 & 0,09 & 1,41 \\
\hline $\begin{array}{l}\text { Radni status } \\
\text { roditelja }\end{array}$ & 0,34 & 0,19 & 3,33 & 0,07 & 0,71 & 0,33 & 0,18 & 3,36 & 0,07 & 0,72 & 0,35 & 0,18 & 3,93 & 0,05 & 0,70 & 0,40 & 0,18 & 4,84 & 0,03 & 0,67 \\
\hline Broj knjiga & 1,00 & 0,25 & 16,79 & 0,00 & 2,73 & 1,02 & 0,24 & 18,40 & 0,00 & 2,77 & 1,04 & 0,24 & 18,90 & 0,00 & 2,82 & 1,00 & 0,24 & 18,25 & 0,00 & 2,73 \\
\hline $\begin{array}{l}\text { Posjedovanje } \\
\text { imovine }\end{array}$ & 0,13 & 0,27 & 0,22 & 0,64 & 1,14 & 0,15 & 0,27 & 0,32 & 0,58 & 1,16 & 0,12 & 0,27 & 0,19 & 0,66 & 1,13 & 0,09 & 0,27 & 0,11 & 0,74 & 1,09 \\
\hline Škola visokog statusa & 0,30 & 0,17 & 3,20 & 0,07 & 1,35 & 0,33 & 0,16 & 4,07 & 0,04 & 1,39 & 0,29 & 0,16 & 3,21 & 0,07 & 1,34 & 0,35 & 0,16 & 4,61 & 0,03 & 1,41 \\
\hline $\begin{array}{l}\text { Akademski } \\
\text { poticajna škola }\end{array}$ & $\overline{-}$ & 0,15 & 0,12 & 0,73 & 0,95 & - & 0,15 & 0,18 & 0,67 & 0,94 & 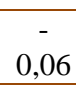 & 0,15 & 0,17 & 0,68 & 0,94 & $\overline{-}$ & 0,14 & 0,31 & 0,58 & 0,92 \\
\hline $\begin{array}{l}\text { Utjecaj } \\
\text { izvaninstitucional. } \\
\text { drugih }\end{array}$ & 0,19 & 0,15 & 1,58 & 0,21 & 1,21 & 0,18 & 0,15 & 1,54 & 0,21 & 1,20 & 0,20 & 0,15 & 1,83 & 0,18 & 1,22 & 0,19 & 0,15 & 1,67 & 0,20 & 1,21 \\
\hline $\begin{array}{l}\text { Lokacija škole } \\
\text { (ref=veliki grad) }\end{array}$ & - & 0,30 & 2,85 & 0,09 & 0,60 & $\begin{array}{c}- \\
0,54\end{array}$ & 0,29 & 3,35 & 0,07 & 0,58 & $\begin{array}{c}- \\
0,49\end{array}$ & 0,30 & 2,79 & 0,10 & 0,61 & $-\overline{0}$ & 0,29 & 3,70 & 0,05 & 0,57 \\
\hline $\begin{array}{l}\text { Rezidencijalno } \\
\text { podrijetlo (ref=RRP) }\end{array}$ & 0,39 & 0,31 & 1,55 & 0,21 & 1,47 & 0,40 & 0,30 & 1,79 & 0,18 & 1,49 & 0,44 & 0,30 & 2,17 & 0,14 & 1,55 & 0,35 & 0,30 & 1,37 & 0,24 & 1,42 \\
\hline Pripadnost & $\begin{array}{c}- \\
0,28\end{array}$ & 0,20 & 1,94 & 0,16 & 0,76 & $0,-$ & 0,17 & 2,10 & 0,15 & 0,79 & & & & & & & & & & \\
\hline Ostanak & - & 0,17 & 0,01 & 0,94 & 0,99 & & & & & & $\begin{array}{c}- \\
0,14\end{array}$ & 0,14 & 1,09 & 0,30 & 0,87 & & & & & \\
\hline $\begin{array}{l}\text { Emocionalna } \\
\text { vezanost }\end{array}$ & 0,04 & 0,23 & 0,02 & 0,88 & 1,04 & & & & & & & & & & & $\begin{array}{c}- \\
0,18 \\
\end{array}$ & 0,18 & 1,02 & 0,31 & 0,83 \\
\hline Constant & - & 1,44 & 22,71 & 0,00 & 0,01 & $-\overline{8}$ & 1,28 & 28,34 & 0,00 & 0,01 & $\begin{array}{c}- \\
6,76 \\
\end{array}$ & 1,29 & 27,27 & 0,00 & 0,01 & - & 1,39 & 24,89 & 0,00 & 0,01 \\
\hline
\end{tabular}

1. korak

2. $\quad$ korak

3. korak
Cox \& Snell $R^{2}=0,07 ;$ Nagelkerke $\mathbf{R}^{\mathbf{2}}=\mathbf{0 , 1 0}$ Cox \& Snell $\mathrm{R}^{2}=0,28$; Nagelkerke $\mathbf{R}^{2}=\mathbf{0 , 3 7}$

Cox \& Snell $R^{2}=0,29$; Nagelkerke $\mathbf{R}^{2}=\mathbf{0 , 3 9}$;
Cox \& Snell $\mathrm{R}^{2}=0,06$; Nagelkerke $\mathbf{R}^{\mathbf{2}}=\mathbf{0 , 9}$

Cox \& Snell $R^{2}=0,28 ;$ Nagelkerke $\mathbf{R}^{2}=\mathbf{0 , 3 8}$

Cox \& Snell $R^{2}=0,29$; Nagelkerke $\mathbf{R}^{2}=\mathbf{0 , 4 0}$;
Cox \& Snell R2=0,07; Nagelkerke R2=0,9;

Cox \&
$\mathbf{R}^{2}=\mathbf{0}, 37$

Cox \& Snell $R^{2}=0,29 ;$ Nagelk $\mathbf{R}^{2}=\mathbf{0 , 3 9}$;
Cox \& Snell $\mathrm{R}^{2}=0,07$; Nagelkerke $\mathbf{R}^{2}=\mathbf{0 , 0 9}$

Cox \& Snell $R^{2}=0,28$; Nagelkerke

$\mathbf{R}^{2}=\mathbf{0 , 3 7}$

Cox \& Snell $\mathrm{R}^{2}=0,30$; Nagelkerke $\mathbf{R}^{2}=\mathbf{0 , 4 0}$; 


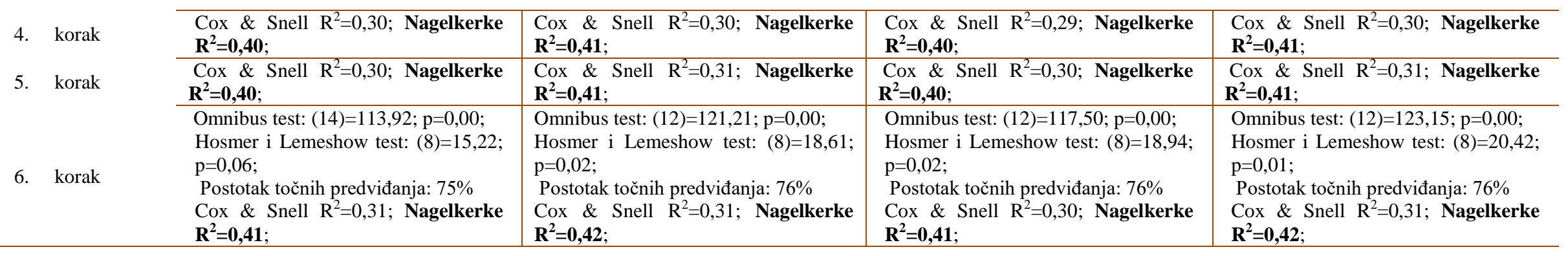


U osnovi, rezultati ne potvrđuju navedene dimenzije kao značajne prediktore objašnjenja učeničkih namjera studiranja. Ipak, zanimljiv nalaz je da kada su uvedene u model, odnosno kada se kontroliraju, doprinose bitno drugačijem djelovanju modela. Ukazujući samo na moguće smjerove djelovanja koje tek treba ispitati, a ograničenja studije to ovdje ne dopuštaju, moguće je da se namjera studiranja - izglednija za one uspješnije učenike visokoobrazovno orijentiranih koji i odrastaju u obiteljima bogatijih kulturnih resursa povezuje i s njihovim dubljim osjećajem nepripadnosti u mjestu svoga odrastanja (negativan predznak). Nasuprot tome, moguće je da se namjera studiranja - izglednija za učenike koji teže društvenoj mobilnosti i odrastaju u obiteljima s kulturnim i ekonomskim većim pogodnostima - povezuje sa želja odlaska iz zajednice odrastanja (negativan predznak). Konačno, namjera studiranja slavonskih maturanata - izglednija za one učenike koji vrednuju učenje i teže društvenoj mobilnosti, odrastaju u obiteljima $\mathrm{s}$ bogatijim kulturnim i ekonomskim resursima, te koji pohađaju i statusne škole u velikim gradovima - povezuje s manje izraženom emocionalnom vezanošću za zajednicu svoga odrastanja.

Do određene mjere navedeno bi ukazivalo da se namjera studiranja u slavonskom kontekstu dijelom odražavaju (iako statistički nepotvrđeno) i kao negativni aspekti odnosa sa zajednicom odrastanja. Prethodne analize i opisi namjera studiranja slavonskih maturanata pokazili su da za barem neke učenike postoji takav odnos s obzirom na to kako vide sebe i svoje mjesto mjesto na kraju srednjeg obrazovanja, te onoga u budućnosti. A također se pokazalo da se učenicima u različoj mjeri to pokazuje kao konflikt koji je dio njihova procesa donošenja odluka. Kako efekti nisu potvrđeni potrebna su dodatna ispitivanja na većim uzorcima, ili moguća upotreba dodatnih analitičkih alata (klaster analize). Također, moguće je i da navedene varijable snažniji utjecaj imaju kada su u pitanju učenički visokoobrazovni izbori, posebno izbor grada studiranja, što je glavna tema narednih analiza. 


\subsubsection{Objašnjenje visokoobrazovnih izbora slavonskih maturanata}

Iako su podaci o uzorku slavonskih maturanata odmah ukazali da neće biti moguće provesti analize kako su one planirane, iz razloga eksploracije, u prvom koraku su ipak testirani modeli za objašnjenje visokoobrazovnih izbora kako su kreirani za nacionalni uzorak. Tabela 4.9 prikazuje rezultate th analiza koji nisu bili posebno informativni, niti su modeli u značajnoj mjeri objasnili učeničke visokoobrazovne izbore od interesa.

Tabela 4.9 Regresijski model objašnjenja visokoobrazovnih izbora slavonskih maturanata ${ }^{114}$

\begin{tabular}{|c|c|c|c|c|c|c|c|c|c|c|c|c|}
\hline \multirow[b]{2}{*}{ Varijable u modelu } & \multicolumn{6}{|c|}{ IZBOR SVEUČILIŠNOG STUDIJA } & \multicolumn{6}{|c|}{$\begin{array}{c}\text { IZBOR ZAGREBA KAO MJESTA } \\
\text { STUDIRANJA }\end{array}$} \\
\hline & B & $\begin{array}{l}\text { S. } \\
\text { E. }\end{array}$ & $\begin{array}{l}\mathrm{W} \\
\text { ald }\end{array}$ & $\mathrm{df}$ & Sig & $\begin{array}{l}\text { Exp } \\
(B)\end{array}$ & B & $\begin{array}{l}\text { S. } \\
\text { E. }\end{array}$ & $\begin{array}{l}\text { W } \\
\text { ald }\end{array}$ & df & Sig & $\begin{array}{l}\operatorname{Exp}( \\
\text { B) }\end{array}$ \\
\hline Školski uspjeh & 0,07 & 0,38 & 0,03 & 1 & 0,86 & 1,07 & 0,47 & 0,28 & 2,73 & 1 & 0,10 & 1,60 \\
\hline Uč. kulturne prakse & 1,24 & 0,52 & 5,68 & 1 & 0,02 & 3,46 & 0,36 & 0,28 & 1,66 & 1 & 0,20 & 1,43 \\
\hline $\begin{array}{l}\text { Uč. izvanškolske } \\
\text { aktivnosti }\end{array}$ & $-1,85$ & 1,06 & 3,07 & 1 & 0,08 & 0,16 & $-0,17$ & 0,78 & 0,05 & 1 & 0,83 & 0,85 \\
\hline Uč. čitalačke prakse & 0,10 & 0,27 & 0,13 & 1 & 0,72 & 1,10 & 0,31 & 0,20 & 2,57 & 1 & 0,11 & 1,37 \\
\hline Obrazovanje roditelja & 0,09 & 0,32 & 0,09 & 1 & 0,77 & 1,10 & $-0,06$ & 0,24 & 0,06 & 1 & 0,81 & 0,95 \\
\hline Radni status roditelja & 0,02 & 0,27 & 0,01 & 1 & 0,93 & 1,02 & $-0,05$ & 0,21 & 0,06 & 1 & 0,81 & 0,95 \\
\hline Broj knjiga kod kuće & 0,29 & 0,34 & 0,76 & 1 & 0,39 & 1,34 & 0,31 & 0,25 & 1,58 & 1 & 0,21 & 1,37 \\
\hline Obiteljska imovina & 0,30 & 0,46 & 0,42 & 1 & 0,52 & 1,35 & 0,02 & 0,34 & 0,00 & 1 & 0,96 & 1,02 \\
\hline Škola visokog statusa & $-0,59$ & 0,27 & 4,80 & 1 & 0,03 & 0,56 & 0,22 & 0,18 & 1,39 & 1 & 0,24 & 1,24 \\
\hline Ugled VO & 0,13 & 0,19 & 0,45 & 1 & 0,50 & 1,14 & $-0,11$ & 0,15 & 0,57 & 1 & 0,45 & 0,89 \\
\hline $\begin{array}{l}\text { LOKACIJA ŠKOLE: } \\
\text { ref=mali } \mathrm{grad}\end{array}$ & 0,57 & 0,46 & 1,49 & 1 & 0,22 & 1,76 & 0,16 & 0,34 & 0,21 & 1 & 0,65 & 1,17 \\
\hline RRP: ref=ruralno & 0,77 & 0,49 & 2,48 & 1 & 0,12 & 2,17 & 0,48 & 0,39 & 1,53 & 1 & 0,22 & 1,61 \\
\hline Constant & $-1,06$ & 2,27 & 0,22 & 1 & 0,64 & 0,35 & $-4,62$ & 1,70 & 7,39 & 1 & 0,01 & 0,01 \\
\hline \multirow{4}{*}{$\begin{array}{lr}\text { 1. } & \text { korak } \\
\text { 2. } & \text { korak } \\
\text { 3. } & \text { korak } \\
\text { 4. } & \text { korak }\end{array}$} & \multicolumn{6}{|c|}{ Cox \& Snell $\mathbf{R}^{2}=0,06 ;$ Nagelkerke $\mathbf{R}^{2}=\mathbf{0 , 1 1}$} & \multicolumn{6}{|c|}{ Cox \& Snell $\mathbf{R}^{2}=0,08$; Nagelkerke $\mathbf{R}^{2}=\mathbf{0 , 1 0}$; } \\
\hline & \multicolumn{6}{|c|}{ Cox \& Snell $\mathbf{R}^{2}=0,08 ;$ Nagelkerke $\mathbf{R}^{2}=\mathbf{0 , 1 3}$} & \multicolumn{6}{|c|}{ Cox \& Snell $\mathbf{R}^{2}=0,09$; Nagelkerke $\mathbf{R}^{\mathbf{2}}=\mathbf{0 , 1 2}$} \\
\hline & \multicolumn{6}{|c|}{ Cox \& Snell $\mathbf{R}^{2}=0,10 ;$ Nagelkerke $\mathbf{R}^{2}=\mathbf{0 , 1 7}$} & \multicolumn{6}{|c|}{ Cox \& Snell $\mathbf{R}^{2}=0,10 ;$ Nagelkerke $\mathbf{R}^{2}=\mathbf{0 , 1 4}$} \\
\hline & \multicolumn{6}{|c|}{ Cox \& Snell $\mathbf{R}^{2}=0,11 ;$ Nagelkerke $\mathbf{R}^{2}=\mathbf{0 , 1 8}$} & \multicolumn{6}{|c|}{ Cox \& Snell $\mathbf{R}^{2}=0,10 ;$ Nagelkerke $\mathbf{R}^{2}=\mathbf{0 , 1 4}$} \\
\hline 5. korak & \multicolumn{6}{|c|}{$\begin{array}{l}\text { Omnibus test: }(12)=23,11 ; p=0,03 ; \\
\text { Hosmer i Lemeshow test: } \quad(8)=13,06 \text {; } \\
p=0,11 ; \\
\text { Postotak točnih predviđanja: } 85 \% \\
\text { Cox \& Snell } \mathbf{R}^{2}=0,12 ; \text { Nagelkerke } \mathbf{R}^{2}=\mathbf{0 , 2 0}\end{array}$} & \multicolumn{6}{|c|}{$\begin{array}{l}\text { Omnibus test: }(12)=21,31 ; p=0,05 ; \\
\text { Hosmer i Lemeshow test: } \quad(8)=15,88 ; \\
\text { p=0,05; } \\
\text { Postotak točnih predviđanja: } 65 \% \\
\text { Cox \& Snell } \mathbf{R}^{2}=0,11 ; \text { Nagelkerke } \mathbf{R}^{2}=\mathbf{0 , 1 5} ;\end{array}$} \\
\hline
\end{tabular}

Ukupna objašnjenost izbora sveučilišnog studija modelom je 20\% (Nagelkerke $\mathrm{R}^{2}$ ), ipak, pojedini koraci malo doprinose ukupnom objašnjenju, izuzev prvog koraka koji sadrži individualne varijable učenika (objašnjava $11 \%$ varijance kriterija). Također, samo dvije varijable pokazale su statističku značajnost, no i njihov iznenađujući smjer djelovanja.

\footnotetext{
${ }^{114}$ Prema pravilu da u na 10 ispitanika u uzorku koji su u manjoj kategoriji (bilo 1 ili 0) u model može ući 1 varijabla, izračunato je da u ova dva testa najveći broj varijabli u modelu može biti 3, odnosno 7. Ipak, s obzirom na eksplorativni karakter analiza, određene analize provedene su i s većim brojem varijabli. Navedene analize služile su kao osnovni uvidi, kao i ranije provedene preliminarne analize, za korigiranje i smanjivanje broja varijabli prediktorskog skupa.
} 
Izglednost izbora sveučilišnog studija veća je za učenike s razvijenijim kulturnim kapitalom $(B=1,24 ; p<0,05)$, ali i manja za one koji pohađaju škole kojima procjenjuju viši status. Pogled u korelacijsku matricu ukazuje da ne postoji direktna povezanost procjena školskog statusa i izbora sveučilišnog studija. Iz tog razloga zaključujemo da je proizvedeni efekt rezultat djelovanja ostalih varijabli uvedenih u model, odnosno međukorelacijama ostalih prediktora.

Općenito, kada se pogledaju direktne korelacije pojedinih varijabli za koje se pretpostavlja prediktorska značajnost na visokoobrazovne izbore (Tablica $4.10^{115}$ ), tek 4 koeficijenta korelacije (Pearson) označavaju statistički značajnu povezanost s izborom sveučilišnog studija, a iznosi tih veza su, iako statistički značajni, relativno niski.

Tabela 4.10 Korelacije (Pearson) nezavisnih varijabli sa zavisnim varijablama visokoobrazovnih izbora

\begin{tabular}{|c|c|c|}
\hline Nezavisne varijable & Tip studija_sveučilišni & Mjesto studiranja_Zagreb \\
\hline Tip studija_sveučilišni & 1,00 & 0,54 \\
\hline Mjesto studiranja_Zagreb & 0,54 & 1,00 \\
\hline Rezidencijalno podrijetlo & $0,15 *$ & $0,16 *$ \\
\hline Lokacija škole - centralitet grada (3kat) & $-0,08$ & $-0,10$ \\
\hline Tip škole & $0,24 * *$ & $0,27 * *$ \\
\hline Opći školski uspjeh na kraju prošlog razreda & 0,04 & 0,08 \\
\hline Učeničke kulturne prakse & $0,16 *$ & $0,22 *$ \\
\hline Učeničke izvanškolske aktivnosti & $-0,04$ & 0,06 \\
\hline Učeničke čitalačke prakse & 0,07 & $0,18 *$ \\
\hline Vrijednost pripisana učenju & 0,04 & 0,08 \\
\hline Želja za društvenom mobilnošću & $-0,04$ & 0,08 \\
\hline Obrazovanje roditelja & 0,10 & 0,11 \\
\hline Radni status roditelja - prihodi & 0,07 & 0,08 \\
\hline Broj knjiga kod kuće & 0,11 & $0,18 *$ \\
\hline Posjedovanje imovine & 0,12 & 0,08 \\
\hline Posjedovanje kulturnih dobara u kućanstvu & 0,08 & $0,15 *$ \\
\hline Roditeljske kulturne prakse & 0,11 & $0,16 *$ \\
\hline Roditelji me ohrabruju da nastavim školovanje & $-0,01$ & $-0,02$ \\
\hline Škola visokog statusa & $-0,07$ & $0,15 *$ \\
\hline Akademski poticajna škola & $-0,12$ & 0,04 \\
\hline Utjecaj izvaninstitucionalnih drugih & $-0,05$ & $-0,15^{*}$ \\
\hline Utjecaj institucionalnih drugih & 0,02 & $-0,02$ \\
\hline Važnost ugleda studija i fakulteta & 0,08 & 0,01 \\
\hline Simbolička vrijednost zajednice - pripadnost & $-0,07$ & $-0,12$ \\
\hline Simbolička vrijednost zajednice - ostanak & $-0,22 * *$ & $-0,21 * *$ \\
\hline Simbolička vrijednost zajednice - emoc. vezanost & $-0,13$ & $-0,13$ \\
\hline$* p<0,05 ; * * p<0,01$ & & \\
\hline
\end{tabular}

\footnotetext{
${ }^{115}$ Varijable u obojanim ćelijama odabrane su za naredne analize.
} 
Za učenike Slavonije, najveća povezanost s izborom sveučilišnog studija pokazuje tip škole kojeg učenici pohađaju $(r=0,24)$, a zatim želja za odlaskom iz zajednice odrastanja $(r=-0,22)$, te učeničke kulturne prakse $(r=0,16)$ i rezidencijalno podrijetlo $(r=0,15)$. Drugim riječima, izbor sveučilišnog studija slavonskih maturanata, na osnovi podataka o direktnim korelacijama, vjerojatniji je za učenike koji odrastaju u gradu, koji pohađaju gimnazije i imaju razvijenije kulturne kompetencije, te izražavaju manji stupanj želje za ostankom u zajednici odrastanja.

S druge strane, pokušaj objašnjenja izbora Zagreba kao mjesta studiranja za slavonske maturante nije polučio niti jedan značajni prediktor $u$ testiranju, iako je objašnjeno $15 \%$ (Nagelkerke $\mathrm{R}^{2}$ ) varijance kriterija. Pogledamo li u korelacijsku matricu (Tablica 4.10), uočavamo da postoji veći broj varijabli koje su statistički značajno povezane s izborom Zagreba; taj izbor vjerojatnijim se čini za učenike koji pohađaju gimnazije ( $\mathrm{r}=0,27)$, koji imaju razvijenije kulturne kompetencije (kulturne $(r=0,22)$ i čitalačke prakse $(r=0,18)$ ), te one koji odrastaju u obiteljima veće razine kulturnog kapitala (broj knjiga $(\mathrm{r}=0,18)$, posjedovanje kulturnih dobara $(\mathrm{r}=0,15)$, roditeljske kulturne prakse $(\mathrm{r}=0,16))$. Također, izbor Zagreba kao mjesta studiranja vjerojatniji je za učenike koji pohađaju škole višeg statusa $(r=0,15)$, i one koji odrastaju u gradovima $(r=0,16)$ te koji iskazuju niže razine želje za ostankom u zajednici odrastanja $(r=-0,23)$ i slabijim procjenjuju utjecaj izvaninstitucionalnih drugih $(r=-0,15)$.

S obzirom na sve navedene rezultate i upozorenja odlučeno je smanjiti broj prediktora u modelu pri čemu su odluke vođene istraživačkim pitanjem, s jedne strane, te uvidima u rezultate preliminarnih analiza i korelacijsku matricu, s druge strane. Odabrane su sljedeće varijable: učeničke kulturne prakse, obrazovanje i radni status roditelja, a od institucionalnih varijabli status škole i ugleda visokog obrazovanja. U posljednja dva koraka analiza stavljene su rezidencijalno podrijetlo učenika te varijabla želje za ostankom u zajednici studiranja.

Dodatna provjera opisanog modela poseban naglasak je stavila na dimenziju blizine, odnosno geografski određene udaljenosti. S obzirom na podatke o željenom mjestu studiranja slavonskih maturanata kreirana je varijabla $s$ obzirom na to koliko je studij udaljen. Kategorije te varijable bile su: 1=studij u regiji, 2=Zagreb, 3=dalje. Za potrebe logističke regresijske analize varijabla je rekodirana na način da je kod 1 dodijeljen izboru studija $u$ regiji (Slavonija), a kod 0 svim ostalim izborima mjesta studiranja. Rezultati tih analiza prikazani su u Tabeli 4.11. U ostalom, pokušaj da se nešto više sazna o istraživanom fenomenu oslanja se na kvalitativne podatke prikupljene intervjuima $\mathrm{s}$ učenicima. 
Tabela 4.11 Rezultati objašnjenja visokoobrazovnih izbora slavonskih maturanata - izbor sveučilišnog studija, izbor Zagreba kao mjesta studiranja, izbor studiranja u regiji korigiranim modelom

\begin{tabular}{|c|c|c|c|c|c|c|c|c|c|c|c|c|c|c|c|c|c|c|}
\hline \multirow[b]{2}{*}{ Varijable u modelu } & \multicolumn{6}{|c|}{ Izbor sveučilišnog studija } & \multicolumn{6}{|c|}{ Izbor Zagreba kao mjesta studiranja } & \multicolumn{6}{|c|}{ Izbor studiranja u regiji } \\
\hline & B & S.E. & $\begin{array}{c}\text { Wal } \\
\text { d }\end{array}$ & $\mathrm{df}$ & Sig. & $\begin{array}{c}\text { Exp } \\
\text { (B) }\end{array}$ & B & S.E. & $\begin{array}{c}\text { Wal } \\
\mathrm{d}\end{array}$ & df & Sig. & $\begin{array}{c}\text { Exp } \\
\text { (B) }\end{array}$ & B & S.E. & $\begin{array}{c}\text { Wal } \\
\mathrm{d}\end{array}$ & df & Sig. & $\begin{array}{c}\text { Exp } \\
\text { (B) }\end{array}$ \\
\hline Učeničke kulturne prakse & 0,56 & 0,41 & 1,83 & 1 & 0,18 & 1,75 & 0,33 & 0,26 & 1,63 & 1 & 0,20 & 1,38 & $-0,20$ & 0,25 & 0,63 & 1 & 0,43 & 0,82 \\
\hline Obrazovanje roditelja & 0,24 & 0,28 & 0,70 & 1 & 0,40 & 1,27 & 0,13 & 0,22 & 0,32 & 1 & 0,57 & 1,13 & $-0,19$ & 0,21 & 0,78 & 1 & 0,38 & 0,83 \\
\hline Radni status roditelja & 0,05 & 0,27 & 0,03 & 1 & 0,86 & 0,96 & 0,08 & 0,21 & 0,16 & 1 & 0,69 & 0,92 & $-0,02$ & 0,20 & 0,01 & 1 & 0,92 & 1,02 \\
\hline Škola visokog statusa & $-0,33$ & 0,24 & 1,95 & 1 & 0,16 & 0,72 & 0,32 & 0,18 & 3,18 & 1 & 0,07 & 1,37 & $-0,25$ & 0,17 & 2,31 & 1 & 0,13 & 0,78 \\
\hline Ugled studija i fakulteta & 0,16 & 0,18 & 0,80 & 1 & 0,37 & 1,17 & $-0,03$ & 0,14 & 0,05 & 1 & 0,83 & 0,97 & 0,03 & 0,13 & 0,04 & 1 & 0,84 & 1,03 \\
\hline Rezidencijalno podrijetlo & 0,49 & 0,49 & 1,00 & 1 & 0,32 & 1,63 & 0,23 & 0,39 & 0,34 & 1 & 0,56 & 1,25 & $-0,32$ & 0,37 & 0,77 & 1 & 0,38 & 0,73 \\
\hline Ostanak & $-0,46$ & 0,21 & 4,83 & 1 & 0,03 & 0,63 & $-0,38$ & 0,17 & 4,95 & 1 & 0,03 & 0,69 & 0,37 & 0,16 & 5,54 & 1 & 0,02 & 1,44 \\
\hline Constant & 1,35 & 1,41 & 0,92 & 1 & 0,34 & 3,86 & $-1,77$ & 1,09 & 2,66 & 1 & 0,10 & 0,17 & 0,87 & 1,02 & 0,74 & 1 & 0,39 & 2,40 \\
\hline
\end{tabular}

1. korak

2. korak

3. korak

4. korak

5. korak
Cox \& Snell $\mathbf{R}^{2}=0,04 ;$ Nagelkerke $\mathbf{R}^{2}=\mathbf{0 , 0 5}$

Cox \& Snell $\mathbf{R}^{2}=0,04$; Nagelkerke $\mathbf{R}^{2}=\mathbf{0 , 0 7}$;

Cox \& Snell $R^{2}=0,05$; Nagelkerke $\mathbf{R}^{2}=\mathbf{0 , 0 9}$;

Cox \& Snell $\mathbf{R}^{2}=0,06$; Nagelkerke $\mathbf{R}^{2}=\mathbf{0 , 1 1 ;}$

Omnibus test: $(7)=16,78 ; \mathrm{p}=0,02$;

Hosmer i Lemeshow test: $(8)=11,94 ; \mathrm{p}=0,15$;

Postotak točnih predviđanja: $86 \%$

Cox \& Snell $R^{2}=0,09$; Nagelkerke $\mathbf{R}^{2}=\mathbf{0 , 1 5}$;
Cox \& Snell $\mathbf{R}^{2}=0,04$; Nagelkerke $\mathbf{R}^{2}=\mathbf{0 , 0 5}$;

Cox \& Snell $\mathbf{R}^{2}=0,05 ;$ Nagelkerke $\mathbf{R}^{\mathbf{2}}=\mathbf{0 , 0 7}$

Cox \& Snell $\mathbf{R}^{2}=0,06$; Nagelkerke $\mathbf{R}^{2}=\mathbf{0 , 0 9}$

Cox \& Snell $\mathbf{R}^{2}=0,07$; Nagelkerke $\mathbf{R}^{2}=\mathbf{0 , 0 9}$

Omnibus test: $(7)=18,41 ; \mathrm{p}=0,01$;

Hosmer i Lemeshow test: $(8)=9,07 ; \mathrm{p}=0,34$;

Postotak točnih predviđanja: $67 \%$

Cox \& Snell $R^{2}=0,10$; Nagelkerke $\mathbf{R}^{2}=\mathbf{0 , 1 3}$
Cox \& Snell $\mathbf{R}^{2}=0,03$; Nagelkerke $\mathbf{R}^{2}=\mathbf{0 , 0 3 ;}$

Cox \& Snell $\mathbf{R}^{2}=0,04$; Nagelkerke $\mathbf{R}^{2}=\mathbf{0 , 0 5}$

Cox \& Snell $\mathbf{R}^{2}=0,05$; Nagelkerke $\mathbf{R}^{2}=\mathbf{0 , 0 6}$;

Cox \& Snell $\mathbf{R}^{2}=0,06$; Nagelkerke $\mathbf{R}^{\mathbf{2}}=\mathbf{0 , 0 8}$

Omnibus test: $(7)=16,93 ; \mathrm{p}=0,02$;

Hosmer i Lemeshow test: $(8)=9,49 ; p=0,30$; Postotak točnih predviđanja: $60 \%$ Cox \& Snell $\mathbf{R}^{2}=0,09 ;$ Nagelkerke $\mathbf{R}^{2}=\mathbf{0 , 1 1}$; 
Kako je vidljivo, novokreirani model u najvećoj mjeri objašnjava izbor sveučilišnog studija slavonskih maturanata, iako tek $15 \%$ varijance (Nagelkerke $\mathrm{R}^{2}$ ), a najslabije objašnjava $11 \%$ varijance - izbor studiranja u regiji, dok je objašnjenost izbora Zagreba 13\%. Pri tom svaki od koraka analize doprinosi malo (1-2\%) objašnjenju , a jedini malo veći doprinos 3-4\% daje posljednji korak u kojem je u analizu uvedena jedna od varijabli simboličke vrijednosti zajednice odrastanja. Konačno, to je i jedini prediktor koji se značajnim pokazuje u sve tri analize pri čemu negativan predznak ima kada je u pitanju izbor sveučilišnog studija i kada je u pitanju izbor Zagreba kao mjesta studiranja, a pozitivan predznak kada je u pitanju izbor studiranja u regiji. Drugim riječima, izbor sveučilišnog studija i Zagreba kao mjesta studiranja izglednije je za slavonske maturante koji u manjoj mjeri iskazuju želju za ostankom u mjestu odrastanja $(\mathrm{B}=-0,46$ i $\mathrm{B}=-0,38)$. S druge strane, veću izglednost izbora studiranja u regiji pokazuju učenici koji iskazuju veću želju za ostankom u mjestu odrastanja $(B=0,37)$, odnosno koji imaju veću sposobnost zamišljanja budućeg života u mjestu odrastanja te preseljenje vide nepotrebnijim i uz njega vezuju veće teškoće prilagodbe. Spomenimo i da se kao „potencijalni““ prediktor ${ }^{116}$, ukazuje procjena školskog statusa u analizi objašnjenja izbora Zagreba.

Provedene analize, dakle, pokazale su konzistentan obrazac prema kojem teorijski predviđeni elementi i mnogo puta u istraživanjima potvrđeni prediktori obrazovnih ishoda nisu značajni kada su u pitanju specifični visokoobrazovni izbori. Oni se u ovim analizama mogu do određene razine objasniti elementima percepcije nečije vlastite prostorne pozicije. Drugim riječima, u specifičnom regionalnom kontekstu, uz neke individualne, obiteljske i školske karakteristike, objašnjenju izbora tipa studija i mjesta studiranja, ali ipak kao dio skupa ostalih varijabli, u najvećoj mjeri pridonosi učenička želja za napuštanjem mjesta odrastanja, pa čak i doživljaj preseljenja nužnim zamišljanjem budućeg života izvan njega, ali i nepercipiranje teškoća prilagodbe na novu sredinu. Tablica 4.12 sažima rezultate analiza provedenih u ovom poglavlju. Sljedeće poglavlje iznosi konačne zaključke studije.

Jedno od osnovnih pitanja koje zadnje analize postavljaju je: kako se taj utjecaj dimenzije ostanka, odnosno odlaska, iskazuje na visokoobrazovne izbore očituje u budućim, širim planovima učenika?

\footnotetext{
${ }^{116}$ Podaci u tablici X ukazuju da u trima provedenim analizama varijabla Škola visokog statusa ima Wald vrijednost blizu ili veći od 2, što upućuje na određeni prediktivni značaj, iako on nije statistički potvrđen ( $\mathrm{p}=$.
} 
Tabela 4.12Osnovna istraživačka pitanja, analize i nalazi vezani uz objašnjenje namjere studiranja i visokoobrazovne izbore slavonskih učenika

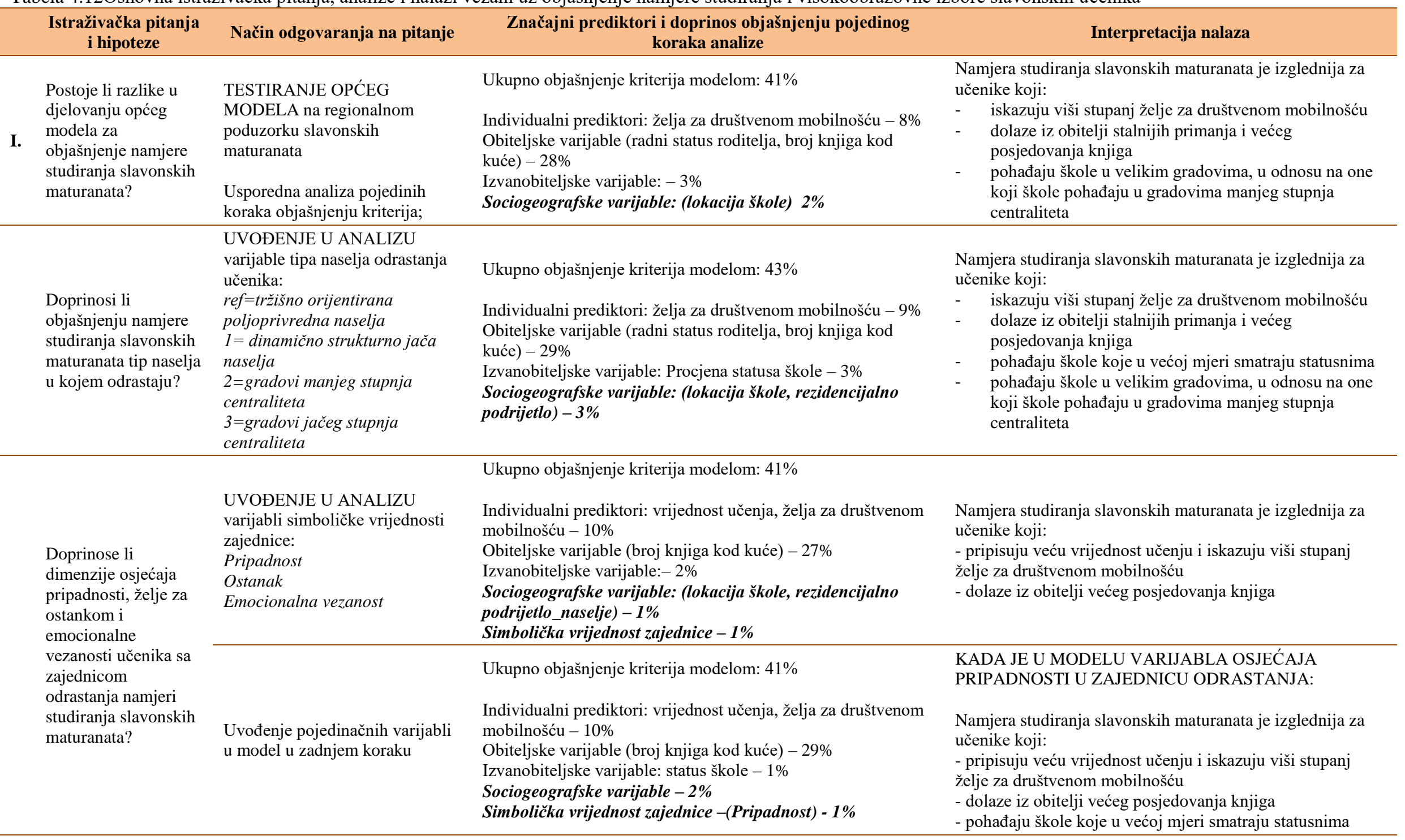


Individualni prediktori: želja za društvenom mobilnošću - 9\% Obiteljske varijable (radni status roditelja, broj knjiga kod

kuće) $-28 \%$

Izvanobiteljske varijable:- $2 \%$

Sociogeografske varijable: $-1 \%$

Simbolička vrijednost zajednice (Ostanak) - 1\%

Ukupno objašnjenje kriterija modelom: 42\%

Individualni prediktori: vrijednost učenja, želja za društvenom mobilnošću - 9\%

Obiteljske varijable (radni status roditelja, broj knjiga kod

kuće) $-28 \%$

Izvanobiteljske varijable: status škole- $3 \%$

Sociogeografske varijable: (lokacija škole) - 1\%

Simbolička vrijednost zajednice - (Emocionalna vezanost) -

$1 \%$

Ukupno objašnjenje modelom - 20\%

6. učeničke kulturne prakse $(11 \%)$

Postoje li razlike

djelovanju općeg

II modela za

objašnjenje

Visokoobrazovnih

izbora slavonskih

maturanata?

1) izbora sveučilišnog

studija

2) izbora Zagreba kao

mjesta studiranja

\section{Doprinos li dimenzija KOREKCIJA MODELA -}

želje za ostanl

zajednici odrastanja

na visokoobrazovne

izbore učenika?

smanjivanje broja varijabli:

1. Učeničke kulturne prakse

2. Obrazovanje roditelja

3. Radni status roditelja

A. Izbor sveučilišnog
6. uč

8. status škole $(4 \%)$

9.

10.

Ukupno objašnjenje modelom - 15\%

1. -

$2 . \quad-$

3.

Ukupno objašnjenje modelom izbora sveučilišnog studija -

$15 \%$

1.

2.

3.
5. Ugled studija i fakulteta
$-$

$-$

Ostanak 4\%
OSTANKOM U ZAJEDNICI ODRASTANJA:

Namjera studiranja slavonskih maturanata je izglednija za učenike koji:

- $\quad$ iskazuju viši stupanj želje za društvenom mobilnošću

- dolaze iz obitelji stalnijih primanja i većeg posjedovanja knjiga

KADA JE U MODELU VARIJABLA EMOCIONALNE

VEZANOSTI ZA ZAJEDNICU ODRASTANJA:

Namjera studiranja slavonskih maturanata je izglednija za učenike koji:

- pripisuju veću vrijednost učenju i iskazuju viši stupanj

želje za društvenom mobilnošću

- dolaze iz obitelji stalnijih primanja i većeg posjedovanja

knjiga

- pohađaju škole koje u većoj mjeri smatraju statusnima

- pohađaju škole u velikim gradovima, u odnosu na one koji škole pohađaju u gradovima manjeg stupnja centraliteta

Veću izglednost izbora sveučilišnog studija pokazuju slavonski maturanti koji:

- imaju višu razinu kulturnih kompetencija, odnosno

učestalije sudjeluju u kulturnim praksama

- pohađaju škole koje procjenjuju statusnima
Veću izglednost izbora sveučilišnog studija pokazuju

slavonski maturanti koji:

- iskazuju manju želju za ostankom u mjestu odrastanja 
studija

B. Izbor Zagreba

C. Izbor studija u

6. Rezidencijalno podrijetlo

7. Ostanak

Ukupno objašnjenje modelom izbora Zagreba kao mjesta

regiji
Veću izglednost izbora studiranja u Zagrebu pokazuju slavonski maturanti koji

- $\quad$ koji iskazuju manju želju za ostankom u mjestu odrastanja

Ostanak 4\%

Ukupno objašnjenje modelom izbora studiranja u regiji - 11\%; 1 .

2

Veću izglednost izbora studiranja u regiji pokazuju slavonski maturanti koji

-
-
-
-

- $\quad$ veću izglednost izbora studiranja u regiji pokazuju učenici koji iskazuju veću želju za ostankom u mjestu odrastanja, 


\section{Zaključno}

Prezentirana studija ispituje namjere studiranja i izbore visokog obrazovanja učenika $\mathrm{u}$ trenutku njihova završavanja srednjoškolskog obrazovanja, s posebnim interesom za prostorne aspekte tih odluka. U najvećoj mjeri, studiju oblikuje Bourdieuov konceptualni okvir kao heurističko sredstvo koje vodi studiju i s obzirom na osnovna pitanja koja treba postaviti, i kada su u pitanju načini njihova empirijskog zahvaćanja, kako se to predlaže u sintagmi ,koncept kao metoda“ (Reay 2004).

$\mathrm{Na}$ najopćenitijoj razini, i najvećim dijelom analiza, prostoru je pristupljeno s obzirom na zahvaćanje socioprostorne distribucije kapitala kojima učenici različitog rezidencijalnog podrijetla imaju pristup u kontekstima odrastanja i školovanja. Te analize provedene su nacionalno i regionalno, i pokazale su konzistentne obrasce razlike u kojima je struktura dostupnih i razvijenih kapitala za učenike odrasle u ruralnim naseljima nepovoljnija. Na općoj razini takvi statistički podaci oslikali su i nacionalno ruralno-urbano polje. Dodatno, kontekst odrastanja i školovanja dodatno su ispitani u dimenzijama simoličkog utjecaja, anketno i kvalitativno. Stoga je osvjetljena i dimenzija prostornog oblikovanjaodluka učenika u načinu kako ih oni opisuju na individualnoj razini, i kako su njihove namjere ocrtane u društvenom i geografskom polju. Osnova tih učeničkih narativa je označavanje pozicija koje zauzimaju i koje žele zauzeti na određeni način, te su time produbljena saznanja toga kako doživljavaju prostore kojima se kreću i kako sebe smještaju unutar njih.

Prvotne analize obuhvaćale su ispitavinje razlika između učenika različitog rezidencijalnog podrijetla prema njihovim namjerama studiranja i visokoobrazovnim odlukama, a rezultati su potvrdili njihovo postojanje, i na nacionalnoj i na regionalnoj razini. Drugim riječima, ANOVA i t-test su potvrdili pretpostavke da se učenici koji odrastaju u ruralnim sredinama $u$ manjoj mjeri odlučuju na nastavak školovanja nakon srednje škole i općenito u Hrvatskoj, a posebno istaknuto u regiji Slavonija (H1a). Također, potvrdilo se i da je manje vjerojatno da će oni maturanti ruralnog rezidencijalnog podrijetla koji namjeravaju studirati birati sveučilišne studije, dok je vjerojatniji njihov upis stručnih studija (H1b). Pretpostavka da će učenici ruralnog rezidencijalnog podrijetla koji se odlučuju na studiranje u manjoj mjeri birati studije na institucijama u glavnom gradu (H1c), potvrdila se samo na regionalnoj razini. 
Uz nevedene osnovne rezultate provjere postojanja razlika između učenika različitog rezidencijalnog podrijetla s obzirom na neke obrazovne ishode vezane uz proces donošenja odluka o visokom obrazovanju, a s ciljem dubljeg razumijevanja pronađenih hipoteziranih razlika, proveden je dodatni veći broj analiza razlika prema elementima nekih drugih obrazovnih karakteristika učenika, te njihovim obrazovno značajnim obiteljskim i školskim resursima.

Osnovni nalazi (3.2.6) ukazuju da, za razliku od učenika koji odrastaju u urbanom i/ili metropolitanskom kontekstu, učenici ruralnog rezidencijalnog podrijetla imaju slabiji pristup ekonomskim i kulturnim resursima u svojim obiteljima, u kojima ih se i u većoj mjeri potiče prema zapošljavanju. Dodatno, svojim školama procjenjuju niži status, no i veću resursnu opremljenost i programsku ponudu, te utjecaj stručnih suradnika kada je u pitanju njihova odluka o studiranju. Također, učenici i u ostalim izvanškolskim kontekstima pronalaze značajne osobe za koje procjenjuju da značajnije utječu na njihove obrazovne namjere nakon srednje škole, iako je on općenito mali, u susjedima i savjetnicima za profesionalno usmjeravanje.

Na općoj razini, učenici različitog rezidencijalnog podrijetla oblikuju drugačije obrazovne putove, a učenici ruralnog rezidencijalnog podrijetla u manjoj se mjeri izborom srednje škole usmjeravaju prema studiranju: u većoj mjeri se odlučuju za strukovno obrazovanje, teže samo završavanju škole, a i očekuju uglavnom niže razine obrazovanja, te im se odluka o studiranju ne podrazumijeva i ne pojavljuje im se kao „normalan“ pravac djelovanja, već nešto što moraju promišljati. Dodatno, učenici ruralnog rezidencijalnog podrijetla imaju niže razina osobno razvijenih kapitala i lošije ocjene. Ipak, prema nekim individualnim karakteristikama, u odnosu na učenike koji odrastaju u gradovima, oni ne pokazuju slabije vrednovanje učenja za postizanje svojih životnih ciljeva, niti iskazuju manju želju za društvenim uspinjanjem od ostalih učenika.

Općenito, namjera studiranja (3.3.2) izglednija je za učenike koji veću vrijednost pripisuju obrazovanju i značajnije ističu želju za društvenom mobilnošću, koji odrastaju u obiteljima većih razina kulturnog i ekonomskog kapitala te pohađaju škole višeg statusa i odrastaju u hrvatskim gradovima u odnosu na one odrasle u selima.

Stoga, obiteljski kulturni i ekonomski kapital učenika ruralnog rezidencijalnog podrijetla te škole koje pohađaju, a kojima procjenjuju niži status, predstavljaju osnovne prepreke njihovom studiranju. U hrvatskom sociogeografskom prostoru, određeni učenici ipak imaju veće izglede da će se odlučiti na studiranje: to su oni koji, uz visoko vrednovanje učenja i sa 
željom za društvenom mobilnošću, odrastaju u obiteljima većih kulturnih kapitala, te pohađaju škole većeg statusa u glavnom gradu, ili odrastaju u određenim tipovima ruralnih naselja koje karakterizira veća ekonomska diferencijacija ili bolja povezanost sa širom mrežom naselja (u odnosu na one koji odrastaju u izrazito poljoprivrednim naseljima).

Pokazalo (3.3.6) se da učenici različitog rezidencijalnog podrijetla koji namjeravaju studirati nemaju značajno različite rezultate školske uspješnosti, iako ih, u odnosu na druge rezidencijalne kategorije učenika, i dalje obilježava nepovoljnija struktura osobno razvijenih kulturnih kapitala, kao i struktura obiteljskih i kulturnih resursa, ali imaju i razvijeniji društveni kapitala s obzirom na utjecaj osoba iz njihova konteksta odrastanja i školovanja; oni snažnijim ističu značaj braće i sestara, susjeda, savjetnika za profesionalno usmjeravanje, nastavnika te stručnih suradnika na njihovu odluku. Svi ti utjecaji iznimno su slabi, ali ukazuju kako učenicima ruralnog rezidencijalnog podrijetla u nedostatku drugih resursa mogu biti značajan društveni resurs pristupa informacijama i/ili podršci za orijentiranje prema studiranju.

Ipak, pokazalo se i da se visokoobrazovni izbori razlikuju značajno za ruralne učenike koji u većoj mjeri upisuju stručne studije, dok se razlika u izboru mjesta studiranja, koja je uvelike geografski određena za druge dvije kategorije učenika, nije potvrdila. Učenici ruralnog rezidencijalnog podrijetla u najvećoj mjeri - preko 50\% - biraju Zagreb, a zatim makroregionalne centre te gradove manjeg stupnja centraliteta.

Općenito, viši prosjek ocjena i više razine osobnih i obiteljskih kulturnih kapitala te školovanje u velikom gradu i odrastanje u urbanom okolišu povećavaju izglednost učenika da će njihov izbor biti sveučilišni studij. Stoga, prepreku učenicima koji odrastaju u ruralnoj sredini čini razina razvijenog kulturnog kapitala uz samu činjenicu da odrastaju ruralnom okolišu. S obzirom na Bourdieuovo shvaćanje rezidencijalnog podrijetla kao pokazatelja kulturnog kapitala, ove analize potvrđuju tu vezu. Stoga je i izglednije da će učenici ruralnog rezidencijalnog podrijetla koji imaju razvijenije kulturne kompetencije, dakle u većoj mjeri pohađaju kulturna događanja, čitaju i sudjeluju u izvanškolskim aktivnostima, te se školuju u velikom gradu (u odnosu na one manje) u kojima im je i pristup kulturnim događanjima veći, izabirati sveučilišni studij (3.4.4).

Konačno, rezidencijalno podrijetlo kao značajan prediktor izbora Zagreba kao željenog mjesta studiranja, pokazalo se samo u jednom očekivanom smjeru (3.3.5). Općenito, izbor Zagreba je izgledniji za učenike koji su školski uspješniji i imaju razvijenije kulturne kapitale, odrastaju u obiteljima stalnijih prihoda u glavnom gradu, gdje pohađaju i škole visokog statusa. Stoga je 
i izbor Zagreba izgledniji za one učenike ruralnog rezidencijalnog podrijetla koji su školski uspješniji i razvijenijih kulturnih kompetencija, te prihodovno stabilnijeg obiteljskog okruženja, i koji se školuju u glavnom gradu ili malom gradu, odnosno za one uspješne učenike koji ionako moraju odseliti, ili za one kojima je taj grad dostupniji.

Regionalno, potvrđen je obrazac da postoje razlike između slavonskih učenika različitog rezidencijalnog podrijetla na svim značajnim obrazovnim ishodima (4.2.6), odnosno, postoje značajne razlike između učenika različitog rezidencijalnog podrijetla kada su u pitanju odluka o studiranju te odabir sveučilišnog tipa studija i Zagreba kao mjesta studiranja. Svi navedeni izbori statistički su značajno manje vjerojatni za ruralne učenike.

Regionalne analize, u svom statističkom dijelu, također su potvrdile konzistentan obrazac urbano-ruralnih razlika na gotovo svim mjerenim aspektima visokoobrazovnih odluka slavonskih maturanata, njihovih obrazovnih karakteristika i orijentacija, te dostupnosti resursa u njihovim obiteljskim i školskim okruženjima. Očekivano, pokazalo se da postoje razlike između slavonskih učenika različitog rezidencijalnog podrijetla na svim značajnim obrazovnim ishodima, pri čemu su namjera studiranja, izbor sveučilišnog studija i studiranja u Zagrebu manje vjerojatnan izbor učenika odraslih na selu.

Općenito, slavonski učenici ruralnog rezidencijalnog podrijetla u manjoj mjeri iskazuju visokoobrazovnu orijentaciju, dok je za njih vjerojatnija orijentiranost stjecanju struke, niže ocjene, odluka o nestudiranju, kao i nepodrazumijevanje studiranja te veće percipirane prepreke postizanja visokog obrazovanja. S osloncem u Bourdieuovoj teoriji, ispitivane obrazovne orijentacije učenika moguće je shvatiti kao indikacije osobnih habitusa učenika (Dumais, 2000). S obzirom da habitus predstavlja socijalizacijom internalizirane mentalne strukture određene društvenim položajem pojedinca koje usmjeravaju njegove načine razumijevanja i djelovanja, ove razlike se mogu promatrati kao habitusom oblikovane obrazovne dispozicije.

Dodatno, učenici ruralnog rezidencijalnog podrijetla imaju i niže rezultate na mjerama osobnog kulturnog kapitala razvijenog izvan školskog konteksta što ih stavlja u dodatno nepovoljnu poziciju kada je namjera o studiranju u pitanju. No, nisu se pokazale razlike među učenicima prema njihovom vrednovanju učenja i želji za društvenom mobilnošću, što su mjere na kojima učenici imaju slične i relativno više rezultate bez obzira na rezidencijalno podrijetlo. 
Socijalizacijsko obiteljsko okruženje slavonskih učenika ruralnog rezidencijalnog podrijetla također pokazuje nepovoljniju strukturu ekonomskih, kulturnih resursa, i u određenoj mjeri slabiji simbolički značaj za učeničke odluke studiranja Za njihove roditelje je vjerojatniji slabiji radni, imovinski, financijski i obrazovni status, te niže razine posjedovanja kulturnih dobara i rjeđe kulturne aktivnosti. Na simboličkoj dimenziji, u skladu s njihovim vjerojatnijim orijentacijama stjecanju struke, roditeljski poticaji zaposlenja značajniji su kod učenika ruralnog rezidencijalnog podrijetla, dok je općeniti roditeljski utjecaj kod donošenja odluke o studiranju snažnije izražen kod onih urbanog rezidencijalnog podrijetla.

No, kako naglašava Bourdieuva teorija, da bi se razumjele obrazovne razlike potrebno je promatrati i obrazovni sustav. Ruralni učenici svojim školama u većoj mjeri pripisuju bolju opremljenost i programsku ponudu, ali isto tako i manji status, čime je škola moguća „prepreka“ odlasku na studij slavonskim učenicima ruralnog rezidencijalnog podrijetla. Procjena višeg statusa školama viša je kod učenika urbanog rezidencijalnog podrijetla koji u većoj mjeri pohađaju gimnazije. U Hrvatskoj, institucionalne karakteristike srednjoškolskog obrazovanja ogledaju se u dualnoj, hijerarhijskoj strukturi statusa škola utemeljenoj u razlikovanju općeg i strukovnog obrazovanja (Baranović, 2015). Time se škole pojavljuju kao mehanizam društvene selekcije koji regulira pristup visokom obrazovanju (Baranović, 2015), stavljajući učenike gimnazija u povoljniju poziciju od učenika strukovnih škola, a odluka o upisu srednje škole postaje ključni trenutak daljih obrazovnih putova i moguća „prepreka“ ulasku u visoko obrazovanje za učenike odrasle u ruralnim naseljima koji u većoj mjeri pohađaju strukovne škole. U takvoj strukturi, analize potvrđuju, stručni suradnici u školama mogu biti važan socijalni resurs učenicima ruralnih sredina kada je u pitanju njihova namjera studiranja (Klepač, 2016).

Te razlike s obzirom na tip školovanja dodatno su podcrtali i nadopunili iskazi učenika iz kojih je vidljivo nesigurnije razmatranje vezano uz njihovu (obrazovnu) budućnost. Učenici koji upisuju gimnazije, bez obzira na rezidencijalno podrijetlo i bez obzira na školski uspjeh, svoje izbore doživljavaju daleko boljim i perspektivnijim za ulazak u visoko obrazovanje, iako postoje veći tereti za učenike odrasle u ruralnim naseljima.

No nasuprot lošijoj strukturi do sada prezentiranih elemenata, širi kontekst odrastanja i školovanja pokazuje se i kao izvor resursa i simboličke vrijednosti s obzirom na učeničku namjeru studiranja; osobe iz školskog konteksta, kao i susjedi u životnom okruženju, mogu biti važan socijalni resurs ruralnim učenicima koji namjeravaju studirati, a možda i značajan (kompenzacijski) mehanizam utjecaja iz okoline. 
Na općoj razini, odluka za studiranje slavonskih maturanata (4.3.1) izglednija je za one koji iskazuju snažniju želja za društvenom mobilnošću te imaju povoljniju strukturu obiteljski dostupnih ekonomskih i kulturnih resursa, pohađanju škole u velikim regionalnim gradovima (u odnosu na učenike koji se školuju u gradovima manjeg stupnja centraliteta) te odrastanju u malim gradovima ( $u$ odnosu na one koji odrastaju u tržišno orijentiranim poljoprivrednim naseljima). Stoga se i regionalno potvrdilo da rezidencijalno podrijetlo statistički značajno, iako samo oko $1 \%$, doprinosi objašnjenju učeničkih visokoobrazovnih izbora. U tom skupu varijabli, varijable obiteljskog konteksta, i to radni status roditelja i broj knjiga u kućanstvu, objašnjavaju najveći dio namjere studiranja slavonskih maturanata, dok je najznačajnija individualna značajka želja za društvenom mobilnošću.

Osnovnu nadopunu regionalnih analiza činilo je dublje ispitivanje simboličkih elemenata odrastanja i školovanja. Na općenitijoj razini, učenici odrasli u ruralnim naseljima u većoj mjeri vide mogućnost budućeg života u mjestu odrastanja i nepotrebnost za preseljenjem, te u većoj mjeri doživljavaju svoju zajednicu kao sigurnu za odrastanje i ugodnu za život zbog njenih sociokulturnih elemenata (veza, vrijednosti, načina života) i prirodnog okruženja. U intervjuima ti elementi su daleko kritičnije sagledani, ali se pokazuje njihova posredovna značajnost u oblikovanju svoji obrazovnih putova.

Ukratko, rezultati potvrđuju pretpostavke H1a i H1b: da se učenici iz ruralnih sredina rjeđe odlučuju na nastavak školovanja na visokoškolskoj razini, te da je za učenike ruralnog rezidencijalnog podrijetla koji se odlučuju na nastavak školovanja veća vjerojatnost odabira stručnih studija nacionalno i regionalno. No samo je regionalno potvrđeno H1c: da je za učenike ruralnog rezidencijalnog podrijetla koji se odlučuju na nastavak školovanja manja vjerojatnost odabira visokoobrazovnih institucija u Zagrebu.

Utvrđeno je da rezidencijalno podrijetlo kao varijabla modela jedinstveno doprinosi objašnjenju visokoobrazovnih odluka učenika, iako uvijek u iznimno maloj mjeri - oko $1 \%$. Time je potvrđena hipoteza H2a na nacionalnoj i regionalnoj razini: Postoji jedinstven doprinos rezidencijalnog porijekla učenika u objašnjenju varijance namjere studiranja

Pretpostavke da rezidencijalno podrijetlo ima jedinstven doprinos u objašnjenju visokoobrazovnih izbora: izbora sveučilišnog studija i Zagreba kao mjesta studiranja (H2b i $\mathrm{H} 2 \mathrm{c}$ ), potvrđene su samo na nacionalnoj razini 
S druge strane, simboličke dimenzije nisu pokazle prediktorski značaj u regresijskom modelu kao značajna odrednica nečijih visokoobrazovnih planova. Stoga nije potvrđena pretpostavka H3: Varijable emocionalne vezanosti za mjesto odrastanja, osjećaja pripadnosti u lokalnoj zajednici te želje za ostankom u svom mjestu doprinose objašnjenju varijance kriterijskih varijabli izbora visokog obrazovanja.

Iako, analize su ukazale da u korigiranom regresijskom modelu, kao jedina značajna varijabla, želja za ostankom odnosno odlaskom objašnjava (2\%) izbor sveučilišnog studija i izbor Zagreba kao željenog mjesta studiranja slavonskih maturanata.

Ipak, simbolički elementi jesu ispitani korištenjem druge vrste podataka - podataka prikupljenih kroz razgovore s maturantima. Njihovi opisi i načini na koje opisuju svoje obrazovne putove, kako doživljavaju svoje pozicije i buduće želje te kako vide svoje mogućnosti za ostvarenje budućih planova dodatno su oslikali i statističke podatke, ali su ukazali i na specifične dinamike i njihovih obrazovnih putova i načina na koji donose odluke o studiranju. Svi ti opisi - reprezentirani kroz osnovni proces „dalje i više“ - ukazuju na prostornu dimenziju takvih odluka koje su duboko isprepletene s onime kako vide sebe i svoju budućnost, a takve slike su duboko prostorno i vremenski određene. U tom kontekstu i ruralnost dobiva različita značenja upravo u odnosu na to mogu li se učenici u budućnosti zamisliti u lokalnom kontesktu u kojem su odrasli ili se kroz obrazovanje postavljaju nasuprot njemu. Kada se slike nađu u sukobu, uglavnom se razrješavaju odabirom odlaska sa stavom „za poslom se ide“. No, najčešće se obrazovanje pokazuje mehanizmom iskorijenjivanja za poboljšanje životnih mogućnosti i micanje iz neželjenih okoliša u društvenoj i geografskoj dimenziji.

U konačnici svi postavljeni ciljevi studije su postignuti, a na najopćenitijoj razini doprinos studije predstavljaju pitanja koja postavlja i način na koji se na njih odgovara.

$\mathrm{S}$ osnovnim pitanjima o procesu ulaska u visoko obrazovanje za različite učenike s obzirom na njihovo rezidencijalno podrijetlo i resurse koji su im dostupni u njihovom okruženju odrastanja i školovanja, studija u prvi plan interesa postavlja pitanja vezana uz prostorno oblikovanje visokoobrazovnih odluka i procesu njegova odvijanja problematizirajući i implikacije konačnih odluka na osobnoj i širim prostornim razinama. Time se propituju i same postavke općeg pristupa obrazovanju, koji je uvelike urbanocentričan, a ističe se potreba razmatranja prostornih aspekata društvenih fenomena, posebno u okviru težnje postizanja socijalne dimenzije u obrazovanju, te s naglašenim problemima regionalnog/ruralnog razvoja. 
Empirijski, doprinos se tiče prikupljanja primarnih raznorodnih podataka i usporedne analize na dvije razine.

Teorijski, iako studiju ne vodi interes za testiranjem Bourdieuove teorije, doprinos provedenog istraživanja odnosi se na propitivanje i modificiranje njegovog konceptualnog okvira, posebno u aspektu kulturnog kapitala izraženog kao učeničke izvanškolske aktivnosti, te općeg razmatranja shvaćanja rezidencijalnog podrijetla kao odrednice kulturnog kapitala $\mathrm{i}$ načina poimanja habitusa. Analize ukazuju da uvelike kulturni kapital značajno razlikuje učenike različitog rezidencijalnog podrijetla. Upotrebom mješovite metodologije s interesom i za statističke obrasce, ali i za značenja i suptilnije aspekte društvenih procesa koje je nemoguće zahvatiti kvantitativnom metodologijom, poseban interes je poklonjen dimenziji prostornosti onih aspekata učeničkih života i školovanja koji se pokazuju značajnim elementima donošenja odluka učenika u prostoru i vremenu. Kako sam Bourdieu nije dublje razmatrao utjecaje mjesta i prostora, istraživanje ovdje prezentirano poseban naglasak stavlja na taj tip produbljivanja Bourdieuovog razmatranja. Također, iako prihvaća opći Bourdieuov okvir i za postavljanje pretpostavki i za interpretaciju podataka, studija upravo naglaskom na specifične kontekstualne aspekte obrazovnog sustava u Hrvatskoj, ukazuje i na druge teorijske doprinose u sociologiji obrazovanja, specifično pozicijske teorije, koji značajno nadopunjava Bourdieuova razmatranja u hrvatskom obrazovnom sustavu.

Metodološki, osnovni doprinos provedenog istraživanja vezan je uz izgradnju modela mješovite metodologije koji u dva zasebna tijeka istraživanja, upotrebom dvaju različitih tehnika prikupljanja podataka, različitim procedurama i tehnikama njihove obrade, te zajedničke interpretacije raznorodnih nalaza kako bi se dublje zahvatila i istražila tema od interesa. Opisom svakog koraka analize i uprimjerenim oblicima izvođenja zaključaka studija ukazuje na prednosti takvog oblika istraživanja, no i na teškoće kada su u pitanju i izazovi prikupljanja i obrade podataka te integracije nalaza. Ovdje izgrađeni model i opisane procedure daju prikaz jednog od mogućih pristupa provedbe socioloških istraživanja.

Također se ističu i određeni problemi u provedbi istraživanja s poduzetim alternativnim rješenjima. Općenito, osnovni problemi određenih koraka analize ticala su se provedbe terenskog rada, odnosno pristupa ispitanicima koji su onemogućili teorijsko selektiranje ispitanika, te time onemogućili u potpunosti dostizanje postavljenih ciljeva, odnosno saturiranu izgradnju osnovnog procesa (Strauss, Corbin, 1990). Drugi problemi vezani su uz provedbu analize te korištene alate za obradu podataka; proces obrade i integracije dviju vrsta 
podataka postavio se iznimno zahtjevnim zadatkom samo jednom istraživaču. U sličnim studijama mješovitog nacrta istraživanja preporuča se sudjelovanje grupe istraživača. Nažalost, iako je proces trebao olakšati programa za obradu kvalitativnih podataka, on je korišten u ograničenom obujmu i nisu se dobile sve koristi koje takav program nudi zbog neupoznatosti s određenim funkcijama, te nedostupnosti u određenom dijelu izrade studije.

Studija označava i doprinos općedruštvenom dijalogu kada se postavljaju pitanja značaja obrazovanja i mogućnosti postizanja obrazovnih ishoda za specifične kategorije učenika, ali i razvojne probleme prostora koji pokazuju manje razine visokoobrazovnih kapitala. Studija upravo takva pitanja postavlja za buduća istraživanja uloge obrazovanja u ruralnim područjima i ulogama škola u nadilaženju negativnih trendova u ruralnom prostoru Hrvatske kako ih percipiraju mladi te kako ih bilježe istraživanja ruralnih sociologa.

$\mathrm{S}$ jedne strane, potrebno je pitati o suvremenim svrhama obrazovanja danas i temeljima na kojima je obrazovanje postavljeno, kako ukazuje Cuervo ističući: „sposobnost aspiriranje je predugo konstruirana kao sposobnost migriranja“ (Cuervo 2016:64), što se razvija unutar okvira obrazovanja koje iznad svega vrednuje ljudski kapital, i potiče individualnu orijentaciju na obrazovanje koje se doživljava meritokratskim s osnovom u osobnom zalaganju i trudu, nad drugim vrijednostima obrazovanja. Prema Cuervou (2016), cilj obrazovanja bi trebao biti osposobiti mlade da sami odabiru gdje pripadati. Okvir takvih pitanja dio je kritičkog razmatranja obrazovanja u neoliberalno vrijeme, a dodatno postavlja pitanje obrazovanja za ruralni razvoj. Ova studija ukazuje na potrebu omogućavanju mladima da se ,zamisle“ i u lokalnim i u ruralnim uvjetima, te osvještavanje stava da diploma nadilazi prostorna ograničenja. U tom smislu, kada se govori o podizanju aspiracija zanimljivu ideju izlažu Zipin i suradnici (2015) o potrebi razmatranja, uz doksičnu i habitusnu logiku aspiriranja, treću logiku koja se usredotočuje na „nastajuće osjećaje budućih potencijala, utemeljenih u življenim kulturama, koje drže mogućnost zamišljanja i slijeđenja alternativnih budućnosti“ (Zipin i sur. 2015:227).

Dodatno, studija je ukazala na izuzetan značaj koji odabir srednje škole ima za buduće obrazovne ishode učenika, i neke načine kako se odabir određenih škola može otežati učenicima postizanje željenih obrazovnih aspiracija, na individualnoj razini, te na regionalnoj, ne zadovoljiti potrebe tržišta rada. Suprotno ranijim istraživanjima (Tamanović 1967), učenici ruralnog rezidencijalnog podrijetla u ovoj studiji izražavaju stav da su njihove škole dobro opremljene i imaju dobru ponudu izvannastavnog programa, no to im ne predstavlja prednost 
kada je namjera studiranja u pitanju. Status škole se pokazuje institucionalnom karakteristikom s najizraženijim prediktivnim značajem nečijih odluka o studiranju, a procjena višeg statusa školama viša je kod učenika urbanog rezidencijalnog podrijetla koji u većoj mjeri pohađaju gimnazije. U Hrvatskoj, institucionalne karakteristike srednjoškolskog obrazovanja ogledaju se u dualnoj, hijerarhijskoj strukturi statusa škola utemeljenom u razlikovanju općeg i strukovnog obrazovanja (Baranović, 2015). Time se škole pojavljuju kao mehanizam društvene selekcije koji regulira pristup visokom obrazovanju (Baranović, 2015), stavljajući učenike gimnazija u povoljniju poziciju od učenika strukovnih škola, a odluka o upisu srednje škole postaje ključni trenutak daljih obrazovnih putova i moguća „,prepreka“ ulasku u visoko obrazovanje za učenike odrasle u ruralnim naseljima koji u većoj mjeri pohađaju strukovne škole. U takvoj strukturi, analize potvrđuju, stručni suradnici u školama mogu biti važan socijalni resurs učenicima sa slabijim pristupom nekim drugim značajnim resursima, kada je u pitanju njihova namjera studiranja.

Ovdje je institucionalni kontekst zahvaćen u ograničenom obujmu, u 14 specifičnih škola, te samo na nekoliko mjera. Potrebna su dodatna ispitivanja upravo institucionalnih okruženja obrazovanja kako bi se dobili dublji uvidi u djelovanje mehanizama s obzirom na pojedine tipove obrazovanja, a posebno u ruralnim sredinama $\mathrm{i} / \mathrm{ili}$ regionalnim okvirima. Buduće obrazovne politike trebaju razmotriti pravce djelovanja za osnaživanje strukovnog obrazovanja, dubljim povezivanjem s lokalnim tržištem rada, ali i institucijama visokog obrazovanja, omogućavajući dodatne i naknadne obrazovne mogućnosti za učenike strukovnih škola, koji su inače u nepovoljnijoj poziciji kada je u pitanju vjerojatnost njihova nastavka školovanja.

Dodatno, unatoč opsežnosti studije, određenim pitanjima nije se mogla posvetiti veća pozornost, iako su se istakli kao vrlo značajni. Pokazalo se kako je u procesu donošenja obrazovnih odluka, osim klasnog i prostornog poimanja, značajna i rodna dimenzija koja čini bitan dio slike učenika i projekcija osoba koje žele postati. Taj aspekt isprepleten s ostalima potrebno je dublje ispitati. 


\section{Literatura}

1. Anchaffenburg, K., Mass I. (1997). Cultural and Educational Careers: the Dinamics of Social Reproduction. American Sociological Review, 62, 573-587

2. Andres L., Looker D. (2001). Rurality and Capital: Educational Expectatons and Attainments of Rural, Urban/Rural and Metropolitan Youth, The Canadian Journal of Higher Education, Vol. XXXI, No. 2, pp 1-46

3. Archer, L., Hutchings, M., Ross, A. (2003) Higher Education and Class. Issues of Exclusion and Inclusion. RoutledgeFalmer, London and New York

4. Bajema, D. H., Miller, W. W., Williams, D. L. (2002). Aspirations of Rural Youth. Journal of Agricultural Education, Vol 43 (3): 61-71

5. Baker, S., Brown, B. J. (2008). Habitus and Homeland: Educational Aspirations, Family Life and Culture in Autobiographical Narratives of Educational Experience in Rural Wales. Sociologia Ruralis, Vol 48(1): 57-72

6. Baranović, B. (2015). Razvoj i socijalna dimenzija visokog obrazovanja u Hrvatskoj. U: Baranović, B. (ur.): Koji srednjoškolci namjeravaju studirati? Pristup visokom obrazovanju i odabir studija. Institut za društvena istraživanja u Zagrebu, Zagreb

7. Bazeley, P, Jackson, K. (2013) Qualitative Data Analysis with NVivo, SAGE, Los Angeles, London, New Delhi, Singapore, Washinton DC

8. Bourdeiu, P. (2013 [1977]). Outline of a Theory of Practice, Cambridge University Press

9. Bourdieu, P. (1977). Cultural Reproduction and Social Reproduction. U: Karabel, J., Halsey, A. H. (eds.). Power and Ideology in Education, 487-511. New York: Oxford University Press.

10. Bourdieu, P. (1997). The Forms of Capital. U: Halsey, A.H., Lauder, H., Brown, P., Stuart Wells,A. (eds.). Education: Culture, Economy, and Society, 47-58. Oxford: Oxford University Press.

11. Bourdieu, P., Wacquant, L. J. D. (1992). An Invitation to Reflexive Sociology, Polity Press

12. Bracken, E. (2007). Off the Beaten Path: Rural Students and the Pursuit of Higher Education. Sociology Honors $\quad$ Projects. http://digitalcommons.macalester.edu/soci_honors/9

13. Bridge, G. (2011). Pierre Bourdieu, In: Hubbard, P, Kitchin, R. (eds.) Key Thinkers on Space and Place, SAGE, Los Angeles, London, New Delhi, Singapore, Washinton DC 
14. Cairns, K. (2011). Mapping Futures, Making Selves: Subjectivity, Schooling and Rural Youth, PhD Thesis, Department of Sociology and Equity Studies in Education, University of Toronto https://tspace.library.utoronto.ca/bitstream/1807/31704/3/Cairns_Kate_201111_PhD_thesi s.pdf

15. Carr, P. J., Kefalas, M. J. (2009). Hollowing Out the Middle. The Rural Barin Drain and What It Means for America. Beacon Press, Boston

16. Cho, J., Trent, A. (2006). Validity in Qualitative Research Revisite, Qualitative Research. SAGE Publications, Vol. 6(3): 319-340

17. Cloke, P. (2006). Conceptualizing ruraliti. U: Cloke, P., Marsden, T., Mooney, P. (eds.) (2006). Handbook of Rural Studies. Sage, London, Thousand Oaks, New Delhi

18. Considine, G., Zappalà, G. (2002). Factors Influencing the Educational Performance of Students from Disadvantaged Backgrounds, in: Eardley, T., Bradbury, B. (eds.): Competing Visions: Refeered Proceedings of the National Social Policy Conference 2001. SPRC Report 102, Social Policy Research Centre, University of New South Wales, Sydeney, 91-107

19. Corbett, M. (2000). Learning to Leave: The Irony of Schooling in a Coastal Community... Some Preliminary Findings. U: Issues Affecting Rural Communities. Proceedings of the International Conference on Rural Communities and Identities in the Global Millenium (Nanaimo, British Columbia, Canada, May 1-5, 2000

20. Corbett, M. (2005a). Rural Education and Out-Migration: The Caseof Coastal Community. Canadian Journal of Education, Vol 28 (1/2): 52-72

21. Corbett, M. (2005b). We're practical people: schooling and identity in a Canadian coastal community. Paper presented to the annual conference of the Australian Association for Research in Education, 28.11.2005. https://www.aare.edu.au/data/publications/2005/cor05727.pdf

22. Corbett, M. (2007). Travels in space and place: identity and rural schooling, Canadian Journal Of Education 30, 3:771-792

23. Corbett, M. (2009). Rural Schooling in Mobile Modernity: Returning to the Places I've Been. Journal of Research in Rural Education Vol 24(7)

24. Corbett, M. (2010). Standardized individuality: cosmopolitanism and educational decision-making in an Atlantic Canadian rural community. Compare: A Journal of Comparative and International Education. 40:2, 223-237, DOI: $10.1080 / 03057920903546088$ 
25. Creswell, J. W. (2003). Research Design: Qualitative, Quantitative and Mixed Methods Approaches, Sage, Thousand Oaks, London, New Delhi

26. Crockett, L. J., Shanahan, M. J., Jackson-Newsom, J. (2000). Rural Youth: Ecological and Life Course Perspectives. In: Montemayor, R., Adams, G. R., Thomas, P. G: Adolescent Diversity in Ethnic, Economic and Cultural Context: Advances in Adolescent Development, Thousand Oaks, Vol 10: 43-74

27. Crozier, G., Reay, D., Clayton, J., Colliander, L., Grinstead, J. (2008) Different Strokes for Different Folks: Diverse Student sin Diverse Institutions - experiences of Higher Education. Reasearch Papers in Education, 23:2, 167-177, DOI:10.1080/02671520802048703

28. Cuervo, H. (2016). Understanding Social Justice in Rural Education. Palgrave Macmillan, New York

29. De Graf, N D., De Graf, P. M., Kraaykamp, G. (2000). Parental Cultural Capital and Educational Attainment in the Netherlands: A Refinement of the Cultural Capital Perspective. Sociology of Education Vol. 73: 92-111

30. Di Maggio, P. (1982). Cultural Capital and School Success: The Impact of Status Culture Participation on the Grades of U.S.High School Students, American Sociological Review, Vol. 47: 189-201

31. Doolan, K. (2009). „My dad studied here too“: Social inequalities and educational (dis)advantage in Croatian higher educational setting, Darwin Colledge

32. Doolan, K., Puzić, S., Baranović, B. (2017). Social Inequalities in Access to Higher Education in Croatia: Five Decades of Resilient Findings. Journal of Further and Higher Education Volume 42, Issue 4, pp 467-481

33. Doolan, K., Puzić, S., Baranović, B. (2017). Social inequalities in access to higher education in Croatia: five decades of resilient findings. Journal of Further and Higher Education, 1

34. Državni zavod za statistiku. (2015). Priopćenje: Srednje škole. Kraj šk. g. 2013./2014. i početak šk. g. 2014./2015. Zagreb: Državni zavod za statistiku

35. Dufur , M. J., Parcel, T. L., Troutman, K. P. (2013). Does Capital at Home Matter More than Capital at School? Social Capital Effects on Academic Achievement. Research in Social Stratificaion and Mobility, 31: 1-21

36. Dumais, S. A. 2002. Cultural Capital, Gender, and School Success: The Role of Habitus. Sociology of Education, Vol. 75: 44-68 
37. Dymitrow, M., Stenseke, M., (2016). Rural-Urban Blurring nad the Subjectivity Within. Rural Landscapes: Society, Environment, History, 3(1):1-13

38. Edington, E. D., Koehler, L. (1987). Rural student achievement: elements for considerationhttps://pdfs.semanticscholar.org/9db0/16e4d39c11dc165d1d1a739be3403b4 e3a10.pdf?.ga=2.79929879.1209505876.1569689455-1913666127.1568018509

39. Farnell, T., Doolan, K., Matković, T., Cvitan, M. (2011). Socijalna i ekonomska slika studentskog života u Hrvatskoj. Nacionalno izvješće istraživanja EUROSTUDENT za Hrvatsku, IRO, Zagreb

40. Filipić, P. (2014). Anatomija destrukcije. Politička ekonomija hrvatskog visokog školstva, Jesenski i Turk

41. Flere, S., Tavčar Krajnc, M., Klanjšek, R., Musil, B., Kirbiš, A. (2010). Cultural Capital and Intellectual Ability as Predictors of Scholastic Achievment: a Study of Slovenian Secondary School Students British Journal of Sociology of Education, Vol. 31 (1):47-58

42. Frigo, T., Bryce, J., Anderson, M., McKenzie, P. (2007). Australian Young People, Their Families and Postschool Plans: a research Review. Australian Council for Educational Research https://www.google.com/url?sa=t\&rct=j\&q=\&esrc=s\&source=web\&cd=1\&ved=2ahUKE wiHyvnRvXkAhXulYsKHehqCzQQFjAAegQIARAC\&url=https\%3A\%2F\%2Fresearch.acer.edu.a u\%2Fcgi\%2Fviewcontent.cgi\%3Ffilename\%3D0\%26article\%3D1000\%26context\%3Dtra nsitions_misc\%26type\%3Dadditional\&usg=AOvVaw1fnR6VzWUvxeMgued-ji9Y

43. Fulkerson, G. M., Thomas, A. R. (2014). Urbanisation, Urbanormativity, and PlaceStructuration, In: Fulkerson, G. M., Thomas, A. R. (eds.) Studies in Urbannormativity. Rural Community in Urban Society, Lexington Books, Lanham, Boulder, New York, Toronto, Plymouth, UK

44. Gándara, P., Gutiáez, D., O'Hara, S. (2001). Planning for the Future in Rural and Urban High Schools. Journal of Education for Student Placed at risk, Vol 6 (1-2): 73-93

45. Garasky, S. (2002). Where are they going? A comparison of urban and rural youths' locational choices after leaving the parental home. Social Science Research 31: 409-431

46. Geldens, P. (2005). Wanted: 'Place' To fill vacancy in roomy, well appointed 'space' within youth sociology. Available immediately, Proceedings of the TASA Conference 2005, University of Tasmania, 6-8 December

47. Geldens, P. M., Bourke, L. (2008). Identity, Uncertainty and Responsibility: Privileging Place in a Risk Society. Children's Goegraphies, Vol 6(3): 281-294 
48. Giddens, A. (1990). The consequences of modernity. Stanford, CA: Stanford University Press

49. Giddens, A. (1991) Modernity and self-identity. Cambridge: Polity Press

50. Grenfell, M., James, D. (1998). Bourdieu and Education: Acts of Practical Theory, Falmer Press, Abingdon

51. Halfacree, K. (2006). Rural Space: Constructing a Three-fold Arhitecture, in: P Cloke, T Marsden, P Mooney (ur.): Handbook of rural studies, SAGE, London, Thousand Oaks, New York

52. Harwood, V., Hickey-Moody, A., MacMahon, S., O'Shea, S. (2017). The Politics of Widening Participation and University Access for Young People. Making Educational Futures. Routledge, London and New York

53. Herzog, M. J. R., Pittman, R. B. (1995). Home, family and community: ingredients in the rural education equation, Phi Delta Kappan, 77, 113-118

54. Holdsworth, C., Morgan, D. (2005). Transition in Context. Leaving Home, Independance and Adulthood. Open University Press, Berkshire

55. Howley, C. W. (2006). Remote Possibilities: Rural Children's Educational Aspirations. Peabody Journal of Education, Vol 81 (2): 62-80

56. Hu, S. (2003). Educational Aspirations and Postsecondary Access and Choice: Students in Urban, Suburban, and Rural Schools Compared. Education Policy Analysis Archives, 11(14).

57. Introduction to NVivo (2011). University of Durham Information Technology Service

58. Jaeger, M. M. (2009). Equal access but unequal outcomes: cultural capital and educational choice in a meritocratic society. Social Forces, 87(4): 1943-1971

59. James, R., Wyn, J., Baldwin, G., Hepworth,G., McInnis,C., Stephanou,A. (1999). Rural and Isolated School Studentsand their Higher Education Choices: A re-examination of student location,socioeconomic background, and educationaladvantage and disadvantage. Centre for the Study of Higher EducationandYouth Research Centre, The University of Melbournehttp://www.detya.gov.au/nbeet/publications/\#hec

60. Jamieson, L. (2001). Migration, place and class: youth in a rural area. The Sociological review, Vol 48(2): 203-223

61. Jenckins, R. (1992). Pierre Bourdieu. Routledge, London, New York

62. Jokić, B., Ristić Dedić, Z. (2014). Postati student u Hrvatskoj, Agencija za znanost i visoko obrazovanje 
63. Kaufman, V., Bergman, M. M., Joye, D. (2004). Motility: Mobility as Capital. International Journal of Urban and Regional Research, Vol 28 (4):745-756

64. Klepač, O. (2015) Regionalni aspekti odluka o studiranju, distribucija kapitala i namjera studiranja, U: Baranović, B. (ur.). Koji srednjoškolci namjeravaju studirati? Pristup visokom obrazovanju i odabir studija. IDIZ, Zagreb

65. Klepač, O. (2016). Namjera studiranja učenika različitog rezidencijalnog podrijetla kapitali i simbolička vrijednost obitelji i zajednica odrastanja, Sociologija i prostor, Vol $54(2)$

66. Koricich, A. (2013). The effects of Rurality on College Access and Choice. Texas Tech University, http://www.aera.net/Portals/38/Newsroom\%20\%20Recent\%20Research/The\%20Effects\%20of\%20Rurality\%20on\%20College\%20Acce ss\%20and\%20Choice.pdf

67. Koricich, A., Chen, X., Hughes, R. P. (2018). Understanding the Effects of Rurality and Socioeconomic Status on College Attendance and Institutional Choice in the United States. The Review of Higher Education, Vol 41 (2): 281-305

68. Košutić, I. (2015). Kulturni kapital i društveni položaj obitelji kao čimbenici obrazovnih nejednakosti. Doktorski rad. Sveučilište u Zagrebu.

69. Lähteenmaa, J. (2006). Home Place in the Countryside: Exploring the Views of Young Peope Living in Three Different Locations in Finland. U: Martti Muukkonen, M., Sotkasiira, T. (eds): Young People at the Crossroads. Proceedings of the 5th International Youth Research Conference in Karelia, Petrozavodsk, September, 2006.

70. Lobao, L. M., Hooks, G. (2007). Advancing the Sociology of Spatial Inequality: Spaces, Places and the Subnational Scale, In: Lobao, L. M., Hooks, G., Tickamyer, R. (eds.) The Sociology of Spatial Inequality, State University of New York Press, Albany

71. Lukić, A. (2012) Mozaik izvan grada - tipologija ruralnih i urbaniziranih naselja Hrvatske. Samobor: Meridijani

72. McIlveen, P., Ford, T., Everton, B. (2005). Facilitating Transition from Rural Schools to University: A Case Study, ACER, Australian Journal of Career Development Vol 14 No 1

73. Morse, J. M., Barrett, M., Mayan, M. M., Olson, K., Spiers, J. (2002). Verification Strategies for Establishing Reliability and Validity in Qualitative Research, International Journal of Qualitative Methods Vol 1 (2)

74. Nacionalno vijeće za visoko obrazovanje (2011). Mreža visokih učilišta i studijskih programa u Republici Hrvatskoj 
75. Nagy Hesse-Biber, S. (2010) Mixed Methods Research. Merging Theory With Practice. The Guilford Press, New York, London

76. Nora, A. (2004). The Role of Habitus and Cultural Capital in Choosing a College, Transitioning From High School to Higher Education, and Persisting in College Among Minority and Nonminority Students. Journal of Hispanic Higher Education, 3(2), 180-208

77. Plano Clark, V. L., Ivankova, N. V. (2016) Mixed Methods Research. A Guide to the Field. SAGE, Los Angeles, Lonon, New Delhi, Singapore, Washinton DC

78. Polašek, O., Kolčić,I. (2006). Academic Performance and Scientific Involvement of Final Year Medical Students Coming from Urban and Rural Backgrounds, Rural Remote Health, 21:346-50

79. Potočnik, D. (2011). Međugeneracijska mobilnost u Hrvatskoj (1984.-2004.). Usporedba socijalističkog i tranzicijskog razdoblja. Doktorski rad. Sveučilište u Zagrebu

80. Puzić, S., Doolna, K., Dolenec, D. (2006). Socijalna dimenzija „Bolonjskog procesa“ i (ne)jednakost šansi za visoko obrazovanje. Sociologija sela, Vol 172-173 (2-3): 243-260

81. Puzić, S., Košutić, I. (2015). Sociološki pristupi razumijevanju društvenih nejednakosti u obrazovanju, U: Baranović, B (ur.). Koji srednjoškolci namjeravaju studirati? Pristup visokom obrazovanju i odabir studija. Zagreb: Institut za društvena istraživanja u Zagrebu.

82. Reay, D. (1998). 'Always Knowing' and 'Never Being Sure': Familial and Institutional Habituses and Higher Education Choice, Journal of Education Policy, 13:4, 519-529

83. Reay, D. (2004). 'It's all becoming a habitus': beyond the habitual use of habitus in educational research. British Journal of Sociology of Education, Vol. 25, No. 4

84. Reay, D. (2005). Beyond Consciousness?: The Psychic Landscape of Social Class

85. Reay, D. (2010). Finding or Loosing Yourself?: Working-class Relationships to Education. Journal of Educational Policy, 16:4, 333-346, DOI: 10.1080/02680930110054335

86. Reay, D., Ball, S. J. (1998). 'Making their Minds Up': family dynamics of school choice. British Educational Research Journal, Vol. 24, No. 4, pp 431-448

87. Reay, D., David, M., Ball, S. (2001). 'Making a Difference?: Institutional Habituses and Higher Education Choice'. Sociological Research Online, vol. 5, no. 4 http://www.socresonline.org.uk/5/4/reay.html

88. Rye, J. F. (2006a). Rural Youths' Images of the Rural. Journal of Rural Studies, Vol 22(1): $409-421$ 
89. Rye, J. F. (2006b). Leaving the Countryside. An Analisys of Rural-to-Urban Migration and Long-term Capital Accumulation. Acta Sociologica, Vol 49(1):47-65. DOI:10.1177/0001699306061899

90. Rye, J. F. (2007). Heading for the Cities? Gender and Lifestyle Patterns in Rural Youth's Residential Preferences, Norwegian Joural of Geography, 60:3, 199-208

91. Rye, J. F. (2011). Youth migration, rurality and class: a Bourdieusian approach. European Urban and Regional Studies DOI: 10.1177/0969776410390747

92. Rye, J. F., Almås, R. (2004). Social stratification and changing division of labour in rural Norway, Paper no 2/04, ISSN 1503-2736, Paper presented at the XI World Congress in Rural Sociology, Trondheim - Norway, July 25 - 302004.

93. Rye, J. F., Blekesaune, A. (2003). Class and rural to urban migration, Paper to the 43th European Congress of the Regional Science Association, Jyväskylä, Finland, August 17$30,2003$.

94. Saldaña, J. (2009). The Coding Manual for Qualitative Researchers, Sage Publications, London, Thousand Oaks, New Delhi, Singapore

95. Scott, J., Marshall, G. (2009). Oxford Dictionary of Sociology. Oxford University Press

96. Seale, C. (2002). Quality Issues in Qualitative Inquiry. Qualitative Social Work, Vol. 1(1): 97-110

97. Shenton, A. K. (2004). Strategies for Ensuring Trustworthiness in Qualitative Research Projects, Education for Information, 22: 63-75

98. Spielhofer, T., Golden, S., Evans, K. (2011). Young People's Aspirations in Rural Areas. NFER, Berkshire

99. Stanton-Salazar, R. D., Dornbusch, S. M. (1995). Social Capital and the Reproduction of Inequality: Information Networks among Mexican-origin High School Students. Sociology of Education, Vol. 68:116-135

100. Strauss, A. L., Corbin, J. (1990). Basics of Qualitative Research: Grounded Theory Proceduress and Techniques, SAGE, Newbury Park

101. Submission by Charles Sturt University (2009). Inquiry into Rural and Regional

Access to Secondary and Tertiary Educational Opportunities

http://www.nteu.org.au/library/download/id/295

102. Štambuk, M. (2014). Lica nigdine. Društveni i prostorni okvir razvitka hrvatskog sela. Institut društvenih znanosti Ivo Pilar, Zagreb

103. Šundalić, A. (2010). Selo - iz autentičnosti u neprepoznatljivost. Sveučilište Josipa Jurja Strossmayera u Osijeku, Ekonomski fakultet u Osijeku 
104. Tashakkori, A., Teddlie, C. (2009). Foundationas of Mixed Methods Research: Integrating Quantitative and Qualitative Approaches in the Social and Behavioral Sciences, SAGE, Los Angeles, London, New Delhi, Singapore, Washington DC

105. Theodori, A. E., Theodori, G. L. (2014). Perceptions of Community and Place and the Migration Intentions of At-risk Youth in Rural Areas. Journal of Rural Social Sciences, Vol 29(1): 103-121

106. Tomanović, V. (1967). Socijalne nejednakosti uslova za obrazovanje. Gledišta. Vol 8(5): 675-690.

107. Van de Werfhorst, H.G., A. Sullivan, Cheung. S.-Y. (2003). Social Class, Ability and Choice of Subject in Secondary and Tertiary Education in Britain. British Educational Research Journal 29 (1): 41-62.

108. Vryonides, M. (2007). Social and Cultural Capital in Educational Research: Issues of Operationalisation and Measurement, British Educational Research Journal, Vol. 33, No. 6, pp. 867-885

109. Wiborg, A. (2001). Education, mobility and ambivalence. Rural student sin higher education. Young, Vol 9 (1): 23-40

110. Wiborg, A. (2004). Place, Nature and Migration: Students' Attachment to their Rural Home Places, Wiley Blackwell (Blackwell Publishing) Sociologia Ruralis Vol 44 (4)

111. Wiborg, A. (2006). Mobility and Migration - Markers of Distinction? Rural Students' Attitudes to Migration and Home Place in Norway, U: Martti Muukkonen, M., Sotkasiira, T. (eds): Young People at the Crossroads. Proceedings of the 5th International Youth Research Conference in Karelia, Petrozavodsk, September, 2006.

112. Winkle-Wagner, Rachel (2010). Cultural Capital: The Promises and Pitfalls in Educational Research, ASHE Higher Education Report: Vol 36, No. 1, 2010.

113. Woods, M. (2005). Rural Geography. Processes, Responses and Experiences in Rural restructuring. SAGE, Los Angeles, London, New Delhi, Singapore, Washington DC

114. Woods, M. (2011). Rural. Key ideas in rural geography. Routledge, New York and London

115. Yan, W. (2002). Postsecondary Enrollment and Persistance of Student From Rural Pennsylvania. Center for Rural Pennsylvania https://files.eric.ed.gov/fulltext/ED459986.pdf

116. Zipin, L., Sellar, S., Brennan, M., Gale, T. (2015). Educating for Futures in Marginalised Regions: a Sociological Framework for Rethinking and Researching Aspirations. Educational Philosophy and Theory, Vol 47(3):227-246 
117. Žutinić, Đ., Bokan, N. (2008) Village - Free Choice or Destiny for the Rural Youth (a Study on the Rural Community Vođinci). Sociologija i prostor 180 (2):146-160 


\section{Dodaci}

\subsection{Upitnik}

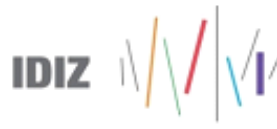

Institut za drustvena istraživania u Zagrebu

\section{UPITNIK O ŠKOLOVANJU za učenice i učenike}

Pred tobom je upitnik koji je izradila grupa istraživača i istraživačica iz Instituta za društvena istraživanja u Zagrebu. U njemu se nalaze pitanjao tvojoj školi, tvojim planovima nakon srednje škole, tvojim interesima $i$ tvojojobitelji.

Molimo te da pažljivo pročitaš uputu za svako pitanje i na njega iskrenoodgovoriš. Nema točnih i netočnih, dobrih $\mathrm{i}$ loš̀h odgovora. Zanima nas tvoje mišljenje. Ispitivanje je u potpunosti anonimno i podaci će biti korišteni isključivo u znanstvene svrhe. Unaprijed puno hvala.

Na pitanja se odgovarazacrnjivaniem odgovarajućih kružića iličitkim upisivaniem odgovora. Molimo te da tamnom olovkom (kemijskom) pažjivo zatamniš cijeli kružić kao štto je prikazano na dici dolje. Ako pogriješiš, prekriži zacrnjeni kružić i zacrni željeni.

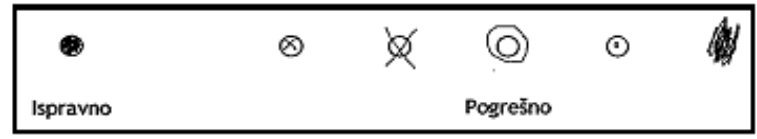

JAKO JE VAŽNO DA PROČITAŠ UPUTU PRIJE NEGO ŠTO ODGOVORIŠ NA PITANJE! AKO TI BILO ŠTO NIJE JASNO, SVAKAKO DIGNI RUKU I ANKETAR ĆE TI POMOĆI!

1. Spol(zacrni svojspol!):

Ž̀enski

○ Muški

\section{Godina rođenja:}

3. Koju školu pohađaš? (zacrni kružić)

Upiši smjer na kojem si upisan/a(npr. kl asična gimnazija, elektrotehničar, tokar, srednja glazbena škola i s.):

Trogodišnju strukovnu školu:

Č̌etverogodišnju strukovnu školu:

Gimnaziju:

Umjetničku srednju školu:

4. Tvoj opći školski uspjeh na kraju prošlog razreda (upiši s jednom decimalom, npr. 4,3):

5. U kojem si razredu zadnji put imao/lamatematiku (ne računaj sadašnji razred)? (zacrni kružić koji odgovara tom razredu)

U 1. srednje

U 2. srednje

U 3. srednje

6. Tvoja ocjena iz matematike na kraju prošle školske godine (ili zadnji put kad si je imao/ la. Zacrni kružić):

7. Tvoja œjena iz hrvatskog jezika na kraju prošle školske godine (ili zadnji put kad si je imao/la):

8. Procijeni koliki će biti tvoj opći školski uspjeh na kraju ove školske godine: 


\section{Matematika}

Napomena: ukoliko sada nemaš matematiku, odgovaraj za razred kad si je zadnii put imao/la!

1. Koliko si dobar/a u matematici u usporedbi s ostalim školskim predmetima?

2. Kdiko si bio/bila uspješan/na u matematici tijekom dosadašnjeg škdovanja?

3. Koliko očekuješ da ćě̌ biti uspješan/na u matematici ove školske godine?

4. Kodiko misliš da bi bio uspješan/na u matematici na državnoj maturi?

5. Kodiko misliš da bi bio/bila uspješan/na nastudiju na kojem su važna znanja iz matematike?

6. Koliko misliš da bi bio/bila uspješan/na u zanimanju koje zahtijeva znanja iz matematike?

7. Koliko ti je zanimljivo učiti matematiku?

8. Koliko ti je zanimljiva nastava iz matematike?

9. Kdiko si zainteresiran/a za matematiku?

10. Koliko je tebi osobno važno biti uspješan/na u matematici?

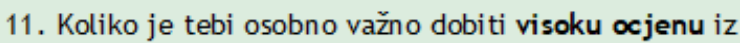
matematike?

12. Koliko bi te uzrujalo da dobiješ lošu ocjenu iz matematike?

13. Koliko će ti ono što učiš iz matematike biti korisno za nastavak školovanja?

14. Koliko ti je matematika korisna u životu izvan škole?

15. Koliko će ti ono što učišiz matematike biti korisno za buduće zanimanje?

\section{Hrvatski}

1. Koliko si dobar/a u hrvatskom u usporedbi s ostalim školskim predmetima?

2. Koliko si bio/bila uspješan/na u hrvatskom tijekom dosadašnjeg školovanja?

3. Koliko očekuješ da ćeš biti uspješan/na u hrvatskom ove školske godine?

4. Koliko misliš da bi bio/bilauspješan/na u hrvatskom na državnoj maturi?

5. Koliko misliš da bi bio/bila uspješan/na nastudiju na kojemu su važna znanja iz hrvatskog?

6. Koliko misliš da bi bio/bila uspješan/na u zanimanju koje zahtijeva znanja iz hrvatskog jezika?

\begin{tabular}{|c|c|c|c|c|c|c|}
\hline puno lošiji/a & 0 & 0 & 0 & 0 & 0 & puno bolji/ \\
\hline $\begin{array}{l}\text { izrazito } \\
\text { leuspješan/na }\end{array}$ & 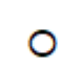 & 0 & 0 & 0 & 0 & $\begin{array}{c}\text { izrazito } \\
\text { uspješan/na }\end{array}$ \\
\hline $\begin{array}{l}\text { tzrazito } \\
\text { euspješan/na }\end{array}$ & $\bigcirc$ & 0 & 0 & 0 & 0 & $\begin{array}{c}\text { izrazito } \\
\text { uspješan/na }\end{array}$ \\
\hline $\begin{array}{l}\text { izrazito } \\
\text { euspješan/na }\end{array}$ & $C$ & 0 & 0 & 0 & 0 & $\begin{array}{r}\text { izraz } \\
\text { uspješ }\end{array}$ \\
\hline $\begin{array}{l}\text { tzraz } \\
\text { euspje }\end{array}$ & 0 & 0 & 0 & ○ & 0 & $\begin{array}{r}\text { izrazi } \\
\text { uspješar }\end{array}$ \\
\hline $\begin{array}{c}\text { izrazito } \\
\text { neuspješan/na }\end{array}$ & 0 & 0 & م & 0 & 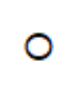 & $\begin{array}{c}\text { izrazito } \\
\text { uspješan/na }\end{array}$ \\
\hline uopće nije & $C$ & 0 & D & 0 & D & izrazito je \\
\hline uopće nije & $C$ & 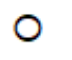 & 0 & & & izrazito je \\
\hline uopće nisam & 0 & $C$ & 0 & 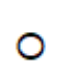 & ( & \\
\hline $\begin{array}{l}\text { pće mi nije } \\
\text { važno }\end{array}$ & 0 & 0 & 0 & 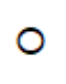 & 0 & $\begin{array}{l}\text { izrazito mi je } \\
\text { važno }\end{array}$ \\
\hline $\begin{array}{l}\text { opće mi nije } \\
\text { važno }\end{array}$ & $C$ & $C$ & 0 & 0 & 0 & $\begin{array}{l}\text { izrazito mi } \\
\text { važno }\end{array}$ \\
\hline $\begin{array}{l}\text { uopće me ne } \\
\text { bi uzrujalo }\end{array}$ & 0 & $C$ & 0 & 0 & 0 & $\begin{array}{l}\text { jako bi me } \\
\text { uzrujalo }\end{array}$ \\
\hline uopće neće & $C$ & $C$ & & & & izrazito hoće \\
\hline uopće nije & $C$ & $C$ & & & & izrazito je \\
\hline pće neće & & & & & & izrazito hoće \\
\hline
\end{tabular}

puno lošiji/a

$\bigcirc \bigcirc \bigcirc \bigcirc \bigcirc$ puno bolji/a

izrazito

neuspješan/na $\bigcirc \bigcirc \bigcirc \bigcirc \bigcirc$ uspješan/na

izrazito neuspješan/na

$\circ 0000$ izrazito uspješan/na

izrazito neuspješan/na

$000000 \quad$ izrazito

izrazito neuspješan/na

$000000 \quad$ izrazito

izrazito neuspješan/na 


\begin{tabular}{|c|c|c|c|c|}
\hline 7. Koliko ti je zanimljivo učiti hrvatski? & uopće ne & 00 & 00 & izrazito da \\
\hline 8. Koliko ti je zaniml jiva nastava iz hrvatskog? & uopće nije & 00 & 00 & izrazito je \\
\hline 9. Koliko si zainteresiran/a za hrvatski? & uopće nisam $\bigcirc$ & 00 & 00 & $\begin{array}{c}\text { izrazito } \\
\text { jesam }\end{array}$ \\
\hline $\begin{array}{l}\text { 10. Koliko je tebi osobno važno biti uspješan/na u } \\
\text { hrvatskom? }\end{array}$ & $\begin{array}{l}\text { uopće mi nije } \\
\text { važno }\end{array}$ & 00 & $0^{i}$ & $\begin{array}{l}\text { izrazito mi je } \\
\text { važno }\end{array}$ \\
\hline $\begin{array}{l}\text { 11. Koliko je tebi osobno važno dobiti visoku ocjenu iz } \\
\text { hrvatskog? }\end{array}$ & $\begin{array}{l}\underset{\text { važno }}{\text { uoṕe mi nije }} \bigcirc \\
\text { a }\end{array}$ & 00 & 00 is & $\begin{array}{l}\text { izrazito mi je } \\
\text { važno }\end{array}$ \\
\hline 12. Koliko bi te uzrujalo da dobiješ lošu ocjenu iz hrvatskog? & $\begin{array}{c}\text { uopće me ne } \\
\text { bi uzrujalo }\end{array}$ & 00 & 00 & $\begin{array}{l}\text { jako bi me } \\
\text { uzrujalo }\end{array}$ \\
\hline $\begin{array}{l}\text { 13. Koliko će ti ono što učiš iz hrvatskog biti korisno za } \\
\text { nastavak školovanja? }\end{array}$ & uopće neće & 00 & $00 \mathrm{i}$ & izrazito hoće \\
\hline 14. Koliko ti je hrvatski koristan u životu izvan škole? & uopće nije & 00 & 00 & izrazito je \\
\hline $\begin{array}{l}\text { 15. Koliko će ti ono što učiš iz hrvatskog biti korisno za } \\
\text { buduće zanimanje? }\end{array}$ & uopće neće & 00 & 00 & izrazito hoće \\
\hline \multicolumn{2}{|c|}{$\begin{array}{l}\text { 11. Uz svako pitanje zacrni odgovor koji najviše odgovara tvom mišljenju o } \\
\text { talentiranosti žena i muškaraca za različita područja. }\end{array}$} & Žene & Jednako & so Muškarci \\
\hline \multicolumn{2}{|l|}{ 1. Tko je talentiraniji za matematiku? } & 0 & 0 & 0 \\
\hline \multicolumn{2}{|l|}{ 2. Tko je talentiraniji za hrvatski? } & 0 & 0 & 0 \\
\hline \multicolumn{2}{|c|}{$\begin{array}{l}\text { 3. Tko je talentiraniji za studij u području tehničkih znanosti kao što su } \\
\text { elektrotehnika, strojarstvo, građevinarstvo? }\end{array}$} & & 0 & 0 \\
\hline \multicolumn{2}{|c|}{$\begin{array}{l}\text { 4. Tko je talentiraniji za studij u području društveno-humanističkih znanosti } \\
\text { kao što su psihologija, pedagogija, jezici, filozofija? }\end{array}$} & & 0 & 0 \\
\hline \multicolumn{2}{|c|}{$\begin{array}{l}\text { 5. Tko je talentiraniji za zanimania u području tehničkih znanosti kao što su } \\
\text { elektrotehnika, strojarstvo, građevinarstvo? }\end{array}$} & & 0 & 0 \\
\hline \multicolumn{2}{|c|}{$\begin{array}{l}\text { 6. Tko je talentiraniji za zanimania u području društveno-humanističkih } \\
\text { znanosti kao što su psihologija, pedagogija, jezici, filozofija? }\end{array}$} & & O & 0 \\
\hline
\end{tabular}

\section{TVOJA OBITELJ}

\section{2. Živiš li u učeničkom domu?}

DA

O NE
13. Ukoliko živiš s obitelji, napiši koliko članova ima obitelj s kojom živiš, uključujući i tebe:

14. S kim živiš? (zacrni kružice uz sve odgovore koji vrijede za tebe i dopiši na crtu ako je potrebno)
S majkom
S ocem
S bakom/djedom
O S bratom/sestrom
Sa skrbnicima
Z Živim u domu za nezbrinutu djecu
S nekim drugim 
15. Gdje si proveo/la veći dio života prije upisa u srednju školu? (zacrni kružić i upiši naziv mjesta na praznu crtu)
O Na selu
U malom gradu
U velikom gradu
○ Z Zagrebu

\section{Najviši završeni stupanj obrazovanja majke} (zacrni jedan odgovor):

Nezavršena osnovna škola

O Osnovna škda

Trogodišnja srednja strukovna škola (za industrijska, obrtnička, zanatska zanimanja)

C Cetverogodišnja srednja strukovna škola (npr. tehnička, ekonomska, medicinska)

○ Gimnazija

○ Viša škd a, visoka škda, veleučilište

Fakultet, umjetnička akademija

O Magisterij ili doktorat

19. Je li netko od tvojih baka/djedova završio fakultet ili višu školu?(zacrni jedan kružić)
$\bigcirc \mathrm{Da}$
$\bigcirc \mathrm{Ne}$
Ne znam

21. Tvoja majka je (zacrni jedan odgovor):

Z Zapostena (puno radno vrijeme, u stalnom radnom odnosu)

○ Nezaposlena (i traži zaposlenje)

Zaposena povremeno (npr. sezonski)

○ Domaćica/kućanica (i ne traži posao)

O Umirovljenica

Nešto drugo (npr. preminula; trajno nesposobna za rad)
16. Gdje sada živiš? (zacrni kružić $i$ upiši naziv mjesta na praznu crtu)
○ Na selu
U malom gradu
U velikom gradu
U Zagrebu

\section{Najviši završeni stupanj obrazovanja oca} (zacrni jedan odgovor):
Nezavršena osnovna škola
O Osnovna škola
Trogodišnja srednja strukovna škda (za
industrijska, obrtnička, zanatska zanimanja)
C Cetverogodišnja srednja strukovna škola (npr. tehnička, ekonomska, medicinska)
○ Gimnazija
○ Viša škda, visoka škola, veleučilište
Fakultet, umjetnička akademija
○ Magisterij ili doktorat

20. Koji stupanj obrazovanja ima većina prijatelja tvojih roditelja?(zacrni jedan kružić)
Osnovnu školu
Srednju školu
Fakultet, visoku škdu ili slično
O Ne znam

\section{Tvoj otac je (zacrni jedan odgovor):}

\section{Zaposlen (puno radno vrijeme, u stalnom} radnom odnosu)

○ezaposten (i traži zaposlenje)

Zaposlen povremeno (npr. sezonski)

Umirovljenik

Nešto drugo (npr. preminuo; trajno nesposoban za rad) 
23. ŠTO JE GLAVNI POSAO TVOJIH RODITELJA?

Upišinaziv posla (npr. kuharica, uči teljica, odvjetnica).

Ako tvoja majka/otac trenutno nije zaposlen/a, upiši njen/ njegov zadnji posao!

Majka:

Otac:

24. ŠTO TVOJI RODITELJI RADE NA TOM POSLU?

Opi š jednom rečenicom glavne dužnosti majke i oca na tom poslu (što radi ili je radila/o na poslu). Npr. priprema hranu u restoranu, poučava učenike u osnovnoj škdi, zastupa stranke na sudu.

Majka:

Otac:

25. GDJE RADE TVOJI RODITELJI - u kakvoj vrsti organizacije/firme i područja rada?

Opiši jednom rečenicomgdje rade ili su radili (npr. u maloj privatnoj firmi koja se bavi automobilima, državnoj firmi za proizvodnju ljekova, pravnom odjelu gradske uprave, osnovnoj školi, trgovačkom lancu, na vlastitom poljoprivrednom imanju).

Majka:

Otac:

26. IMAJU LI TVOJA MAJKA ILI OTAC SVOJU VLASTITU TVRTKU, OBRT ILI REGISTRIRANO POLJOPRIVREDNO GOSPODARSTVO? (zacrni kružic uz svakog roditelja)

Ako DA, upiši koliko otprilike tvrtka, obrt ili poljoprivredno gospodarstvo ima zaposlenih!

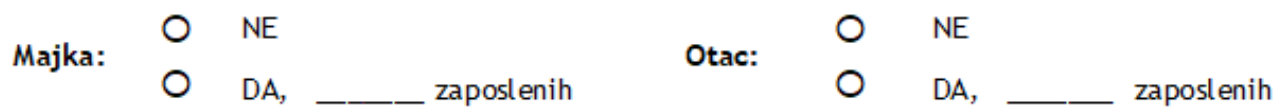

27. Ako majka ili otac imaju vlastitu (ili zajedničku)tvrtku ili obrt, napiši čime se bavi tvrtka ili obrt!

28. Koliko otprilike imaš knjiga kod kuće (bez časopisa i školskih udžbenika)?(na metar police za knjige stane oko 40 knjiga)

\begin{tabular}{ll|}
\hline & $0-10$ \\
$\bigcirc$ & $11-25$ \\
$\bigcirc$ & $26-100$ \\
$\bigcirc$ & $101-200$ \\
$\bigcirc$ & $201-500$ \\
$\bigcirc$ & Više od 500 knjiga \\
\hline
\end{tabular}

29. Koliko od navedenih stvari ima obitelj u kojoj živiš?

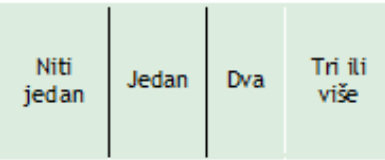

1. Stolnih ili prijenosnih računala

2. Automobila

3. Nekretnina (npr. stan, kuća, vikendica, i dr.) $\begin{array}{llll}0 & 0 & 0 & 0 \\ 0 & 0 & 0 & 0 \\ 0 & 0 & 0 & 0\end{array}$ 


\section{Vlastitu sobu}

2. Računalo koje možeš koristiti za izvršavanje školskih obaveza

3. Stručne knjige ili priručnike (npr. iz medicine, tehnike, informatike)

4. Knjige klasične literature (npr. Krleža, Šenoa, Dostojevski)

5. Knjige pisane na stranom jeziku (npr. na engleskom, njemačkom i dr.)

6. Umjetnička djela (npr. umjetničke slike ili skulpture)

7. CD-e ili druge nosače zvuka klasične ili jazz gl azbe

\section{Koliko često tvoii roditelii:}

1. Citaju publicistiku (npr. putopisi, bi ografije poznatih osoba, knjige povijesne tematike)

2. Čitaju prozu i poeziju (romane, pripovijetke, priče, i s.)

3. Pohađaju obrazovne tečajeve, programe ili predavanja

4. Posjećuju muzeje ili umjetničke galerije

5. Idu na kazališne predstave

6. Posjećuju operu, balet ili koncerte klasične glazbe
Nikad $\begin{gathered}\text { Vrlo } \\ \text { rijetko Ponekad Često Vrio često }\end{gathered}$

$\begin{array}{lllll}0 & 0 & 0 & 0 & 0 \\ 0 & 0 & 0 & 0 & 0 \\ 0 & 0 & 0 & 0 & 0 \\ 0 & 0 & 0 & 0 & 0 \\ 0 & 0 & 0 & 0 & 0 \\ 0 & 0 & 0 & 0 & 0\end{array}$

\section{Koliko se slažeš sa sljedećim tvrdnjama?}

1. Kada mi treba, roditelji mi pomažu kod školskih obaveza.

2. Moji roditelji su zainteresirani za ono što radim u škodi.

3. Roditelji me ohrabruju da nastavim školovanje.

4. Roditelji me ohrabruju da se što prije zaposlim.
Uopće se Uglavnom Niti se slažem se slažem

$\begin{array}{lllll}0 & 0 & 0 & 0 & 0 \\ 0 & 0 & 0 & 0 & 0 \\ 0 & 0 & 0 & 0 & 0 \\ 0 & 0 & 0 & 0 & 0\end{array}$

\begin{tabular}{|c|c|c|}
\hline \multirow{3}{*}{$\begin{array}{l}\text { 33. U našem društvu postoje } \\
\text { skupine ljudi za koje kažemo } \\
\text { da imaju viši ili niži STATUS u } \\
\text { društvu, tj.da se nalaze više } \\
\text { ili niže nadruštvenoj ljestvici. }\end{array}$} & 0 & 10najvišs status u druð̌vu \\
\hline & 0 & 9 \\
\hline & 0 & 8 \\
\hline \multirow{7}{*}{$\begin{array}{l}\text { Kako bi procijenio/la } \\
\text { društveni statussebe } i \\
\text { svoje najuže obitelji na } \\
\text { ljestvici od1 (najniži } \\
\text { status) do } 10 \text { (najviši } \\
\text { status)? }\end{array}$} & 0 & 7 \\
\hline & 0 & 6 \\
\hline & 0 & 5 \\
\hline & 0 & 4 \\
\hline & 0 & 3 \\
\hline & 0 & 2 \\
\hline & 0 & 1 najniži status u društvu \\
\hline
\end{tabular}

\section{Koja tvrdnja najbolje opisuje} financijsku situaciju tvoje obitelji? Moja obitelj...

jedva spaja kraj s krajem

ima za ono što je nužno

ima dovoljno za prosječan/ normalan žvot

○e prilično dobrostojeća

$\bigcirc$ je bogata 


\section{TVOJE AKTIVNOSTI, INTERESI I MIŠLJENJA}

35. Koliko se svako od sljedećih ponašanja i osobina odnosi na tebe (koliko je karakteristično za tebe)?

1. Aktivno se bavim sportom.

2. Volim plesati.

3. Volim čitati časopise o modi i kozmetici.

4. Razumijem se u automobile.

5. Obavljam kućanske poslove kao što su čišćenje kuće, pranje posuđa i glačanje.

6. Volim gledati sportska natjecanja.

7. Volim provoditi vrijeme u obilasku trgovina.

8. Volim izgledati fizički snažno.

9. Kad igram igre, volim pobijediti.

10. Volim se uljepšavati.

11. U školi volim biti bolji/a od drugih u znanju.

12. Volim biti vođa u svom društvu.

13. Volim romantiku.

14. Nježan/na sam.

15. Pozivam osobu koja mi se sviđa na spoj.

16. Jako sam osjećajan/na.

17. Volim bebe i malu djecu.

18. Volim se natjecati.

19. Obavljam manje popravke po kući.

20. Nekada se rasplačem pred drugima.

Uopće ne $\mid$\begin{tabular}{cc|c|c} 
Uglavnom & Niti da niti \\
ne & ne & $\begin{array}{c}\text { Uglavnom } \\
\text { da }\end{array}$ & $\begin{array}{c}\text { potpunosti } \\
\text { da }\end{array}$
\end{tabular}

$\begin{array}{lllll}0 & 0 & 0 & 0 & 0 \\ 0 & 0 & 0 & 0 & 0 \\ 0 & 0 & 0 & 0 & 0 \\ 0 & 0 & 0 & 0 & 0 \\ 0 & 0 & 0 & 0 & 0\end{array}$

$\begin{array}{lllll}0 & 0 & 0 & 0 & 0\end{array}$

$\begin{array}{lllll}0 & 0 & 0 & 0 & 0\end{array}$

$\begin{array}{lllll}0 & 0 & 0 & 0 & 0\end{array}$

$\begin{array}{lllll}0 & 0 & 0 & 0 & 0\end{array}$

$\begin{array}{lllll}0 & 0 & 0 & 0 & 0\end{array}$

$\begin{array}{lllll}0 & 0 & 0 & 0 & 0\end{array}$

$\begin{array}{lllll}0 & 0 & 0 & 0 & 0\end{array}$

$\begin{array}{lllll}0 & 0 & 0 & 0 & 0\end{array}$

$\begin{array}{lllll}0 & 0 & 0 & 0 & 0\end{array}$

$\begin{array}{lllll}0 & 0 & 0 & 0 & 0\end{array}$

$\begin{array}{lllll}0 & 0 & 0 & 0 & 0\end{array}$

$\begin{array}{lllll}0 & 0 & 0 & 0 & 0\end{array}$

$\begin{array}{lllll}0 & 0 & 0 & 0 & 0\end{array}$

$\begin{array}{lllll}0 & 0 & 0 & 0 & 0\end{array}$

$\begin{array}{lllll}0 & 0 & 0 & 0 & 0\end{array}$

\section{U zadnjih godinu dana, koliko si često:}

1. Posjetio/la muzeje ili umjetničke galerije

2. Išao/la na kazališne predstave

3. Posjetio/la operu, balet ili koncerte klasiǒne glazbe

$\begin{array}{llll}0 & 0 & 0 & 0 \\ 0 & 0 & 0 & 0 \\ 0 & 0 & 0 & 0\end{array}$

1. Dramsku grupu (npr. u kazalištu)

2. Balet ili suvremeni ples

3. Pjevački zbor

4. Glazbenu školu

5. Školu stranih jezikaili individualnu poduku iz stranih jezika 


\section{Koliko često čitaš dolje navedene tekstove, a da nisu \\ školska obaveza?}

1. Članke o unutarnjoj politid, vanjskoj politici ili kulturi u dnevnim ili tjednim novinama

2. Popularno-znanstvene časopise ili časopise kulturne tematike (Geo, National Geographic, Zarez, Vijenac, Priroda)

3. Publicistiku (npr. putopise, biografije poznatih osoba, knjige povijesne tematike)

4. Prozu i poeziju (romane, pripovijetke, priče, isl.)

\begin{tabular}{c|c|c|cc} 
Nikad ili & Nekoliko & Otprilike & Nekoliko & Nekoliko \\
gotovo & puta & jedanput & puta & puta tjedno \\
nikad & godišnje & mjesečno & mjesečno & ili svaki dan
\end{tabular}

00

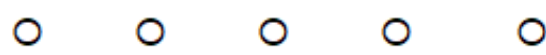

00

00
39. Koliko se slažeš sa sljedećim tvrdnjama? biti korisne za posao.

2. Učim prvenstveno jer je učenje vrijedno samo po sebi.

3. Učim prvenstveno kako bih u budućnosti lakše našao/la posao.

4. Učim prvenstveno zbog svog osobnog razvoja.

5. Učim prvenstveno kako bih mogao/la nastaviti školovanje.

\begin{tabular}{cc|c|c|c} 
Uopće se & $\begin{array}{c}\text { Uglavnom } \\
\text { se ne } \\
\text { ne slažem } \\
\text { slažem }\end{array}$ & $\begin{array}{c}\text { Niti se } \\
\text { stažem, } \\
\text { niti se ne } \\
\text { stažem }\end{array}$ & $\begin{array}{c}\text { Uglavnom } \\
\text { se slažem }\end{array}$ & $\begin{array}{c}U \\
\text { potpunosti } \\
\text { se stažem }\end{array}$
\end{tabular}

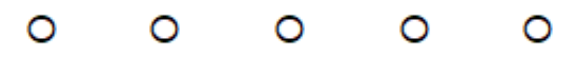

40. Procijeni kakve su šanse za zaposlenje danas u Hrvatskoj: (zacrni kružić uz jedan odgovor na svako pitanje, na ljestvici od 1-vrlo loše šanse, do 5- odlične šanse)

1. za fakul tetski obrazovane osobe

2. za osobe sa završenom srednjom školom, bez fakul tetskog obrazovanja
Vrlo loše šanse

Vrlo loše šanse
00000

Odlične šanse

$\bigcirc \bigcirc 000$ Odlične šanse

41. Procijeni koliko seniže navedene tvrdnje odnose na tebe:

(zacrni kružić uz jedan odgovor na svako pitanje, na ljestvici od 1-uopće se ne odnosi na mene, do 5- u potpunosti se odnosi na mene)

1. Važno mi je da imam bolji posao nego moji roditelji.

2. Želim postići viši stupanj obrazovanja od mojih roditelja.

3. Važno mi je da kasnije u životu zarađujem barem kdiko i moji roditelji.

4. Mojim roditeljima se ne bi svidjel o kada bih imao/la lošiji posao od njihovog.

5. Želim imati jednako visok položaj na društvenoj ljestvici kao i moji roditelji.

6. Strah me da ću kasnije u životu imati nižistatus u društvu od mojih roditelja.

\begin{tabular}{|c|c|c|c|c|c|c|}
\hline $\begin{array}{l}\text { Uopóe se ne } \\
\text { odnosi na mene }\end{array}$ & 0 & 0 & 0 & 0 & 0 & $\begin{array}{l}\text { U potpunosti se } \\
\text { odnosi na mene }\end{array}$ \\
\hline $\begin{array}{l}\text { Uopće se ne } \\
\text { odnosi na mene }\end{array}$ & 0 & 0 & 0 & 0 & 0 & $\begin{array}{l}\text { U potpunosti se } \\
\text { odnosi na mene }\end{array}$ \\
\hline $\begin{array}{l}\text { Uopóe se ne } \\
\text { odnosi na mene }\end{array}$ & 0 & 0 & 0 & 0 & 0 & $\begin{array}{l}\text { U potpunosti se } \\
\text { odnosi na mene }\end{array}$ \\
\hline $\begin{array}{l}\text { Uopóe se ne } \\
\text { odnosi na mene }\end{array}$ & 0 & 0 & 0 & 0 & 0 & $\begin{array}{l}\text { U potpunosti se } \\
\text { odnosi na mene }\end{array}$ \\
\hline $\begin{array}{l}\text { Uopóe se ne } \\
\text { odnosi na mene }\end{array}$ & 0 & 0 & 0 & 0 & 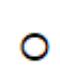 & $\begin{array}{l}\text { U potpunosti se } \\
\text { odnosi na mene }\end{array}$ \\
\hline $\begin{array}{l}\text { Uopóe se ne } \\
\text { odnosi na mene }\end{array}$ & 0 & 0 & 0 & 0 & 0 & $\begin{array}{l}\text { U potpunosti se } \\
\text { odnosi na mene }\end{array}$ \\
\hline
\end{tabular}


42. Koliko se slažeš s dolje navedenim tvrdnjama o tvojoj srednioj školi?

\begin{tabular}{c|cc|c|c} 
Uopće se & $\begin{array}{c}\text { Uglavnom } \\
\text { ne slažem }\end{array}$ & $\begin{array}{c}\text { Niti se } \\
\text { slažem, } \\
\text { niti se ne } \\
\text { slažem }\end{array}$ & $\begin{array}{c}\text { Uglavnom } \\
\text { se stažem }\end{array}$ & $\begin{array}{c}U \\
\text { potpunosti } \\
\text { se stažem }\end{array}$
\end{tabular}

1. Većina učenika u mom razredu je iz dobrostojećih obitelji.

2. U školi možemo dobiti informacije u vezi daljnjeg obrazovanja.

3. Naši nastavnici nas potiču da upišemo neki studij.

4. Moja škola ima bogat program izvannastavnih aktivnosti.

5. Moja je škola dobro opreml jena (npr. informatička učionica).

6. Moju je školu teško upisati.

7. Moja škola je ugledna.

8. Moja škola me dobro priprema za studij.

$\begin{array}{lllll}0 & 0 & 0 & 0 & 0 \\ 0 & 0 & 0 & 0 & 0 \\ 0 & 0 & 0 & 0 & 0 \\ 0 & 0 & 0 & 0 & 0 \\ 0 & 0 & 0 & 0 & 0 \\ 0 & 0 & 0 & 0 & 0 \\ 0 & 0 & 0 & 0 & 0 \\ 0 & 0 & 0 & 0 & 0\end{array}$

\section{NASTAVAK ŠKOLOVANJA}

43. Koji najviš stupanj obrazovanja želiš posticí? (zacrni jedan kružić)
- Završena srednja škola
○ Završen preddiplomski studij (prvostupnik/ca)
Z Završen diplomski studij (magistar/ca)
Završen posijediplomski/doktorski studij (doktor/ica znanosti)

\section{Koja od sljedećih tvrdnji te najbolje} opisuje?(zacrni jedan kružić)

Podrazumijeva mi se da ću upisati studij

O Podrazumijeva mi se da neću upisati studij

Niti mi se podrazumijeva, niti ne podrazumijeva da ću upisati studij
44. Koji najviš stupanj obrazovanja očekuješ da ćeš stvarno postići? (zacrni jedan kružić)
- Završena srednja škola
Završen preddiplomski studij (prvostupnik/ca)
Z Završen diplomski studij (magistar/ca)
Završen posijediplomski/doktorski studij (doktor/ica znanosti)

46. Koliko duģo si razmišljao/lahoćeš li uopće ići na studij?(zacrni jedan kružić)
○ Nisam uopće razmił̌jao/la
Kratko sam razmišljao/la
Osrednje sam razmišljao/la
Dugo sam razmið̌ jao/la

47. Osim tebe, koliko su sljedeće osobe utjecale na tvoju odluku hoćeš li nastaviti školovanje?

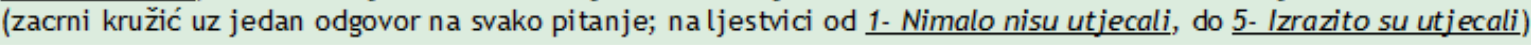
1. Roditelji
2. Braća/sestre
3. Članovi šre rodbine
4. Prijatelj/i
5. Dečko/ cura
6. Školski kolege
7. Prijatelji ili poznanici tvojih roditelja
8. Susjedi
9. Nastavnici
10. Netko od stručnih suradnika u škdi (pedagog, psihdog..)
11. Savjetnik za profesionalno usmjeravanje izvan škde

$\begin{array}{lllll}0 & 0 & 0 & 0 & 0 \\ 0 & 0 & 0 & 0 & 0 \\ 0 & 0 & 0 & 0 & 0 \\ 0 & 0 & 0 & 0 & 0 \\ 0 & 0 & 0 & 0 & 0 \\ 0 & 0 & 0 & 0 & 0 \\ 0 & 0 & 0 & 0 & 0 \\ 0 & 0 & 0 & 0 & 0 \\ 0 & 0 & 0 & 0 & 0 \\ 0 & 0 & 0 & 0 & 0 \\ 0 & 0 & 0 & 0 & 0\end{array}$


48. Namjeravaš li studirati?

$\bigcirc \mathrm{DA} \rightarrow$ idi napitanje 50!

○ NE

○ NE ZNAM \}idi na sljedeće pitanje!

\section{Ukoliko NE namieravaš studirati (ili još ne znaš hoćeš li) Procijeni koliko se dolje navedeni razlozi za odluku o neupisivanju studija odnose na tebe:}

Uopće se
ne stažem $\left|\begin{array}{c}\text { Uglavnom } \\ \text { se ne } \\ \text { șž̃em }\end{array}\right|$

\begin{tabular}{c|c}
$\begin{array}{c}\text { Niti se } \\
\text { slažem, } \\
\text { niti se ne } \\
\text { slažem }\end{array}$ & $\begin{array}{l}\text { Uglavnom } \\
\text { se slažem }\end{array}$ \\
\end{tabular}

$U$

tpunosti se stažem

1. Ne vidim smisla u studiranju

2. Želim raditi u svojoj struci, a za to mi ne treba više obrazovanje

$\begin{array}{lllll}0 & 0 & 0 & 0 & 0\end{array}$

00000

3. Želim što prije početi zarađivati (osamostaliti se)

4. Trenutno nemam financijska sredstva za troškove studiranja

5. Studiranje nije za mene

6. Nisam dobro pripremljen/a za ono što se traži na studiju

000000

$\begin{array}{lllll}0 & 0 & 0 & 0 & 0\end{array}$

$\begin{array}{lllll}0 & 0 & 0 & 0 & 0\end{array}$

00000

7. Ne želim se seliti zbog studiranja

000

0

8. UKOLIKO IMAŠ NEKI DRUGI RAZLOG, MOLIMO UPIŠI: 


\section{Ispunjavaju samo oni koji su ODLUČILI STUDIRATI!}

50. Kada si znao/la da želiš studirati?(zacrni kružić uz jedan odgovor)

Oduvijek sam to znao/la

U osnovnoj školi

U U srednjoj školi

51. Ako namieravaš studirati, koliko je vjerojatno da ćeš školovanje pokušati nastaviti:

1. Na fakultetu ili umjetničkoj akademiji

2. Na veleučilištu ili visokoj školi

52. Koliko je vjerojatno da ćeš pokušati upisati studij iz sljedećih PODRUČJA?

1. Studij matematike ili prirodnih znanosti, npr. studij fizike, geologije, kemije, biologije ili geofizike

2. Studij iz tehničkih znanosti, npr. elektrotehniku, računarstvo, strojarstvo, brodogradnju, građevinarstvo

3. Studij iz područja biomedicine i zdravstva, npr. medicinu, veterinu, stomatologiju, farmaciju

4. Studij iz biotehničkih znanosti, npr. agronomiju, šumarstvo, drvnu tehndogiju, biotehnologiju, prehrambenu tehnologiju

5. Studij iz društveno - humanističkih znanosti, npr. ekonomiju, pravo, politologiju, sociologiju, psihdogiju, filozofiju, arheologiju, povijest, etnologiju

6. Studij iz umjetničkog područja, npr. kazališna, filmska, primijenjena, plesna umjetnost, likovne umjetnosti, dizajn

\section{KOJI STUDIJ (ili SMJER) NAMJERAVAŠ UPISATI?} (upiši čitko na crtu.Npr. psihologiju; biologiju)

54. Na kojem fakultetu/ veleučilištu/ visokoj školi?(npr. Prirodoslovno-matematičkifakul tet; Filozofski fakul tet)

55. U kojem gradu?

56. Je li taj studij javni (državni) ili privatni?(zacrni)
javni (državni)
privatni

\begin{tabular}{c|cccc}
$\begin{array}{c}\text { Sigurno } \\
\text { neću }\end{array}$ & $\begin{array}{c}\text { Vjerojatno } \\
\text { neću }\end{array}$ & $\begin{array}{c}\text { Nisam } \\
\text { siguran/na }\end{array}$ & $\begin{array}{c}\text { Vjerojatno } \\
\text { hoću }\end{array}$ & $\begin{array}{c}\text { Sigurno } \\
\text { hoću }\end{array}$
\end{tabular}

00

$0 \quad 0$

000

O

○

\begin{tabular}{l|c|cc|c} 
Sigurno & $\begin{array}{c}\text { Vjerojatno } \\
\text { neću }\end{array}$ & $\begin{array}{c}\text { Nisam } \\
\text { neću }\end{array}$ & $\begin{array}{c}\text { Vjerojatno } \\
\text { siguran/na }\end{array}$ & $\begin{array}{c}\text { Sigurno } \\
\text { hoću }\end{array}$ \\
hoću
\end{tabular}

$0 \quad 0$

00

00

000

000

00

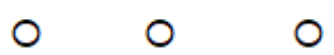

000

$0 \quad 0 \quad 0$

$0 \quad 0 \quad 0$

00

$0 \quad 0 \quad 0$

\section{O}

no 


\begin{tabular}{c|cccc} 
Sigurno & $\begin{array}{c}\text { Vjerojatno } \\
\text { neću }\end{array}$ & $\begin{array}{c}\text { Ne mogu } \\
\text { procijeniti }\end{array}$ & $\begin{array}{c}\text { Vjerojatno } \\
\text { hoću }\end{array}$ & $\begin{array}{c}\text { Sigurno } \\
\text { hoću }\end{array}$
\end{tabular}

58. Procijeni koliko je vjerojatno da ćeš upisati namjeravani studij

59. Procijeni koliko je vjerojatno da ćeš završiti studij
0

○
0

○

$\bigcirc$

$\circ$ $\circ$

$\circ$

○

\section{Koliko je svaki od sljedećih razloga važan za tvoj izbor studija kojeg namjeravaš upisati?} Procijeni na ljestvici od1- to mi uopce nije bilo važno, do5- to mi ie bilo iznimno važno.

1. Taj studij odgovara mojim sposobnostima.

2. Taj studij mi pruža dobre mogućnosti za zaposlenje.

3. Voljela/o bih se baviti zanimanjem kojeg mi taj studij omogućava.

4. Imam kvalitete potrebne da budem uspješan/a na tom studiju.

5. Nakon što završm taj studij mogu dati vrijedan doprinos društvu.

6. Taj studij će mi omogućiti bavljenje poslom koji je dobro plaćen.

7. Završavanje tog studija mi može donijeti uvažavanje i ugl ed u društvu.

8. Ljudi s kojima sam okružen/a smatraju da bih se trebao/la upisati na taj studij.

9. Zanima me taj studij.

10.Roditelji smatraju da bih trebao/la upisati taj studij.

11. Moji roditelji su završli taj studij.

12.Taj studij mi omogućava brzo ostvarivanje financijske neovisnosti.

13.Troškovi studija nisu visoki.

$\begin{array}{lllll}0 & 0 & 0 & 0 & 0 \\ 0 & 0 & 0 & 0 & 0 \\ 0 & 0 & 0 & 0 & 0 \\ 0 & 0 & 0 & 0 & 0 \\ 0 & 0 & 0 & 0 & 0 \\ 0 & 0 & 0 & 0 & 0 \\ 0 & 0 & 0 & 0 & 0 \\ 0 & 0 & 0 & 0 & 0 \\ 0 & 0 & 0 & 0 & 0 \\ 0 & 0 & 0 & 0 & 0 \\ 0 & 0 & 0 & 0 & 0 \\ 0 & 0 & 0 & 0 & 0 \\ 0 & 0 & 0 & 0 & 0\end{array}$

\section{Koliko se slažeš s dolje navedenim tvrdnjama?}

1. Važno mi je da je fakultet/veleučilište koji namjeravam upisati cijenjen.

2. Važno mi je da je područje studija (npr. medicina, poljoprivreda, strojarstvo, psihologija...) koji upisujem cijenjeno.

3. Na moju odluku o izboru studija utječe i to smatram li ga primjerenim za moj spol.

\begin{tabular}{c|c|c|c|c}
$\begin{array}{c}\text { Uopće se ne } \\
\text { ș ažem }\end{array}$ & $\begin{array}{c}\text { Ug avnom se } \\
\text { ne slažem }\end{array}$ & $\begin{array}{c}\text { Niti se } \\
\text { stažem, niti } \\
\text { se ne slažem }\end{array}$ & $\begin{array}{c}\text { Uglavnom se } \\
\text { stažem }\end{array}$ & $\begin{array}{c}\text { U potpunosti } \\
\text { se slažem }\end{array}$
\end{tabular}

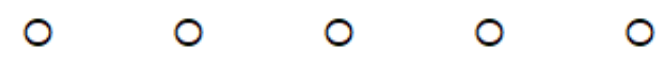

○

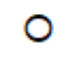

0

0

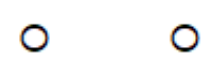


62. Koliko se slažeš sa sljedećim tvrdnjama o tvom mjestu stanovanja?

\begin{tabular}{|c|c|c|c|c|}
\hline $\begin{array}{l}\text { Uopće } \\
\text { se ne } \\
\text { st ažem }\end{array}$ & $\begin{array}{l}\text { Uglavnom } \\
\text { se ne } \\
\text { slažem }\end{array}$ & $\begin{array}{c}\text { Niti se } \\
\text { sažem, } \\
\text { niti se } \\
\text { ne }\end{array}$ & $\begin{array}{l}\text { Ug av avnom } \\
\text { se ș ažem }\end{array}$ & $\begin{array}{c}\mathrm{U} \\
\text { potpunosti } \\
\text { se } ₫ \text { s ažem }\end{array}$ \\
\hline & & șǎ̌em & & \\
\hline
\end{tabular}

1. Volim prirodu koja okružuje moju životnu sredinu.

2. Ponosnim me čini kulturna povijest moga kraja

3. Volim ovdje živjeti jer su mi tu prijatelji i obitelj.

4. Moja životna sredina je ugodno mjesto za stanovanje.

5. Mjesto u kojem živim je sigurna sredina za odrastanje.

6. Mislim da bih se teško prilagodio na promjenu životne sredine.

7. Trenutno mjesto stanovanja odgovara mojim potrebama $i$ nadama za budućnost.

8. U mojoj životnoj sredini ljudi dijele moje vrijednosti i način život.

9. U mojoj sredini ljudi ne razumiju kako želim živjeti.

10. Osjećam se bitnim pripadnikom svoje zajednice.

11. Rado se uključujem u aktivnosti zajednice.

12. Svojim radom žel im doprinijeti svojoj zajednici.

13. Rado pomažem sumještanima.

14. Osjećam da bi mi ostali sumještani pomogli kada bi mi pomoć bila potrebna.

15. Svojim obrazovanjem žel im doprinijeti svojoj zajednici.

16. Ako žel im postići nešto u životu moram se preseliti

17. Ne vidim budućnost u mjestu u kojem živim.

18. Jedva čekam napustiti mjesto u kojem živim.

19. Svoj budući život vidim u velikom gradu.

$\begin{array}{lllll}0 & 0 & 0 & 0 & 0\end{array}$

000000

000000

$\begin{array}{lllll}0 & 0 & 0 & 0 & 0\end{array}$

000000

00000

00000

000000

$\begin{array}{lllll}0 & 0 & 0 & 0 & 0\end{array}$

000000

000000

000000

$\begin{array}{lllll}0 & 0 & 0 & 0 & 0\end{array}$

00000

$\begin{array}{lllll}0 & 0 & 0 & 0 & 0\end{array}$

000000

000000

00000

000000

\section{Zahval jujemo na suradnji!}

Ukoliko želiš sudjelovati u nastavku istraživanja i razgovarati o svojim iskustvima u školi i planovima za budućnost, molimo te napiš nam svoj kontakt (e-mail ili/i broj mobitela): 
7.2 Protokol za polustrukturirane intervjue

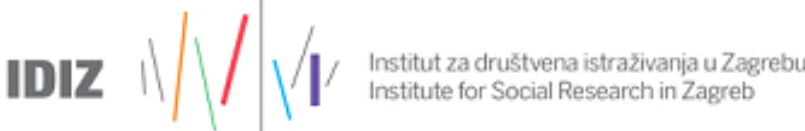

\section{PROTOKOL ZA INTERVJU za učenice i učenike koji planiraju nastaviti školovanje}

\begin{tabular}{|c|c|}
\hline $\begin{array}{c}\text { Pitanja 1: o nastavku } \\
\text { školovanja }\end{array}$ & Teme \\
\hline $\begin{array}{l}\text { Zašto si se odlučio/la studirati? } \\
\text { Možeš li mi opisati kako si donio/d on ijela } \\
\text { tu od luku? } \\
\text { Kada si se na to od lučio/h? }\end{array}$ & $\begin{array}{r}\text { Općenito o odluci nastavka } \\
\text { školovanja }\end{array}$ \\
\hline $\begin{array}{l}\text { Misliš li da roditelji imaju utjecaj na svoju } \\
\text { djecu u pogledu njihovih odluka vezanih } \\
\text { za nastavak školovanja? Što tvoja obitelj } \\
\text { misli o tvojoj odluci? Jesu li te roditelji } \\
\text { savjetovali? Kako se o stud iranju priča } \\
\text { kod tebe doma? } \\
\text { Misliš li da neki učenici imaju veće šanse } \\
\text { da studiraju od drugih? Koji su to učen ici? } \\
\text { Misliš li da veću šansu za studiranjem } \\
\text { imaju učenici/e čiji su rod itelji sami } \\
\text { studirali } \\
\text { A čiji su rod itelji dobrostojeći? Možeš li mi } \\
\text { reći nešto više o svom odgovoru? }\end{array}$ & Uloga obitelji \\
\hline $\begin{array}{l}\text { Jedno od pitanja u upitniku je vezano uz } \\
\text { procjenu koliko su druge osobe utjecale na } \\
\text { tvoju odluku i ti si naveo/ha xyz. Možeš li } \\
\text { mi reći nešto više o tome kako su utjecali? }\end{array}$ & Uloga važnih drugih \\
\hline $\begin{array}{l}\text { Jesi li u donošenju odluke o nastavku } \\
\text { školovanja raz mišljao/la i o novcu } \\
\text { potrebnom za studij? Kako ćeš financirati } \\
\text { studij? Planiraš li raditi uz studij? Možeš li } \\
\text { studirati bez neke stịpendije? }\end{array}$ & Financijska sredstva \\
\hline $\begin{array}{l}\text { Koju ulogu misliš da je činjenica što } s i \\
\text { učenik/ca ova škole utjecalo na tu od luku? } \\
\text { Kako te škoh pripremila za nastavak } \\
\text { školovanja? Jesu li te nastavnici poticali? } \\
\text { Informirali? Jesu li organizirani dodatni } \\
\text { nastavni sadrž aji? } \\
\text { Je li tvoja osnovna škola bila poticajna za } \\
\text { nastavak školovanja? Štto ju je } \\
\text { činilo(ne)poticajnom? }\end{array}$ & Uloga škole \\
\hline
\end{tabular}




\section{Pitanja 2: o odabiru studija}

\section{Teme}

U upitniku si naveo/la da planiraš upisati studij na xyz. Zašto si se odlučio/la baš za to sveučilište/veleučilište/visoku školu?

Zašto baš taj studij? Jesi li razmišljao i o nekoj drugoj opciji (kako vez ano uz studij, tako $\mathrm{i}$ instituciju)?

Što tvoja obitelj misli o tvojoj odluci? Uloga obitelji

Je li te netko savjetovao oko upisa ovog studija? Je li to utjecalo na tvoju odluku?

Je li financijsko stanje tebe i tvoje obitelji utjecalo na odabir tog studija? Kako? Jesi

li informiran o mogućnostima

stipend iranja?

Misliš li da je činjen ica što si učenik/ca ova škole utjeca lo na tu od luku?

Misliš li da završavanje studija doprinosi boljem statusu u društvu? Koliko ti je to važno za odabir studija?

Jedno od pitanja u upitniku je vezano uz to koliko je vjeroja tno da ćeš upisatiželjeni studij. Možeš li mi reći nešto više o svom odgovoru?

Što misliš da su ghavni raz lozi z ašto netko uspije upisati studii, a netko ne?

Š to očekuješ od studen tskog života?

Kako misliš da izgleda studentski život u usporedbi sa srednjoškolskim (prednosti, mane)?

Čemu se veseliš u pogledu studija?

Ima li nešto što te brine?

Jedno od pitanja u upitniku je vezano uz to koliko je vjeroja tno da ćeš zavišiti upisani studij. Zašto to misliš?

O čemu misliš da ovisi taj (ne)uspjeh? 


\section{Pitanja 3: rodna dimenzija $\quad$ Teme odabira studija}

U upitniku si naveo/la da su ž ene/muškarci talentiraniji za društven e/tehničke studije (ili pak da su jednako ta lentirani). Zašto to misliš?

Je li ti tvoje mišljenje (o tome) u tjecalo na tvoju odluku o odabiru studija?

Što je s pitanjima vezanim uz matematiku i hrvatski i talentiranost? Zašto?

Rodni profil predmeta

Misliš li da je to utjecalo na tvoju motivaciju za učenje tih predmeta? Kako?

Misliš li da je to utjecalo na tvoju odluku o odabiru studija? Kako?

Misliš li da postoje srednje škole koje su primjerenije za djevojke ili mladiće? Je li to utjecalo na tvoju odluku o odabiru srednje škole? A na odabir studija?

Misliš li da postoje zanimanja koja su primjerenija za muškarce ili ž ene? Je li to Rodni profil zanimanja utjecalo na tvoju odluku o odabiru srednje škole? A studija? 


\section{Pitanja 4: socijalni identiteti}

\section{Teme}

Kako bi sebe opisa o/la?

Općenito o sebi

Jedno od pitanja u upitniku vezano je uz to

kako vidiš sebe i svoju obitelj na

Klasni identitet

društvenoj ljestvici i ti si označio/la xyz.

Zašto si se za to od hučio/la?

Utječe li to gdje si na ljestvici na tvoj život

(je li važno gdje je netko na toj ljestvici)?

Kako?

Utječe li to što si djevojka/mladić na tvoj život? Kako?

Rodni identitet

Što tebi zn ači bitižena/muškarac? Je li ti

to važno? Zašto?

Od sljedećih karakteristika, što bi rekao/la

da je važan dio toga tko si (kako ti sebe

Samoidentifikacija

vidiš): učenik/ca,

gimnazijalac/stıukovnjak, muško/žensko,

iz dobrostojeće/siromašne obitelji, sa

sela/iz grada, moja nacionalnost, moja

(ne)religioznost, moja slobodna aktivnost.

Zašto ti je to važno? Što ti to znači (u

odnosu na ono što nisi)?

Postoji li neka druga tvoja karakteristika

koja ti jevažnija od navedenih?

Je li ti nešto od toga što si spomenuo/la

važno za tvoju odluku o nastavku

školovanja/odabiru studija?

Od sljedećih karakteristika, što bi rekao/la

da je važan dio toga kako te drugi vide:

Identifikacija drugih

učenik/ca, gimnazija lac/strukovnjak,

muško/žensko, iz dobrostojeće/siromašne

obitelji, sa sela/iz grada, moja

nacionalnost, moja (ne)religiozn ost, moja

slobodna aktivnost. Odgovara li ti to?

Smeta li te? Zašto?

Kako vidiš sebe u svojoj 30-toj godini

(specificirati posao)?

Projekcija sebe 
7.3 Analitička matrica - slučajevi

Obrazovne karakteristike i orijentacije te visokoobrazovni izbori

Slučajevi

\begin{tabular}{|c|c|c|c|c|c|c|c|c|c|c|c|c|c|c|c|c|c|}
\hline 'Gordana' RRP_TP GIM_VG & + & ++ & & & & & & & + & + & PT & + & + & $\mathrm{ZG}$ & & + & + \\
\hline 'Marija' RRP_TP GIM_mg & & & & & $*$ & & & & & + & $\mathrm{DH}$ & & + & $\mathrm{ZG}$ & & & \\
\hline RRP_TP 4SŠ_VG & & & & & $* *$ & & & & & & PT & & & & $*$ & + & \\
\hline 'Andrea' RRP_TP 4SŠ_mg & + & & $*$ & & & & & & + & & $\mathrm{DH}$ & & + & $\mathrm{ZG}$ & & + & \\
\hline 'Marina' RRP_TP 4SŠ_mg & & & & $*$ & $* *$ & & & & $*$ & & PT & & & & & $*$ & *** \\
\hline 'Ivana' RRP_DSJ $\quad$ 4SŠ_mg & & & $*$ & $*$ & $*$ & & & & + & & $\mathrm{DH}$ & $*$ & $*$ & REG & *** & $*$ & \\
\hline 'Mislav' RRP_DSJ $\quad$ 4SŠ_VG & + & ++ & & & $* *$ & + & & & + & & PT & + & + & $\mathrm{ZG}$ & & $*$ & + \\
\hline 'Marijan' RRP_DSJ 4SŠ_mg & ++ & & $*$ & $*$ & $*$ & & & & & & PT & $*$ & & & $*$ & $*$ & + \\
\hline 'Dominik' RRP_DSJ 3SŠ_mg & & $*$ & & $*$ & $*$ & + & & $*$ & & & & & & & & & \\
\hline 'Lidija' $\quad$ DSJ_RRP 3 SŠ__VG & $*$ & $*$ & & $*$ & $*$ & + & $*$ & $*$ & $*$ & & & & & & & & \\
\hline 'Jan' $\quad$ URP_nc 4 4Š̌_mg & & * & & *** & & * & *** & & & & & & & & & & \\
\hline 'Andrej' URP_mg GIM_VG & & & & & & & $* *$ & & & & $\mathrm{DH}$ & & + & $\mathrm{ZG}$ & & + & \\
\hline 'Bernarda' URP_mg GIM_mg & & & & & & & & + & & + & $\mathrm{DH}$ & & & & $*$ & & $* *$ \\
\hline 'Dejan' URP_mg GIM_mg & & & & & & & + & & & & $\mathrm{DH}$ & & & REG & + & & \\
\hline 'Aneta' URP_mg 4SŠ_mg & + & ++ & $*$ & & $* *$ & & + & & + & & PT & & & & $*$ & & \\
\hline 'Agata' URP_mg 4SŠ_mg & & & $*$ & $*$ & $*$ & + & + & & ++ & & $\mathrm{DH}$ & & & & $*$ & & \\
\hline 'Frane' URP_mg 3SŠ_mg & & & & $*$ & $*$ & & & & $*$ & & $\mathrm{DH}$ & & & & + & $*$ & \\
\hline 'Krešimir' URP_mg 3SŠ_mg & & $*$ & & $* *$ & & & & $*$ & & & & & & & & & \\
\hline 'Jakov' URP_VG GIM_VG & & & & & & & + & + & & + & PT & $*$ & $*$ & $\mathrm{ZG}$ & & + & \\
\hline 'Anica' URP_VG GIM_VG & + & ++ & $*$ & & & & & + & & + & $\mathrm{PT}$ & & + & $\mathrm{ZG}$ & & + & \\
\hline
\end{tabular}




\begin{tabular}{|c|c|c|c|c|c|c|c|c|c|c|c|c|}
\hline \multirow[t]{2}{*}{ Obiteljski kontekst } & \multicolumn{4}{|c|}{$\begin{array}{l}\text { OBITELJSKI KULTURNI } \\
\text { KAPITAL }\end{array}$} & \multicolumn{5}{|c|}{ OBITELJSKI HABITUS } & \multicolumn{3}{|c|}{ OBITELJSKI EKONOMSKI KAPITAL } \\
\hline & 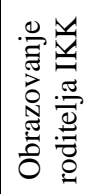 & 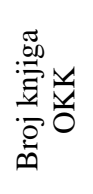 & 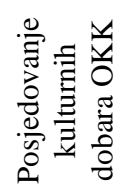 & 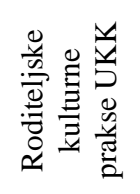 & 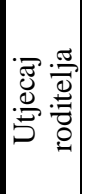 & 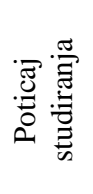 & 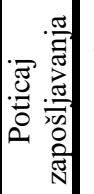 & 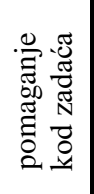 & 高 & $\begin{array}{l}\bar{\nabla} \\
\bar{D} \\
\bar{E}\end{array}$ & 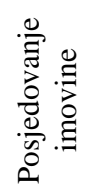 & 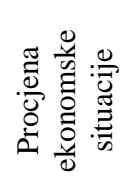 \\
\hline 'Gordana' RRP_TP $\quad$ GIM_VG & & & & & & & $*$ & $*$ & *** & $*$ & $*$ & \\
\hline $\begin{array}{lll}\text { 'Marija' } & \text { RRP_TP } & \text { GIM_mg }\end{array}$ & & & & & & & & & + & & & $* *$ \\
\hline $\begin{array}{lll}\text { 'Silvija' } & \text { RRP_TP } & \text { 4SŠ_VG }\end{array}$ & $*$ & & & $*$ & $*$ & & & & + & **** & & $*$ \\
\hline 'Andrea' $\quad$ RRP_TP 4 4SŠ_mg & & $*$ & & & & *** & $*$ & $*$ & & $*$ & & \\
\hline 'Marina' $\quad$ RRP_TP $\quad$ 4SŠ_mg & & $*$ & & & $*$ & & & + & & $*$ & & + \\
\hline $\begin{array}{lll}\text { 'Ivana' } & \text { RRP_DSJ } & \text { 4SŠ_mg } \\
\end{array}$ & $*$ & $*$ & & & $*$ & & & & & *冰 & & *** \\
\hline $\begin{array}{lll}\text { 'Mislav' } & \text { RRP_DSJ } & \text { 4SŠ_VG }\end{array}$ & + & & + & & + & & & & *** & $*$ & ++ & \\
\hline 'Marijan' RRP_DSJ $\quad$ 4SŠ_mg & $*$ & & & & & & & & & & & $*$ \\
\hline 'Dominik' RRP_DSJ 3SŠ_mg & $*$ & & + & & & & & & & $*$ & & \\
\hline 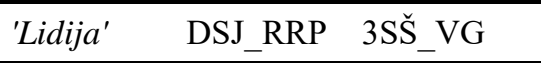 & + & & & + & + & & & + & & & + & \\
\hline 'Jan' $\quad$ URP_nc $\quad$ 4SŠ_mg & 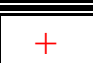 & * & 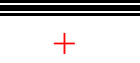 & & * & & & . & & & 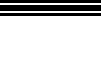 & \\
\hline 'Andrej' $\quad$ URP_mg GIM_VG & + & + & + & ++ & $*$ & & $*$ & & + & & & \\
\hline 'Bernarda' URP_mg GIM_mg & & $*$ & & + & & & & + & + & & & + \\
\hline 'Dejan' $\quad$ URP_mg GIM_mg & + & + & & + & + & *** & $*$ & & + & + & $*$ & + \\
\hline 'Aneta' $\quad$ URP_mg 4 4SŠ_mg & & & & & + & & $*$ & $*$ & & & & $*$ \\
\hline 'Agata' URP_mg 4SŠ_mg & & $*$ & & & & & & & & & & + \\
\hline 'Frane' $\quad$ URP_mg 35 Š_mg $^{\prime}$ & & & + & + & $*$ & & & $*$ & & & & $*$ \\
\hline 'Krešimir' URP_mg 3SŠ_mg & & $*$ & & $*$ & & & & & & + & & + \\
\hline $\begin{array}{lll}\text { 'Jakov' } & \text { URP_VG } & \text { GIM_VG }\end{array}$ & + & & + & ++ & & & $*$ & & & + & & \\
\hline 'Anica' $\quad$ URP_VG GIM_VG & + & + & + & + & + & & $*$ & + & + & + & ++ & + \\
\hline
\end{tabular}




\begin{tabular}{|c|c|c|c|c|c|c|c|c|}
\hline \multirow{2}{*}{$\begin{array}{l}\text { Izvanobiteljski kontekst } \\
\text { Slučajevi }\end{array}$} & \multicolumn{3}{|c|}{$\begin{array}{c}\text { INSTITUCIONALNA } \\
\text { KARAKTERISTIKE } \\
\text { SREDNJOŠKOLSKOG POLJA }\end{array}$} & \multirow{2}{*}{ 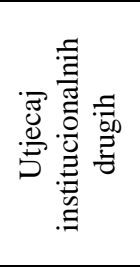 } & \multirow{2}{*}{ 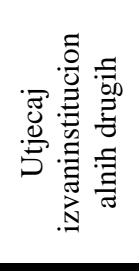 } & \multicolumn{3}{|c|}{$\begin{array}{c}\text { SIMBOLIČKI ZNAČAJ ZAJEDNICE } \\
\text { ODRASTANJA }\end{array}$} \\
\hline & $\begin{array}{l}\text { Status } \\
\text { škole }\end{array}$ & $\begin{array}{l}\text { Akademska } \\
\text { poticajnost }\end{array}$ & $\begin{array}{l}\text { Opremljeno } \\
\text { st škole }\end{array}$ & & & PRIPADNOST & OSTANAK & $\begin{array}{l}\text { EMOCIONAL } \\
\text { NA } \\
\text { VEZANOST } \\
\end{array}$ \\
\hline 'Gordana' RRP_TP GIM_VG & + & & $*$ & + & & $* *$ & & $*$ \\
\hline 'Marija' $\quad$ RRP_TP $\quad$ GIM_mg & & & & & & + & & \\
\hline 'Silvija' $\quad$ RRP_TP $\quad$ 4SŠ_VG & & $*$ & $*$ & & & & & \\
\hline 'Andrea' $\quad$ RRP_TP $\quad$ 4SŠ_mg & & + & $*$ & + & & $*$ & $*$ & $* *$ \\
\hline 'Marina' RRP_TP 4SŠ_mg & $*$ & & $*$ & & & & & + \\
\hline $\begin{array}{lll}\text { 'Ivana' } & \text { RRP_DSJ } & \text { 4SŠ_mg }\end{array}$ & $*$ & & $*$ & & & & + & \\
\hline 'Mislav' RRP_DSJ 4SŠ_VG & & & ++ & + & + & + & + & + \\
\hline 'Marijan' RRP_DSJ $\quad$ 4SŠ_mg & $*$ & & & & & & & \\
\hline 'Dominik' RRP_DSJ 3SŠ_mg & $*$ & & & & & $*$ & & $* *$ \\
\hline DSJ_RRP 3SŠ_VG & & & & & & & & + \\
\hline 'Jan' $\quad$ URP_nc $\quad 4$ SŠ_mg & & + & & & $*$ & & $*$ & \\
\hline 'Andrej' $\quad$ URP_mg GIM_VG & + & & $*$ & & & $*$ & $*$ & $*$ \\
\hline 'Bernarda' URP_mg GIM_mg & + & & & & & & & \\
\hline URP_mg GIM_mg & & $*$ & & + & & & & \\
\hline URP_mg 4SŠ_mg & & & & & & & $*$ & + \\
\hline 'Agata' URP_mg 4SŠ_mg & $*$ & $* *$ & $*$ & & $*$ & & & \\
\hline $\begin{array}{lll}\text { 'Frane' } & \text { URP_mg } & \text { 3SŠ_mg }\end{array}$ & & & & & $*$ & & & \\
\hline 'Krešimir' URP_mg 3SŠ_mg & & & & & & & $*$ & \\
\hline URP_VG GIM_VG & + & & + & & & & & \\
\hline 'Anica' $\quad$ URP_VG GIM_VG & & & & & & + & & \\
\hline
\end{tabular}




\section{Životopis autora}

Olgica Klepač (1982) diplomirala je sociologiju i stekla zvanje diplomirane sociologinje i profesorice sociologije 2006. godine na Filozofskom fakultetu u Zagrebu gdje je završila i Poslijediplomski doktorski studij sociologije. Njena doktorska disertacija Rezidencijalno podrijetlo $i$ odabir studija, s temom pristupa visokom obrazovanju za učenike različitog rezidencijalnog podrijetla, odražava njene osnovne interese za razumijevanje društvenih fenomena iz područja sociologije prostora i obrazovanja.

Radna iskustva stjecala je na Filozofskom fakultetu u Rijeci (2008.-2012.) gdje je pomagala izvođenje kolegija Uvod u sociologiju, Sociologija kulture, Uvod u kulturalne studije, Uvod u znanost o društvu te Spolni i rodni identiteti, dok je istraživačke interese dublje oblikovala kao dio interdisciplinarnog istraživačkog tima Instituta za društvena istraživanja u Zagrebu na projektu Socijalni identiteti, pristup visokom obrazovanju i odabir studija (2013.-2016.) te na Agronomskom fakultetu u Zagrebu (2016.-2017.) izvedbom kolegija Urbana i ruralna sociologija, Ruralna sociologija, Ruralni razvoj i Sociologija održivih zajednica. Osim u akademskom okruženju, nastavne kompetencije razvijala je održavajući nastavu Sociologije i Politike i gospodarstva u srednjim školama, Tehničkoj školi u Virovitici, te Klasičnoj gimnaziji u Virovitici (2018.-2019.). Kao ruralna sociologinja, trenutno radi na Zavodu za bioekonomiju i ruralni razvoj Fakulteta agrobiotehničkih znanosti u Osijeku, gdje asistira u izvedbi društvenoznanstvenih modula Ruralna sociologija, Regionalni i ruralni razvoj, Vođenje i ocjena razvojnih projekata te Poslovne komunikacije i savjetodavni rad.

Aktivno sudjeluje u znanstvenom usavršavanju pohađanjem brojnih tečajeva i ljetnih školi, (npr. ECPR Summer School in Methods and Techniques), dok druge vrste suradnji i projekata (npr. s Dubrovačkom razvojnom agencijom, s Hrvatskim pravnim centrom, u istraživačkoj grupi Ruralije) predstavljaju praktičnu nadogradnju istraživačkih znanja i kompetencija.

Njen rad prezentiran je na brojnim konferencijama, a uz prevoditeljske aktivnosti, objavila je i nekoliko jednoautorskih radova u časopisima te kao poglavlja u knjigama ili zbornicima. Popis radova: https://www.bib.irb.hr/pregled/profil/11060 